Szegedi Tudományegyetem Bölcsészettudományi Kar

Történelemtudományi Doktori Iskola

Medievisztika Doktori Program

\title{
Vámok és vámszedés a középkori Magyar Királyságban Nagy Lajos korában (1342-1382)
}

Doktori (PhD) értekezés

Készítette:

Kovács Viktória

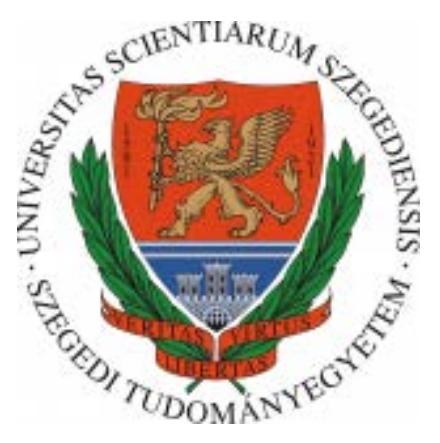

Témavezető:

Weisz Boglárka, PhD 


\section{TARTALOMJEGYZÉK}

BEVEZETÉS

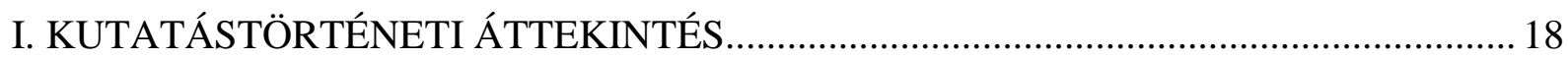

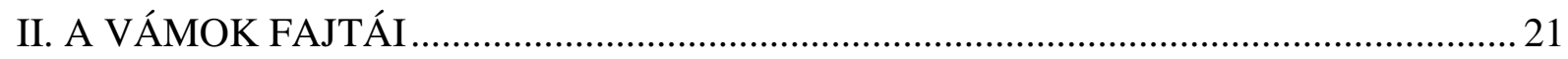

II.1. Közlekedési vámok............................................................................................... 22

II.2. Kereskedelmi vámok ......................................................................................... 26

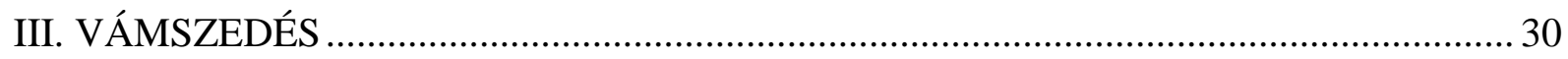

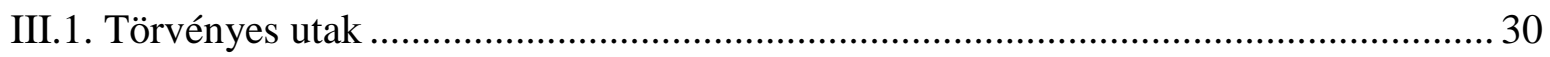

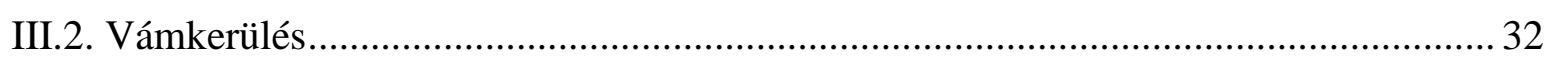

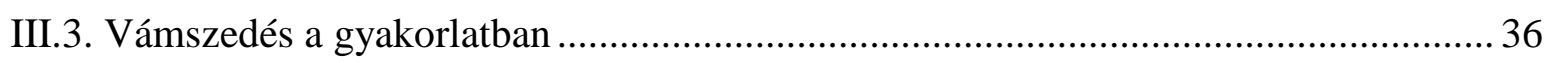

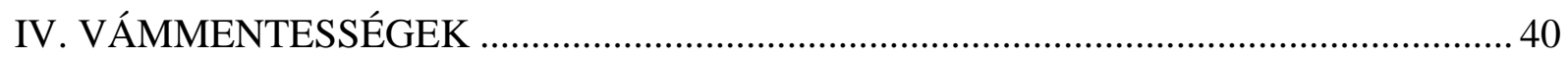

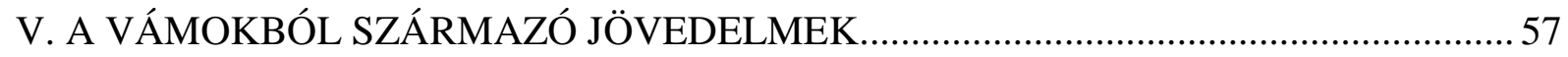

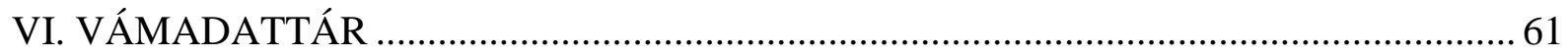

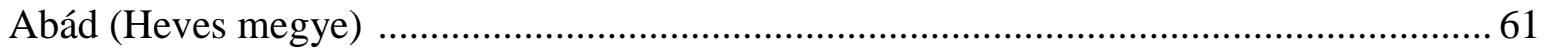

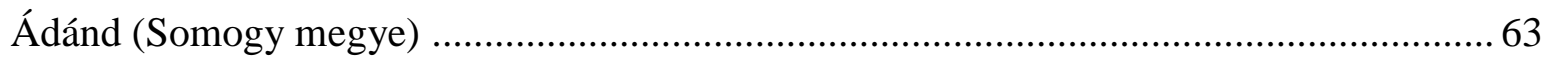

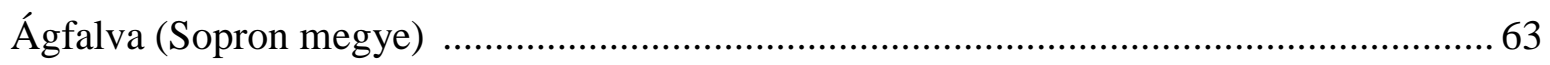

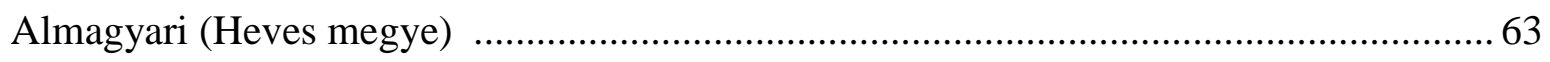

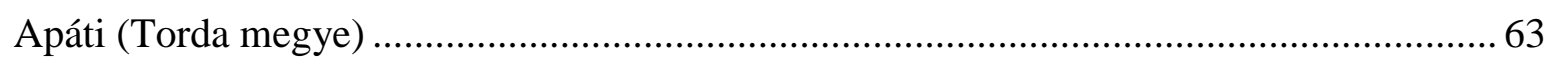

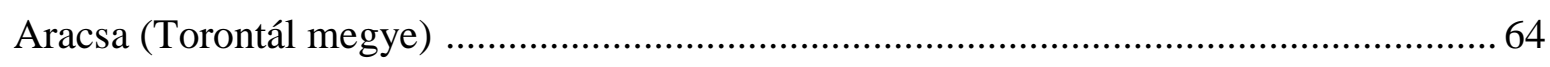

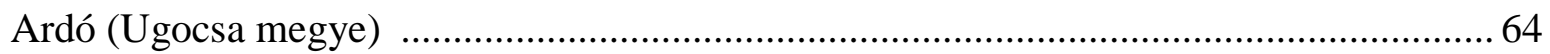

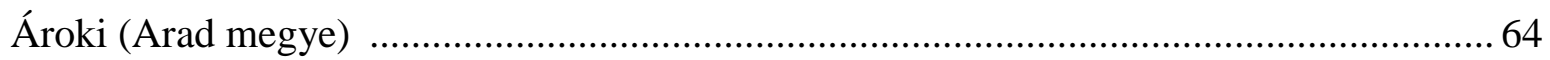

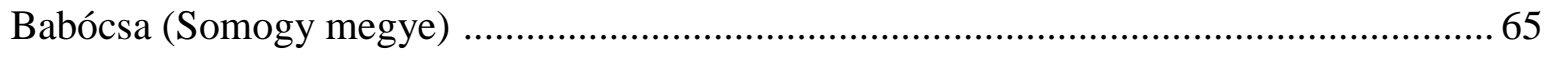

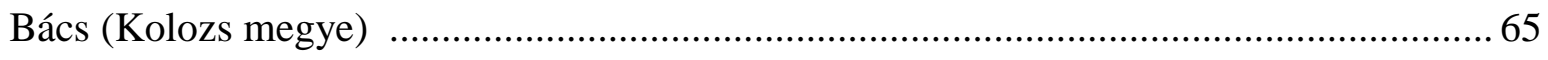

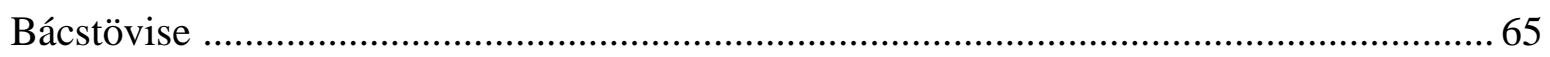

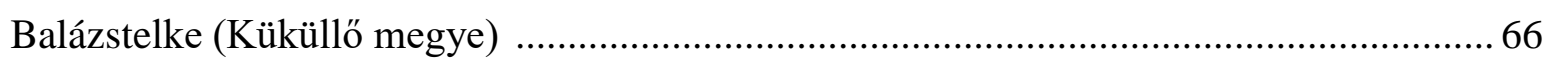

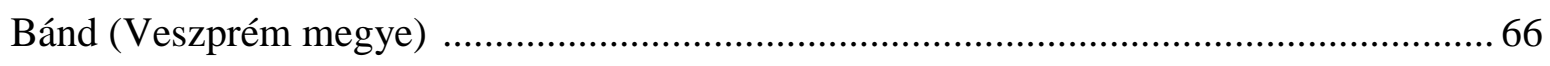

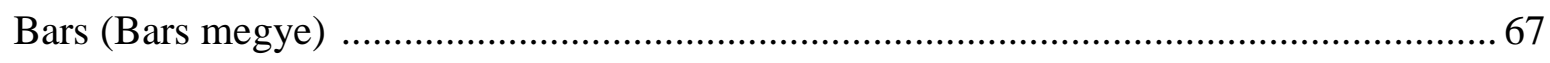

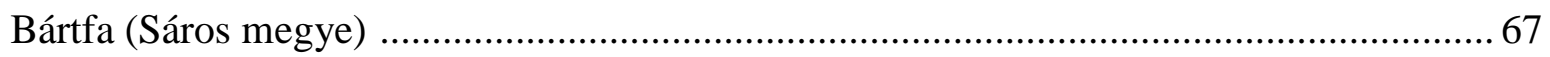

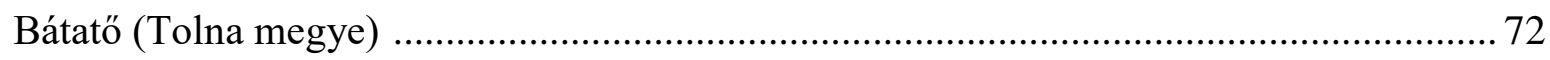




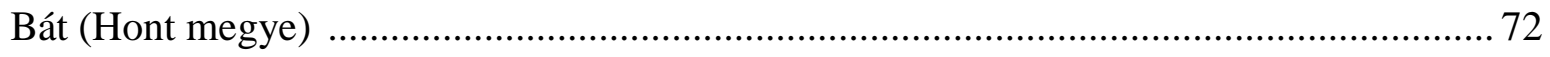

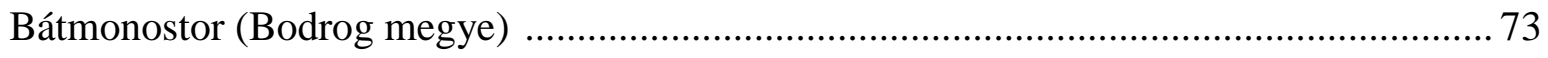

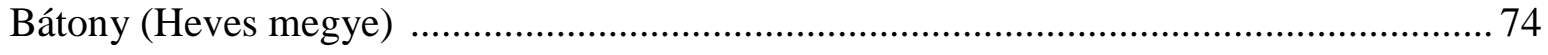

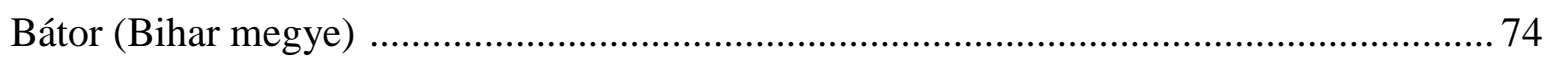

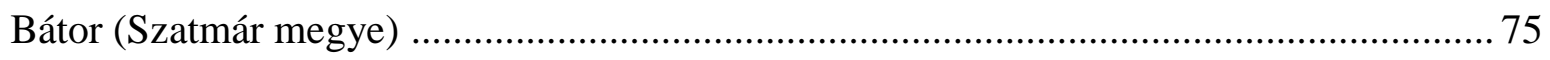

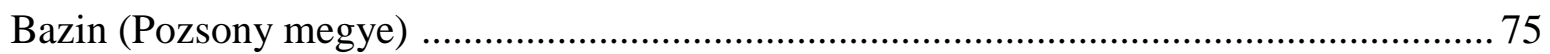

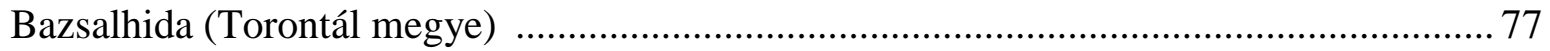

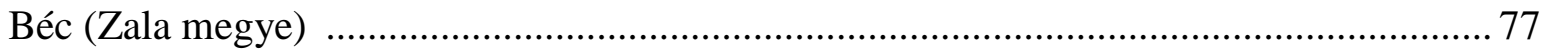

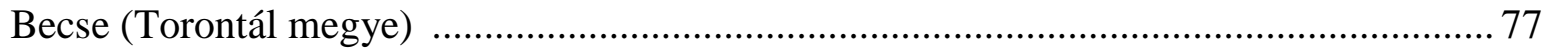

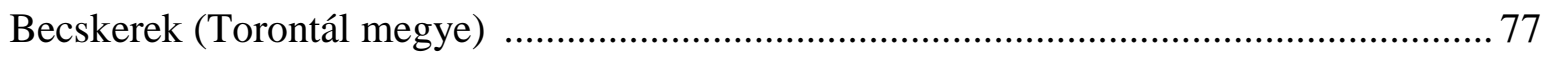

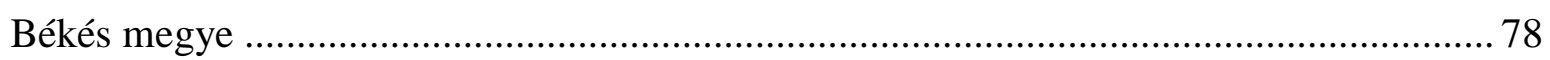

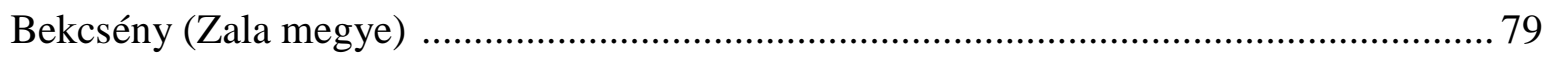

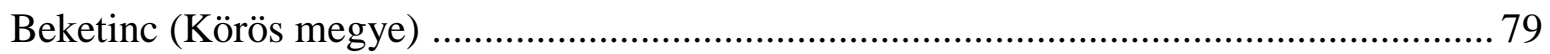

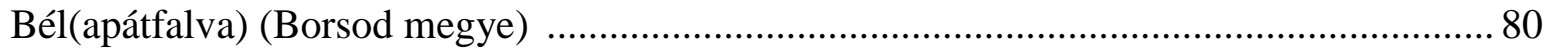

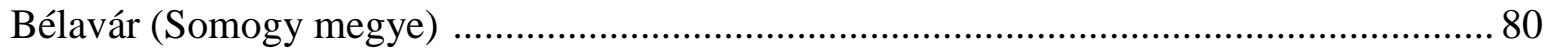

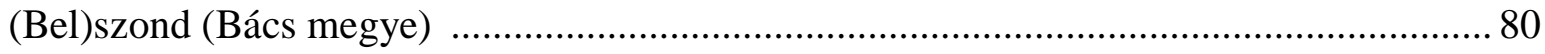

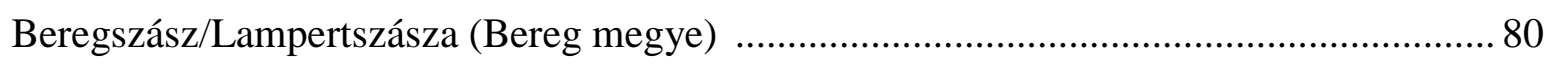

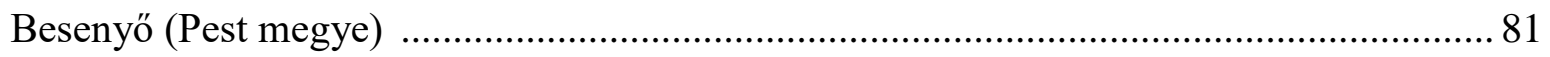

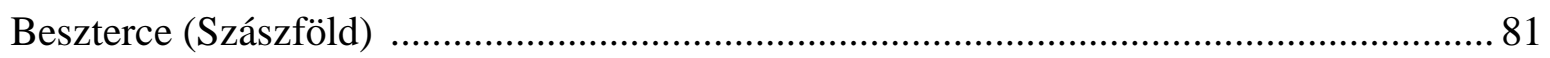

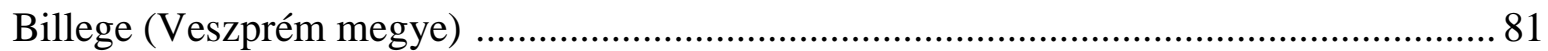

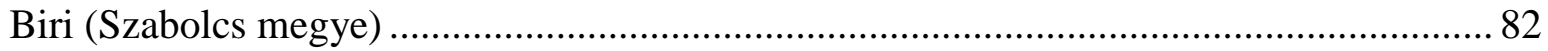

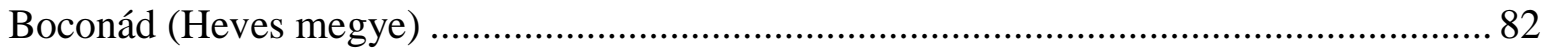

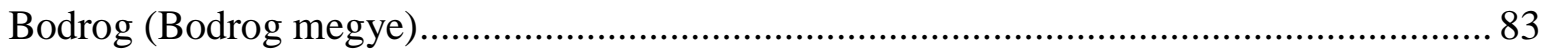

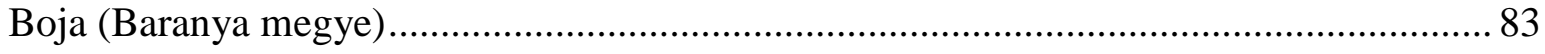

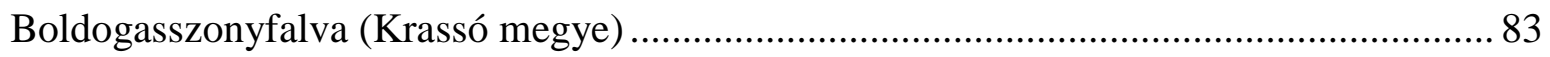

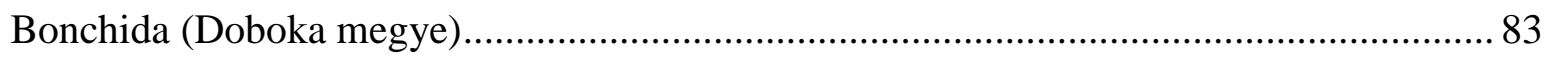

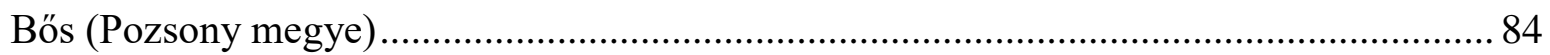

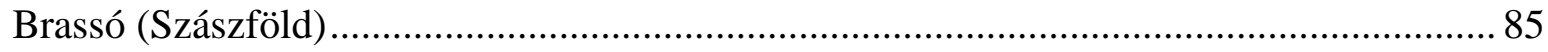

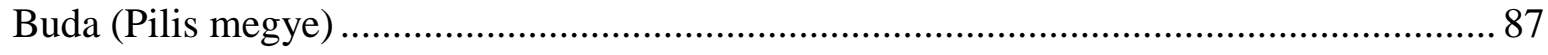

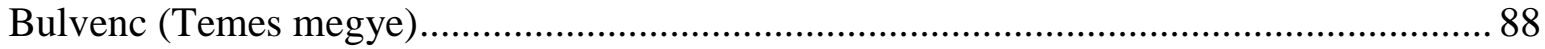

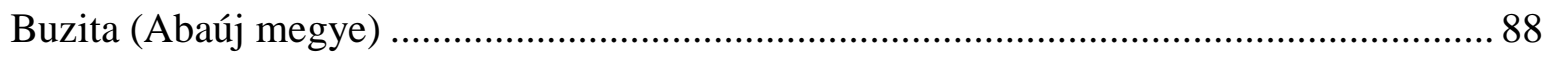

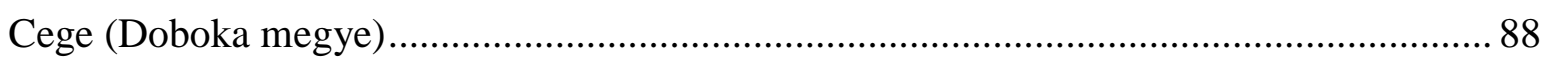

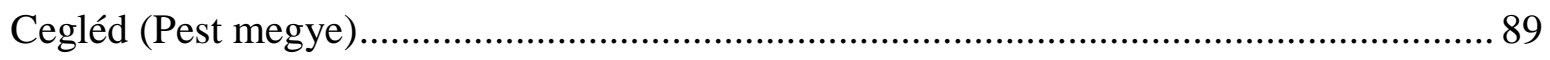

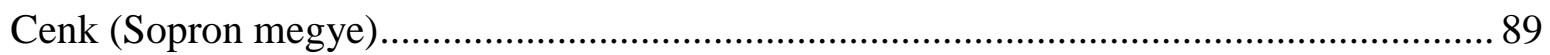

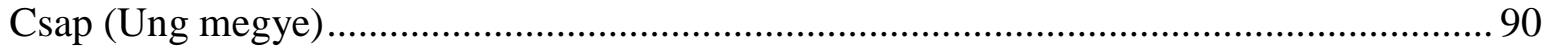

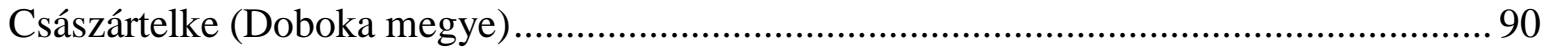

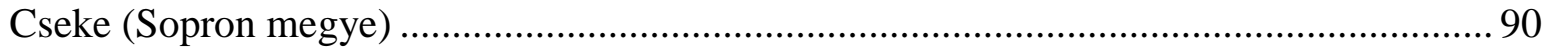




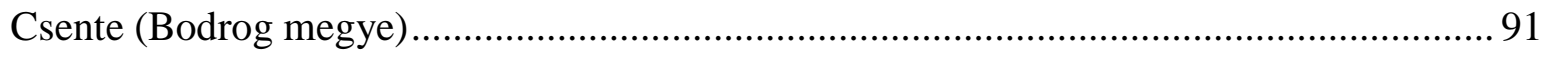

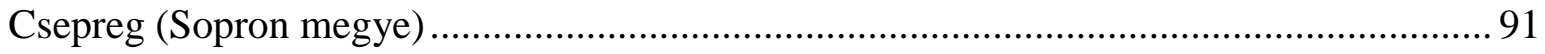

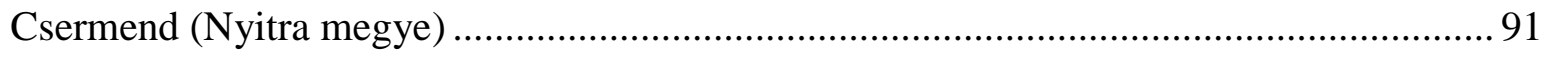

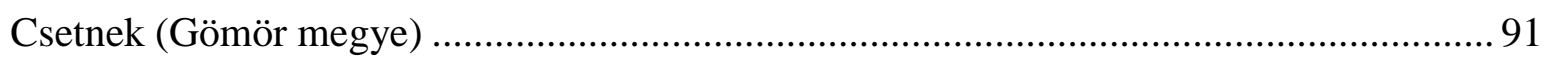

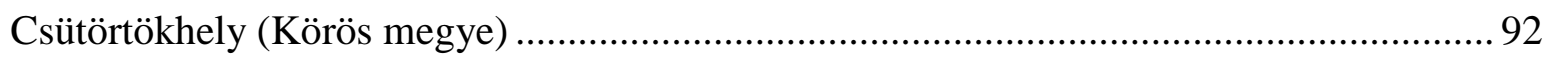

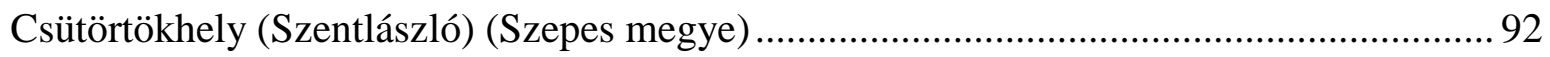

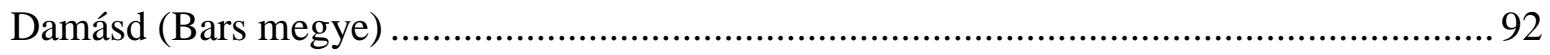

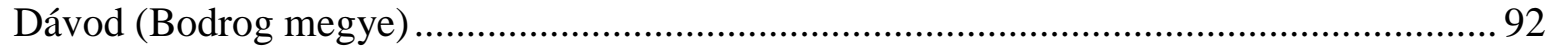

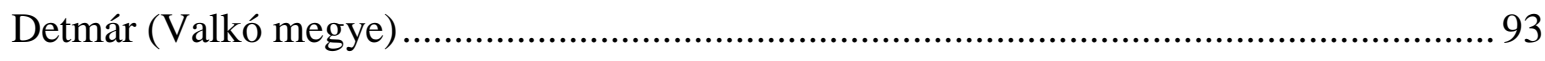

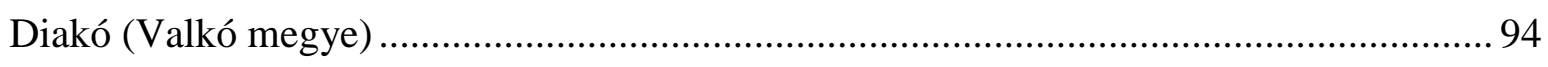

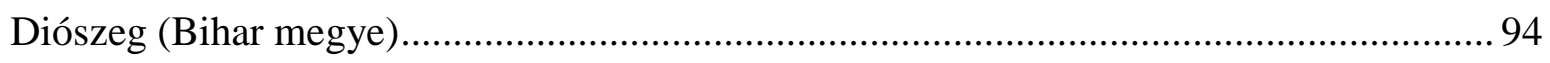

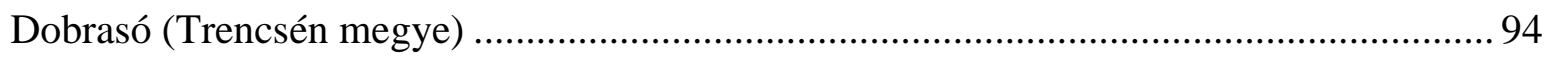

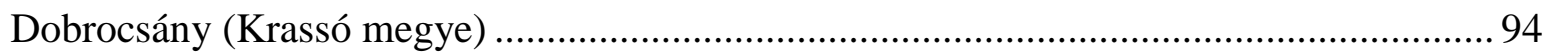

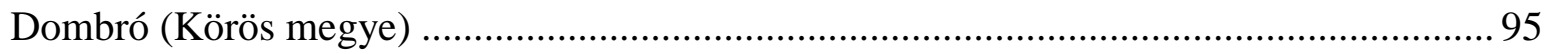

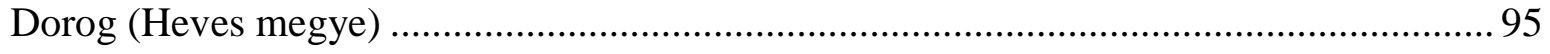

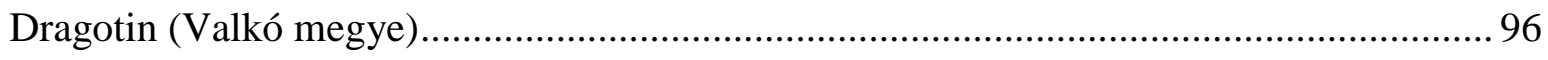

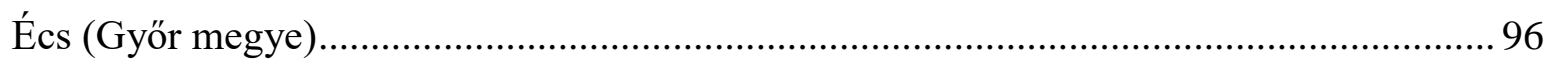

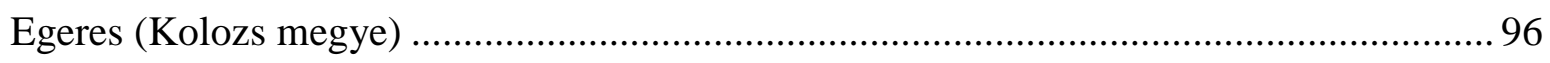

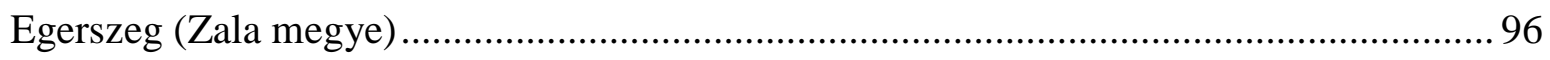

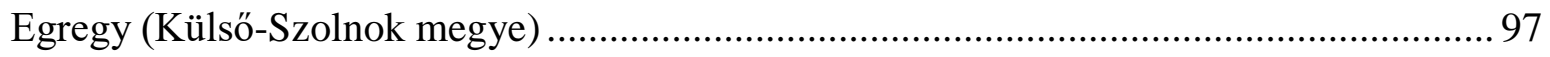

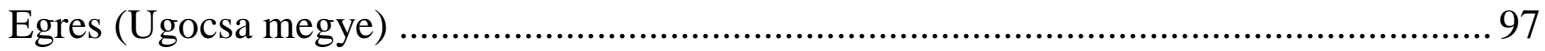

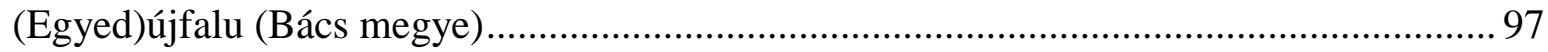

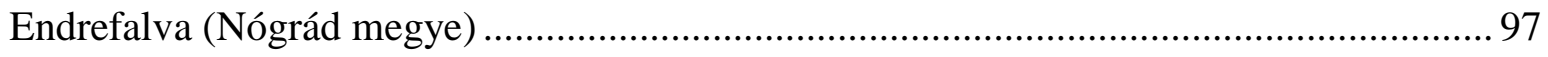

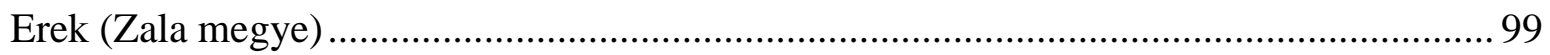

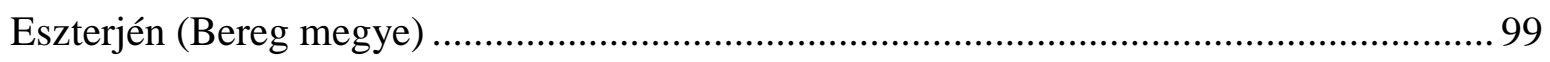

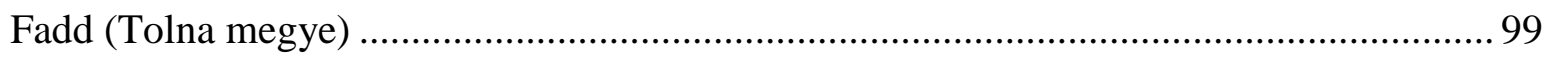

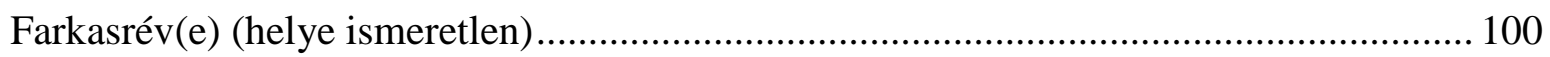

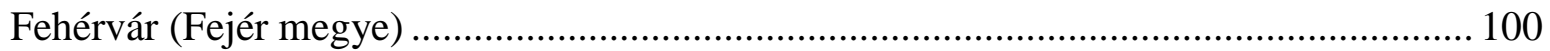

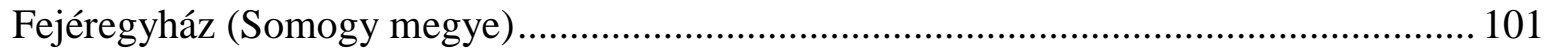

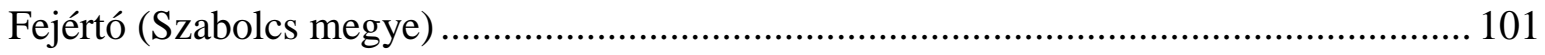

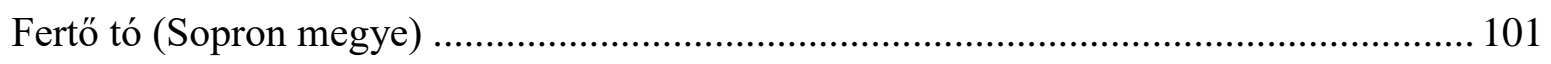

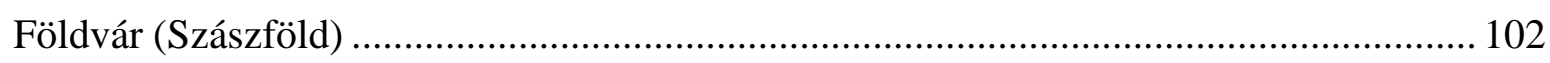

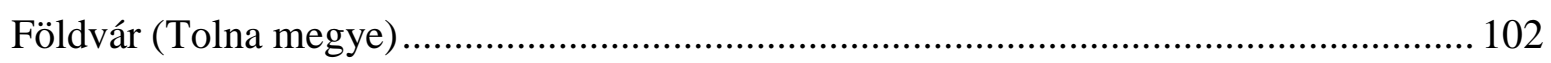

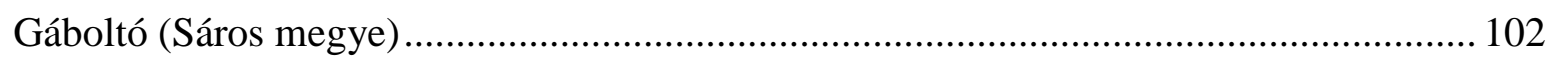

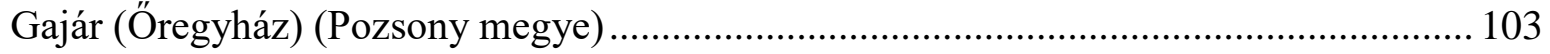

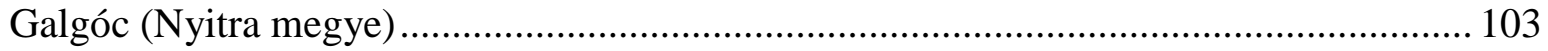

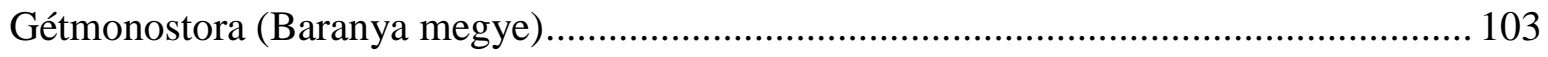




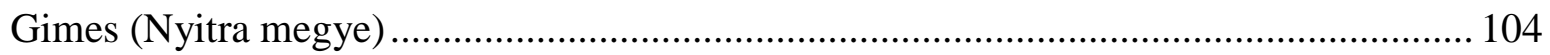

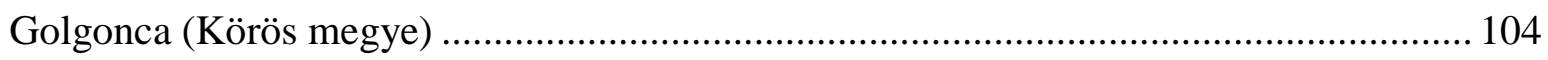

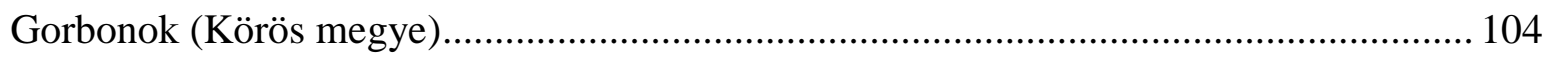

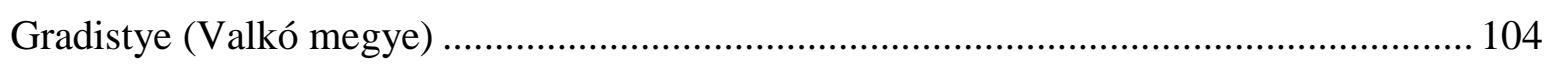

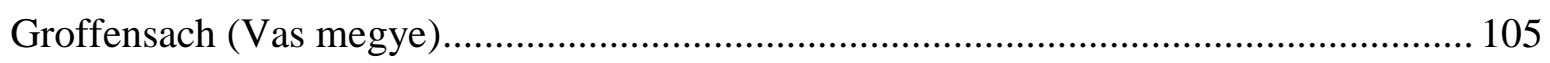

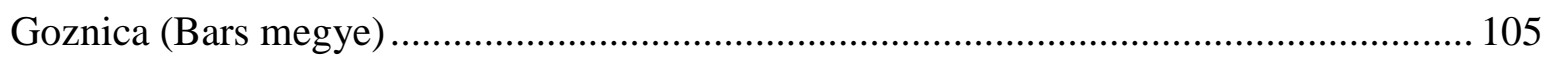

Gyánfalva (Diankfalva vagy Divankovc) (Valkó megye) ............................................. 106

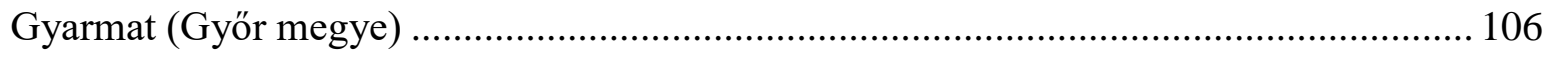

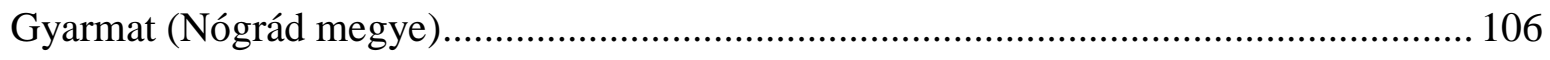

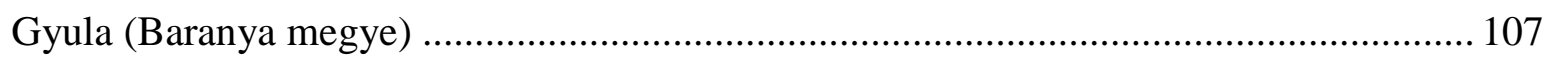

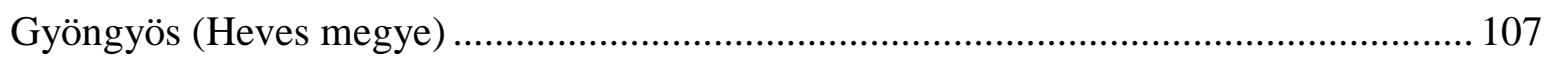

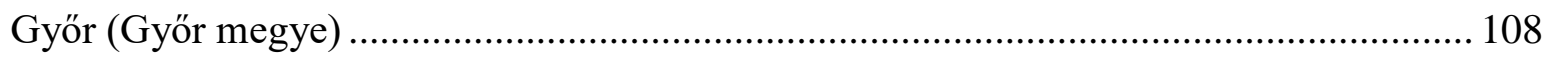

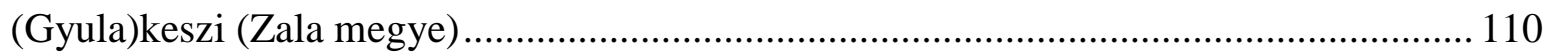

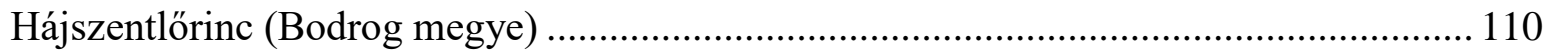

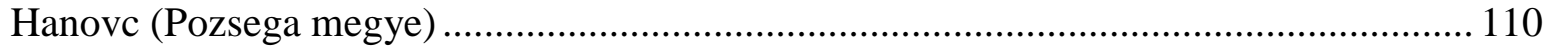

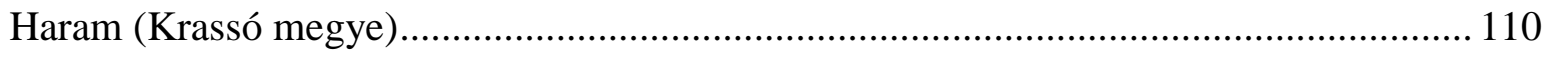

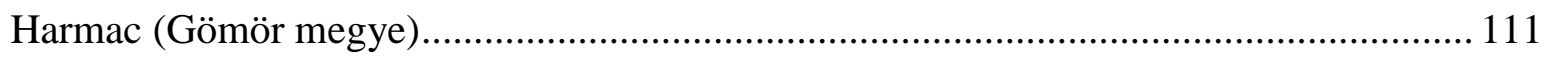

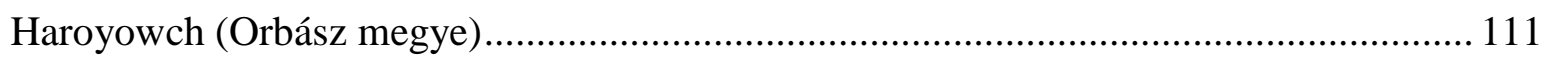

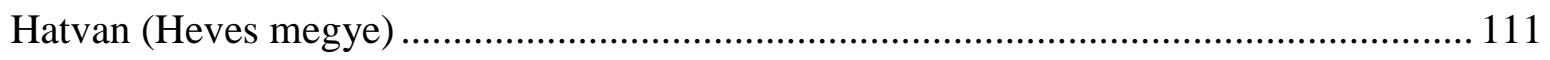

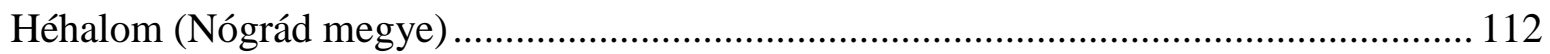

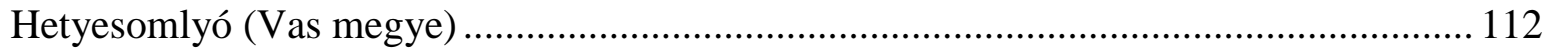

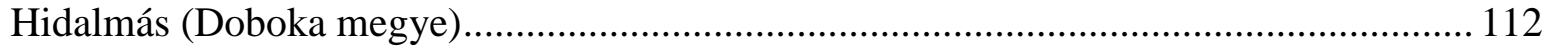

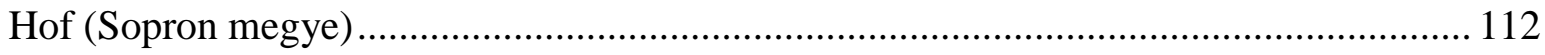

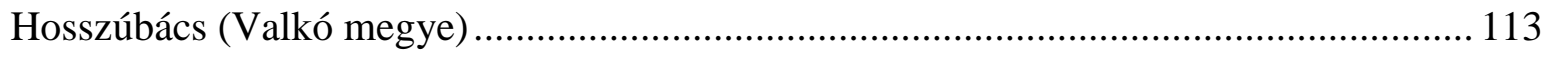

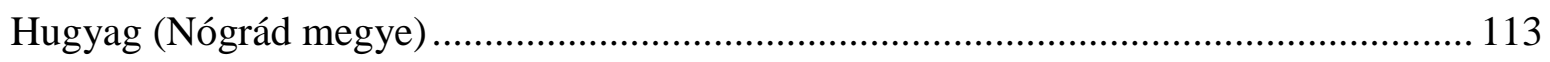

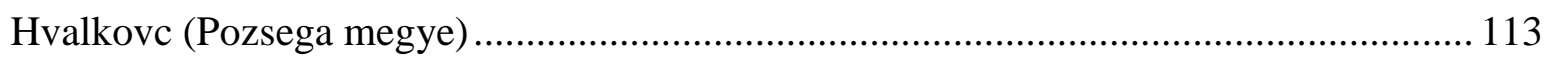

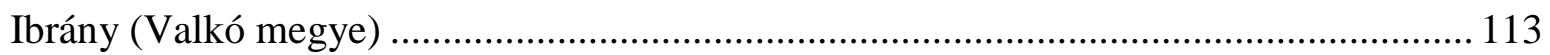

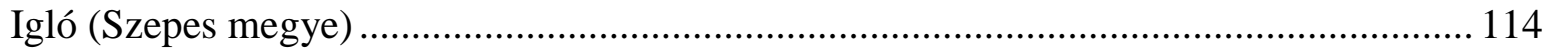

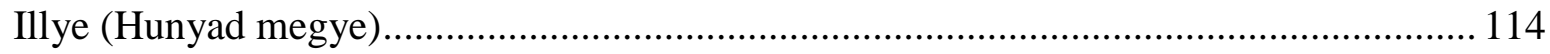

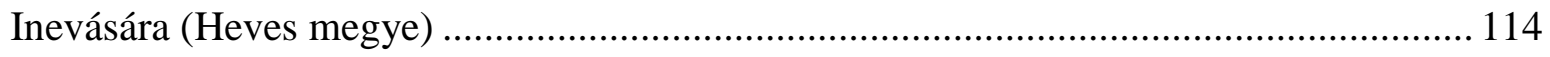

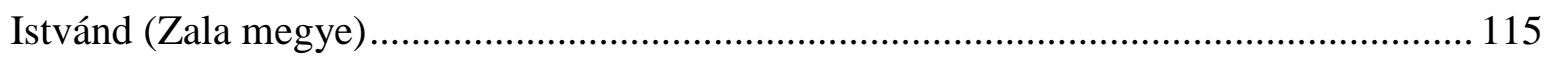

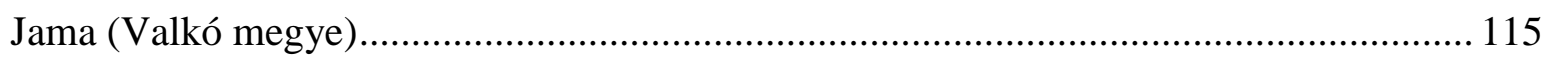

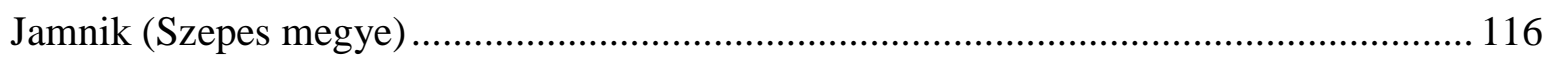

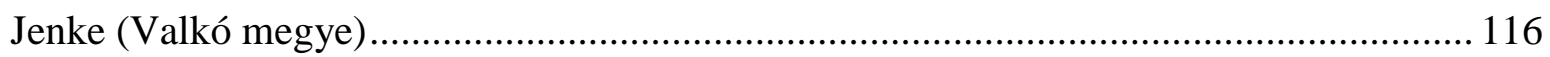

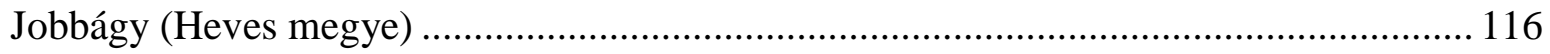

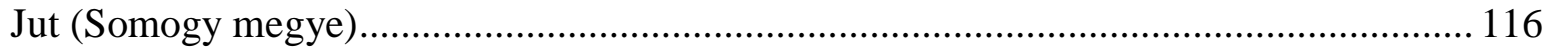

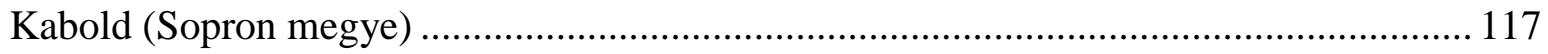




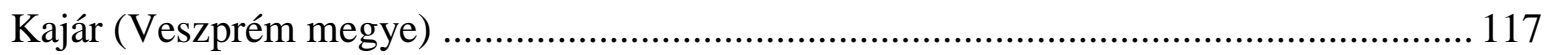

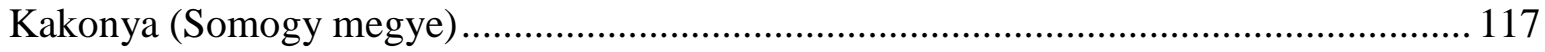

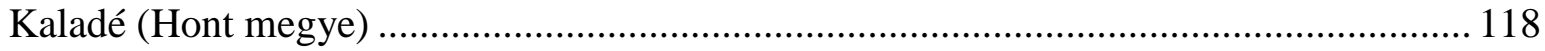

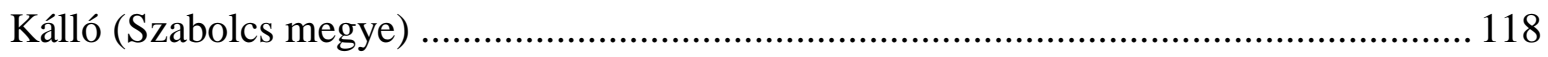

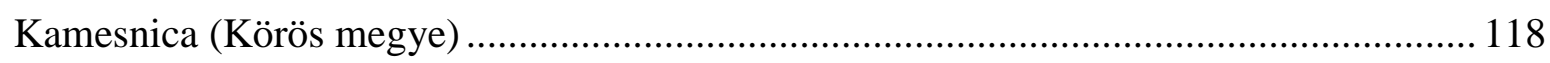

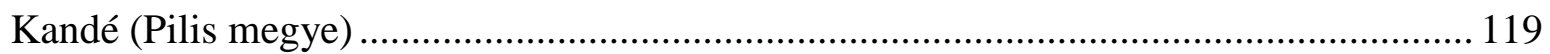

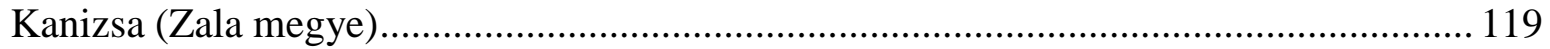

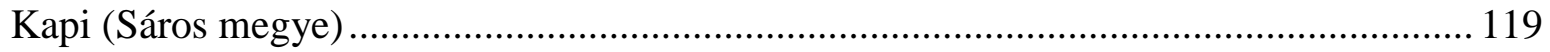

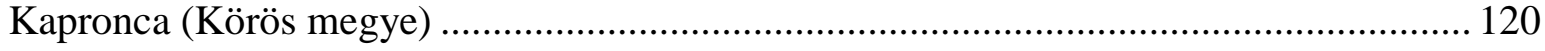

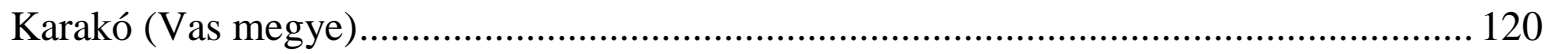

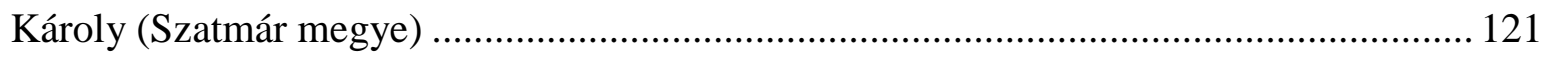

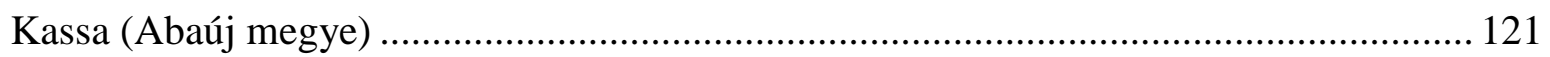

Keddhely (Borsmonostor) (Sopron megye) …................................................................. 121

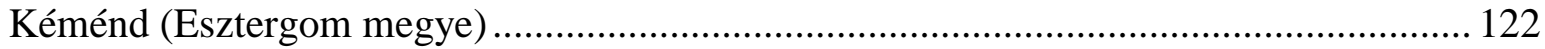

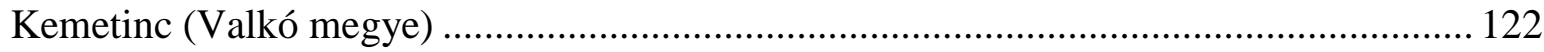

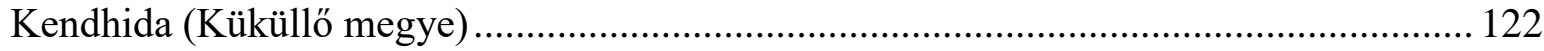

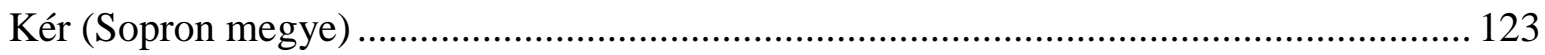

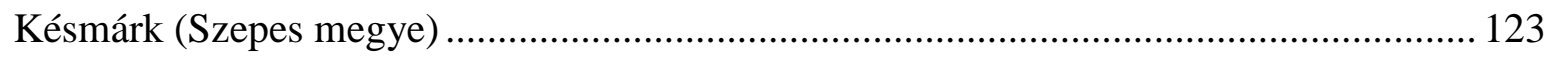

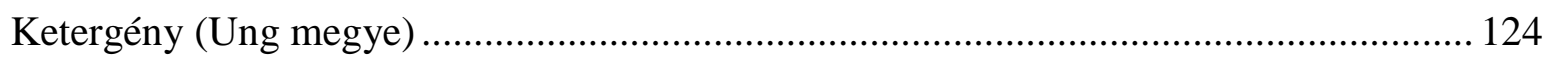

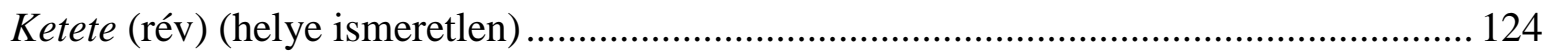

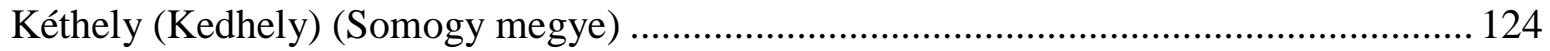

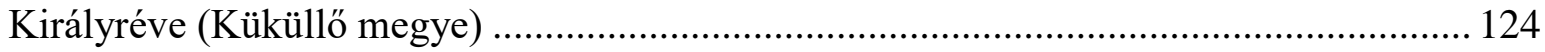

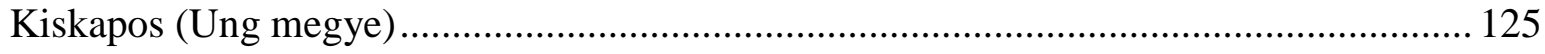

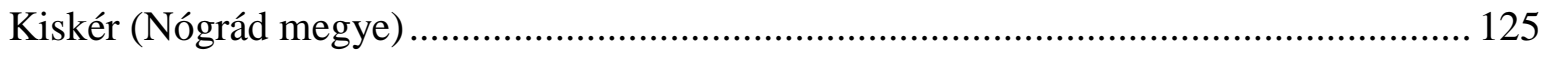

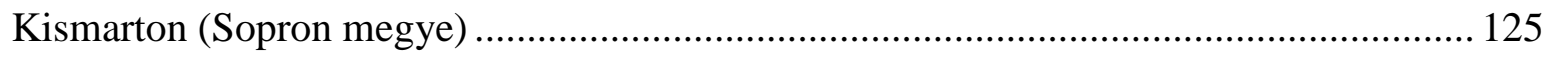

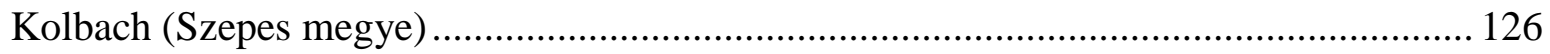

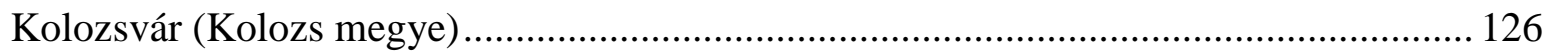

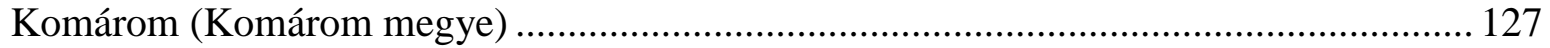

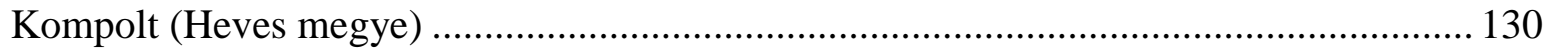

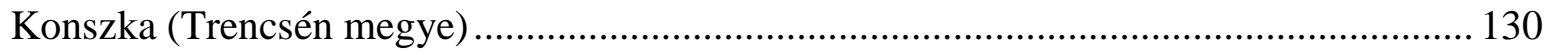

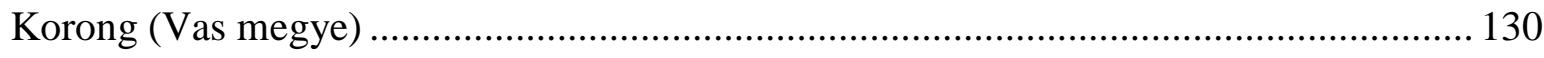

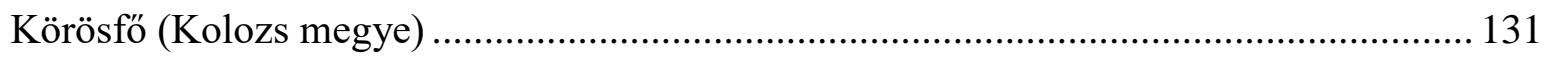

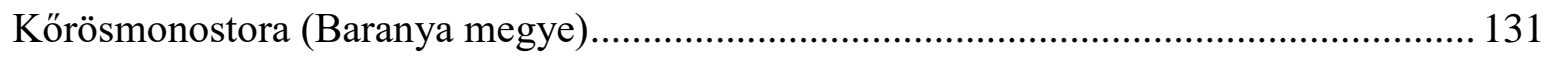

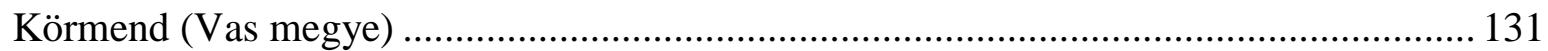

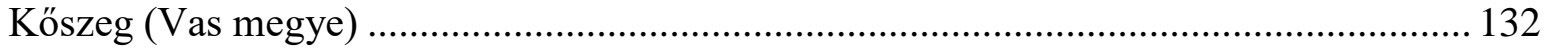

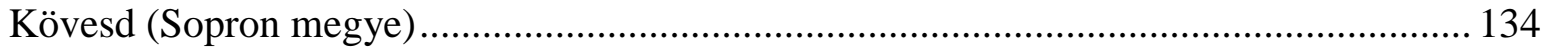

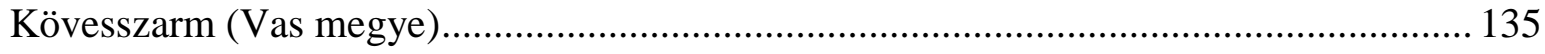




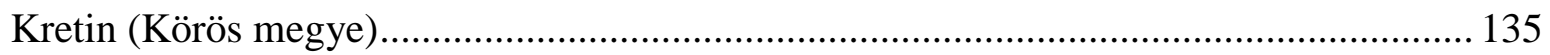

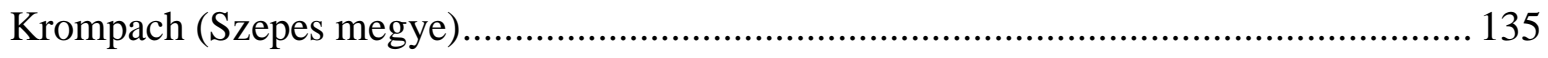

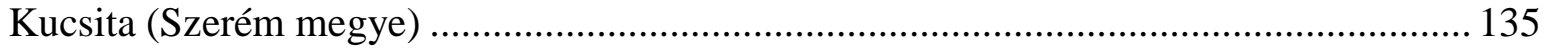

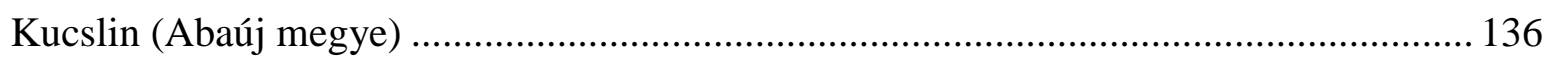

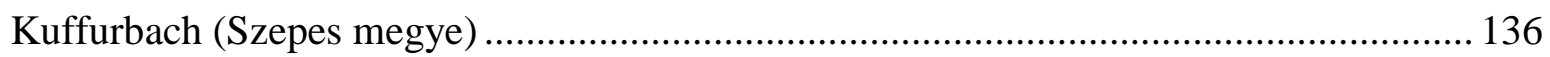

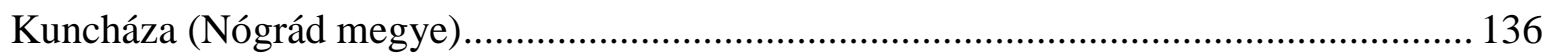

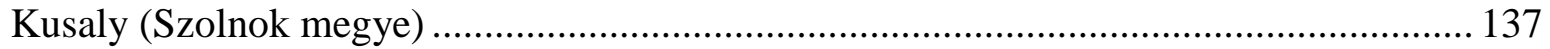

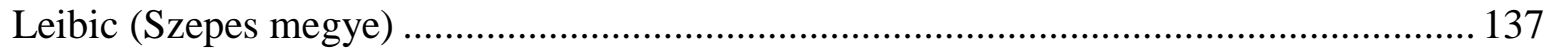

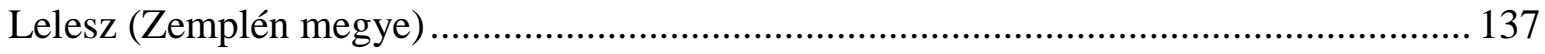

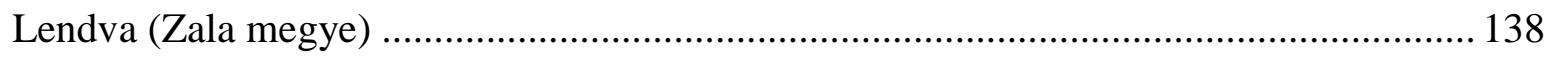

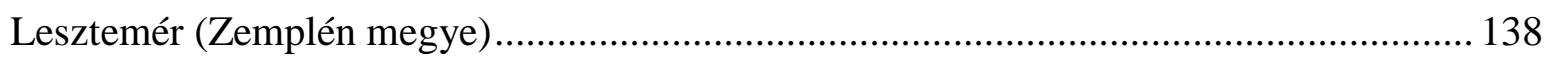

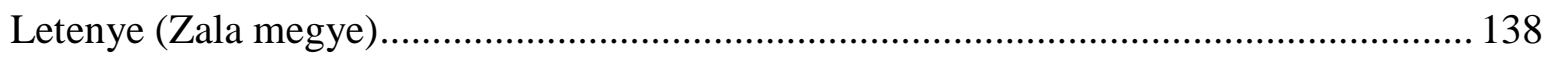

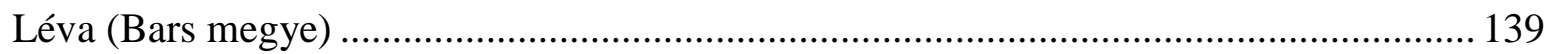

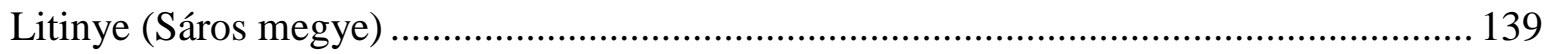

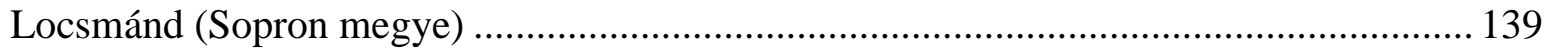

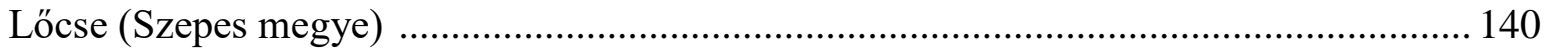

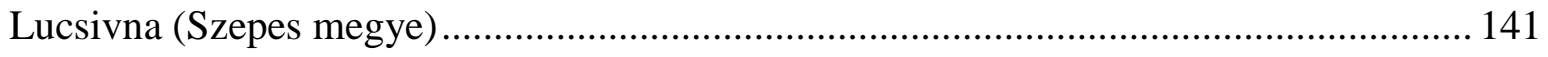

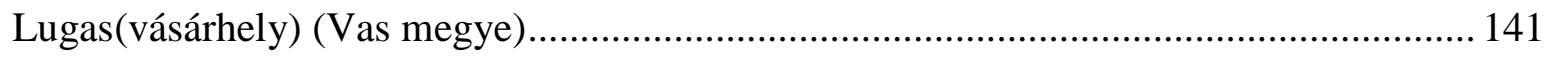

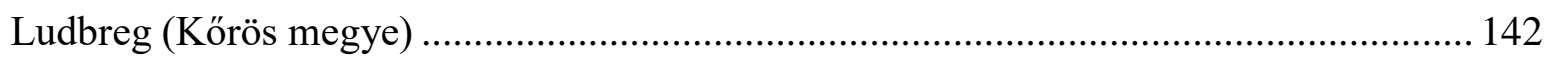

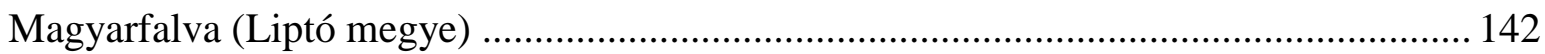

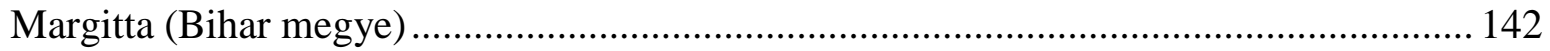

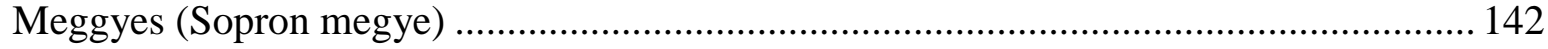

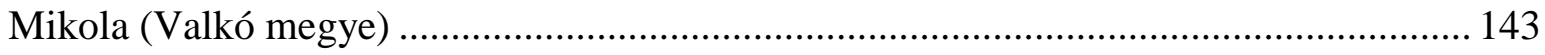

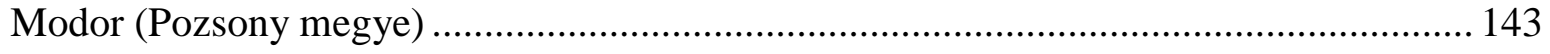

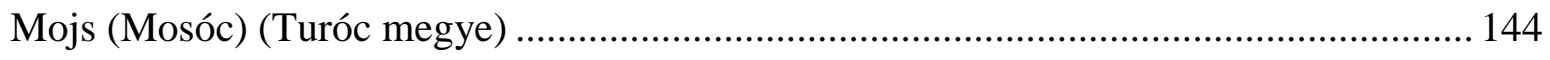

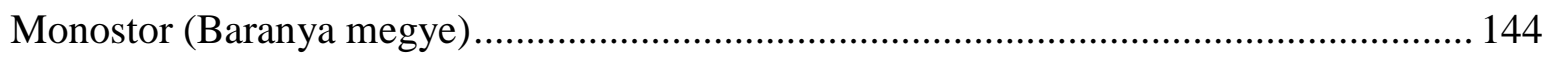

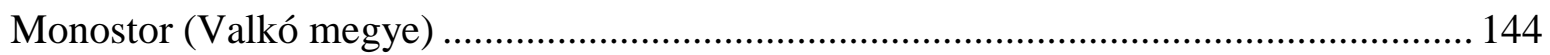

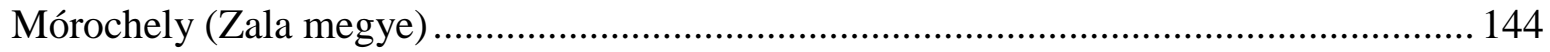

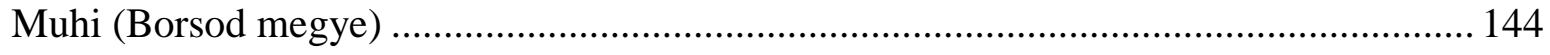

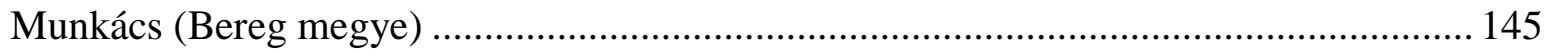

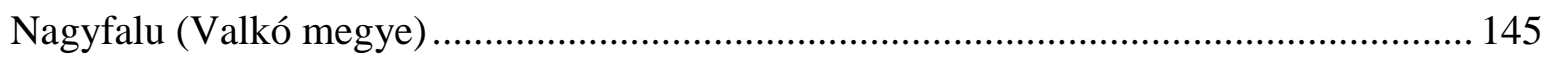

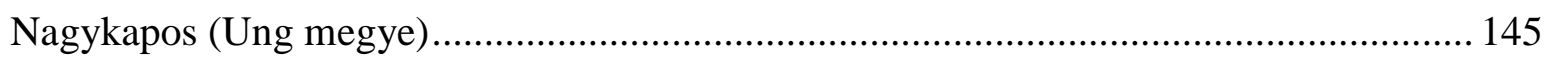

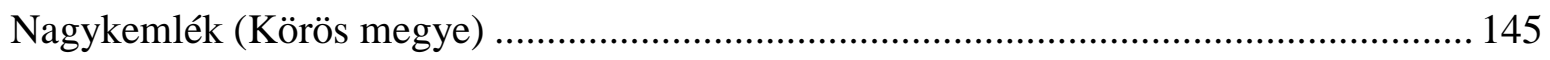

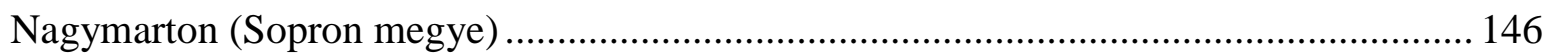

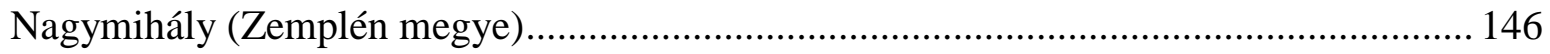

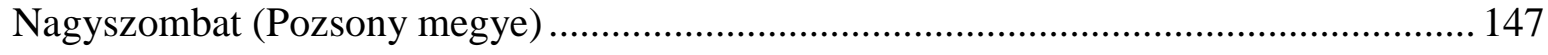

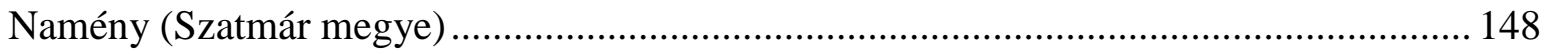




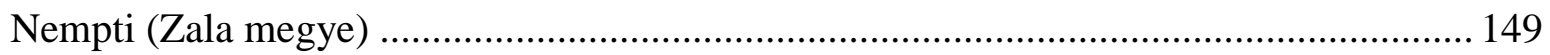

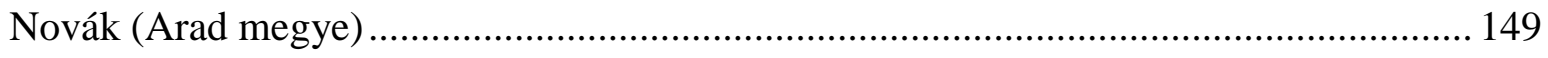

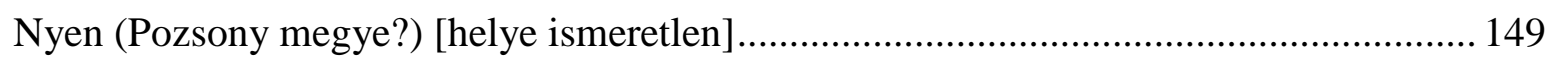

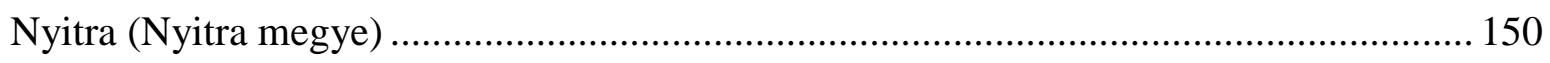

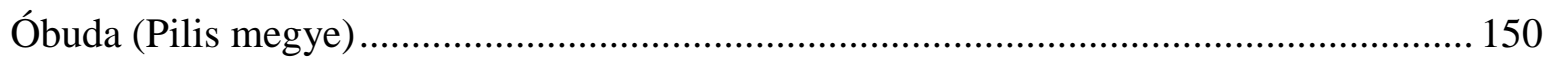

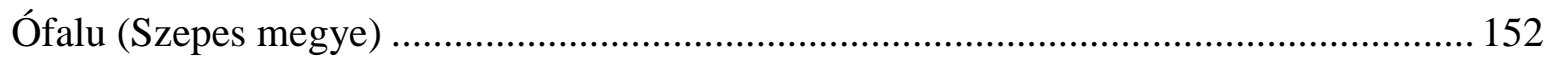

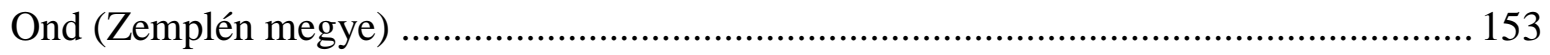

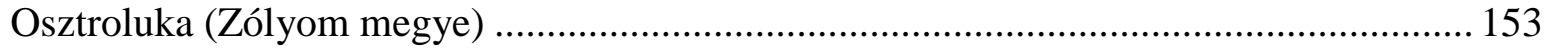

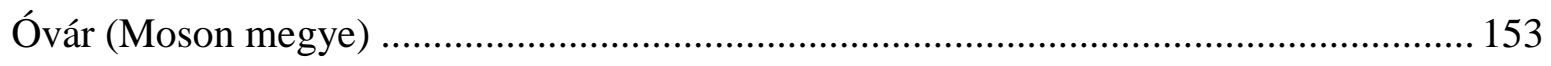

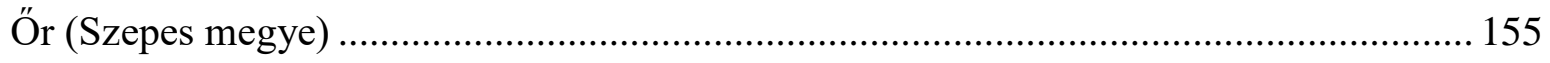

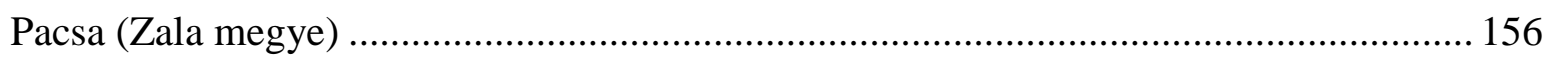

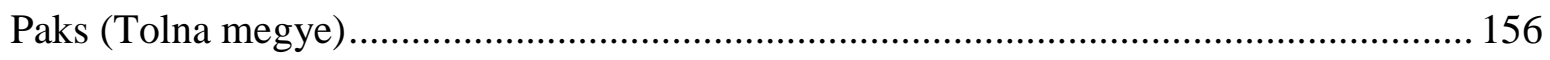

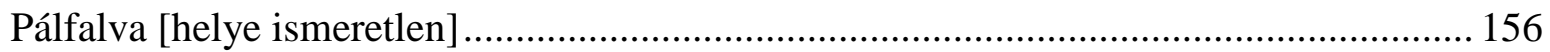

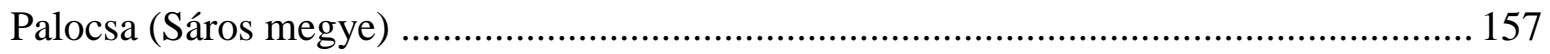

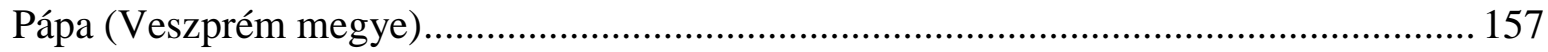

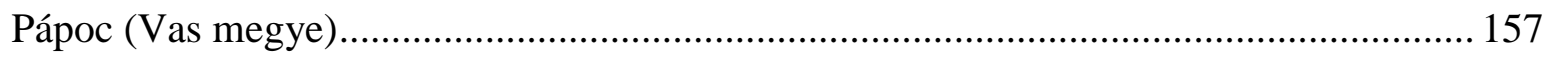

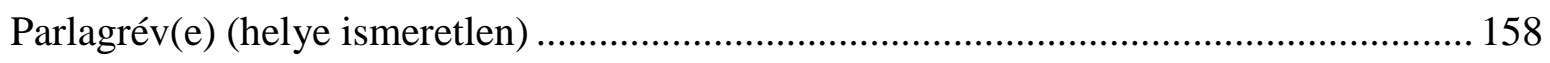

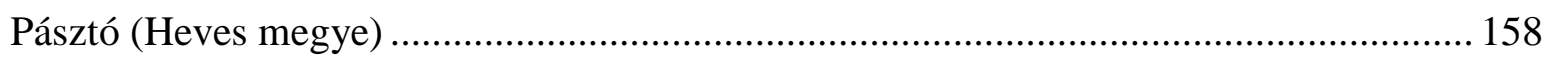

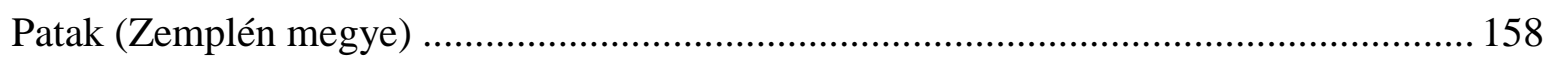

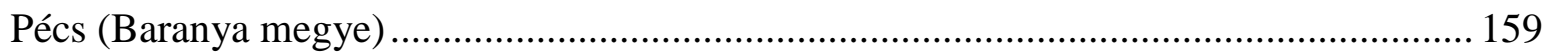

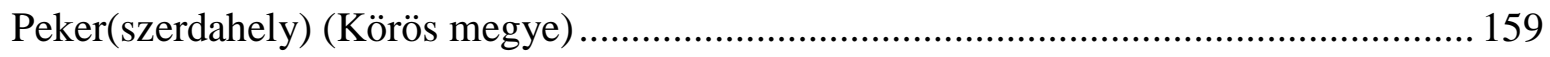

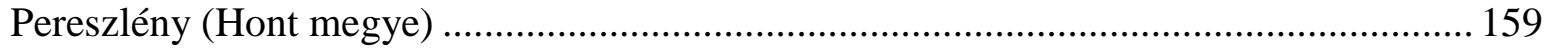

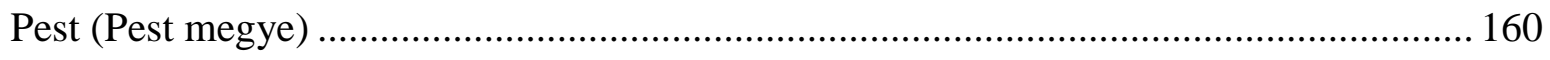

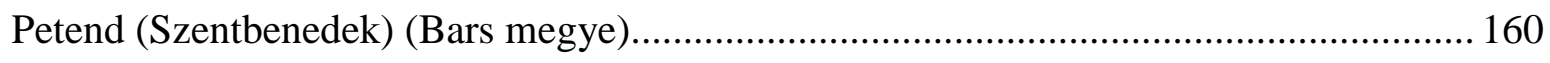

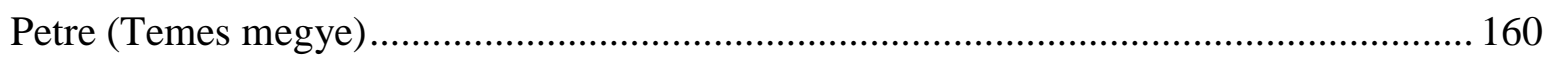

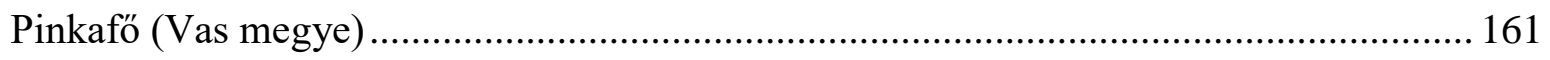

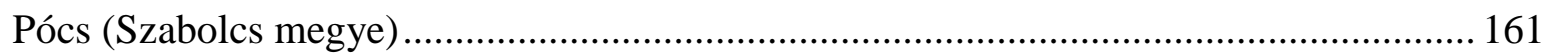

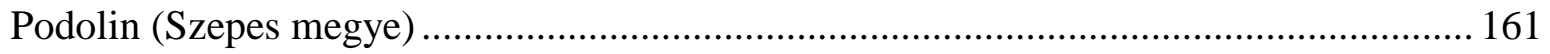

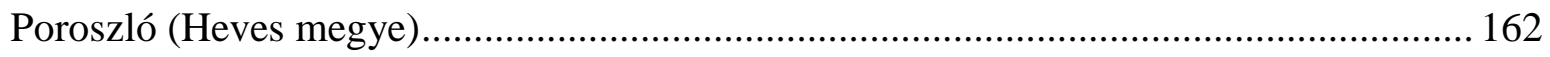

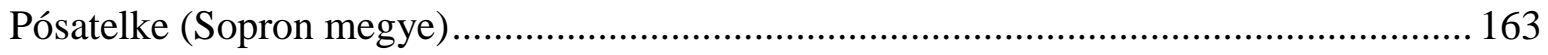

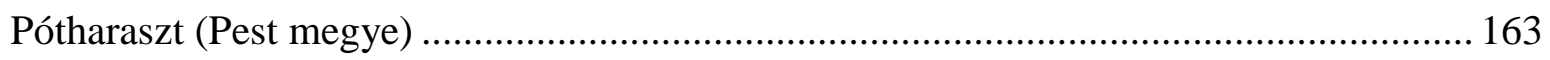

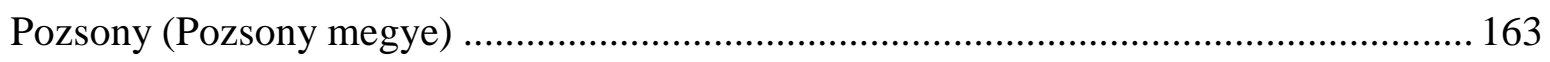

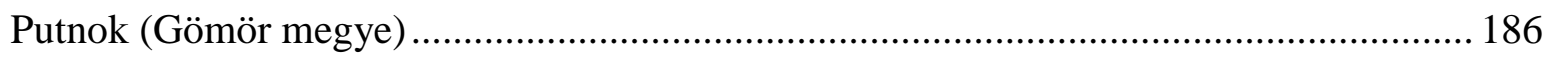

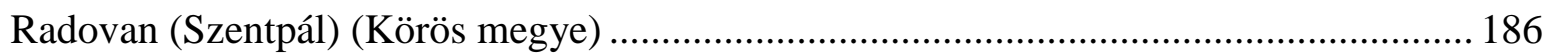

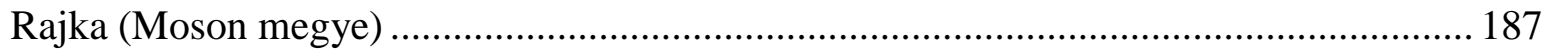

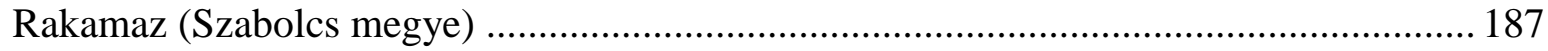

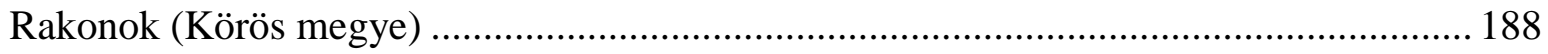




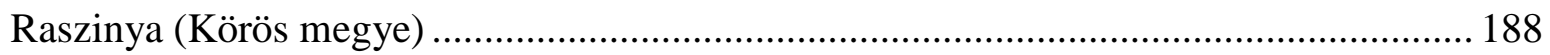

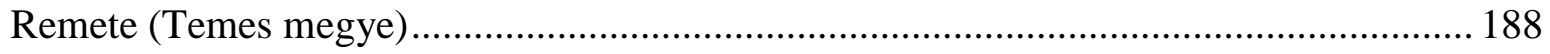

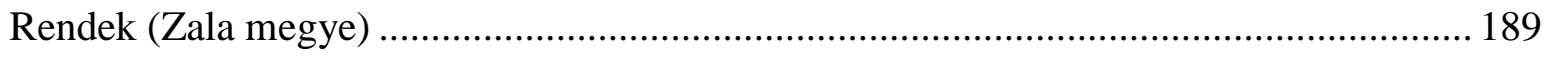

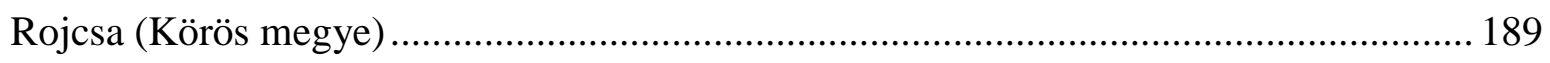

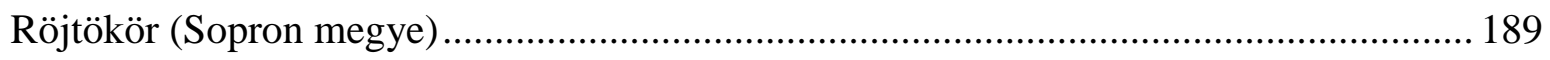

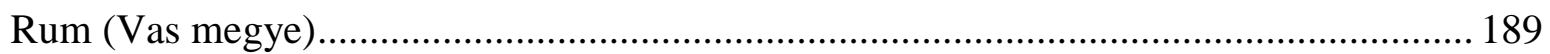

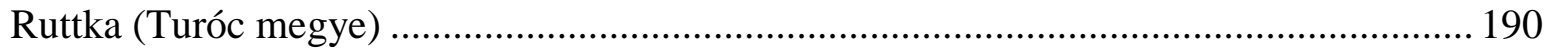

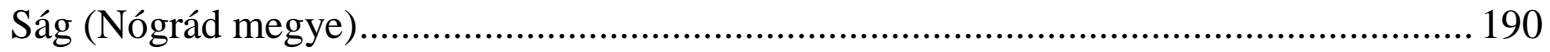

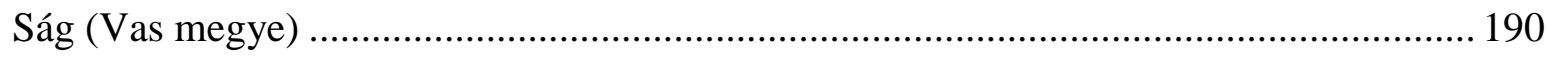

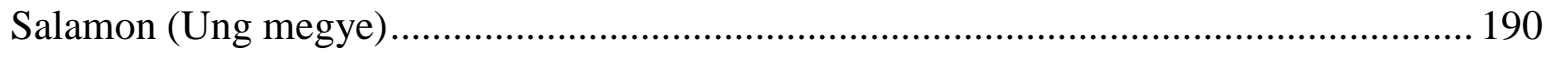

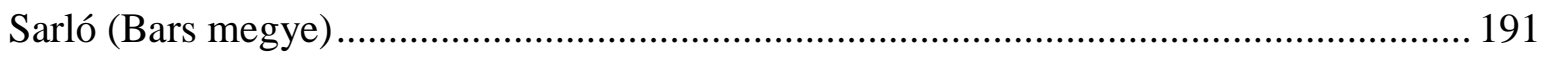

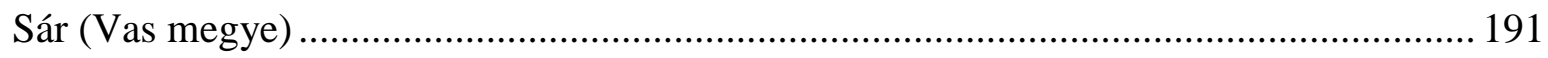

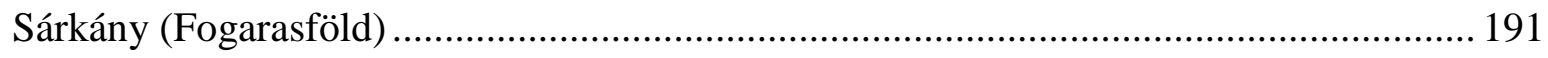

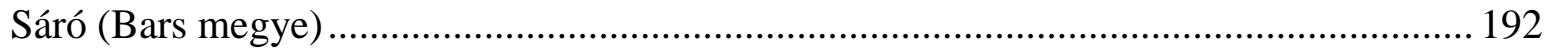

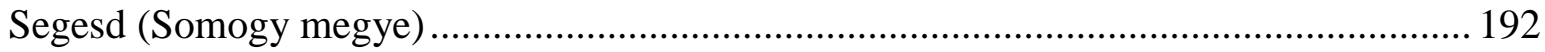

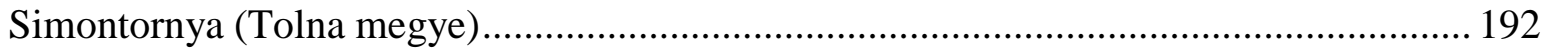

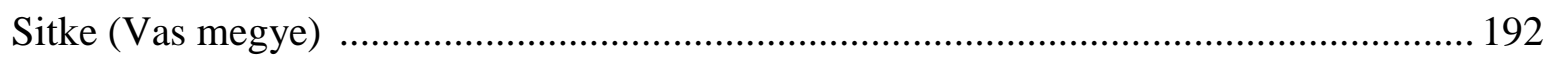

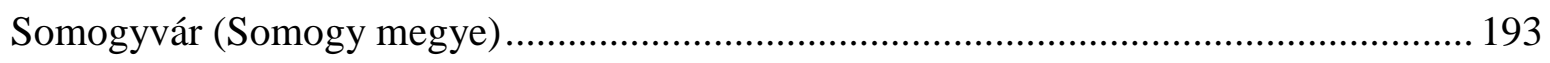

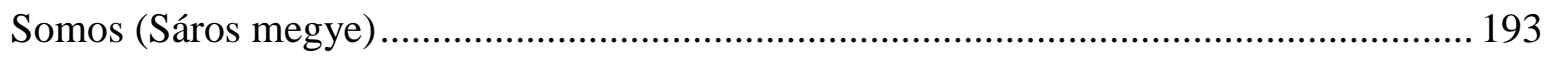

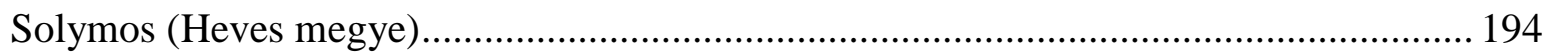

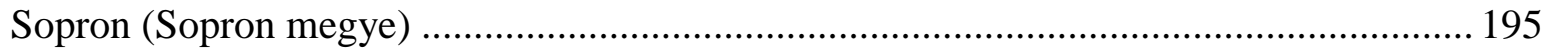

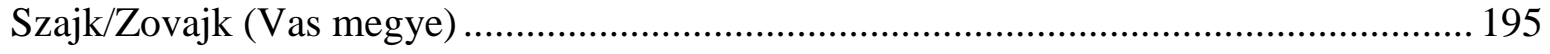

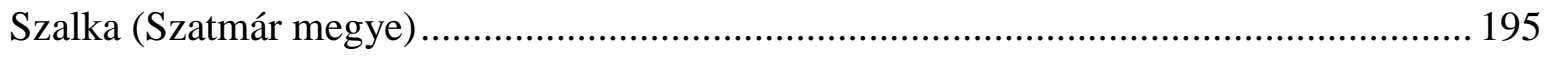

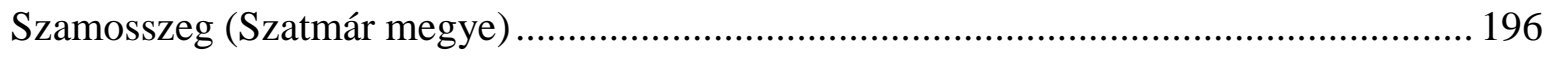

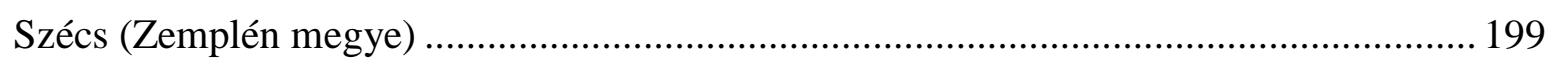

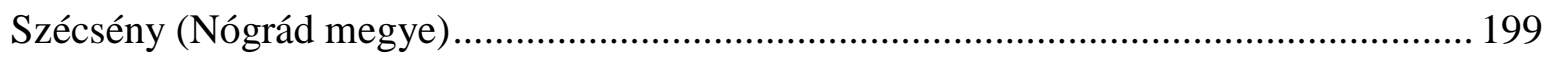

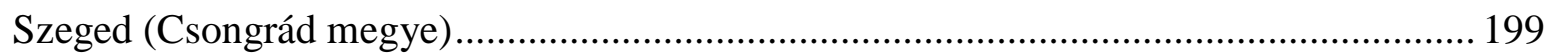

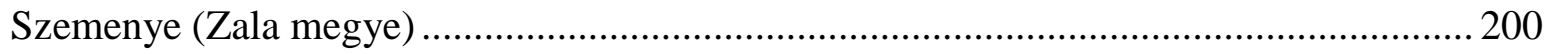

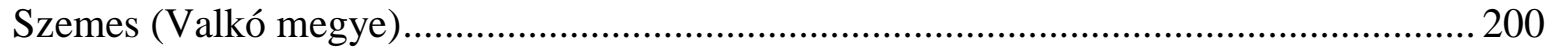

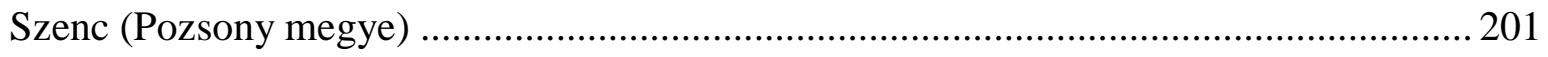

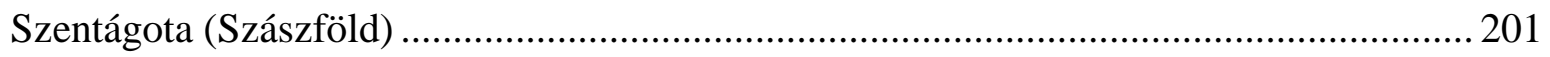

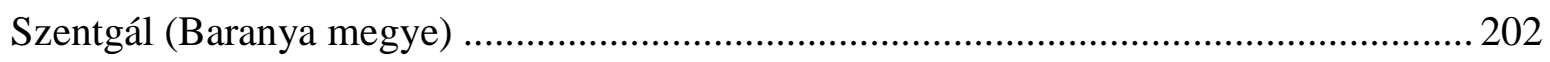

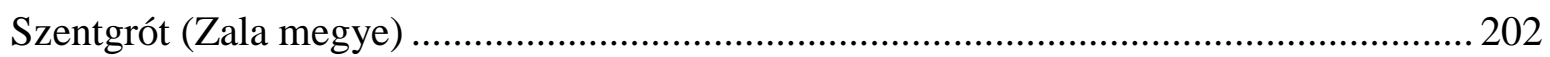

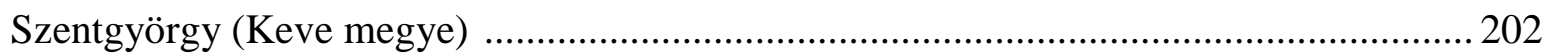

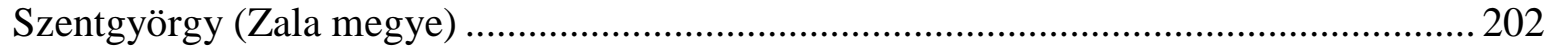

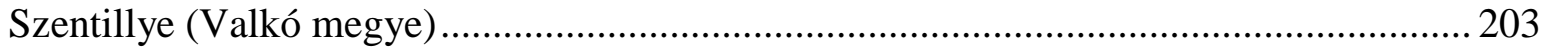

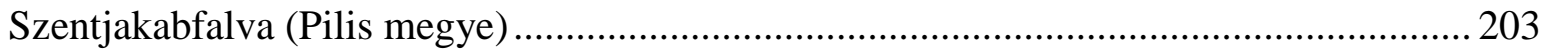




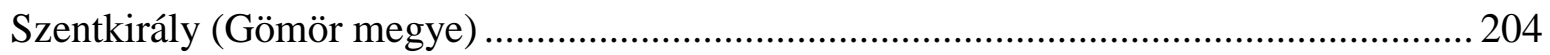

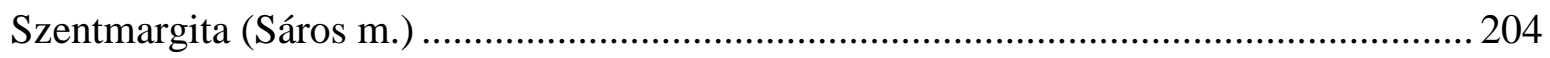

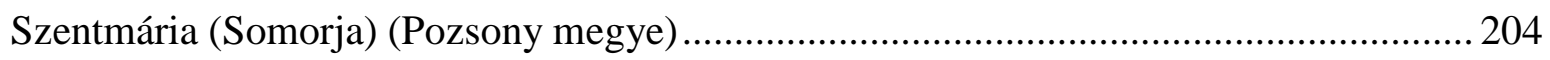

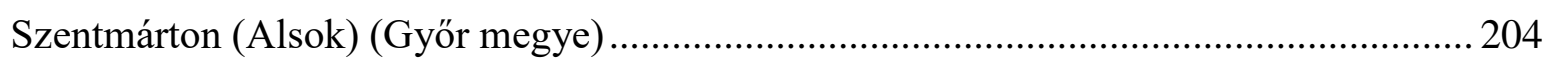

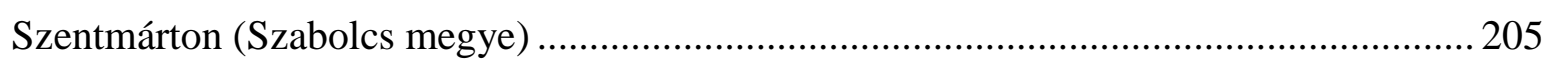

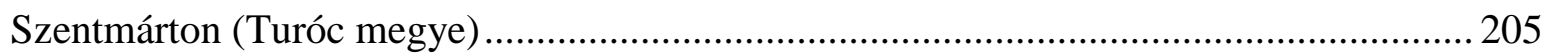

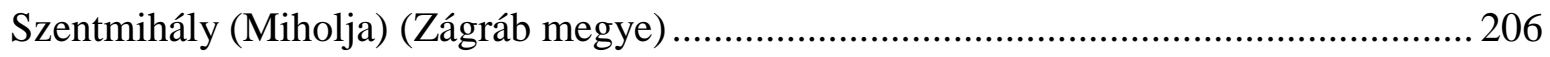

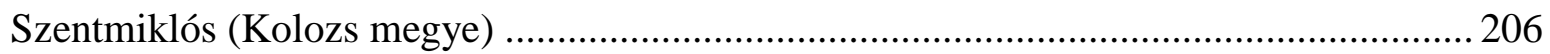

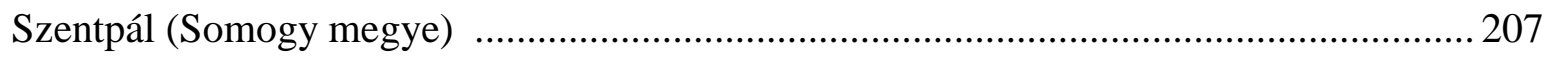

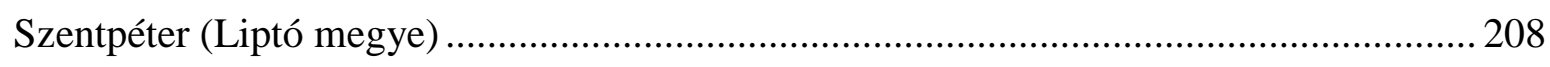

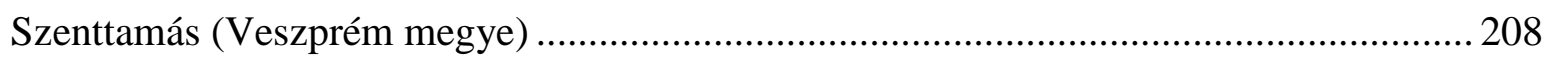

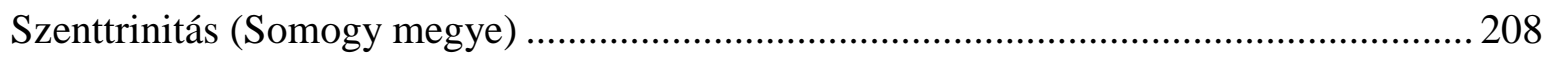

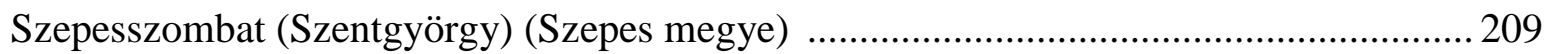

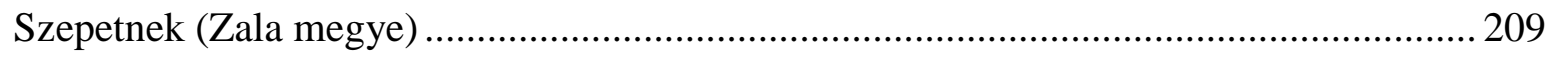

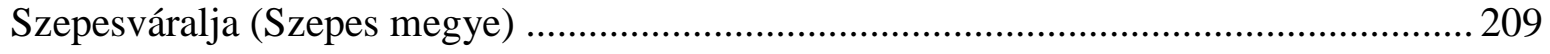

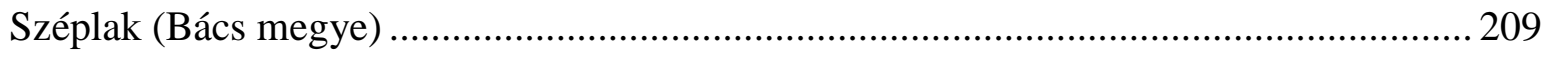

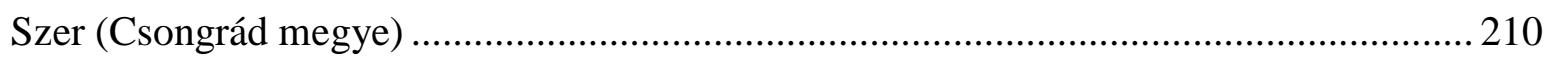

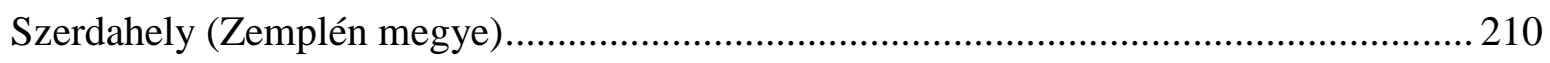

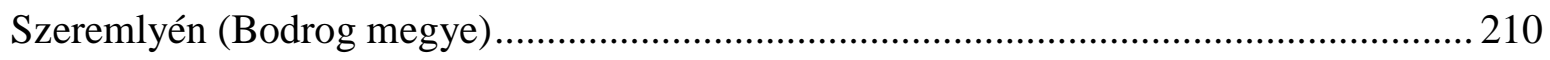

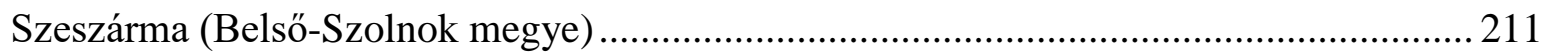

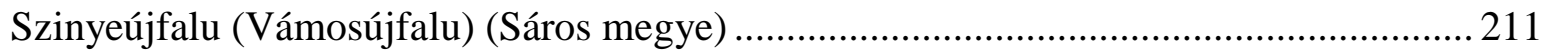

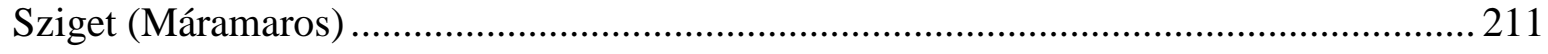

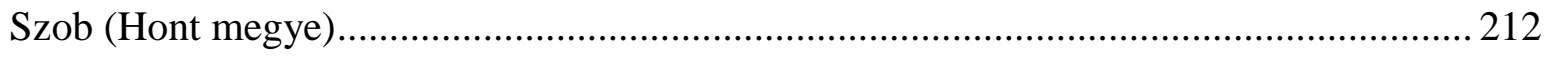

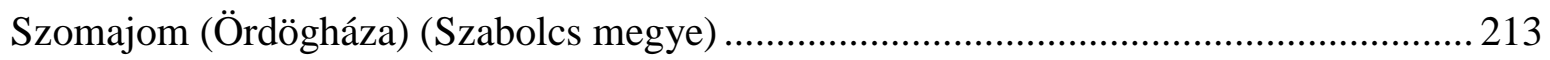

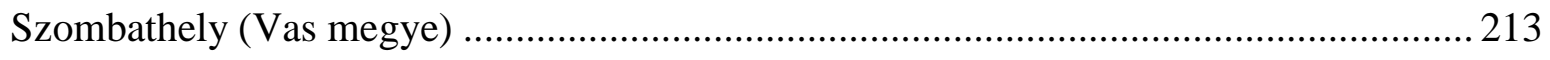

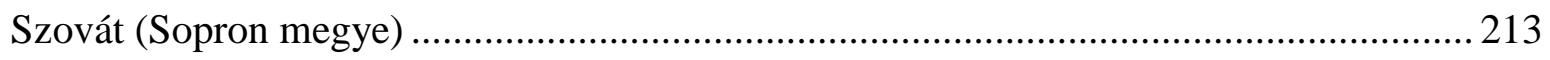

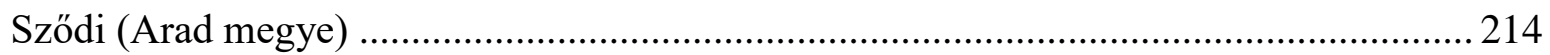

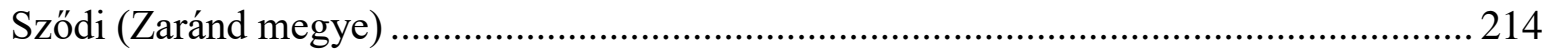

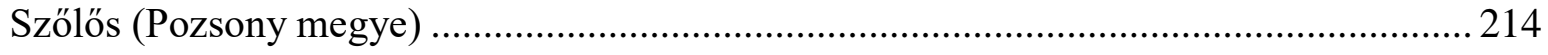

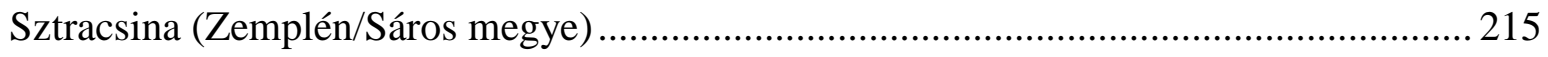

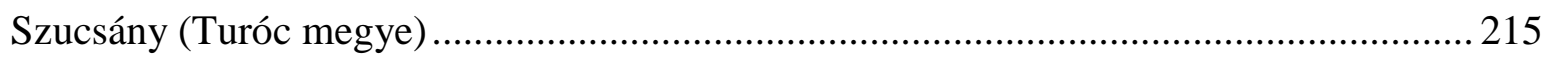

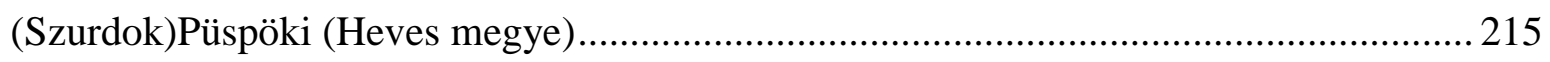

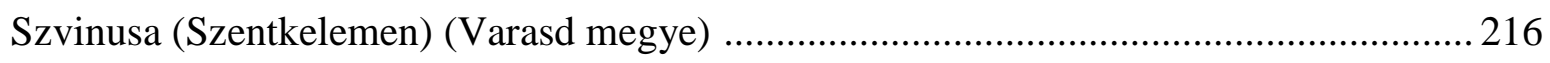

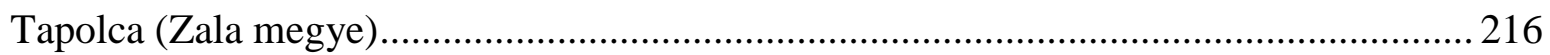

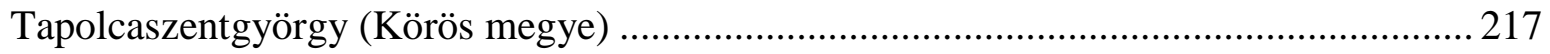

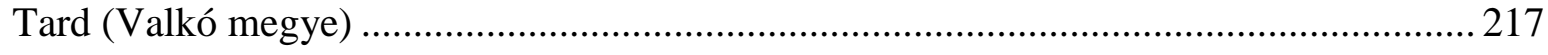

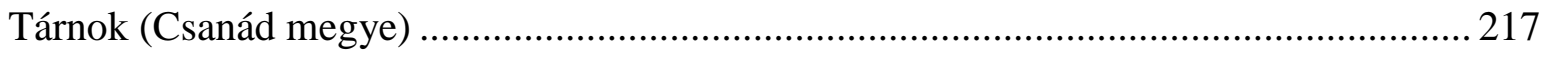




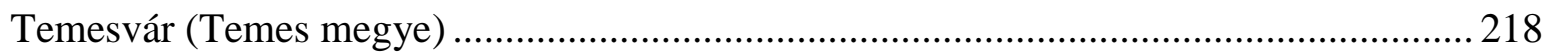

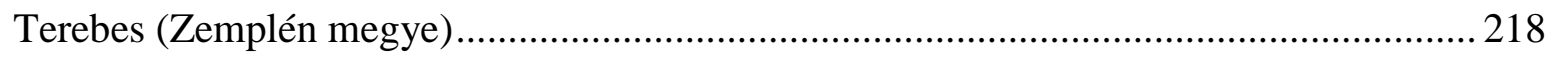

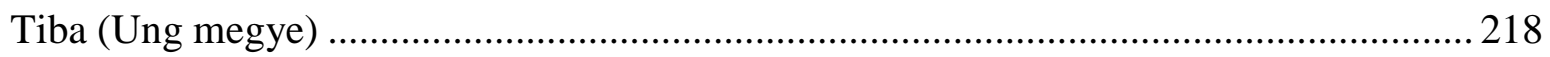

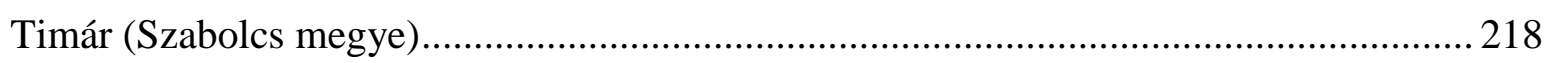

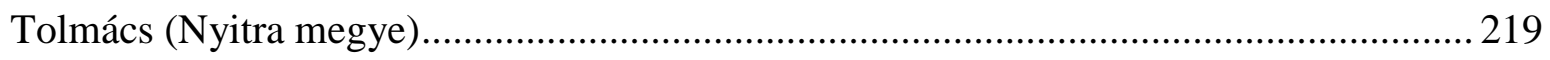

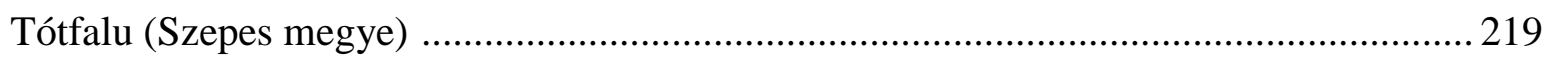

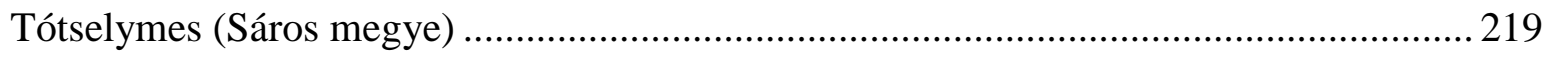

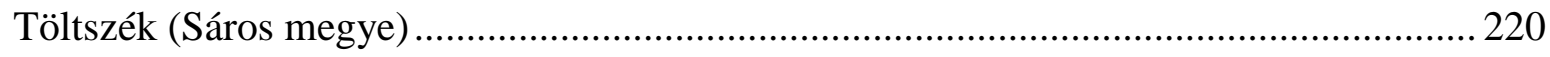

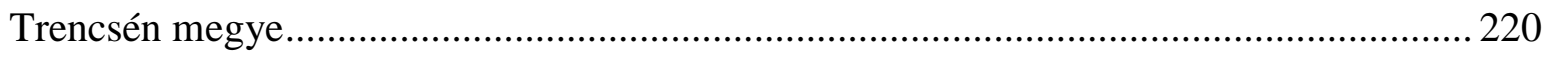

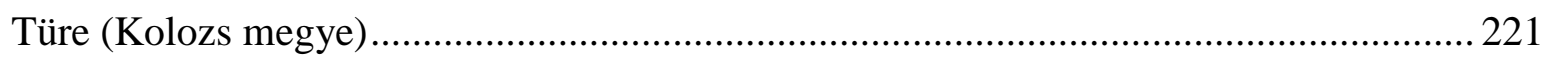

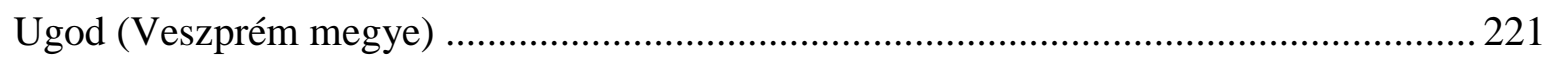

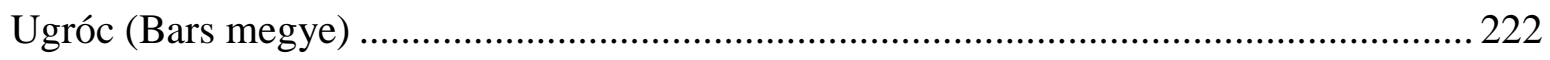

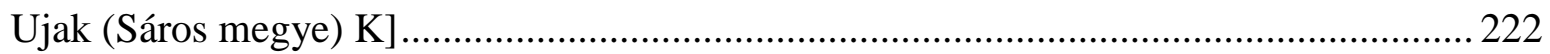

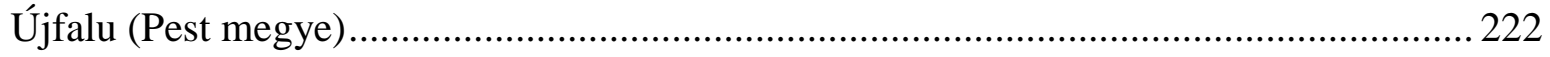

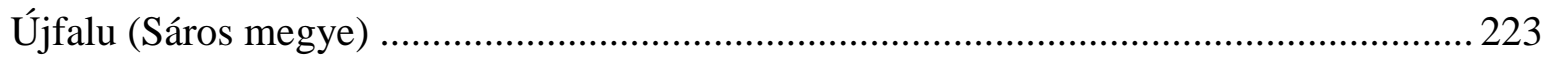

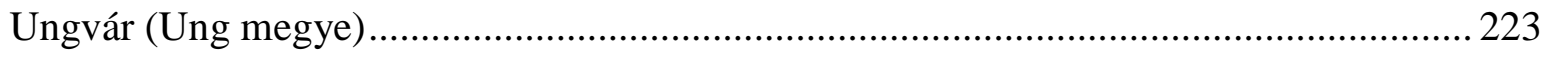

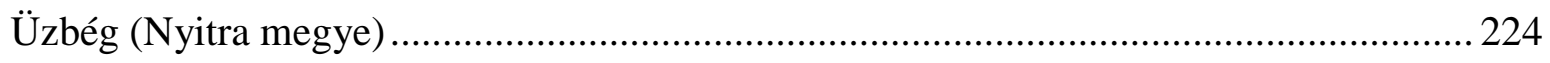

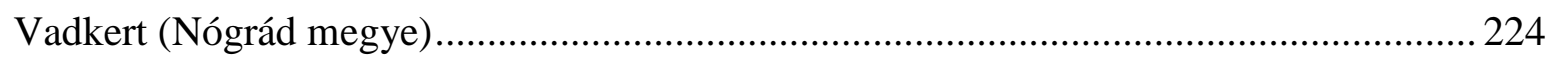

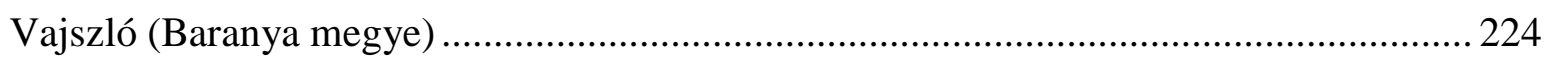

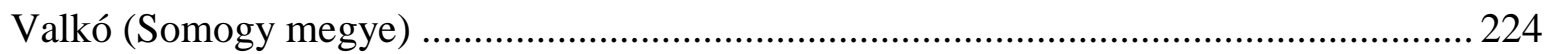

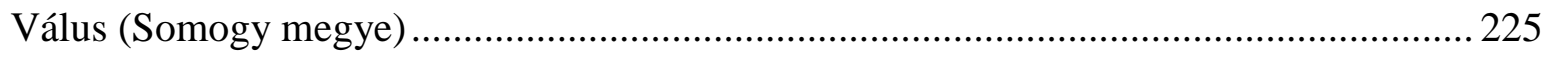

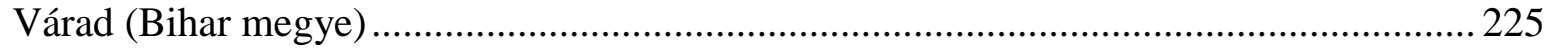

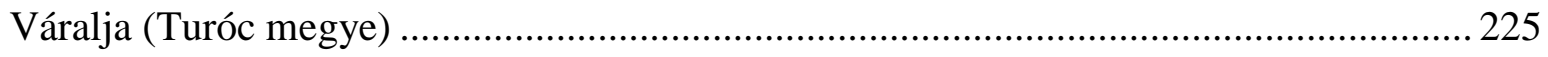

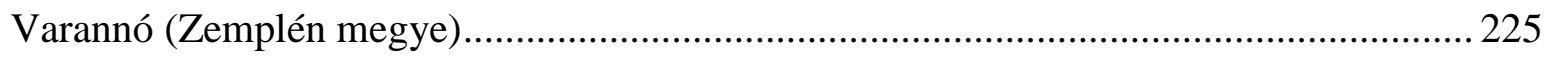

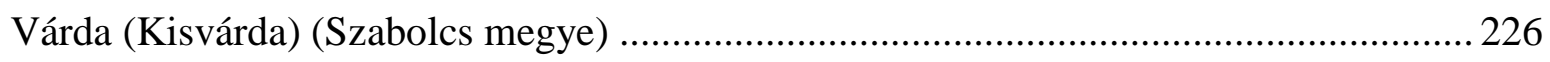

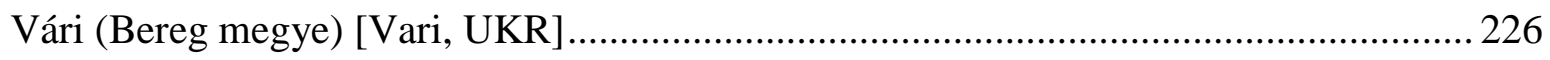

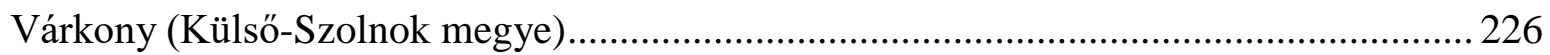

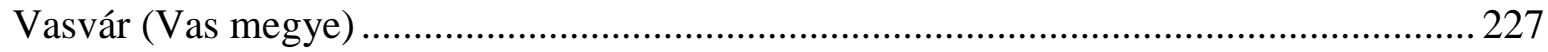

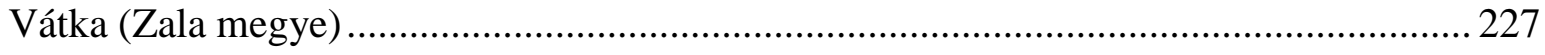

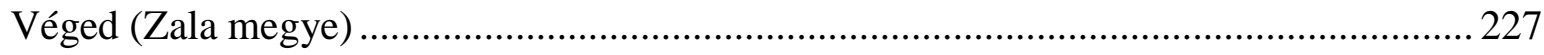

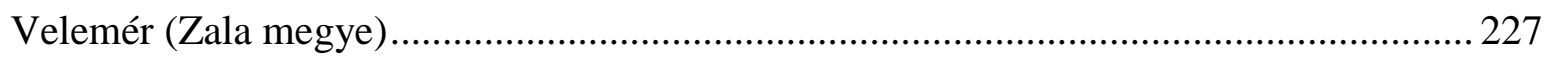

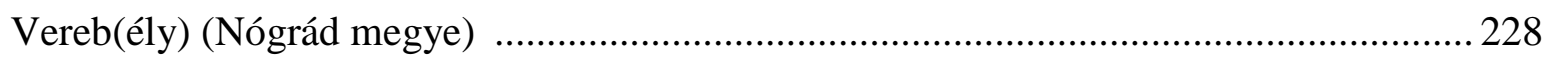

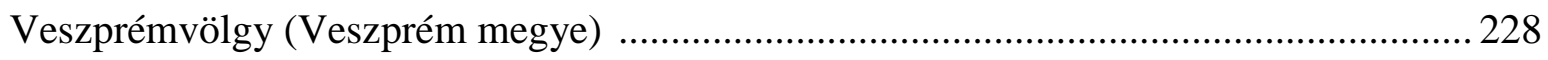

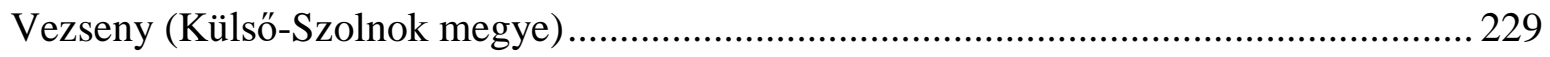

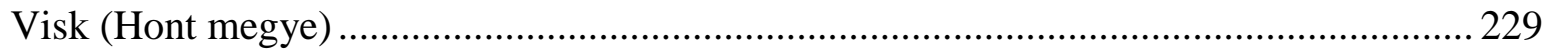

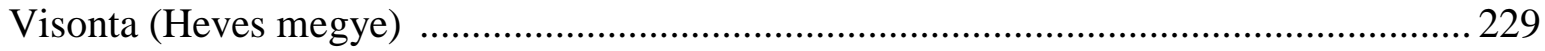

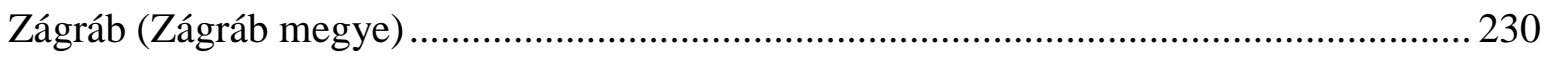




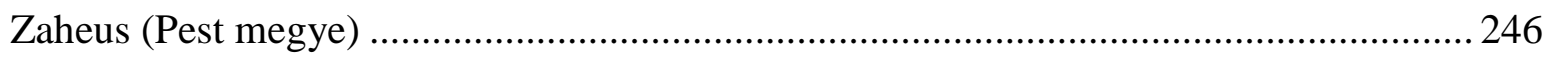

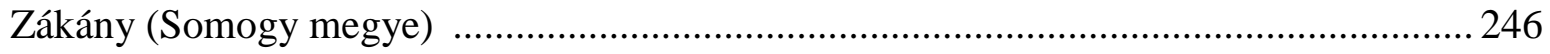

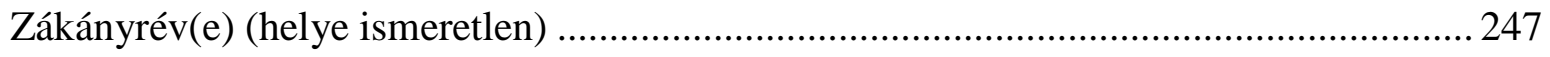

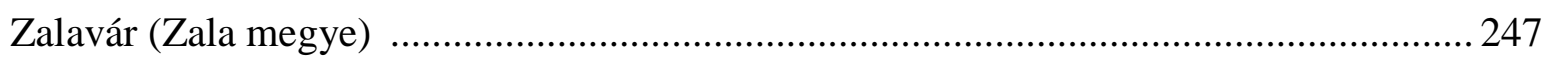

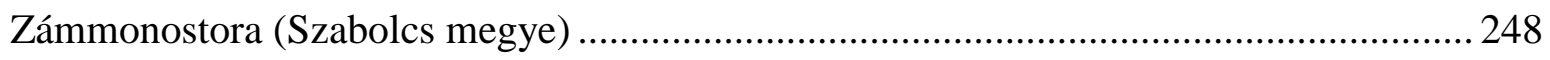

Zazárbánya (Nagybánya/Asszonypataka) (Szatmár megye) ............................................. 248

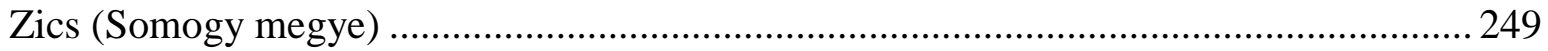

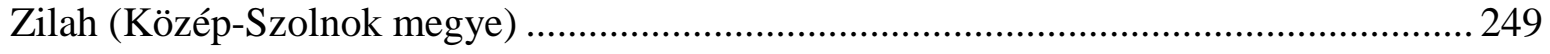

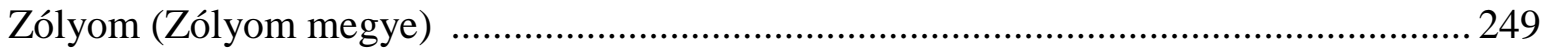

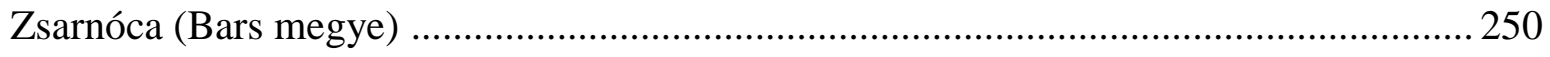

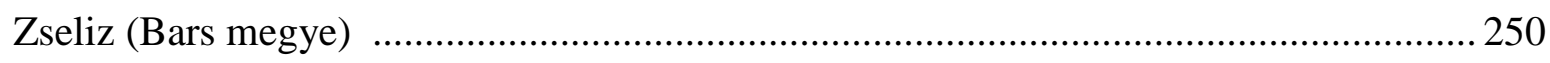

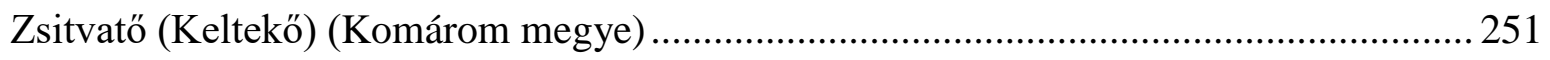

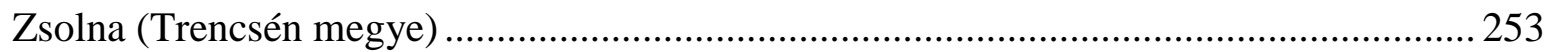

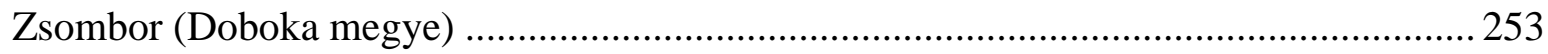

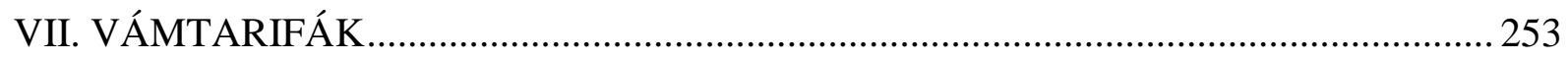

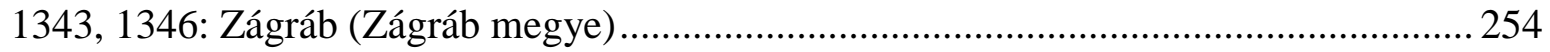

1343: Bihar (Bihar megye) - révvám............................................................................ 256

1350: Bény (Pozsony megye), Bikszárd (Pozsony megye), Farkashida (Pozsony megye), Szentjakabfalva (Pilis megye), Sasvár (Nyitra megye), Sempte (Nyitra megye), Szenic (Nyitra megye), Nyárhíd (Nyitra megye), Udvard (Komárom megye) - csökkentett közlekedési vám, Nyárhídon hídvám ............................................................................... 256

1350: Jablonca (Nyitra megye) - csökkentett hídvám ................................................... 257

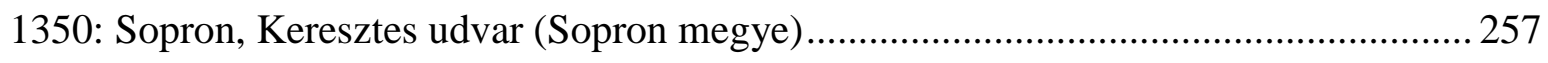

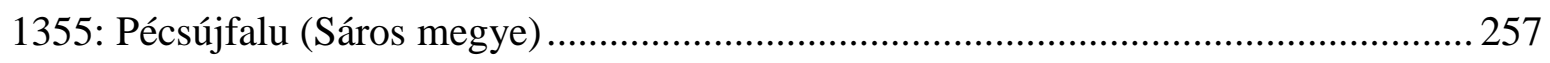

1366: Rajka (Moson megye), Győr (Győr megye), Komárom (Komárom megye), Zsitvatő (Komárom megye), Esztergom (Esztergom megye), Szob (Hont megye), Visegrád (Pilis megye), Óbuda (Pilis megye) - dunai vámtarifa............................................................. 259

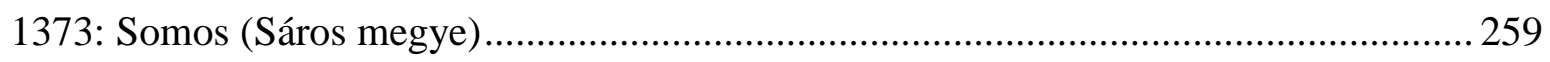

1379: kolozsváriak csökkentett vámtarifája (fél vám) a Drági nemesek vámjain ............. 260

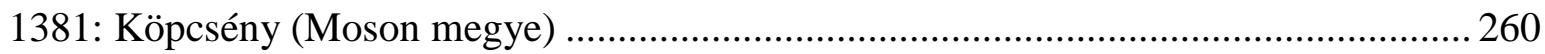

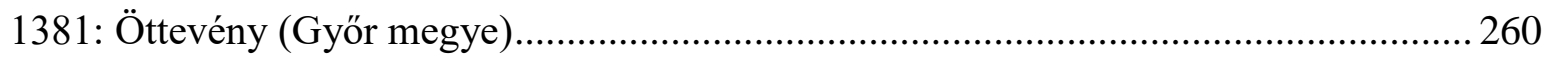

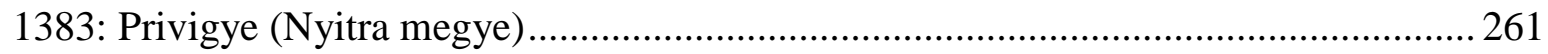

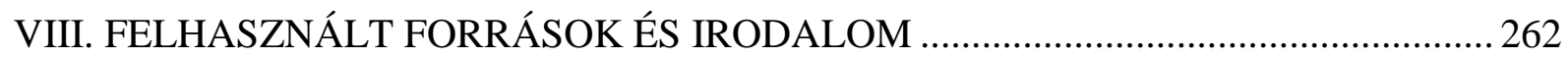




\section{KÖSZÖNETNYILVÁNÍTÁS}

E helyütt szeretnék köszönetet mondani minden kollégának és barátnak, akik hozzájárultak jelen dolgozat elkészültéhez.

Név szerint közülük elsőként témavezetőmet, Weisz Boglárkát illeti köszönet, akinek a révén 2015 és 2018 szeptembere között tudományos segédmunkatársként a Magyar Tudományos Akadémia Bölcsészettudományi Kutatóközpont (MTA BTK) „Lendület” Középkori Magyar Gazdaságtörténet Kutatócsoport munkájában is részt vehettem. Ennek köszönhetően elsősorban az MTA BTK Történettudományi Intézete (TTI) Középkori Osztályának kutatóival - Bácsatyai Dániel, Csákó Judit, Csukovits Enikő, E. Kovács Péter, Horváth Richárd, Kádas István, Neumann Tibor, Nógrády Árpád, Pálosfalvi Tamás, Péterfy Bence, Skorka Renáta, Szentpéteri József, Teke Zsuzsa, Tringli István és Zsoldos Attila - és a TTI könyvtárosaival - Adamecz Szilvia és Lehoczky Viktória - egy kivételesen értékes, szakmailag és emberileg is inspiráló közösségben volt szerencsém létezni és dolgozni.

Ugyancsak köszönettel és hálával vagyok adósa Karlinszky Balázsnak és Varga Tibornak (Veszprémi Főegyházmegyei Levéltár), Szende Katalinnak és Szilágyi Magdolnának (Magyar Várostörténeti Atlasz Projekt), továbbá Arany Krisztinának, Laczlavik Györgynek és Rácz Györgynek (Magyar Nemzeti Levéltár Országos Levéltára) az irányomban megnyilvánuló bizalmukért és segítségükért.

Ezúton is szeretnék köszönetet mondani Draskóczy István és Petrovics István előopponenseknek a dolgozat mühelyvitájára elkészített konstruktív bírálataikért, továbbá a mühelyvita résztvevőinek előremutató kritikáikért, észrevételeikért.

Köszönettel tartozom a Szegedi Tudományegyetem, Bölcsészettudományi Kar, Történettudományi Doktori Iskola, Medievisztika PhD-programjának, amiért 2013-2016. között teljes doktori ösztöndíj biztosításával lehetővé tette számomra a doktori képzés elvégzését.

Végül köszönöm nektek, Győrfy Eszter, Maléth Ágnes, Simon Anita és Takács Melinda, kitartó támogatásotokat. 


\section{BEVEZETÉS}

Jelen munkát megalapozó kutatásaim célja eredetileg a késő Anjou- és a kora Zsigmondkor (értve itt az 1387-től 1405-ig tartó időszakot) vámjaira és vámszedésére vonatkozó, alapvetően okleveles adatok összegyüjtésében állt - Dalmáciát kivéve a középkori Magyar Királyság egész területéről. Az összegyüjtött adatokból egyrészt egy vámszedőhely-kataszter létrehozását, másrészt a korabeli vámszedés sajátosságainak leírását, rendszerezését terveztem.

A munkába 2013 táján doktori témavezetőm, Weisz Boglárka Árpád-kori vámkatasztere folytatásának szándékával kezdtem bele. Ő akkoriban az adattárába már javában a Károlykori adatokat dolgozta be (munkája hamarosan meg is jelent a Királyketteje és az ispán harmada. Vámok és vámszedés Magyarországon a középkor első felében ${ }^{1}$ [a fejezet további részében: vámkönyv] címmel), így a vállalkozást Lajos, Mária és Zsigmond korát illetően szerettem volna továbbvinni. A kutatómunkát nagyban megkönnyítette, hogy támaszkodhattam a vámkönyv eredményeire, amiben Weisz Boglárka az Árpád- és a Károlykori vámszedés intézményének szervesen müködő rendszerét rekonstruálta. Jelen disszertáció formailag a vámkönyvben kidolgozott szerkesztési elveket követi, és megközelítőleg azonos szerkezeti egységekből épül fel: egy előtanulmány jellegü, tematikusan tagolt, hosszabb bevezetéssel kezdődik a témával kapcsolatos alapvető fogalmakról, kérdésekről, jelenségekről, amit a legnagyobb lélegzetű fejezet követ a vizsgált időszak vámszedőhelykataszterével és az egyes vámszedőhelyek történetével. Szintén tartalmaz egy rövidebb adattárat a korszakból - általam - ismert vámszabályzatokkal, amiket táblázatos formában, magyar fordításban közöltem. A munkát a felhasznált források és szakirodalmak jegyzéke zárja. Habár alapvetően alapkutatást végeztem, nagyban támaszkodtam a korábbi kutatások eredményeire, adataira is; a historiográfiai előzményeket külön alfejezetben (Kutatástörténeti áttekintés c.) foglaltam össze. A téma tágabb irodalmából - a település- és családtörténeti munkákból, a történeti földrajzi adattárakból és feldolgozásokból (Györffy György és Csánki Dezső elszórtan Lajos- és Zsigmond-kori adatokat is tartalmazó sorozatai, ${ }^{2}$ Engel Pál digitális birtoktörténeti térképéhez tartozó, nem publikált település-adatbázisa ${ }^{3}$ és az egy-egy megyére vonatkozó, hasonló munkák) - kinyerhető adatok felgyűjjtése munkám jelen állapotában nem teljes.

\footnotetext{
${ }^{1}$ Weisz B.: Vámok és vámszedés.

${ }^{2}$ Gy.; Csánki.

${ }^{3}$ Engellex.
} 
A kutatás számomra erősen optimistának bizonyult célkitűzése az volt, hogy az adattári gyüjtés és feldolgozás a Magyar Királyság egész területét illető, 1342 és 1405 között keletkezett teljes okleveles anyagot lefedje - a kiadott és a kiadatlan anyagot egyaránt. (Söt, eleinte még a kutatás esetleges kiterjesztésének is fenntartottam a lehetőségét a Zsigmond-kor végéig, 1437-ig.) A vámtörténet tekintetében a kutatás tervezett időbeli végpontja, az 1405-ös év korszakhatárnak tekinthetö. Luxemburgi Zsigmond 1405. április 15-én kiadott városi dekrétumának 17. cikkelye egyértelmüen kimondta, hogy a harmincadvámot az országból kivitt áruk után éppúgy meg kell fizetni, mint az országba behozottak esetében: ezzel a harmincad deklaráltan általános (a kivitelre és a behozatalra egyaránt kiterjedö) külkereskedelmi vámmá vált. A rendelkezéssel pont került annak az 1340-es évektől adatolható vitának a végére, amelynek során a harmicadfizetésre kötelezett kereskedők újra és újra kétségbe vonták az uralkodó (harmincadszedői) által követelt, az országból kivitt áruk után fizetendő tricesima jogszerüségét. ${ }^{4}$ Ugyanakkor a kereskedők számára a belvámok alól vámmentességet biztosított az uralkodó a tricesima fizetéséből származó káruk enyhítésére, és a következő években (1405-1419) több város is kérte a dekrétum e pontjára hivatkozva a vámmentességi privilégium kibocsátását. ${ }^{5}$

A kutatómunka az egyik oldalról az okmány- és regesztatárak, valamint a különálló oklevélközlések, a másik részről a DL-DF adatbázis átfésülését jelentette. A merítésbe nem vettem bele az Országos Levéltár mikrofilmtárában feltalálható hungarikákat. Az oklevéltermés ebben az időszakban nagyjából 1000 oklevél/év, és nem-igazán lehet különböző szempontok alapján adott oklevélcsoportokat kizárni, amikben ne lehetne valamilyen vámokra, vásárokra, hidakra, révekre, gázlókra, kikötőkre, illetve vámmentességet élvező személyekre, közösségekre és intézményekre vonatkozó adat. Ezeket ugyanis hasonlóan a vámkönyvhöz - mind belevontam a gyüjtőkörbe. Az I. Lajos uralkodásának első felében keletkezett okleveles anyag feldolgozását megkönnyíti, hogy az Anjou-kor csaknem három évtizede folyó diplomatikai feltárása napjainkra jócskán túljutott Károly Róbert regnálásának évein. A korszak okleveles forráshagyatékának teljes körü tudományos feldolgozását célul kitűző vállalkozás, az Anjou-kori oklevéltár ${ }^{6}$ 2007-ben megjelent XXVI. kötetében már az 1342-es évben kibocsátott oklevelek tartalmi kivonatait közölte. 2013-ban, a kutatómunka kezdetekor még csak az 1343-as, 1344-es és 1347-es kötetek voltak forgathatók. A sorozatban azóta újabb és újabb Lajos-kori évek regesztái láttak napvilágot (1345-46.,

\footnotetext{
${ }^{4}$ Pach Zs. P.: A harmincadvám az Anjou-korban passim.

${ }^{5}$ Vö. Weisz B.: Debrecen 139-141.

${ }^{6}$ Anjou-oklt.
} 
1348-54., 1356, 1358, 1362-64.). (A régebbi, Anjoukori Okmánytár címmel kiadott forráskiadvány-sorozat nem jutott el 1360-ig: utolsó, 1920-ban megjelent hetedik kötete 1359 tavaszáig közölt - a formulás részek kihagyásával, de gyakorlatilag teljes terjedelemben forrásokat.) ${ }^{7}$ Mindez alig árnyalja a tényt, hogy a Nagy Lajos kori okleveles anyag jelentős része kiadatlan. A korszakra vonatkozó, 1945-től 1990-ig Magyarországon nyomtatásban megjelent forráspublikációk kiadási helyeit Draskóczy István és Soós István folyóiratmélységig regisztrálta Középkori oklevél-publikációk Magyarországon: 1945-1990 cím alatt. ${ }^{8}$ Az oklevélközléseket felsoroló bibliográfiát másfél évtizeddel később Horváth Richárd folytatta, kiegészítve az 1991-2004 között kiadott oklevélszövegek kiadási helyeivel. $^{9}$ A Magyarországon megjelent oklevélközléseket összegyüjtő bibliográfiák mintájára W. Kovács András 2009-ben közreadta a Romániában 1920-2008 között nyomtatásban megjelent, magyar vonatkozású, 1542 előtt kiadott oklevelek kiadási helyeinek katalógusát. ${ }^{10} \mathrm{Az}$ elkészített jegyzéket nemrégiben kibővítette az összeállításból kimaradt oklevélközlésekkel, valamint kiegészítette a bibliográfia megjelenését követően közölt forráspublikációkkal. ${ }^{11}$ A Zsigmond-kor okleveles forrásainak tartalmi kivonatai a kutatás tervezett időbeli végpontjáig, 1405-ig megtalálhatók a Zsigmondkori oklevéltárban.

$\mathrm{Az}$ okleveles anyag megközelítésére és a teljességre törekvés igényével történő feldolgozására két út kínálkozott: az oklevélpublikációk és -regeszták, illetve a DL-DF adatbázis felől. Tetemes időráfordítás és néhány „súlyosabb” okmánytár átnézése, feldolgozása és a benne lévő iratok (akár tartalmaztak a kutatás szempontjából releváns adatot, akár nem) DL-DF számokkal való konkordálása után nyilvánvalóvá vált, hogy több időt vesz el annak az adiminisztrálása, hogy melyik oklevelet „vettem kézbe” és melyiket nem, mint a relevanciával bíró adatokat tartalmazó oklevelek komplett feldolgozása. Ezért egy idő után megfordítottam a megközelítést, ami „technikailag” úgy zajlott, hogy kronologikus oklevéllistákat exportáltam a Hungaricana (www.hungaricana.hu) közgyüjteményi portál levéltári adatbázisának A Középkori Magyarország Levéltári Forrásai nevet viselő felületéről havi bontásban, és gyakorlatilag elkezdtem végigolvasni a DL-DF adatbázis okleveleit abból a megfontolásból, hogy még mindig gyorsabb és hatékonyabb csak a kutatás szempontjából releváns adatokat tartalmazó oklevelekhez kiadást keresni, mint DL-

\footnotetext{
${ }^{7} \mathrm{AO}$.

${ }^{8}$ Draskóczy I. - Soós I.: Középkori oklevélpublikációk 1945-1990.

${ }^{9}$ Horváth R.: Középkori oklevelek publikálása 1991-2004.

${ }^{10}$ W. Kovács A.: Oklevélközlések Romániában.

${ }^{11}$ W. Kovács A.: Pótlások.
} 
DF számoknak megfeleltetni egy sor, a téma szempontjából teljesen felesleges, publikált oklevelet. Ezen a ponton a kutatás kronologikus határait már leszükítettem a Lajos-korra.

A vonatkozó okleveles források között találhatók perhalasztó oklevelek (vámperekben), vizsgálati oklevelek (hatalmaskodások), adásvételi vagy más contractusok, végrendeletek, ítéletlevelek, birtokosztályt rögzítő és/vagy határjáró oklevelek, adomány- vagy más kiváltságlevelek (például városprivilégiumok), illetve különféle parancslevelek. A források másképpen kategorizálva őket - különbözö tematikus csoportokra oszthatók: vannak közöttük vám/rév/vásárengedélyek (valamint áthelyezésüket, megszüntetésüket előíró rendelkezések), ezen kívül vámok/révek/hidak/vásárok müköd(tet)ésére (vám/harmincadszedési gyakorlat, vámmentességi kiváltságok „in situ” érvényesítése, vásári joghatóság, vásári kikiáltások, hidak/révek/utak fenntartása stb.) vonatkozó források, stb. Különösen értékes forrásaink a vámtarifák és a vámvizsgálatok/vámkatalógusok. Sajnos utóbbiak jobbára a Zsigmond-korban lefolytatott vámvizsgálatok révén maradtak ránk (például: Bars megye: 1424, ${ }^{12}$ Nógrád megye: $1405^{13}$ ), de azért a Lajos-korból is ismerünk néhányat: 1349-ben a Szécsi Miklós horvát-szlavón bán elrendelte szlavóniai vámhelyek revízióját, ${ }^{14}$ 1355-ben uralkodói parancsra a sárosi vámok felülvizsgálatára került sor. ${ }^{15} 1366$ májusában Lackfi Dénes erdélyi vajda is tartott a király parancsára vámvizsgálatot Erdélyben, ennek anyaga azonban sajnos nem maradt ránk. ${ }^{16}$ A vizsgálatok nyomán született vámkatalógusok azért kivételes források, mivel feljegyezték bennük a felülvizsgált vámhelyeken szedett vámok fajtáját, birtokosait, továbbá megállapították, hogy az adott vámhely jogosan vagy jogtalanul áll-e fent és müködik (a szlavóniai esetben eleve csak az inkriminált, jogtalanul felállított vámhelyeket írták össze $)^{17}$ - sőt, a sárosi vámvizsgálat alkalmával rögzítették a pécsújfalusi vám tarifáját is. ${ }^{18}$ Számos forrásunk van a vizsgált intézmények körüli hatalmaskodásokra, vitákra, túlkapásokra, pereskedésekre is. ${ }^{19}$ Az okleveles anyagon kívül a dolgozathoz - részben a DLDF adatbázis természetéből adódóan - más típusú forrásokat, kisebb részben leveleket, ${ }^{20}$ káptalani ${ }^{21}$ és városi statútumokat ${ }^{22}$ és feljegyzéseket is felhasználtam. ${ }^{23}$

\footnotetext{
12 ZsO. XI. 477-479. (1170. sZ.).

${ }^{13} \mathrm{ZsO}$. II. 3890. sZ.

${ }^{14}$ Smič. XI. 525-526.

${ }^{15}$ Draskóczy I.: Sáros megye vámhelyei 57-61.

${ }^{16}$ de mandato eiusdem domini regis universis nobilibus et alterius cuiusvis status et preeminentiae hominibus tributa tam in terris quam in aquis habentibus in eadem congregacione nostra instrumenta sua super tributo suo confecta coram nobis exhiberi commissimus - ZW. II. 240.

${ }^{17}$ Vö. Smič. XI. 528-529.

${ }^{18}$ Draskóczy I.: Sáros megye vámhelyei 59-60.

${ }^{19}$ Vö. Kádas I. - Skorka R. - Weisz B.: Kereskedelmi források 331-333.

${ }^{20}$ [1379-1382]: DF 239 222. (Szentgyörgyi Tamás tárnokmester levele Pozsonyhoz).

${ }^{21}$ Zágrábi káptalan: Tkalčić, Mon. ep. Zagr. II.; váradi káptalan: Vár. Kápt. Stat.
} 
Hozzávetőlegesen megbecsülve: az Anjou-kori oklevéltár (14 kötet) segítségével és - az oklevéltárból még hiányzó évek esetében - a DL-DF adatbázis átnézésével a Lajos-kori anyag körülbelül háromnegyed részéből sikerült feltárnom és tematikusan listáznom a vonatkozó okleveleket. A feltárt iratok körülbelül felét sikerült feldolgoznom jelen írás keretei között vagyis helyhez kötni az adatokat, ahol lehet, megállapítani a vámtípust és a birtokost és beépíteni őket az adott vámhely történetének kontextusába. Tehát a teljes feldolgozást doktori dolgozatom keretei között nem tudtam megvalósítani. Az összegyüjtött és feldolgozott anyag, habár nem teljes, a korszak sajátosságainak mindenképpen reprezentatív tükre, egy reményeim szerint - meggyőző merítés úgy a kiadott, mind a kiadatlan anyagból és eddig nem publikált adatokból, aminek a révén jelen munka értelmező, elemző része megnyugtatóan széles bázison nyugszik.

Végül néhány szóban az adattárról: abban a vámhelyeken kívül alfabetikus rendben szerepelnek a (lokalizálható és nem lokalizálható) vásárokra, hidakra, révekre, kikötőkre, valamint a vámmentességet élvező személyekre, közösségekre és intézményekre vonatkozó adatok is. Az egyes települések lokalizásásánál alapvetően Engel Pál Magyarország a középkor végén címü térképére ${ }^{24}$ és adattárára ${ }^{25}$ támaszkodtam. Hosszú távon, ha a kitüzött munkával elkészülök, és a szöveg netalántán kiadásra kerül, nem vetném el a lehetőségét annak, hogy az adatok - egy-egy megye vámjainak könnyebb áttekinthetősége végett - a kataszterben megyei bontásban, térképekkel szerepeljenek. Ebben az esetben a kötethez mindenképpen mutató is szükségeltetik majd. Olyan esetekben, amikor egy településhez kötődően többféle intézményre is volt adat (tehát például tartottak éves és hetivásárt, vámot szedtek és esetleg rév is müködött), ott az adatokat az adott szócikken belül, a munka könnyebb használhatósága végett igyekeztem vám>vámmentesség>vízi átkelő>vásár sorrendbe rendezni. Ezt azonban nem minden esetben tettem meg, mivel elöfordult, hogy az adatok kronológiáját, vagy a tárgyalt jelenség belső logikáját nem akartam az átszerkesztéssel megbontani. A Lajos-kori adatok mellett a dolgozatba (úgy az elemző, mint az adattári részbe) szórványosan a kutatás „,melléktermékeként” kikutatott késő(bbi) középkori adatokat is beledolgoztam.

\footnotetext{
22 1425: Tkalčić, Mon. civ. Zagr. II. 47-50. (ZsO. 1358. sz.) (1425. évi zágrábi városi statútumok).

23 [1422-1433]: DF 207 973. (ZsO. XII. 1375. sz.) (a komáromi dunai rév hajóinak beszerzési és javítási költségeit tartalmazó 15. század eleji nyugta) Vö. Sörös P.: A komáromi rév és vám 140-141.

${ }^{24}$ Engel P.: Térkép.

${ }^{25}$ Engellex (Engel Pál „Magyarország a középkor végén” című térképének település-adatbázisa).
} 


\section{KUTATÁSTÖRTÉNETI ÁTTEKINTÉS}

„Történelmünk elhanyagoltabb kérdései közé tartozik az egykori vámhelyeknek általánosabb topograficus meghatározása; mely noha magában véve magasabb országos jelentöséggel nem bir, mégis több föfontosságu más kérdéssel oly szorosan függ össze, hogy a hazai történet néhány nevezetes szaka, p. o. a kereskedés és a közlekedési viszonyok történeti topographiája, általa nevezetes felvilágositást nyerhet. Ezen szempontból én a hazai egykori vámhelyek minél teljesebb és részletesebb tanulmányozását és meghatározását buváraink különös figyelemre méltó feladatának tekintem...” - hangsúlyozta Wenzel Gusztáv a vámok kutatásának fontosságát akadémiai székfoglalójában, ami 1872. május 6-án Nyitra vármegyének $X V$. századbeli vámhelyei. Tanulmány hazánk közlekedési viszonyainak történetéhez címmel hangzott el. ${ }^{26}$ Wenzelén kívül a 19. század utolsó és a 20. század első harmadában több hasonló, rövidebb-hosszabb dolgozat látott napvilágot, ami jobbára egy-egy megye vagy település vámszedőhelyeinek általában - az Árpádok korához képest természetszerüleg sokkal kedvezőbb forrásadottságú - késő középkori (14-15. század) történetét dolgozta fel. Tanulmányok születtek a pozsonyi (nagy-)dunai révvám²7 (1890), a komáromi vám²8 (1899), a dunai vámok ${ }^{29}$ (1901), az esztergomi vámº (1904), a bihari és barsi vámok ${ }^{31}$ (1905), a tiszalúci vám ${ }^{32}$ (1906), a zalai vámhelyek ${ }^{33}$ (1917) és a Turóc megyei vámok (1919)³ történetéröl.

A magyar vámrendszer kialakulása és középkori története iránt ebben az időszakban ugyanakkor összefoglaló munkák létrehozásában megnyilvánuló kutatói érdeklődés is támadt: Csánki Dezső Hazánk kereskedelmi viszonyai I. Lajos korában (1880) címü monográfiájában önálló fejezetet szentelt a „vám- és harminczadügynek”, 35 Takács Sándor 1907-ben jelentette meg A magyar vámrendszer az Árpádok és Anjouk alatt című dolgozatát, ${ }^{36}$ 1908-ban Eckhart Ferenc A királyi adózás története Magyarországon 1323-ig címü könyvében szintén olvasható egy vámokkal foglalkozó fejezet, ${ }^{37}$ majd 1933-ban Sólyom Jenő írt egy monográfiát a

\footnotetext{
${ }^{26}$ Wenzel G.: Nyitra megye vámhelyei 3.

${ }^{27}$ Király J.: Pozsonyi vám- és révjog.

${ }^{28}$ Sörös P.: A komáromi vámpör.

${ }^{29}$ Kováts F.: Dunai hajózás.

${ }^{30}$ Pór A.: Esztergomi vám.

${ }^{31}$ Iványi B.: Bihar- és Bars-vármegyék.

${ }^{32}$ Iványi B.: Tiszaluczi vám.

${ }^{33}$ Holub J.: Zala vármegye vámhelyei.

${ }^{34}$ Mályusz E.: Turóczmegye vámhelyei.

${ }^{35}$ Csánki D.: Hazánk kereskedelmi viszonyai.

${ }^{36}$ Takács S.: Vámrendszer.

${ }^{37}$ Eckhart F.: Királyi adózás.
} 
témában (A magyar vámügy fejlödése 1519-ig). ${ }^{38}$ 1961-ben Fügedi Erik Középkori magyar városprivilégiumok címü dolgozatának Gazdasági kiváltságok címü fejezetében a kiváltságolt települések vámmentességi jogáról (szabadságáról) értekezett. ${ }^{39}$

A vámtörténet és a vámszedőhelyek célzott kutatása - az Árpád-korra vonatkozóan - a '90-es évektől újra napirendre került: 1991-ben a Soproni Szemle Mollay Károly a soproni Szélmalom utcai vámról írt kimerítő dolgozatát közölte, ${ }^{40}$ majd 1994-ben napvilágot látott Dettné Légrády Ibolya kandidátusi disszertációja A magyar vámszedés kialakulása és fejlödése a honfoglalástól 1300-ig címmel, illetve 1995-ben a szerző Középkori magyar vámtarifák címü dolgozata. ${ }^{41}$ 1998-ban Draskóczy István egy-egy tanulmányában Sáros megye 14. századi, valamint a somosi vám 13-14. századi történetét dolgozta fel. ${ }^{42}$

Napjaink legtermékenyebb „vámkutatója” Weisz Boglárka, aki más gazdaságtörténeti tematikájú kutatásai mellett csaknem húsz éve publikál rendszeresen a szükebb-tágabb témában. A 2000-es évek elején főleg az Árpád-kor foglalkoztatta, eredményei sorra jelentek meg tanulmányok formájában: Bars megye vámhelyeiröl ${ }^{43}$ (2001), az Árpád-kori törvények vámokkal kapcsolatos rendelkezéseiről ${ }^{44}$ (2001), II. András vámmentességadományozásairól ${ }^{45}$ (2001, 2003), a győri és az esztergomi vámról ${ }^{46}$ (2003), Abaúj megye vámszedőhelyeiről ${ }^{47}$ (2004), a Felső-Tisza vidék vámszedéséről ${ }^{48}(2004,2005)$ és az Árpádkori közlekedésivám-tarifákról ${ }^{49}$ (2005). Weisz Boglárka doktori disszertációjában végül teljesen feldolgozta 11-13. századi vámrendszerre vonatkozó forrásanyagot: a Vámok és vámszedés az Árpád-kori Magyarországon ${ }^{50}$ címmel elkészített értekezést 2006-ban védte meg, majd az I. Károly-kori adatok feldolgozásával kiegészítve 2013-ban jelentette meg könyv formájában (A királyketteje és az ispán harmada. Vámok és vámszedés Magyarországon a középkor első felében). ${ }^{51}$ Újabb írásai a só Árpád-kori vámolásának

\footnotetext{
38 Sólyom J.: A magyar vámügy.

${ }^{39}$ Fügedi E.: Középkori magyar városprivilégiumok passim, kül. 36-41.

${ }^{40}$ Mollay K.: Szélmalom utcai vám.

${ }^{41}$ Dettné I.: Vámszedés; Dettné I.: Középkori vámtarifák.

${ }^{42}$ Draskóczy I.: Sáros megye vámhelyei; Draskóczy I.: A somosi vám.

${ }^{43}$ Weisz B.: Bars megye vámhelyei.

${ }^{44}$ Weisz B.: A vásár és a vám.

45 Weisz B.: II. András vámmentesség adományai világiak számára; Weisz B.: II. András vámmentességadományai.

${ }^{46}$ Weisz B.: Az esztergomi vám; Weisz B.: A győri vám.

47 Weisz B.: Abaúj megye vámszedőhelyei.

${ }^{48}$ Weisz B.: A Felső-Tisza vidék vámszedése I-II.

${ }^{49}$ Weisz B.: Közlekedési vámtarifák.

${ }^{50}$ Weisz B.: Vámok és Vámszedés az Árpád-korban (http://doktori.bibl.u-szeged.hu/537/1/de_3439.pdf [utolsó letöltés: 2019. 07. 14]).

${ }^{51}$ Weisz B.: Vámok és vámszedés.
} 
gyakorlatával $^{52}$ (2007), a debreceni ${ }^{53}$ (2011), a kolozsvári ${ }^{54}$ és a kassai polgárok vámmentességével $^{55}$ (2013, 2014, 2015), a váradi egyház középkori vámjaival (2014) ${ }^{56}$ és a bihari vámok (2016) kérdésével foglalkoznak. ${ }^{57}$ Említhető még Skorka Renáta 2013-ban megjelent tanulmánya, amiben a Csehországot és Budát Bécs elkerülésével összekötő, 1336ban létesített kereskedelmi útvonal kijelölésének külpolitikai, diplomáciai hátterét vizsgálta. ${ }^{58}$

Máig külön csapásirányt képez a vámkutatásban a tricesima, a harmincadvám kutatása, ami még mindig a legalapvetőbb kérdések körül forog: Pontosan mi a tricesima? Hogyan alakult ki? Hol és miért szedték? Hogyan adminisztrálták? A harmincadolás alá eső áru értékének hány százalékát kellett vámként kifizetni? A kapcsolódó munkák közül elsőként Kováts Ferenc Nyugatmagyarország áruforgalma a XV. században a pozsonyi harmincadkönyv alapján címü, az 1457-1458. évi pozsonyi harmincadkönyv bázisán készített elemzése említhető. ${ }^{59}$ „Középkori történetünknek megoldásra váró problémái közt sok gazdaság- és pénzügytörténeti kérdés van. Az adatok gyér száma és homályos volta sok esetben nagyon megnehezíti, söt nem egyszer szinte lehetetlenné teszi a minden tekintetben kielégitő megoldást, mit a hasonló természetü kérdések fölött folytatott vitatkozások eléggé bizonyítanak" - írta Szentpétery Imre ${ }^{60}$ Domanovszky Sándor A harminczadvám eredete ${ }^{61}$ című akadémiai székfoglaló értekezéséről (1916) készített recenziójában. Idézett megállapításai jól jellemzik az Árpád-kori vám- és különösen a harmincadtörténet kutatásának nehézségeit. Domanovszky munkájának csak több mint hét évtized múlva, 1990ben akadt folytatója, Pach Zsigmond Pál, aki azonos című dolgozatában (A harmincadvám eredete $)^{62}$ alapjaiban szállt vitába Domanovszky időt próbált megállapításaival. Pach nem ragadt meg az Árpád-kor kutatásánál, 1995-ben Hogyan lett a harmincadból huszad?, ${ }^{63}$ majd 1999-ben a Történelmi Szemlében A harmincadvám az Anjou-korban és a 14-15. század fordulóján ${ }^{64}$ címmel jelentetett meg tanulmányt - utóbbi írása a Lajos-kori harmincadállomások történetének máig legteljesebb, időtálló összefoglalója, katalógusa és

\footnotetext{
52 Weisz B.: Sóvámolás.

${ }^{53}$ Weisz B.: Debrecen.

${ }^{54}$ Weisz B.: Kolozsvár.

${ }^{55}$ Weisz B.: Kassa kereskedelmi életének jogi háttere I-II. (angol és szlovák nyelven: Weisz, B.: Košice; Weisz, B.: Právne pozadie obchodného života Košíc); Weisz B.: A kassaiak vámmentessége.

${ }^{56}$ Weisz B.: A váradi vámper. (románul: Weisz B.: Proces vămilor din Oradea).

${ }^{57}$ Weisz B.: Vámvizsgálatok Bihar megyében. (román nyelven: Weisz, B.: Operaţiuni de vămuire în comitatul Bihor).

${ }^{58}$ Skorka R.: Csökkentett vámtarifájú út.

${ }^{59}$ Kováts F.: Pozsonyi harmincad.

${ }^{60}$ Szentpétery I.: A harminczadvám eredete 525.

${ }^{61}$ Domanovszky S.: A harminczadvám.

${ }^{62}$ Pach Zs. P.: „A harmincadvám eredete”.

${ }^{63}$ Pach Zs. P.: Huszad.

${ }^{64}$ Pach Zs. P.: A harmincadvám az Anjou-korban.
} 
adattára. 1993-ban megjelent munkájában Mollay Károly a soproni harmincad történetét dolgozta fel. ${ }^{65}$ A témában legújabban Weisz Boglárka Az Árpád-kori harmincadvám ${ }^{66}$ (2011), valamint Haraszti Szabó Péter Harmincadbérlők, harmincadispánok, ispánok. A harmincadvám szedése Magyarországon a 14. század első feléig ${ }^{67}$ (2014) címmel publikált tanulmányt. 2010-ben született a tárgyban egy forráspublikáció is: Stanisław Sroka Sredniowieczny Bardiów i jego kontakty z Malopolska (A középkori Bártfa és kapcsolatai Kis-Lengyelországgal) címü, 2016-ban magyar nyelven is megjelent monográfiájának függelékeként kiadta Bártfa 1479-ben és 1480-ban keletkezett koronavámnaplóit. ${ }^{68}$

\section{A VÁMOK FAJTÁI}

A vámokat (tributum, ${ }^{69} \mathrm{t}(\mathrm{h})$ elonium/t(h)eloneum, ${ }^{70}$ vectigal $^{71}$ ) két típusra lehet osztani: kereskedelmi és közlekedési vámokra. ${ }^{72}$ „Középkori értelemben az utak, hidak, révek használatáért szedett illetéket kell vám alatt értenünk” - határozta meg Sólyom Jenő 1933-ban a közlekedési vámok definícióját. ${ }^{73}$ A közlekedési vámok ismét két csoportba sorolhatók: beszélhetünk száraz- vagy vízi vámokról (tributum aquaticum) ${ }^{74}$. Előbbin a szárazföldi útvonalakon (in terris) ${ }^{75}$ közlekedőktől behajtott útvámok (,szárazuti vám”) ${ }^{76}$ értendők, utóbbit a folyókon réven vagy hídon átkelőktől (révvám, hídvám), valamint - a sokszor a révek mellett müködő kikötőkben - a hajózóktól (hajóvám) szedték in/super aquis. ${ }^{77} \mathrm{~A}$ kereskedelmi vámok lehettek bel- vagy külkereskedelmi vámok. Belkereskedelmi vámokon a vásárvámokat értjük, külkereskedelmi vámon a Lajos-korban a harmincad, a hatvanad és a nyolcvanad (a határkapuban szedett vám) értendő.

\footnotetext{
${ }^{65}$ Mollay K.: Soproni harmincad.

${ }^{66}$ Weisz B.: Az Árpád-kori harmincadvám.

${ }^{67}$ Haraszti Szabó P.: Harmincad.

${ }^{68}$ Sroka, S. A.: A középkori Bártfa 229-250. (Sroka, S. A.: Sredniowieczny Bardiów 241-265.).

69 1344: F. IX/1. 99. (Tapolca, Zala megye), 1347: F. IX/1. 497. (Kompolt, Heves megye); 1380: DL 38494. (Sztenicsnyák, Zágráb megye)

70 1347: F. IX/1. 497. (Kompolt, Heves megye); 1375: ZW. II. 438 (Kocs, Komárom megye); 1380: DL 38494. (Sztenicsnyák, Zágráb megye); 1382: DF 248660 (Kemetinc, Valkó megye).

71 1349: P.. II. 401. (Guido pápai legátus oklevelében).

${ }^{72}$ Vö. Weisz B.: Vámok és vámszedés 9.

${ }^{73}$ Sólyom J.: A magyar vámügy 10.

74 Teleki, Huny. X. 376.

${ }^{75}$ Vö. 1350: Wenzel, Dipl. Eml. 390.

${ }^{76}$ Takács S.: Vámrendszer 8. Weisz B.: Vámok és vámszedés 13.

${ }^{77}$ Vö. 1350: Wenzel, Dipl. Eml. 390.; 1354: F. IX/2. 326.
} 
Weisz Boglárka monográfiájához hasonlóan ${ }^{78}$ jelen írás sem foglalkozik az olyan, adókat jelölő, magyarul sokszor szintén vámnak hívott tributumokkal, mint például a hegyvám, ${ }^{79}$ makkoltatásért fizetett tributum, ${ }^{80}$ vagy a malomvám. ${ }^{81}$

\section{II.1. Közlekedési vámok}

Az útvámmal a forrásokban tributum viaticum, ${ }^{82}$ tributum in via, ${ }^{83}$ tributum super terris siccis $^{84}$ és pedagium ${ }^{85}$ néven találkozhatunk, a hajóvámot az 1351. évi törvény a következőképpen írta körül: tributum super fluviis ab infra descendentibus et supra euntibus (exigi consuetum), vagyis „a folyókon a lefelé vagy felfelé haladóktól (hajózóktól) szedni szokott vám”. 86

I. Lajos 1351. évi törvényeinek 8. articulusa jogtalannak minősítette és megtiltotta mindkettő, a száraz- és hajóvámok szedését is, „mivel - így a király - úgy látjuk, ezeken országunk nemeseit és nemtelenjeit szerfelett terhelik”. A tiltás a hidakon és réveken az átkelésért lefizetett vámokat nem érintette: ${ }^{87}$

„Tributa eciam injusta super terris siccis, et fluviis; ab infra descendentibus, et supra euntibus non exigantur; nisi in pontibus, et navigiis, ab ultra transeuntibus solvantur; cum in eis, nobiles et ignobiles regni nostri, multo, et nimium percepimus aggravari.”88

Amint ismeretes, a király a törvény ellenére (universa tributa in sicciis terris et fluviis hactenus exigi consueta amplius non exigerentur) már a következő évben, 1352-ben engedélyezte a szentjakabfalvi szárazvám beszedését, arra hivatkozva, hogy a vám jövedelme alamizsnaként a klarissza apácák megélhetését szolgálta: a szentjakabfalvi vám 1352-es “müködési engedélyének” megadására szokás a király első, az 1351. évi törvénnyel ellenkező vámrendeleteként hivatkozni. ${ }^{89}$ A törvényt, nem meglepő módon, lehetetlen volt végrehajtani,

\footnotetext{
${ }^{78}$ Vö. Weisz B.: Vámok és vámszedés 9-10.

79 Lásd például 1343: tributum vinearum - DL 3577; 1351: tributum montis - DL 87 257; 1358: tributum montium - AO VII. 61.

${ }^{80}$ Lásd például 1363: et insuper centum porcos de eadem silva eorum absque aliqua tributi exaccione ... potencialiter abduxisset - DF 219493.

${ }^{81}$ Lásd például 1371: DL 5956; 1375: in eodem molendino ... nullum tributum dare - DL 62523.

82 1346: Sopron vm. I. 187. (Kövesd, Sopron megye); 1382: DL 6905 (Egyedújfalu, Bács megye)

83 1346: Sopron vm. I. 187. (Röjtökör, Sopron megye); 1347: Zala I. 466-467. (Letenye, Zala megye).

84 1351/VIII: Corpus Iuris Hungarici 173. (DRMH online 51).

85 1371: DF 238 873; 1379: Historiae Patriae Monumenta II. 855.; 1405: ZsO. II. 3890. sz.

86 1351/VIII: Corpus Iuris Hungarici 173. (DRMH online 51).

${ }^{87}$ 1351/VIII: Corpus Iuris Hungarici 173. (DRMH online 51).

88 1351/VIII: Corpus Iuris Hungarici 173. (DRMH online 51).

${ }^{89}$ Vö. pl. Sólyom J.: A magyar vámügy 67., Holub J.: Zala vármegye vámhelyei 46.
} 
hiszen nyilvánvalóan szembement a vámbirtokosok érdekeivel. Ha ugyanis nem vámolták volna a folyókon hajózókat, miért szabályozta volna a király dunai hajóvámok tarifáját 1366ban és 1370-ben? ${ }^{90}$ Miért kellett volna például 1356-ban a pozsonyiak dunai (hajó)vámok fizetése alóli mentességére emlékeztetni az illető vámbirtokosokat? ${ }^{91}$ Ha 1353 után nem szedtek volna szárazvámokat, miért nem tükrözte a változást az 1353 után a vámok birtokosaihoz (és vámszedőikhez) intézett parancslevelek formulája? Azok ugyanis továbbra is a tributa tam in terris quam super aquis habentibus et tenentibus eorumque tributariis szólnak. ${ }^{92}$

Egy 1371. évi királyi oklevélből - amivel kapcsolatban persze kétséges, a király akaratát deklarálja, avagy a „közfelfogást” (már ha beszélhetünk ilyenről) tükrözi-e - úgy tünik, a korszakban alapvetően nem magát a száraz-, vagy hajóvámszedést tekintették jogtalannak, hanem azt a gyakorlatot, amikor e vámok fizetésére a kereskedőkön kívül (értve a kereskedőkön a hivatásos távolsági kereskedőket épp úgy, mint a vásárra árujukat szállító jobbágyokat) olyan országlakosokat (vagy külföldieket) köteleztek, akik áruk nélkül (sine rebus mercimonialibus) keltek útra, és magukkal vitt dolgaikat nem eladásra, hanem saját felhasználásra szánták (non causa mercimonii (sic!) sed pro eorum usu) - legyenek akár világi papok, szerzetesek, gyalog vagy lóháton utazó zarándokok, egyszerű országlakosok (ceteri in(co)le et habitatores regni nostri hinc inde de loco ad locum sine rebus mercimonialibus suos gressus pedes simpliciter facientes), vagy a királyságba költözés szándékával érkező külföldiek cuiuscumque ydiomatis existant. 1371-ben Lajos a felsoroltaktól még a hídvám szedését is megtiltotta, csak a réveknél kellett fizetniük ( $a b$ omni solucione p(ed)agii seu cuiuslibet tributi exaccione tam in terris quam in pontibus (sic!) semper salvi liberi et perpetuo exempti habeantur navigio solum ex(ce)pto). ${ }^{93}$ Ugyanez a felfogás tükröződik a király 1364. július 15-i, az országos gabonahiány mérséklése érdekében kiadott rendeletében. Az uralkodó ekkor 1 évig vámmentessé tette a gabonafélék (búza, rozs, árpa, zab, köles), a maláta, a liszt, a kenyerek, a lencse, a borsó, a bab és a káposzta(?) (olus) belföldi szállítását a száraz- és vízi vámokon, azonban a réveken ekkor is fizetni kellett az átkelésért (excepto solo naulo seu tributo portuum quod iusto et levi modo ab ipsis exigi volumus). ${ }^{94}$

\footnotetext{
90 1366: DF 258 545_092-090.; Teleki, Huny. X. 376-377.; 1370: ZW. II. 337-338. (Vö. Szeben)

${ }^{91}$ Vö. Pozsony.

92 1366: ZW. II. 268; Lásd még például 1360: Házi 123.; 1364: VVOS 272.

93 1371: DF 238873.

${ }^{94}$ statuimus quod de bladis seu frugibus videlicet tritico silignibus ordeo avena milio brasio farina panibus necnon de lentibus pisis fabis oleribus et aliis leguminibus undecumque et ad quecumque loca per quoscumque et quotiescumque a data presencium infra unius anni integri spacium intra limites regni nostri et non extra
} 
A folyókon réven (portus, transitus) vagy hídon (pons) átkelőktől rév- (tributum portus, ${ }^{95}$ tributum in portu seu navigio, ${ }^{96}$ tributum navigii ${ }^{97}$ ) illetve hídvámot (tributum pontis, ${ }^{98}$ tributum in ponte ${ }^{99}$ ) szedtek. A hidak ebben az időszakban föleg fa-, ${ }^{100}$ kisebb részben kőépítmények voltak, ${ }^{101}$ de a forrásokban kötél- ${ }^{102}$ és földhíd ${ }^{103}$ is előfordul.

A középkori révek és hidak, az utakhoz hasonlóan, részben magánhasználatúak, kizárólag birtokosuk famíliája, népei számára fenntartottak, részben, vámfizetés fejében, a kereskedők és utazók által is igénybe vehetők voltak. Utóbbi (köz)utakat a libera/publica via, ${ }^{104}$ míg a „közréveket” a portus generalis, ${ }^{105}$ transportus communis ${ }^{106}$ kifejezések jelölhetik. 1348-ban Bojti Mihály fia Tamás kékesi birtokrészén (Bihar megye) épített hídjáról azt állította, magánhídként funkcionál, amit úgy írt körül, hogy „,a hidat nem az utazók és a kereskedők számára, hanem Kékes birtoka haszonvételeinek igénybevétele céljából építette” (quem quidem pontem non pro viatoribus et mercatoribus sed ut usus et utilitates eiusdem possessionis Kekus percipere et percipi facere possit fecisset edificari). ${ }^{107}$ A két révtípus közti különbség jól megfogható az ari, matolcsi-kóródi ${ }^{108}$ (Szatmár megye), az eberhardi-csallói, vereknyei $^{109}$ (Pozsony megye), vagy az abádi-poroszlói ${ }^{110}$ (Heves megye) révek körüli

regnicolis nostris vendicioni exponenda deferuntur nullum tributum nullumque telonium in terris et in aquis in locis tributorum regalium reginalium ecclesiarum prelatorum abbatum monialium prepositorum priorum et fratrum cuiuscumque ordinis et religionis existant excepto solo naulo seu tributo portuum quod iusto et levi modo ab ipsis exigi volumus ab eisdem exigatur sed eadem blada et res iam nominate usque prefixum terminum ab omni tributaria exaccione libera et exempte habeantur - F. IX/3. 409-410.

95 1346: DF 219457 (Szomajom, Szabolcs megye)

96 1353: DL 4089 (Galgóc, Nyitra megye).

97 1353: DL 4089 (Galgóc, Nyitra megye).

98 1342: DL 51187 (Kálló, Szabolcs megye); 1353: DF 263067 (Dombró, Körös megye).

99 1344: DL 70550 (Kölcse, Szatmár megye).

100 1352-ben a zalai konvent kiszállt Árpásra (Győr megye), ahol jelentésük szerint jól látszottak a régi Rába-híd cölöpjei (prout eciam adhuc in dicta terra arpas stipites seu palos et alia evidencia signa ipsius antiqui pontis fide oculata conspexissent - P. VIII/1. 329-330.).

101 1358: pons lapideus - AO VII. 60. (Visonta, Heves megye). Vö. Szilágyi, M.: On the Road 186-193.; Szilágyi, M.: Mobility, Roads and Bridges 71.

${ }^{102}$ A Krassó megyei Dobrocsány hídja kötélhíd lehetett, erre utal, hogy tönkretételét a decido és a deseco (levág) igékkel írták le. 1355: unum pontem suum in sua possessione Dobochan vocata super aquam Karaso decidisset vel desecate fecisset et ad illam facientem aquam posuisset - DL 91475.

103 1343: pons terreus - DL 35186 (Kaneuicha, azonosítása bizonytalan, Körös megye).

104 Szilágyi, M.: On the road 96-101.

105 1369: DL 7459.

106 1345: DF 230 394. (Smič. 187-188.) (Anjou-oklt. XXIX. 60 sz.).

107 Z. II. 323. (Anjou-oklt. XXXII. 712. sz.).

108 1374: non extranei et forensi homines seu mercatores sed solummodo sui iobagiones proprii per ipsum portum in dicta villa Korog transitum faciendi habeant facultatem - DL 70558.

109 1369: ex gracia concessimus speciali ut ipsi et eorum heredibus (sic!) in possessione eorum Eberhad vocata in comitatu Posoniensi existenti in fluvio Danubii portum seu navigium pro transiectancium comodo et utilitate in perpetuum tenere et servare possint et valeant ex presentis nostre concessionis annuencia speciali ita tamen quod dumtaxat iobagionis ipsorum et ad ipsos pertinentes inibi transiecare et transuadare possint navigio in eodem temporis in successu comites vero nostri posonienses nunc et pro tempore constituti ac eorum vicesgerentes et tributarii alios mercatores et forenses homines cum rebus mercimonialibus procedentes ad portum seu navigium 
vitáknál. A szabolcsi Monyorós, Ladány és Himes, Anarcsi (Berencsi) László fia Tamás semptei várnagy 1371-ben engedélyezett tiszai átkelői (portus seu transitus), úgy tünik, egyszerre töltötték be a két funkciót. ${ }^{111}$

A vámszedésért cserébe az utakat és hidakat a megfelelő karban kellett tartani, a révekben pedig az átkeléshez szükséges révhajók fenntartása volt a vámbirtokos részéről nélkülözhetetlen.

1347-ben, amikor a vásári (ajkai) nemesek ${ }^{112}$ felosztották a Bihar megyei Gyarakot, Ajkai Péter fia Mihálynak jutott Bereck Gyepes (Gyepus) folyó melletti sessiója azzal a feltétellel, hogy a kertje mögött lévő, Péntektava (Pentektowa) nevü mocsár közelében lévő szekér(?)utat, amin át lehetett kelni a mocsáron, fenn kell tartania. ${ }^{113}$ Sajnos nem tudható, hogy a birtokosztályos oklevélben említett (vélhetően töltés)út köz- vagy magánút volt-e. Az 1355. évi sárosi vámvizsgálat a szinyeújfalusi vámnál azt is megállapította, hogy „a köves út” (valószínűleg a vám útja) ki lett javítva az arra közlekedőknek. ${ }^{114}$ Zámmonostora 1343. évi osztályakor a felek (Ősi István fiai, Lőrinc és János, ${ }^{115}$ továbbá Káta nembéli Gúg fia Gúg; ${ }^{116}$ Dózsa néhai nádor fiai, Jakab és Pál) a Hortobágy folyón szedett hídvámot (a folyó áradásaikor: révvám) is két részre osztották. A zámmonostori híd neki jutó (fele) részét mindkét félnek karban kellett tartania, a Hortobágy áradásaikor pedig közösen tartottak fenn révhajókat, bevételeiket és esetleges karbantartási költségeiket pedig megosztották. ${ }^{117} \mathrm{~A}$ szabolcsi Szomajom felosztásakor 1346-ban a szomajomi nemesek - Péter fia Kozma és fiai, Péter, István és János, illetőleg Pál fia László és Pál fia János fiai, Tamás litteratus és

posoniensem compellere et coartare aut tributum consuetum ibidem exigere et extorquere liberam et absolutam habeant facultatem ab eisdem - DL 5750. (F. IX/4. 170.); Vö. 1378: DF 238957.

110 1395: DL 8003. (ZsO. I. 3973. sz.). A regeszta a két révtípus közti különbséget nem érzékelteti megfelelően. Vö. Abád.

111 duximus annuendum, ut ipsi in possessionibus eorum Ladan, Hymus et Monyoras vocatis prope fluvium Tyzie adiacentibus propriis personis familiaribus et iobagionibus naves et portum seu transitum sed eciam pro aliquibus hominibus parandi tenendi et habendi perpetuis temporibus plenam liberam et securam haberent facultatem sine preiudicio tamen nostrorum regiorum portuum et tributorum - DL 96467.

112 Vö. Engel P.: Genealógia: Vásári (2) Ajkai.

113 ut retro ortum suum circa paludem pentektowa viam per qua posse transire currus(?) servare tenebitur - DF 278 512. (Anjou-oklt. XXXI. 860. sz.).

114 competentes pontes necessarii servarentur et via petrosa pertranseuntibus diceretur emendari - Draskóczy I.: Sáros megye vámhelyei 59.

115 Vö. Engel P.: Genealógia: Káta nem 1. tábla: elágazás.

${ }^{116}$ Vö. Engel P.: Genealógia: Káta nem 6. tábla: Kátai (Csekekátai).

117 quandocunque tempore inondacionis dicti fluvii Hortobag pro transfretantibus naves necessarie existerent, ipsas naves dicte partes communiter ordinare et ibi servare ac proventus earundem navium sicut tributi equaliter percipere et inter se dividere temporeque necessitatis preallegatas naves de communi expensa ex reditibus seu lucris earundem navium provenienti semper reparare et reintegrari facere teneruntur naves supradictas; pontem eciam super annotato fluvio Hortobag in quantum ipsos dictus pons contingeret similiter reparare deberent et inter se conservare - Z. II. 56-59. (Anjou-oklt. XXVII. 98. sz.). 
Mátyás ${ }^{118}$ - a birtok Hortobágy folyón lévő hídjának vámját is kettéosztották, és elöírták, hogy a híd negyedrészét (a közepén) László és János fiai, másik negyedét (a végén) pedig Kozma és fiai kötelesek karban tartani. ${ }^{119}$ 1358-ban a király arra intette a garamszentbenedeki monostor apátját, hogy - a barsi vámból való részesedése okán, annak arányában - hozzá kell járulnia a Bars városának szélén álló, megsérült Garam-híd javításához, „ahol a vámot szedik”. ${ }^{120}$ Lörinc fia János lévai várnagyot ugyanakkor arra utasította, hogy amennyiben az apát a királyi parancsnak nem tenne eleget, vonja el (debeat sequestrare) vámjövedelmeit, és a hidat a barsi népekkel és hospesekkel javíttassa ki - részesedésének arányában az apát költségén. ${ }^{121}$ 1373-ban az uralkodó a Tárca folyón történő átkelést lehetővé tévő híd fenntartásának fejében újította meg Ivánka fia Péter somosi (Sáros megye) vámszedési jogát. ${ }^{122}$ I. Lajos 1381-ben, Somosi Péterhez intézett parancslevele ugyancsak a vám(szedés) meghatározott feltételekkel történt visszaállítását említette - tudniillik, hogy a vámbirtokos cserébe köteles hidat fenntartani a Tárcán. ${ }^{123}$

\section{II.2. Kereskedelmi vámok}

A vásárvámot a források nagyrészt a tributum fori ${ }^{124}$ kifejezéssel jelölik. 1351-ben a kassaiak sérelmezték, hogy Leleszen - belépti vámnak fordítható - tributum introvenienst kérnek tölük. A konfliktus nyomán indított per során kiderült, hogy a prépost a vásári napon, hétfőn, a vásározni érkező, halakat szállító szekerekről vásárvámként egy halat szedetett a monostor szerzeteseinek ellátására iuxta antiquam ipsius monasterii consuetudinem. ${ }^{125}$ A jogvitát az országbíró a lelesziek javára döntötte el, amit a következőképpen indokolt: a királyság régi szokása szerint minden birtokosnak joga van a vásárain a kisebb javak (res minute) után vásárvámot szedni. ${ }^{126}$

\footnotetext{
${ }^{118}$ Vö. Engel P.: Genealógia: Szomajomi (Szabolcs m.). (Hiányos, néhol téves családfa Engelnél!).

${ }^{119}$ preterea quartam partem ipsius pontis in medio prefati Ladislaus Thomas et Mathyas quartam vero partem in fine Cosmas cum filiis suis et successoribus in perpetuum reficere tenerentur - DF 219457.

${ }^{120}$ cum vos in tributo, quod in civitate nostra Borsiensi exigitur, porcionem habere dinoscamini, ex eoque fractura pontis super fluvio Gron in fine eiusdem civitatis nostre habiti, ubi dictum tributum exigi consuevit, per vos quantum ad vestram porcionem debeat reparari - AO VII. 37.

${ }^{121}$ AO VII. 36-37. (Anjou-oklt. XLII. 93. sz.).

${ }^{122}$ Lásd a Vámtarifák c. mellékletben!

${ }^{123}$ undecum vobis ipsum tributum sub certis limitacionibus restituemur ut dicitur et specialiter ut pontem bonum conservaretis - DF 228 497. (Iványi, Eperjes 39. [93. sz.]).

124 1342: DL 51187 (Kálló, Szabolcs megye); 1353: DF 263067 (Dombró, Körös megye).

125 DF 269298.

${ }^{126}$ unde quia quilibet possessionati homines in suis possessionibus fora habentes de juris equitate et regni antiqua consuetudine requirente in eorum foris de rebus minutis tributum fori nobis et regni baronibus exigere posse videbantur - DF 269298.
} 
A külkereskedelmi vámok közöl a harmincad tricesima, a hatvanad sexagesima, a nyolcvanad octoagesima néven fordul elö a forrásokban.

A Lajos-kori harmincadszedőhelyek történetének máig legteljesebb, időtálló összefoglalója, katalógusa és adattára Pach Zsigmond Pál A harmincadvám az Anjou-korban és a 14-15. század fordulóján címü, a Történelmi Szemlében 1999-ben publikált írása. ${ }^{127}$ Nem véletlenül. Pach cikkében irigylésre méltó alapossággal aknázta ki az akkoriban elérhető, publikált források és szakmunkák adatait és eredményeit, amelyek alapján összesen tizenhat Lajos-kori harmincad létét mutatta ki, vagy legalábbis feltételezte: (betürendben) a bártfai (Sáros m.), a budai (Pilis m.), az esztergomi (Esztergom m.), a fehérvári (Fejér m.), a nagyszombati (Pozsony m.), a győri (Győr m.), a kassai (Abaúj m.), a lőcsei (Szepes m.), a lublói (Szepes m.), a pozsonyi (Pozsony m.), a sárvári (Vas m.), a semptei (Nyitra m.), ${ }^{128}$ a soproni (Sopron m.), a szakolcai (Nyitra m.), a zágrábi (Zágráb m.), valamint a zsolnai (Trencsén m.) állomásokét. Pach katalógusát a Moson megyei Óvárral egészíthetjük ki. ${ }^{129}$

A Lajos-korban müködő harmincadhivatalokat a következő alfabetikus lista tartalmazza; közülük az ebben az időszakban létesítetteket félkövérrel szedtem. Az utóbbi harmincadhelyek után szereplö évszámok fennállásuk legkorábbi, egyértelműen adatolható időpontját, míg a dőlttel szedett évszámok a hivatal feltételezett, korábbi működési idejét jelzik. A korábbi időkben felállított, és a Lajos-korban is funkcionáló harmincadhivatalok esetében zárójelben adtam meg a fennállás legkorábbi, egyértelműen adatolható időpontját (dőlttel a feltételezett, korábbi működési időpont). A nem zárójelben szereplő évszámok a működésüket alátámasztó legkorábbi Lajos- (illetve Nagyszombat esetében Zsigmond-)kori adatot jelzik. A Lajos-korban megszünt/áthelyezett hivatalok - Sárvár és Győr - esetében a második dátum fennállásuk utolsó adatolható/feltételezett időpontjait jelzi. Úgy tünik, az áthelyezett hivatalok esetében egy ideig a régi és az új állomások párhuzamos működésével kell számolnunk.

127 Pach Zs. P.: A harmincadvám az Anjou-korban. A Lajos-kori „vám- és harminczadügyet” korábban (viszonylagos részletességgel) Csánki Dezső is tárgyalta: Csánki D.: Hazánk kereskedelmi viszonyai 15-22.

${ }^{128}$ Adatok hiányában inkább csak felvetés szintjén. Pach Zs. P.: A harmincadvám az Anjou-korban 236., és uo. 25. jz.

${ }^{129}$ Vö. Óvár. 


$\begin{array}{lll}\text { Bártfa } & 1355^{130} & \\ \text { Buda } & (1336)^{131} & \\ \text { Esztergom } & (1289)^{132}, 1372^{133} & \\ \text { Fehérvár } & 1372,{ }^{134} 1383^{135} & \text { áthelyezés Galgócról? }{ }^{138} \\ \text { Nagyszombat } & (1336))^{136} 1402^{137} & \text { áthelyezés Pozsonyba } \\ \text { Győr } & (1208)^{139}-1365^{140} & \\ \text { Kassa } & 1311,{ }^{141} 1361^{142} & \\ \text { Lőcse? } & 1364 ?^{143} 1402^{144} & \\ \text { Lubló } & 1365^{145} & \\ \text { Óvár } & 1359^{146} & \text { áthelyezés Győrből } \\ \text { Pozsony } & 1364)^{147} 1369^{148} & \text { áthelyezés Sopronba } \\ \text { Sárvár } & (1341)^{149}-1368^{150} / 1383^{151} & \text { áthelyezés Pozsonyba } \\ \text { Sempte } & \text { Lajos-kor elött }^{152} & \text { áthelyezés Sárvárról } \\ \text { Sopron } & 1364^{153} / 1368^{154} / 1383^{155} & \\ \text { Szakolca } & 1372^{156} & \\ \text { Zágráb } & (1316) & \\ \text { Zsolna } & 1364^{158} & \end{array}$

130 1355. február 3.: Draskóczy I.: Sáros megye vámhelyei 58.

131 1336. január 6.: Wenzel, Dipl. Eml. I. 343-345. Pach Zs. P.: A harmincadvám az Anjou-korban 238. Weisz B.: Az Árpád-kori harmincadvám 269-270.

132 1289. szeptember 15.: Bp. I. 247-249. Weisz B.: Az Árpád-kori harmincadvám 271.

133 1372. március 4.: DF 236 306. Pór A.: Háborúság a vám miatt 197. Vö. Pach Zs. P.: A harmincadvám az Anjou-korban 260.

134 1372. szeptember 3.: ZW. II. 393-394. Idézi: Pach Zs. P.: A harmincadvám az Anjou-korban 257-258.

135 1383. április 11.: Házi I/1. 197. Idézi: Pach Zs. P.: A harmincadvám az Anjou-korban 258.

136 1336. január 6.: Wenzel, Dipl. Eml. I. 343-345. Pach Zs. P.: A harmincadvám az Anjou-korban 238. Weisz B.: Az Árpád-kori harmincadvám 269-270.

137 1402. január 22.: DF 279583.

${ }^{138}$ Weisz Boglárka szerint elképzelhetö, hogy a forrásainkban egyetlenegyszer felbukkanó galgóci harmincadot (1318. augusztus 26.: Apponyi I. 54-57.) I. Károly Nagyszombatra helyezte át. Weisz B.: Az Árpád-kori harmincadvám 270., 274. 79. jz.

139 1208: Bgl. I. 55. (Reg. Arp. 236. sz.). Idézi: Weisz B.: Az Árpád-kori harmincadvám 267.

140 1365. április 26.: F. IX/3. 489-490. Idézi: Pach Zs. P.: A harmincadvám az Anjou-korban 235.

141 1311. október 3.: F. VIII/1. 408. Idézi: Pach Zs. P.: A harmincadvám az Anjou-korban 242.

142 1361. augusztus 9.: F. IX/3. 241-243. Idézi: Pach Zs. P.: A harmincadvám az Anjou-korban 243.

${ }^{143}$ Pach Zsigmond Pál feltevése szerint. Pach Zs. P.: A harmincadvám az Anjou-korban 247-249.

144 1402. január 22.: ZsO. II/1. 142. sz. Idézi: Pach Zs. P.: A harmincadvám az Anjou-korban 249-250. Az oklevél hitele Weisz Boglárka szerint legalábbis kétséges. Weisz B.: Vásárok és lerakatok 64-65.

145 1365. május 1.: F. IX/1. 52. Idézi: Pach Zs. P.: A harmincadvám az Anjou-korban 249. Az oklevél keltére lásd ui.

146 1359. augusztus 17.: DF 226 978. Idézi: Csánki III. 676.

${ }^{147}$ Vö. Pozsony.

148 1369. október 29.: F. IX/4. 177. Idézi: Pach Zs. P.: A harmincadvám az Anjou-korban 235.

149 1341. február 17.: F. VIII/4. 666-667. (Anjou-oklt. XXV. 120 sz.). Idézi: Pach Zs. P.: A harmincadvám az Anjou-korban 233. Weisz B.: Vámok és vámszedés 332-333.

${ }^{150}$ L. a 154. jegyzetet.

${ }^{151}$ Mollay K.: Soproni harmincad 133.

152 1385. augusztus 16.: F. X/8. 180. Vö. Pach Zs. P.: A harmincadvám az Anjou-korban 235-236.

${ }^{153}$ Vö. Pozsony.

154 1368. február 18.: Házi I/1. 147. Idézi: Pach Zs. P.: A harmincadvám az Anjou-korban 234.

${ }^{155} \mathrm{~L}$. a 151. jegyzetet.

${ }^{156}$ 1372. október 6.: F. IX/4. 421-423. (a fejregesztában 1373. évi kelettel). Idézi: Pach Zs. P.: A harmincadvám az Anjou-korban 239. (szeptember 29-i kelettel).

${ }^{157}$ A Zágráb melletti, királyrévi harmincad 1316-tól folyamatosan adatolható. Erre legújabban lásd Kovács V.: Vámszedés Zágrábban 255-260.

158 1364. október 5.: DF 269 299. Pach Zs. P.: A harmincadvám az Anjou-korban 240-241. 
Lajos 1379. évi ${ }^{159}$ kiváltságlevele értelmében az országba a Dunán, szárazföldön Orsova és Temesvár felől, vagy a zárai úton kereskedni érkező genovai kereskedők a budai harmincadon csak fél harmincaddal, tehát hatvanaddal (medietas tricessime seu sexagessima) tartoztak. ${ }^{160}$

A nyolcvanad (octoagesima) szedése az Árpád-korban a Zágráb megyei Szamobornál és a Szepes megyei Sztagárnál mutatható ki, míg az Anjou-korban - úgy Károly, mint Lajos idején - az országba a Nyitra megyei Újvárnál (Holics, Fehéregyháza) belépőkre vetették ki. ${ }^{161} 1350$ augusztusában I. Lajos öccse, István szlavón-dalmát-horvát herceg felhívta a vámszedők figyelmét arra, hogy a kölni, a hoyai és más Rajna-melléki kereskedőktől a Holics-Buda útvonalon (Újvár- Sasvár vagy Szenic -Jablánc- Bikszárd vagy Bény -NagyszombatFarkashida-Sempte-Nyárhíd-Udvard-Esztergom-Csaba-Szentjakabfalva ${ }^{162}$-Buda) bátyja rendelkezése szerint úgy kell szedni a vámot, mint a prágai kereskedőktől - vagyis apjuk, I. Károly 1336. évi előírásainak megfelelően. ${ }^{163}$ Az 1350. évi oklevél a Holicsnál fizetendő nyolcvanadot is felsorolta. ${ }^{164}$ I. Lajos a kölni, a hoyai és más Rajna-melléki kereskedőknek a prágai kereskedők e kiváltságát 1344-ben ${ }^{165}$ és 1365 -ben ${ }^{166}$ is megerősítette, ahogy 1357ben ${ }^{167}$ a prágai és a nürnbergi, 1364-ben ${ }^{168}$ ismét a nürnbergi, 1366-ban a kölni és a nürnbergi, ${ }^{169}$ 1359-ben és 1369-ben ${ }^{170}$ a regensburgi, és ugyancsak 1369-ben ${ }^{171}$ az ambergi kereskedőknek is. ${ }^{172} 1370$ februárjában, amikor a király szabályozta a szebeniek a város Bécs felé irányuló kereskedelmét sújtó vámokat, tarifaként Szebenből Csehországba menet, vagy onnan jövet minden vámhelyen 4 cseh garas fizetését írta elö egy nagy szekér (rudasszekér)

\footnotetext{
159 Az oklevelet Wenzel (erősen hiányosan) kiadta (Wenzel, Bányászat 158. és uo. 2. jz.) 1349. évi kelettel. Regesztáját lásd Anjou-oklt. XXXIII. 470. (Wenzel kiadása alapján). 1857. évi, Wenzel által használt kiadásában (Historiae Patriae Monumenta II. 854-858.) az oklevél 1379. évi kelettel szerepel, amit támogat, hogy I. Lajos címei közt a lengyel király is fel van sorolva, valamint hogy feltünik az oklevélben bizonyos Nicolaus de Guarcho dux, vagyis Nicolò Guarco, Genova 1378-83 közötti dózséja. Musso, R.: GUARCO, Nicolò.

160 de rebus autem propriis mercimonialibus tributum solvere tenebuntur more consueto eo tamen salvo et sane interiecto quod omnes ianuenses et qui pro ianuensibus reputantur ut supra teneantur et obligati esse intelligantur pro dictis mercibus et mercimoniis in buda et non alibi medietatem tricesime seu sexagesimam solvere atque dare - Historiae Patriae Monumenta II. 856.

${ }^{161}$ Weisz B.: Vámok és vámszedés 9.

162 Az 1350. évi oklevélben Csaba hiányzik az 1336-os út vámhelyei közül. Kérdés, hogy csak Wenzel kiadásából maradt-e ki. Az irat eredetije Wenzel szerint a Köln város levéltárában található. Wenzel, Dipl. Eml.II. 390-392. (Anjou-oklt. XXXIV. 587. sz.).

${ }^{163}$ Wenzel, Dipl. Eml.II. 390-392. (Anjou-oklt. XXXIV. 587. sz.). Vö. 1336: Wenzel, Dipl. Eml.I. $343-345$. (Anjou-oklt. XX. 6. sz.).

164 quod in primo intruitu ad metas dicti regni Hungarie in alba ecclesia in wlgari Wyuar nominata debet solvi octouigesima de rebus mercimonalibus - Wenzel, Dipl. Eml.II. 391.

165 Wenzel, Dipl. Eml.II. 47.

166 Wenzel, Dipl. Eml.II. 633.

167 Wenzel, Dipl. Eml.II. 484.

168 Wenzel, Dipl. Eml.II. 617.

169 DF 267836.

${ }^{170}$ Wenzel, Dipl. Eml.II. 664.

${ }^{171}$ Wenzel, Dipl. Eml.II. 677.

172 Skorka R.: Csökkentett vámtarifájú út 468. 92. jz.
} 
után, míg egy kis ajoncásszekér ${ }^{173}$ után 2 cseh garast kellett fizetni - Fehéregyházán ${ }^{174}$ is. Vagyis a szebeniek a cseh kereskedőkkel ellentétben nem nyolcvanadot fizettek Holicsnál. ${ }^{175}$

\section{VÁMSZEDÉS}

\section{III.1. Törvényes utak}

A 15. században az volt az általános szabály, hogy ha valaki egy mérföldre ${ }^{176}$ megközelített egy királyi, vagy fél mérföldre egy nemesi vagy egyházi tulajdonban lévő vámszedőhelyet, oda mindenképpen be kellett térnie, és a vámot meg kellett fizetnie ${ }^{177}$ - még akkor is, ha a kitérő megnövelte útja hosszát. A gyakorlatban ezt úgy kell elképzelni, hogy a vámszedőhelyeknek törvényes útjai voltak: a törvényes utakra a források a vera via, ${ }^{178}$ a via consueta, ${ }^{179}$ a via iusta, ${ }^{180}$ a via recta ${ }^{181}$ vagy a via directa ${ }^{182}$ kifejezéseket használják. Az úthasználatot elsősorban a szokás (consuetudo) határozta meg, vitás esetekben azonban ténylegesen lemérték egy vitatott státuszú út és egy vámhely távolságát: 1360-ban Cselenfi János királynéi ajtónállómester amiatt pereskedett Tornai Egyeddel és Jánossal, hogy utóbbiak jobbágyai elkezdtek egy olyan új utat használni, ami az Abaúj megyei Somodi és Jánok nemesi birtokban lévő vámhelyei között, azok elkerülésével Péder birtokon vezetett át. Miután a fehérvári káptalan lemérte az új út és a két vámhely közti távolságot (az út Somoditól 730, Jánoktól 850 királyi mérőre [mensura] volt) ${ }^{183}$, Bebek István országbíró

\footnotetext{
173 A két szekértípusra lásd Domanovszky S.: Mázsaszekér 47-51.

174 in loco tributi nostri castri Wywar nuncupati in vulgari Tewtonicali Wezker vocati - ZW. II. 339. A Wezker a Weißkirche (Fehéregyház) romlott alakja lehet.

175 et quod iidem mercatores Zybinienses de eorum curribus vel rebus mercimonialibus oneratis versus Bohemiam vel de partibus Bohemyae in Hungariam in Zybinium transeuntibus tam in eundo quam in redeundo in locis universorum tributorum regni nostri et specialiter sicut in aliis sic in loco tributi nostri castri Wywar nuncupati in vulgari Tewtonicali Wezker vocati non obstante privilegio quondam domini Karoli regis genitoris nostri carissimi super relaxacione medietatis tributarie solucionis premisse olim mercatoribus regni Bohemie per eundem facta confecta de curru magno vulgariter rudaszeker vocato quatuor grossos Bohemicales de curru parvo ayanthaszeker vulgariter nominato duos grossos similiter Bohemicales persolvant nullumque munus ipsis tributariis dare teneantur nec ipsi tributarii in locis eorum tributorum aliquid ultra hoc ab eisdem recipere presumant - ZW. II. 338.

176 Bogdán szerint 1 magyar mérföld kb. 8000 méternek (8 kilométer) felelt meg. Bogdán I.: Magyarországi hossz- és földmértékek 85.

177 1415: via etiam cuiuslibet tributi si regale fuerit ad unum, si vero nobilis exstiterit ad medium miliaria ex utraque parte pro sua meta secundum communem et consuetudinem extendi debere censetur - Teleki, Huny. I. 412. Idézi Weisz B.: Vámok és vámszedés 41.

178 1376: DL 87495.

179 1347: F. IX/1. 496. (Anjou-oklt. XXXI. 491. sz.).

180 1347: F. IX/1. 496. (Anjou-oklt. XXXI. 491. sz.).

181 1416: DF 239369.

182 1416: DF 239369.

183 ditanciam vie litigose ad Sumugy cum regali mensura mensurando in septingentis et triginta mensuris reperissent, ad possessionem vero Januk eandem viam litigosam similiter cum regali mensura mensurando in
} 
Cselenfi János javára döntötte el a pert: az inkriminált útvonalat eltörölte, és eltiltotta használatától a tornai nemesek jobbágyait, akiknek a vámot - ítélete szerint akár Somodin, akár Jánokon - meg kellett fizetnie. ${ }^{184}$ Lackfi Dénes erdélyi vajda 1361-ben, Gönyüi Péter fia Tamás és Raholcai Kont Miklós vajdák rendeleteit jóváhagyva, megerősítette a bonchidai (Doboka megye) és a szentmiklósi (Kolozs megye) vám útjait: a Buza, Teke, (Szász)Régen, Sárpatak, Monyoró és Székelyvásárhely felé tartó kolozsváriak Szentmiklóson és vámján át közlekedhettek a Kályánon és Ménesen áthaladó úton, ${ }^{185}$ Bonchidát és vámját pedig nem kellett útba ejteniük. ${ }^{186} \mathrm{~A}$ bonchidai vám érintését a vajdák a Besztercébe utazó rettegi, désvári, lekencei és kolozsvári kereskedőknek írták elő. ${ }^{187}$ 1381-ben, a június17-i barsi generalis congregación a béli apát és a báti bíró együtt tiltakozott amiatt, hogy a Solymosról Bakára árut szállító kereskedők újabban nem érintik a báti vámot. ${ }^{188}$ 1424-ben a Bars megyei vámvizsgálat felderítette, hogy „az esztergomi érsekség Verebély birtokán lévő, régóta felállított vám útjai a következőképpen alakulnak": ${ }^{189}$ aki Nagysáriból vagy Marótról Sallóra megy, az nem, aki azonban Sallóról Töhölre tart, az - jókora vargabetűt téve - köteles bemenni Verebélyre, és ott vámot fizetni. ${ }^{190}$

A törvényes utak ${ }^{191}$ hálózata nem volt állandó, egy új útvonal megnyitásával vagy egy régi út áthelyezésével módosulhatott. 1345-ben I. Lajos a kuffurbachi királyi vámot Kolbachba helyezte át, miután módosította a királyi bányavárosokba vezető útvonalat. Így az oda tartó kereskedőknek ettől fogva Kolbachon át kellett közlekedniük. Az útvonal (majd a vám)

octingentis et quinquaginta mansuris invenissent, tamen distancia dixtarum duarum possessionum Sumugy et Januk vocatarum ad unum miliare prout visu considerare potuissent non distaret - DL 37 367. Sajnos az oklevél nem írja le, a mérő (mensura) alatt milyen mérték értendő - másképpen: mi volt a mérésre használt kötél(?) alapegysége. Mivel a két vámhely (Somodi, Jánok) távolságát a fehérvári káptalan kevesebb, mint egy mérföldre becsülte (Engel térképén légvonalban kb. 7 km-re van egymástól a két település), mértékként esetleg a kb. 3 méter hosszúságú királyi öl jöhet szóba. Vö. Bogdán I.: Magyarországi hossz- és földmértékek 97.

184 predictam viam litigosam inter ipsas duas possessiones Sumugy et Janok existentem aboliri et anichilari committentes adiudicantes comisimus ut a modo et deinceps tam iobagiones magistrorum videlicet Egidii et Iohannis ac aliorum quorumlibet a transitu huiusmodi indebite et illegitime vie cessent et compescantur nec quoquomodo presumpmant eandem perambulare sed omnes qui per ipsam litigosam viam transire consueti extiterant ipsa via indebita obmissa et derelicta ad unum dictorum tributorum videlicet in Januk vel in Sumugy ire et consueta tributa persolvendo transire teneantur - DL 37367.

185 si autem versus Reugun, Teke et forum Syculorum accesserint per villam et tributum sancti Nicolai in via per Kalyan et Menus eunte transire permittatis - ZW. II. 192.

${ }^{186}$ ut dum ipsi et ad eos pertinentes cum rebus ipsorum mercimonialibus per viam Klyan versus villa Buza, Teke, Regun, Sarpatak, Monyorow et forum Siculorum procedere vellent in villam Bonchyda ire non tenerentur sed recta via ipsorum esset ad villam sancti Nicolai per viam de Kalyan euntem et sic ad tributum solvendum in predictam villam Bonchyda de via eorum directa compelli non deberent sed per viam de Kalyan et Menyus euntem ad villam sancti Nicolai procedere deberent - ZW. II. 191.

187 ZW. II. 191-192.

188 P. VIII/1. 410-411.

189 item tributum in possessione Verebel archiepiscopatus Strigonyensis tributum ab antiquo fuisset institutum, cuius vie eo modo haberentur, quod ... - ZsO. XI. (1170. sz.).

190 ZsO. XI. (1170. sz.).

${ }^{191}$ A témában lásd Szilágyi, M.: On the Road 96-107.; Weisz B.: Vásárok és lerakatok 108-115. 
áthelyezését a király kuffurbachi régi út rossz minőségével indokolta. ${ }^{192}$ A király 1373-ban a cseh és a magyar területek között új utat nyitott: a cseh kereskedők Újvárról (Fehéregyháza/Holics) Pozsonyba Ör, Küküllő, Malacka és Stomfa érintésével juthattak el. ${ }^{193}$

\section{III.2. Vámkerülés}

Az utazók és a kereskedők egy része nyilvánvalóan arra törekedett, hogy a vámköteles utak, hidak, révek (kikötők) és vásárok vámszedőit kijátszva lehetőleg minél kisebb anyagi ráfordítással közlekedjen és kereskedjen a királyságban. Szintén az említett barsi vámvizsgálat mondta ki, hogy „akik Sallóról Szencséig, és Szencséről Agacsnak mennek, azok a mányai vám álútját járják”. ${ }^{194}$ A közlekedők ugyanis nem ritkán szándékosan letértek a vámszedőhelyek, avagy a rájuk vonatkozó útkényszer által előírt útvonalról és úgynevezett álutakon (alwth, ${ }^{195}$ falsa via, ${ }^{196}$ frauda via,${ }^{197}$ via sinistra, ${ }^{198}$ via iniusta, ${ }^{199}$ via inconsueta, ${ }^{200}$ via indirecta, ${ }^{201}$ via indebita, ${ }^{202}$ via insolita, ${ }^{203}$ via extranea, ${ }^{204}$ via occulta, ${ }^{205}$ via obliqua ${ }^{206}$ ) haladtak. A Valkó megyei Kemetinc predium egy földdarabjának határjárásakor érintett álutat a boszniai káptalan úgy írta körül, mint olyan utat, „amin az emberek nem merészelnek járni a vám miatt”. 207

\footnotetext{
192 1345/1350: Máriássy 28-29. (DL 74 813.) (Anjou-oklt. XXIX. 223. sz.).

193 DF 238 896. (F. IX/4. 488.). Habár az Újvár és Pozsony között fizetendő vámokról az útvonal létesítéséröl szóló királyi parancs hallgat, feltehető, hogy a kereskedőktől Újváron nyolcvanadot, Pozsonyban harmincadot, míg a többi állomáson közlekedési vámot szedtek. Újvárra lásd Weisz B.: Vámok és vámszedés 412. Vö. Pozsony.

194 item quicumque de possessione Sarlo predicta usque possessionem Zenche transirent et de Zenche ad Agoch transirent, illi in falsa via tributi de ipsa Manya ambularent - ZsO. XI. (1170. sz.).

195 DF 284881.

196 1376: DL 87495.

197 1376: DL 87495.

198 1382: DF 248660.

199 1347: F. IX/1. 496. (Anjou-oklt. XXXI. 491. sz.).

200 1347: F. IX/1. 496. (Anjou-oklt. XXXI. 491. sz.).

201 1428: DF 239498.

202 1366: P. VIII/1. 346.

203 1366: P. VIII/1. 346.

204 1366: P. VIII/1. 346.

205 1343: DL 40904 (F. IX/1. 101-102.).

206 1439: DF 236363 (Bp. III/2. 313-314.).

207 ad quandam viam sinistram per quam homines non presummunt procedere et ambulare propter thelonium DF 248660.
} 


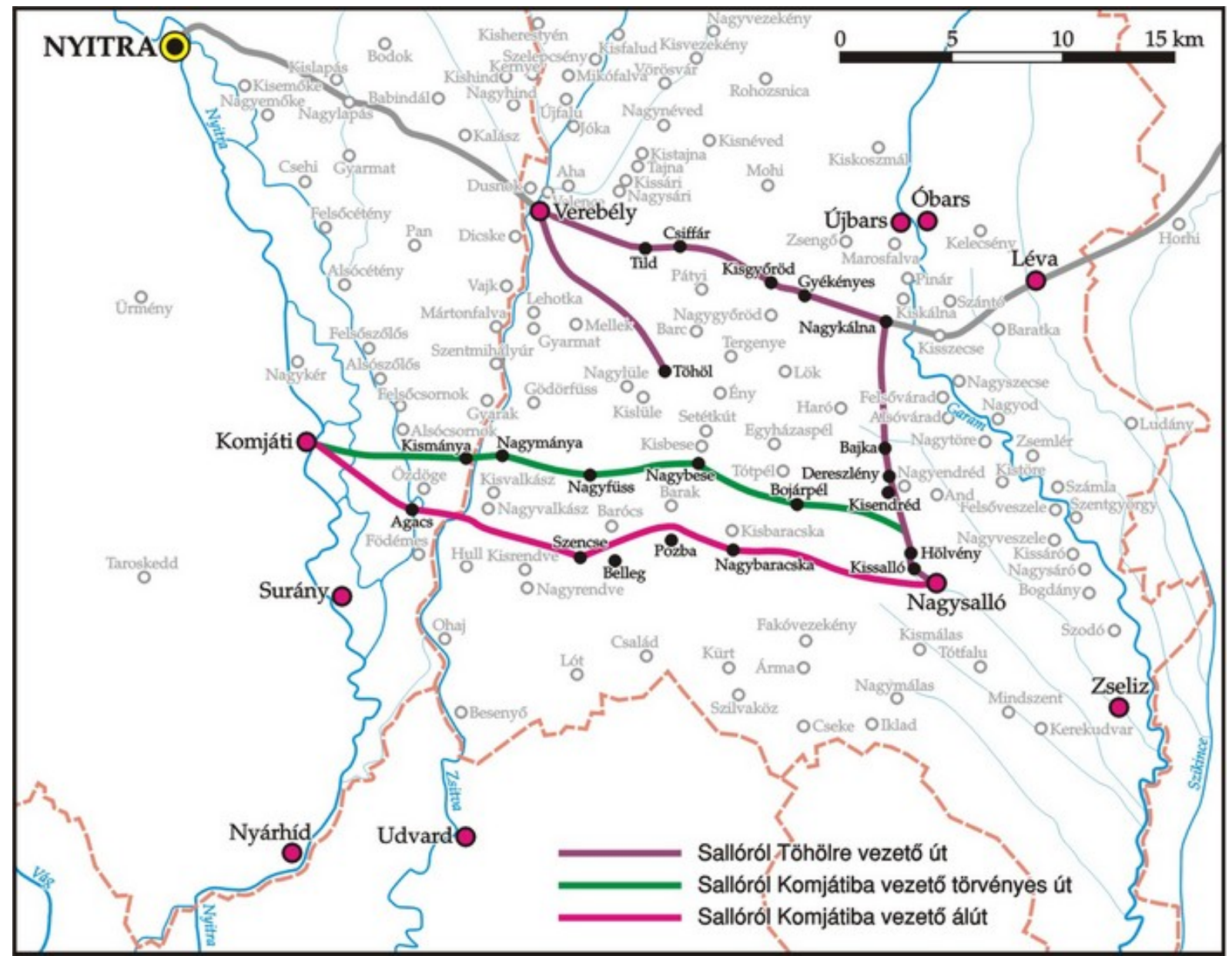

Akiket a vámszedők álúton, vámkerülésen értek, azok javait - jogszerüen lefoglal(hat)ták, ${ }^{209}$ amint erre a király 1343-ban a Billege falu vámját, ${ }^{210}$ 1345-ben pedig a leleszi premontrei prépostság Ketete nevü révjét elkerülni szándékozók figyelmét felhívta. ${ }^{211}$ Az „álutazók” a vámok fizetése fejében elnyert királyi (a király nevében gyakorolt) védelemre sem tarthattak igényt: ${ }^{212}$ „akiket efféle jogtalan és idegen utakon találnak közlekedni, és

\footnotetext{
${ }^{208}$ Kovács V.: Álutazó átutazók.

${ }^{209}$ 1362: quod ipse dictos sex boves ipsius Iohannis ... quia idem Iohannes ad locum tributi sui non venisset sed per aliam viam furtive transi(re v)oluisset iuste et legitime recepisset ab eodem - DF 259 861; 1376: quicquam de viatoribus indebite procedentibus recipere poterint de talibus rebus ... - DL 26868.

${ }^{210}$ F. IX/1. 101-102. (Anjou-oklt. XXVII. 94. sz.).

${ }^{211}$ quicunque ex vobis in falsis semitis et viis reperti extiterint illi tanquam de tribu[tis] fugitive recedentes in rebus dampnificabitur - DF 233 649. (Anjou-oklt. XXIX. 648. sz.).

212 1347: quia si secus feceritis et per inconsuetas vias procedere volueritis tunc in personis vestris inhonestabimini et in rebus dampnificabimini - F. IX/1. 496-497. (Anjou-oklt. XXXI. 491. sz.); 1352: quicunque vestrorum super falsis semitis et viis reperti fuerint et extiterint illi tanquam de tributo fugitive recedentes in personis inhonestabuntur et in rebus condempnabuntur - DF 238789.
} 
javaikban vagy személyükben valami sérelmet, esetleg kárt szenvednének, nálunk ne tehessenek panaszt” - intette Lajos 1366-ban a báti vámot kikerülőket. ${ }^{213} 1411$ körül a szamosszegi vámosok a Szatmárról Namény felé - állításuk szerint álúton - tartó Kis Tamás szállítmányát erővel elvették. Az affér következtében a leleszi prépost, Csicseri Miklós állítólag 1400 forintnyi kárt szenvedett. ${ }^{214}$

Az álutazóktól elkobzott javakból esetenként az uralkodónak is bevétele származott: Mária királynő 1384. évi parancsa értelmében a Szebenből az áruikkal a Havasalföldre történő továbbutazást megkísérlő idegen kereskedők (mercatores forenses) lefoglalt rakományaival a szebeniek teljes egészében a mindenkori vajdának tartoztak elszámolni, aki a javakat király(nő)i kamara részére (pro camera nostra) gyüjtötte. ${ }^{215}$ 1402-ben Zsigmond a Bártfát álutakon elkerülők lefoglalt javairól úgy rendelkezett, annak kétharmad része őt, egyharmad része a várost, a bártfaiakat illeti. ${ }^{216}$

Páratlanul ritka részletességgel körülírt vámkerülő-kezelési gyakorlatot rögzített az esztergomi káptalan és a szentkirályi stefaniták 1439. évi jogvitájának anyaga. A pert az esztergomi káptalan indította a stefaniták szentkirályi révje miatt, fellépve a számára nemkívánatos szokás ellen, hogy a Budáról Esztergom felé utazók a Dorog-Esztergom útra rátérve a káptalan esztergomi és dorogi vámjainak kikerülésével juthassanak át a Dunán. A két fél vitája megegyezéssel zárult: ennek értelmében a káptalani vámosok a vámkerülőket elfoghatták útközben, vagy ha eljutottak volna Szentkirályig, a révhajóra való felszállás előtt a falu officialisa vagy villicusa kérésükre le kellett, hogy tartóztassa őket. Abban az esetben azonban, ha a káptalan vámjainak elkerülői anélkül, hogy a vámszedők feltartóztatták volna őket, hajóra tudtak szállni, akadály nélkül átkelhettek a folyón. ${ }^{217}$

\footnotetext{
213 si qui in huiusmodi iniustis viis et extraneis procedentes reperti in rebus vel personis ipsorum aliquam molestiam incurrerint forsitan atque dampna nobis tandem non poterunt imputare - P. VIII/1. 346.

${ }^{214}$ DF 284881.

215 si aliqui mercatores forenses exponerent mercantias eorum ad partes Transalpinas ex tunc iudex et cives habeant facultatem prohibendi bona talium mercatorum et eadem pro camera nostra magnifico viro domino Ladislao vel alteri vaivode Transsilvano pro tempore constituto debeant assignare - ZW. II. 590.

${ }^{216}$ quicumque autem tam ex forensibus quam nostris propriis et aliorum incolarum nostrorum subditis contra premissa statuta nostra sua contraierit industria, presertim tamen ad vias inconsuetas a dicta civitate nostra se dirigendo cum eorum mercibus se absentaverint, huius bona decernimus omnia et singula fore per ipsos eiusdem civitatis nostre incolas auferenda quorumlibet adiutorio pro ipsos eiusdem civitatis nostre incolas auferenda quorumlibet adiutorio pro ipsis nostre maiestatis intuitu invocandorum ac eisdem nostris fidelibus res huiusmodi arrestandi et recipiendi plenam damus et facultatem concedimus, quarum due nobis, tertia vero partes ipsis nostris fidelibus cedere debeant et conservari - ZsO. II/1. 1411. sz.

${ }^{217}$ ut universi mercatores et alterius cuiusvis status homines tributa solvere debentes de partibus inferioribus puta per viam de Buda versus dictum Strigonium ducentem proficissci volentes derelicta ipsa via per aliam viam scilicet obliquam inter dictam civitatem Strigoniensem ac pretactam villam Dorogh existentem ad prefatam possessionem Zenthkyral vocatam prescripta tributa prefati capituli locis in predictis exigi solita surripere machinando proficissci voluerint talesque in dicta via obliqua et falsa per tributarios dicti capituli reperire poterint pena non soluti tributi per eosdem tributarios puniantur ubi vero iidem manus dictorum tributariorum evadendo ad prefatam possessionem Zenthkyral pervenerint et ante ingressum navis in dicto portu in prefata
} 
A vámszedőhelyeket elkerülők (vagy a vám kifizetését egyszerüen megtagadók) és a vámosok között támadt nézeteltérésekben sok esetben az utóbbiak húzták a rövidebbet. A nosztrai pálos remeték szobi út- és vízivámjukon rendre nem tudtak kellő eréllyel fellépni a fizetésre hajlandóságot nem mutatók ellen a 15. század elején. ${ }^{218} 1419$-ben Lőrinc vikárius arról panaszkodott, hogy a Duna melletti vámjukról sokan „bármiféle fizetés nélkül, erőszakkal távoznak, és kényük kedve szerint mennek tovább”. ${ }^{219}$ Zsigmond először a visegrádi, majd a damásdi királyi vár elöljáróit is megsegítésükre rendelte. ${ }^{220} 1454$ szeptemberében a baranyai Danóc vámszedői sikertelenül próbálták feltartóztatni a bátmonostori Töttösök familiárisait, illetve géti és laki jobbágyait: a fegyveresen rájuk rontó „álutazóktól” vám helyett verést kaptak. ${ }^{221}$ 1410-ben a körösszegi Csákiak egyik károlyi vámszedőjét Ladánytól Károlyig üldözték, majd miután utolérték, 200 aranyforint értékü lefoglalt holmit vettek el tőle, míg egy másikat foglyul ejtettek. ${ }^{222}$ Náluk is rosszabbul járt 1317-ben Pottendorfi Rudolf soproni ispán egyik vámosa. Amikor Rudolf a Németújvári Jánosnak küldött levelében felsorolta Kőszegi András erőszakoskodásait, nem mulasztotta el megírni, hogy „az egyik emberemnek, aki az én uram, Magyarország királya vámjánál szolgált, levágta az egyik lábát”. ${ }^{223}$ Még ennél is véresebb összetüzés történt 1349 márciusában a vöröskői vár ciferi vámjánál. A várnagy, Ugodi Csenik famulusai uruk parancsára éppen a vámbevételt készültek elvinni, amikor megláttak valakit az úton, aki vélhetően a helyzetet kihasználva - megpróbált megállás nélkül (furtive) átmenni a vámon. Az illetőt, aki Pap János jobbágyainál keresett menedéket, nemhogy elkapni nem sikerült, de Pap János lóra kapott, majd famulusaival és jobbágyaival a közeli Vistuk faluig hajszolta Csenik embereit. Közülük egyet megöltek, egy másikat megsebesítették, míg a várnagynak szállított 100 font súlyú pénzt lovaikkal és ruháikkal együtt eltulajdonították. ${ }^{224}$

Zsigmond 1435-ben igyekezett előmozdítani a tiltott utak kérdésének rendezését: „meg kell határozni a vámok ál- és kerülőútjait, és azt, hogyan jogszerü és mi van szokásban arra

\footnotetext{
Zenthkyral habito per officialem seu villicum ipsius ville ad requisicionem dictorum tributariorum arestati fuerint tales simulcum universis rebus et bonis eorum prefati dominus Ladislaus de Chethnek et conventus aut iidem officialis et villicus eorundem manibus dictorum tributariorum iuxta regni consuetudinem corrigendos dare et assignare teneantur; ubi vero iidem ante arestacionem dictorum tributariorum navem asscendi seu ingredi poterint liberam sine omni impedimento habeant transsfretandi facultatem - Bp. III/2. 313-314.

218 1409: DL 9542 (ZsO. II/2. 6743. sZ.); 1419: DL 10837 (ZsO. VII. 774. sz.); 1419: DL 8823 (ZsO. VII. 878. SZ.); 1439: DL 13383.

${ }^{219}$ DL 8823.

220 1419: DL 8823. (ZsO. VII. 878. sz.). Vö. Engel P.: Archontológia I. 297., 461.

${ }^{221}$ homines prefati exponentis super dictos populos et iobagiones in dictis falsis viis repertos tributum de regni consuetudine levare voluissent - DL 81 189. (Kőfalvi T, Pécsváradi konvent 742. sz.).

222 DL 71 444. (ZsO. II/2. 7220. sz.).

223 Sopron vm. I. 80. Idézi Weisz B.: Vámok és vámszedés 31.

${ }^{224}$ DF 227 576. (Str. III. 674.) (Anjou-oklt. XXXIII. 160. sz.).
} 
nézve, mekkora az a távolság, ameddig az álutakat vámosok ellenőrizhetik, utazókat tilthatnak el [a használatuktól], illetve tartóztathatják fel őket rajtuk. Utakat pedig senki ne merészeljen új helyeken - ahol korábban soha nem volt út -, a földjein át létesíteni az általános utasforgalom számára, a szomszédos vámszedőhelyek sérelmére és kárára”. 225

\section{III.3. Vámszedés a gyakorlatban}

Aki vámszedőhelyhez érkezett, áruival mindenképpen meg kellett állnia. Árpád-kori forrásaink még hallgatnak a vámszedésre figyelmeztető szimbólumokról, bár gyaníthatóan már ebben a korszakban is alkalmazták őket. A 14. században a vámszedőhelyeket kereszttel jelölték. 1342-ben, egy Keve megye hatósága elötti tiltakozás alkalmával hangzott el, hogy amikor Becskereki „vámos” Domokos és társai a becsei várnagy parancsára fegyveresen rajtaütöttek a Kartal nembeli Etele Szentgyörgy birtokán, ott széttörték a vámot jelző keresztet (signum tributi videlicet crucem), a vámházból pedig 3 márkányi dénárt és 500 sót magukkal vittek. ${ }^{226}$ 1391-ben Zsigmond az erdélyi szász kereskedők panaszára eltörölte azt a 40 dénáros büntetéspénzt, amivel a vámszedőhelyeken sújtották őket, ha lovaikat kikötötték a vámfizetést jelző oszlophoz vagy a vámsorompóhoz. ${ }^{227}$ A későbbi, 15. századi forrásokban már a vámhelyeket jelző kerekekkel találkozunk. 1425-ben az Abaúj megyei Vizsolyon Mosticius, János és vámszedőik önkényesen egy második vámkereket (rota pro signo tributi seu thelonei erecta) is felállítottak, és mindkét helyen vámot szedtek az arra járóktól. ${ }^{228}$

A személyi és anyagi kárral fenyegető félreértések elkerülése érdekében a kereskedőknek nem volt javallott olyan visszaélésekre módot adó szituációkba „keveredni”, mint az áruikkal elöször a szállásra menni, és utána felkeresni a vámosokat, vagy éppen a vámfizetés meggyorsítására hivatkozva elöreküldeni valakit az úton, hogy kifizesse a vámot, és utána az árukkal megállás nélkül áthaladni a vámhelyen. Ugyancsak nem volt szerencsés a szekérhúzó

\footnotetext{
${ }^{225}$ similiter inquiratur, discutiatur et moderetur, que et ubi sint false vie et indirecte quorumlibet tributorum, et quantum longe vel prope huiusmodi vias falsas singuli tributarii obsidendi et itinerantes in eisdem prohibendi vel impediendi iustam et consuetudinariam habuerint et habere debeant facultatem. Vias autem novas in locis, quibus vie ab olim nunquam esse consueverunt, nemo pro communi et universali transitu itinerantium in detrimentum et dampnum tributorum vicinorum in faciebus suarum terrarum adinvenire presumat - DRMH I/2. 75. Idézi Szilágyi, M.: On the Road 107.

${ }^{226}$ ÓMO. 158-159. (Anjou-oklt. XXVI. 602. sz.).

${ }^{227}$ quod cum ipsi fideles cives et hospites nostri aut aliqui ex eisdem simul ut puta vel singillatim ad loca dictorum tributorum pervenientes equum vel equos ipsorum ad columnam seu statuam signum tributarie solucionis decernentem vel ad parietem seu domum tributariam contingenter alligaverint ex tunc tributarii super eos quadriginta denarios ... exigerent et extorquerent - 1391: ZW. III. 8. Vö. 1391: ZW. III. 26-29., 1393: III. 65-67., 1397: ZW. III. 187-190., 1404: ZW. III. 187-190., 1405: ZW. III. 314-317. (szebeniek); 1404: ZW. III. 317-320. (kolozsváriak); 1391: ZW. III. 13-16., 1395: ZW. III. 120-123. (brassóiak).

${ }^{228}$ ZsO. XII. 292. sz.
} 
lovakkal túlfutni a vám jelén vagy a vámházon (domus tributi, ${ }^{229}$ domus tributaria, ${ }^{230}$ domus theulonaria $\left.{ }^{231}\right)$, vagy fegyveresen belépni oda. ${ }^{232}$

A fizetendő vámot az egyes vámhelyek vámszabásai alapján határozták meg. Ezeket vélhetően kifüggesztették, hogy bárki tudomást szerezhessen róluk. 1284-ben a Sebes-Körös átkelőjénél szedett bertényi vám tarifájának megállapításakor kikötötték, hogy a vámszabást „azon a helyen, a Körös említett révjénél a vámszedők nyilvánosan őrizzék, hogy minden átkelő tisztában legyen vele, így ne tudjanak a kellőnél magasabb vámot kiróni”. ${ }^{233}$

Általában véve mégis se szeri, se száma a kereskedők, utazók reklamációinak a vámosok túlkapásaira: néha a szokásostól eltérően vámoltak, ${ }^{234}$ máskor túl magas vámot hajtottak be, ${ }^{235}$ de nem ritka, hogy a jogos vámösszegen felül természetbeni javakra tartottak igényt ${ }^{236}$ - noha utóbbi követelések egy része valószínűleg törvényes volt. 1381-ben a Budára és Fehérvárra kereskedni járó osztrák kereskedők arra panaszkodtak, hogy a vámszedők a vámon felül áruikból ajándékok (bors, lándzsák, kesztyük) adására kényszerítik őket. ${ }^{237}$ Ugyancsak osztrák, a Dunán Buda felé lehajózó kereskedők panaszára I. Lajos 1374-ben vasból készült, címerpajzsával hitelesített mértéket (1 királyi láb = 31,26 cm hosszúságút) ${ }^{238}$ küldött a bécsi kereskedőknek. Az eset hátterében feltehetően az állt, hogy a magyar vámszedők

${ }^{229}$ 1342: ÓMO. 158-159. (Anjou-oklt. XXVI. 602. sz.).
${ }^{230}$ 1391: ZW. III. 8.
${ }^{231}$ 1422: Dreska G.: A pannonhalmi hiteleshely 24. (ZsO. IX. 1064. sz.).
232 1391: vel si eciam iidem cives et hospites nostri aut aliqui ex ipsis cum eorum curribus et rebus 232 1391: vel si eciam iidem cives et hospites nostri aut aliqui ex ipsis cum eorum curribus et rebus
mercimonialibus ad loca dictorum tributorum pervenerint et equi eorum ipsos currus trahentes eandem statutam seu columnam sive domum tributariam aliquantulum pertansierint et aliquantisper post tergum reliquerint aut si ipsi cum dictis eorum curribus et rebus in hospicio descenderint et de eodem hospicio ad dictos tributarios accesserint iustum et verum tributum persoluturi vel si aliqui ex eisdem civibus nostris cum dictis rebus eorum mercimonialibus ad dicta loca tributorum pergentes certum hominem ipsorum a campo propter celeriorem expedicionem premisse tributarie solucionis antemitterent et de ipsis rebus eorum iustum tributum persolvi faciendo in ipsisque locis dictorum tributorum non pausando pertransierint prefati tributarii illico calumnia eis imposita asserentes ipsos cum eorum rebus predictis de dictorum tributorum locis fugitive et clendestine recessisse ipsos rebus eorum premissis prorsus spoliarent damnificarent et creberrime disturbarent - ZW. III. 89.

233 1284: Et hoc ipso loco tributarii in predicto portu Chrysii publice volumus observari, ut omnibus transeuntibus in exaccione dicti tributi certa noticia habeatur, ne maior exaccio fi eri possit, quam deberet. - W. IX. 401. Idézi Weisz B.: Vámok és vámszedés 35.

234 1355: item de singulis curribus cuprum aut ferrum seu blumbum deferentibus singulos tres grossos, si autem idem currus unum centenarium solummodo contineret, de ipso curru similiter tres grossos, licet minus plene esset oneratus - Draslóczy I.: Sáros megye vámhelyei 59.

235 1344: DF 287 451_7. (Anjou-oklt. XXVIII. 814. sz.).

236 1380: conqueruntur nobis fideles nostri cives et hospites de civitate Coloswariensi quod vos in locis vestris tributalibus ab ipsis preter consuetum tributum panes et vinum reciperetis et recipi faceretis incessanter et per hoc ipsos quadam abusione et novitate adinventa nimium aggravateris - ZW. II. 532-533.

237 F. IX/5. 487-489. Vö. 1380: AT WStLA HAUrk 979. (In: monasterium.net, URL <http://monasterium.net/mom/AT-WStLA/HAUrk/1005/charter> [utolsó letöltés: 2017. 08. 03.] (különösen rossz kiadása: F. IX/5. 384-386.). Vö. 1366: nec tributarii ipsos mercatores ad ampliorem tributi solucionem vel piperis aut alterius munusculi prestacionem compellere audeant modo aliquali imo neque a benevole dantibus ipsa munera recipere presumant ne in consuetudinem deducatur et ex hoc tandem ipsi mercatores successive infestentur - DF 258 545: 092-090.; Teleki, Huny. X. 376-377.

${ }^{238}$ Bogdán I.: Magyarországi hossz- és földmértékek 79. 
meghamisították a hajófenék mérésére szolgáló mértéket (vagyis a bevettnél rövidebb mértéket alkalmaztak): ${ }^{239}$ a vámösszeget ugyanis a király 1366. évi rendelkezéseinek megfelelően a hajófenék szélességétől és a rakománytól függően kellett kiszabni. ${ }^{240}$

A vám megfizetését bizonyító, a kereskedőnek adott igazolással (pecséttel) a Lajos korban a harmincadvám esetében találkozunk - sajnos nem magyar területen, de a hasonló gyakorlat legalábbis feltehető. László (Vlad) havavalföldi vajda és szörényi bán 1368-ban Lajos kérésére garantálta, hogy a Havasalföldön - a brăilai kivételével - bármelyik úton ${ }^{241}$ áruikkal átutazó brassóiak a vajdának két harmincaddal tartoznak: egy tricesimával odafelé, Hosszúmezőnél (Câmpulung, ma Románia, a Déli-Kárpátok lábánál, a Brassót Havasalfölddel összekötő Törcsvári-hágó déli nyílásánál) a másikkal visszafelé, a Duna átkelőjénél(?) (circa Danubium). A vám megfizetését követően a harmincados pecsétjének birtokában (sigillo tricesimatoris nostri recepto) szabadon átkelhettek Lajk földjén. ${ }^{242}$ Egy 1439. évi adat szerint az esztergomi és a dorogi vámot kifizetők az ottani vámosoktól more solito szintén pecsétet(?) (signetum) kaptak. ${ }^{243}$

Aki fel volt mentve az adott vám fizetése alól, ${ }^{244}$ annak ezt az előjogát igazolnia kellett. Forrásaink elég kevés támpontot adnak arra nézve, hogy ez a gyakorlatban hogy történt: késő középkori (16. századi) adatok alapján a vámmentességre jogosító kiváltságlevél, vagy - ha a kereskedő polgár volt - az illető város pecsétjének felmutatásával. ${ }^{245} \mathrm{~A}$ dolgot természetszerüleg nem úgy kell elképzelnünk, hogy például a városi kereskedők a - jobb esetben - féltve őrzött, vámmentességüket is garantáló városprivilégiumot hordták volna magukkal. Lajos 1367-ben a Lajta és a Rába közti terület vámbirtokosainak kimondottan megtiltotta, hogy a soproniaktól felmentésük igazolására az eredeti (primordialis), erre jogosító kiváltságlevelet követeljék. Helyette hitelt kellett adniuk a nekik szóló, a soproniak kiváltságának tényét és hatályát kivonatoló királyi parancsnak, ${ }^{246}$ ami voltaképpen menlevélként szolgálhatott, ahogy a hasonló uralkodói mandátumok is, például a

\footnotetext{
${ }^{239}$ Wenzel, Dipl. Eml. III. 73-74.

240 DF 258 545: 092-090; Teleki, Huny. X. 376-377.

${ }^{241}$ A Câmpulungnál elágazó út Târgovișten, Târgşorun, Gherghiţan, Buzăun keresztül vezetett Brăilaba. A másik út Argeșen, Piteștin, Slatinán és Turnun keresztül vitt Nikápolyba, illetve Slatináról el lehetett jutni Olteniaba és Vidinbe. Rădvan, L.: At Europe's Borders 223.

242 ZW. II. 306-307.

${ }^{243}$ quicumque vero mercatorum et aliorum hominum ad predictum Strigonium vel ad Dorogh accesserint tales ibidem persoluto tributo et signeto tributariorum more solito pro se recepto - Bp. III/2. 313-314.

${ }^{244}$ Vö. Vámmentességek c. fejezet.

245 Weisz B.: Vámok és vámszedés 41.

${ }^{246}$ nec eciam ipsos ad exhibendum primordialia eorum instrumenta super presmissa tributaria relaxacione eis ut premittitur graciose concessa nuncque per eosdem coram nobis exhibita cogere ausi sitis sed semper exhibicionem presencium plenam fidem habentes per omnia debeatis contentari - DF 201829.
} 
Nagyszombatra költözők vámmentességét garantáló 1360. évi királyi oklevél. ${ }^{247}$ A Zsigmond korban ezek között már névre szóló oklevelekkel is találkozunk: 1418. február 20-án Zsigmond, a pozsonyiak vámmentességére hivatkozva, a Trelesch András pozsonyi polgártól és kereskedőtől, 1429. május 1-jén pedig a Langwiser Lénárttól történő vámszedést tiltotta meg. ${ }^{248}$ Arra is találunk példát, amikor a vámon megkérdőjelezték a felmentő oklevél hitelét: 1506-ban László bártfai polgár megrakott szekerével útban Kassa felé a somosi vámon felmutatta vámmentességét ${ }^{249}$ igazoló iratát (litteras suas ostendisset, quod ipse esset liber), amiről a helyszínen azt mondták, „hogy azt a levelet ... kutya és lator írta”, nem érvényes. ${ }^{250}$ A rágalmazási ügy ${ }^{251}$ Storkel Lénárt és Volgeroth György bártfai esküdtek panasza nyomán a sárosi megyei ítélőszék elé került. ${ }^{252}$

A vámfizetés alól mentesítő kiváltságokkal persze valóban vissza lehetett élni, így a vámfizetés elkerülésének egyik útja-módja - némileg paradox módon - éppen a vámhelyeken át vezetett. Akadtak ugyanis olyan kereskedők, akik vámmenteségüket (nyilvánvalóan némi ellentételezés fejében) kihasználva hajlandóak voltak vámfizetésre kötelezett személyeket átjuttatni, vagy áruikat átcsempészni a vámokon. A jelenség jól illusztrálható az 1291 óta országos vámmentességgel rendelkező pozsonyi kereskedők példáján. Tudjuk, hogy a 14-15. században a pozsonyiak útjába eső vámhelyek, Bazin, Bodak, Hédervár és Öttevény vámbirtokosai és -szedői kifejezetten ügyeltek arra, hogy ezt a kiskaput zárva tartsák: 1430. március 3-án Hédervári Lőrinc összes vámszedőjét, főleg a bodakit, a hédervárit és az öttevényit figyelmeztette: ügyeljenek arra (cauentes tamen et perspicaciter revidentes), nehogy a pozsonyiak vámmentességük örve alatt tacite ac sub silencio árukkal utazó külföldieket (extraneos) vigyenek magukkal. ${ }^{253}$ A pozsonyiak és a bazini nemesek közti vámpert lezáró, a pozsonyi káptalan által írásba foglalt 1384. évi megállapodásban a polgárok vámmentességük elismeréséért cserébe garantálták, hogy a városi bíróság büntetését vonja magára közülük az, aki a város szabadságaival nem élő idegent visz a bazini vámhoz, vagy azt a személyt ráadásul átjuttatja rajta, amennyiben ezt törvényesen rá tudják bizonyítani. 254

\footnotetext{
${ }^{247}$ quatenus de illis hominibus qui cum omnibus bonis et rebus eorum de quibuslibet partibus regni nostri aut aliis regnis extraneis commorandi causa in civitatem nostram Tirnaviensem presencium testimonio se transferunt nullum tributum nullamque tributariam exaccionem exigere vel exigi facere presumpmatis - DF 279571.

${ }^{248}$ DF 239386 (ZsO. VI. 1526. sz.); DF 239500.

249 quod ipse a solucione theoloni liber esset - DL 57851.

${ }^{250}$ quod istas litteras ... canis et latro scripsisset - DL 57850.

251 Az oklevél hátlapján későbbi kéz írásával: dehonestatoria accio. DL 57850.

252 DL 57 850, DL 57 851. Az oklevelekre Kádas István hívta fel a figyelmem, szívességét ezúton is köszönöm.

${ }^{253}$ Kováts F.: Dunai hajózás 470.

254 e converso vero assumpmentes predicti cives Posonienses quod si aliquis ex ipsis aliquam alienam personam non utentem libertate dicte civitatis Posoniensis secum duceret ad locum tributi in dicta Bozen nomine libertate ipsius civitatis et asserens ipsam personam alienam frui libertate eiusdem civitatis seu eciam ipsam personam
} 
A héderváriak vámszedőihez intézett parancs a kihágást elkövetők javainak elvételét és városi bíróság elé állítását helyezte kilátásba. ${ }^{255}$ A pozsonyiak efféle „szolgáltatásait” igénybe vevőket - amint arról Zsigmond király 1430. évi okleveléből értesülünk -, miután megfosztották javaiktól, szélnek eresztették. ${ }^{256}$

\section{VÁMMENTESSÉGEK}

A vámfizetés alóli felmentés lehetett országos érvényü, területileg vagy árucikk szempontjából korlátozott, valamint találkozunk alkalmi mentességekkel is. ${ }^{257}$ 1354-ben országos, a száraz- és a vízi vámokon is érvényes vámmentességet kaptak Piast Erzsébettől Óvár/Vári(?) ${ }^{258}$ királynéi villa/civitas polgárai és hospesei, akik Buda szabadságaival élhettek. ${ }^{259} \mathrm{~A}$ csak egy adott területre érvényes felmentésre jó példa a kolozsváriak a király által 1353-ben megerősített erdélyi vámmentessége, ${ }^{260}$ az árucikk szempontjából korlátozottra pedig I. Lajos 1363. évi kiváltsága, amivel építőanyagot (fát, cementetet, követ) a városukba szállító nagyszombatiakat, valamint Gerencsér, Magyarád, Szili és Parna lakóit perpetuo mentesítette a vámfizetés alól. ${ }^{261}$ A király sokszor biztosított alkalmi vámmentességet egyegy birtok vagy város benépesítése érdekében. 1347-ben a somogyi Gyugy királyi birtokra

alienam ultra ipsum locum tributi in Bozen fraudulenter deduceret et ubi id contra ipsum civem Posoniensem alienam personam deducentem legitime possent approbare extunc iidem iudex et iurati cives in Posonio et in futurum constituendi eundem concivem ipsorum modo premisso repertum punire teneantur iusticia predicte civitatis Posoniensis mediante - DF 239 039, DL 7078.

${ }^{255}$ Kováts F.: Dunai hajózás 470.

${ }^{256}$ si qui vero forsitan ex eisdem civibus et hospitibus nostris Posoniensibus huiusmodi extraneos et forenses homines eorundemque res et mercimonia in eorum societate aut in curribus secrete occulte et celative conducere et portare conarentur et presumerent extunc omnes tales tam videlicet conductores quam eciam conducti qui ultra unius anni spacium reperti fuerint perdicionem et ammissionem omnium rerum et bonorum apud eos tunc reperiendorum prefatisque Philippo Pokkl et domine Walpurge prolibusque eorundem prenotatis dandarum et assignandarum incurrant eo facto - DF 239 513, DF 239512.

${ }^{257}$ Weisz B.: Vámok és vámszedés 42.

${ }^{258}$ Azonosítása bizonytalan. DL 4470-ben (F. IX/2. 324-327.) a kiváltságolt királynéi falu Owuar ... villa nostra (sc. reginalis) alakban szerepel. Az adatot Csánki a Moson megyei Óvárhoz kötötte (Csánki III. 676.). DL 4471ben (újkori átírás), aminek szövege nagymértékben hasonlít DL 4470-éhez Erzsébet átírt oklevelében Vary ... civitas nostra szerepel. Utóbbi oklevél Várija a Bereg megyei Várival azonosítható, mivel a kérdéses irat szerint a váriak 1479-ben Beregszásszal pereskednek bizonyos Czytikfölde predium miatt (MOL-regeszta), ami talán inkább Czybikföldének olvasható (DL 4471_4), ami a Bereg megyei Vári mellett található (Gy. I. 536.).

259 committimus eciam ut ipsi cives seu hospites nostri de Owuar nullas in regno nostro Hungarie tam in terris quam in aquis tributum dare et solvere teneantur - DL 4470 (F. IX/2. 326.); committimus eciam ut ipsi cives et hospites nostri de Vary nullum in regno nostro Hungarie tam in terris quam super aquis tributum dare et solvere teneantur - DL 4471.

260 item concessimus eciam eisdem hospitibus nostris quod intra terminos parcium Transsilvanarum tam in civitatibus quam eciam in aliis locis de mercibus et rebus ipsorum nullum tributum solvere tenebuntur $-\mathrm{ZW}$. I. 320. 1353: ZW. II. 96-97.

${ }^{261}$ quod ipsi de lignis de cemento de lapidibus per eosdem ad dictam civitatem undecunque deferentibus a solucione cuiuslibet tributi perpetuo exempti haberent nullumque tributum nullamque tributariam exaccionem de eisdem rebus iamnominatis solvere tenerentur - DF 279 577. Vö. Lexikon stredovekých miest 525. 
költözőktől, ${ }^{262}$ 1360-ban a Nagyszombatra bel- vagy külföldről letelepedés céljából utazóktól (commorandi causa ... se transferunt), ${ }^{263}$ 1368-ban az osztrák területekröl Sopronba áttelepülőktől történő vámszedést tiltotta meg. ${ }^{264}$ Más esetekből úgy tünik, a király tulajdonképpen a külföldről betelepülők és az országban egyik helyről a másikra átköltözők általános vámmentességének biztosítására törekedett. 1360-ban úgy rendelkezett, hogy „Ausztria, Csehország vagy bármilyen más külföldi területek lakóitól, népeitől vagy jobbágyaitól, akik az országba, a király, a királyné, a prelátusok, a bárók vagy a nemesek vagy mások városaiba és birtokaira családostól, javakkal a költözés szándékával érkeznek, vagy a királyságban egyik városból vagy birtokról a másikra költöznek, ... ne szedjenek semmilyen vámot és harmincadot”. ${ }^{265}$ Az intézkedés a soproni városi levéltárban fennmaradt egyik királyi parancslevélből ismert, és leginkább egy országos rendelkezés helyi interpretációjának tünik. A külföldről beköltözők vámmentessége az 1366. évi dunai vámtarifában $^{266}$ és a király egyik 1371 . évi rendeletében is szerepelt. ${ }^{267}$ Más volt a helyzet azokkal, akik elköltöztek a királyságból: tőlük 40 dénárt kellett szedni. ${ }^{268}$ A 40 dénáros „költözésvám” a néhány évvel korábban (1355) rögzített pécsújfalusi (Sáros megye) vámtarifában is feltünt, ami szerint azoktól, ,akik családjukkal egyik birtokról a másikra költöztek" (a transferentibus se cum familia de una possessione ad aliam), 40 dénár vámot szedtek.

Ugyancsak az alkalmi vámmentességek biztosításának esetei közé sorolható a király 1357. évi parancsa, amivel Losonci Dénes fia Tamás fia Tamás udvari lovag losonci curiájába szállított ellátmányának (victualia diversarum rerum in animalibus et aliis necessariis) vámolását tiltotta meg a vámszedőknek Erdélytől Losoncig. ${ }^{269}$ 1376-ban Szencsei Pál, Garai

\footnotetext{
262 volumus eciam ut in nullis locis tributorum a jobagionibus seu populis dictam possessionem nostram venire volentibus tributum aliquod exigatur - DL 3890 (AO IV. 24.).

263 DF 279571.

264 ab hominibus de partibus Austrie in civitatem nostram Soproniensem causa commorandi venientibus et de rebus bonis ac domorum utensilibus eorundem ac curribus in quibus ducuntur et ad ipsos spectantibus presencium exhibitoribus in adventu ipsorum nullum tributum nullamque tricesimam recipere vel exigi facere audeatis sed eos simulcum ad se pertinentibus curribus et rebus suis per loca vestra transire permittatis libere et pacifice - Házi I/1. 147.

265 ab incolis populis seu iobagionibus de Austria seu Bohemia vel de aliis quibuscunque partibus extraneis ad regnum nostrum et ad civitates seu possessiones nostras regales et reginales ac prelatorum baronum nobilium cum eorum familia rebus atque bonis commorandi causa venientibus vel de una civitate et possessione ad aliam in partibus regni nostri se transferentibus quaquam temeritatis audacia tributum seu tributariam et tricesimariam exaccionem petere exigere recipere audeat vel presumpmat sed tales iobagiones et incole ab omni solucione tributorum et tricesimarum perpetuis temporibus absoluti habeantur penitus et exempti - Házi I/1. 123.

266 statuimus eciam ut nullus a ... hominibus in regnum nostrum causa commorandi cum uxoribus liberis et familia venientibus tributum recipere presumat - Teleki, Huny. X. 376-377.

267 1371: DF 238873.

268 1366: de hominibus autem de regno nostri causa residencie exeuntibus quadraginta denarii exigantur pro tributo - Teleki, Huny. X. 377.

${ }^{269}$ Bánffy 214-215.
} 
Miklós óvári várnagya írt minden vámszedőnek és harmincadosnak Nyentől Óvárig. A menlevélben a várnagy Garai Miklós nádor kérését tolmácsolva arra kérte a címzetteket, hogy a fákat (de una strue lignorum), amiket a nádor házainak építéséhez visznek Visegrádra, illetve az épületfák szóban forgó levelét felmutató szállítóit ne vámolják és harmincadolják meg. ${ }^{270}$

A Lajos-korban úgy tủnik, nem volt jogszerü áru nélkül utazó gyalogosokat (pedites) vagy lovasokat (equites) megvámolni. 1344-ben a király megtiltotta, hogy a „régi szokás ellenére” Szinán, Középnémetiben és Somoson vámolják a gyalogosokat (de peditibus contra veterem consuetudine tributum exigere inceperant). ${ }^{271}$ Somoson az eperjesiek és a kisszebeniek panaszára I. Lajos 1381-ben is megtiltotta a gyalogosoktól való vámszedést. ${ }^{272}$ A király 1360ban, 1365-ben és 1366-ban fellépett a gyakorlat ellen, cum igitur hoc inconveniens sit et iniustum, hogy a lóháton közlekedő (equites) nagyszombatiakat a vámhelyeken megvámolják. $^{273}$ Egy 1371. évi királyi oklevél megtiltotta az áruk nélkül (sine rebus mercimonialibus) útra kelő, és magukkal vitt dolgaikat nem eladásra, hanem saját felhasználásra szánó (non causa mercimonii (sic!) sed pro eorum usu) világi papok, szerzetesek, gyalog vagy lóháton utazó zarándokok és egyszerü országlakosok (ceteri in(co)le et habitatores regni nostri hinc inde de loco ad locum sine rebus mercimonialibus suos gressus pedes simpliciter facientes) vámolását - csak csak a réveknél kellett fizetniük az átkelésért (ab omni solucione p(ed)agii seu cuiuslibet tributi exaccione tam in terris quam in pontibus (sic!) semper salvi liberi et perpetuo exempti habeantur navigio solum ex(ce)pto). ${ }^{274}$

Nagyjából ezt a képet mutatják az ismert vámtarifák tételei is: a bihari (rév)vámtarifa (1343) alapján a gyalogosok ott semmit nem fizettek (és az üres szekerek sem); Pécsújfalun 1355-ben - valószínüleg jogtalanul - a gyalogosoktól és a zarándokoktól is 1 dénárt szedtek, és 1 újabb dénárt, ha a vámhelyen történő áthaladást követő nap nem tértek vissza, csak a harmadik napon vagy később; a somosi tarifa (1373) szerint a málhát nem szállító lovasnak vagy gyalogosak és az üres szekereknek nem volt vámfizetési kötelezettsége; Privigyén (1383) a gyalogos, aki nem vitt semmit, vámmentes volt, a terhet cipelő gyalogostól azonban 1 dénárt szedtek. ${ }^{275}$

Az egyháziak a vizsgált időszakban a személyüket illetően, úgy tủnik, vámmentessek voltak - úgy a világi papok, mint a szerzetesek. A kegyes céllal útnak induló zarándokok

\footnotetext{
${ }^{270}$ DF 238940.

${ }^{271}$ DF 287 451_7. (Anjou-oklt. XXVIII. 814. sz.).

272 DF 228 497. (Iványi, Eperjes 39. [93. sz.]).

273 1360: DF 279 572; 1365: DF 279 573, DF 279 574; 1366: DF 279575.

274 1371: DF 238873.

${ }^{275}$ Vö. Vámtarifák c. fejezet.
} 
szintén. A király 1371. évi, már említett rendelete szerint a réveken az átkelésért azért fizetniük kellett. ${ }^{276}$ 1355-ben a sárosi vámvizsgálat a tapasztalt jogtalanságok között kitért arra, hogy Eperjesen a szerzeteseket is vámolták. ${ }^{277}$ Pécsújfalunál ugyanekkor a zarándokoktól is 1 dénárt szedtek vámként. ${ }^{278}$ 1357-ből fennmaradt (másolatban) a király a karthauzi rend számára kiállított kiváltságvele, ami mentesítette a rend fratereit, jobbágyait, a birtokaikra költözőket, gondnokaikat, adminisztrátoraikat, a saját és a rend ügyeiben eljáró szerzeteseket a vámfizetés alól. A saját ruházkodásukra szállított posztó és ellátásukhoz szükséges élelmiszer után sem kellett fizetniük. Egyedül jobbágyaik tartoztak vámmal akkor, ha áruikat szállították. ${ }^{279}$ A királyon kívül a pápa is garantálhatott egy adott rendnek mentességet - kérdés, mennyi foganattal. 1385-ben az óbudai klarisszák mindenesetre átíratták a győri káptalannal VIII. Bonifác pápa 1296. évi bulláját a rendjüknek biztosított vámmentességről. ${ }^{280}$ Egy gondolat erejéig visszatérve a karthauziak kiváltságlevelére, a posztókra vonatkozó része hasonló a pozsonyi és a soproni királyi polgárok 1364. június 11-i privilégiumaihoz. A király ekkor a harmincadfizetés alóli mentesítette a városiakat eladandó élelmiszereik - „amik nélkül egy város sem tud létezni” - és saját háztartásaik szükségletére bárhonnan (de quibuslibet Regnorum partibus) a városba vitt (feltehetően import)posztót illetően. Az eladásra szánt posztók után a tricesimát le kellett róni. ${ }^{281}$ A monostorok népeinek vámmentességét illetően figyelemre méltó a garamszentbenedeki bencés apát (és a király) 1380-ban tett megnyilvánulása falvai jobbágyainak az esztergomi érsek keresztúri vámjánál (Bars megye) történő rendszeres vámolása kapcsán. Az apát a vámszedést azért minősítette

\footnotetext{
276 1371: omnes persone ecclesiastice tam regulares quam seculares cuiuscumque ordinis status vel dignitatis existant necnon omnes peregrini ad limam beatorum apostolorum vel aliorum sanctorum intra vel extra confinia regni nostri causa devocionis eques vel pedes proficiscentes ... ab omni solucione $\mathrm{p}(\mathrm{ed})$ agii seu cuiuslibet tributi exaccione tam in terris quam in pontibus semper salvi liberi et perpetuo exempti habeantur navigio solum ex(ce)pto - DF 238873.

${ }^{277}$ nam in ipsa Epperies eciam a monachis exegissent tributum et eos suis rebus dampnificassent - Draskóczy I.: Sáros megye vámhelyei 60.

278 Vö. Vámtarifák (Pécsújfalu).

279 universos fratres predicti ordinis Cartusiensis itemque iobagiones eorumdem ubique in regno nostro constitutos et homines ad ipsos et possessiones eorum causa commorandi undecunque confluentes nec non cunctos eorumdem curam gerentes administracionem habentes quocunque in ipsorum fratrum et propriis negociis proficiscentes exceptis duntaxat iobagionibus eorum cum mercimoniis publicis procedentibus a solucione cuiuslibet tributi in quibuscunque partibus regni nostri et personis et bonis eorum facienda perpetue exemimus abstraximus liberavimus libertatosque et exemptos presencium serie perpetuis temporibus pronunciamus ex speciali gracia libertatis regie maiestatis ita quod ipsos fratres ordinis Cartusiensis et iobagiones eorum universos ac sequaces et ministros undecumque vel ex quibuscunque partibus seu provinciis regni nostri cum eorum rebus et bonis victualibus et pannis pro indumentis ipsorum fratrum et aliis omnibus necessariis et eorundem iobagionum propriis deferendis preter mercimonia iobagionum proficiscantur ac ab exaccione tributaria liberos et exemptos sic esse volumus ut nil penitus telonii seu tributi in eundo vel redeundo super ipsos exigi valeat per quempiam vel imponi - DL 36776.

280 ac ad exhibendum pedagia telonia et alias exacciones quibusvis regibus principibus seu aliis personis secularibus minime teneamini nec ad id aliquatenus valeatis - DF 283 416. (Bp. III/1 11.).

281 1364. június 11.: F. IX/3. 389.; Házi I/1.130-131.
} 
törvénytelennek „mivel a mondott jobbágyok az említett vámot soha nem szokták fizetni, hanem a király ottani jobbágyainak módjára mentesek alóla”. ${ }^{282}$

Az egyházak mint birtokosok a nemesekhez hasonlóan szabadon szállíthatták (szállíttathatták jobbágyaikkal) birtokaik között, azok ellátására az élelmiszereket. Az erre vonatkozó általános „szabály” a király veszprémvölgyi apácáknak kiállított 1364. évi oklevelében a következőképpen szerepel: cum de victualibus nobilium et aliorum possessionatorum hominum que de una possessione ipsorum ad aliam possessionem vel ad alia loca mansionis eorundem deferuntur, tributum exigi non liceat aliquale. ${ }^{283}$ I. Lajos vonatkozó oklevele a veszprémvölgyieknek a bor, a gabona és a marhák vámmentes szállítását erősítette meg, 1389-ben a leleszi prépostnak adott hasonló oklevelében Zsigmond a victualia gyüjtőnév alatt az egyházak szabadságára (libertas ecclesiarum regni nostri requirente) hivatkozva marhák, takarmány és gabona vámmentes szállítását tette lehetővé. ${ }^{284}$ 1363-ban I. Lajos az óbudai klarisszák birtokairól az apácák fenntartására (pro sustentacione) szárazföldi vagy vízi úton vitt élelmiszerek és szállítóik vámmentességét biztosította. ${ }^{285}$

A nemesek birtokai közötti vámmentes élelmiszerszállításra 1381-ből vehetünk példát: ekkor a király megtiltotta a vámosoknak Gyulai Miklós fia Mihály egyik birtokáról a másikra szállított élelmiszerei (és szállítói) vámolását. ${ }^{286}$

Több példa hozható a 14. század második feléből a királyi, illetve a királynéi udvarba igyekvők vámmentességének biztosítására. 1363-ban Lajos - mint nem illő dolgot (sicut non decet) - megtiltotta, hogy akárki vámot (és harmincadot) szedjen a soproniaktól, amikor ajándékaikat és adóikat szálltják a királyi udvarba. ${ }^{287}$ Zsigmond 1389. évi, hasonló rendelkezésével szintén biztosította a királyi udvarba ajándékokat - és kiemelten az újévi ajándékot - vivő soproniak vámmentességét. ${ }^{288}$ I. Lajos 1378. évi rendelete szerint a szebeniek a király vagy a királyné elé küldött követeitől (de ... ambasiatoribus seu nunciis specialibus) sem lehetett vámot követelni - abban az esetben legalábbis, ha a küldöttek áruk nélkül indulnak útnak. ${ }^{289}$ 1391-ben pedig, amikor a szebeniek, a szászok hét székét is képviselve, beszámoltak Zsigmondnak a vámhelyeken őket ért különböző sérelmekről, az is előkerült, hogy a király vagy a királyné udvarába „ügyintézni” igyekvő polgárokat (illetve

\footnotetext{
${ }^{282}$ cum tamen dicti iobagiones iamdictum tributum nunquam persolvere assuetissent sed ad instar iobagionum nostrorum regalium illius partis exempti haberentur - DF 237194.

${ }^{283}$ VVOS 272.

${ }^{284}$ DF 233986.

285 DL 5189.

${ }^{286}$ DF 259876.

${ }^{287}$ Házi I/1. 130.

${ }^{288}$ Házi I/1. 224. (ZsO. I. 875. sZ.).

289 ZW. II. 488-489.
} 
követeiket), valamint az uralkodópár ajándékait vivőket is vámokkal sújtják - jogtalanul. ${ }^{290}$ 1376-ban I. Lajos a királyi vagy a királynéi udvarba lóháton, gyalogosan, illetve szekérrel ajándékok vagy ajándékok nélkül ügyeikben eljárni igyekvő báni (Trencsén megye) polgárokat (cives nostri de civitate nostra Baan vocata) mentette fel a vámfizetés alól amennyiben árukat nem visznek magukkal. ${ }^{291}$

1357. január 19-én annak érdekében, hogy a pozsonyi polgárok és az esztergomi káptalan időről időre kiújuló, az esztergomi vám miatti konfliktusainak véget lehessen vetni, a felek közt I. Lajos parancsára oklevél-bemutatásra került sor. A pozsonyiaknak vámmentességüket, a káptalannak pedig vámszedési jogát kellett igazolnia. ${ }^{292}$ A káptalan részéről Miklós honti főesperes IV. László király - Imre, III. Béla, II. András és IV. Béla kiváltságait tartalmazó privilégiumával állt elő. ${ }^{293}$ Eszerint az Esztergomon keresztül és a várost elkerülve, az innenső parton szárazföldi úton vagy a Dunán szállított dolgok (res) minőségének megfelelően szedett vám királyi adományból a káptalant és prépostját illeti. ${ }^{294}$ A bevételen a káptalan az Esztergom-előhegyi Szent Tamás-prépostsággal, továbbá az esztergomszigeti apácákkal osztozott. ${ }^{295}$ A pozsonyiak vámmentességük bizonyítására I. Károly második nagypecsétje alatt átírt és megerősített, első pecsétje alatt kiadott kiváltságlevelét mutatták be, ${ }^{296}$ amely minden bizonnyal III. András 1291-ben kiadott, kereskedőik országos vámmentességét (is) biztosító városi kiváltságlevele ${ }^{297}$ 1313-ban kelt megerősítő oklevelének $^{298}$ az uralkodó új pecsétje alatt átírt, 1323. évi megerősítése lehetett. ${ }^{299}$ A király

\footnotetext{
290 cumque etiam praefati cives et hospites nostri aut nuncii seu ambasiatores eorum aliqui ad nostram vel reginalem maiestates in factis et necessitatibus ipsorum venire voluerint $[\ldots]$ ex tunc praefati tributarii super ipsos et a [...] clenodiis seu muneribus nostrae vel reginali maiestatibus per ipsos portandis et exhibendis [...] tributariam exactionem peterent, reciperent et indefesse extorquerent - ZW. III. 9. Zsigmond az oklevelet a szebeniek kérésére még ebben az évben kiadta újra (ZW. III. 27-29.), majd 1397-ben (ZW. III. 187-190.), 1404ben (ZW. III. 315-317.) és 1405-ben is (ZW. III. 334-337.), ezenkívül még ismert belőle egy 1393. évi, a szebeniek és a hét szász szék folyamodására Szécsényi Frank erdélyi vajda által kibocsátott példány (ZW. III. 65-67.). A felsorolt oklevelek szövege lényegében megegyezik, nagyobb eltérés csak a vajda által kiadott példány szövegében figyelhető meg, miután Szécsényi Frank az rendelkezéseinek betartatását értelemszerüen csak a vajdai joghatósága alatt álló területekre nézve garantálhatta. Az uralkodó az oklevelet 1391-ben (ZW. III. 13-16.) és 1395-ben (ZW. III. 120-123.) a brassóiak részére is kiadta.

${ }^{291}$ quatenus dum et quando providi viri iudex iurati et cives nostri de civitate nostra Baan vocata vel aliqui ex eis eques vel pedes aut in curribus cum muneribus vel sine muneribus pro eorum exequendis negociis nos et dominas reginas genitricem et consortem nostras carissimas venerint visitaturi dummodo res mercimoniales secum non deferant ipsos per loca dictorum tributorum testimonio sub presencium transeuntes in nullo molestari pacifice et absque aliquali tributaria sew quavis alia exaccione libere abire et transire permittatis - DL 6340.

${ }^{292}$ F. IX/2. 568-569.

${ }^{293}$ DF 237 234. (F. IX/2. 569.). A káptalan kiváltságleveleire lásd Weisz B.: Vámok és vámszedés 137-140.

294 tributum quod de quibuslibet rebus, quae per Strigonium, vel extra prope cis et citra, per terram vel per Danubium quoque deferuntur, iuxta qualitatem rerum delatarum exigitur - F. IX/2. 569.

${ }^{295}$ F. IX/2. 569.

${ }^{296}$ F. IX/2. 569.

297 Juck 75-76. (Reg. Arp. 3837. sz.).

${ }^{298}$ DF 238 656., F. X/7. 762-763. (Anjou-oklt. III. 644. sz.).
} 
az ítélethozatal során egyrészt a káptalan számára annak idején tett adomány alamizsna mivoltát mérlegelte, másrészt, ami ennél is fontosabb, miután prelátusaival és báróival tisztázta, melyik kiváltság a korábbi (de prioribus prior speculatio habeatur) - a felmutatott oklevelek alapján: az esztergomi káptalané -, megállapította, hogy annak a későbbi adomány, tudniillik a pozsonyiaké, nem érvénytelenítette (priori donationi posterior praeiudicare minime videatur), a jogvitát az esztergomi káptalan javára döntötte el. ${ }^{300}$

Az esztergomi vám iménti ügye két egymásnak ellentmondó, vámszedési, illetve mentességi jogot biztosító kiváltság ütközését és az emiatt kialakult, elhúzódó konfliktushelyzet feloldásának egy lehetséges módját demonstrálja - azaz a két előjog közül a régebben adományozottat kell érvényesnek tekinteni. ${ }^{301}$

A jogelv, amely a római jogban qui prior est tempore, potior est iure formában volt ismert, ${ }^{302}$ Werbőczy Hármaskönyvében (1514) is megtaláható: „A mennyiben tehát a kiváltság a fejedelem kizárólagos hatalmából ered, mint például a birtokjogok adományozása, a vám és harminczad fizetése alól való mentesítés a szabad vásár és közönséges sokadalom, a rév és vám adományozása a mi egyedül a fejedelmet illeti, azt mindig meg kell tartanunk, hacsak másoknak nyilván sérelmére nincsen. Éppen ezért az ilyen kiváltságlevelek végére ezt a záradékot: «salvo jure alieno» mindig be szokták tenni és iktatni. Mert ha valamely paraszt embert, avagy várost, maga a fejedelem a vámfizetés alól jelenben fölmentene is, szabadsággal megajándékozna, holott megelőzőleg hívei közül valakinek az igazságos vámszedést már eladományozta, akkor az utóbbi, tudniillik: a felmentő kiváltság, mivel a vámszedésről kiadott előbbi kiváltságot nyilván sérti, az elsőt meg nem erőtlenítheti és az ilyen vámszedést el nem törölheti. De a kiváltságot adó fejedelem fekvő jószágaira és vámjaira nézve az ilyen fölmentés megáll és helyén marad”. ${ }^{303}$ Tehát II. Ulászló király idején

299 DF 238 664., F. X/7. 762-765. (Anjou-oklt. VII. 91. sz.). Az 1357. évi ítéletlevél ugyan nem ejt szót III. András okleveléről, sőt a kiváltságot Károly kegyének tulajdonítja, azonban sokat sejtető, hogy az 1323 . évi oklevelet I. Lajos Jakab pozsonyi bíró és néhány esküdt kérésére éppen az oklevél-bemutatást megelőző nap, január 18-án írta át és erősítette meg (DF 238 757.). Kovács V.: A pozsonyiak vámmentessége 345-346., 350.

${ }^{300}$ DF 237 234. (F. IX/2. 570.).

${ }^{301}$ Vö. Petrik I.: Vámkonfliktusok 234-235.; Tringli I.: Pest megye 129-130.

302 Petrik I.: Vámkonfliktusok 234-235.

303 Werbőczy: Hármaskönyv 178. Duplex est autem privilegii consideratio scilicet in quantum ex mera principis authoritate riteque \& legitime procedit. Et inquantum non sed in damnum aliorum vergit vel alias constitutioni communi derogare videtur. [\$1] Inquantum igitur privilegium ex mera principis authoritate procedit prout iurium possessionariorum Donatio a tributaria tricesimarumque solutione exemptio, Fororum liberorum ac nundinarum generalium Vadorumque \& tributorum collatio quę ad solum principem spectat semper observari debet dummodo iuribus aliorum manifeste non preiudicet. [§2] Et propterea in calce huiusmodi privilegiorum clausula ista semper apponi inserique solet SALVO IURE ALIENO. [§3] Nam si princeps ipse quempiam hominem ruralem vel civitatem a solutione tributorum de presenti eximeret \& libertate donaret prius tamen tributariam exactionem iuste fiendam alicui fidelium suorum contulisset tunc per istud posterius privilegium scilicet exemptionale quia priori privilegio super tributo confecto palam preiudicaret primum invalidare $\&$ huiusmodi 
- a vámoknál maradva - elvileg hiába adományozott az uralkodó egy személynek (vagy testületnek) vámmentességet, az előjog a kiváltságlevél kibocsátásának idején csak a királyi vámokon volt érvényesíthető; nem tartották érvényesnek a magánvámok tekintetében, mivel a fentiekből logikusan adódóan - kiadásának elvi pillanatában minden vámszedési jog régebbi volt nála. Kérdés, miképp illeszkedtek ebbe a „rendszerbe” a régi, korábbi uralkodók által biztosított, de az újabb és újabb uralkodói megerősítések révén meg-megújuló érvényre szert tevő, nem csak a királyi vámok fizetése alól mentességet adó kiváltságok. Hogyan fért össze a korábbi adományok elvével ${ }^{304}$ a tény, hogy a vámszedés a középkorban, amint azt Werbőczy is kimondta, „a fejedelem kizárólagos hatalmából” eredt, vagyis regálé, uralkodói felségjog volt?

Az Anjou-kor első felében a jogelv a hetivásár-tartási engedélyekben egyértelmü kifejezést nyert, alkalmazták az egymást tönkretevő, közeli vásárok tartói közti viták eldöntésére, és expressis verbis hivatkoztak rá birtokperekben. A jogelv úgy azonos, mint különböző jogcímen - királyi vagy magánadomány (örökül hagyás; tartozás birtokkal való kiegyenlítése; hitbér és jegyajándék, leánynegyed birtokban történő kiadása; zálog), vétel - követelt birtokok, birtokrészek miatti jogvitákban is feltünt. A Lajos-kori és későbbi adiudicatoriak formulává redukálódott ítéletindoklásaival szemben e korábbi birtokvitákban a jogelv figyelembe vételével történő ítélkezés mikéntje jobban megragadható. A jogelv megtörése a perbeli ellenfélénél korábbi oklevél felmutatásával - tehát korábbi jogcím igazolásával -, vagy pedig a régebbi kiváltság/adomány érvénytelenítésével volt lehetséges. A 14. század '40-es éveitől a korábbi adományok elvének formulája a „posterior donacio priori aliquod preiudicium generare non potest” formában (és változataiban) állandósult, de kivéletesen előfordulhatott az is, hogy a bevett formulát a konkrét ügy sajátosságaihoz igazították. ${ }^{305}$

1295-ből maradt fent az első oklevél, amely a jogelv vámperben történt alkalmazásáról tanúskodik, mégpedig az óbudai káptalan és a budai polgárok jogvitájában. ${ }^{306}$ A király, miután a káptalan előtte összesereglő kanonokai - Werner budai rector füle hallatára bepanaszolták a polgárokat a káptalan vámján elkövetett jogtalanságaik miatt, az ügy eldöntését október 18-án az udvarában időző Lodomér esztergomi érsekre bízta, aki október 20-ra meg is hozta ítéletét a felek oklevelei alapján. ${ }^{307}$ A budaiak védelmüket IV. Béla -

tributariam exactionem tollere non potest. [§4] Verum in bonis \& tributis propriis principis qui privilegium donavit exemptio ipsa tenebit atque locum habebit. DRMH V. 236.

${ }^{304}$ A jogelvre a továbbiakban ezt a - forrásokban elő nem forduló - elnevezést használom.

${ }^{305}$ Részletesen, példákkal illusztrálva lásd Kovács V.: Korábbi adományok elve 265-270.

${ }^{306}$ Bp. I. 296-298. Idézi: Weisz B.: Vámok és vámszedés 308-309.

${ }^{307}$ Bp. I. 296-297. 
eredetileg a pesti hospeseknek adott - kiváltságlevelére (1244) eng $^{308}$ étették, ami az óbudai egyház sóvámját (és a harmincadot) kivéve minden vám fizetése alól mentesítette őket. A káptalan erre II. Géza privilégiumával (1148) ${ }^{309}$ állt elő, amelyben az uralkodó egyházuknak biztosította a Dunán borral és sóval felhajózó, illetve áruikkal lefelé tartó dunai hajók vámját; vagyis - érveltek - a polgárok nem csak a só után vámolhatók, továbbá hangsúlyozták, hogy a hajóvámot (ascendens tributum) ${ }^{310}$ a káptalan emberemlékezet óta zavartalanul birtokolta. Az érsek ítélethozatala során utóbbin (háborítatlan birtoklás) kívül két dolgot mérlegelt: azt, hogy „az egyházak és kegyes helyek részére tett uralkodói kedvezéseket nem csökkenteni, hanem növelni kell”; 311 illetve, hogy Béla király oklevelében nem említette, tehát semmilyen tekintetben nem is hatálytalanította a káptalan „„öbb mint száz évvel” korábban kapott kiváltságát. ${ }^{312}$ Habár Lodomér érsek ítéletlevelében a jogelv expressis verbis nem szerepel, döntését kétségtelenül erre alapozta.

Az Anjou-kor tekintetében elöljáróban elmondható, hogy a jogelvet egyrészt, amint az iménti esetben is, vámmentességi és vámszedési jog ütközésekor, másrészt olyankor alkalmazhatták - kimondva vagy kimondatlanul - a korábbi intézmény javára, amikor két-két vámhely, vízi átkelő vagy hetivásár kölcsönösen csökkentette egymás bevételét: így egymáshoz túl közel üzemelő, a kereskedők és utazók közlekedésére (is) szolgáló révek, vagy szomszédos, ugyanaznap tartott (heti)vásárok elszívták egymás forgalmát.

Jelen írás legelején előkerült, hogy az esztergomi káptalan 1357 januárjában sikerrel szállt szembe a pozsonyiakkal az esztergomi vámszedési jogáért. 1357 nyarán az esztergomi káptalan, a Szent Tamás-prépostság és az esztergomszigeti apácakolostor küldöttei némiképp talán az év eleji sikeren felbuzdulva - a vásárvám fizetésére 13 éve nem hajlandó (propria temeritate, soluere non curassent) esztergomi polgárok ellen is panaszt tettek I. Lajosnál. Az esztergomi egyházak jogigényüket, ahogy a januári perben, ezúttal is Imre, II. András, III. Béla, IV. Béla és IV. László királyok kiváltságleveleire alapozták; a legrégebbi adomány, amit segítségükkel tanúsítani tudtak, III. Béla 1188-ban foganatosított donatioja volt. A városiak a király előtt vámmentességükkel védekeztek, amiről IV. Béla privilégiumát mutatták be. ${ }^{313}$ A perből, miután a király ítéletét a jól ismert jogelvre alapozta, a későbbi

\footnotetext{
${ }^{308}$ EFHU 40. (Reg. Arp. 781. sz.). Vö. Weisz B.: Vámok és vámszedés 101.

${ }^{309}$ EFHU 11. (Reg. Arp. 77. sz.). Vö. Weisz B.: Vámok és vámszedés. 309.

310 Bp. I. 296.

311 beneficia principum ecclesiis seu piis locis [...] debeant [...] non minui sed augeri - Bp. I. 297.

312 Bp. I. 297-298.

${ }^{313}$ DF 236 302. (F. IX/2. 598-600.).
} 
kiváltság birtokosai, a polgárok kerültek ki vesztesen ${ }^{314}$ - ami a valóságban egyébként vajmi keveset számított. Az igazság ugyanis az, hogy a káptalan 1357 előtt 1347-ben, ${ }^{315}$ majd utóbb 1365-ben ${ }^{316}$ is pert nyert a város polgárai ellen. 1347-ben az esztergomiakat egyenesen hatalmaskodásban marasztalták el a káptalannal szemben, miután nem tudtak olyan dokumentumot felmutatni, ami a káptalan vámja alól mentesítette volna őket. A királyné megbízásából ítélkező Olivér (királyi) tárnokmestert és bírótársait - aligha meglepő módon sem I. Károly pátense, amely a polgárokat a királyi vámok fizetése alól mentette fel tíz évre, sem az uralkodó, I. Lajos hasonló tartalmú (similem tenorem continentes) oklevele nem győzte meg erről. ${ }^{317} \mathrm{Az}$ 1365. évi jogvita ugyanolyan forgatókönyv szerint zajlott, mint az 1357-es ${ }^{318}$ - a hatása is éppen ugyanannyi volt a polgárokra: semennyi. 1370 körül a káptalan a pápához fordult segítségért, ${ }^{319}$ mindhiába: a városlakókat a Lajos-korban sem világi, sem egyházi hatalom nem tudta a káptalan vámján fizetésre bírni. ${ }^{320}$

A régebb óta megtartott vásárt károsító újabbat az uralkodók megszüntették, vagy más napra helyezték át. A korábban engedélyezett vásárok helyzetelőnye a hetivásár-tartási engedélyekben egyértelmü kifejezést nyert: a „más megyebeli/szomszédos vásárok sérelme nélkül” formula valamilyen formában beépült legnagyobb részükbe. ${ }^{321}$

Így kerülhetett sor 1325-ben a kállói szombati hetivásárnak kárt okozó - szintén szombaton tartott - böszörményi vásár megszüntetésére, 1347-ben a Bát városát károsító petendi vásár hétfőről péntekre helyezésére, vagy éppen 1350-ben Écs falu szerdai, a szentmártonira sérelmes vásárának a hétföi napokra való áttételére. ${ }^{322}$

1355-ben a poroszlói tiszai rév birtokosa, Neszmélyi Miklós pécsi püspök ${ }^{323}$ és a folyón a poroszlói révtől délebbre üzemelő abádi átkelő működtetője, Tomaj nembéli Losonci István

\footnotetext{
${ }^{314}$ quia donationes praedictorum regum, in facto ipsius tributi fori factae, litteras dicti D. Belae regis exemtorias praecedebant, posterioresque donationes prioribus, iuxta antiquam regni nostri consuetudinem, non poterant praeiudicium aliquod generare; ob hoc vigore ipsius priuilegii se solucione dicti tributi fore exemtos non valebant, nec poterant comprobare - F. IX/2. 600. (DF 236 302.).

315 Str. III. 627-628. (Anjou-oklt. XXXI. 480. sz.), Str. III. 629-630. (Anjou-oklt. XXXI. 481. sz.), Str. III. 629. (hiányosan) (Anjou-oklt. XXXI. 483. sz.), Str. III. 629. (hiányosan) (Anjou-oklt. XXXI. 484. sz.)., Str. III. 643644. (kihagyásokkal) (Anjou-oklt. XXXI. 629. sz.).

${ }^{316}$ F. IX/3. 470-488.

317 Str. III. 627-628.

${ }^{318}$ Az ítélet ismét a káptalan korábbi kiváltságainak javára történt. A jogelv formulája az ítéletlevélben a következő: posterioresque collationes prioribus donationibus rite et legitime factis de iuris aequitate, nullum praeiudicium valent generare. F. IX/3. 484.

319 1370/1372: DF 236306.

${ }^{320}$ Az elhúzódó konfliktusra lásd Pór A.: Háborúság a vám miatt.

${ }^{321}$ 1338: tamen foris vicinis non valeat preiudicium generare - DL 60 968.; 1340: quod si in illa prouincia aliud forum tam propinquum non existat ut, ei detrimentum, aliquod, possit generare - Z. I. 584.; 1346: sine preiudicio tamen fororum comprovincialium - Károlyi I. 167.; 1348: salvis foris comprovincialibus - AO V. 216. Erről részletesen lásd: Tringli I.: Vásártér és vásári jog 1339-1341.

${ }^{322}$ Weisz Boglárka: Vásárok és lerakatok 28.

${ }^{323}$ Engel P.: Archontológia I. 73.
} 
fia, Dénes ${ }^{324}$ között jogvita támadt a két rév fenntartása és a hozzájuk kötődő vámszedés miatt. ${ }^{325}$ A királyi jelenlét előtti per folyományaképp eltiltották a kereskedőket és utazókat az abádi átkelő használatától. Az ügy, annak fényében, hogy a Tomaj nem a rév müködtetésének jogát akkor már több mint egy évszázada bírta (már a tatárjárás előtt megszerezte), ${ }^{326}$ a perbe vont Losonci Dénes számára különösen szerencsétlen kimenetelünek bizonyult. Hiába tanúsította eskü alatt Druget Miklós kérdésére 1349-ben az Eger folyó mellett tartott nádori közgyülésen Heves megye közössége, hogy Losonci István és Dezső ,abádi birtokán a Tiszán, miként felmenőiktől hallották, régtől fogva rév üzemelt és üzemel jelenleg is jogszerüen" - a pécsi püspök (képviselője) által bemutatott 1347. évi királyi privilégium szerint az uralkodó Poroszlót tiszai rév- és szárazvámjával együtt a püspöknek és testvérének, Neszmélyi Mátyásnak ${ }^{327}$ adományozta, és egyúttal megtiltotta, hogy az átkelő kárára Poroszló és Várkony között bárki - a kereskedők és utazók előtt is nyitva álló - révet létesítsen a folyón. ${ }^{328}$ Miután pedig Dénes a rév müködését bizonyító korábbi iratot, mint az eszközölt tudományvételt tanúsító oklevél királyi megerősítését (1349) - amelyben a király engedélyezte az átkelő müködését, és visszaállítását is elrendelte - nem mutatott be, a pécsi püspök két évvel korábbi oklevele felé billent a mérleg nyelve: mert „úgy látták, a Miklós püspöknek tett korábbi adomány nagyobb erővel és érvénnyel bír István bánénál, posteriores autem collaciones prioribus iuxta antiquam regni consvetudinem nequeunt preiudicare et preiudicium generare”. ${ }^{329}$

Az abádi átkelő birtokosainak a probléma áthidalására (az ítélet megsemmisítésére) két lehetőségük maradt: megtörni a jogelvet, vagyis elérni a pécsi püspök régebbi kiváltságának érvénytelenítését az uralkodónál, vagy a saját előnyükre fordítani azt - ehhez mindenképpen a főpap oklevelénél korábbival kellett előállni. Végül az utóbbi módon, negyven év múlva, 1395-ben sikerült elérni, hogy a rév újfent nyitva állhasson a kereskedők és utazók előtt is. Ekkor Losonci István volt bán Ilosvai Lesták nádor előtt felmutatta IV. Béla 1251-es pátensét őseinek, Pelbárt és Csák fiainak ${ }^{330}$ kiegyezéséről az abádi rév jövedelmének felosztását

\footnotetext{
${ }^{324}$ Engel P.: Genealógia: Tomaj nem 2. tábla: Losonci.

${ }^{325}$ AO VI. 304-310.

${ }^{326}$ Weisz B.: Átkelöhelyek a Tiszán 24-25.

${ }^{327}$ Engel P.: Genealógia: Poroszlói (Neszmélyi).

328 adiecisset eciam ipse .. Lodovicus rex, quod quia inter predictam possessionem Porozlow et possessionem Warkun nominatam in aliquo locorum portus seu transitus viatorum aliquo unquam tempore inventum fuisse minime prohiberetur, obhoc commisisset, ut nullus omnino hominum inter dictas duas possessiones Porozlow et Warcun nominatas qualicunque modo portum seu transitum viatorum quorumlibet in preiudicium porti in dicta possessione Porozlow habiti ad invenire vel pro se ipso construere minime posset atque valeret - AO VI. 305.

${ }^{329}$ ipsaque prior collacio eidem ... Nicolao episcopo facta, maioris firmitatis et vigorositatis, quam ipsa posterior collacio eidem Stephano bano facta fore et existere videbatur - AO VI. 307.

${ }^{330}$ Engel P.: Genealógia: Tomaj nem 1. tábla: elágazás.
} 
illetően. ${ }^{331}$ Az Árpád-házi király oklevele pedig bizonyítani tudta, amit az 1349. évi tudományvétel nem: azt hogy az abádi révet nem önkényesen, hanem „a király tudtával, jóváhagyásával és engedélyével” (non simpliciter sed ex scitu annuencia et concessione sepefati domini Bele regis), müködtették régtől fogva, azaz törvényesen (és sokkal régebb óta) üzemelt, mint a poroszlói. 332

Az egymással ütköző vámkiváltságokból eredő konfliktusok rendezése másképp is megvalósulhatott: ha az uralkodó(k) jóindulatú befolyását, kegyét a felek valamelyike a saját javára tudta fordítani, elérhette a rá sérelmes - vámmentességi vagy vámszedési kiváltság(ok) részleges érvénytelenítését, vagy akár teljes visszavonását.

1328-ban a Vörös Ábrahám fiai, András és testvérei ${ }^{333}$ és a pozsonyiak közötti cseklészi vámperben az uralkodói kegy a polgárok javára nyilvánult meg. ${ }^{334}$ Habár a helyi nemeseknek joguk volt rá, hogy kivétel nélkül mindenkitől vámot hajtsanak be, a király cseklészi vámszedési jogukat az országos vámmentességükkel (1291) ${ }^{335}$ érvelő pozsonyiakra nézve felfüggesztette. ${ }^{336}$ Andrásék kiváltságleveléről az 1328. évi oklevél sajnos semmi közelebbit nem árul el: mindössze annyit említ, hogy a nemesek „privilégiummal bírtak” (privilegium habere dignoscantur), de arra nézve, hogy azt I. Károly vagy elődei adták-e ki, ennélfogva régebbi-e, mint a pozsonyi hospeseké, nem szolgáltat információt. ${ }^{337}$

Kolozsvár polgárainak Drági Jakabbal ${ }^{338}$ és unokaöccsével (frater patruelis), Zsombori János fia Miklóssal ${ }^{339}$ először 1360 táján támadt nézeteltérése, utóbbival a magyarzsombori állítólag nagybátyja akarata ellenére történő - vámszedés miatt. ${ }^{340}$ 1379-ben aztán a város bírája, Tamás fia Miklós és János fia Miklós kolozsvári polgár kereste fel I. Lajost azért, mert Drági Jakab és rokonai áruik után erdélyi birtokaikon kiváltságuk ellenére vámot szedtek. ${ }^{341}$ A két Miklós a kolozsvári kereskedők erdélyi vámmentességét I. Károly privilégiumával $(1316 / 1331 / 1336)^{342}$ igazolta a király előtt, Jakab pedig I. Károly és Dénes erdélyi vajda

\footnotetext{
${ }^{331}$ DL 8003. (ZsO. I. 3973. sz.).

${ }^{332}$ DL 8003. (ZsO. I. 3973. sz.).

333 Engel P.: Genealógia: Cseklészi.

334 Juck 113-114. (hibás napi kelettel).

335 Juck 75-76. (Reg. Arp. 3837. sz.).

336 et quamvis iidem filii Abraam Rufi super eo, quod ab omnibus tributa exigere valeant, sine differencia aliquali privilegium habere dignoscantur, tamen nos deinceps privilegium, quantum ad ipsos cives Posonienses, et non alios, auctoritate regia cassamus et viribus ac vigore reddimus et commisimus cariturum - Juck I. 114.

${ }^{337}$ Vö. Juck 114.

${ }^{338}$ Engel P.: Genealógia: Brassói-rokonság 2. tábla: Drági.

${ }^{339}$ Vö. Engel P.: Genealógia: Brassói-rokonság 1. tábla: Zsombori (Sombori).

340 1360: ZW. II. 181-182. Magyarzsomboron kívül a Drágiaknak a Doboka megyében Örmezőn és Drágon voltak a késő középkorban - és lehettek ekkor is - vámhelyei. Jakó: Kolozsmonostor II. 2635. sz.

${ }^{341}$ ZW. II. 508.

${ }^{342}$ I. Károly a kolozsvári hospesek erdélyi vámmentességét - többi, V. Istvántól kapott kiváltságukkal együtt elsőként 1316-ban biztosította. ÁÚO VIII. 266-268. (Anjou-oklt. IV. 313.). ZW. szerint 1316. évi oklevelét a
} 
okleveleit mutatta fel - ezek a Drágiak (nem megnevezett) vámjait érintették. A király végül ahelyett, hogy az írásos bizonyítékok alapján az egyik vagy a másik fél kizárólagos javára ítélt volna, hosszú távú megbékélésüket szem előtt tartva rendelkezett: ${ }^{343}$ fél vám megfizetését írta elő a kolozsváriaknak, egyszersmind jegyzékbe foglalta, mekkora összegü vám szedhető halak, sajt, szalonna, bor, élőállatok (disznó, ló, ökör), posztó és állatbőrök szállítása esetén, valamint lekötött mázsaszekereik után. ${ }^{344}$

A vámszedési jognak ellentmondó mentesítő kiváltságok visszavonására is sor kerülhetett. A 14. század derekán a király és az anyakirályné nem szünő jóindulatát élvező óbudai apácák - 1351-ben a nyúl-szigeti domonkosok, majd mintájukra ${ }^{345}$ 1365-ben az óbudai klarisszák is arra hivatkozva, hogy vámjaikat ${ }^{346}$ alamizsnaként kapták, kijárták, hogy az uralkodó hatálytalanítsa mind a külföldi, mind a hazai kereskedők vámmentességet biztosító okleveleit vámjaik vonatkozásában. ${ }^{347}$ A Margit-szigeti apácáknak budai kapu- (vásár)vámjukat ${ }^{348}$ illetően régebb óta volt ilyen kiváltságuk: 1298 körül nyerték el III. András királytól, és a belföldi, kiemelten a soproni kereskedőkre vonatkozott. ${ }^{349}$ Amikor I. Lajos 1359-ben, majd 1369-ben is megerösítette a regensburgi kereskedőknek az 1336. évi csökkentett vámtarifájú Fehéregyháza-Sasvár/Szenic-Jablonca-Bikszárd/Bény-Nagyszombat-Farkashida-SempteNyárhíd-Udvard-Esztergom-Csaba-Szentjakabfalva-Buda út ${ }^{350}$ vámszabását, egyetlen ponton kivételt tett: a regensburgiaknak Buda kapujában a Margit-szigeti apácáknak járó

király 1331-ben, majd utóbbival együtt 1336-ban is átírta: ennek eredetije a kolozsvári városi levéltárban található. ZW. I. 319.

343 perpetuae pacis tranquillitas in aevum valeat gloriari huiusmodi moderativam ordinationem perpetue duraturam duximus faciendam - ZW. II. 508.

${ }^{344}$ ZW. II. 508-509.

${ }^{345}$ Kiváltságleveleik (lásd következő jegyzet) szövege gyakorlatilag megfelel egymásnak.

${ }^{346}$ A 15. század közepén az óbudai, a ceglédi, a szondi, a széplaki és az egyedújfalusi vámok voltak az óbudai klarisszák birtokában. 1449: DL 14 211. Az óbudai hajóvámhoz 1366-ban jutottak, a szentjakabfalvi vámért cserébe (1366: F. IX/3. 528-531. Vö. 1351: F. IX/2. 53-55.); a Bács megyei Széplak útvámját, Egyedújfalu útés vásárvámját, valamint Belszond vámját (tributum fori Danubium) 1382-ben kapták meg I. Lajostól, cserébe többek közt a szepesi Lucsivna, Podolin és Tótfalu, valamint a Szabolcs megyei Révbács vámjaiért. 1382: DL 6905.

${ }^{347}$ quod quamquam plerisque hominibus, regnicolis nostris et extraneis ac hospitibus, instantiis eorumdem, et supplicationibus interuenientibus, huiusmodi gratiam fecisse dignoscimur: vt ipsi nullas in regno nostro tributa dare et soluere teneantur ... nam volumus, et testimonio praesentium committimus mediante, vt omnes homines tam regnicolae nostri, quam extranei, tributum soluere debentes, in locis tributorum earumdem Dominarum tributum consuetum plene dare et soluere teneantur; non obstante gratia eisdem facta praenotata; cui, vt praemittitur, praesentibus volumus derogari - 1351: F. IX/2. 73-74.; 1365: F. IX/3. 498-500. Az idők folyamán mindkét kolostor gondosan ügyelt arra, nehogy kiváltsága érvényét veszítse. A Margit-szigetiek oklevélmegerősítéseit lásd 1365: F. IX/3. 493-495. (I. Lajos), 1393: DL 7823. (Mária), 1397: DL 4181. (Zsigmond). Óbudai klarisszák: 1393: Bp. III/1. 78. (Zsigmond), 1406: DL 9123. (Zsigmond).

348 Weisz B.: Vámok és vámszedés 99.

${ }^{349}$ HO. VIII. 418. (Reg. Arp. 4349. sz.).

${ }^{350}$ Térképen lásd: Weisz B.: Vámok és vámszedés 462. 2. térképmelléklet. Az útról részletesen lásd Skorka R.: Csökkentett vámtarifájú út. 
teljes vámot meg kellett fizetniük. ${ }^{351}$ I. Lajos 1369-ben az ambergi (Bajorország) kereskedők számára is garantálta az 1336-os vámtarifát - a csökkentett vámszabás az apácák budai vámjára ezúttal sem vonatkozott. ${ }^{352}$ A kapuvám kivétele, amint Skorka Renáta megfigyelte, hiányzik viszont a nürnbergi (1364), a kölni és a hoyi (1365) kereskedők hasonló megerősítő okleveleiből. ${ }^{353}$

Magáról a jogelvről elmondható, hogy az udvari bíróságok vámjogi ítélkezési gyakorlatában már az Árpád-kor végén kimutatható, a Lajos-korban pedig, a jelek szerint, elismertté vált. De vajon utat talált-e, illetve mikor és hogyan talált utat a jogelv az alsóbb szintű bíróságok jogalkalmazásába?

A válasz a középkor második fele vámtörténetének feldolgozása híján ${ }^{354}$ egyelőre várat magára, a Lajos-korban mindenesetre nem tünik úgy, mintha a gyakorlat kilépett volna a curia bíróságainak falai közül. Sokat mondó a pozsonyiak bazini vámolása miatti pereskedés 1378-ban a város és Bazini Sebes fia, János közt. ${ }^{355}$ Habár a felek kijárták Szepesi Jakab országbírónál, a királyi városok bírájánál, hogy a vitát Pozsonyban, a pozsonyi káptalan tanúi előtt döntőbíráskodással rendezhessék, az ügy később újra előtte kötött ki. ${ }^{356}$ A vita eldöntésére kijelölt napon, miután a - név szerint nem ismert - választott bírák megvizsgálták a felperes ponyonyiak vámfizetés alóli mentességét (1291), ${ }^{357}$ illetőleg az alperesnek a bazini vámszedés jogszerüségét igazoló okleveleit, „mivel világosan látták, hogy a felek oklevelei uralkodók adományait tartalmazzák mindkét fél részére, és a királyi kegy adományai ellenében nem merészeltek döntést hozni, az ügyet a felek okleveleivel együtt az országbíró és az ország báróinak ítéletére (bízva) visszaküldték a királyi udvarba”. 358 A bazini várhoz tartozó vámszedőhely felállításának pontos ideje ismeretlen. 1339-ben János apja, Bazini Sebes I. Károly előtt azt állította, a vámmal már elődei is rendelkeztek, és királyi adomány (ex regia collacione) révén jutottak hozzá. ${ }^{359}$ Az erről tanúskodó oklevelet I. Lajos kétszer (1361,

\footnotetext{
351 dempto tamen et excepto vno articulo superius expresso, in quo dicitur In porta vrbis Budensis; volumus enim, et presencium serie committimus, vt tributa religosarum dominarum sanctimonialium de Insula Leporum in predicta porta Ciuitatis Budensis exigi consueta ... per predictos mercatores et alios quoslibet indempniter persoluantur - Wenzel, Dipl. Eml. II. 666. Vö. Skorka R.: Csökkentett vámtarifájú út 468.

${ }^{352}$ Wenzel, Dipl. Eml. 677-679. Skorka R.: Csökkentett vámtarifájú út 468.

353 Skorka R.: Csökkentett vámtarifájú út 468. 95. jz.

${ }^{354}$ Egyelőre az Árpád- és a Károly-kor vámtörténetéről rendelkezünk teljességre törekvő feldolgozással. Vö. Weisz B.: Vámok és vámszedés.

355 DF 238968.

${ }^{356}$ Vö. 1378: DF 241363.

357 Vö. 335. sz. jz.

358 eo quod in dictis litteris instrumentalibus parcium antedictarum donaciones serenissimorum regum utriusque partis in se lucidius contineri vidissent et sic ipsi contra premissas graciosas donaciones dictorum regum non extitissent ausi arbitrare obhoc ipsam causam predictarum parcium suo ordine simulcum dictis litteris ipsorum instrumentalibus ad vestram et baronum regni deliberacionem in curiam regiam remissent - 1378: DF 238968. ${ }^{359}$ AO III. 608. (Anjou-oklt. XXIII. 703. sz.). Vö. Weisz B.: Vámok és vámszedés 76.
} 
1364) is megerősítette; ${ }^{360}$ János talán az 1361. évi, megerősítő záradékkal ellátott példánnyal állt elő a döntőbíráskodáskor. ${ }^{361}$

A jogelv szélesebb körben való terjedésére utaló jeleket elsőként a Zsigmond-kor vége felé találunk: 1419-ben a jól ismert formula - kilépve az ítéletlevelekből - ${ }^{362}$ már királyi parancsokban is feltünt. ${ }^{363}$ Ez év decemberében az erdélyi szász székek érdekében Szebeni András comes, Jakab fia Jakab szebeni esküdt és fenyőfalvi „Sámson” Jakab járult Temesváron a király elé, vámmentességi joguk lépten-nyomon történő megsértéséről panaszkodva. Miután oklevelükből - ami nem más volt, mint az Andreanum - a király megállapította, hogy kereskedőik 1224-ben nyertek vámmentességet, ${ }^{364}$ amit a korábbi uralkodókhoz hasonlóan ő maga is helyben hagyott, parancsba adta, hogy ettől fogva senki ne merje a panaszosokat e szabadságuk ellenére vámolni, és előtte sem most bemutatott kiváltságlevelük, sem más királyi oklevél felmutatására kényszeríteni - kivéve jelen parancsát. ${ }^{365}$ Akinek vámjáról régebbi oklevél volt a birtokában, mint az Andreanum, az oklevelet annak a megyének az alispánjának vagy ispánjának volt köteles bemutatni, ahol a vámvita felmerült. ${ }^{366} \mathrm{~A}$,recept” innentől ismerős: ha a vámbirtokos oklevele - kiváltsága régebbi, mint a szászoké, a szászoknak az adott vámhelyen fizetniük kellett, ha későbbi, nem kellett fizetniük. ${ }^{367}$

Néhány hónappal korábban, 1419 augusztusában a király a szobi vámot illetően adott hasonló parancsot. ${ }^{368}$ A Hont megyei ${ }^{369}$ Szob és a Duna túlpartján fekvő Nagymarót közt már az Árpád-korban is rév müködött, így - bár a szobi vámot elsőként az 1366. évi dunai vámtarifa ${ }^{370}$ említi - az itteni vámszedés feltehetően korábbi keletü. ${ }^{371}$ A királyi falu szárazés vízi vámját I. Lajos 1382 júliusában adományozta az általa alapított ${ }^{372}$ nosztrai pálos

\footnotetext{
${ }^{360}$ Weisz B.: Vámok és vámszedés 76. 664. jz.

${ }^{361}$ DL 5023.

362 1395: DL 8003 (ZsO. I. 3973. sz.).

363 1419: DL 8823 (ZsO. VII. 878. sz.), 1419: ZW. IV. 113-115. (fennmaradt példányai: DF 244 677, DF 246 191, DF 244 676, Direcţia Judeţeană Sibiu a Arhivelor Naţionale. Colecția de documente ale parohiilor evanghelice C.A. sătești. Sibiu 3.).

364 praedictos universos mercatores adhuc ab anno domini millesimo ducentesimo vicesimo quarto a solutione tributaria exemptos vidimus et emancipatos - ZW. IV. 114. A panaszosok az Andreanumot Zsigmond 1406. évi átíró oklevelében (DF 244 731) mutathatták be.

365 ZW. IV. 114.

366 ZW. IV. 114.

${ }^{367}$ quae si antiquioris datae exstiterint quam literalia instrumenta praedictorum exponentium ex tunc praedicti mercatores in eo casu tributum solvere teneantur, si vero literalia instrumenta praedictorum exponentium de antiquiori data comperta fuerint, ex tunc iidem mercatores ad nullam solutionem tributariam sint astricti - ZW. IV. 114. Zsigmond oklevelét 1453-ban V. László jóváhagyta és kihirdetni rendelte. DF 244790.

${ }^{368}$ DL 8823 (ZsO. VII. 878. sz.).

${ }^{369}$ A birtokot a késő középkorban elvétve Nógrád megyéhez számítják. Csánki I. 108.

${ }^{370}$ DF 258545.

${ }^{371}$ Weisz B.: Vámok és vámszedés 382.

${ }^{372}$ Romhányi B.: Kolostorok és társaskáptalanok: 'Nosztre (Nosztra)'.
} 
kolostornak. ${ }^{373}$ A remeték a 15 . század elején nem igazán tudtak kellő eréllyel fellépni a vámfizetést megtagadók ellen, ${ }^{374}$ emiatt Zsigmond már 1409-ben lehetővé tette, hogy a nosztrai pálosok a vámszedés körüli fennakadások esetén a mindenkori visegrádi várnagytól (vagy alvárnagytól) kérjenek segítséget. ${ }^{375}$ 1419-ben, miután Lőrinc nosztrai pálos vikárius arról panaszkodott, hogy sokan, azt állítva, hogy a vámfizetés alól mindenhol mentesek ( $a$ solucione tributi ubique fienda liberos), ,,a vámhelyről mindenféle fizetés nélkül erőszakkal távoznak, és kényük kedve szerint mennek tovább”, ${ }^{376}$ a király Reznik damásdi, illetve András és Köte visegrádi várnagyoknak adta parancsba, hogy ilyenkor álljanak a pálosok rendelkezésére. $^{377}$ Zsigmond ugyanakkor világossá tette, hogy a szobi vámon nem kell fizetnie annak, akiknek a vámmentességi joga régebbi, mint I. Lajosnak a pálosok részére tett vámadománya. ${ }^{378}$ Aki azonban mentességéhez akár az ő, akár más jóvoltából ezt követően jutott, a vámot megfizetni tartozik. ${ }^{379}$

Hogy a király parancsainak mennyire volt foganatja, nem tudjuk. Hiába adtak világos iránymutatást a vámviták megoldására, a hely(szín)i érdekek ellenük dolgoztak - újabb és újabb konfliktusok csíráit magukban rejtve. Nehéz elképzelni, hogy az újabb keletű vámmentességek kedvezményezettjei ne próbáltak volna előjoguknak minden áron érvényt szerezni, az újdonsült vámbirtokosok ugyanakkor - jelen esetben a szobi vám jövedelmét alig négy évtizede (1382-1419) élvező pálosok - ezáltal jóval kevesebb bevételt remélhettek. A király ráadásul augusztus 19-i mandátumánál egy hónappal korábban, július 18-án ${ }^{380}$ még azt adta parancsba, hogy a szobi vámot kivétel nélkül mindenki ${ }^{381}$ fizetni tartozik, hiába jutottak - vagy jutnak a jövőben - a jóvoltából bármilyen ennek ellentmondó oklevélhez. ${ }^{382}$ Könnyen elképzelhető, hogy a júliusi és az augusztusi parancslevél közül az utóbbit rövid úton a

\footnotetext{
373 DL 6937.

374 1409: DL 9542 (ZsO. II/2. 6743. sZ.); 1419: DL 10837 (ZsO. VII. 774. sz.); 1419: DL 8823 (ZsO. VII. 878. SZ.); 1439: DL 13383.

${ }^{375}$ DL 9542 (ZsO. II/2. 6743. sz.).

376 in dicta Zob tributum solvere nollent et penitus recusarent de loco tributi violenter absque aliqua solucione recedendo et ulterius iuxta ipsorum voluntatis placitum procedendo - DL 8823.

${ }^{377}$ DL 8823 (ZsO. VII. 878. sz.). Vö. Engel P.: Archontológia I. 297., 461.

378 omnes et singuli cuiusvis status regni nostri homines qui certis et sufficientibus litteris prius et ante donacionem ipsi claustro et fratribus per [...] Lodovicum regem de dicto tributo factam se a solucione tributi liberos et exemptos poterunt demonstrare tales ad solucionem annotati tributi in dicta Zob non compellantur et nec astringantur - DL 8823.

379 alii autem qui post datam seu emanacionem litterarum annotati domini Lodovici regis super donacione dicti tributi ipsi claustro et fratribus facta confectarum tam per nostram maiestatem quam quoscumque alios a solucione tributi se eximi et libertari procurassent et optinuissent non obstantibus litteris tam nostris quam aliorum quorumvis superinde confectis ad solvendum huiusmodi tributum in dicta Zob realiter teneantur astringantur et efficaciter compellantur - DL 8823.

${ }^{380}$ DL 10 837. (ZsO. VII. 774. sz.).

${ }^{381}$ universis et singulis mercatoribus et alterius cuiusvis status et condicionis hominibus - DL 10837.

382 aliis litteris nostris in harum contrarium cuipiam ex vobis sub quacumque forma seu expressione verborum datis vel dandis non obstante quibuscumque - DL 10837.
} 
sekrestye mélyére süllyesztették - ugyanis aligha véletlen, hogy Albert királynak 1439-ben a számukra előnyös értelmezéseknek nagyobb teret adó júliusit mutatták be. ${ }^{383}$

Végül, a korábbi adományok elve a Zsigmond-korban a kolozsvári és a fehérvári polgárok vámmentességének kapcsán is előkerült. 1421 áprilisában a kolozsváriak a király tudomására hozták, hogy vámmentességük ellenére Vásárhelyen és Erdélyben máshol is vámfizetésre kényszerítik őket. Zsigmond a küszöbön álló jogviták eldöntését Csáki Miklós erdélyi vajdára (és alvajdáira) bízta, akiket az ítélethozatalra nézve pontos instrukciókkal látott el: ${ }^{384} \mathrm{az}$ nyerje a pert, akinek írásos bizonyítékai alapján régebbi a vámmentességi/vámszedési joga. ${ }^{385}$ A vajda tehát abban az esetben minősíthette a kolozsváriak vámolását jogszerünek, ha az adott vámbirtokos a vámjáról 1316-nál ${ }^{386}$ régebbi oklevelet tudott felmutatni.

A fehérvári polgárok 1421 nyarán egyeztek ki egy sor, a vámmentességi kiváltságukat megsértő vámbirtokossal Ozorai Pipó temesi és Rozgonyi István bakonyi comes közbenjárásával a király előtt, elállva perindítási szándékuktól, amit korábban, a Pozsony és Moson megyék nemesei számára tartott generalis congregacion helyeztek kilátásba. A fehérváriak elmondása alapján őket személyük, dolgaik és áruik után jogtalanul vámolta Vöröskői Volfurt özvegye és fiai, a fehérvári káptalan és a pilisi apátság óvári és pozsonyi vámján; Hédervári Mihály fia, György, a győri káptalan és a zirci apátság Győrben; a győri káptalan Abdán; Hédervári Mihály fia, György ${ }^{387}$ és Hédervári Miklós fia, Lörinc ${ }^{388}$ Öttevényen; valamint Bazini Gróf György ${ }^{389}$ Farkashida birtokon, Sempte oppidumban, illetve Sempte várában és tartozékain. ${ }^{390}$ Miután a vámbirtokosok képviselői a fehérváriak okleveleiből meggyőződtek arról, hogy a fehérvári polgárok és hospesek „,az ország határai között mindenütt mentesek és szabadok a vámfizetés terhe alól, jelenleg és jóval régebb óta, minthogy az ő vámhelyeiket felállították és nekik adományozták volna" (a solutione cuiuslibet tributi ubicunque intra ambitum regni nostri exigendi, praesens et longe antea, quam dicta eorum tributa instituta eisque data fuissent et concessa, exemptos et gratiose

\footnotetext{
${ }^{383}$ DL 13 383. A jelzet alatt három eredetije található.

384 ZW. IV. 135-136.

${ }^{385}$ si et in quantum praedictos cives et hospites nostros in huiusmodi eorum exemptione et libertatione tributaria antiquiorem datam suorum literalium instrumentorum quam antedictos nobiles et alterius status possessionatos homines rite et legitime reperieritis, ex tunc eosdem cices et hospites per amplius ad ullam solutionem tributariam compelli nullatenus permittatis. Ubi vero praedictos nobiles et alterius status possessionatos homines in eorum literalium instrumentorum super eorum tributis confectorum data antiquiores agnoveritis, ex tunc praedictos cives et hospites nostros ad solutionem tributariam iustam et consuetam astringi permittere debeatis ZW. IV. 136.

${ }^{386}$ Vö. 100. jz.

${ }^{387}$ Vö. Engel P.: Genealógia: Héder nem 2. tábla: Hédervári.

${ }^{388}$ Vö. Engel P.: Genealógia: Héder nem 3. tábla: Hédervári (nádori ág).

${ }^{389}$ Vö. Engel P.: Genealógia: Hontpázmány nem 9. Szentgyörgyi-ág 2. tábla: Szentgyörgyi és bazini.

${ }^{390}$ F. X/6. 376-378.
} 
libertatos exoneratosque exstitisse), ígéretet tettek kiváltságuk betartására - cserébe a fehérváriak eltekintettek kárigényüktől, és érvénytelenítették az ügyben addig kiadott vizsgálati és más okleveleket. ${ }^{391}$

\section{A VÁMOKBÓL SZÁRMAZÓ JÖVEDELMEK}

A Lajos-korból a vámok jövedelmét adminisztráló jegyzék/regisztrumjellegű források szinte nem is maradtak fenn - pedig biztosan készültek ilyenek: 1364. június 11-én, amikor a király Sopronnak és Pozsonynak harmincadmentes borkivitelt tett lehetővé egyévi időtartamra, előírta, hogy tricesimatorai vagy a két város erre kijelölt emberei az exportált borokról vezessenek jegyzéket az év leteltéig, amivel aztán a királynak tételesen el kellett számolniuk. ${ }^{392}$ Olyan átfogó jellegü összeírást, mint az Árpád-kori királyi vámjövedelmek megbecsülésére alkalmas III. Béla-féle jövedelemjegyzék a 12. század végéről, ${ }^{393}$ sajnos hiába keresünk az 1342 és 1382 közötti időszakban. Engel Pál, amikor 1982-ben kiadta a temesi ispáni háztartás 1372. április 28. és június 27. közötti bevételeit és kiadásait regisztráló, 6 lapos papírfüzetke szövegét, ${ }^{394}$ a számadás(töredék)ben felfigyelt egy nehezen meghatározható, valószínűleg Temesvárra vonatkozó tételre, bizonyos Szent László-napi (június 27.) 40 forintra (item in festo sancti regis Ladislai XXXX flor.), ami véleménye szerint akár a temesvári éves vásár bevételeként is interpretálható. ${ }^{395}$ A tétel annyiból nem ad pontos képet a sokadalom vásárvámbevételéről, hogy az összeg egy részét feltehetően a helyszínen beszedett bírságpénzek tették ki, ezek aránya pedig nem tudható. A számadás a temesvári vám (tributum Themesiensis) bevételeit is feltünteti: két hónap alatt összesen 12 és fél forintot. ${ }^{396}$

1349-böl ismert egy konfliktus, ami a vöröskői vár ciferi vámja bevételének eltulajdonításával végződött, de nem tudjuk, hogy az elvett 100 fontot (centum libras) mennyi

\footnotetext{
${ }^{391}$ F. X/6. 378-380.

392 volumus, quod tricesimator noster, vel homo suus, per ipsum ad hoc deputatus, huiusmodi vinorum exportandorum numerum certum habeat in Registro usque completionem Anni prenotati, et seriatim sub certo numero nostrae referre teneatur Maiestati - F. IX/3. 390.

393 Erre lásd Weisz B.: Vámok és vámszedés 32.

${ }^{394}$ Engel P.: Honor 917-920.

395 Engel P.: Honor 890-891.

${ }^{396}$ In tributo habuimus III flor.; Item secundario habuimus I flor.; Item de tributo Themesiensi I flor.; Item de tributo 0,5 flor.; Item de tributo Themesiensi habuimus IIII flor.; Item de tributo III flor. - Engel P.: Honor 919.
} 
idő alatt szedték be a vámon - ráadásul, ha tudnánk, akkor is elképzelhető lenne, hogy az összeg, mivel kárjelentésről van szó, többé-kevésbé túlzó. ${ }^{397}$

A vámok értékére vagy bevételére a korszakból mindenesetre jellemzően olyan források világítanak rá, amelyek a vámok bérbe adásáról, elzálogosításáról vagy eladásáról tudósítanak, illetve amelyekkel a bevételükböl rendelnek egy meghatározott összeget egyszeri juttatásként vagy járadékként - kiutalni. Utóbbira jó példa az az évi 240 forintos apanázs, amit Piast Erzsébet 1366-ig az óbudai, majd 1367-től a szentjakabfalvi vám jövedelméből írt elő kiutalni az opuliai herceg lányának, az óbudai klarissza kolostorban apácaként élő Kunigundának. ${ }^{398}$ 1348-ban Garai János veszprémi püspök végrendeletében 100 forintot hagyott a barsi Újbánya vámjának jövedelméből a domonkosok garai kolostorának építésére. ${ }^{399}$

Vámok el-, bérbe vagy zálogba adásánál két tényező nehezíti értékük megbecsülését: nem minden esetben egyértelmü, a vám mekkora részéről rendelkeztek, másrészt sok esetben nem önállóan, hanem birtokkal együtt cseréltek gazdát. 1344-ben Magyar Pál gimesi várnagy 60 budai márkáért (pro sexaginta marcis ad numerum Budensium) jutott hozzá a Haraszt nembéli tárnoki nemesek Bodrog megyei Felsőadorján birtokához és annak tiszai (valószínűleg hajó)vámjához ${ }^{400}$ (tributum fluvii in eodem fluvio Tycie exigere consuetum). ${ }^{401}$ 1346-ban Harsundorfi Wlueng udvari lovag és testvére, Sedul a Pest megyei Újfalut és vámját 100 márka bécsi dénárért (centum marcis vienensium denariorum) zálogosította el három évre a Telegdieknek, akiknek a Hont megyei Visket (szintén vámos hely) ${ }^{402}$ ígérte arra az esetre, ha Újfalu és vámja birtokában nem tudnák őket szavatolni. ${ }^{403}$ 1353-ban a Fejér megyei Bicske birtok és vámja felének harmadát (a birtok és a vám őt illető 1/6 részét) Bicskei Miklós 23 márkáért (minden márkát 1 forinttal számolva) és egy fertóért akarta visszaváltani az országbíró előtt Vörös Mihálytól, aki a birtok felét 70 forintért vette zálogba. ${ }^{404}$

1344-ből ismert egy adásvétel: a pozsonyi Kunigunda asszony, Fehér Péter özvegye a város melletti Vödric falunál müködő nagy-dunai révben bírt részét sógorának egy szőlővel

\footnotetext{
397 pecuniam domini sui quem Chifur in tributo congregata fuerat ad mandatum dicti domini sui in dictum castrum Weresku deferre voluisset - DF 227 576. (Str. III. 674.) (Anjou-oklt. XXXIII. 160. sz.).

398 DL 5631.

399 pro fabrica monasterii fratrum predicatorum de Gara cum centis florenis, quos debet de pecunia tributi de Kenispergh provenienti - DF 200906 (Gutheil, Veszprém 131-133.).

${ }^{400}$ Weisz B.: Vámok és vámszedés 159.

401 1344: DL 3735 (AO IV. 466-468.) (Anjou-oklt. XXVIII. 772. sz.), 1345: DL 3737 (tartalmi átírása: AO VII. 175-177.) (Anjou-oklt. XXIX. 21. sz.). Vö. Gy. I. 704.

402 1347/1353: DL 64 714. (HO. VII. 403.) (Anjou-oklt. XXXI. 967. sz.).

403 cum omnibus suis utilitatibus et pertinenciis quibuslibet ac proventibus et specialiter tributo in eadem existenti - DL 30644.

${ }^{404}$ DL 50167.
} 
együtt 36 talentumért adta el. ${ }^{405}$ A pozsonyi nagy-dunai (vödrici) és kis-dunai (csallói) átkelők vámrészeinek bérbe vagy zálogba adásairól a pozsonyi városi és káptalani levéltárban meglehetősen sok forrás maradt fenn. Vödric vámjának 1/3-a a pozsonyi ispáné, további egyegy harmada a pannonhalmi bencés, illetve a pilisi ciszterci apátságé volt. ${ }^{406}$ A csallói vám jövedelme elvileg ugyanígy oszlott meg. Király János véleménye szerint a Lajos-korban a pilisi monostor vámharmadai kerülhettek az apátságnak adott kölcsönök fedezetének zálogaként magánszemélyek kezébe ${ }^{407}$ - vagyis az iménti adásvételkor a nagy-dunai vámnak csak egy kisebb hányada cserélt gazdát. ${ }^{408}$ 1356-ban Vogl Henrik pozsonyi polgár és felesége, Erzsébet végrendeletükben misealapítványt tettek a városi Szent Márton-egyház plébánosa számára - évenként 15 font bécsi dénár kiutalásával. A pénzt a plébános évi három meghatározott időpontban, 5 fontonként kapta meg. Az első, április 24-én esedékes részlet(ek) 5 fontjából 3-at a végrendelkezők vödrici rév/kikötőrészéböl (de portu navigii in Wedricz) kellett folyósítani. ${ }^{409}$ 1371-ben a pozsonyi káptalan kiszállt a néhai Bertalan pozsonyi polgár felesége, Erzsébet betegágyához, aki családja, a vödrici bíró és több vödrici révmester (magister nautarum) beleegyezésével két örökjogon bírt vödrici révrésze egyikét - vámjával együtt - 46 dénárfontért (pro quatraginta sex libris denariorum quamlibet cum sex pensis computando) eladta Adee Slaymkauf ${ }^{410}$ pozsonyi polgárnak. ${ }^{411}$ A most idézetteknél jobban értelmezhetők azok a tranzakciók, amik a pannonhalmi és a pilisi apátság vámharmadait, vagy a pozsonyi káptalan vámrészét érintették. (Utóbbi intézmény rendelkezett 1306 óta a pozsonyi vámok tizedével). ${ }^{412}$ Jakus (Jakab) pozsonyi bíró és Jakab, a pilisi apát vámszedője 1350-ben 1 évre 28 márka bécsi dénárért (pro viginti octo marcis Wyennensium denariorum singulis marcis decem pensis computatando) vette bérbe Vilmos apáttól a pannonhami apátság „pozsonyi” (vödrici?) és csallói révvámjának harmadát; 413 majd a bíró 1356-ban 10 évre évi 240 forintért bérelte az apátság nagy-dunai és vereknyei vámharmadait. ${ }^{414}$ Tudjuk azt is, hogy

\footnotetext{
${ }^{405}$ partem seu porcionem suam in navigio seu in portu circa domum [...] portus videlicet Posoniensi - Str. III. 542. (Anjou-oklt. XXVIII. 460. sz.).

${ }^{406}$ Weisz B.: Vámok és vámszedés 316.

${ }^{407}$ Király J.: Pozsonyi vám- és révjog 17-18.

408 Király János adatai szerint 1402-ben a Unger Mihály adta el vödrici 1/12 révrészét Gilgen pozsonyi esküdtnek 84 magyar forintért. 1417-ben Peskó János pozsonyi kanonok szintén értékesítette nagy dunai révrészét: Gebiltl János esküdtnek, 2 font pfennigért. Király J.: Pozsonyi vám- és révjog 16.

${ }^{409}$ DF 238 752. (Anjou-oklt. XL. 114. sz.).

${ }^{410}$ Király János olvasata: Slaginkauf.

${ }^{411}$ unam partem duarum porcionum suarum in portu in dicta vidricia exigi consueto iure hereditario ipsam precise contingentium habitam cum omnibus reditibus et proventibus earundem - DF 238869.

412 Weisz B.: Vámok és vámszedés 316., Király J.: Pozsonyi vám- és révjog 14.

413 porciones nostras seu portus tributi Posoniensis et in Challo portuum nobis annis singulis proveniri debitas DF 207 482. (Anjou-oklt. XXXIV. 342. sz.).

414 tertias partes tributorum nobis et monasterio nostro ab antiquo provenientes super magnam aquam Danubii in Posonio et in Challo in villa videlicet Verkenye exigi consuetas - P. II. 423.
} 
1370-ben a bíró egy évre a pozsonyi káptalan kis- és nagy-dunai vámrészeit - nyilván tizedeit - 30 dénárfontért (pro triginta libris denariorum libram quamlibet cum sex pensis computando) vette bérbe. ${ }^{415}$

A 14. század második feléből akad még néhány, a vámok értékére vonatkozó szórványos adat: a Körös megyei Dombró híd- és vásárvámját 1353-tól György mester és testvére, András deák óbudai várnagy 1 évig 120 magyar forintért - vagy jó súlyú dukátokért (vel ducatis bonis veri et iusti ponderis) bérelte János egri olvasókanonoktól, Apáti Miklós zágrábi püspök kancellárjától. ${ }^{416}$ Hantzmann báti bíró özvegye valamikor 1364-1385 táján Pál bakonybéli apátnak Pünkösd táján küldött levelében kért haladékot az apátság báti vámjának bérleti díjára (census theolonei), amivel időközben meghalt férje maradt adós. Az asszony az apát szervitoraival elküldött 3 márkát (marcas latoribus), és ígéretett tett kétmárkás hátraléka decemberi törlesztésére. ${ }^{417}$ 1367-ben István nyitrai püspök a zsitvatői kikötő és vám jövedelmét (proventus portus et tributi) újra ${ }^{418}$ bérbe adta a már többször említett Jakab pozsonyi bírónak. A bérlet február 22-től egyévi időtartamra szólt, amiért Jakab bíró 400 forintot (forintját 100 dénárral számolva) fizetett azzal a kikötéssel, hogy a vámként szedett halak és minden más élelmiszer felét a püspök zsitvatői házának és lakóinak juttatja. ${ }^{419}$ Verenyei Lörinc fia András 1373-ban 20 dénármárkáért (pro viginti marcis denariorum quamlibet marcam cum decem pensis computando) zálogosította el a vereknyei (Pozsony mellett) révrészét (hatodát) a Csallón Szentgyörgyi Tamásnak, Jánosnak és Péternek. ${ }^{420} 1376$ ban Mosdatlan András comes dési polgár 100 aranyforintért vette zálogba Drági Jakab zsombori (Doboka megye) vámjának felét. ${ }^{421}$ 1388-ban a garamszentbenedeki apátság egy évre 60 aranyforintért adta bérbe Sárói (Lévai) Lászlónak barsi vámrészét (harmadát) ${ }^{422}$ a

\footnotetext{
${ }^{415}$ porciones nostras quas in tributo in vidricia et in challow exigi consueti - DF 238866.

${ }^{416}$ DL 263 067. Kivonata: F. IX/2. 301.

417 P. VIII/1. 415.

418 sicut aliis temporibus quibus dictos nostros proventus sub arrenda tenuit - DL 41696 (F. IX/7. 260.).

${ }^{419}$ medietatem piscium et omnium aliorum victualium in dicto nostro tributo proveniencium ad nostram curiam in Sythuatw existentem ac ibidem commorantibus plene et absque fraude faciet amministrari - DL 41696 (F. IX/7. 260.).

${ }^{420}$ totalem porcionem suam videlicet sextam partem portus seu navigii in Challo ibidem scilicet in Verekenye exigi consueti - DF 238 898. Vö. 1373: DF 238 900. Vö. Engel P.: Genealógia: Hontpázmány nem 9. Szentgyörgyi-ág 2. tábla: Szentgyörgyi és Bazini.

${ }^{421}$ quod ipsi totalem porcionem eorum in tributo de Sumbur habitam videlicet rectam dimidietatem ipsius tributi cum universis pertinentibus et lucris eiusdem medietatis predicti tributi quibusdam necessitatibus ipsorum evitandis eos ad presens urgentibus per centum florenis in specie auris coram nobis habitis et receptis plene predicto comiti Andree dicto Mosdathlan civi de Dees pignori obligassent - DL 26868.

422 Vö. Bars.
} 
barsi vámhoz tartozó, Ludány, Léva, Solymos és Almás birtokokon tartott vásárok vámjainak harmadával együtt. ${ }^{423}$

\section{VÁMADATTÁR}

Az adattárban a települések betürendben szerepelnek. A középkori településnév után zárójelben feltüntettem a középkori megyét, ahol feküdt, majd szögletes zárójelben mai hivatalos nevét (már nem létező település esetén a lokalizációt segítő megjegyzést), végül annak az országnak a betüjelét, ahol a település ma található.

Országrövidítések:

$\mathrm{A}=$ Ausztria

$\mathrm{H}$ = Magyarország

HR = Horvátország

RO = Románia

$\mathrm{SLO}=$ Szlovénia

$\mathrm{SRB}=$ Szerbia

SVK = Szlovákia

$\mathrm{UKR}=$ Ukrajna

\section{Abád (Heves megye) [Abádszalók, H]}

1355-ben ${ }^{424}$ a poroszlói tiszai rév birtokosa, Neszmélyi Miklós pécsi püspök ${ }^{425}$ és a folyón a poroszlói révtől délebbre üzemelő abádi átkelő működtetője, Tomaj nembéli Losonci István fia, Dénes ${ }^{426}$ között jogvita támadt a két rév fenntartása és a hozzájuk kötődő vámszedés miatt. ${ }^{427}$ A királyi jelenlét előtti per folyományaképp eltiltották a kereskedőket és utazókat az abádi átkelő használatától. Az ügy, annak fényében, hogy a Tomaj nem az abádi rév müködtetésének jogát akkor már több mint egy évszázada bírta (már a tatárjárás előtt

\footnotetext{
${ }^{423}$ porcionem seu porciones eorum tributi in opido Bors et in aliis foribus eiusdem videlicet in possessionibus Ludan Lewa Solmos et Almas vocatis exigi consuetis ad ipsum tributum in Bors exigi consueto pertinentibus DF 208 847. (ZsO. I. 378. sz.).

${ }^{424}$ Korábbi történetére lásd Weisz B.: Vámok és vámszedés 48-50.

${ }^{425}$ Engel P.: Archontológia I. 73.

${ }^{426}$ Engel P.: Genealógia: Tomaj nem 2. tábla: Losonci.

${ }^{427}$ AO VI. 304-310.
} 
megszerezte), ${ }^{428}$ a perbe vont Losonci Dénes számára különösen szerencsétlen kimenetelünek bizonyult. Hiába tanúsította eskü alatt Druget Miklós kérdésére 1349-ben az Eger folyó mellett tartott nádori közgyülésen Heves megye közössége, hogy Losonci István és Dezső „abádi birtokán a Tiszán, miként felmenőiktől hallották, régtől fogva rév üzemelt és üzemel jelenleg is jogszerüen" - a pécsi püspök (képviselöje) által bemutatott 1347. évi királyi privilégium szerint az uralkodó Poroszlót tiszai rév- és szárazvámjával együtt a püspöknek és testvérének, Neszmélyi Mátyásnak ${ }^{429}$ adományozta, és egyúttal megtiltotta, hogy az átkelő kárára Poroszló és Várkony között bárki - a kereskedők és utazók előtt is nyitva álló - révet létesítsen a folyón. ${ }^{430}$ Miután pedig Dénes a rév működését bizonyító korábbi iratot, mint az eszközölt tudományvételt tanúsító oklevél királyi megerősítését (1349) - amelyben a király engedélyezte az átkelő müködését, és visszaállítását is elrendelte - nem mutatott be, a pécsi püspök két évvel korábbi oklevele felé billent a mérleg nyelve: mert „úgy látták, a Miklós püspöknek tett korábbi adomány nagyobb erővel és érvénnyel bír István bánénál, posteriores autem collaciones prioribus iuxta antiquam regni consvetudinem nequeunt preiudicare et preiudicium generare". ${ }^{431}$

Végül negyven év múlva, 1395-ben sikerült elérni, hogy a rév újfent nyitva állhasson a kereskedők és utazók előtt is. Ekkor Losonci István volt bán Ilosvai Lesták nádor előtt

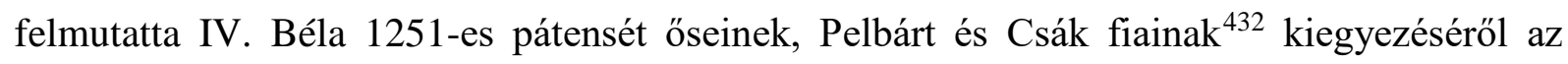
abádi rév jövedelmének felosztását illetően. ${ }^{43}$ Az Árpád-házi király oklevele pedig bizonyítani tudta, amit az 1349. évi tudományvétel nem: azt hogy az abádi révet nem önkényesen, hanem „a király tudtával, jóváhagyásával és engedélyével” (non simpliciter sed ex scitu annuencia et concessione sepefati domini Bele regis), müködtették régtől fogva, azaz törvényesen (és sokkal régebb óta) üzemelt, mint a poroszlói. ${ }^{434}$

\footnotetext{
${ }^{428}$ Weisz B.: Átkelőhelyek a Tiszán 24-25.

${ }^{429}$ Engel P.: Genealógia: Poroszlói (Neszmélyi).

430 adiecisset eciam ipse ... Lodovicus rex, quod quia inter predictam possessionem Porozlow et possessionem Warkun nominatam in aliquo locorum portus seu transitus viatorum aliquo unquam tempore inventum fuisse minime prohiberetur, obhoc commisisset, ut nullus omnino hominum inter dictas duas possessiones Porozlow et Warcun nominatas qualicunque modo portum seu transitum viatorum quorumlibet in preiudicium porti in dicta possessione Porozlow habiti ad invenire vel pro se ipso construere minime posset atque valeret - AO VI. 305.

431 ipsaque prior collacio eidem ... Nicolao episcopo facta, maioris firmitatis et vigorositatis, quam ipsa posterior collacio eidem Stephano bano facta fore et existere videbatur - AO VI. 307.

${ }^{432}$ Engel P.: Genealógia: Tomaj nem 1. tábla: elágazás.

${ }^{433}$ DL 8003. (ZsO. I. 3973. sz.). IV. Béla oklevelét lásd W. VII. 324-325. (Reg. Arp. 953. sz.).

${ }^{434}$ DL 8003. (ZsO. I. 3973. sz.). Vö. Kovács B.: Középkori vámok 16.
} 


\section{Ádánd (Somogy megye) [Ádánd, H]}

A somogyvári konvent 1356-ban Ugali Pál fia Miklós ${ }^{435}$ érdekében lefolytatott vizsgálata arra a megállapításra jutott, hogy Torvaji Ugrin fiai, Miklós és László ${ }^{436}$ Ugali Miklós Jut birtokának régi, hétfői hetivásárát Ádánd birtokukra helyezték át, és már három hétfőn megtartották - hogy az áthelyezés királyi vagy királynéi engedéllyel történt, avagy önhatalmúlag valósították meg, azt a konvent nem tudta kideríteni. ${ }^{437}$

\section{Ágfalva (Sopron megye) [Ágfalva, H]}

Ágfalván két híd is állt, amelyek között a Lőrinc fia Lörinc és Péter földjein át vezető út (via ... inter duos pontes transiens) az ágfalvi gyümölcsösbe tartott. Az út használatán és fenntartásán Lőrinc és Péter lánytestvérükkel, „Chertil” Péter soproni polgár feleségével osztoztak $^{438}$ - a hidak közelebbi elhelyezkedéséröl és fenntartásáról sajnos nincs információnk.

\section{Almagyari (Heves megye) [Eger része, $\mathrm{H}$ ]}

I. Lajos 1362-ben az egri káptalan kérésére pénteki hetivásár (forum liberum) tartását engedélyezte az egyház Almagyari nevü birtokán avagy utcájában (in possessione seu vico). ${ }^{439}$

\section{Apáti (Torda megye) [helye ismeretlen] ${ }^{440}$}

Apáti 1356. évi határjárása a Maros folyó révjét (portus fluvii Marwsii) is érintette. ${ }^{441}$

\footnotetext{
${ }^{435}$ Vö. Engel P.: Genealógia: Ugali (Somogy megye).

${ }^{436}$ Vö. Engel P.: Genealógia: Ugron (torvaji).

${ }^{437}$ DL 87 315. (Anjou-oklt. XL. 180. sz.).

${ }^{438}$ Házi I/1. 140-142.

${ }^{439}$ DF 209 992. (F. IX/3. 297.) (Anjou-oklt XLVI. 488. sz.). Kovács B.: Középkori vámok 18.

${ }^{440}$ Szászrégen és Abafája határosa. ZW. II. 118-119.

${ }^{441}$ ZW. II. 118. (Anjou-oklt. XL. 28. sZ.).
} 


\section{Aracsa (Torontál megye) [Novi Bečejtöl (Törökbecse) ÉK-re, SRB]}

Aracsa falu szerdai hetivására 1381-ben háromvásáros kikiáltásnak adott otthont. ${ }^{442}$

\section{Ardó (Ugocsa megye) [Pidvinohragyiv (Szőlősvégardó), UKR]}

Lajos 1361-ben érdemeiért az ardói nemeseknek - Lőkös fiainak, Bertalannak, Jánosnak és másik Jánosnak, Miklós fiainak, Istvánnak és Mártonnak, János fia Jánosnak, ${ }^{443}$ továbbá Zoárd fiainak, Györgynek és Jánosnak, ${ }^{444}$ - keddi hetivásár tartását tette lehetővé Ardó birtokukon más szomszédos és megyebeli vásárok sérelme nélkül.445

\section{Ároki (Arad megye) [Aradtól Ny-DNy-ra, RO]}

A Szeri Pósafiak Ároki és a Lackfiak Novák birtoka között rév üzemelt a Maroson (portus aque Morusy inter possessiones Noak et Aruky vocatas); 446 a folyó a két birtok határát képezte. 447 1360. július 27-én, Kont Miklós temesvári nádori közgyülésén Szeri Pósa fia István ${ }^{448}$ azt állította, Lackfi András ${ }^{449}$ a két birtok között hajókat tart fent, vámot szed az átkelőktől (naves conservari et tributum ab hominibus inibi transitum facientibus exigi faceret), és az egész bevételt megtartja, holott annak fele őt illeti. ${ }^{450}$ Néhány évvel később, 1363. augusztus 1-jén Szeri Arad megye előtt is tiltakozott, amiért András örökösei, Lackfi Pál és Miklós a rév egész jövedelmét maguknak szedik be, holott az átkelőt közösen bírják, így jövedelmének fele az övé. ${ }^{451}$

\footnotetext{
${ }^{442}$ DL 52 379. (1331. évi kelettel F. X/3. 288.). Weisz B.: Vásárok és lerakatok 166.

443 Vö. Engel P.: Genealógia: Hontpázmány nem 11. Ugocsai ág 1. tábla.

444 Vö. Engel P.: Genealógia: Hontpázmány nem 11. Ugocsai ág 2. tábla: Zoárdfi.

445 DL 38178.

446 DL 91693.

${ }^{447}$ DL 91556.

448 Vö. Engel P.: Genealógia: Bár-Kalán nem 1. Szeri ág 2. tábla: Pósafi (szeri, sződi).

449 Vö. Engel P.: Genealógia: Hermán nem 2. tábla: Lackfi. Engel Pál adatai alapján Lackfi András, akit a nádor a közgyülésről való távolmaradása miatt megbírságolt, ekkor már nem élt.

450 DL 91 556. (Domokos N.: Források 21-22.).

${ }^{451}$ DL 91693.
} 


\section{Babócsa (Somogy megye) [Babócsa, H]}

1356-ban Babócsa faluban hetivásárt tartottak: ez év június 7-én (keddi nap) a veszprémi püspök több, a vásárról szekérrel hazafelé tartó görgetegi jobbágyát elfogták és kifosztották. 452

\section{Bács (Kolozs megye) [Baciu, RO]}

1371-ből vámszedésre van adatunk a kolozsmonostori apát Bács birtokán: ${ }^{453}$ a birtok vámja biztosan nem az apáté volt, mivel ekkor (és 1374-ben is) ${ }^{454}$ Bebek György ${ }^{455}$ királynéi tárnokmester és liptói comes körösfői officialisa szedte be, ${ }^{456}$ György a vámot királyi adományból bírta. ${ }^{457}$ A bácsi a kolozsváriak szerint a Kolozsvárról Bácson át Hunyadra és Almásra tartó út vámhelye volt - állításukat a Tordán 1377-ben tartott generalis congregacio megerösítette. ${ }^{458}$

\section{Bácstövise [Opatița (Magyarapáca) körül, RO]}

1370-ben Lajos Himfi Benedek volt bolgár bán érdemeire tekintettel Benedek, testvérei, Péter és Miklós és frater patruelise, János fia László ${ }^{459}$ Temes megyei Remete és Krassó megyei Bácstövise birtokaira szerdai, továbbá az ugyancsak temesi Bulvenc birtokukra szombati hetivásár tartására adott engedélyt a szomszédos és más megyebeli vásárok sérelme nélkül. ${ }^{460}$

\footnotetext{
452 DF 200951.

${ }^{453}$ Csánki V. 330.

454 ZW. II. 417-418.

455 Vö. Engel P.: Genealógia: Ákos nem 1. Bebek-ág 4. tábla: Bebek (vámosi ág).

${ }^{456}$ DF 281 132. (ZW. II. 365.).

457 declaramus quod nos vobis tributum de dicta Bach non dedimus ea de causa quod tributum a civibus et hospitibus nostris de Coloswar recipere deberetis - ZW. II. 418.

458 quod quicumque mercatores seu forenses homines qui cum eorum rebus et mercibus de ipsa civitate nostra Cluswar ad villam Bach vocatam et abhinc ad Hunyad et ad Almas gressus eorum facere vellent, ille vie semper et ab antiquo tute et libere fuissent ac secure tributaria exaccione absque omni nec a dicta civitate nostra Cluswar usque ad easdem possessiones Hunyad et Almas vocatas aliquod tributum preterquam in ipsa Bach haberetur ZW. II. 456.

${ }^{459}$ Vö. Engel P.: Genealógia: Him rokonsága 2. tábla: Himfi.

${ }^{460}$ DL 70 654. (Tringli I.: Perényi 120. sz.).
} 


\section{Balázstelke (Küküllő megye) [Blăjel, RO]}

1345-ben Balázstelke egy részének határjárásakor megemlítenek egy hidat Denyl István háza előtt, illetve egy másik híd (alterius pons) végét is. ${ }^{461}$

\section{Bánd (Veszprém megye) [Bánd, H]}

Bándon, Essegváron és a bándi vámon 1341 novemberéig fele-fele arányban az Igmánd nembéli Lőrinc fia Miklós ${ }^{462}$ és fiai, Miklós, János és András, valamint a Lőrinte nembeli Lőrinte fia Beke, testvére, Tamás és fiai, (Essegvári) Miklós és János ${ }^{463}$ osztoztak. Az Essegváriak november 25-i birtokosztályukig bándi birtok- és a vámrészüket is osztatlanul bírták - a bándi vám felét az osztály során is osztatlanul, közös birtoklásra hagyták (dimidietatem tributi eiusdem ville Band equalem communiter percipient et habebunt inter se). ${ }^{464}$ Tamás fia Miklós és János bándi (és billegei) vámjáról 1358-ban hallunk újra, a zalai konvent július 28-i okleveléből, ami a veszprémi káptalan és Miklós kiegyezését rögzítette. A testület Kont Miklós Mándhida mellett rendezett nádori közgyülésén (július 23.) ${ }^{465}$ szólalt fel a káptalant és jobbágyait sújtó jogszerütlen bándi és billegei vámszedés ellen (indebita exaccio tributi ... super ipsum capitulum et suos iobagiones facta). ${ }^{466}$ Miklós a július végi megállapodásban testvére, János nevében is 10 márka bírság (a bírói kétharmad rész nélkül) kifizetésének terhe alatt vállalta, hogy ettől fogva csak az áruikkal és szekereikkel közlekedő káptalani jobbágyoktól szedet vámot. ${ }^{467}$

\footnotetext{
${ }^{461}$ DF 277 306_21. (Anjou-oklt. XXIX. 370. sz.).

462 Vö. Karácsonyi J.: Magyar nemzetségek II. 240.

${ }^{463}$ Vö. Engel P.: Genealógia: Lőrinte nem Essegvári.

464 alia dimidietate equali eidem magistro Nicolao et filiis suis remanente - DL 66 623. (VVOS 242.) (Anjouoklt. XXV. 817. sz.). Weisz B.: Vámok és vámszedés 65. (ugyanitt l. Bánd részletes birtoklástörténetét az Árpádkortól a Károly-korig).

465 Gábor Gy.: A megyei intézmény 45.

466 DF 200 944. (Anjou-oklt. XLII. 800. sz.).

${ }^{467}$ assumpsit, ut ipse a die datarum presencium nunquam de cetero tributum in dictis suis et eiusdem magistri Iohannis fratris sui possessionibus Bylige et Band vocatis super ipsum capitulum nec eius iobagiones preter iobagiones eiusdem capituli cum rebus mercimonialibus ez curribus pergentes tributum exigeret nec exigi faceret per ad ipsum pertinentes - DF 200944.
} 


\section{Bars (Bars megye) [Starý Tekov (Óbars), SVK]}

Barsban már az Árpád-korban is közlekedési- és vásárvámot szedtek - bevételük harmadát, a királyi rész (királyketteje) felét (tributum in Borsu et in omnibus foris eiusdem civitatis ... in qualibet earum medietatem regie partis) I. Géza 1075. évi adománya révén a garamszentbenedeki apátság birtokolta. A közlekedési vámot (hídvámot) az apátság vámszedői a barsi Garam-hídnál szedték, itt Verner barsi ispán adományából 1246 óta egy telket is bírt a monostor. ${ }^{468}$ A garamszentbenedeki apátság barsi vámrésze a Lajos-korban is kimutatható: 1358 februárjában a király arra emlékeztette a monostor apátját, hogy - a barsi vámból való részesedése okán, annak arányában - hozzá kell járulnia a város szélén álló, megsérült Garam-híd javításához, „ahol a vámot szedik”. ${ }^{469}$ Lőrinc fia János lévai várnagyot ugyanakkor arra utasította, hogy amennyiben az apát a királyi parancsnak nem tenne eleget, vonja el (debeat sequestrare) vámjövedelmeit, és a hidat a barsi népekkel és hospesekkel javíttassa ki - részesedésének arányában az apát költségén. ${ }^{470}$

Bars csütörtöki hetivására 1366-ban háromvásáros kikiáltásnak adott teret. ${ }^{471}$

\section{Bártfa $^{472}$ (Sáros megye) [Bardejov, SVK]}

Miután Cudar Péter sárosi comes alispánja, István mester és a szepesi káptalan olvasókanonoka, Miklós 1355-ben kiszálltak a sárosi vámvizsgálatra, a megyében összesen tíz vámot írtak össze: lajstromukban harmadikként a bártfai vám (tributum), míg negyedikként a helyi harmincad (unum tricesimum in civitate Bardfa) szerepelt. ${ }^{473}$

Pach Zsigmond Pál szerint a bártfai harmincadhivatal müködésének terminus ante quemje Zsigmond király 1402. január 22-én, Szakolcán kiadott kiváltságlevele, ${ }^{474}$ amely a város számára - egyebek mellett - árumegállító jogot biztosított. ${ }^{475}$ Zsigmond 1402. január 22-i

\footnotetext{
468 Weisz B.: Vámok és vámszedés 69.

469 cum vos in tributo, quod in civitate nostra Borsiensi exigitur, porcionem habere dinoscamini, ex eoque fractura pontis super fluvio Gron in fine eiusdem civitatis nostre habiti, ubi dictum tributum exigi consuevit, per vos quantum ad vestram porcionem debeat reparari - AO VII. 37.

${ }^{470}$ AO VII. 36-37. (Anjou-oklt. XLII. 93. sz.).

${ }^{471}$ P. VIII/1. 352.

472 Korábbi történetére lásd Weisz B.: Vámok és vámszedés 70.

${ }^{473}$ Draskóczy I.: Sáros megye vámhelyei 58.

${ }^{474}$ DF 212 715. (ZsO. II/1. 1411. sz.).

${ }^{475}$ Pach Zs. P.: A harmincadvám az Anjou-korban 252.
} 
intézkedéssorozata révén aznap több másik város, így Nagyszombat, ${ }^{476}$ Pozsony ${ }^{477}$ és Sopron $^{478}$ és Lőcse ${ }^{479}$ is árumegállító jogot nyert. ${ }^{480}$ Az öt privilégium közül négy tartalma szinte azonos. Az uralkodó garantálta az árumegállítás jogát az adott városnak a rajta keresztül akár hazai (tam nostri proprii quam aliorum quorumcumque regni nostri prelatorum, baronum et nobilium [...] mercatores), akár külföldi (forenses) kereskedők által kül- vagy belföldre (a Magyar Királyságba) exportálni vagy importálni szándékozott mindenfajta árura nézve - a szállítmányokat kötelező volt a kiváltságolt városban lerakni, felbontani, mérlegelni, és eladni, vagy elcserélni. Az elöírás áthágóit a király áruik lefoglalásával fenyegette: a konfiskált javakon kétharmad-egyharmad részben az uralkodó és a város osztozhatott. Az érintett városok polgárai kölcsönösen mentesültek az egymás városaiban - és akárhol máshol (vélhetően Budán) - való lerakodás kötelezettsége alól, és az egész országban, a Tengermelléket is beleértve, szabadon kereskedhettek. Tilos volt külföldiekkel kereskedelmi társulást létrehozni - ez a kiváltságolt városok lakóira is vonatkozott. A rendelkezések ugyancsak elöírták, hogy az adott városokat elhagyó kereskedők indulás előtt áruikkal kötelesek felkeresni a harmincadosokat, és tőlük igazolást kérni úticéljukról. A soproniak kiváltságlevele az előbbieken kívül lehetővé tette még, hogy a Pozsonyban áruikat lerakodó kereskedők üres szekereikkel Sopronba hajtsanak, és ott a városlakóktól bort vásároljanak. 481

A bártfai polgárok január 22-i kiváltságlevele több ponton eltér a másik négy város okleveleitől, kifejezetten előnyös kereskedelmi feltételeket teremtve a Sáros megyei város lakóinak. A harmincadszedők utazás előtti felkeresését érintő előírás ugyan hiányzik belőle, ettől eltekintve viszont több plusz kiváltságelemet is tartalmaz: a bártfai árumegállítás hatálya - elvileg - az összes hazai kereskedöre (indigene vero universi universaliter et singuli singulariter) kiterjedt, alóla a király nem vette ki a többi kedvezményezett város lakóit; a bártfaiak országos felmentést kaptak a királyi vámok fizetése alól; 482 a többi oklevélhez hasonlóan - amelyek azonban a budai lerakatra csak implicite utaltak - az uralkodó explicite

\footnotetext{
${ }^{476}$ DF 279583 (Pleidell A.: A nyugatra irányuló külkereskedelem 71. 1. j. - az árumegállítást érintő rész kiadása).

477 DF 239237 (F. X/4. 112-116.).

${ }^{478}$ DF 201953 (F. X/4. 108-112.).

${ }^{479}$ DF 271293 (ZsO. II/1. 1412. sz.). Az oklevél hitele Weisz Boglárka szerint legalábbis kétséges. Weisz B.: Vásárok és lerakatok 64-65.

${ }^{480}$ Más kérdés, hogy az uralkodó a januárban biztosított kiváltságokat már október 1-jén visszavonta. Erre részletesen lásd: Weisz B.: Vásárok és lerakatok 63-67.

${ }^{481}$ F. X/4. 112.

482 de universis rebus ipsorum mercimonialibus per omnia regna nostra in nostris tributis regalibus in eundo et redeundo nullum tributum nullamve tributariam pensionem solvere teneantur - ZsO. II/1. 1411. sz.
} 
mentesíti a helyi kereskedőket Buda bármilyen kiváltsága alól; ${ }^{483}$ a bártfai fuvarosoknak megengedi, hogy a külföldi kereskedők áruit a szokott bérért szállítsák ki-be a városból és az országból; 484 valamint - ami témánk szempontjából a legfontosabb - Zsigmond a lengyel és a halicsi (orosz) kereskedőknek elengedte az áruikra kirótt tricesima összegének negyedét, „minden negyedik dénárt”. 485 „Kétségtelen tehát, hogy Bártfa is harmincadhely volt már 1402-ben. A bártfai harmincadról korábbi időpontból nincsen adatunk”, állapította meg Pach. ${ }^{486}$

Weisz Boglárka - Pach véleményével vitatkozva - amellett érvelt, hogy az 1402-es oklevélből nem következik feltétlenül, hogy Bártfán ekkoriban harmincadszedő hely müködött. A bártfai harmincad fennállását biztosan alátámasztó legkorábbi adat véleménye szerint Rozgonyi Simon 1407. június 13-i, a bártfai harmincadszedőkhöz intézett levele. ${ }^{487}$ Később azonban módosította véleményét, és a bártfai harmincadot a már a 14. század közepén fennállónak tekintette. ${ }^{488}$ A hivatal működését Sáros megye 1355. évi, említett vámvizsgálata cáfolhatatlanul igazolja. ${ }^{489}$ A bártfai harmincad Lajos-kori fejezete a soltésztelepülés kiváltságolásának előzményeiröl tudósító, a bártfai levéltár egy, a DF-adatbázisban is megtalálható, 1383-1400. keltezésű történeti feljegyzésével folytatódik, ${ }^{490}$ amelyet Iványi Béla regesztakötetében „XIV. század vége felé. Valami feljegyzés egy lapja, szól pedig a bártfai advocatia XIV. századi történetéről" formában kivonatolt, illetve inkább írt le, ${ }^{491}$ újabban pedig Stanisław Sroka érintett a közelmúltban megjelent Bártfa-monográfiájában. 492 A feljegyzés a bártfai soltészság I. Lajos általi „kivásárlásának” körülményeiről tudósítva megemlékezett az advocatiát annak idején olcsón megvásárló, majd családi okokból Budára költöző, és a soltészságot rokonaira hagyó Konrád harmincadszedőről (Conradus trecesimator), akitől végül a király 2700 forintért vette meg a hivatalt, hogy azután a városnak adja. $^{493}$ Ha hihetünk a feljegyzésnek, az I. Lajos (felicis recordacionis gloriosus rex

\footnotetext{
483 libertate quapiam nostre civitati Budesnsi per nos prius concessa penitus non obstante - ZsO. II/1. 1411. sz.

${ }^{484}$ indulgemus etiam, ut vectores seu aurige ipsius civitatis nostre Bartfa forensium mercatorum res et bona commutabilia extra et intra regnum nostrum pro mercede solita adducendi et educendi in ipsam civitatem nostram Bartfa liberam habeant facultatem - ZsO. II/1. 1411. sz.

485 forenses de Polonia et Russia, quibus propter bonum et comodum ipsorum nostrorum fidelium incolarum et civitatis de Bartfa quemlibet quartum denarium de solvendis tricesimis nostris presencium patrocinio graciose relaxamus - DF 212 715. (ZsO. II/1. 1411. sz.).

${ }^{486}$ Pach Zs. P.: A harmincadvám az Anjou-korban 252.

${ }^{487}$ DF 212 739. (ZsO. II/2. 5568. sz.). Weisz B.: Vásárok és lerakatok 65-66.

${ }^{488}$ Weisz B.: Vámok és vámszedés 70.

${ }^{489}$ Draskóczy I.: Sáros megye vámhelyei 57-61.

490 DF 212714.

${ }^{491}$ Iványi, Bártfa 36. sz.

${ }^{492}$ Sroka, S. A.: A középkori Bártfa 32-33.

${ }^{493}$ Sroka, S. A.: A középkori Bártfa 32-33.
} 
Lodovicus) halála után papírra vetett, Konrád - feltehetően helyi - harmincadoshoz ${ }^{494}$ kapcsolódó eseményeknek 1376. március 7. előtt kellett történniük, Bártfa város e napon kelt városprivilégiuma ugyanis kitért a soltészság bizonyos Henriktől való megvásárlására, aki eszerint az említett Konrád rokonságába tartozhatott. ${ }^{495}$ A következő évben, Bártfa 1377. szeptember 21-én kiadott Egyed-napi vásárengedélyével a király minden kereskedőnek lehetővé tette, hogy a bártfai éves vásáron vám- és harmincadfizetés nélkül üzleteljen. A kedvezmény azokra az árukra, amiket a vásárról elszállítottak az ország más területeire, már nem volt érvényes. ${ }^{496}$ Hasonló kiváltságot - vám- és harmincadmentességet - kaptak néhány évvel korábban, 1372-ben a Szakolca városának szerdai hetivásárát felkereső idegen (tehát nem helyi ${ }^{497}$ ) kereskedők. A felmentéssel azok a külföldi kereskedők (mercatores forenses extranei), akik a vásár napján áruikkal csak áthaladtak a városon, nem élhettek. ${ }^{498} \mathrm{~A}$ kedvezmény minden bizonnyal Bártfa esetében is a külföldi (orosz, lengyel) kereskedők vásárra csábítására, a város kereskedelmi forgalmának fellendítésére irányult.

Bártfa az idők során négy különböző, tartalmában kisebb-nagyobb eltéréseket mutató országosvásár-tartási engedélyt gyüjtött be városi plébániatemplomának védőszentje, Szent Egyed hitvalló napjához (szeptember 1.) kötődően: hármat I. Lajostól (1352, 1365, 1377), egyet pedig Zsigmondtól (1403). ${ }^{499}$ I. Lajos először 1352-ben engedélyezett Bártfán szeptember 1-től, Egyed napjától kezdődően nyolcnapos éves vásárt a város erődítési munkáira hivatkozva. A vásárra jövő kereskedőket pedig a király mentesítette a vámfizetés alól (dantes et concedentes ... de omni exaccione occupacione seu arestacione teloniorum quorumcunque plenam securam et omnimodam libertatem). ${ }^{500}$ A király 1365-ben Henrik bártfai soltész és a város kérésére újfent jóváhagyta a vásárt, amelyet a budai sokadalom mintájára, a patrónusszent ünnepét megelőző és követő nyolc-nyolc napon lehetett megtartani. ${ }^{501}$ Lajos 1377. szeptember 21-én, Kassán kiadott harmadik vásárengedélye a vásározást a patrónus ünnepén és az azt megelőző és követő 3-3 napon tette lehetővé (in festo beati Egidii confessoris et aliis tribus diebus procedenti et sequenti). ${ }^{502}$ A Janota ${ }^{503}$ és Iványi

\footnotetext{
${ }^{494}$ Sroka városi hamincadszedőként említi. Sroka, S. A.: A középkori Bártfa 33.

${ }^{495}$ Vö. Wagner, Sáros 100.

${ }^{496}$ statuimus ut universi mercatores et alii homines forenses in dictis nundinis res eorum in vendendo vel emendo sine tributi et tricesime solucione perficere et negociare possint et valeant exceptis dumtaxat rebus de ipsis nundinis ulterius in Hungariam deferentibus et removendibus - DF 212705.

497 1372. október 6.: vniuersos etiam forenses mercatores extraneos et comprouinciales - F. IX/4. 422. (1373. évi kelettel).

${ }^{498}$ F. IX/4. 421-423.

${ }^{499}$ Vö. Sroka, S. A.: A középkori Bártfa 32. 121. j.

${ }^{500}$ Janota, E.: Bardyjów 147. 52. jz.

501 DF 212697.

502 DF 212705.
} 
által is említett, ${ }^{504} 1377$. évi vásárengedélyt Fejér - tévesen - az általa közölt, a városnak 1352. március 7-én szintén Szent Egyed napjára éves vásárt adományozó királyi oklevél átírásaként tüntette fel. ${ }^{505} \mathrm{Az}$ oklevélről, amelyet Pach sem méltatott különösebb figyelemre (disposicióját talán 1352. évi oklevélével megegyezőnek vélte), ${ }^{506}$ újabban a szlovák várostörténeti lexikon közölt rövid, de a tényleges tartalmát tükröző regesztát. ${ }^{507}$ Érdekes, hogy előfordul - és ugyancsak nem tünik helytállónak - Bártfa 1365. évi, szintén Egyed napjára szóló sokadalomtartási engedélyének az 1352-ben nyert vásártartási jog egyszerü megerősítéseként interpretáló olvasata sem. ${ }^{508}$ Bártfa 1403-ban Zsigmondtól kapott, ugyancsak Egyed-napra szóló vásárengedélye megint nyolc-nyolc napra szólt. ${ }^{509}$ De vajon mi lehet a magyarázata a kivételes oklevéldömpingnek? Lehetséges, hogy Bártfa Egyed-napi évesvásár-tartási jogának érvényét - némileg szokatlan módon - nem, pontosabban csak részben a korábbi vásártartási engedélyének időnkénti megerősíttetésével tartotta fenn, hanem arra időről időre új adománylevelet eszközölt ki. Az is elképzelhető ugyanakkor, hogy az újabb és újabb engedélyek kieszközlése mögött a soltészfaluból éppen ebben az időszakban $\left(1376^{510}\right)$ szabad királyi várossá váló település - amelynek szombati hetivásárát is csak 1400ból tudjuk kimutatni ${ }^{511}$ - elvetélt sokadalomtartási (-felfuttatási) próbálkozásai rejlenek. Ha így is volt, a Zsigmond-kor második felére az ezzel kapcsolatos problémák minden bizonnyal megszüntek: 1427. június 19-én Zsigmond nemcsak Lajos 1352-ben kiadott, Egyed-napra (szeptember 1.) szóló vásárengedélyét erősítette meg, hanem egy újabb, Keresztelő Szent János (a másik bártfai plébániatemplom patrónusa) ünnepéhez (június 24.) kötődő éves vásár megtartásához is hozzájárult. ${ }^{512}$ A város számadáskönyvei alapján ráadásul egy harmadik, Imre-napi (november 5.) bártfai sokadalom is kimutatható ebből az évből. ${ }^{513}$

\footnotetext{
503 Janota, E.: Bardyjów 147. 53. j.

504 Iványi, Bártfa 27. sz.

${ }^{505}$ Hoc ius nundinarum confirmauit idem Ludouicis litteris datis in Kassa, in festo beati Matthaei Ap. et Euang. Anno Domini MCCCLXXVII - F. IX/2. 143. Fejér nyomán szintén átírásként feltüntetve: Szende K.: Sokadalomtartási engedélyek 258.

${ }^{506}$ Vö. Pach Zs. P.: A harmincadvám az Anjou-korban 252.

${ }^{507}$ Lexikon stredovekých miest 81.

508 Sroka, S. A.: A középkori Bártfa 32., és nyomán Szende K.: Sokadalomtartási engedélyek 238.

${ }^{509}$ DF 212723.

${ }^{510}$ Sroka, S. A.: A középkori Bártfa 32. Vö. Wagner, Sáros 99-100.

${ }^{511}$ Weisz B.: Vásárok és lerakatok 156.

512 F. X/6. 892-895.

${ }^{513}$ Weisz B.: Vásárok és lerakatok 156.
} 
Bártfa Szent Egyed-napjára szóló sokadalomtartási engedélyei

\begin{tabular}{|l|l|}
\hline \multicolumn{1}{|c|}{ Vásártartási engedély kiadásának ideje } & \multicolumn{1}{|c|}{ Szent Egyed-napi vásár ideje } \\
\hline 1352. március $7 .^{1}$ & $\begin{array}{l}\text { in termino prenotato [in die beati Aegidii } \\
\text { confessoris] octo diebus continue sibi sequentibus }\end{array}$ \\
\hline 1365. augusztus $2 .^{2}$ & $\begin{array}{l}\text { in festo beati Egidii confessoris et octo diebus } \\
\text { ipsum festum immmediate procedentibus et } \\
\text { sequentibus }\end{array}$ \\
\hline 1377. szeptember $21 .{ }^{3}$ & $\begin{array}{l}\text { in festo beati Egidii confessoris et aliis tribus } \\
\text { diebus procedenti et sequenti }\end{array}$ \\
\hline 1403. szeptember $29 .{ }^{4}$ & $\begin{array}{l}\text { in festo sancti Egidii confessoris incipiendo octo } \\
\text { diebus ante ipsum festum et terminando totidem } \\
\text { diebus sequentibus }\end{array}$ \\
\hline
\end{tabular}

${ }^{1}$ Janota E.: Bardyjów 147. 52. j. Átírásai és megerősítései: 1352. május 17.: István szepesi és sárosi herceg ( $B$. Halász É.: Hercegek és hercegnők 159-160. [DF 212 854., DF 212 865]); 1427. június 19.: Zsigmond király (CD X/6. 892-895., Iványi: Bártfa 175. sz. [DF 212 854]. A DL-DF adatbázisban 1426. június 19-i kelettel); 1427. december 22.: Szepesi káptalan (DF 212 865).

${ }^{2}$ DF 212 697., Iványi: Bártfa 20. sz.

${ }^{3}$ DF 212 705. Átírása: 1387. május 28.: Szepesi káptalan (DF 212 705).

${ }^{4}$ DF 212 723., Iványi: Bártfa 45. sz.

\section{Bátatő (Tolna megye) [Báta, H]}

1349 májusában a pécsi káptalan vizsgálata kiderítette, hogy a Héder nembéli Henrik bán fia, „Herceg” Péter ${ }^{514}$ a Becseiek ${ }^{515}$ bátmonostori vásárára tartóktól Töttös, Vesszős és fiaik Bátatő birtokán(!) folyamatosan vámot szedet. ${ }^{516}$

\section{Bát (Hont megye) [Batovce, SVK]}

Bát ${ }^{517}$ hétfői hetivására $1345-$ ben $^{518}$ és $1366-$ ban $^{519}$ háromvásáros kikiáltás színtere volt. A vásár kárára lévő, ${ }^{520}$ a garamszentbenedeki apátság Petend birtokán létesített hétfői hetivásár engedélyét a király 1347-ben visszavonta, és utóbbit pénteki napokra helyezte át. ${ }^{521}$

\footnotetext{
514 Vö. Engel P.: Genealógia: Héder nem 4. tábla: Kőszegi (és Rohonci).

515 Vö. Engel P.: Genealógia: Töttös (bátmonostori).

516 scivisset eciam quod predictus magister Petrus super populis ad forum inpossessione prenominatorum magistrorum Theuthus et Vessceus ac filiorum eiusdem magistri Theuthus Bothmonustura vocata celebrari consuetum euntibus in villa Bathateu nuncupata que eorundem magistrorum Theuthus et vessceus ac filiorum eiusdem magistri Theuthus esset tributum recipi fecisset et faceret incessanter in preiudicium eorundem non modicum et gravamen - Z. II. 378. (Anjou-oklt. XXXIII. 365. sz).

${ }^{517}$ Korábbi történetére lásd Weisz B.: Vámok és vámszedés 70.
} 


\section{Bátmonostor ${ }^{522}$ (Bodrog megye) [Bátmonostor, H]}

Becsei Töttös Bátmonostor birtokának 1344. évi határjárása megemlítette András hídját ${ }^{523}$ (pontem Andree), ami Bátmonostort a szomszédos Szeremlyéntől válaszotta el. ${ }^{524}$

1347. március 16-án Lajos Bátmonostoron, Töttös ${ }^{525}$ királyi ajtónállómester, pilisi comes és visegrádi várnagy ${ }^{526}$ birtokán hétfőnként hetivásár (forum) tartására adott engedélyt - a megyebeli vásárok sérelme nélkül. ${ }^{527} \mathrm{~A}$ bátmonostori vásár azonban komoly konkurenciát jelentett a szekcsői Hercegek ${ }^{528}$ közeli, dávodi, keddi hetivásárának. ${ }^{529} 1347$ júniusában, alig három hónappal a Bátmonostorra vonatkozó vásárengedély kiadását követően a szekszárdi konvent tanúságával Bodrog és Baranya megyékben lefolytatott vizsgálat igazolta Becsei Töttös panaszát a Héder nembéli Henrik bán fia, „Herceg” Péter bodrogi comes ${ }^{530}$ ellenében, aki május (pünkösd) óta Töttös hétfői vásárának tönkretételére törekedett: famulusaival lezáratta a Budáról, Szegedről, valamint Szerém és Baranya megyékből Bátmonostorra vezető utakat, a vásárra tartókat pedig személyükben inzultálta, javaikat elvetette, és a dávodi vásárán (forum suum feria tercia in possessione sua Dauch vocata celebrari consuetum) való részvételre kényszerítette. ${ }^{531}$ A rákövetkező év, 1348 októberében az a hír járta Bodrog megyében, hogy a dávodi vásáron „Herceg” Péter megverette és megsebesíttette Töttös egyik jobbágyát, akinek a holmijait is elvetette, ráadásul utasítására figyelték és fosztogatták a Baranya megyéből a bátmonostori vásárra tartókat. ${ }^{532}$ Az ügyben vizsgálódó pécsi káptalan pedig azt derítette ki, hogy Péter március 2-tól fogva saját jobbágyainak, „famíliájának”, és más megyebelieknek is tiltja a bátmonostori vásár látogatását. ${ }^{533}$ Péter, úgy tünik, nem

\footnotetext{
${ }^{518}$ DL 40 992. (Anjou-oklt. XXIX. 754. sz.).

${ }^{519}$ DF 207 314. (P. VIII/1. 351-352. Hiányosan, a báti vásári kikiáltást nem írja át).

${ }^{520}$ forum ad feriam secundam ad possessionem religiosi viri Syffridi abbatis monasterii Sancti Benedicti de iuxta Gron Pelend vocatam per nos datum foro in possessione seu ciuitate nostra Baat vocata existenti prejudicium generare videbatur - Juck I. 157.

521 Juck I. 157. (Anjou-oklt. XXXI. 1002. sz.).

${ }^{522}$ Korábbi történetére lásd Weisz B.: Vámok és vámszedés 72.

${ }^{523}$ A híd eddig csak egy 14. századi hamisítványból volt adatolható. Weisz B.: Vámok és vámszedés 378.

524 1344. március 30.: DL 87 162. (Anjou-oklt. XXVIII. 282. sz.).

${ }^{525}$ Vö. Engel P.: Genealógia: Töttös (bátmonostori).

${ }^{526}$ Vö. Engel P.: Archontológia I. 163.

${ }^{527}$ Z. II. 234. (Anjou-oklt. XXXI. 219. sz.).

${ }^{528}$ Vö. Engel P.: Genealógia: Héder nem 6. tábla: Herceg (szekcsői)

529 Vö. Dávod.

${ }^{530}$ Vö. Engel P.: Genealógia: Héder nem 4. tábla: Köszegi (és Rohonci).

${ }^{531}$ Z. II. 261-262. (Anjou-oklt. XXXI. 607. sZ.).

532 Z. II. 298-299. (Anjou-oklt. XXXII. 670. sz.).

533 jobagiones suos et universos ad ipsum pertinentes ac alios de provincia ad forum ipsius magistri Theuteus in villa sua Bothmonostura vocata singulis feriis secundis celebrari consuetum a dominica esto mihi anno in presenti preterita propria sua auctoritate et potencia ire non permisisset et prohibuisset nec nunc permitteret $-\mathrm{Z}$. II. 320. (Anjou-oklt. XXXII. 690. sz.).
} 
válogatott az eszközökben: 1349 májusában arra derült fény, hogy a vásárra menő népektől Töttös, Vesszős és fiaik Bátatő birtokán(!) folyamatosan vámot szedet. ${ }^{534}$

\section{Bátony (Heves megye) [Nagybátony: Bátonyterenye része, $\mathrm{H}$ ]}

Kazai Kakas fia László ${ }^{53}$ 1380-ban arra kérte a királyt, engedélyezze újra Bátony és Dorog birtokán a már elődei ideje óta szokásos vámszedést, amiről szóló oklevelei azonban elvesztek. Lajos, miután meggyőződött arról, hogy Bátonyt, Dorogot és a vámokat a kérelmező és elődei mindaddig békésen birtokolták, a két vám szedését László hüségére és érdemeire való tekintettel újfent lehetővé tette. ${ }^{536}$ Dorog és Bátony vámjait az 1405 . évi Nógrád megyei vámvizsgálat is említette, ami megállapította, hogy a Tarján birtokról Verebélyre, onnan Tarra, majd Tarról Pásztóra vezető utat járók csak a tari vámot kötelesek leróni - Dorogra és Bátonyba menni, és ott vámot fizetni nem tartoznak. ${ }^{537}$

\section{Bátor (Bihar megye) [Batăr (Feketebátor), RO]}

Bátorban a Fekete-Körösön vízivámot szedtek, miután 1321 és 1324 között Nekcsei Sándor fia Sándor körösszegi várnagy a sződi vámot ide telepítette. ${ }^{538}$ A Károly korban kimutatható vámszedést a Lajos korban ezidáig nem sikerült igazolni.

Bátorban szerdánként hetivásárt tartottak, ami 1374-ben háromvásáros kikiáltás színhelye volt. $^{539}$

\footnotetext{
534 scivisset eciam quod predictus magister Petrus super populis ad forum inpossessione prenominatorum magistrorum Theuthus et Vessceus ac filiorum eiusdem magistri Theuthus Bothmonustura vocata celebrari consuetum euntibus in villa Bathateu nuncupata que eorundem magistrorum Theuthus et vessceus ac filiorum eiusdem magistri Theuthus esset tributum recipi fecisset et faceret incessanter in preiudicium eorundem non modicum et gravamen - Z. II. 378. (Anjou-oklt. XXXIII. 365. sz).

${ }^{535}$ Engel P.: Genealógia: Rátót nem 5. tábla: Kakas (kazai).

536 DL 89488.

${ }^{537}$ ZsO. II. 3890. sz.

${ }^{538}$ Weisz B.: Vámok és vámszedés 72.

${ }^{539}$ DF 233883.
} 


\section{Bátor $^{540}$ (Szatmár megye) [Nyírbátor, H]}

Bátor szerdai hetivására 1351-ben háromvásáros kikiáltás színhelye volt. ${ }^{541}$

\section{Bazin $^{542}$ (Pozsony megye) [Pezinok, SVK]}

1363-1364-ben a nagyszombatiak Bazini Sebes fia János és Miklós ellen pereskedett Bebek István országbíró előtt, mivel „boraikból és szőlőik után, amiket ezek földjein telepítettek és termeltek, a polgárok privilegializált szabadsága ellenére túlzott hegyvámot avagy vámot szedetnek" (de eorum vinis et vineis in ipsorum terris plantatis et procreatis contra eorundem civium libertatem privilegiatam terragium seu tributum superfluum exigi facerent). Az oklevél szövegében először is meg kell különböztetnünk a szőlők után fizetett járandóságokat (hegyvámot) érintő visszaéléseket a vámfizetésre vonatkozóktól - ez egyébként meglehetősen nehéz feladat, mert, ahogy a per tárgyának megjelölésében, úgy a lentebb idézett vizsgálati oklevelekben is erősen mixtim szerepelnek. A nagyszombatiaknak a Baziniak földjein művelt szőlői után fizetendő járandóságait ${ }^{543}$ még Károly idején, 1335. szeptember 12-én rögzítette a város (továbbá négy faluja: Gerencsér, Magyarád, Szili és Parna ${ }^{544}$ ) és Bazini Sebes közötti szerződés, aminek a tartalmát részben azért ismerjük, mert az 1363-1364. évi perben a nagyszombatiak bemutatták azt. ${ }^{545}$ A vámok ügyében ebben a contractusban Sebes azt ígérte, hogy az összes birtokán mentesíti a nagyszombatiakat és javaikat minden vám (tributum), census, debitum és solucio megfizetése alól - akár boraikat szállítják, akár szőlőik művelése miatt kelnek útra, akár bármi más természetü ügyeikben járnak el. ${ }^{546}$ Sebes fiai, János és Miklós nem tartották magukat az apjuk által kötött

\footnotetext{
${ }^{540}$ Korábbi történetére lásd Weisz B.: Vámok és vámszedés 73.

541 Z. II. 449.

542 Korábbi történetére lásd Weisz B.: Vámok és vámszedés 75-76.

543 1325-ben Bazini Sebes többek között a következők betartására tett ígéretet: a nagyszombatiakkal korábban egy egész szőlő után 3 pensa széles bécsi dénár censust és más, közelebbről nem ismert debitumokat fizettetett: mostantól egész szőlő után 40, fél után 20, negyed után 10 széles bécsi dénárt kért metszéskor; a borokat a felek Pozsony bírája, esküdtjei és polgárai jelenlétében pozsonyi akóval fogják mérni, és Pozsony pecsétjével pecsételik le (et signo eorum tenebuntur consignare); szüretkor a nagyszombatiak egész szőlő után 1, fél szőlő után fél, negyed szőlő után negyed akó borral tartoznak neki és utódainak, amit a pozsonyiak pecsétjével (signum) kellett ellátni. DL 5169. (Anjou-oklt. XIX. 557. sz.).

${ }^{544}$ Engel térképén Rosindol néven. Vö. Engel P.: Térkép.

${ }^{545}$ Lásd még: 1335. március 6.: F. VIII/4. 77-80. (Anjou-oklt. XIX. 92. sz.), 1335. március 6.: AO III. $132-137$. (Anjou-oklt. XIX. 95. sz.).

546 tam iidem iude iurati et universi cives zyldarii institores et cuius condicionis et status homines de Tyrna quam universi populi dictarum villarum Gerencher Magyarad Parna et Zyly vocatarum per anni circulum singulis annis in translacione vini ipsorum procuracione vinearum suarum aliisque omnibus eorum peragendis negociis et
} 
szerződésben foglaltakhoz - sem a vámok, sem a hegyvám terén. Az esztergomi káptalan 1360. évi vizsgálata kiderítette a nagyszombatiak minden hordó (tunella) bora után hat dénár vámot kényszerítettek ki; ${ }^{547}$ ugyanebben az évben a nyitrai káptalan inquisicioja szerint „vámhelyükön” (in loco tributo eorum - valószínüleg Bazinban) az üres szekerek után két dénárt szedtek, az emberektől jöttükben és mentükben is 1 dénárt, visszafelé a bort szállító szekerek után pedig tizenkét dénárt. ${ }^{548}$ 1362-ben a nyitrai káptalan és a zobori konvent vizsgálódott a környéken a nagyszombatiak érdekében: jelentéseik szerint János és Miklós egy négy dénár árú korsó(?), egy három dénár árú quartale ${ }^{549}$ és négy mérő, hét dénár árú zab után is 1 dénár vámot szedetett, sőt, a terhelt szekerek esetén a rakományt és magát a szekeret is megvámoltatták. ${ }^{550}$ Ráadásul a hegyvámot a várba (Bazinba) szállítókat is megvámolták: minden akó után öt dénárt szedtek. ${ }^{551} 1363$ februárjában az esztergomi káptalan pozsony megyei vizsgálata hasonló eredményre jutott: János és Miklós birtokain a nagyszombatiak javai (megrakott szekerei) után szabadságuk ellenére kétszeres vámot szedtek (mivel külön vámolták a szállított árukat és külön magukat a szekereket), ${ }^{552}$ és öt dénárt hajtottak be minden akónyi hegyvámként (terragium) beszedett bor után. ${ }^{553}$

1363-ban Bazini Sebes fiai, János és Miklós mesterek és Szentgyörgyi Péter mester és fiai, Tamás (Temlin), János és Péter ${ }^{554}$ megegyeztek a Bazin és Szentgyörgy várak közti vitás határok ügyében: a két terület elkülönítése során a Hylmik folyó révénél, a Pozsonyból

processibus in quibuslibet possessionibus nostris ab omni ab (sic!) exaccione tributi census debiti et solucionibus penitus et per omnia cum eorum rebus liberi sint et exempti - DL 5169. A „zyldarii institores” kifejezés lehetséges értelmezésére lásd: Surányi B.: Kereskedőgilde Nagyszombaton 249-253., 267-270.

${ }^{547}$ de singulis tunellis vini sex denarios pro tributo extorquei fecisset - DL 5169.

548 item in loco tributi eorum de quolibet curru vacuo per duos denarios et de singulis hominibus tam in eundo quam in redeundo singulos denarios in redeundo vero de singulis curribus vinum deferentibus singulos duodecim denarios exigi facerent minus debite ab eisdem lite pendente inter ipsos - DL 5169.

${ }^{549}$ Bogdán szerint a száraz- és hígürmértékként használt quartale (kvartále, magyarul fertály) használata Pozsony megyében és Esztergomban dívott a 16. századig. A szentgyörgyi quartale 1278-ban az akó ötödét jelentette. Bogdán I.: Ür-, térfogat-, súly- és darabmértékek 238.

550 magistri Iohannes et Nicolaus filii Sebus de dicta Bozyn a civibus Tyrnaviensibus de uno urceo quod emitur quatuor denariis et de uno quartali quod emitur pro tribus denariis ac de quatuor metretis avene que valent septem denarios unum denarium facerent recipere et de curru honerato et de omnibus rebus super ipsum currum inpositis specialiter facerent recipere tributum modo simili de eodem curru sub honere existente specialiter tributum recipi faciendo - DL 5169. (Anjou-oklt. XLVI. 512-513. sz.).

${ }^{551}$ de unoquoque akone portitoribus recipi facerent quinque denarios ad castrum castrum deportandum (sic!) DL 5169. (Anjou-oklt. XLVI. 512. sz.)

552 predicti Iohannes et Nicolaus filii Sebus predictos cives et universos hospites impedirent et molestarent indebite et minus iuste in eo videlicet quod de universis rebus et bonis in eorum possessionibus contra libertatem privilegiatam tributum exigerent superfluum item de curru honerato exigerent tributum duppliciter scilicet de rebus mercimonialibus per se et de curru similiter per se - DL 5169. (Anjou-oklt. XLVII. 63. sz.)

553 item de vino quod pro terragio ab ipsis exigerent de singulis akonis singulos quinque exigerent denarios indebite - DL 5169.

${ }^{554}$ Engel P.: Genealógia: Hontpázmány nem 9. Szentgyörgyi-ág 2. tábla: Szentgyörgyi és Bazini. 
Bazinba vezető nagy út felső része felöl (a parte superiori ipsius vie virca portum eiusdem fluvii) egy földhatárjelet emeltek. ${ }^{555}$

\section{Bazsalhida (Torontál megye) [Bašaid (Basahíd), SRB]}

Bazsalhida falu keddi hetivására 1381-ben háromvásáros kikiáltásnak adott otthont. ${ }^{556}$

\section{Béc (Zala megye) [Letenye része, $\mathrm{H}$ ]}

1347-ben Felsőlendvai Miklós bán fia Miklós özvegye, Margit, illetve fiai, Amádé és János $^{557}$ visszaadta (resignasset) a letenyei útvámot ${ }^{558}$ Béci István fia Mátyásnak és rokonának, Creiniknek (Creynek), hogy a vámot Béc birtokukon szedhessék be. ${ }^{559}$ Holub József szerint a béci útvámot korábban jogtalanul helyezhették át Letenyére, hiszen a vám és egyes béci földek - visszaszolgáltatása ellentételezés nélkül történt. ${ }^{560}$

\section{Becse $^{561}$ (Torontál megye) [Novi Bečej (Törökbecse), SRB]}

Becse civitas hétfői hetivására 1381-ben háromvásáros kikiáltás színhelye volt. ${ }^{562}$

\section{Becskerek (Torontál megye) [Zrenjanin (Nagybecskerek), SRB]}

1344-ben a csőszi (Cheusci-i) falubíró képviselője a titeli káptalan előtt tiltakozott, amiért László fia János becskereki vámos társaival rátámadt, kirabolta és megsebesítette a csanádi káptalant felkeresni igyekvő famulusát, Antalt. ${ }^{563}$

\footnotetext{
${ }^{555}$ DL 5211. (Anjou-oklt. XLVII. 212. sz.).

${ }^{556}$ DL 52 379. (1331. évi kelettel F. X/3. 288.). Weisz B.: Vásárok és lerakatok 166.

${ }^{557}$ Vö. Engel P.: Genealógia: Gútkeled nem 3. Amadé-ág.

558 tributum seu telonium quod in possessione eorum Lethenye vocata in via exigitur - Zala I. 467.

559 Zala I. 466-467. (Anjou-oklt. XXXI. 909. sz.).

${ }^{560}$ Holub J.: Zala megye vámhelyei 53.

${ }^{561}$ Korábbi történetére lásd Weisz B.: Vámok és vámszedés 77.

562 DL 52 379. (1331. évi kelettel F. X/3. 288.). Weisz B.: Vásárok és lerakatok 166.
} 


\section{Békés megye}

I. Lajos, miután Bátori András váradi püspök ${ }^{564}$ és a székeskáptalan felmutatta neki az Imre király 1203. évi - IV. Béla, IV. László, V. István és I. Károly által is elismert adományát igazoló oklevele(ke)t, amik biztosították számukra a Bihar megyében, úgy Bihar, mint Zaránd körül, és a békési falvakban és vásárokon szedett vámok (tam de villis, quam de foris totius comitatus Bichoriensis tam circa Byhor, quam circa Zarand et de Bekes) királyi részét (kétharmadát) (a Bihar megyei Akjel, Kölesér, Jánosd és Asszonyvására települések vásáraihoz tartozó vámok ${ }^{565}$ kivételével), 1342. december 10-én visszadta az egyháznak e felsorolt, tőle időközben jogtalanul elidegenített vámokat, továbbá ugyane vámok harmadik vámharmadát is nekik juttatta. A vámharmad jövedelmét kétharmad-egyharmad arányban kellett a püspök, illetve a székeskáptalan között megosztani. ${ }^{566}$ A király 1342 . évi adománylevelét 1356-ban ${ }^{567}$ és $1364-$ ben $^{568}$ (új pecsétje alatt) is megerősítette. Ismert Imre oklevelének 1355., majd 1364. évi, tartalmában némileg eltérő királyi megerősítése is, ebből a változatból, ugyanis mind a békési vámok említése, mind a korábbi adomány 1342. évi kibővítése (a harmadik vámharmad adományozása) hiányzik. ${ }^{569}$ A vámadomány szövegét fenntartó két Lajos-megerősítést (1342, 1355), a váradi statútumok és a Váradi Krónika vonatkozó részeit tüzetes tartalmi elemzés alá véve Weisz Boglárka újabban világos, meggyőző érveléssel (1374 és 1477 között készíttett) hamisítványak minősítette az 1342. évi, a váradi vámperben 1477. május 20-án felmutatott Lajos-adománylevelet. Elgondolása szerint a hamisítvány részben Imre 1203. évi oklevele, részben az 1355. évi Lajos-oklevél, valamint egy 1342-ben kibocsátott, hiteles királyi megerősítő oklevél alapján készült, amiben Lajos Imre adományai közül azt hagyta jóvá, ami az Újvár és Békés megyékben szedett vámok királyi részét (kétharmadát) a váradi egyháznak jutatta. ${ }^{570} \mathrm{~A}$ békési vámok királyi részének birtoklását az 1370-es évek elején keletkezett Váradi Krónika ${ }^{571}$ és az azt magában foglaló káptalani statútumok ${ }^{572}$ egyaránt említik.

\footnotetext{
563 DL 51 317. (Anjou-oklt. XXVIII. 713. sz.).

${ }^{564}$ Engel P.: Archontológia I. 76.

565 exceptis tributis, quae ad quatuor spectant fora - ZW. II. 4.

${ }^{566}$ ZW. II. 3-4. (Anjou-oklt. XXVI. 642. sz.).

567 ZW. II. 119-121.

568 ZW. II. 221.

${ }^{569}$ Amint erre Weisz Boglárka felhívta a figyelmet.

${ }^{570}$ Weisz B.: Váradi vámper 157-158.

${ }^{571}$ Henricus rex duas partes tributorum totius comitatus Byhoriensis, tam circa Byhar, quam circa Zarand, et partem suam tributi, quod in comitatu Novi Castri, tam circa ipsum Novum Castrum, quam circa Hewes et in comitatu de Bekes, tam in villis, quam in foris exigitur donavit ecclesie nostre Waradiensi, in duabus partibus
} 


\section{Bekcsény ${ }^{573}$ (Zala megye) [Becsehely, H]}

Bekcsényen csütörtökönként ${ }^{574}$ hetivásárt tartottak, ami legkorábban 1340-ből adatolható. ${ }^{575} 1340$-ben, amikor Simon fia Györgyöt ${ }^{576}$ Druget Vilmos nádor hatalmaskodás miatt fej- és jószágvesztésre ítélte Balai Henrik fia János és Kaba Demeter fia Miklós ${ }^{577}$ ellenében, Bekcsény és vásárja a Szalók nem erdélyi ágának birtokában volt. György közeli rokonsága (testvérei és fiai) - akik György tettében ártatlannak mondták magukat - 1342-ben kiegyeztek Jánossal és Miklóssal, ami révén Göröcsét és Bekcsényt teljes egészében megtarthatták a hegy- és vásárvámmal együtt ${ }^{578}$ - talán nem követünk el hibát azzal, ha a vásárt és vásárvámszedést is Bekcsényhez kötjük.

\section{Beketinc (Körös megye) [Palešniktöl D-re, HR]}

1347-ben, amikor Dénes fia Jakab kőrösi comes, Nagykemlék várnagya ${ }^{579}$ előtt Zuilan (vagy Sciuilan) fiai, Benedek és Beke, illetve Tóth Péter, fia, János és e János fratere, István fia János már hosszabb ideje peresedtek birtokrészeik elválasztása miatt, a csázmai káptalan tanúsága mellett végül sikerült ellentmondás nélkül felosztani azokat. A káptalan erről kiállított oklevelének hátoldalán olvasható Metales ad Beketyncz feljegyzésbő1 ${ }^{580}$ kiindulva a felek a Körös megyei Beketincen birtokolhattak. A felosztás során a két rész határai között megjelent egy rév, amely a Grobesa folyónál, az út mellett (in portu iuxta fluvium Grobesa prope viam) helyezkedett el. ${ }^{581}$

\footnotetext{
episcopo, et in tertia parte nobis, prout in privilegio eiusdem, confirmato per Belam quartum, Stephanum, Ladislaum, Karolum et Lodovicum reges continetur - Vár. Kápt. Stat. 12.

572 Sunt et alia tributa, quorum dominium ab ecclesia nostra est alienatum, videlicet due partes tributorum civitatis Byhoriensis et circa Zarand, exceptis paucis; item tributa, que in civitate Novi Castri tam circa ipsum Novum Castrum, quam circa Hewes, et in comitau de Abawywar, de Bekes colligitur - Vár. Kápt. Stat. 57.

${ }^{573}$ Vö. Weisz B.: Vámok és vámszedés 78.

${ }^{574}$ A hetivásár (forum generalis) napja a zalai konvent 1354. évi okleveléből tudható: Zala I. 550-551. (Anjouoklt. XXXVIII. 406. sz.).

575 foro et tributo in eadem Bekchen exigi solito - DL 3537. (Anjou-oklt. XXVI. 664. sz.).

${ }^{576}$ Vö. Engel P.: Genealógia: Szalók nem 2. tábla: erdélyi ág.

${ }^{577}$ Vö. Engel P.: Genealógia: Szalók nem 1. tábla: Balai (Szentmártoni).

578 cum omnibus earum utilitatibus et pertinentiis ac proventibus quibuslibet nec non tributis vinearum montis et fori - DL 3537.

${ }^{579}$ Engel P.: Archontológia I. 253.

580 Vö. DL 35189.

581 Smič. XI. 374-375. (Anjou-oklt. XXXI. 605. sz.). A csázmai káptalan az oklevelet Kamesnicai (de Kanyenycha) Beke fia Péter kérésére 1378. szeptember 16-án átírta (DL 35 190).
} 


\section{Bél(apátfalva) (Borsod megye) [Bélapátfalva, H]}

1371-ben Lajos Wekayardus bélháromkúti ciszterci apát, királyi káplán kérésére az apátság Bars megyei(!) (valójában: Borsod - K. V.) Bél birtokán sokadalom és hétfői hetivásár megtartását engedélyezte. ${ }^{582}$

\section{Bélavár (Somogy megye) [Bélavár, H]}

1359-ben Bélavár faluban hetivásárt tartottak - ez év szeptember 28-án (szombati nap) néhány, a vásárról jövő görgetegi jobbágyot kiraboltak. ${ }^{583}$ Bélavár szombati hetivására 1369ben háromvásáros kikiáltás helyszíne volt. ${ }^{584}$

\section{(Bel)szond (Bács megye) [Sonta, SRB]}

1382-ben a király és az óbudai klarisszák között több birtokot, vámot és az illető birtokok kamarahasznáját érintő birtokcserére került sor: ennek során Belszond (Zond interior) dunai vásárvámjával (cum tributo fori Danobio), továbbá az itt szedett kamarahasznával együtt az apácáké lett. 585

\section{Beregszász/Lampertszásza ${ }^{586}$ (Bereg megye) [Beregove, UKR]}

Beregszász szombati hetivására 1348-ban és 1351-ben is háromvásáros kikiáltás színhelye volt. $^{587}$

\footnotetext{
582 ad eandem possessionem abbatie sue Beel appellatam in comitatu Borsyensi (sic!) sitam forum liberum singulis anniis singulisque feriis secundis perpetuo celebrandum duximus annuendo concedendum - DF 274118.

583 DF 200951.

${ }^{584}$ DL 101 694. Weisz B.: Vásárok és lerakatok 157.

${ }^{585}$ DL 6905.

${ }^{586}$ Korábbi történetére lásd Weisz B.: Vámok és vámszedés 81.

587 1348: Z. II. 349. (Anjou-oklt. XXXII. 924. sz.); 1351: Z. II. 449-450.
} 


\section{Besenyő (Pest megye) [Máriabesnyő (Gödöllő része), H]}

I. Lajos 1345-ben a hüségére visszatérő Nelipac fia Jánosnak (Ivánnak) ${ }^{588}$ adományozta a Pest megyei Besenyő királyi birtokot - vámjával együtt. ${ }^{589}$

\section{Beszterce $^{590}$ (Szászföld) [Bistriţa, RO]}

1353-ban Lajos Besztercén éves vásár (nundine seu congregacio generalis ac forum annuale) tartását engedélyezte a budai sokadalom mintájára Szent Bertalan apostol napjától az ünnep quindenájáig (augusztus 24. - szeptember 7.). A vásárra érkezők a város területén - a sokadalom ideje alatt - felmentést kaptak a vámfizetés alól, egyben tilos volt feltartóztatásuk és áruik lefoglalása is. A vásár feletti joghatóságot a besztercei esküdtek gyakorolták, az ott felmerülő ügyekben sem az erdélyi vajda és helyettesei, sem a besztercei királybíró (comes de Byztricia seu iudex noster) nem ítélkezhetett. ${ }^{591}$

\section{Billege $^{592}$ (Veszprém megye) [Tótvázsonytól É-ra, H]}

Billege a 14. században vámos hely volt, 1343-ban a falu és vámja Lörinte fia Tamás özvegye és fiai, Miklós és János ${ }^{593}$ birtokában volt ${ }^{594}$ - panaszukra az uralkodó (vásárokon való kihirdetés útján) „emlékeztette” a Billegét álutakon elkerülni igyekvő utazókat és kereskedőket, ${ }^{595}$ hogy áruikkal kötelesek áthaladni a vámhelyen. ${ }^{596}$ Tamás fia Miklós és János billegei (és bándi) vámjáról 1358-ban hallunk újra, a zalai konvent július 28-i okleveléből, ami a veszprémi káptalan és Miklós kiegyezését rögzítette. A testület Kont Miklós Mándhida mellett rendezett nádori közgyülésén (július 23.) ${ }^{597}$ szólalt fel a káptalant és jobbágyait sújtó,

\footnotetext{
${ }^{588}$ Engel P.: Archontológia II. 174.

${ }^{589}$ Smič. XI. 249-252. (Anjou-oklt. XXIX. 836. sz.). Az oklevelet I. Lajos 1365. december 17-én megerősítő záradékkal látta el (DL 38 487).

590 Korábbi történetére lásd Weisz B.: Vámok és vámszedés 83.

591 ZW. II. 97-99.

${ }^{592}$ Korábbi történetére lásd Weisz B.: Vámok és vámszedés 87-88.

${ }^{593}$ Engel P.: Genealógia: Lőrinte nem Essegvári.

${ }^{594}$ Billege birtoklástörténetére lásd Weisz B.: Vámok és vámszedés 87-88.

595 vniuersis viatoribus, et cuiusvis status et conditionis hominibus cum rebus mercimonialibus procedere consuetis - F. IX/1. 101.

${ }^{596}$ F. IX/1. 101-102. (Anjou-oklt. XXVII. 94. sz.).

${ }^{597}$ Gábor Gy.: A megyei intézmény 45.
} 
jogszerütlen, billegei és bándi vámszedés ellen (indebita exaccio tributi ... super ipsum capitulum et suos iobagiones facta). ${ }^{598}$ Miklós a július végi megállapodásban testvére, János nevében is, 10 márka bírság (a bírói kétharmad rész nélkül) kifizetésének terhe alatt vállalta, hogy ettől fogva csak az áruikkal és szekereikkel közlekedő káptalani jobbágyoktól szedet vámot. ${ }^{599}$

\section{Biri (Szabolcs megye) [Biri, H]}

1358. március 13-án, a Kállóban tartott generalis congregación Bátori Bereck fia Lőkös fia Péter Szabolcs megye előtt bepanaszolta Biri Tamás fia Lászlót, ${ }^{600}$ aki a biri vásáron jobbágyától, Német Pétertöl, miután az kifizette a vámot (persoluto tributo), 4 vég posztót és 4 forintot vett el hatalmaskodva, ráadásul más jobbágyait is kifizetésekkel terhelte és károkat okozott nekik (marcam fertonem ac alia dampna quamplurima in foro in eodem ${ }^{601}$ habito recepisset et intulisset). ${ }^{602}$ Az oklevél alapján Biriben a 14. század közepén (valószínűleg heti)vásárt tartottak, és ott vásárvámot szedtek.

\section{Boconád (Heves megye) [Boconád, $\mathrm{H}$ ]}

Demeter fia István, a királyi udvar jegyzője 1343-ban adományba kapta a királytól a hevesi Boconád birtokot. ${ }^{603}$ 1345-ben, amikor Boconádot új adomány címén is elnyerte, a birtok haszonvételei és tartozékai között immár vásárát is megemlítették (cum foro et aliis omnibus utilitatibus suis et pertinenciis universis). ${ }^{604}$

\footnotetext{
${ }^{598}$ DF 200 944. (Anjou-oklt. XLII. 800. sz.).

599 assumpsit, ut ipse a die datarum presencium nunquam de cetero tributum in dictis suis et eiusdem magistri Iohannis fratris sui possessionibus Bylige et Band vocatis super ipsum capitulum nec eius iobagiones preter iobagiones eiusdem capituli cum rebus mercimonialibus ez curribus pergentes tributum exigeret nec exigi faceret per ad ipsum pertinentes - DF 200944.

${ }^{600}$ Vö. Engel P.: Genealógia: Balogsemjén nem 1. Kállai 3. tábla: kállói Vitéz.

${ }^{601}$ Bár az oklevél kiadója szerint az irat nem mondja meg, melyik az a vásár, amin a jogtalan vámszedés történt (vö. AO VII. 84.), az in eodem szinte biztosan a László nemesi előnevében szereplő Byri-re vonatkoztatható.

${ }^{602}$ AO VII. 84-85. (Anjou-oklt. XLII. 263. sz.).

${ }^{603}$ AO IV. 356. (Anjou-oklt. XXVII. 475. sz.).

${ }^{604}$ DL 3604. (Anjou-oklt. XXIX. 61. sz.).
} 


\section{Bodrog ${ }^{605}$ (Bodrog megye) [Bački Monoštor (Monostorszeg) helyén, SRB]}

Bodrog szombati hetivására 1363-ban ${ }^{606}$ és $1366-$ ban $^{607}$ is háromvásáros kikiáltásnak adott otthont.

\section{Boja (Baranya megye) [puszta Beremendtől É-ra, H]}

Boja a 14. század közepén vásáros hely volt, Becsei Vesszős és testvére, Töttös ${ }^{608}$ birtoka. 1349-ben Vesszős és Töttös birtokcserék révén megszerezte Gunya fia Istvántól és Domonkostól ${ }^{609}$ a tolnai Máré várát és tartozékait, amelyek István birtokában lévő feléért többek között - Boja birtokukat adták cserébe vásárával (forum) együtt. ${ }^{610}$

\section{Boldogasszonyfalva ${ }^{611}$ (Krassó megye) [Berzovia (Zsidovin) mellett, RO]}

Boldogasszonyfalva egy 1370. évi adat szerint vásáros hely volt ${ }^{612}$ - a helyi hetivásárt valószínűleg csütörtökönként tartották. ${ }^{613}$

\section{Bonchida ${ }^{614}$ (Doboka megye) [Bonţida, RO]}

Bonchida neve a településen épített hídra utal, amin a Kis-Szamos folyón lehetett átkelni. ${ }^{615}$ A településen, minden bizonnyal a hídhoz kötődően, a Lajos-korban közlekedési vámot szedtek. 1361-ben Lackfi Dénes (1359-1367) erdélyi vajda a kolozsvári polgárok és hospesek folyamodására jóváhagyta Raholcai Kont Miklós (1351-1356) és Gönyűi Péter fia

\footnotetext{
${ }^{605}$ Korábbi történetére lásd Weisz B.: Vámok és vámszedés 90.

${ }^{606}$ DL 5158. (Anjou-oklt. XLVII. 369. sz.), DL 6483. (Anjou-oklt. XLVII. 495. sz.), DL 5218 (Anjou-oklt. XLVII. 288. sz.).

${ }^{607}$ DL 5363. Weisz B.: Vámok és vámszedés 140.

${ }^{608}$ Vö. Engel P.: Genealógia: Töttös (bátmonostori).

${ }^{609}$ Vö. Engel P.: Genealógia: Máréi (Gunyafi).

${ }^{610}$ DL 87 235. (Anjou-oklt. XXXIII. 253. sz.).

${ }^{611}$ Korábbi történetére lásd Weisz B.: Vámok és vámszedés 92.

${ }^{612}$ Vö. Weisz B.: Vásárok és lerakatok 150., 172.

${ }^{613}$ Krassó 99-100.

${ }^{614}$ Korábbi történetére lásd Weisz B.: Vámok és vámszedés 92.

${ }^{615}$ Vö. Weisz B.: Vámok és vámszedés 92.
} 
Tamás (1350-1351) volt erdélyi vajdák rendelkezéseit a Besztercébe utazó dési, rettegi, lekecei és kolozsvári kereskedők számára elrendelt útvonalról, ami előírta Bonchida érintését, és az ottani vám kifizetését. ${ }^{616}$ A rendelkezés tiszteletben tartását Lackfi Dénes minden erdélyi comesének, várnagyának és officialisának meghagyta - közülük kiemelten Járai Mihály fia Péter ${ }^{617}$ alvajdának és Nagy Lászlónak, a bonchidai vajdai officialisnak és vámszedőinek. ${ }^{618}$ A kolozsváriak a rendelkezést 1368-ban az új vajdával, Lackfi Miklóssal (1367-1368) is megerősíttették, ${ }^{619}$ aki újra utasította betartására Járai Péter alvajdát és Nagy Lászlót, saját bonchidai officialisát. ${ }^{620}$ 1376-ban a király Losonci László erdélyi vajda (1376$1385)^{621}$ bonchidai (és szentmiklósi) vámszedőihez intézte parancsát, amivel megtiltotta, hogy a „városaiba” (ad ipsas civitates nostras) - vélhetően Désaknára és Désvárra - élelmiszereket szállító désaknai hospeseit, laboratorait és sóvágóit ne vámolják, vámot csak abban az esetben szedjenek tőlük, ha árut szállítanak. ${ }^{622}$ Mindezek alapján erősen valószínűsíthető, hogy a bonchidai vám, a bonchidai uradalommal együtt, ${ }^{623}$ annak tartozékaként a Lajoskorban, sőt már I. Károly idején is, ${ }^{624}$ az erdélyi vajdai honor részét képezte, jövedelme a mindenkori vajda bevételeit gyarapította.

\section{Bős ${ }^{625}$ (Pozsony megye) [Gabčíkovo, SVK]}

Lajos 1355-ben a Gútkeled nembéli Lothárd fia János fiai, Amadé, Lothárd, Miklós és István ${ }^{626}$ Bős birtokán keddenként hetivásár tartására adott engedélyt. ${ }^{627}$

\footnotetext{
${ }^{616}$ mercatores autem de Rettegh, Deeswar, Lekenche et de Cluswar versus Byztriciam procedere volentes per Banchyda ire tenerentur tributum solvendo in ibidem si qui vero predictis viis eorum relictis contra ordinacionem premissam in aliis viis reperirentur illos in rebus ipsorum damnificandi prebuissent auctoritatem - ZW. II. 191. ${ }^{617}$ Engel P.: Archontológia I. 12.

618 ZW. II. 191-192.

${ }^{619}$ ZW. II. 308-309. A vajdák hivatalviselési idejére lásd Engel P.: Archontológia I. 12.

620 ZW. II. 309.

${ }^{621}$ Engel P.: Archontológia I. 13.

622 quatenus de victualibus cuiuscumque generis existant que quandocumque et quotiescumque per loca ipsorum tributorum hospitibus et laboratoribus nostris ac eciam excisoribus salium nostrorum de Desakana ad ipsas civitates nostras deferuntur exceptis mercantiis et de conductoribus eorundem numquam tributum petere vel exigere audeatis sed sinatis ipsa victualia semper deferri absque recepcione tributi aliqualis ut excisio salium nostrorum per hoc facilius et melius expediatur demptis rebus et mercantiis de quibus tributum recipere non inhibetur - ZW. II. 454.

${ }^{623}$ Engel P.: Archontológia I. 11.

${ }^{624}$ 1321-ben a Kacsics nembéli Szécsényi Tamás rendelkezett a bonchidai vámmal. Weisz B.: Vámok és vámszedés 92.

${ }^{625}$ Korábbi történetére lásd Weisz B.: Vámok és vámszedés 95.

${ }^{626}$ Vö. Engel P.: Genealógia: Gútkeled nem 3. Amadé-ág.

${ }^{627}$ HO. I. 214. Weisz B.: Vásárok és lerakatok 155.
} 


\section{Brassó (Szászföld) [Braşov, RO]}

1377-ben, amikor a király Brassót Törcsvárnak a város költségén történő felépítésére utasította, megígérte, hogy csökkenti a városban a brassóiaktól a számára szedett vámot. ${ }^{628}$

László (Vlad) havavalföldi vajda és szörényi bán 1368 januárjában Lajos kérésére garantálta, hogy a Havasalföldön - a brăilai kivételével - bármelyik úton ${ }^{629}$ áruikkal átutazó brassóiak a vajdának két harmincaddal tartoznak: egy tricesimával odafelé, Hosszúmezőnél (Câmpulung, ma Románia, a Déli-Kárpátok lábánál, a Brassót Havasalfölddel összekötő Törcsvári-hágó déli nyílásánál) a másikkal visszafelé, a Duna átkelőjénél(?) (circa Danubium). A vám megfizetését követően szabadon átkelhettek Vlad földjén. ${ }^{630}$ Ha a brăilai úton utaztak át a Havasalföldön, az áruik után tricesimát csak a visszaúton kellett fizetniük, Câmpulungban. A tranzitkereskedelem feltételeinek körülírása mellett a vajda vám- és harmincadmentességet garantált a brassóiaknak abban az esetben, ha adásvételeket bonyolítottak le a Havasalföldön - a câmpulungi vám (tributum) kivételével, ami alól nem mentesültek. ${ }^{631}$ A vajda ekkor tulajdonképpen a brassóiak már meglévő, régi szabadságait (in univeris eorum libertatibus per eos ab antiquis in terra nostra Transalpina habitis conservando confirmaremus) erősítette meg a „transzalpin” területeken, ahol már egy évtizeddel korábban is feltűntek: 1358-ban I. Lajos szabad közlekedést tett lehetővé számukra a Bodza és a Prahova folyók között (előbbi a Szeret, utóbbi a Jalomica mellékfolyója), onnan, ahol a Jalomica (Ilonca) a Dunába ömlik, addig, ahol a Szeret folyik bele a Dunába ${ }^{632}$ vagyis, Pach Zsigmond Pál értelmezése szerint, „a Bodzai-szoroson a Tömösi- meg a Törcsvári-hágón át Havasalföldre egészen az Ilontha (Ialomiţa) és a Szeret folyók dunai torkolatáig; ebben a délkelet-kelet felé húzódó területsávban, ahol fô úti céljuk Brăila volt” ${ }^{633} 1368$ júniusában, fél évvel azután, hogy I. Lajos ráhatására Vlad vajda írásba foglalta a brassóiaknak a Havasalföldre irányuló és az azon átmenő kereskedelmének feltételeit, a király a város kereskedőinek érdekében a Duna-delta és a Bug közötti területet uraló Dimitrij

\footnotetext{
${ }^{628}$ et ut ipsi fideles nostri Saxones recompensam predictorum suorum serviciorum et laborum eo melius sentiant preemiatam ipsos de solucione tributi quod in civitate pro nostra dant maiestate promittumus sicut nobis videbitur alleviare - ZW. II. 480.

${ }^{629}$ A Câmpulungnál elágazó út Târgovișten, Târgşorun, Gherghiţan, Buzăun keresztül vezetett Brăilaba. A másik út Argeșen, Piteștin, Slatinán és Turnun keresztül vitt Nikápolyba, illetve Slatináról el lehetett jutni Olteniaba és Vidinbe. Rădvan, L.: At Europe's Borders 223.

630 ZW. II. 306-307.

${ }^{631}$ cum autem ipsi mercatores bona mercimonialia infra terram nostram vendiderint aut mercati fuerint nullum ex tunc tributum nec tricesimum de eisdem bonis nisi in Longo Campo vel iuxta non tricesimum sed tantum iustum et antiquum tributum nobis solvere tenebuntur - ZW. II. 307.

632 ZW. II. 306-307.

${ }^{633}$ Pach Zs. P.: Levante 15.
} 
tatár kánnal (princeps) is megállapodást kötött: ${ }^{634}$ elengedte Dimitrij kereskedőinek a harmincadot királysága területén, cserébe a brassóiaknak sem kellett tricesimát fizetniük a kán földjén. ${ }^{635} \mathrm{~A}$ kereskedőváros mindemellett törekedett a Kárpátokon túlra irányuló kereskedelmet kisajátítani. 1369-ben Brassó I. Lajostól Buda mintájára a külföldi (konkrétan: lengyel, német) távolsági kereskedőket sújtó árumegállító jogot eszközölt ki, akik ennek értelmében posztójukat nagy tételben kellett, hogy eladják a városban, mivel onnan nem szállíthatták tovább. Az árumegállítás a magyarországi, nevezetesen a kassai kereskedőkre nem vonatkozott. ${ }^{636}$

A brassóiak kereskedelme a Lajos-korban részben nyugat felé irányult, például az Adriára, Zárába, ahová, akárcsak a Fekete-tenger partvidékére, szintén levantei áruk beszerzése miatt keltek útra. ${ }^{637}$ A király számukra - Szeben és Pozsony kereskedőihez hasonlóan ${ }^{638}$ - a Brassó-Zára útvonalon vámmentes közlekedést tett lehetővé; egyedül a budai harmincadot kellett kifizetniük. A királyi kiváltságlevél alapján kiállított védlevél birtokában indulhatott útnak Brassóból Zára felé 1370-ben Seidlini Miklós, „Toyhan” János és Seidlini György. ${ }^{639}$ A brassóiak (a szebeniekhez hasonlóan) viasszal is kereskedtek, főleg Budán, ahol az olvasztás után formába öntött viaszt rányomott városi pecsétjük alatt hozták forgalomba. ${ }^{640}$

1364. június 10-én Lajos Brassóban éves vásár (nundine seu fori annui congregaciones libere) tartását tette lehetővé a Mindenszentek ünnepe (november 1.) körüli időszakban (in dicto omnium sanctorum festo et diebus debitis ante et post ipsum festum). A sokadalmat a budai mintájára kellett megtartani ${ }^{641}$ - ennek érdekében a király október 18-án parancsba adta a budai városvezetésnek, hogy a brassóiak részére saját pecsétjük alatt írják át a budai éves vásár jogait és szabadságait. ${ }^{642}$ A budaiak a királyi parancsnak december 20-án tettek eleget,

\footnotetext{
${ }^{634}$ Vásáry, I.: Cumans and Tatars 164. Vö. Tardy L.: A tatárországi rabszolgakereskedelem 162.

635 pro statu vestro meliori et commodo potiori tricesimam quam mercatores domini Demetrii principis Tartarorum de suis rebus mercimonialibus in regno nostro solvere deberent non faciemus recipi ita ut et vos in terra ipsius domini Demetrii secure et libere possitis transire sine solucione tricesime cum rebus vestris et bonis mercimonialibus - ZW. II. 315.

636 ZW. II. 336.

${ }^{637}$ Vö. Pach Zsigmond Pál ezzek kapcsolatos írásait: Pach Zs. P.: Levante; Pach Zs. P.: Levante-kereskedelem; Pach Zs. P.: A középkori Levante.

${ }^{638}$ Vö. 1370: ZW. II. 337-339. (Szeben); 1361: DF 238791 = DF 239015 (F. IX/7. 198-199.); 1366: DF 238 835. (Pozsony).

639 ZW. II. 354-355.

640 1374: ZW. II. 416-417.

${ }^{641}$ ZW. II. 212-213. Lajos a sokadalmat engedélyező oklevelét 1364. okt. 28-án átírta és megerősítette. ZW. II. $219-220$.

642 quatenus universa jura et libertates fori annui vobis dati prout in nostro privilegio exinde confecto exprimuntur Hermanno et Jacobo civibus de dicta Brassow ostensoribus presencium in transscripto sub vestro sigillo concedatis et emanari facere debeatis - ZW. II. 219.
} 
amikor Hermann és Jakab brassói polgárok részére átírták IV. László 1287. évi ${ }^{643}$, ezzel kapcsolatos oklevelét. ${ }^{644}$

\section{Buda (Pilis megye) [Budapest része, $\mathrm{H}$ ]}

A 14. század derekán a király és az anyakirályné nem szűnő jóindulatát élvező óbudai apácák - 1351-ben a nyúl-szigeti domonkosok, majd mintájukra ${ }^{645}$ 1365-ben az óbudai klarisszák is - arra hivatkozva, hogy vámjaikat ${ }^{646}$ alamizsnaként kapták, kijárták, hogy az uralkodó hatálytalanítsa mind a külföldi, mind a hazai kereskedők vámmentességet biztosító okleveleit vámjaik vonatkozásában. ${ }^{647}$ A Margit-szigeti apácáknak budai kapu(vásár)vámjukat ${ }^{648}$ illetően régebb óta volt ilyen kiváltságuk: 1298 körül nyerték el III. András királytól, és a belföldi, kiemelten a soproni kereskedőkre vonatkozott. ${ }^{649}$ Amikor I. Lajos 1359-ben, majd 1369-ben is megerősítette a regensburgi kereskedőknek az 1336. évi csökkentett vámtarifájú ～Fehéregyháza-Sasvár/Szenic-Jablonca-Bikszárd/BényNagyszombat-Farkashida-Sempte-Nyárhíd-Udvard-Esztergom-Csaba-SzentjakabfalvaBuda út ${ }^{650}$ vámszabását, egyetlen ponton kivételt tett: a regensburgiaknak Buda kapujában a Margit-szigeti apácáknak járó teljes vámot meg kellett fizetniük. ${ }^{651}$ I. Lajos 1369-ben az ambergi (Bajorország) kereskedők számára is garantálta az 1336-os vámtarifát - a csökkentett

${ }^{643}$ Vö. ZW. I. 153-154.

644 ZW. II. 222-223.

${ }^{645}$ Kiváltságleveleik (lásd következő jegyzet) szövege gyakorlatilag megfelel egymásnak.

${ }^{646}$ A 15. század közepén az óbudai, a ceglédi, a szondi, a széplaki és az egyedújfalusi vámok voltak az óbudai klarisszák birtokában. 1449: DL 14 211. Az óbudai hajóvámhoz 1366-ban jutottak, a szentjakabfalvi vámért cserébe (1366: F. IX/3. 528-531. Vö. 1351: F. IX/2. 53-55.); a Bács megyei Széplak útvámját, Egyedújfalu útés vásárvámját, valamint Belszond vámját (tributum fori Danubium) 1382-ben kapták meg I. Lajostól, cserébe többek közt a szepesi Lucsivna, Podolin és Tótfalu, valamint a Szabolcs megyei Révbács vámjaiért. 1382: DL 6905.

${ }^{647}$ quod quamquam plerisque hominibus, regnicolis nostris et extraneis ac hospitibus, instantiis eorumdem, et supplicationibus interuenientibus, huiusmodi gratiam fecisse dignoscimur: vt ipsi nullas in regno nostro tributa dare et soluere teneantur ... nam volumus, et testimonio praesentium committimus mediante, vt omnes homines tam regnicolae nostri, quam extranei, tributum soluere debentes, in locis tributorum earumdem Dominarum tributum consuetum plene dare et soluere teneantur; non obstante gratia eisdem facta praenotata; cui, vt praemittitur, praesentibus volumus derogari - 1351: F. IX/2. 73-74.; 1365: F. IX/3. 498-500. Az idők folyamán mindkét kolostor gondosan ügyelt arra, nehogy kiváltsága érvényét veszítse. A Margit-szigetiek oklevélmegerősítéseit lásd 1365: F. IX/3. 493-495. (I. Lajos), 1393: DL 7823. (Mária), 1397: DL 4181. (Zsigmond). Óbudai klarisszák: 1393: Bp. III/1. 78. (Zsigmond), 1406: DL 9123. (Zsigmond).

${ }^{648}$ Weisz B.: Vámok és vámszedés 99.

${ }^{649}$ HO. VIII. 418. (Reg. Arp. 4349. sz.).

${ }^{650}$ Térképen lásd: Weisz B.: Vámok és vámszedés 462. 2. térképmelléklet. Az útról részletesen lásd Skorka R.: Csökkentett vámtarifájú út.

651 dempto tamen et excepto vno articulo superius expresso, in quo dicitur In porta vrbis Budensis; volumus enim, et presencium serie committimus, vt tributa religosarum dominarum sanctimonialium de Insula Leporum in predicta porta Ciuitatis Budensis exigi consueta ... per predictos mercatores et alios quoslibet indempniter persoluantur - Wenzel, Dipl. Eml. II. 666. Vö. Skorka R.: Csökkentett vámtarifájú út 468. 
vámszabás az apácák budai vámjára ezúttal sem vonatkozott. ${ }^{652}$ A kapuvám kivétele, amint Skorka Renáta megfigyelte, hiányzik viszont a nürnbergi (1364), a kölni és a hoyi (1365) kereskedők hasonló megerősítő okleveleiből. ${ }^{653}$

\section{Bulvenc (Temes megye) [Vermeș (Krassóvermes), RO]}

1370-ben Lajos Himfi Benedek volt bolgár bán érdemeire tekintettel Benedek, testvérei, Péter és Miklós és frater patruelise, János fia László ${ }^{654}$ Temes megyei Remete és Krassó megyei Bácstövise birtokaira szerdai, továbbá az ugyancsak temesi Bulvenc birtokukra szombati hetivásár tartására adott engedélyt a szomszédos és más megyebeli vásárok sérelme nélkül. ${ }^{655}$

\section{Buzita (Abaúj megye) [Buzica, SVK]}

1358-ban a jászói konvent tanúságával Buzita birtokot és az ott szedett vám felét (medietas tributi) Buzitai Kardos István fia Jánosnak ${ }^{656}$ iktatták. ${ }^{657}$

\section{Cege (Doboka megye) [Taga, RO]}

1363-ban a király Vas Miklós fiai, László, János, ${ }^{658}$ István és Pál mesterek és frater patrueliseik, Vas László fia Simon és Lőkös, illetve Tamás fia János ${ }^{659}$ kérésére birtokukon, a Doboka megyei Cegén szerdai hetivásár (forum liberum) tartására adott engedélyt a szomszédos vásárok sérelme nélkül (sine tamen preiudicio fororum vicinorum). ${ }^{660}$

\footnotetext{
${ }^{652}$ MDA 677-679. Skorka R.: Csökkentett vámtarifájú út 468.

${ }^{653}$ Skorka R.: Csökkentett vámtarifájú út 468. 95. jz.

${ }^{654}$ Vö. Engel P.: Genealógia: Him rokonsága 2. tábla: Himfi.

${ }^{655}$ DL 70 654. (Tringli I.: Perényi 120. sz.).

${ }^{656}$ Vö. Engel P.: Genealógia: Kardos (buzitai, Abaúj megye).

${ }^{657}$ DL 84 789. (Anjou-oklt. XLII. 129., 133. sz.).

${ }^{658}$ László és János Wass 131. sz. kiegészítései.

${ }^{659}$ Vö. Engel P.: Genealógia: Vas (Wass; cegei, szentegyedi).

${ }^{660}$ Hokl. 270. Wass 131. sz. (Anjou-oklt. XLVII. 298. sz.).
} 


\section{Cegléd (Pest megye) [Cegléd, H]}

Lajos Cegléd királyi birtokot avagy falut (possessionem seu villam nostram regalem) 1358-ban - vámjával (tributum) együtt - kérésére anyjának, Piast Erzsébet királynénak adományozta. Erzsébet Cegléddel a továbbiakban teljesen szabadon, királyi jóváhagyás nélkül rendelkezhetett, akár el is idegeníthette. ${ }^{661}$ A királyi adománylevél szerint Cegléd emberemlékezet óta királyi birtok volt, ${ }^{662}$ majd Lajos Avignont többször megjárt nunciusának, ${ }^{663}$ Praunspeck/Jägerndorfer Pálnak adta (a karintiai Gurk püspöke 1351-1359 között, korábban királynéi káplán, szepesi kanokok ${ }^{664}$ és nyitrai főesperes). ${ }^{665}$ Pál, amikor a királyságból püspökségébe távozott, Ceglédet 1000 forintért Wlueng Miklós comesnek zálogosította el, kiváltását pedig a királynak tartotta fent. ${ }^{666}$ A birtokot végül Erzsébet királyné váltotta ki 1200 forintért, aki aztán - a király beleegyezésével - tíz évvel később, 1368-ban vámjával együtt, alamizsnaként az általa alapított óbudai klarissza kolostornak adományozta. $^{667}$

1364-ben a király Erzsébet anyakirályné közbenjárására az egész országban felmentette Cegléd királynéi (nunc reginales) polgárait és hospeseit a személyük és javaik (de rebus et bonis ipsorum) utáni vámfizetés alól. ${ }^{668}$

\section{Cenk (Sopron megye) [Nagycenk, H]}

A cenki vám fizetése alól I. Károly 1328-ban felmentette a sárvári vendégeket. ${ }^{669}$ Vámmentességüket 1344-ben I. Lajos is elismerte. ${ }^{670}$ Cenken vásár és/vagy közlekedési vámot szedhettek a 14. században. ${ }^{671}$

\footnotetext{
661 AO VII. 5-7.

662 AO VII. 5.

${ }^{663}$ Pór A.: Jegerndorfi Pál 694.

${ }^{664}$ Pór A.: Jegerndorfi Pál passim.

665 Vö. AO VII. 5. 2. jz. Eubel, K.: Hierarchia catholica I. 270.

${ }^{666}$ AO VII. 5.

${ }^{667}$ DL 5698., DL 5699. Határjárása: DL 5696.

668 iidem cives et hospites de dicta Ceegled nunc reginales nullas in regno nostro de rebus et personis ipsorum tributum solvere teneantur sed ab omni tributaria exaccione penitus et per omnia exempti habeantur - DL 5301.

${ }^{669}$ Weisz B.: Vámok és vámszedés 103.

${ }^{670}$ DL 3743. (Anjou-oklt. XXVII. 835. sz.: F. alapján tévesen 1343. december 20-i kelettel). Vö. F. IX/1. 99.

${ }^{671}$ Weisz B.: Vámok és vámszedés 103.
} 


\section{Csap (Ung megye) [Chop, UKR]}

Gerényi Druget János fia, Druget Miklós ${ }^{672}$ ungi comes $^{673} 1346$ februárjában Csapi Tamás fia, János ${ }^{674}$ Csap birtokán a Latorca folyóra hatalmaskodva hidat építtetett. ${ }^{675}$

\section{Császártelke (Doboka megye) [helye ismeretlen] ${ }^{676}$}

1347-ben Császártelke határjárásakor érintették a Zaruastho-t (Zaruasto) ${ }^{677}$ és annak hosszú hídját (de qua descendissent ad Zaruastho ad pontem longum). ${ }^{678}$

\section{Cseke (Sopron megye) [Wimpassing an der Leitha, A]}

Csekén, a Lajta folyó mellett vámot szedtek (tributum in villa Cheken iuxta fluvium Saar existens habitum), aminek a tényéről a király 1349. évi, a mindenkori soproni comeshez (akkor éppen Raholcai Kont Miklós töltötte be a tisztet) ${ }^{679}$ és alispánhoz, továbbá a szarvkői várnagyhoz intézett parancsából értesülünk. Lajos ebben megtiltotta a csekei vám jogtalan szedését - amit a soproniak panasza szerint az országlakos és a külföldi, különösen Ausztriából jövő, a városukba (Sopronba) igyekvő kereskedők kárára megemeltek -, valamint a kereskedők zaklatását, föleg Szarvkő vára alatt. ${ }^{680}$

\footnotetext{
${ }^{672}$ Vö. Engel P.: Genealógia: Druget 1. tábla: gerényi ág.

${ }^{673}$ Vö. Engel P.: Archontológia I. 219.

${ }^{674}$ Vö. Engel P.: Genealógia: Baksa rokonsága 8. tábla: Csapi (Eszenyi).

675 Z. II. 187. (Anjou-oklt. XXX. 145. sz.); Z. II. 187-188. (Anjou-oklt. XXX. 173. sz.); Z. II. 202. (Anjou-oklt. XXX. 281. sz.); Z. II. 202-203 (Anjou-oklt. XXX. 339. sz.).

${ }^{676}$ Cege és Szentiván határosa (DF 252 895), talán Császárival (Cesariu, Sântioana [Vasasszentiván] része, RO) azonos. Vö. Engel P.: Térkép.

677 DF 257 548. (újkori egyszerủ másolatban).

${ }^{678}$ DF 252 895. (Anjou-oklt. XXXI. 361. sz.).

${ }^{679}$ Engel P.: Archontológia I. 179.

680 F. IX/1. 651-652. (AT WStLA HAUrk 334. In: monasterium.net, URL

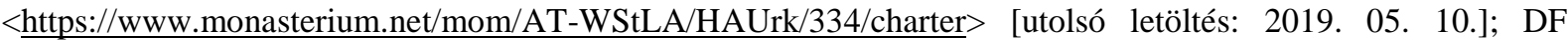
248 545_96, 94.).
} 


\section{Csente ${ }^{681}$ (Bodrog megye) [Kupusina (Bácskertes) vidékén, SRB]}

Csente keddi hetivására 1366-ban háromvásáros kikiáltás színhelye volt. ${ }^{682}$

\section{Csepreg (Sopron megye) [Csepreg, H]}

Csepreg falu csütörtöki hetivására 1355 -ben, ${ }^{683} 1363-$ ban $^{684}$ és $1378-$ ban $^{685}$ is háromvásáros kikiáltás színhelye volt.

\section{Csermend (Nyitra megye) [Čermany, SVK]}

Csermend csütörtöki hetivására 1381-ben háromvásáros kikiáltás színtere volt. ${ }^{686}$

\section{Csetnek (Gömör megye) [Štítnik, SVK]}

Csetneken bizonyíthatóan már a Károly-korban szombati hetivásárt tartottak és vámot szedtek. ${ }^{687}$ 1367-ben, amikor az Ákos nembéli Bebek Domonkos fiai, Domonkos csanádi püspök, István országbíró, György királynéi tárnokmester és Miklós, ${ }^{688}$ másrészről rokonaik, Csetneki László fia László, „Kun” Miklós fiai, Ákos és György, valamint „Veres” Miklós fia, György felosztották egymás között Csetneki Benedek utód nélkül elhalt fiai, János és Péter 689 birtokait, egyúttal mentesítették Bebek Domonkos fiainak szombatonként Csetnek faluba vásározni tartó veszverési jobbágyait a csetneki vám fizetése alól. ${ }^{690}$

\footnotetext{
${ }^{681}$ Korábbi történetére lásd Weisz B.: Vámok és vámszedés 111.

${ }^{682}$ DL 5363. Weisz B.: Vámok és vámszedés 140.

683 Sopron vm. I. 255. (Anjou-oklt. XL. 321. sz.).

${ }^{684}$ DL 87 383. (Anjou-oklt. XLVII. 328. sz.).

${ }^{685}$ Sümeghy 79. Weisz B.: Vásárok és lerakatok 158.

${ }^{686}$ DL 75 553. Weisz B.: Vásárok és lerakatok 154.

${ }^{687}$ Weisz B.: Vámok és vámszedés 113.

${ }^{688}$ Vö. Engel P.: Genealógia: Ákos nem 1. Bebek-ág 3. tábla: Bebek (pelsőci ág).

${ }^{689}$ Vö. Engel P.: Genealógia: Ákos nem 1. Bebek-ág 2. tábla: Csetneki.

${ }^{690}$ DL 75018.
} 


\section{Csütörtökhely (Körös megye) [Daruvar (Daruvár) területén, HR]}

1358-ban Lajos Csütörtökhely királyi birtokot vásárvámjával együtt (simul cum tributo fori) Himfi Pál fia Benedek mester visegrádi várnagynak, testvéreinek, Miklósnak és Péternek, valamint Pál fia János fia Lászlónak ${ }^{691}$ adta új adomány címén. ${ }^{692}$ Csütörtökhely csütörtöki hetivására legkorábban 1338-ból adatolható. ${ }^{693}$

\section{Csütörtökhely ${ }^{694}$ (Szentlászló) (Szepes megye) [Spišský Štvrtok (Szepescsütörtök), SVK]}

1353-ban Szentlászló csütörtöki hetivására háromvásáros kikiáltás színtere volt. ${ }^{695}$

\section{Damásd (Bars megye) [Domaša (Garamdamásd), Hronovce (Lekér) része, SVK]}

Az esztergomi káptalan Damásd falujában a 14. század közepén „régóta” (ab antiquo) vasárnaponként tartották a hetivásárt. A király 1352. évi oklevele szerint a vásárt Vesszős mester ${ }^{696}$ saját falujába, a közeli Zselizbe helyezte át, de miután a káptalan in publico et privato is igazolta jogait a vásárra, az visszakerülhetett Damásdra. ${ }^{697}$ A vásár visszahelyezéséről a király a kereskedőket vásári kikiáltással rendelte el értesíteni. ${ }^{698}$

\section{Dávod (Bodrog megye) [Dávod, H]}

Dávod a Lajos-korban vásáros hely volt, keddi hetivására elsőként 1342-ből adatolható. ${ }^{699}$ A 14. század közepén a birtok és vására a szekcsői Hercegeké ${ }^{700}$ volt, akik szemlátomást

\footnotetext{
${ }^{691}$ Vö. Engel P.: Genealógia: Him rokonsága 2. tábla: Himfi.

${ }^{692}$ Smič. XII. 515-516. (Anjou-oklt. XLII. 1182. sz.).

${ }^{693}$ Weisz B.: Vámok és vámszedés 116.

${ }^{694}$ Korábbi történetére lásd Weisz B.: Vámok és vámszedés 119.

${ }^{695}$ DF 272 391. (Anjou-oklt. XXXVIII. 70. sz.).

${ }^{696}$ Vö. Engel P.: Genealógia: Töttös (bátmonostori).

${ }^{697}$ renunciavit et omne ius quod ex ipso foro sibi usurpaverat eidem capitulo remisisset et remisit - DF 235838. (Str. IV. 74.).

${ }^{698}$ DF 235 838. (Str. IV. 74.). Lajos az oklevelet 1365-ben átírta és megerősítette. DF 235838.

${ }^{699}$ Weisz B.: Vásárok és lerakatok 140.

${ }^{700}$ Vö. Engel P.: Genealógia: Héder nem 6. tábla: Herceg (szekcsői).
} 
komoly konkurenciát láttak Becsei Töttös ${ }^{701}$ ajtónállómester, visegrádi várnagy ${ }^{702}$ közeli, Bátmonostoron tartott hétfői hetivásárában. 1347 júniusában a szekszárdi konvent tanúságával Bodrog és Baranya megyékben lefolytatott vizsgálat igazolta Becsei Töttös panaszát a Héder nembéli Henrik bán fia, „Herceg” Péter bodrogi comes ${ }^{703}$ ellenében, aki május (pünkösd) óta Töttös hétfői vásárának tönkretételére törekedett: famulusaival konkrétan lezáratta a Budáról, Szegedről, valamint Szerém és Baranya megyékből Bátmonostorra vezető utakat, a vásárra tartókat pedig személyükben inzultálta, javaikat elvetette, és a dávodi vásárán (forum suum feria tercia in possessione sua Dauch vocata celebrari consuetum) való részvételre kényszerítette. ${ }^{704}$ A rákövetkező évben, 1348-ban az a hír járta Bodrog megyében, hogy a dávodi vásáron „Herceg” Péter megverette és megsebesíttette Töttös egyik jobbágyát, akinek a holmijait is elvetette, ráadásul utasítására figyelték és fosztogatták a Baranya megyéből a bátmonostori vásárra tartókat. ${ }^{705}$

Dávod vására később, 1363-ban háromvásáros kikiáltás színhelye volt. ${ }^{706}$

\section{Detmár (Valkó megye) [Kešincitől K-re, HR]}

1348. március 31-én Anna (Gilét fia János mester felesége, a néhai Sáfár István mester leánya), ${ }^{707}$ valamint Anna lányai, Erzsébet és Mária, ${ }^{708}$ másrészről Erzsébet (Maróti István mester udvari lovag felesége, a néhai Ibrányi Györk mester lánya) ${ }^{709}$ (képviselői) a király előtt azt a bevallást tették, hogy húsvét quindenáján (május 4.) fogott bírák közremüködésével, a bácsi egyház tanúsága mellett két részre osztják Ibrányt, Detmárt és Jamát tartozékaikkal, haszonvételeikkkel és jövedelmeikkel, kiváltképpen a vámokkal és a vásárokkal együtt (cum quibuslibet earum pertinenciis et utilitatibus ac proventibus specialiter tributis foris). ${ }^{710} \mathrm{Az}$, hogy a királyi oklevél szövegében a vám és a vásár szavak is

\footnotetext{
${ }^{701}$ Vö. Engel P.: Genealógia: Töttös (bátmonostori).

702 Vö. Engel P.: Archontológia I. 163.

${ }^{703}$ Vö. Engel P.: Genealógia: Héder nem 4. tábla: Kőszegi (és Rohonci).

${ }^{704}$ Z. II. 261-262. (Anjou-oklt. XXXI. 607. sz.). Az ügyet részletesen tárgyalja Földesi F.: Dávod 57-58.; Weisz B.: Vásárok és lerakatok 28-29.

705 Z. II. 298-299. (Anjou-oklt. XXXII. 670. sz.).

${ }^{706}$ DL 5158. (Anjou-oklt. XLVII. 369. sz.), DL 6483. (Anjou-oklt. XLVII. 495. sz.), DL 5218 (Anjou-oklt. XLVII. 288. sz.).

${ }^{707}$ Vö. Engel P.: Genealógia: Sáfár (csévi, taranyai). Anna anyja, Sáfár István felesége is Ibrányi Györk lánya volt. Engel P.: Genealógia: Gútkeled nem 2. Maróti.

${ }^{708}$ Vö. Engel P.: Genealógia: Smaragdus nem 2. tábla: Gilétfi (Zsámboki).

${ }^{709}$ Vö. Engel P.: Genealógia: Gútkeled nem 2. Maróti.

${ }^{710}$ Smič. XI. 449-450. (Anjou-oklt. XXXI. 141. sz.).
} 
többes számban szerepelnek, Ibrányon a Zsigmond-kor előtti vásártartást, ${ }^{711}$ Detmáron és (vagy) Jamán pedig egyáltalán vásártartást enged feltételezni, illetve legalább a háromból két helyen vámszedéssel számolhatunk.

\section{Diakó (Valkó megye) [Djakovo, HR]}

Diakó civitas szombati hetivására 1377-ben háromvásáros kikiáltás színhelye volt. ${ }^{712}$

\section{Diószeg ${ }^{713}$ (Bihar megye) [Diosig (Bihardiószeg), RO]}

Diószeg keddi hetivására 1374-ben háromvásáros kikiáltás helyszíne volt. ${ }^{714}$

\section{Dobrasó (Trencsén megye) [Petrova Lehota-tól (Péterszabadja) É-ra, SVK]}

Dobrasó (Dobras) 1379. évi határjárása érintett egy hidat egy holtág felett (prope unum pontem qui est super unum ryvulum mortuum seu fluvium). ${ }^{715}$

\section{Dobrocsány (Krassó megye) [lam (Jám) környékén, RO] ${ }^{716}$}

Dobrocsánynál a Krassó folyón hídon lehetett átkelni. A birtok 1355-ben Szeri Pósafi Balázsé $^{717}$ volt, akinek az állítását, miszerint a dobrocsányi hidat az április 24-25. közötti éjszakán, hajnaltájt Jánki Miklós ${ }^{718}$ és cinkosai hatalmaskodva elpusztították, 1355. április 30-

\footnotetext{
${ }^{711}$ A legkorábbi adatunk Ibrányi (keddi) hetivásárára 1402-ből való. Weisz B.: Vásárok és lerakatok 169.

${ }^{712}$ DL 91841.

713 Korábbi történetére lásd Weisz B.: Vámok és vámszedés 125.

714 DF 233883.

${ }^{715}$ DF 273433.

716 Vö. Gy. III. 480. Szeri Pósafiakról szóló doktori dolgozatában Szaszkó Elek vetette fel az 1347-ben Dobrovicaként (Dobrouicha) és az 1355-ben Dobrocsányként (Dobrochan) említett birtokok esetleges azonosságát. (Szaszkó E.: A Szeri Pósafiak 138.) Véleményét azóta megváltoztatta, Dobrocsányt valahová a mai Jám környékére lokalizálja. (Szaszkó Elek személyes közlése).

${ }^{717}$ Vö. Engel P.: Genealógia: Bár-Kalán nem 1. Szeri ág 2. tábla: Pósafi (szeri, sződi).

${ }^{718}$ Vö. Engel P.: Genealógia: Jánki. DL 91 475-ben Ivanc-i Miklós szerepel.
} 
án Krassó megye, ${ }^{719}$ majd november 21-én a megyei közgyülés is megerösítette. ${ }^{720}$ A híd talán valamiféle kötélhíd lehetett, erre utal, hogy tönkretételét a decido és a deseco (levág) igékkel írták le. ${ }^{721}$ 1360-ban Krassó megye közgyülése igazolta Szeri Pósafi Balázs állítását, hogy Jánki Miklós bizonyos krassói hídját (quendam pontem suum in Karasou habitum) lerombolta ${ }^{722}$ - az adat talán szintén a dobrocsányi Krassó-hídra vonatkoztatható.

\section{Dombró (Körös megye) [Dubraca, HR] ${ }^{723}$}

Dombrón egy 1353. évi oklevél tanúsága szerint híd- és vásárvámot (tributa pontis et fori de Dombro) is szedtek, ami a zágrábi püspök bevételeit gyarapította. A vámokat 1353. október 3-án Apáti „Keszei” Miklós püspöktől ${ }^{724}$ honor gyanánt János egri olvasókanonok, a föpap kancellárja bírta (pro honore conservaret), tőle vette bérbe a vámjövedelmeket 1 évre 120 magyar forintért - vagy jó súlyú dukátokért (vel ducatis bonis veri et iusti ponderis) György mester és testvére, András deák, Óbuda várnagya. ${ }^{725}$

\section{Dorog (Heves megye) [Dorogpuszta Dorogházától Ny-ra, H]}

Kazai Kakas fia László ${ }^{226}$ 1380-ban arra kérte a királyt, engedélyezze újra Bátony és Dorog birtokán a már elődei ideje óta szokásos vámszedést, amiről szóló oklevelei azonban elvesztek. Lajos, miután meggyőződött arról, hogy Bátonyt, Dorogot és a vámokat a kérelmező és elődei mindaddig békésen birtokolták, a két vám szedését László hűségére és érdemeire való tekintettel újfent lehetővé tette. ${ }^{727}$ Dorog és Bátony vámjait az 1405 . évi Nógrád megyei vámvizsgálat is említette, ami megállapította, hogy a Tarján birtokról

\footnotetext{
${ }^{719}$ DL 91475.

${ }^{720}$ DL 91483.

${ }^{721}$ unum pontem suum in sua possessione Dobochan vocata super aquam Karaso decidisset vel desecate fecisset et ad illam facientem aquam posuisset - DL 91475.

722 DL 91557.

${ }^{723}$ A szóba jöhető települések közül az oklevélben szereplő Dombro valószínüleg a Körös megyei Dombróval azonosítható, legalábbis ennek birtokosai közt mutatható ki - habár csak a 15-16. században (1494, 1517) - a zágrábi püspök. Csánki D.: Körös megye 72, 113., Engel P.: Térkép: „Dombró” - Körös megye.

${ }^{724}$ Engel P.: Archontológia I. 79.

${ }^{725}$ DL 263 067. Kivonata: F. IX/2. 301. Vö. Engel P.: Archontológia I. 379.

${ }^{726}$ Engel P.: Genealógia: Rátót nem 5. tábla: Kakas (kazai).

${ }^{727}$ DL 89488.
} 
Verebélyre, onnan Tarra, majd Tarról Pásztóra vezető utat járók csak a tari vámot kötelesek leróni - Dorogra és Bátonyba menni, és ott vámot fizetni nem tartoznak. ${ }^{728}$

\section{Dragotin (Valkó megye) [Dragotin, HR]}

Dragotin falu hétfői hetivására 1377-ben háromvásáros kikiáltás színhelye volt. ${ }^{729}$

\section{Écs (Győr megye) [Győrszentmárton határában, H]}

Az écsi királyi népeknek avagy jobbágyoknak (populi seu jobagiones) Lajos szerdai napokon hetivásár (forum liberum) tartását tette lehetővé. 1350-ben a király az écsi vásár napját hétfőre módosította, hogy ne okozzon kárt a pannonhalmi apát szentmártoni hetivásárának. ${ }^{730}$

\section{Egeres (Kolozs megye) [Aghireşu, RO]}

1370-ben Lajos a kolozsmonostori konvent Egeres birtokán hetivásár (forum) tartását engedélyezte. ${ }^{731}$

\section{Egerszeg $^{732}$ (Zala megye) [Zalaegerszeg, $\mathrm{H}$ ]}

Egerszeg hétfői hetivására 1344-ben háromvásáros kikiáltás színhelye volt. ${ }^{733}$

\footnotetext{
${ }^{728} \mathrm{ZsO}$. II/1. 3890. sz.

${ }^{729}$ DL 91841.

730 1350. május 28.: P. II. 404-405. (Anjou-oklt. XXXIV. 436. sz.). Az oklevelet 1350. július 18-án Erzsébet királyné Vilmos pannonhalmi apát kérésére átírta és megerősítette. (Anjou-oklt. XXXIV. 537. sz.)

731 DL 36 403_10. Jakó: Kolozsmonostor 192. Weisz B.: Vásárok és lerakatok 147.

${ }^{732}$ Korábbi történetére lásd Weisz B.: Vámok és vámszedés 132.

733 Zala I. 443. (Anjou-oklt. XXX. 913. sz.).
} 


\section{Egregy $^{734}$ (Külső-Szolnok megye) [Românași (Alsóegregy), Románia]}

1363-ban Lajos Dobokai János fia László udvari vitéz, apja, és rokonai, Miklós fia László és Lőkös ${ }^{735}$ Külső-Szolnok megyei Egregy birtokán hétfői hetivásár (forum liberum) tartását engedélyezte. ${ }^{736} 1367-b e n$ a vásárt a király László kérésére, amit azzal indokolt, hogy a vásárt Egregyen „alkalmasan nem lehet megtartani” ${ }^{737}$, Szolnok és Doboka megyei Hidalmás birtokukra helyezte át - szombati napra. ${ }^{738}$

\section{Egres (Ugocsa megye) [Oleshnyk (Szőlősegres), UKR]}

Egres birtok 1356. évi határjárása érintette a Kövecses rév (kuuechesrew) nevü átkelőt (vadum seu transitum) a Verbőcpataka nevü vízfolyáson. A rév a Verbőcpataka egy keletről nyugatra folyó szakaszán működött, ${ }^{739}$ és a Szőlősből Egresbe tartó út átkelőhelye volt. ${ }^{740}$

\section{(Egyed)újfalu (Bács megye) [Sontától (Szond) ÉK-re, SRB]}

1382-ben a király és az óbudai klarisszák között több birtokot, vámot és az illető birtokok kamarahasznáját érintő birtokcserére került sor: ennek során Újfalu út- és vásárvámjával (cum tributo viatico et fori), továbbá az itt szedett kamarahasznával együtt az apácáké lett. ${ }^{741}$

\section{Endrefalva (Nógrád megye) [Endrefalva, $\mathrm{H}]$}

Endrefalván 1348-ig hétfői napokon hetivásárt tartottak. 1348. július 6-án a vásárt napjának változatlanul hagyásával - az Endrefalvát birtokló Szécsényi Tamás krassói és kevei

\footnotetext{
734 Korábbi történetére lásd Weisz B.: Vámok és vámszedés 133.

735 Vö. Engel P.: Genealógia: Kökényesradnót nem 1. tábla: Dobokai.

${ }^{736}$ DL 73 695. (Anjou-oklt XLVII. 363. sz.).

${ }^{737}$ comode non posse celebrari - DL 73721.

${ }^{738}$ DL 73 721. Weisz B.: Vásárok és lerakatok 142.

739 quemdam vadum seu transitum ryvuli verbeuchpataka nuncupati fluentis ab oriente in occidentem kuuechesrew dictum ubi eundem ryvulum quedam via publica pertransivit - DF 209 668. (Anjou-oklt. XL. 601. sz.).

${ }^{740}$ Weisz B.: Vámok és vámszedés 158.

${ }^{741}$ DL 6905.
} 
comes, továbbá fia, Kónya ${ }^{742}$ szepesi és sárosi comes I. Lajos hozzájárulásával a nógrádi Ság faluba, Cselen fia Sándor fia, János ${ }^{743}$ gömöri és csongrádi comes, szegedi várnagy birtokára helyezték át. ${ }^{744}$ (Vö. Ság)

\section{Eperjes (Sáros megye) [Prešov, SVK]}

Eperjesen ${ }^{745}$ az 1355. évi sárosi vámrevízió több hiányosságot és visszásságot tapasztalt: nem volt híd, ${ }^{746}$ ami a helyi királyi vámszedést legitimálta volna, „cserébe” túl magas vámokat szedtek (például a szekerek után), sőt állítólag a szerzeteseket is megvámolták. ${ }^{747}$

Röviddel azután, hogy a lengyel-magyar perszonálunió Lajos lengyel trónra léptével realizálódott (1370), egy sor magyar kereskedőváros (elsősorban Kassa, Lőcse és Brassó, másodsorban Szeben és Eperjes) igyekezett kiaknázni az új politikai helyzetet, nevezetesen uralkodói privilégiumokat kieszközölni annak érdekében, hogy minél kedvezőbb feltételekkel kereskedhessenek a lengyel területeken. ${ }^{748}$ A városok törekvései nyomán 1371-ben valóságos kis “kiváltságlevél-robbanás” tapasztalható e téren: Kassa, Lőcse és Szeben után ${ }^{749}$ - két lépésben - Eperjesnek is sikerült kivívnia a jogot, hogy a krakkói kereskedőkkel megegyező feltételekkel kereskedhessen Lengyelországban. 1371-ben Erzsébet királyné lehetővé tette számukra, hogy annyi vámot fizessenek Lengyelországban a saját vámjain, mint a krakkói kereskedők, ${ }^{750}$ majd 1372-ben Lajos a kiváltság hatályát kiterjesztette az összes vámhelyre Krakkóig és azon túl is - azzal a kitétellel, hogy habár a krakkóiak a saját városukban vámmentességet élveztek, Krakkóban az eperjesi kereskedők annyi vámot kötelesek fizetni, mint amennyit a krakkóiaknak kell Szandecben. ${ }^{751}$

\footnotetext{
${ }^{742}$ Vö. Engel P.: Genealógia: Kacsics nem 4. tábla: Szécsényi.

${ }^{743}$ Vö. Engel P.: Genealógia: Ákos nem 2. Sági.

${ }^{744}$ Károlyi I. 175-176. (Anjou-oklt. XXXII 441. sz.). Az oklevelet a király 1354-ben megerősítette. Károlyi I. 217-220. (Anjou-oklt. XXXVIII. 97. sz.).

${ }^{745}$ Korábbi történetére lásd Weisz B.: Vámok és vámszedés 135.

${ }^{746}$ [tributum] in civitate Epperies carens ponte - Draskóczy I.: Sáros megye vámhelyei 59.

747 tributarii in supradictis possessione Sumus et civitate Epperies pro tempore constituti similiter tributa excessiva a similibus curribus et quibuscunque rebus exegissent, ymo immoderacius ac rigidius, nam in ipsa Epperies eciam a monachis exegissent tributum et eos suis rebus dampnificassent - Draskóczy I.: Sáros megye vámhelyei 60.

${ }^{748}$ A magyar-lengyel kereskedelemre és útvonalaira lásd például: Divéky A.: Felső-Magyarország 6-11., 43.; Csánki D.: Hazánk kereskedelmi viszonyai 26-40. passim; Gárdonyi A.: Felső-Magyarország 9., 12-13., 22.; Szende, K.: Kraków and Buda 34. (Trade routes from Kraków in the $14^{\text {th }}-16^{\text {th }}$ century c. térkép).

${ }^{749}$ 1371: ZW. II. 369-370., F. IX/4. 372-373.

${ }^{750}$ Sroka, S.: Dokumenty polskie I. 24.

${ }^{751}$ Sroka, S.: Dokumenty polskie I. 24-25.
} 
1378-ban a király a sárosi vár(uradalom) vámjainak fizetése alól felmentette az eperjesi városfal építési munkálataihoz szánt fa-, kő- és mészszállítmányokat. ${ }^{752}$

Eperjesen hétfőnként hetivásárt tartottak, ami valamikor 1357 és 1367 között, Kont Miklós nádorsága idején ${ }^{753}$ háromvásáros kikiáltásnak adott helyet. ${ }^{754}$ A vásár vámja 1435 -ig a király birtokában volt. ${ }^{755}$

\section{Erek (Zala megye) [Sümegtől D-re, H]}

Lajos 1353-ban Garai János veszprémi püspök kérésére, a veszprémi egyház Erek birtokán keddi hetivásár (forum liberum) tartására adott engedélyt. ${ }^{756}$

\section{Eszterjén (Bereg megye) [Tiszaadonytól ÉNY-ra, H]}

1344-ben az egri káptalan tanúságával sor került a Kerecseny, Eszterjén és Hetyen birtokokat a szomszédos Mátyus possessiótól elválasztó határ megjárására. A határjárás a Csarnóca (Charnolcha) folyó hídját is érintette. ${ }^{757}$

\section{Fadd $^{758}$ (Tolna megye) [Fadd, H]}

1381-ben Palizsnai ${ }^{759}$ János vránai perjel gyánti (Ganth) officialisa, Miklós fia György Tolna megye előtt tiltakozott amiatt, hogy a fehérvári káptalan mintegy 5 évvel korábban a perjel faddi birtokrészén csütörtökönként tartani szokott hetivásárt áttette saját faddi

\footnotetext{
752 de lignis lapidibus et cemento que ad opus murorum civitatis nostre Epperyes sub presencium testimonio quandocunque et quociescunque deferuntur et de conductoribus eorundem necnon curribus et animalibus in quibus ducuntur nullum tributum nullamque tributariam exaccionem petere vel exigere audeatis - DF 228490 (Wagner, Sáros 218.) (Iványi, Eperjes 85. sz.).

${ }^{753}$ Vö. Engel P.: Archontológia I. 3.

${ }^{754}$ DL 5896.

755 Weisz B.: Vámok és vámszedés 135. Vö. Fügedi E.: Eperjes város hetipiacjövedelme 3-5.

${ }^{756}$ Zala I. 534. (Veszpr. Reg. 447. sz.).

757 DF 76 728. (Z. II. 99.) (Anjou-oklt. XXVIII. 51. sz.). A vízfolyást Csarnocza néven feltünteti a Második Katonai Felmérés Kerecsénytől ÉK-re, Mátyustól K-DK-re.

${ }^{758}$ Korábbi történetére lásd Weisz B.: Vámok és vámszedés 153.

${ }^{759}$ Engel P.: Archontológia I. 81.
} 
birtokrészére, ahol sosem tartottak vásárt. ${ }^{760}$ Szeptemberben a faddi hetivásár háromvásáros kikiáltásnak adott otthont. $^{761}$

\section{Farkasrév(e) (helye ismeretlen)}

A Dráva folyón Ludbreg és Apajkeresztúr térségében a Farkasrév(e) (Farkasriwy ${ }^{762}$ Farcasriw $^{763}$ ) nevü réven lehetett átkelni, ami 1357-ben Chanouch-i Imre fia Dénes örökölt birtokán, a Dráva Zákányrév(e) és Parlagrév(e) nevü átkelői között feküdt. Ekkor Dénes panaszt tett a királynál, amiért Ludbreg várnagya és az apajkeresztúri nemesek folyamatosan zaklatják a Farkasréven átkelőket, holott a rév régtől fogva szabad volt (portum seu transitum ... ab antiquo liberum habuisset) - amint ezt a zágrábi káptalan vizsgálata is megállapította (semper liberum transitum habuisset). ${ }^{764}$

\section{Fehérvár ${ }^{765}$ (Fejér megye) [Székesfehérvár, H]}

1344-ben, amikor Lajostól Pozsony városa megkapta Szent Lőrinc napjára (augusztus 10.), valamint az azt megelőző és követő hét-hét napra szóló sokadalomtartási engedélyét, abban az éves vásárt az uralkodó a „maguk idejében tartott” budai, a fehérvári és soproni sokadalmak mintájára engedélyezte: ${ }^{766}$ vagyis 14 . század közepén Fehérváron (adatolhatóan) sokadalmat tartottak.

\footnotetext{
760 capitulum ecclesie Albensis in anno cuius nunc quinta preterisset revolucio anualis fori (sic!) in porcione possessionaria dicti domini prioris in villa Fad vocata habita singulis feriis quintos (sic!) celebrare consuetum ad porcionem eorum suam possessionarie (sic!) in dicta Fad habita ubi nunquam forum celebrare fuisset consuetum potencialiter transduxisset celebrandum - DL 106 192. (Tolna 29. sz.). Vö. Weisz B.: Vásárok és lerakatok 165.

${ }^{761}$ A vásár napjának említése nélkül. DF 106 191. (F. IX/5. 524.).

${ }^{762}$ DF 101907.

${ }^{763}$ DF 103295 = DF 106786.

${ }^{764}$ DF 101907 = DF 103295 = DF 106 786. (Anjou-oklt. XLII. 35. sz.).

${ }^{765}$ Korábbi történetére lásd Weisz B.: Vámok és vámszedés 155-158.

${ }^{766}$ liberum forum annuale in ipsa civitate nostra Posonyensi ita libere celebretur, sicut in civitatibus Budensi, Albensi et Supprunyensi ipsum annuale forum in suis terminis celebratur - Juck I. 138. Weisz B.: Vásárok és lerakatok 143.
} 


\section{Fejéregyház (Somogy megye) [Karádtól ÉK-re, H]}

Fejéregyház keddi hetivására 1379-ben háromvásáros kikiáltásnak adott otthont. ${ }^{767}$

\section{Fejértó (Szabolcs megye) [Ófehértó, H]}

Lajos 1379-ben keddi napokon hetivásár tartását tette lehetővé Bátori György fia János ${ }^{768}$ Fejértó birtokán. ${ }^{769}$

\section{Fertő tó (Sopron megye)}

A fertői vám felét (medietas tributi Fertev) IV. Béla valamikor 1254 előtt a soproni polgároknak adományozta: a vámbevételt a soproni vár tornyainak javítására és fenntartására (pro reparacione et conservacione turrium in eodem castro Supruniensi existencium) $)^{770}$ kellett fordítani. A vám felén - Károly-kori adatokból kiindulva - a királyi rész (királyketteje) felét, tehát a vámjövedelem egyharmadát kell értenünk. Weisz Boglárka valószínüsíti, hogy a vám egy része (alkalmasint tehát a maradék 1/3-a) a mindenkori soproni ispán jövedelmeit gyarapította. ${ }^{771}$ Ugyancsak ő mutatott rá arra, hogy a fertői vám felén minden bizonnyal az összes, a Fertő tavon szedett vám felét kell értenünk - legalábbis a soproniak az erre vonatkozó királyi adományt, amit I. Károly IV. Béla, IV. László és V. István okleveleit megerősítő privilégiumában mutattak be, 1366-ban ekképp interpretálták. ${ }^{772}$ 1340-ben I. Károly a fertői vám (királyi részének) másik felét is - salua alia dimidietate, quam idem nostri fideles hospites ab olim dignoscuntur possedisse - a városnak juttatta 4 évre, hogy azt a soproniak városuk erődítési munkáira (falak, árok) fordítsák - a négyéves intervallum a király korábbi, azonos tágyú, két évre szóló adománya lejártakor vette kezdetét. ${ }^{773}$

Lajos uralkodása alatt először 1353-ból hallunk a fertői vámról: a király Paksi Olivér királynéi udvarbírót, soproni és vasi ispánt (és a jövőbeli soproni ispánokat is) arra utasította,

\footnotetext{
767 DF 233 330. (Borsa I.: A somogyi konvent oklevelei 427. sz.).

${ }^{768}$ Engel P.: Genealógia: Gútkeled nem 1. Rakamazi ág 4. tábla: Bátori (somlyói).

${ }^{769}$ DL 30025.

${ }^{770}$ Sopron vm. I. 241.

${ }^{771}$ Weisz B.: Vámok és vámszedés 160-162.

772 Weisz B.: Vámok és vámszedés 160. Vö. Sopr. vm. I. 241.

773 Weisz B.: Vámok és vámszedés 161-162. Bgl. IV. 289.
} 
hogy fertői vám IV. Béla adományából a soproniaknak járó felét adja vissza a soproniaknak annak ellenére, hogy, miként a király fogalmaz, Olivér unokaöccse, Paksi Leusták ${ }^{774}$ somogyi comes (1349-1362) ${ }^{775}$ nemrég (nuper) éppen a király nevében tiltotta el a soproniakat e vámrésztől. ${ }^{776}$

\section{Földvár (Szászföld) [Feldioara, RO]}

1379-ben Lajos Földváron csütörtöki hetivásár tartásához járult hozzá, és a vásár biztonságos felkereséséről biztosította az erdélyi, székely és brassói területek kereskedőit. ${ }^{777}$ A földvári vásár (forum in Mergenborg habitum) megtartása mindazonáltal már 1378-ból adatolható. ${ }^{778}$

\section{Földvár (Tolna megye) [Dunaföldvár, H]}

Földvár keddi hetivására 1381-ben háromvásáros kikiáltás helyszíne volt. ${ }^{779}$

\section{Gáboltó $^{780}$ (Sáros megye) [Gaboltov, SVK]}

Gáboltónál az 1355. évi sárosi vámvizsgálat szerint vámot szedtek a király részére, habár hídja, ami a helyi vámszedés jogszerüségét megalapozta volna, nem volt. ${ }^{781}$

\footnotetext{
${ }^{774}$ Vö. Engel P.: Genealógia Rátót nem 2. tábla: Paksi.

${ }^{775}$ Engel P.: Archontológia I. 176.

${ }^{776}$ medietatem predicti tributi Fertew ex donacione priorum predecessorum nostrorum Bele scilicet Stephani et Ladislai olim illustrium regum Hungarie piarum recordacionum ut in literis privilegialibus confirmatoriis domini Karoli regis nostri progenitoris karissimi bone memorie nobis per Johannem iudicem et Martinum magistrum civium ac Stephanum cives de Suprunio exhibitis vidimus contineri pro reparacione et conservacione turrium in eodem castro Supruniensi existencium efficacissimorum instrumentorum ex titulis semper habuisse dinoscuntur - Sopr. vm. I. 240-241.

777 ZW. II. 509-510.

778 ZW. II. 484.

779 DL 106 191. (F. IX/5. 524.). Weisz B.: Vásárok és lerakatok 165.

${ }^{780}$ Korábbi történetére lásd Weisz B.: Vámok és vámszedés 167.

${ }^{781}$ Gyboltho carens [ponte - K. V.] difficultate transitus, in quo pons esse deberet - Draskóczy I.: Sáros megye vámhelyei 58.
} 


\section{Gajár (Őregyház) (Pozsony megye) [Gajary, SVK]}

1380-ban Lajos Szentgyörgyi Temlin tárnokmester, testvére, Péter és rokonaik, János fiai, Tamás és Péter ${ }^{782}$ Öregyház (németül: Gajár) birtokán szerdai napokon hetivásár tartását tette lehetővé. $^{783}$

\section{Galgóc $^{784}$ (Nyitra megye) [Hlohovec, SVK]}

1362-ben Lajos Kont Miklós nádor kérésére éves vásár (nundinas seu congregacionem generalem ac forum annuum) tartására adott engedélyt Galgóc birtokon Szent Mihály arkangyal ünnepétől (szeptember 29.) kezdődően az ünnep quindenájáig (október 13.). A vásárt a budai sokadalom mintájára kellett megtartani, és amíg tartott, a vásártéren (in area ipsius fori) senkitől - sem az áruikkal és javaikkal érkező magyar és külföldi kereskedőktől, kalmároktól és másoktól, sem a birtok lakóitól - nem lehetett vámot szedni, továbbá senki nem tartóztathatott le (arestare) senkit. A sokadalmon felmerülő minden ügyben Miklós nádor officialisa és Galgóc bírája, esküdtjei, illetve polgárai bíráskodhattak. ${ }^{785}$

\section{Gétmonostora (Baranya megye) [Majstól délkeletre, H]}

I. Lajos 1349-ben Becsei Töttös ajtónállómester, visegrádi és óbudai várnagy, pilisi comes $^{786}$ Gétmonostora birtokán csütörtöki hetivásár tartására adott engedélyt. ${ }^{787}$

\footnotetext{
${ }^{782}$ Vö. Engel P.: Genealógia: Hontpázmány nem 9. Szentgyörgyi-ág 2. tábla: Szentgyörgyi és Bazini.

${ }^{783}$ DL 6747. A vásárengedélyt a király 1381-ben privilegiális formában is kiadta és megerősítette. DL 6768.

${ }^{784}$ Korábbi történetére lásd Weisz B.: Vámok és vámszedés 168-169.

785 forum annuum ab omni iurisdiccione et potestate quorumlibet magnatum baronum et nobilium regni nostri vel vices eorum gerentium penitus liberum et exemptum [...] annuimus $[\ldots]$ nec in ipsa congregacione magnatum quicunque et baronum specialiter autem comes Nitriensis ac vices eorum gerentes seu iudex regius in ipsa possessione iurisdiccionem seu potestatem habere possint et exercere sed universe cause in ipsa congregacione emergende per officialem eiusdem Nicolai palatini et iudices iuratos et cives dicte possessionis sue Galgouch discutiantur et fine debito terminarentur - DL 5133. (Anjou-oklt. XLVI. 414. sz.).

${ }^{786}$ Vö. Engel P.: Genealógia: Töttös (bátmonostori), Engel P.: Archontológia II. 27.

${ }^{787}$ Z. II. 363. (Anjou-oklt. XXXIII. 304. sz.).
} 
Gimes (Nyitra megye) [Jelenec, SVK]

I. Lajos 1350-ben csütörtöki hetivásár tartására adott engedélyt a (nagy)gimesi királyi hospeseknek, avagy jobbágyoknak. ${ }^{788}$

\section{Golgonca (Körös megye) [Glogovnica, HR]}

Amikor Iván fia Demeter fiai, István és Miklós 1354-ben Körös megye hatósága előtt megosztoztak birtokaikon, az Istvánnak jutó Golgonca és Raan birtokok határai között felsorolták a Glogonca folyó révjét is. ${ }^{789}$

\section{Gorbonok (Körös megye) [Kalinovac, HR] ${ }^{790}$}

Gorbonok szombati hetivására 1363-ban ${ }^{791}$ háromvásáros kikiáltás színhelye volt.

\section{Gradistye (Valkó megye) [Gradište, HR]}

Gradistye vámos hely volt: ${ }^{792}$ 1376-ban a boszniai káptalan vizsgálata igazolta, hogy a birtokos, Jenkei Pál fia Pál mester ${ }^{793}$ ottani vámszedőit (tributarios) és famulusait Pál mester rokona, Udvarhelyi István fia Pál állandóan megvereti és elkergeti, ráadásul a vám felé igyekvő kereskedőket is régóta fosztogatja és zaklatja. ${ }^{794}$

\footnotetext{
${ }^{788}$ F. IX/1. 764-765. (Anjou-oklt. XXXIV. 191. sz.).

${ }^{789}$ venit ad fluvium Gloguncha ubi circa portum est meta terrea - DL 100 058. (Anjou-oklt. XXXVIII. 169. sz.). A regeszta szerint a folyón híd volt.

${ }^{790}$ Engel Pál térképe szerint.

${ }^{791}$ DL 41 513. (Anjou-oklt. XLVII. 67. sz.).

792 Engel Pál szerint Gradistyén rév müködött, sajnos az ezt alátámasztó adatot nem találtam meg. Vö. Engellex.

${ }^{793}$ Engel P.: Genealógia: Dorozsma nem 2. tábla: Garai Bánfi.

${ }^{794}$ DL 91833.
} 


\section{Groffensach (Vas megye) [Grafenschachen (Vasárokszállás), A]}

Groffensachi Gotthárd fia László Groffensach birtokának 1358-ban, a vasvári káptalan tanúságával megjárt határa a Laponch folyó révje (portus ipsius fluvii) melletti füzfánál végződött, ahová ekkor új földhatárjelet emeltek. ${ }^{795}$

\section{Goznica $^{796}$ (Bars megye) [Voznica (Garamrév), SVK]}

Goznica falu garami vízivámját (tributum supra aquam Goron in villa Gozancha exigi consuetum), aminek a harmada a garamszentbenedeki monostort illette, Léva (1321-1332) ${ }^{797}$ és Saskő várnagya (1325-1327), ${ }^{798}$ Becsei Imre barsi ispán (1321-1333) ${ }^{799}$ hatalmaskodva Zsarnóca faluba helyezte át - amint ezt a zobori konvent, ${ }^{800} \mathrm{az}$ esztergomi ${ }^{801}$ és a nyitrai káptalanok ${ }^{802}$ 1344-ben, Szigfrid garamszentbenedeki apát érdekében lefolytatott vizsgálatai is igazolták - a vámharmad elidegenítésének céljából. ${ }^{803}$ A vám Zsarnócára történő áthelyezése maradandónak bizonyult: amikor 1391-ben Revistye várát és tartozékait (köztük Goznica falut) Zsigmond elcserélte Sárói Péter fia Lászlóval, a Lévaiak ősével ${ }^{804}$ annak néhány nyitrai birtokáért, ${ }^{805}$ nem említették a falu vámját. Goznicát szintén hiába keressük az 1424. évi barsi vámvizsgálat „vámkataszterében”. ${ }^{806}$

\footnotetext{
795 DF 100 070. (Anjou-oklt. XL. 226. sz.).

${ }^{796}$ Korábbi történetére lásd Weisz B.: Vámok és vámszedés 177-178.

${ }^{797}$ Engel P.: Archontológia I. 358.

${ }^{798}$ Engel P.: Archontológia I. 406.

799 Engel P.: Archontológia I. 106.

${ }^{800}$ Str. III. 540-541. (Anjou-oklt. XXVIII. 364. sz.).

${ }^{801}$ Str. III. 546-547. (Anjou-oklt. XXVIII. 611. sz.).

${ }^{802}$ Str. III. 552-553. (Anjou-oklt. XXVIII. 813. sz.).

803 ut predictum ius ipsius ecclesie sancti Benedicti, in ipsa tercia porcione posset suffocare - Str. III. 541.; ut ius ipsius monasterii quod in eodem habuisset usurpare valuisset - Str. III. 547.

${ }^{804}$ Vö. Engel P.: Genealógia: Lévai 1. tábla.

${ }^{805}$ DL 87619.

${ }^{806} \mathrm{ZsO}$. XI. 477-479. (1170. sz.).
} 


\section{Gyánfalva (Diankfalva vagy Divankovc) (Valkó megye) [Morović-tól DNy-ra, SRB]}

1346-ban Maróti István fia István ${ }^{807}$ Gyánfalva (Gyanfolua) és Lekcsei Iván fia Miklós fia András mester macsói várnagy ${ }^{808}$ Zelenzad $^{809}$ birtoka között a régi határjeleket bejárták és felújították, amik között szerepelt a Surkybozanál egy közönségesen Órév nevü régi rév. ${ }^{810}$

\section{Gyarmat (Győr megye) [Gyarmat, H]}

1380-ban Lajos Kechen-i (Kecsői?) Miklós özvegyének és rajta keresztül Monoszlói Csupor János fia Lászlónak, Miklós fia Jakab lánya (az özvegy unokája), Borbála férjének Gyarmat birtokon csütörtöki napokon hetivásár tartására adott engedélyt. ${ }^{811}$

\section{Gyarmat $^{812}$ (Nógrád megye) [Balassagyarmat, H]}

1374 novemberében Biter fia Péter, fia, Kékkői (Gyarmati) György udvari vitéz, György testvére, Miklós fiai, Balázs és János, valamint e Miklós fia László fiai, Frank és Miklós ${ }^{813}$ birtokukat, Gyarmatot vámjával együtt új adományba kapták a királytól, miután a birtokról és vámról szóló oklevelük elveszett. ${ }^{814}$ Az oklevél kieszközlése Péter fia György Gyarmat birtok, vámja és sokadalma ügyében folytatott pereskedésével (prosecucio) állhat kapcsolatban. György 1374 decemberében a közelebbröl nem ismert per költségeinek felét, 40 forintot (100 dénárral számolva), továbbá a különböző oklevelek kiállíttatásának költségeiből 2 aranyforintot és 100 dénárt követelt rokonaitól, az említett Kékkői Miklós fiaitól, Balázstól és Jánostól, akik ennek megtérítését megtagadták, ezért a sági konvent a királyi jelenlét elé idézte őket. ${ }^{815}$ Miklós fiai, úgy tünik, az összeg megfizetésétől és a pertől is távol tartották magukat: 1375 áprilisában Szepesi Jakab országbíró háromvásáros kikiáltással idéztette őket a

\footnotetext{
${ }^{807}$ Engel P.: Genealógia: Gútkeled nem 2. Maróti.

${ }^{808}$ Vö. Engel P.: Archontológia I. 364.

${ }^{809}$ Vö. Engellex (Szelezen, Szlezena), Csánki II. 364. (Zele(ze)n-szád).

810 incipiendo primo et principaliter a Surkyboza, iuxta antiquum portum vulgariter Orew vocatum, ubi sunt due nove mete terree per ipsos erecte - AO V. 147. (Anjou-oklt. XXX. 120. sz.).

${ }^{811}$ DL 6681. (F. IX/5. 369.).

${ }^{812}$ Korábbi történetére lásd Weisz B.: Vámok és vámszedés 181.

${ }^{813}$ Engel P.: Genealógia: Zólyomi rokonság 1. tábla.

${ }^{814}$ DL 65784.

815 DL 39136.
} 
színe elé, és szólította fel öket György felé fennálló tartozásuk és az idöközben felhalmozott, 18 márkára rúgó bírságuk megfizetésére. ${ }^{816}$

A háromvásáros kikiáltás második, 1375. április 12-i állomása éppen a csütörtöki gyarmati hetivásár volt. ${ }^{817}$ A hetivásárra - bár napja említése nélkül - 1380-ból is van adatunk, egy hatalmaskodási perből, amit Nényei Dacsó fia János indított Gyarmati György ellen, mivel utóbbi állítólag Nagygyarmaton, a vásár napján megverette János egyik jobbágyát, és elvetetett töle két lovat. ${ }^{818}$

A hetivásáron kívül Gyarmaton 1374-ben már biztosan tartottak sokadalmat - részben a gyarmati éves vásár képezte a fentebb említett, 1374. évi per tárgyát. 819

\section{Gyula (Baranya megye) [Belvárdgyula, H]}

Gyula hetivására 1373-ban háromvásáros kikiáltás színtere volt. ${ }^{820}$

\section{Gyöngyös (Heves megye) [Gyöngyös, H]}

Gyöngyösnek két hetivására adatolható a 14. századból: a szerdai, ami 1363-ban háromvásáros kikiáltásnak adott otthont, ${ }^{821}$ és a szombati(?) ${ }^{822}$ (forum publicum), amiről 1376-ból Kónya bán fiai, Miklós és Simon két gyöngyösi hospesének és jobbágyának hatalmaskodása kapcsán értesülünk. ${ }^{823}$ Az oklevél egy része leszakadt, a 4. sor vége is, ahol a rendelkezésre álló hely alapján legvalószínübben az in festo kifejezés állhatott (esetleg in vigilia - ebben az esetben pénteki vásárral számolhatunk). A vonatkozó szöveghely a

\footnotetext{
${ }^{816}$ DL 65 787. Gyarmat (Gyarmati Balázs fia Miklós) vámja az 1405-ös nógrádi vámvizsgálatban is szerepelt (item in possessione N[icolai de] Naghgyarmath in eadem ab antiquo fuisset et ad presens exigi scirent ZsOZsO. II/1. 3890. sz.), és 1423-ban is feltünt egy sor vámhely között, ahol az esztergomi érsekség népeinek vámmentességét sérelem érte. DF 248615 (F. X/6. 583-584).

${ }^{817}$ DL 65787.

${ }^{818}$ DL 42173.

${ }^{819}$ DL 39 136. Weisz Boglárka egyetlen gyarmati sokadalomra talált adatot, amit a 16. század közepén (1562) március 25-én tartottak. Weisz B.: Vásárok és lerakatok 152.

${ }^{820}$ Z. III. 525. Weisz B.: Vásárok és lerakatok 136.

${ }^{821}$ DL 64 067. (Anjou-oklt. XLVII. 175. sz.). Vö. Draskóczy I.: Gyöngyös 106. 49. jz.

${ }^{822} \mathrm{Az}$ oklevél egy része leszakadt, a 4. sor vége is, ahol a rendelkezésre álló hely alapján legvalószínúbben az in festo kifejezés állhatott (esetleg in vigilia - ebben az esetben pénteki vásárral számolhatunk). A szöveg a követezőképpen folytatódik: beati Nicolai confessoris in anno iam preterito [1376 - K. V.] in foro publico in dicta villa Geunges celebrari consueto - DL 28095.

${ }^{823}$ DL 28095.
} 
követezőképpen folytatódik: beati Nicolai confessoris in anno iam preterito [1376 - K. V.] in foro publico in dicta villa Geunges celebrari consueto. ${ }^{824}$

\section{Győr ${ }^{825}$ (Győr megye) [Győr, H]}

Győrben legkésőbb a 12. század óta közlekedési vámot szedtek az átmenő - akár vízi, akár szárazföldi - forgalom megvámolására. ${ }^{826}$ A győri vámszedést 1255-ben, illetve 1260-ban IV. Béla szabályozta: a két időpont egyikéhez, esetleg mindkettőhöz köthető a győri vámszabályzat kibocsátása. ${ }^{827}$ A vámtarifát 1270-ben V. István, majd 1279-ben IV. László király írta át. ${ }^{828}$ A győri vám egy-egy harmadát III. Béla az általa alapított zirci és a pilisi ciszterci apátságoknak juttatta, akinek adományára IV. Béla hivatkozott, amikor azt 1254-ben megerősítette. A vám harmadik harmada a győri ispán birtokában maradt. ${ }^{829} \mathrm{Az}$ iménti felosztás vélhetően a közlekedési vám jövedelmére vontkozott, és nem a győri szombati hetivásár vámjáéra, amelynek bevételét - egy 1271. évi adat szerint - kizárólag az ispán élvezte. ${ }^{830}$

A zirci apátság győri vámrészét még a Zsigmond-korban, és később is birtokolta. 1406-ban a király kimondta, hogy a soproni polgárok fizetni kötelesek a zirci és pilisi monostorok győri (és óvári) vámharmadait. ${ }^{831}$ 1421-ben a zirci ciszterciek képviselője elismerte a fehérvári polgárok vámmentességét a győri (és az óvári) vámon. ${ }^{832} \mathrm{~A}$ zirci apátnak vámháza (domoque theulonaria) is volt Győrben, 1422. október 22-én a pannonhalmi konvent itt idézte a király elé András apátot egy hatalmaskodási ügy miatt. ${ }^{833}$ 1455-ben Garai László nádor oklevele a győri vámot hédervári nemesekhez, a pilisi és a zirci apáthoz tartozóként írta le. ${ }^{834}$

A pilisi apát győri vámrésze az 1406. és az 1455. évi oklevélben is megjelent, ${ }^{835} \mathrm{az}$ említett, fehérváriakkal kapcsolatos 1421. évi oklevél azonban a győri vám birtokosaként a

\footnotetext{
${ }^{824}$ DL 28095.

${ }^{825}$ Korábbi részletes történetére lásd Weisz B.: Vámok és vámszedés 181-184.

${ }^{826}$ Weisz B.: A győri vám 227.

${ }^{827}$ Weisz B.: A győri vám 231-232., kül. 232. 24. sz. jz.

${ }^{828}$ Weisz B.: A győri vám 230.

${ }^{829}$ Weisz B.: A győri vám 229-230.

${ }^{830}$ Weisz B.: A győri vám 228., 229-230.

${ }^{831}$ Házi I/1. 296. Az oklevelet átírta Zsigmond király 1407. febr. 20-án. DF 201982.

${ }^{832}$ Neumann T.: Székesfehérvár 66-67. (ZsO. VIII. 785. sz.).

${ }^{833}$ Dreska G.: A pannonhalmi hiteleshely 23-24. (ZsO. IX. 1064. sz.).

834 AT WStLA HAUrk 3615, in: monasterium.net, URL <http://monasterium.net/mom/ATWStLA/HAUrk/3615/charter> [utolsó letöltés: 2015. 10. 2.].

835 Házi I/1. 296. (ZsO. II/1. 4909. sz.); AT-WStLA HAUrk 3615, in: monasterium.net, URL <http://monasterium.net/mom/AT-WStLA/HAUrk/3615/charter> [utolsó letöltés: 2015. 10. 2.].
} 
zirci apát és Hédervári Mihály fia György mellett nem a pilisi apátot, hanem a győri káptalant jelölte meg. ${ }^{836}$ 1427-ben ugyanakkor Zsigmond megerősítette Konrád pilisi apátot és a monostort pozsonyi, győri, szigeti, óvári és csütörtöki vámharmadainak birtokában. ${ }^{837}$

Vélhetően a győri közlekedési vám ispáni részének (harmadának) továbbélését kell látnunk I. Lajos 1376. évi oklevelében. A király ekkor megtiltotta, hogy a pozsonyi polgároktól a győri ispán, Gönyüi Tamás fia János mester győri, a győri káptalan abdai és a héderváriak öttevényi vámosai vámot szedjenek. ${ }^{838}$ 1384. május 13-án Mikcsfi Ákos fejéri comes Budáról adta parancsba vámszedőinek, különösen a győrinek és a királyszigetinek (tibi tributario nostro de Jaurino et de Kyralzyge), hogy hagyjon fel a pozsonyiak jogtalan feltartóztatásával, mivel neki, következésképpen vámosának nem tartoznak vámfizetéssel. A rendelkezés apropója a pozsonyiak friss sérelme volt: elmondásuk szerint a királyszigeti vámon az oklevél kiadását megelőző nap (pridie) az útjukat állták, és elvettek tőlük egy páncélt (unum pancerium seu loricam). ${ }^{839}$ Ákos mester az oklevélben ugyan csak fejéri comesnek mondja magát, de a győri vám felett ezen a jogcímen nem rendelkezhetett volna: így feltehetően ő volt a győri ispán is, amire az is utal, hogy 1380-1384. között a kezében volt a jellemzően a győrivel együtt járó bakonyi ispánság is. ${ }^{840}$ A győri vám ispáni része valamikor 1384-1421. között a héderváriakhoz került, a ciszterci apátságok mellett ugyanis 1421-ben, majd 1455ben is őket említették vámbirtokosként. ${ }^{841}$ Utóbbi alkalommal a budai káptalan Garai László nádor parancsára Hédervári Pált, Ostvátot és Jánost, ${ }^{842}$ illetve Hédervári Lőrinc özvegyét, Margitot $^{843}$ idézte perbe győri vámrészük miatt. ${ }^{844}$

1363-ban Győr egyik hetivására (a pénteki vagy a szombati) ${ }^{845}$ háromvásáros kikiáltás színhelye volt. ${ }^{846}$

A szombati győri hetivásár 1375-ben háromvásáros kikiáltásnak adott otthont. ${ }^{847}$

\footnotetext{
${ }^{836}$ Neumann T.: Székesfehérvár 66. (ZsO. VIII. 785. sz.).

${ }^{837}$ tollendi, retractandi terciam partem totius in Posonio, Iaurieno, Siget, Owar, Chwthwrtek de omnibus rebus tam victualibus, quam mercimonialibus, tam in terris, quam in aquis in foris ebdomadalibus, nundinis et aliis quibuslibet a mercatoribus civitatum nostrarum regalium liberarum et aliis quibuscumque provenientibus - Győr megye 142.

${ }^{838}$ Kováts F.: Dunai hajózás 467-468.

${ }^{839}$ Kováts F.: Dunai hajózás 468-469. (máj. 11-i napi kelettel).

${ }^{840}$ Vö. Engel P.: Archontológia I. 102.

${ }^{841}$ Neumann T.: Székesfehérvár 66. (ZsO. VIII. 785. sz.); AT WStLA HAUrk 3615, in: monasterium.net, URL $<$ http://monasterium.net/mom/AT-WStLA/HAUrk/3615/charter> [utolsó letöltés: 2015. 10. 2.].

${ }^{842}$ Vö. Engel P.: Genealógia: Héder nem 2. tábla: Hédervári.

${ }^{843}$ Vö. Engel P.: Genealógia: Héder nem 3. tábla: Hédervári (nádori ág).

844 AT WStLA HAUrk 3615, in: monasterium.net, URL <http://monasterium.net/mom/ATWStLA/HAUrk/3615/charter> [utolsó letöltés: 2015. okt. 2.].

${ }^{845}$ Vö. Weisz B.: Vásárok és lerakatok 145.

${ }^{846}$ DL 5196. (Anjou-oklt. XLVII. 102. sz.).

${ }^{847}$ DF 238932.
} 


\section{(Gyula)keszi (Zala megye) [Gyulakeszi, H]}

1347-ben Keszi Ábrahám fia Miklós és fratere, János Keszi birtokból leánynegyedet adott ki Miklós lánytestvérének, Margitnak - többek közt egy kaszálót. A kaszáló melletti erdő felé tartó út Salamon révén (portus Salomonis) vezetett keresztül. ${ }^{848}$ Az átkelő vélhetően az Egervíz patakon müködött.

\section{Hájszentlőrinc (Bodrog megye) [Koluttól (Küllőd) K-re, SRB]}

Hájszentlörinc vasárnapi hetivására 1363-ban ${ }^{849}$ és 1366-ban ${ }^{850}$ is háromvásáros kikiáltásnak adott otthont.

\section{Hanovc (Pozsega megye) [Slavonski Brod (Bród, Nagyrév) és Tomica vidékén, HR] ${ }^{851}$}

1371-ben a Pozsega megyei Szapolyai Demeter fia János több részbirtokot elzálogosított Treutel Ferencnek és Jánosnak ${ }^{852} 100$ pozsegai számítású dénármárkáért, így Hanovc és Hvalkovc falvak felét is: ezeket az oklevél a Száva folyó révjéhez lokalizálja (ville Hanouch et Hwalkouch vocate in portu Zaue existentes). ${ }^{853}$

\section{Haram $^{854}$ (Krassó megye) [Banatska Palanka (Bánát Palánk), SRB]}

1344-ben Himfi Pál fia Benedek Mihály nevü remetei jobbágyát, aki Homból jött (venientem de Hom), többen elfogták a mezőn, és Bede falujába, Boldogasszonyfalvára vitték, ahol 1 márka dénárt, egy kardot, puzdrát, íjat, egy tunikát, és egy tournai nehéz posztóból

\footnotetext{
${ }^{848}$ DF 257 277. (Anjou-oklt. XXXI. 443. sz.).

${ }^{849}$ DL 5158. (Anjou-oklt. XLVII. 369. sz.), DL 6483. (Anjou-oklt. XLVII. 495. sz.), DL 5218 (Anjou-oklt. XLVII. 288. sz.).

${ }^{850}$ DL 5363. Weisz B.: Vámok és vámszedés 140.

${ }^{851}$ Azonosítás: Csánki II. 410.

${ }^{852}$ Vö. Engel P.: Genealógia: Treutel-rokonság 1. tábla: Treutel (nevnai).

853 DF 229868

${ }^{854}$ Korábbi történetére lásd Weisz B.: Vámok és vámszedés 187.
} 
készült mentét ${ }^{855}$ is elvettek tőle - a javak mind a vásárból (forum provincialis) származtak. ${ }^{856}$ Bár az oklevél explicite nem mondja ki, hogy a homi vásárból, megfogalmazása alapján valószínüsíthetően onnan.

\section{Harmac (Gömör megye) [Chrámec, SVK]}

Harmac egy részének 1342. évi határjárása érintette a Rima folyó hídját, ${ }^{857}$ míg 1347-ben a birtok Aszóval közös határai közt felsorolták a Rima Olsobouicha faluval szembeni, Swrew ${ }^{858}$ (Swryn, Suryn $)^{859}$ nevü régi gázlóját (vadus). ${ }^{860}$

\section{Haroyowch (Orbász megye) [helye ismeretlen]}

Haroyowch birtok 1362. évi kettéosztásakor a birtokrészeket elválasztó határvonal Zdenach víz (aqua) révén (in portu seu transitu) keresztül húzódott. ${ }^{861}$

\section{Hatvan $^{862}$ (Heves megye) [Hatvan, $\mathrm{H}$ ]}

Hatvanban a 14. század közepén csütörtöki és pénteki napokon tartották a hetivásárokat: ${ }^{863}$ csütörtöki vásár 1363-ban, ${ }^{864}$ a pénteki 1347-ben ${ }^{865}$ háromvásáros kikiáltás színhelye volt. Ugyancsak valamelyik hatvani hetivásáron kiáltatta ki Zsámboki Miklós nádor 1345 áprilisában Csécsei Demeter fia Keményt a Pál fia Beke elleni hatalmaskodási ügyében. ${ }^{866}$

\footnotetext{
855 unam marcam denariorum, gladium, pharetram et arcum, tunicam cum clamide gravis dorneti - Krassó 15.

${ }^{856}$ Krassó 14-15. (Anjou-oklt. XXVIII. 233.).

${ }^{857}$ prima meta inciperet a parte orientali in fluvio Ryma unde exiret prope quendam pontem - DL 1384. (Anjouoklt. XXXI. 786. sz.).

${ }^{858}$ DL 41 062. (Kub. 156).

${ }^{859}$ DL 3969. (Anjou-oklt. XXXII. 703. sz.).

${ }^{860}$ Kub. 156. (Anjou-oklt. XXXI. 1076. sz.).

${ }^{861}$ Smič. XIII. 237-238. (Anjou-oklt. XLVI. 310. sz.).

${ }^{862}$ Korábbi történetére lásd Weisz B.: Vámok és vámszedés 189.

${ }^{863}$ Vö. Weisz B.: Vásárok és lerakatok 145.

${ }^{864}$ DL 64 067. (Anjou-oklt. XLVII. 175. sz.)

${ }^{865}$ DL 38 963. (Anjou-oklt. XXXI. 459. sz.).

${ }^{866}$ DL 38 962. (Anjou-oklt. XXXI. 171. sz.).
} 


\section{Héhalom (Nógrád megye) [Héhalom, H]}

Héhalom szombati hetivására 1347-ben ${ }^{867}$ háromvásáros kikiáltás helyszíne volt. ${ }^{868}$

\section{Hetyesomlyó (Vas megye) [Kissomlyó része, H]}

Hetyesomlyó egy részének 1349. évi határjárása érintette a Pereszteg folyó révjét (portus). ${ }^{869}$ Somlyó a Sárvár-Karakó út egyik állomása volt (Sárvár-Gérce-Káld-SomlyóJánosháza-Karakó). ${ }^{870}$

\section{Hidalmás (Doboka megye) [Hida, RO]}

1367-ben Lajos Dobokai János fia László udvari vitéz, apja, és rokonai, Miklós fia László és Lőkös ${ }^{871}$ hétfői, Külső-Szolnok megyei, egregyi hetivásárát (forum liberum), amit másik oklevelével $^{872}$ megtartani engedélyezett, László kérésére, mivel a vásárt Egregyen „alkalmasan nem lehet megtartani” ${ }^{873}$, Szolnok és Doboka megyei Hidalmás birtokukra helyezte át - szombati napra. ${ }^{874}$

\section{Hof (Sopron megye) ${ }^{875}$ [Hof am Leithaberge, A]}

A hofi szerdai hetivásár 1363-ban háromvásáros kikiáltás színhelye volt. ${ }^{876}$

\footnotetext{
${ }^{867}$ Az első adatolható háromvásáros kikiáltás, ami Héhalmot is érintette, 1345-ből ismert, a forrás azonban mellőzi a vásár napjának feljegyzését. DL 38962.

${ }^{868}$ DL 38963.

${ }^{869}$ AO VI. 469. (Anjou-oklt. XXXIII. 660. sz.).

${ }^{870}$ Szilágyi, M.: Road Systems in Western Transdanubia 323-324.

${ }^{871}$ Vö. Engel P.: Genealógia: Kökényesradnót nem 1. tábla: Dobokai.

872 Vö. DL 73695.

${ }^{873}$ comode non posse celebrari - DL 73721.

${ }^{874}$ DL 73 721. Weisz B.: Vásárok és lerakatok 142.

${ }^{875}$ Csánki szerint hol Moson, hol Sopron megyéhez sorolják. Csánki III. 681.

${ }^{876}$ DL 87 383. (Anjou-oklt. XLVII. 328. sz.).
} 


\section{Hosszúbács (Valkó megye) [Bačinci (Hosszúbács), SRB]}

Hosszúbácson 1355. március 5-én, csütörtökön vásárt (forum) tartottak. ${ }^{877}$

\section{Hugyag 878 (Nógrád megye) [Hugyag, H]}

Hugyag falu szombati hetivására 1375-ben háromvásáros kikiáltásnak adott otthont. ${ }^{879}$

\section{Hvalkovc (Pozsega megye) [Slavonski Brod (Bród, Nagyrév) és Tomica vidékén, HR] ${ }^{880}$}

1371-ben a Pozsega megyei Szapolyai Demeter fia János több részbirtokot elzálogosított Treutel Ferencnek és Jánosnak ${ }^{881} 100$ pozsegai számítású dénármárkáért, így Hanovc és Hvalkovc falvak felét is: ezeket az oklevél a Száva folyó révjéhez lokalizálja (ville Hanouch et Hwalkouch vocate in portu Zaue existentes). ${ }^{882}$

\section{Ibrány (Valkó megye) [Petrovcitól ÉK-re, HR]}

1348. március 31-én Anna (Gilét fia János mester felesége, a néhai Sáfár István mester leánya), ${ }^{883}$ valamint Anna lányai, Erzsébet és Mária, ${ }^{884}$ másrészről Erzsébet (Maróti István mester udvari lovag felesége, a néhai Ibrányi Györk mester lánya) ${ }^{885}$ (képviselői) a király elött azt a bevallást tették, hogy húsvét quindenáján (május 4.) fogott bírák közremüködésével, a bácsi egyház tanúsága mellett két részre osztják Ibrányt, Detmárt, Jamát tartozékaikkal, haszonvételeikkkel és jövedelmeikkel, kiváltképpen a vámokkal és a vásárokkal együtt (cum quibuslibet earum pertinenciis et utilitatibus ac proventibus

\footnotetext{
877 1355/1356: DF 265 646. (Anjou-oklt. XL. 286. sz.).

${ }^{878}$ Korábbi történetére lásd Weisz B.: Vámok és vámszedés 199.

${ }^{879}$ DL 65787.

${ }^{880}$ Azonosítás: Csánki II. 412.

${ }^{881}$ Vö. Engel P.: Genealógia: Treutel-rokonság 1. tábla: Treutel (nevnai).

${ }^{882}$ DF 229868.

${ }^{883}$ Vö. Engel P.: Genealógia: Sáfár (csévi, taranyai). Anna anyja, Sáfár István felesége is Ibrányi Györk lánya volt. Engel P.: Genealógia: Gútkeled nem 2. Maróti.

${ }^{884}$ Vö. Engel P.: Genealógia: Smaragdus nem 2. tábla: Gilétfi (Zsámboki).

885 Vö. Engel P.: Genealógia: Gútkeled nem 2. Maróti.
} 
specialiter tributis foris). ${ }^{886} \mathrm{Az}$, hogy a királyi oklevél szövegében a vám és a vásár szavak is többes számban szerepelnek, Ibrányon a Zsigmond-kor előtti vásártartást, ${ }^{887}$ Detmáron és (vagy) Jamán pedig egyáltalán vásártartást enged feltételezni, illetve legalább a háromból két helyen vámszedéssel számolhatunk.

\section{Igló (Szepes megye) [Spišská Nová Ves, SVK]}

1380-ban Lajos Igló faluban szombati hetivásár (forum liberum) tartását tette lehetővé. 888

\section{Illye (Hunyad megye) [llia (Marosillye), RO]}

Illye a Lajos-korban vásáros hely volt. 1350-ben, amikor az Ákos nembéli András mester fiai, Sándor mester illyei nemes és Erne mester ${ }^{889}$ Lackfi István erdélyi vajda előtt megállapodott Illye oláh részeinek kettéosztását illetően, ${ }^{890}$ az osztály a magyar Illye faluban (villa eorum Hungaricalis) tartott vásár utcáját is érintette. Az utca, ahol a vásárt tartották, a leírás szerint Vak (Vok) Miklós és Szőcs (Zeuch) házai között volt észak felöl, valamint „Dico” Miklós és Nyerges Miklós házai között futott a Marosig. Sándor és Erne arról is megegyezett, hogy vásár ideje alatt felmerülő ügyekben ők vagy officialisaik közösen ítélkeznek, a vásár elmúltával pedig ki-ki maga bíráskodik a saját utca- (birtok)részén az ott támadó esetekben. ${ }^{891}$

\section{Inevására (Heves megye) [Tiszaörs és Kunmadaras között, H]}

\footnotetext{
${ }^{886}$ Smič. XI. 449-450. (Anjou-oklt. XXXI. 141. sz.).

${ }^{887}$ A legkorábbi adatunk Ibrányi (keddi) hetivásárára 1402-ből való. Weisz B.: Vásárok és lerakatok 169.

${ }^{888}$ DF 280 775. (Schmauk, Supplementum 134-135.).

${ }^{889}$ Vö. Engel P.: Genealógia: Ákos nem 7. Illyei (Folti).

${ }^{890}$ cum inter ipsos super eo, ut in quo loco medium, sive recta dimidietas possessionum ipsorum Olacalium ad dictam possessionem eorum Elya vocata pertinentium esse dinoscatur, litigionarie questionis materia coram comite nostro Hunyadiensi et iudicibus nobilium eiusdem comitatus diutius ventilata fuisset - Doc. Val. 118.

${ }^{891}$ forum autem quod in eadem villa Elya celebratur in predicto communi loco videlicet in platea in qua ipsa villa ut mremittitur ab invicem est divisa celebrare comisissent isto modo quod qualicunque causa in ipso foro donec ipsum forum durabit et stabit orta fuerit ipsam causam partes vel earum officiales communiter judicarent sed foro discesso et aliis diebus qualiscunque causa in domibus vel in descensu orietur ipsam causam ipsa una pars judicabit in cujus porcione orta extiterit - Doc. Val. 119. (Anjou-oklt. XXXIV. 547. sz.).
} 
Neve alapján vásáros birtok volt, amelyről Erdőtelki Vörös Mátyás fiai, „Polhos” István, Vörös János és Lack, valamint e Lack fia Lack felperesek 1358-ban a Tomaj nembéli Losonci Dénes fia Tamás fiai, Tamás és István, István szörényi bán fia, Dénes ${ }^{892}$ és Dénes fia Dezső fia, László ${ }^{893}$ alperesek ellen indított perükben azt állították, annak idején ajándék gyanánt (in signum muneris) kapták az alperesek elődeitől - erről szóló oklevelüket Szécsi Miklós országbíró és az általa kijelölt személyek előtt kellett bemutatniuk. ${ }^{894}$

\section{Istvánd (Zala megye) [Zalaistvánd, H]}

Istvánd szombati hetivására 1344-ben háromvásáros kikiáltás színhelye volt. ${ }^{895}$

\section{Jama (Valkó megye) [Daljtól DK-re, HR]}

1348. március 31-én Anna (Gilét fia János mester felesége, a néhai Sáfár István mester leánya), ${ }^{896}$ valamint Anna lányai, Erzsébet és Mária, ${ }^{897}$ másrészről Erzsébet (Maróti István mester udvari lovag felesége, a néhai Ibrányi Györk mester lánya) ${ }^{898}$ (képviselői) a király előtt azt a bevallást tették, hogy húsvét quindenáján (május 4.) fogott bírák közremüködésével, a bácsi egyház tanúsága mellett két részre osztják Ibrányt, Detmárt, Jamát tartozékaikkal, haszonvételeikkkel és jövedelmeikkel, kiváltképpen a vámokkal és a vásárokkal együtt (cum quibuslibet earum pertinenciis et utilitatibus ac proventibus specialiter tributis foris). ${ }^{899} \mathrm{Az}$, hogy a királyi oklevél szövegében a vám és a vásár szavak is többes számban szerepelnek, Ibrányon a Zsigmond-kor előtti vásártartást, ${ }^{900}$ Detmáron és (vagy) Jamán pedig egyáltalán vásártartást enged feltételezni, illetve legalább a háromból két helyen vámszedéssel számolhatunk.

\footnotetext{
${ }^{892}$ Vö. Engel P.: Genealógia: Tomaj nem 2. tábla: Losonci.

${ }^{893}$ Vö. Engel P.: Genealógia: Tomaj nem 6. tábla: Losonci Dezsőfi.

${ }^{894}$ Bánffy 220-224., kül. 223. Vö. Weisz B.: Vásárok és lerakatok 146.

${ }^{895}$ Zala I. 443. (Anjou-oklt. XXX. 913. sz.).

${ }^{896}$ Vö. Engel P.: Genealógia: Sáfár (csévi, taranyai). Anna anyja, Sáfár István felesége is Ibrányi Györk lánya volt. Engel P.: Genealógia: Gútkeled nem 2. Maróti.

${ }^{897}$ Vö. Engel P.: Genealógia: Smaragdus nem 2. tábla: Gilétfi (Zsámboki).

${ }^{898}$ Vö. Engel P.: Genealógia: Gútkeled nem 2. Maróti.

${ }^{899}$ Smič. XI. 449-450. (Anjou-oklt. XXXI. 141. sz.).

900 A legkorábbi adatunk Ibrányi (keddi) hetivásárára 1402-ből való. Weisz B.: Vásárok és lerakatok 169.
} 


\section{Jamnik (Szepes megye) [Jamník (Szepesárki), SVK]}

1349-ben a szepesi káptalan Erzsébet királyné parancsára másfél ekealjnyi (75 hold) földet iktatott Peskinus feleségének, Gehannának. A jamniki föld egyik, 25 holdas tagja egy, a Hernád folyóba ömlő patakon lévő hídnál, dél felöl, a falu kertjei mögött helyezkedett el, ( $a$ quodam ponte a parte meridionali in rivulo retro ortos ville eiusdem fluente in Harnad), 26 hold pedig egy ösvénynél, az említett patakon lévő hídnál, a falu felső részén feküdt ( $a$ quadam semita et ponte eodem rivulo in superiori parte eiusdem ville). ${ }^{901}$

\section{Jenke (Valkó megye) [Stari Jankovci (Ójankovác) területén, HR]}

Jenke falu szombati hetivására (forum generalis) 1355-ben háromvásáros kikiáltásnak adott otthont. ${ }^{902}$

\section{Jobbágy $^{903}$ (Heves megye) [Jobbágyi, H] ${ }^{904}$}

Lajos 1344. évi, Aba nembeli Petőc fia Sirokai Miklós ${ }^{905}$ erdélyi vajda és szolnoki comes $^{906}$ számára kiadott oklevele, amelyben a vajda Jobbágy és Püspöki nevü birtokainak határain belül engedélyezte a gonosztevők elfogását és elítélését, a két birtok vásárait (fora) is említette. ${ }^{907}$

\section{Jut $^{908}$ (Somogy megye) [Siójut, H]}

\footnotetext{
901 DF 272 466. (Anjou-oklt. XXXIII. 457. sz.).

902 DL 33 604., DL 33 605. Weisz B.: Vásárok és lerakatok 169.

903 Korábbi történetére lásd Weisz B.: Vámok és vámszedés 209.

${ }^{904}$ Vö. Gy. III. 105.

905 Vö.: Engel P.: Genealógia: Aba nem 13. Szalánci ág 2. tábla: Sirokai, Fricsi, Hedri.

906 Vö. Engel P.: Archontológia I. 12.

${ }^{907}$ AO V. 548-550. (Anjou-oklt. XXVIII. 449. sz.). A jobbágyi hétfői hetivásár megtartását I. Károly 1329-ben engedélyezte Nekcsei Demeter tárnokmesternek. DL 60 964. Vö. Weisz B.: Vásárok és lerakatok 146.

908 Korábbi történetére lásd Weisz B.: Vámok és vámszedés 210.
} 
A somogyvári konvent 1356-ban Ugali Pál fia Miklós ${ }^{909}$ érdekében lefolytatott vizsgálata arra a megállapításra jutott, hogy Torvaji Ugrin fiai, Miklós és László ${ }^{910}$ Ugali Miklós Jut birtokának régi, hétfői hetivásárát Ádánd birtokukra helyezték át, és már három hétfőn megtartották - hogy az áthelyezés királyi vagy királynéi engedéllyel történt, avagy önhatalmúlag valósították meg, azt a konvent nem tudta kideríteni. ${ }^{911}$

\section{Kabold $^{912}$ (Sopron megye) [Kobersdorf, A]}

Kabold várának, amelyet 1319-ben I. Károlytól kaptak adományba Nagymartoni Simon fiai, Pál és Lőrinc, ${ }^{913}$ a 14. században útvámja volt, amelyet 1346-ban ,a régi időktől fogva” szedettnek írtak le (castrum Kabold vocatum simul cum tributo in via exigere ab antiquo consueto). Kabold várán és vámján - Kövesd faluval és útvámjával, valamint Röjtökör faluval és vámjával egyetemben - 1346-ban Nagymartoni Simon comes fia Pál országbíró és unokaöccse, Lőrinc fia Miklós; továbbá rokonuk, Mihály comes fia Nyklul fia Miklós ${ }^{914}$ felefele arányban osztozott meg. ${ }^{915}$

\section{Kajár (Veszprém megye) [Balatonfőkajár, H]}

1377-ben Pál fia Miklós özvegye, Erzsébet és fia, Kajári Miklós egy Kajár birtokukon lévő jobbágytelket adtak el a veszprémi káptalan kajári jobbágyának, Péter fia Benedeknek. A telekhez tartozó 25 hold szántóból 11 a Balaton réve körül (quasi circa portum Balatini) feküdt. ${ }^{916}$

\section{Kakonya (Somogy megye) [Őrtilostól ÉNY-ra, H]}

\footnotetext{
${ }^{909}$ Vö. Engel P.: Genealógia: Ugali (Somogy megye).

${ }^{910}$ Vö. Engel P.: Genealógia: Ugron (torvaji).

${ }^{911}$ DL 87 315. (Anjou-oklt. XL. 180. sz.).

912 Korábbi történetére lásd Weisz B.: Vámok és vámszedés 210-211.

${ }^{913}$ Weisz B.: Vámok és vámszedés 211.

${ }^{914}$ Vö. Engel P.: Genealógia: Fraknói (Nagymartoni, Gróf).

915 Sopron vm. I. 186-189. (Anjou-oklt. XXXI. 657-658. sz.).

${ }^{916}$ DF 200 276. (Veszp. Reg. 715. sz.).
} 
1358-ban Mikefalvi Mike fia Péter felesége, Margit kakonyai és szenttrinitási birtokrészeit minden haszonvéleleikkel - köztük a Mura és a Kanizsa folyók hídjainak vámjaival (tributis pontium fluviorum Mura et Kanysa vocatorum) - eladta Hahóti Mihály fia Jánosnak 20 bécsi dénármárkáért (minden márkát 10 pensával számolva). ${ }^{917}$

\section{Kaladé (Hont megye) [Drégelypalánktól keletre, H]}

Kaladé birtok 1347-es határjárásában feltünt az Ipoly folyó révje (portus) és egy Csekeréve (Chekorewy, Chekereui, Chekerewe) nevü átkelő (vadum) is. ${ }^{918}$ A határjárás alapján a két átkelőhely azonossága legalábbis feltételezhető, ugyanis mindkettő István rekesztéke mellett volt található. ${ }^{919}$

\section{Kállóg20 (Szabolcs megye) [Nagykálló, H]}

Kálló szombati hetivására 1351-ben ${ }^{921}$ és 1370-ben ${ }^{922}$ háromvásáros kikiáltás színhelye volt.

\section{Kamesnica (Körös megye) [Kamešnica, HR]}

1343-ban a csázmai káptalan Scyuilan fiai, Benedek és Beke, továbbá Ysou fia Miklós kérésére kiküldte tanúságát Kamesnica birtokosztályához, amelynek révén Kamesnica nyugati fele Scyuilan fiainak birtokába került: e rész határai között szerepelt egy földhíd (pons terreus) is. ${ }^{923}$

\footnotetext{
${ }^{917}$ AO VII. 344. (Anjou-oklt. XLII. 982. sz.).

${ }^{918}$ DF 243 853, DF 248 268, DF 248 274. (F. IX/1. 542.). (Anjou-oklt. XXXI. 600. sz.).

919 item incipiuntur mete a parte septemtrionali in fine obstaculi Stephani, fily Gelleg in portu fluvii Ipol [...] inde ad vadum qui vulgariter Chekorewy appellatur inde iterum ad primam metam, videlicet ad obstaculum Stephani prenotati et sic terminatur - DF 243 853. (F. IX/1. 542-543).

${ }^{920}$ Korábbi történetére lásd Weisz B.: Vámok és vámszedés 213.

${ }^{921}$ Z. II. 450.

${ }^{922}$ Bánffy 321 . (Erdődy 568 . sz.).

${ }^{923}$ DL 35 186. (Anjou-oklt. XXVII. 67. sz.).
} 


\section{Kandé (Pilis megye) [Csobánkától DK-re]}

Bakács István szerint az óbudai klarisszák Kandé nevü birtokának 1367. évi határjárása többször is érintett volna egy Voyoncha nevü révet, ${ }^{924}$ valójában azonban nem révről (portus), hanem rétről (pratum) van szó. ${ }^{925}$

\section{Kanizsa (Zala megye) [Nagykanizsa, $\mathrm{H}$ ]}

Kanizsán Szepesi Jakab országbíró 1374. évi oklevele tanúsága szerint vámot szedtek. A birtok és vámja ekkor Kanizsai Lőrinc fia János fia Miklósé ${ }^{926}$ volt, aki a királyi jelenlét előtt perbe vonta Mórochelyi Basót kanizsai vámját tönkretévő mórochelyi vámszedése miatt. ${ }^{927}$

1371-ben Kanizsa keddi hetivására háromvásáros kikiáltás színtere volt. ${ }^{928}$

\section{Kapi $^{929}$ (Sáros megye) [Kapušany, SVK]}

Kapi a Hanusfalva-Eperjes útvonal mellett feküdt. ${ }^{930}$ 1345-ben a birtokot - amelyet a király megbízásából tartozékaival együtt Pohárnok Péter mester királyi udvari lovag (miles) tiszttartója, Mihály igazgatott - és Sinka fia Péter mester ${ }^{931}$ Sebes birtokát elválasztó határok között felsorolták a Szekcső folyó (Zeckchew/Zekchew) gázlóját (vadum seu transitum), amelyen keresztül Finta falu felé szoktak átkelni. Ugyanekkor Péter mester Szénégető falvát a kapi népek földjeitől elkülönítő határjelek közt megemlítették a Kövesrév (Kouesreu/Kewesrew) nevű gázlót. ${ }^{932}$

\footnotetext{
924 832. sz.

${ }^{925}$ Vö. DL 5623.

${ }^{926}$ Vö. Engel P.: Genealógia: Osli nem 5. tábla: Kanizsai.

927 idem [...] tributum in dicta possessione sua Morochel in detrimentum et diminucionem tributi predicti Nicolai filii Iohannis in possessione sua Kanisa [...] exigi faceret minus iuste - DL 24 915. (a hiányzó részeken az oklevél szövege nem olvasható).

${ }^{928}$ DL 41864.

${ }^{929}$ Korábbi történetére lásd Weisz B.: Vámok és vámszedés 215.

${ }^{930}$ Draskóczy I.: Sáros megye vámhelyei 56. (Sáros megye vámhelyei és főbb útjai a 13-14. században c. térkép.).

931 Vö. Engel P.: Genealógia: Sebesi.

${ }^{932}$ DL 64 030. (Anjou-oklt. XXIX. 787. sz.), DL 64 178. (Anjou-oklt. XXIX. 788. sz.).
} 
Kapi 1349-es határjárása érintette a Kistöltszéktől keletre folyó Hidaspatakot (Hydospatak), ${ }^{933}$ és a Sinka fia Péter birtokai felől határt képező Lengyelréve (Lengenriuy) nevü révet (portus) is a Királypataka (Kyralpatoka) folyón. ${ }^{934}$

Az 1355. évi sárosi vámvizsgálat alapján az iménti vízi átkelők egyikénél sem szedtek vámot - a kapi vámra csupán 1332-ből, Hanusfalva kiváltságleveléből van adatunk. ${ }^{935}$ Draskóczy István véleménye szerint a kapi vámszedést Töltszékre helyezhették át, méghozzá valamikor 1347 előtt, mivel Kapi 1347. évi eladományozásakor az itteni vámot nem említették. A töltszéki vámszedés ugyanakkor éppen 1347-től mutatható ki. ${ }^{936}$

\section{Kapronca (Körös megye) [Koprivnica, HR]}

Kapronca hétfői hetivására 1350-ben ${ }^{937}$ és 1363-ban ${ }^{938}$ is háromvásáros kikiáltás színhelye volt. Miután a hetivásártartás a településen már 1350-ben is kimutatható, biztosra vehető, hogy amikor Kaproncát I. Lajos Zágráb mintájára 1356-ban kiváltságolta, ${ }^{939}$ és hetivásárát hétfőnként rendelte megtartani, a már élő gyakorlatot szentesítette. Az 1356-os királyi privilégium a hetivásár mellett napi piac tartását is engedélyezte, ${ }^{940}$ továbbá a városi bíró ítélkezési jogkörébe utalta azokat az eseteket, amikor a városba érkező idegenek az utcán, otthon (szálláshelyükön), vagy a piacon követtek el valamit. ${ }^{941}$

\section{Karakó $^{942}$ (Vas megye) [Karakó, H]}

\footnotetext{
933 AO VII. 101.

934 AO VII. 103.

935 Draskóczy I.: Sáros megye vámhelyei 48. Weisz B.: Vámok és vámszedés 215.,

${ }^{936}$ Draskóczy I.: Sáros megye vámhelyei 48.

937 DL 101903 (Anjou-oklt. XXXIV. 579. sz.).

${ }^{938}$ DL 41 513. (Anjou-oklt. XLVII. 67. sz.).

${ }^{939}$ Smič. XII. 373-376. (Anjou-oklt. XL. 558. sz.).

${ }^{940}$ Item, statuimus, quod in eadem ciuitate forum solempne in ebdomada, videlicet die lune celebretur et preter hoc forum cottidianum, cottidie habeatur - Smič. XII. 375.

${ }^{941}$ Item, si quis de extraneis intrans ciuitatem, siue in vico, siue in domo, siue in foro similia ut supra notatum est, perpetrauerit, per iudicem ciuitatis iudicetur et eisdem penis subiaceat condempnatus - Smič. XII. 374.

942 Korábbi történetére lásd Weisz B.: Vámok és vámszedés 216.
} 
A karakói vám fizetése alól I. Károly 1328-ban felmentette a sárvári vendégeket. ${ }^{943}$ Vámmentességüket, amelyet nagy valószínüséggel a helyi vásáron tudtak érvényesíteni, ${ }^{944}$ 1344-ben I. Lajos is elismerte. ${ }^{945}$

\section{Károly (Szatmár megye) [Carei (Nagykároly), RO]}

Lajos 1346-ban Károlyi „Ördög” András fiai, Simon, Mihály, Miklós és Merhard ${ }^{946}$ érdemeiért, kérésükre Károly birtokukon szombatonként hetivásár tartását hagyta jóvá. 947

\section{Kassa (Abaúj megye) [Košice, SVK]}

Kassa csütörtöki hetivására valamikor 1357 és 1367 között, Kont Miklós nádorsága idején ${ }^{948}$ háromvásáros kikiáltásnak adott otthont. ${ }^{949}$

\section{Keddhely ${ }^{950}$ (Borsmonostor) (Sopron megye) [Klostermarienberg, A]}

A borsmonostori ciszterci apátság szállított javai után az országban - különösen Vas és Sopron megyékben - nem lehetett vámot szedni. ${ }^{951}$ A szabadság realizálása, érvényesítése terén kevéssel I. Lajos trónra lépését követően problémák támadtak: 1342 októberében Henrik borsmonostori apát panaszt tett Besenyő Mihály kőszegi várnagynál, hogy monostora jobbágyait a várnagy vámszedői a régi utakon (in antiquis viis et stratis) zaklatják. Mihály a megye lakosai és a kőszegi polgárok körében vizsgálatot tartott az ügyben, ami kiderítette, hogy az apátság jobbágyai - különösen a peresznyeiek - szabadon járhatnak a Rebenze folyón innen és túl, boraikhoz, gabonájukhoz, terményeikhez és más termésükhöz (vinea, blada, fructus, vel quavis ipsis provenientia) Mihály vámszedői nem nyúlhatnak. A kőszegi

\footnotetext{
943 Weisz B.: Vámok és vámszedés 216.

${ }^{944}$ Weisz B.: Vámok és vámszedés 216.

${ }^{945}$ DL 3743. (Anjou-oklt. XXVII. 835. sz.: F. alapján tévesen 1343. december 20-i kelettel). Vö. F. IX/1. 99.

946 Vö. Engel P.: Genealógia: Kaplyon nem 1. tábla: Károlyi.

${ }^{947}$ Károlyi I. 167-168.

948 Vö. Engel P.: Archontológia I. 3.

${ }^{949}$ DL 5896.

${ }^{950}$ Korábbi történetére lásd Weisz B.: Vámok és vámszedés 221.

${ }^{951}$ Weisz B.: Vámok és vámszedés 221.
} 
várnagynak Lackfi István tárnokmester ezt parancsba is adta ${ }^{952}$ - tette ezt minden bizonnyal vasi ispáni minőségében. ${ }^{953}$

Keddhely falu keddi hetivására 1355-ben háromvásáros kikiáltás színhelye volt. ${ }^{954}$

\section{Kéménd (Esztergom megye) [Kamenín, SVK]}

1346-ban Kéménd és Patacs birtokok új határjelek állításával történő elkülönítésekor a révnél, a Garam folyó mindkét partján földhatárjeleket emeltek. ${ }^{955}$

\section{Kemetinc (Valkó megye) [Otoktól ÉK-re, Vrdovo mellett, HR]}

Kemetinc predium közelében (talán Garán?) vámhellyel számolhatunk: 1382-ben, amikor Garai Miklós nádor eladott a Gara oppiduma határain belül fekvő prediumból egy darab szántót Elevejárói Egyed fiainak, Bakónak és Lászlónak, a szántó határai között felsoroltak egy álutat, mellette akasztófával, amin „az emberek nem merészelnek közlekedni és járni a vám miatt”. ${ }^{956}$

\section{Kendhida (Küküllő megye) [Chendu (Kend), RO]}

Kendhidán a Kis-Küküllő folyó hídjánál vámot szedtek az átkelőktől. 1325-ben a Szalók nembéli Simon bán fiainak és unokáinak birtokosztályakor a kendhidai vám jövedelmét is felosztották egymás közt: a vám egyik fele (medietas tributi de Kendhyda) Simon bán Mihály, Tamás és György, a másik fele Miklós, Demeter és Jakab ${ }^{957}$ nevü fiának jutott. ${ }^{958} \mathrm{Az}$

\footnotetext{
952 Bgl. IV. 353-354. (Anjou-oklt. XXVI. 560. sz.).

953 Vö. Engel P.: Archontológia I. 226.

954 Sopron vm. I. 255. (Anjou-oklt. XL. 321. sz.).

955 dehinc vero in eodem cursu versus orientem veniret ad fluvium Noggron vocatum in cuius portu ex ista parte ipsius fluvii Gron duas metas terreas erexissent ubi et in alio portu eiusdem fluvii mete predicte possessionis Kemend a predicta possessione Patach separarentur et terminarentur - Str. III. 605-606. (Anjou-oklt XXX. 438. sz.).

${ }^{956}$ ad quandam viam sinistram per quam homines non presummunt procedere et ambulare propter thelonium penes quam viam sinistram eciam prope existit locus patibuli a parte vero aquilonis adiacet via publica - DF 248660 .

${ }^{957}$ Vö. Engel P.: Genealógia: Szalók nem 2. tábla: erdélyi ág.

958 ZW. I. 394.
} 
osztálylevelet Miklós 1349-ben privilegiális formában átíratta az erdélyi káptalannal. ${ }^{959} 1344$ től Miklós elvileg csak a kendhidai vám negyedét (a felének a felét) bírta, mivel Demeterrel és Jakabbal ekkor tett birtokosztályukkor a Küküllő megyei Cikmántor, Egrestő, Pipe és Zsákod birtokok mellett a vám fele (valójában negyede) is utóbbiaknak jutott. ${ }^{960} 1366$. május 4-én, Lackfi Dénes erdélyi vajda tordai generalis congregacióján, amikor minden erdélyi vámbirtokosnak igazolnia kellett a vajda előtt vámjához való jogát, Cikmántori Demeter fia László és Kendi Tamás fia István (Simon unokái) elmondták, hogy a Kis-Küküllőn hídjuk van, ahol vámot szednek (quod ipsi super fluvium Kykullew minori pontem constructum haberent super quem tributum consuetum exigerent super quo eciam tributo regalia munimenta habuissent) (itt nyilván a kendhidai vámról van szó), ám arról szóló okleveleiket a néhai Tamás kendi házára támadó kőrösi és bogácsi szászok állításuk szerint eltulajdonították. A történteknek a közgyülés által megerősített tényéről a vajda számukra igazolást állított ki. $^{961}$

\section{Kér (Sopron megye) [Újkér, H]}

Kéren nagy valószínűséggel vásárvámot szedtek a 14. században. ${ }^{962}$

A kéri vám fizetése alól I. Károly 1328-ban felmentette a sárvári vendégeket. ${ }^{963}$ Vámmentességüket 1344-ben I. Lajos is elismerte. ${ }^{964}$

\section{Késmárk ${ }^{965}$ (Szepes megye) [Kežmarok, SVK]}

1353-ban Késmárk hétfői hetivására háromvásáros kikiáltás színtere volt. ${ }^{966}$

\footnotetext{
${ }^{959}$ ZW. II. 57-58.

${ }^{960}$ ZW. II. 16-17. (Anjou-oklt. XXVIII. 246. sz.).

961 ZW. II. 240-241.

962 Weisz B.: Vámok és vámszedés 224.

963 Weisz B.: Vámok és vámszedés 224.

${ }^{964}$ DL 3743. (Anjou-oklt. XXVII. 835. sz.: F. alapján tévesen 1343. december 20-i kelettel). Vö. F. IX/1. 99.

965 Korábbi történetére lásd Weisz B.: Vámok és vámszedés 226.

${ }^{966}$ DF 272 391. (Anjou-oklt. XXXVIII. 70. sz.).
} 


\section{Ketergény (Ung megye) [Rozivka, UKR]}

Ketergény birtok Homok possessio felőli részének 1344. évi határjárása érintette a Hidaspatak (Hyduspatak) nevü folyót. ${ }^{967}$ A vízfolyáson nevéből adódóan híd állhatott.

\section{Ketete (rév) (helye ismeretlen [Csicser és Lelesz térségében]) ${ }^{968}$}

1345-ben Lajos, miután Balázs leleszi prépost tudatta vele, hogy az utazók és a kereskedők $^{969}$ elkerülik Keteterévet és vámját, emiatt pedig az átkelő tönkremegy, felszólította őket a szokásos utak használatára, és a réven történő vámfizetésre. ${ }^{970} 1365$-ben a szepesi káptalan Péter leleszi prépost érdekében Ung és Zemplén megyékben lefolytatott vizsgálata kiderítette, hogy Druget Miklós fia János (akivel a prépost éppen perben állt) veréssel és javaik elkobzásával fenyegetve igyekezett távol tartani jobbágyait a Ketheterevy használatától és az ottani vámfizetéstől. ${ }^{971}$

\section{Kéthely 972 (Kedhely) (Somogy megye) [Kéthely, H]}

Kéthely (Keedhel) keddi hetivására 1374-ben ${ }^{973}$ háromvásáros kikiáltás színtere volt.

\section{Királyréve (Küküllő megye) [Micăsasétól (Mikeszásza) K-re, RO]}

1356-ban vita támadt a Mikeszásza és Kisekemező között fekvő Királyréve (Kyralreue) nevü telek (sessio) hovatartozását illetően: Mihály fia János és Domokos fia László csekelakai

\footnotetext{
${ }^{967}$ DL 69 670. (Anjou-oklt. XXVIII. 384. sz.).

${ }^{968}$ Vö. Weisz B.: Vámok és vámszedés 114., 252.

969 DF-képe alapján az oklevél egy részének írása elhalványult, olvashatatlan, így a címzettek sem vehetők ki (saját kiegészítés). DF 233649.

${ }^{970}$ cum igitur nos ipsum portum ketete in quo ab antiquis temporibus tributum exigi esse consuetum anichilari non velimus fidelitati vestre firmiter et districte precipiendo mandamus, quatenus relictis iniustis semitis et viis veris per iustas vias veras ad dictum portum transeuntes procedatis et ibi iustum et consuetum tributum verum persolvatis more consuetudo - DF 233649.

${ }^{971}$ DF 233752.

972 Korábbi történetére lásd Weisz B.: Vámok és vámszedés 227.

${ }^{973}$ DL 6190. (Borsa I.: A somogyi konvent oklevelei 363. sz.).
} 
nemesek szerint a sessio az ö örökbirtokuk, és nem Mikeszászához tartozik, hanem az ő Királyréve (Kyralreue) nevü birtokuk (possessio) része. ${ }^{974}$ Királyréve neve alapján biztosra vehető, hogy a területén rév müködött - a rév a Nagyküküllőn biztosított átkelést. ${ }^{975}$

\section{Kiskapos (Ung megye) [Malé Kapušany (Kiskapos), Vel'ké Kapušany (Nagykapos) része, SVK]}

1379-ben, amikor Lajos egyrészről Druget János fia János ${ }^{976}$ és Homonnai Druget János fia Miklós, ${ }^{977}$ másrészről Domonkos leleszi prépost Kapos nevü, 8 ekényire becsült földdarab (particula terre) miatti vita ügyében intézkedett (esküt írt elő a prépostnak, illetve lehetőséget adott a felek számára a megegyezésre), kikötötte, hogy a helyszínen a falu, a vásár és a vám ügyében nem dönthetnek (sed de facto ville fori et tributi nil habeat disponere vel de ipsius facere mencionem). ${ }^{978}$ Nem világos, hogy az említett vásár és vám a Drugtek Nagykapos, vagy a leleszi prépostság Kiskapos birtokához ${ }^{979}$ köthető-e.

\section{Kiskér (Nógrád megye) [Kiarovtól (Ipolykér) K-re, SVK]}

1356-ban Kiskér ${ }^{980}$ egy részének határjárása a birtok Hugyag és Óvár (Olwar) falu felé eső részein érintett egy tavat és rajta egy révet/kikötőt (portus). ${ }^{981}$

\section{Kismarton (Sopron megye) [Eisenstadt, A]}

Kismarton szombati hetivására 1378-ban háromvásáros kikiáltás színtere volt. ${ }^{982}$

\footnotetext{
${ }^{974}$ DL 31 101. (Anjou-oklt. XL. 188. sz.).

975 Weisz B.: Vámok és vámszedés 228.

${ }^{976}$ Vö. Engel P.: Genealógia: Druget 1. tábla: gerényi ág.

${ }^{977}$ Vö. Engel P.: Genealógia: Druget 2. tábla: Homonnai.

${ }^{978}$ DF 233923.

${ }^{979}$ Vö. Engel P.: Térkép.

${ }^{980}$ Az oklevél hátoldalán olvasottak alapján (metales super Kysker ex parte Saasto Zobor et aliorum) Kiskérről van szó.

${ }^{981}$ DL 72 987. (Anjou-oklt. XL. 305. sz.).

982 Sümeghy 79. Weisz B.: Vásárok és lerakatok 159.
} 


\section{Kolbach (Szepes megye) [Studenec (Hidegpatak), SVK]}

1345-ben I. Lajos a királyi bányavárosokhoz (ad montanas nostras) vezető úton működő kuffurbachi királyi vámot, mivel az út nehezen volt járható, ${ }^{983}$ Kolbachba helyezte át, István fia, Máriás (Márk) és fraterei, illetve Kassan fia, Márk és fraterei ${ }^{984}$ falujába. A kuffurbachi vám áthelyezésével a bányavárosok felé vezető út is megváltozott - az oda tartó kereskedőknek ettől fogva Kolbachon át kellett közlekedniük. Az immár Kolbachban szedett vám jövedelme továbbra is az uralkodót gyarapította, fizetése alól - a birtokukon való királyi vámszedés lehetővé tételéért cserébe - Márk, Máriás és fratereik jobbágyai mentesültek. ${ }^{985}$

\section{Kolozsvár ${ }^{986}$ (Kolozs megye) [Cluj Napoca, RO]}

Kolozsvár polgárainak Drági Jakabbal ${ }^{987}$ és frater patruelisével, Zsombori János fia Miklóssal $^{988} 1360$ táján nézeteltérése támadt, utóbbival a zsombori - állítólag nagybátyja akarata ellenére történő - vámszedés miatt. ${ }^{989}$ 1379-ben aztán a város bírája, Tamás fia Miklós és János fia Miklós kolozsvári polgár kereste fel I. Lajost azért, mert Drági Jakab és rokonai áruik után erdélyi birtokaikon kiváltságuk ellenére vámot szedtek. ${ }^{990}$ A két Miklós a kolozsvári kereskedők erdélyi vámmentességét I. Károly privilégiumával $(1316 / 1331 / 1336)^{991}$ igazolta a király elött, Jakab pedig I. Károly és Dénes erdélyi vajda okleveleit mutatta fel - ezek a Drágiak (nem megnevezett) vámjait érintették. A király végül ahelyett, hogy az írásos bizonyítékok alapján az egyik vagy a másik fél kizárólagos javára ítélt volna, hosszú távú megbékélésüket szem előtt tartva rendelkezett: ${ }^{992}$ fél vám megfizetését írta elő a kolozsváriaknak, egyszersmind jegyzékbe foglalta, mekkora összegü vám szedhető

\footnotetext{
983 quia illa via, que per Kufurbah ad montanas nostras transit est dificilis aditus per ipsam transeuntibus est nimis durus - 1345/1350: Máriássy 28-29. (DL 74 813.) (Anjou-oklt. XXIX. 223. sz.).

984 Vö. Engel P.: Genealógia: Batiz rokonsága (Márkusfalvi, Máriási, Gömöri).

985 Máriássy 28-29.

${ }^{986}$ Korábbi történetére lásd Weisz B.: Vámok és vámszedés 233-234.

${ }^{987}$ Engel P.: Genealógia: Brassói-rokonság 2. tábla: Drági.

${ }^{988}$ Vö. Engel P.: Genealógia: Brassói-rokonság 1. tábla: Zsombori (Sombori).

989 1360: ZW. II. 181-182. Magyarzsomboron kívül a Drágiaknak a Doboka megyében Örmezőn és Drágon voltak a késő középkorban - és lehettek ekkor is - vámhelyei. Jakó: Kolozsmonostor II. 2635. sz.

990 ZW. II. 508.

${ }^{991}$ I. Károly a kolozsvári hospesek erdélyi vámmentességét - többi, V. Istvántól kapott kiváltságukkal együtt elsőként 1316-ban biztosította. W. VIII. 266-268. (Anjou-oklt. IV. 313.). ZW. szerint 1316. évi oklevelét a király 1331-ben, majd utóbbival együtt 1336-ban is átírta: ennek eredetije a kolozsvári városi levéltárban található. ZW. I. 319.

992 perpetuae pacis tranquillitas in aevum valeat gloriari huiusmodi moderativam ordinationem perpetue duraturam duximus faciendam - ZW. II. 508.
} 
halak, sajt, szalonna, bor, élőállatok (disznó, ló, ökör), posztó és állatbőrök szállítása esetén, valamint lekötött mázsaszekereik után. ${ }^{993}$

Miklós és Henlinus kovácsok, kolozsvári polgárok 1362-ben eladták közös, Híd utcai (in platea pontis) curiájukat Székely Jakab mester kőhalmi várnagynak. ${ }^{994}$

\section{Komárom 995 (Komárom megye) [Komárom, H; Komárno, SVK]}

Komáromnál a 14-15. századi források alapján vásárvámot, halvámot (tributum pisscium), révvámot és hajóvámot is szedtek, a vámjövedelmekből pedig a komáromi ispán pontosabban a komáromi vár birtokosa -, a bakonybéli Szent Móric bencés apátság és a komáromi Szüz Mária domonkos kolostor részesült. A négy vámtípus közül leggyakrabban a rév- és a vásárvám jelenik meg oklevelekben. A Dunán és a Vágon müködő átkelők és a „komáromi kikötőben a Vág folyón és a mellette lévő” piacon ${ }^{996}$ (locum fori ... in portu Komaroniensi super et iuxta fluvium Vagh stantis) keddi napokon tartott hetivásár vámjának egy része az Árpád-kortól fogva a bakonybéli apátságé volt - a bencések komáromi vámbirtoklása a monostor ún. alapítólevelén, vagyis I. (Szent) István 1037. évi, 1230 körül hamisított oklevelén alapult. ${ }^{997}$ A rév- és vásárvám maradék harmada az Árpád-korban a komáromi ispánt illette, ${ }^{998}$ később, úgy tünik, a vár uradalmához tartozott.

1341-ben Druget Vilmos nádor Győr mellett tartott congregacio-ján Miklós bakonybéli apát arról számolt be, hogy Zólyomi Doncs komáromi comes a rév- és vásárvám monostort illető kétharmadát elfoglalta. ${ }^{999}$ Az apátnak végül 1343 májusában sikerült - az 1037. évi oklevélre hivatkozva - visszaszereznie a vámrészt Doncstól, ${ }^{1000}$ akivel azonban néhány hónappal később, november 25-én úgy egyezett meg, hogy a vámbevételt nem kétharmadegyharmad, hanem fele-fele arányban osztják meg egymás közt (equaliter ... inter se

\footnotetext{
993 ZW. II. 508-509.

${ }^{994}$ Makkai, Kolozsvár 5-6. (Anjou-oklt. XLVI. 180.).

995 Korábbi történetére lásd Weisz B.: Vámok és vámszedés 234-235.

996 Piacon, piactéren azt a helyet értjük, ahol a vásárt tartani szokták. Vö. Tringli I.: Vásártér és vásári jog 13011302. A super fluvium Vagh talán úgy értelmezhető, hogy a vásározás a kikötőben lévő hajókon/hajókról is folyt.

997 Vö. Reg. Arp. 9. sz. Vö. Weisz B.: Vámok és vámszedés 234.

${ }_{998}$ Weisz B.: Vámok és vámszedés 235.

999 P. VIII/1. 316.

1000 P. VIII/1. 316-317.
} 
divident), cserébe az ispán gondoskodik a rév (navigium) működtetéséről, átkelésre alkalmas, új hajók beszerzéséről és a régiek karbantartásáról. ${ }^{1001}$

Bár a bakonybéliek az erről szóló oklevelet 1409-ben átíratták, ${ }^{1002}$ korántsem biztos, hogy a szerződés túlélte Doncs halálát. 1414-ből és abból az időszakból is, amikor Komárom Garai Miklós nádor zálogbirtoka volt (1422-1433), ránkmaradt egy-egy irat, amely megvilágítja a vági és a dunai átkelő fenntartásának körülményeit: mindkét alkalommal sor került két-két (rév)hajó vásárlására, vételáruk egy részét, utóbbi esetben a felét pedig a bakonybéli apát fizette - például egy Bécsből beszerzett kerephajó árába 40 forintot adott. ${ }^{1003}$ De már ennél jóval korábban, 1368-ban újfent a rév- és vásárvám monostort illető kétharmadát - és nem a felét - emlegette Pál apát, amikor arról panaszkodott a királynak, hogy Doncsfi Péter és anyja elfoglalta azt: sőt, elmondása szerint a kétharmadra, amit Miklós apát annak idején visszaperelt Doncstól, fia, (az ekkor már néhai) Miklós újra rátette a kezét. ${ }^{1004}$

A Doncsfiak vámbirtoklása hívja fel figyelmet a fentebb már említett tényre, hogy a komáromi vám fennmaradó harmadával ekkor már Komárom várának birtokosa rendelkezett, és nem a megye ispánja, mint az Árpád-korban, ami azt mutatja, hogy a vámot ekkor már a vár tartozékának tekintették: ez pedig nyilvánvalóan már korábban is így volt, miután a Doncsfiak komáromi birtoklását I. Károly 1333. évi, Zólyomi Doncsnak tett adománya alapozta meg, amely révén Doncs Sztrigó és Csáktornya várakért cserébe megkapta Komárom várát és tartozékait, köztük a vár - tételesen nem felsorolt - vámjait (tributa) is. ${ }^{1005}$ 1368-ban például, amikor az imént említett konfliktus lezárásaképpen a béli apát 4 nehéz dénármárkáért egy évre bérbe adta vámrészét Doncsfi Péternek, ${ }^{1006}$ Gönyüi János töltötte be a megye ispáni tisztjét. ${ }^{1007}$ A komáromi vámot felsorolták a vár tartozékai közt Komárom 1387. évi, Lackfi István nádornak és rokonainak történő eladományozásakor és 1422-ben is, amikor Zsigmond a Garai Miklós nádortól kölcsönvett 6840 aranyforint fejében a várat neki zálogosította el. ${ }^{1008}$

\footnotetext{
1001 P. VIII/1. 318.

1002 DF 207550.

1003 1414: P. VIII/1. 442-443.; [1422-1433]: Item unum magnum navem vulgo kerep de Vienna, quam portaverant abbas de Bely ad medium partem XL fl. per centum - ZsO. XII. 1375. sz.

1004 P. VIII/1. 362.

1005 DL 2787.

${ }^{1006}$ P. VIII/1. 377-378.

1007 Vö. Engel P.: Archontológia I. 141.

1008 1387: specialiter vero tributis ... necnon in aquis seu fluviis Danubii et Vaagh ex utraque parte predicti castri exigi consuetis et ab antiquo habitis - DL 7258.; 1422: preterea proventibus portuum seu vadorum tributis quoque super fluminibus Danubii et Wag in possessionibus Almas et Komaron ac alias ubilibet in ipsorum castri et opppidorum pertinenciis habitorum - Bp. III. 67.
} 
1455-ben a komáromi vámot - Neszmély, Szőny, Ásványtő, Bana és Tany vámjaival együtt ugyancsak a várhoz tartozónak mondták. ${ }^{1009}$

A rév- és vásárvám részletesebb áttekintére azért kerítettünk sort, mert valószínűnek tartjuk, hogy az 1366. évi dunai vámtarifából ${ }^{1010}$ és a pozsonyiak vámmentes dunai élelmiszer-szállítását érintő rendelkezésekből $(1371,1374)^{1011}$ ismert komáromi hajóvám bevételén szintén a vár birtokosa és a bakonybéli monostor osztozkodhatott a fent részletezett arányban. Nincs olyan adat, ami ezt a feltevést kizárná, sajnos azonban a mellette szóló kevés is bizonytalan - a fő nehézséget a révnek a kikötőtől, ennek nyomán a révvámnak a hajóvámtól való elkülönítése jelenti. A fentieken kívül mindössze egy 1393-ban kelt oklevelet ismerünk, amelynek megfogalmazása nem-igen utalhat másra, mint a komáromi hajóvámra, benne a várbirtokos Lackfi István komáromi ispán István nevű várnagya a Komárom felé vízi vagy szárazföldi úton (in aquis vel in terris) tartó pozsonyiaknak a vám megfizetése fejében szabad továbbhaladást ígért (abire permittemus). ${ }^{1012}$ Vagyis a hajóvámmal ekkor a várnagy rendelkezett - vagy legalábbis egy részével, mivel úgy véljük, a bakonybéli monostor, ahogy a többi komáromi vámból, ebből is részt kapott. Az elgondolást alátámaszthatja egy 1414. évi nyugta, amelyet Komárom városa állított ki László vámosnak a saját és a vár akkori birtokosa, Dubai Vencel komáromi ispán nevében tett bevallását követően. Az irat szerint az apát is hozzájárult két, az ispán által vásárolt és ácsoltatott nagy hajó árához, méghozzá de proventibus vadorum et navigiorum super aquis Danubii et Wag hic scilicet in dicta Komaron habitorum et existencium ... cui scilicet pars dicti vadii et navigii ac proventum eorumdem pertinet, azaz talán a komáromi átkelők és kikötők részben őt illető bevételeiből. Nem kizárt azonban, hogy a szövegben a vadii és a navigii egymás szinonimáiként szerepelnek, és itt csupán a révekről van szó. ${ }^{1013}$ megegyezik. Vö. 1370. febr. 22.: ZW. II. 337-339. Vö. Kubinyi A.: Budapest története 47.

${ }^{1011}$ Kováts F.: Dunai hajózás 460-461.; DF 238 909. (F. IX/4. 569-571.).

1012 DF 239 120. (ZsO. I. 2929. sz.).

1013 A navigium révvámként való értelmezése ez esetben kizárható, mivel az oklevél később a hajókról megjegyzi, hogy azok in dictis vadis seu navigiis habitarum P. VIII/1. 442-443.
} 


\section{Kompolt (Heves megye) [Kompolt, H]}

Kompolton 1280 óta közlekedési vámot szedtek a falun áthaladóktól, mely a helyi apátság birtokában volt. ${ }^{1014}$ A vámszedés a 14. században is kimutatható: 1347-ben (vagy talán inkább 1367-ben) ${ }^{1015}$ - miután Miklós, a monostor apátja a király tudomására hozta, hogy a kereskedők és az utazók a kompolti apátság vámját újabban álutakon kerülik el - Lajos vásári kihirdetés útján hagyta meg a megszokott utak használatát és a vám felkeresését. ${ }^{1016}$

\section{Konszka (Trencsén megye) [Konská (Kunfalva), SVK]}

1354-ben Druget Miklós országbíró, turóci comes Konszka falu soltészságát Helbrandus fia Miklósnak adta, a faluba letelepedés szándékával érkezőknek pedig mentességet adott vámhelyein. ${ }^{1017}$

\section{Korong (Vas megye) [Krog, SLO]}

Korong birtokon a Lajos-korban egy Orbocsán réve nevü átkelöhely (portus Orbochanrevy dictus) üzemelt, amihez vámszedés is kapcsolódott. 1356-ban Korong felosztásakor a révvám egyik fele Korongi Simon fia, Miklós, a másik fele Nagymartoni Lőrinc fia, Nykul ${ }^{1018}$ birtokába került. ${ }^{1019}$ Orbocsán réve minden bizonnyal azonos a Korong birtok határain belül lévő Orbocsán birtok 1331-ben említett murai révével. ${ }^{1020}$

\footnotetext{
1014 Weisz B.: Vámok és vámszedés 236.

1015 Könnyen lehet, hogy a két Úrnapra keltezett, Miklós kompolti apát panaszát tartalmazó, Fejér által kiadott oklevél valójában egy és ugyanaz: szövegük szóról szóra megegyezik, csak évi keletük tér el (1347 és 1367), amit egy elírás is eredményezhetett. 1347-es csak Fejér kiadásában ismert (F. IX/1. 496-497.), aki azt elvileg Opuliai László nádor 1372. évi átírásából („Ex originali membrana archiui Cameralis Hung. Transumtum a Ladislao Palatino. A. 1372.”) közölte. Az 1367-es (F. IX/4. 51-52.) oklevelet, ami Opuliai László 1370. évi átírásában maradt fent, Fejér Hevenesi alapján közölte („Orig. in archiuo Primatiali”, F. IX/4. 315.), DF 278296 alatt hiteles, 1699. évi másolata található (Erdődy család levéltára). A két oklevél tekintetében már csak azért is hasznos lenne tisztán látni, mert a bennük szereplő Miklós kompolti apát méltóságviselési idejének meghatározása (1347-1367) minden bizonnyal ezeken alapul. Paradisum plantavit 498. (https://paradisumegyeosb.hu/a29.htm). Vö. Kovács B.: Elpusztult kolostorok 84.

${ }^{1016}$ F. IX/1. 496-497. (Anjou-oklt. XXXI. 491. sz.). Vö. Kovács B.: Középkori vámok 20.

1017 insuper ut homines ad eandem causa conmorandi venire volentes in nullis locis tributorum nostrorum tributum dare teneantur - DF 261 459. (Anjou-oklt. XXXVIII. 310. sz.).

1018 Vö. Engel P.: Genealógia: Fraknói (Nagymartoni, Gróf).

1019 DL 98399 (Anjou-oklt. XL. 606. sz.).

${ }^{1020}$ Weisz B.: Vámok és vámszedés 289.
} 


\section{Körösfő (Kolozs megye) [lzvoru Crişului, RO]}

1371-ből vámszedésre van adatunk az erdélyi püspök Körösfő birtokán: ${ }^{1021}$ a birtok vámja biztosan nem a püspöké volt, mivel ekkor Bebek György ${ }^{1022}$ királynéi tárnokmester és liptói comes körösföi officialisa szedte be. ${ }^{1023}$

\section{Kőrösmonostora (Baranya megye) [Körös puszta Kisasszonyfától É-ra, H]}

Keresmonostora vasárnapi hetivására 1376-ban háromvásáros kikiáltás színhelye volt. ${ }^{1024}$

\section{Körmend ${ }^{1025}$ (Vas megye) [Körmend, H]}

A körmendi polgárok és hospesek (cives seu hospites) IV. Béla jóvoltából 1244 óta ${ }^{1026}$ nem fizettek vámot áruik után Zala és Vas megyében. E kiváltságukat 1270-ben ${ }^{1027}$ V. István, majd 1328-ban ${ }^{1028}$ I. Károly is biztosította. 1354-ben a körmendiek Lajosnak apja kiváltságlevelét mutatták be vámmentességük bizonyítására, amit a zalai és vasi ispánok (Mikcsfi István és Paksi Olivér), ${ }^{1029}$ valamint alispánok - Erzsébet anyakirálynő korábbi figyelmeztetése ellenére is - vonakodtak elismerni. ${ }^{1030}$ A király ezért a két megye ispánjainak, alispánjainak, várnagyainak és alvárnagyainak is parancsba adta a kiváltság tiszteletben tartását. ${ }^{1031}$ Ugyanígy tett (újra) 1358-ban, négy évvel később Erzsébet királyné is. ${ }^{1032}$

\footnotetext{
1021 Csánki V. 372.

1022 Vö. Engel P.: Genealógia: Ákos nem 1. Bebek-ág 4. tábla: Bebek (vámosi ág).

1023 DF 281 132. (ZW. II. 365.).

1024 DL 6388.

1025 Korábbi történetére lásd Weisz B.: Vámok és vámszedés 241.

1026 item quod mercatores ex ipsis in parochia ferrei castri aut in Zala nullum de suis mercimoniis tributum soluere teneantur - HO. VI. 43. (Reg. Arp. 786. sz.).

1027 HO. VI. 177. (Reg. Arp. 2063. sz.).

1028 Bgl. IV. 33-34. (Anjou-oklt. XII. 301. sz.).

${ }^{1029}$ Vö. Engel P.: Archontológia I. 235, 227.

1030 in literis privilegialibus ... Karoli ... regis ... nobis exhibitis vidimus contineri quod cives seu hospites nostri de predicta Kurmend hanc habeant libertatem quod in predictis comitatibus Castriferri et Zaladiensi de eorum rebus nullum tributum solvere teneantur - AO VI. 177.

${ }^{1031}$ AO VI. 177. (Anjou-oklt. XXXVIII. 131. sz.; Erdődy 400. sz.).

1032 AO VII. 375-376. (Anjou-oklt. XLII. 1056. sz.; Erdődy 454. sz.).
} 
1381-ben Körmend Rába menti kaszálójának (fenetum seu pratum) és Gönyüi Tamás fia János Vámosfölde nevü birtokának (pratum seu possessio) határjárása érintette a Rába folyó hídját, ${ }^{1033}$ amin János Szecsőd falujába lehetett átkelni. ${ }^{1034}$

Körmendnek a 14. század utolsó harmadában két éves vására volt: Szent Márton (november 11.) és utóbb Szent Anna (július 26.) napjához kötődően. A Márton-napi sokadalom (forum annuum seu nundine) megtartását 1372-ben Lajos tette lehetővé az oppidum polgárainak és hospeseinek kérésére. A király a vásár időtartamát nem határolta be, a vásárengedély csupán annyit ír, hogy a Márton-napi éves vásárt a szent ünnepét megelőző és követő „alkalmas és elegendő” (congruus et sufficiens) napokon, a budai sokadalom mintájára kell megrendezni. Az éves vásár ideje alatt a városban a király emberei senkitől nem szedhettek vámot áruja vagy személye után. ${ }^{1035}$ A júliusi, Anna-napi sokadalmat (nundine sive forum annuale) Zsigmond jóvoltából tarthatta meg a város (civitas) 1393-tól, az ünnepet megelőző és követő 8-8 napon, a megye többi civitasa éves vásárainak mintájára. A városban a vásár idején a kereskedők és a vásározók nem tartoztak vámot fizetni. ${ }^{1036}$

\section{Kőszeg ${ }^{1037}$ (Vas megye) [Kőszeg, H]}

1345. július 12-én az anyakirályné eltiltotta a kereskedőket az újonnan létrejött (noviter est exortum et inchoatum), a sopronit tönkretevő Gunchyl-i vásár (forum) felkeresésétől. ${ }^{1038}$ Házi Jenő Gunchylt - jobb híján - Kőszeggel azonosította. ${ }^{1039}$ Ugyanígy tett az Urkundenbuch des Burgenlandes is, ahol a helynévmutatóban Köszeg német neve, Güns alatt találjuk Gunchylt. ${ }^{1040}$ Elképzelhető ugyanakkor, hogy itt az osztrák-magyar határ két oldalán fekvő

\footnotetext{
1033 Süttő Sz.: Okmányi kalászat 30-32. (Erdődy 596. sz.).

1034 usque ad pontem super predictum fluvium Raba existentem, per quem in prescriptam villam dicti magistri Iohannis transiretur - Süttő Sz.: Okmányi kalászat 31.

1035 annuentes ut mercatores et negociatores ac alii quilibet homines ad ipsas nundinas confluentes de eorum rebus et mercibus cuiuscumque generis vel speciei existant seu personis in dicta Kurmend ipsis nundinis durantibus nobis vel nostris officialibus nullum tiributum seu telonium ullounquam tempore dare teneantur sed a solucione cuiuslibet tributi exempti habeantur opido solummodo in eodem - Bándi Zs.: Körmend 258. (Erdődy 563.).

1036 nundinas sive forum annuale in dictis festis beate Anne in dicta civitate nostra Kewrmend annis singulis celebrandis liberum ac more et adinstar aliarum comprovincialium civitatum signanter a solucione tributaria quam mercatores institores ac alii forenses homines in ipsa civitate solvere tenentur quamque octo diebus ante et octo diebus post dictum festum beate Anne libertandam duximus imo presentibus libertamus peragendam perpetuo annuendo duximus concedendum sine tamen preiudicio aliarum comprovincialium nundinarum - Bándi Zs.: Körmend 259-260.

${ }^{1037}$ Korábbi történetére lásd Weisz B.: Vámok és vámszedés 243-244.

1038 1345: Házi II/6. 6-7. (Anjou-oklt. XXIX. 435. sz.).

1039 „Vajjon Gunchyl alatt valóban csak Köszeget értsük-e, egész biztosan nem merem állítani”. Házi II/6. 7.

${ }^{1040}$ Bgl. V. 285.
} 
Bruck an der Leitha - Gölcölhida/Királyhida vásáráról lehet szó. ${ }^{1041}$ A névalakon kívül (Gunchyl/Gölcöl) erre, egy külföldi, osztrák vásárra utalhat az intézkedés sajátossága: a királyné érdekes módon nem a sopronira sérelmes vásár megszüntetését, lerombolását rendelte el, csupán annak ellehetetlenítését igyekezett elérni. Fontos kérdés, hogy a Gunchyl-i forum heti, avagy éves vásár, sokadalom volt-e? Egymás hátrányára nyilván csak két azonos rangú (heti-heti/éves-éves) vásár lehet, habár éves vásár megszüntetésére vagy áthelyezésére ezidáig nem ismerünk példát. ${ }^{1042}$ A tekintetben, hogy a királynéi parancs egy „új” brucki éves vásár ellen irányult volna, némileg elbizonytalanít, hogy Bruckban Szép Frigyes engedélyezett sokadalmat, még 1316-ban, Orbán-napra (május 25.), ${ }^{1043}$ míg a sopronit Margit-nap körül, július 6. - július $20^{1044}$ között tartották. Mindenesetre 1345. július 12-én, a királynéi oklevél kiadásakor - miután I. Lajos vásártartási engedélye 1344. januári keletü elvileg éppen a második soproni sokadalom zajlott. ${ }^{1045}$ Ezzel együtt a körülmény, hogy az oklevél írója az új - kőszegi? brucki? - vásárra a forum szót használja, sokkal inkább hetivásárra utal, miután az éves vásárokat leggyakrabban a forum annuale, forum annuale liberum, nundinae, congregacio kifejezések jelölik az Anjou-kori okleveles anyagban (is). ${ }^{1046}$ Sopronban 1277 óta keddenként zajlott a hetivásár, ${ }^{1047}$ vagyis forgalmának leginkább egy keddi vásár tehetett volna be, de miután a Bruck és Sopron távolsága meglehetősen nagy, körülbelül 50 kilométer, az időigényes oda- és visszaút miatt elvileg egy hétfői, szerdai, sőt akár csütörtöki napokon tartott brucki vásár is csökkenthette a soproni forgalmát. Hetivásárt a Lajta menti Bruckban hétfőn, ${ }^{1048}$ Kőszegen pedig - 1328 óta biztosan - szerdán tartottak. ${ }^{1049}$ Kőszeg szerdai hetivásárán 1362-ben háromvásáros kikiáltásra került sor. ${ }^{1050}$

\footnotetext{
1041 Weisz Boglárka közlése.

1042 Weisz B.: Vásárok és lerakatok 36.

1043 Kretschmayr, H.: Bruck an der Leitha 191. http://mapire.eu/oesterreichischer-staedteatlas/bruck-an-derleitha/\#OV 7 _ 3 _7, [utolsó letöltés: 2017. 02. 13.]

1044 Házi I/1. 82-83.

1045 Házi I/1. 82-83.

1046 Weisz B.: Vásárok és lerakatok 15.

1047 Weisz B.: Vásárok és lerakatok 159.

1048 ?/1410: http://mapire.eu/oesterreichischer-staedteatlas/bruck-an-der-leitha/\#OV_7_3_7, [utolsó letöltés: 2017. 02. 13.]

1049 Weisz B.: Vásárok és lerakatok 170. A jelenlegi adatok alapján a sopronit tönkretevő gunchyli vásár problémakörének meggyőző megoldása véleményem szerint nem lehetséges.

${ }^{1050}$ F. IX/7. 516. (Anjou-oklt. XLVI. 457. sz.).
} 


\section{Kövesd ${ }^{1051}$ (Sopron megye) [Müllendorf (Szárazvám), A]}

Kövesden - ahogy már az Árpád-korban is - a 14. században útvámot szedtek, amelyet I. Károly 1320-ban Kövesd földesurainak, a Nagymartoniaknak (Mihály és Simon fiainak) ${ }^{1052}$ engedett át. ${ }^{1053} 1345$-ben közelebbről nem ismert konfliktus támadhatott a kövesdi vám körül Nagymartoni Pál országbíró és a Sopron, továbbá Vasvár megyék ispánságát betöltő Mikcsfi István és Ákos között ${ }^{1054}$ - erre utal, hogy Erzsébet királyné a győri káptalannal küldetett levelet a vám miatt a testvéreknek. ${ }^{1055}$ István a királynénak személyes válaszadást ígért, levelét pedig megtartotta magának. ${ }^{1056}$ A falun és útvámján (Kwesd similiter cum tributo viatico) a következő évben, 1346-ban - Röjtökör faluval és útvámjával, valamint Kabold várával és vámjával egyetemben - Nagymartoni Pál országbíró és unokaöccse, Lőrinc fia, „Német” Miklós, továbbá rokonuk, Mihály comes fia Nykul fia „Magyar” Miklós fele-fele arányban megosztoztak. ${ }^{1057}$ 1363-ban Lörinc fia, „Német” Miklós vámrészét, a kövesdi vám felét (medietatem tributi in possessione sua Kwesd nuncupata exigi consueti) a soproni Pordányon lévő birtokrészével együtt Lackfi István fia Imre királyi lovászmesternek annak az 1000 talentumnyi, általa visszafizetni nem tudott készpénzkölcsönnek a fejében, amit apja (Lőrinc) és nagybátyja (Pál országbíró) testvérétől, Katalintól (aki Lackfi Imre lovászmester felesége volt) ${ }^{1058}$ kapott. A vámot és a birtokrészt tartozásának visszafizetésével „Német” Miklós bármikor visszaválthatta. ${ }^{1059}$ A kövesdi vámot (vagy egy részét) 1380-ban még mindig a család birtokában találjuk, Fraknói János (Nykul fia „Magyar” Miklós fia) a soproniakkal pereskedett a szedése miatt Szentgyörgyi Temlin tárnokmester előtt. ${ }^{1060}$

\footnotetext{
1051 Korábbi történetére lásd Weisz B.: Vámok és vámszedés 244.

1052 Vö. Engel P.: Genealógia: Fraknói (Nagymartoni, Gróf).

1053 Weisz B.: Vámok és vámszedés 244.

1054 Vö. Engel P.: Archontológia 179.

1055 Bgl. V. 69. (Anjou-oklt. XXIX. 35. sz.).

1056 Bgl. V. 78. (Anjou-oklt. XXIX. 118. sz.).

1057 Sopron vmegye I. 186-189. (Anjou-oklt. XXXI. 657-658. sz.).

1058 Vö. Engel P.: Genealógia: Fraknói (Nagymartoni, Gróf).

1059 F. IX/3. 315-316.

${ }^{1060}$ Házi I/1. 191.
} 


\section{Kövesszarm (Vas megye) [Rátóttól D-re, H]}

1375-ben a Kövesszarmot Gyarmattól elválasztó határok bejárásakor érintettek két révet (transitus). ${ }^{1061}$

\section{Kretin (Körös megye) [Daruvartól NY-ra, HR]}

István szlavón-horvát-dalmát herceg 1354-ben Beke fia Leontius ${ }^{1062}$ Kretin $^{1063}$ (Crechen) birtokán hétfői hetivásár (forum) tartását engedélyezte, egyben megtiltotta, hogy a vásár napján vagy az azt követő napokon kamaraispánjai vagy annak officialisai új dénárokat hozzanak forgalomba. ${ }^{1064}$

\section{Krompach (Szepes megye) [Krompachy (Korompa), SVK]}

1348-ban Lajos Perényi Miklós comes fiai, István és Miklós ${ }^{1065}$ Krompach birtokán szombati napokon tartandó hetivásárt engedélyezett más megyebelibeli vásárok sérelme nélkül. ${ }^{1066}$

\section{Kucsita (Szerém megye) [Jaraktól Ny-ra, SRB]}

1368-ban a Kucsitai István Kucsita és a szenternyei káptalan Diós (Gyos) birtoka közti határok bejárásakor érintettek egy révet a Száván (portus Zawe). ${ }^{1067}$

\footnotetext{
1061 de quoquidem transitu ... ubi prope esset transitus aqu[e ...]igolth nominate - DL 41 968. (az oklevél szakadozott, írása sok helyen elhalványult, nehezen olvasható).

1062 Engel P.: Genealógia: Antimus (tapsonyi).

${ }^{1063}$ Azonosítás Csánki D.: Körös megye 80. alapján.

${ }^{1064}$ duximus faciendam ut in dicta sua possessione Crechen vocata die fori vel aliis diebus subsequentibus comites camerarum nostrarum nunc et pro tempore constituti vel constituendi denarios novarum monetarum per se vel per suos officiales exponere non presumpmant atque valeant - DL 94424 (Anjou-oklt. XXXVIII. 362. sz.).

${ }^{1065}$ Vö. Engel P.: Genealógia: Perényi 3. tábla: rihnói ág.

${ }^{1066}$ DF 262 928. (Juck I. 161.). (Anjou-oklt. XXXII. 526. sz.).

${ }^{1067}$ DL 5681.
} 


\section{Kucslin (Abaúj megye) [Brezina és Kazimír térségében, SVK]}

A Kázmér és Kolbása szomszédságában fekvő, Abaúj megyéhez tartozóként leírt Kucslin (Kuthlyn) birtok 1350. évi határjárása érintette a Megyepatak átkelőjét (vadum) és egy másik, Fajszrév (Fayzreu) nevű révet (vadum). ${ }^{1068}$ A Megyepatak talán az Abaúj és Zemplén megyék közti határt képezhette a térségben.

\section{Kuffurbach (Szepes megye) [Rudňany, SVK]}

Kuffurbachban királyi vámhely müködött, itt haladt át a királyi bányavárosokba (ad montanas nostras) vezető út. 1345-ben I. Lajos a királyi vámot, mivel a Kuffurbachon át vezető út nehezen volt járható, ${ }^{1069}$ Goldbachba helyezte át, István fia, Máriás (Márk) és fraterei, illetve Kassan fia, Márk és fraterei ${ }^{1070}$ falujába.

\section{Kuncháza ${ }^{1071}$ (Nógrád megye) [helye ismeretlen] ${ }^{1072}$}

Lajos 1347-ben Szécsényi Kónya ${ }^{1073}$ mester sárosi comesnek, udvari lovagnak és feleségének, Harsundorfi Wlueng mester lánytestvérének, Erzsébetnek adományozta a Zára alatt örökös nélkül meghalt Wlueng összes birtokát, köztük a nógrádi Kuncházát ${ }^{1074}$ és hídvámját (tributum quod ibidem super ponte exigitur). ${ }^{1075}$ A vám az 1405 . évi nógrádi vámvizsgálatból sem maradt ki, amely megállapította, hogy Szécsényi Kónya fia, „Frank comes országbíró Kuncháza nevü birtokán régóta igaz és jogos vám áll fenn”. ${ }^{1076}$

\footnotetext{
1068 AO V. 420-421. (Anjou-oklt. XXXIV. 733. sz.).

1069 quia illa via, que per Kufurbah ad montanas nostras transit est dificilis aditus per ipsam transeuntibus est nimis durus - 1345/1350: Máriássy 28-29. (DL 74 813.) (Anjou-oklt. XXIX. 223. sz.).

${ }^{1070}$ Vö. Engel P.: Genealógia: Batiz rokonsága (Márkusfalvi, Máriási, Gömöri).

1071 Korábbi történetére lásd Weisz B.: Vámok és vámszedés 246-247.

1072 Vö. Gy. IV. 263. Engel Pál kérdőjellel Ecseg környékére lokalizálta. Engellex ’Konchida, Koncháza, Kuncháza’.

1073 Vö. Engel P.: Genealógia: Kacsics nem 4. tábla: Szécsényi.

1074 item possessionem Kwnchhaza (DL 3941: Konchaza) nominata in dicto comitatu Neugradiensi existentem nomine possessionis hominis sine herede decedentis - DL 64 714. (F. IX/2. 207-210., HO. VII. 402-403.).

1075 DL 64 714. (F. IX/2. 207-210., HO. VII. 402-403.). Az adománylevelet a király 1353-ban megerősítette. DL 64714.

$1076 \mathrm{ZsO}$. II/1. 3890. sz.
} 


\section{Kusaly (Szolnok megye) [Coşeiu, RO]}

Lajos 1353-ban Jakcs királyi udvari lovag és fiai (György, István, László és András) ${ }^{1077}$ Kusaly birtokán szerdai hetivásár tartását engedélyezte más megyebeli vásárok sérelme nélkül. ${ }^{1078}$ A következő évben, 1354-ben, amikor a kusalyiak (egyik részről Tamás fia Jakcs és fiai, a másik részről Domokos fia Jakab és fiai) megosztoztak Kusalyon, a vásárt közös birtoklásban hagyták, rendjét pedig úgy határozták meg, hogy azt egyik héten a közös utcán, míg a rákövetkezőn Jakcs vásárlás címén bírt részén kell megtartani. ${ }^{1079}$

\section{Leibic (Szepes megye) [L'ubica, SVK]}

1364-ben Lajos a leibici királyi polgárok és hospesek kérésére a településen (civitas nostra) szerdai hetivásár (forum liberum) tartását tette lehetővé non obstantibus aliis foris comprovincialibus. ${ }^{1080}$

\section{Lelesz $^{1081}$ (Zemplén megye) [Leles, SVK]}

1357-ben Péter leleszi prépost (képviselője) az egri káptalan elött tiltakozott, miután Lelesz Kaponya felőli határait Kaponyai Márton fia, Miklós és lánytestvére ${ }^{1082}$ a monostor birtokának rovására módosította. Az új határ érintette a Csicserpataka folyó átkelőjét (in utraque fine portu fluvii Chyserpataka vocati). ${ }^{1083}$

\footnotetext{
1077 Vö. Engel P.: Genealógia: Jakcs(i) (kusalyi) 1. tábla.

1078 Doc. Trans. C. X. 226-227. (DF 254 797).

1079 insuper forum, feria quarta singulis septimanis celebrari consuetum, per excellentissimum principem dominum Lodovicum, dei gracia regem Hungarie annotato magistro Jakch, pro suis fidelibus serviciis datum et collatum necnon universas alias utilitates eiusdem possessionis Kusal eedem partes communi usui deputarunt, hoc tamen expresso, quod dictum forum in una septimana in communi platea, in alia vero porcione possessionaria sepedicti magistri Jakch empticia perpetuo ... debet celebrari - Doc. Trans. C. 10. 281. (AO XXXVIII. 446. sz.). A vásárolt részek a birtok felét tették ki, ezeket nem érintette a birtokosztály, csak Kusaly másik felét, amit a kusalyiak Szatmár megyei Portelek birtokukért cserével szereztek. Vö. Weisz B.: A Szilágyság helye 244., Tringli I.: Vásártér és vásári jog 1313.

1080 DF 266 956. Weisz B.: Vásárok és lerakatok 163.

${ }^{1081}$ Korábbi történetére lásd Weisz B.: Vámok és vámszedés 252.

${ }^{1082}$ Vö. Engel P.: Genealógia: Pinkóci (Ung m; Kaponyai, Zemplén megye).

${ }^{1083}$ DF 233693.
} 
A hétfői leleszi hetivásár 1348-ban, majd 1361-ben is háromvásáros kikiáltás helyszíne volt. ${ }^{1084}$

I. Lajos 1350-ben Péter, a leleszi Szent Kereszt premontrei monostor prépostja kérésére a királyi patronátus alatt álló egyház Lelesz falujában két évenkénti vásár (nundinae seu forum annuale) tartására adott engedélyt - a prépostság patrocíniumának ünnepeihez kötődően. A vásárengedély a Szent Kereszt megtalálásának és felmagasztalásának napjaira (május 3. és szeptember 14.), illetve a jeles napokat megelőző és követő 3-3 napra vonatkozott. ${ }^{1085}$

\section{Lendva ${ }^{1086}$ (Zala megye) [Lendava (Alsólendva), SLO]}

Lajos 1366-ban Alsólendvai Bánfi István és János ${ }^{1087}$ zagoriai comesek kérésére Lendva birtokukon Szent Simon és Júdás apostolok ünnepén (október 28.) éves vásár (nundinas seu forum annuum) tartására adott engedélyt - a megyebeli sokadalmak sérelme nélkül. A vásárt a budai mintájára kellett megtartani. ${ }^{1088}$

\section{Lesztemér (Zemplén megye) [Lastomír, SVK]}

A szepesi káptalan 1344. évi, Lesztemér falu osztályát és a birtokrészek határait írásba foglaló oklevele Houkhyda nevü hidat említ a falun átfolyó patakon. ${ }^{1089}$

\section{Letenye (Zala megye) [Letenye, $\mathrm{H}$ ]}

Letenyén a Lajos korban hetivásárt tartottak, útvámot szedtek, és rév ${ }^{1090}$ is üzemelt. A letenyei útvámot ${ }^{1091}$ 1347-ben Felsőlendvai Miklós bán fia Miklós özvegye, Margit, illetve

\footnotetext{
1084 1348: DF 252596 (Anjou-oklt. XXXII. 909. sz.); 1361: DL 31 301. Vö. Weisz B.: Vásárok és lerakatok 175. 1085 DF 233 669. (Anjou-oklt. XXXIV. 629. sz.). Weisz B.: Vásárok és lerakatok 175.

1086 Korábbi történetére lásd Weisz B.: Vámok és vámszedés 253.

1087 Vö. Engel P.: Genealógia Hahót nem 3. tábla: Bánfi (alsólendvai).

1088 Zala II. 9-10.

1089 transilit ryvulum currentem per eandem Leztemer [...] in fine cuiusdam pontis Houkhyda nominati recidit in ipsum ryvulum et in ipso ryvulo currit secundum meatum ipsius versus meridiem - DL 40 935. (Anjou-oklt. XXVIII. 17. sz.). Weisz B.: Vámok és vámszedés 253.

1090 Lásd Szemenye.

1091 tributum seu telonium quod in possessione eorum Lethenye vocata in via exigitur - Zala I. 467.
} 
fiai, Amádé és János ${ }^{1092}$ visszaadta (resignasset) Béci István fia Mátyásnak és rokonának, Creiniknek (Creynek), hogy a vámot Béc birtokukon szedhessék be. ${ }^{1093}$ Holub József szerint a béci útvámot korábban jogtalanul helyezhették át Letenyére, hiszen a vám - és egyes béci földek - visszaszolgáltatása ellentételezés nélkül történt. ${ }^{1094}$

Lajos 1367-ben adott engedélyt a birtokos Szécsi Miklós szlavón bánnak, hogy Letenye birtokán szerdánként hetivásárt (forum liberum) tartson - a szomszédos és más megyebeli vásárok sérelme nélkül. ${ }^{1095}$

\section{Léva (Bars megye) [Levice, SVK]}

Léva keddi hetivására 1345-ben háromvásáros kikiáltás színtere volt. ${ }^{1096}$

\section{Litinye (Sáros megye) [L’utina, SVK]}

A sárosi vámvizsgálat során István sárosi alispán megkérdezte azokat, akik az 1355. január 31-én Nagysárosban tartott generalis congregatióra a Szepességből jöttek (a gyülésen a 24 szepesi város küldöttekkel képviseltette magát), ${ }^{1097}$ hogy Ákos nembéli Mikcs fia Lorándnak ${ }^{1098}$ valóban van-e vámhelye Litinye faluban, ahol az átutazókat állítólag igen zaklatják. Míg azonban a szepesiek tudtak erről a vámról (és meg is emlékeztek egy konkrét esetről, amikor egy néhai szepességi polgártól, aki Litinyén ökröket hajtott át, Loránd annak idején 40 ökröt vetetett el), addig Sáros, Eperjes és Kisszeben lakói nem is hallottak róla. ${ }^{1099}$

\section{Locsmánd ${ }^{1100}$ (Sopron megye) [Lutzmannsburg, A]}

Locsmánd falu hétfői hetivására 1355-ben háromvásáros kikiáltás színhelye volt. ${ }^{1101}$

\footnotetext{
1092 Vö. Engel P.: Genealógia: Gútkeled nem 3. Amadé-ág.

1093 Zala I. 466-467. (Anjou-oklt. XXXI. 909. sz.).

${ }^{1094}$ Holub J.: Zala megye vámhelyei 53.

1095 DF 100 120. Weisz B.: Vásárok és lerakatok 173.

1096 DL 40 992. (Anjou-oklt. XXIX. 754. sz.).

${ }^{1097}$ Draskóczy I.: Sáros megye vámhelyei 57.

1098 Vö. Engel P.: Genealógia: Ákos nem 4. Mikcs ága 1. tábla: Mikcsfi.

${ }^{1099}$ Draskóczy I.: Sáros megye vámhelyei 60.

1100 Korábbi történetére lásd Weisz B.: Vámok és vámszedés 257.
} 


\section{Lőcse $^{1102}$ (Szepes megye) [Levoča, SVK]}

Amilyen jelentős (kereskedő)városnak mutatják a szepességi Lőcsét kiváltságai (árumegállító jog, ${ }^{1103}$ a Szepesség „fővárosa” ${ }^{1104}$ ) a 14. század első felében, olyan kevés forrás maradt fenn a Lajos-korból, hogy prosperálásáról érdemben tudósítson. ${ }^{1105}$ 1364-ben, a város privilégiumainak ellopását ${ }^{1106}$ követően I. Lajos többek között Lőcse külföldi kereskedőkre érvényes árumegállító jogát is újfent garantálta: ${ }^{1107}$ e kiváltság - amit a szepesi város 1321-ben I. Károlytól nyert el ${ }^{1108}$ - értelmében Lőcsén átutazó külföldieknek (alattuk főleg a Lubló felől jövő lengyel kereskedők értendők) ${ }^{1109}$ szállítmányaikat le kellett rakniuk, és áruikat 15 napig áruba kellett bocsátaniuk a városban, csak utána „távozhattak az ő (ti. Lajos) királyságának bármely részébe vagy indulhattak haza” (ad quamlibet regni sui partem recedendi et etiam domum redeundi). ${ }^{1110}$ Röviddel azután, hogy a lengyel-magyar perszonálunió Lajos lengyel trónra léptével realizálódott (1370), egy sor magyar kereskedőváros (Kassa, Lőcse, Brassó, Szeben, Eperjes) igyekezett kiaknázni az új politikai helyzetet. Lőcsének (és Kassának) az elsők között sikerült I. Lajostól privilégiumot kieszközölnie arra, hogy a krakkói kereskedőkkel egyenlő feltételekkel kereskedhessen Lengyelországban. ${ }^{1111}$ 1378-ban Lajos kérésére Piast Erzsébet ${ }^{1112}$ felmentette Lőcse és a többi szepesi város, továbbá Kassa Krakkóba, vagy azon túlra útnak induló kereskedőit a KisLengyelországi Czchów (Alba Ecclesia sive Chyhou) vámja felének fizetése alól. ${ }^{1113}$

\footnotetext{
1101 Sopron vmegye I. 255. (Anjou-oklt. XL. 321. sz.).

1102 Korábbi történetére lásd Weisz B.: Vámok és vámszedés 258-259.

1103 1321: Reg. Slov. II. 300.

1104 civitas nostre provincie capitalis - Juck I. 89. Idézi Weisz B.: Vámok és vámszedés 258. A civitas capitalisra lásd: Ladányi E.: Terminológiai kérdések 465-466.

1105 Vö. Lexikon stredovekých miest 252-258.

1106 Bővebben lásd Domanovszky S.: Szepesi városok 29-30.

1107 Domanovszky S.: Szepesi városok 197-198. (okmánytári rész).

1108 Reg. Slov. II. 300.

1109 Weisz B.: Vámok és vámszedés 258.

1110 Domanovszky S.: Szepesi városok 198. (okmánytári rész).

1111 1371: ut ipsi a modo et deinceps et eorum quilibet de ipsa civitate cum rebus mercibus suis quibuslibet ad partes et provincias regni nostri Polonie sub ea libertatis prerogativa et solucione telonii qua ceteri mercatores nostri de Cracovia necnon de Cassa et de Leucha quibus similem graciam fecimus in ipso regno Polonie transire sunt consueti profiscantur - ZW. II. 369-370. A magyar-lengyel kereskedelemre és útvonalaira lásd például: Divéky A.: Felső-Magyarország 6-11., 43.; Csánki D.: Hazánk kereskedelmi viszonyai 26-40. passim; Gárdonyi A.: Felsö-Magyarország 9., 12-13., 22.; Szende, K.: Kraków and Buda 34. (Trade routes from Kraków in the $14^{\text {th }}$ $-16^{\text {th }}$ century c. térkép).

1112 Lengyelországot Lajos nevében 1377 és 1379 között Opuliai László herceg kormányozta. Csukovits E.: Az Anjouk Magyarországon II. 93.

${ }^{1113}$ DF 269302.
} 


\section{Lucsivna $^{1114}$ (Szepes megye) [Lučivná, SVK]}

1356-ban az egri káptalan Mikcsfi Ákosnak iktatta a szepesi Somogy birtokot, valamint Lucsivna, Podolin, és Ófalu vámját, amelyek - így az oklevél - Ákost a király és a néhai Druget Fülöp ${ }^{1115}$ nádor özvegye, Margit adománya révén illetik. ${ }^{1116}$ A szóban forgó adományozás tényéről Margit 1350. évi, - többek között - Somogy birtokot és az őri vámot lányának, Klárának és rajta keresztül férjének, Mikcsfi Ákosnak ${ }^{1117}$ átruházó oklevele ${ }^{1118}$ és I. Lajos 1351. évi, I. Károly és Margit adományát tanúsító oklevele tudósít. ${ }^{1119}$ A két irat alapján Somogyot és az őri vámot még I. Károly engedte át - csupán említésből ismert pátensével - valamikor 1327 és 1342 között Druget Fülöp nádor özvegyének, Margitnak és árváinak életük tartamára. ${ }^{1120}$ 1351-ben a király jóváhagyta apja, Károly (és Margit) adományát, sőt Mikcsfi Ákos örököseire is kiterjesztette. ${ }^{1121}$ Somogy említett, 1356. évi iktatását talán Klára halála indokolta, a birtok felesége halálával Ákos közvetlen birtokába kerülhetett. Feltünő, hogy az 1356 előtti, Somogy átruházását tárgyazó oklevelek egyike sem említi a lucsivnai, a podolini és az ófalusi vámot, holott a háromból kettő - Podolin és Lucsivna vámja - 1382-ben is a birtokkal együtt cserélt gazdát, így joggal gyanítható, hogy a birtok tartozékai voltak. A lucsivnai vám a podolinival és a tótfalusival, Somogy birtokkal és kamarahasznájával együtt 1382-ben az óbudai klarisszáké volt; 1382. május 3-án az apácák és I. Lajos széleskörü, országszerte több birtokot, vám- és kamarahaszna-jövedelmet érintő „birtokcseréje” értelmében a király kezébebe került.. ${ }^{1122}$

\section{Lugas(vásárhely) (Vas megye) [Viszáktól Ny-ra, H]}

Lugasvásárhelyen a 14. században vámot szedtek - 1346-ban a jövedelem Ivánci (Ajakas) Miklós fiainak ${ }^{1123}$ birtokosztálya folytán Domonkoshoz és Lászlóhoz került. ${ }^{1124}$

\footnotetext{
1114 Korábbi történetére lásd Weisz B.: Vámok és vámszedés 260.

1115 Vö. Engel P.: Genealógia: Druget 1. tábla: gerényi ág.

${ }^{1116}$ AO VI. 485-486. (Anjou-oklt. XL. 382. sz.).

1117 Vö. Engel P.: Genealógia: Ákos nem 4. Mikcs ága 1. tábla: Mikcsfi.

1118 Tringli I.: Perényi 58-59. (Anjou-oklt. XXXIV. 150. sz.).

${ }^{1119}$ DL 42781.

${ }^{1120}$ Weisz B.: Vámok és vámszedés 292.

${ }^{1121}$ DL 42781.

1122 Somogy in comitatu Scepsiensi cum tribus tributis in possessionibus Paladyn Tothfaluw et Luchyna vocatis in eodem comitatu habitis exigi consuetis - DL 6905.

1123 Vö. Engel P.: Genealógia: Ivánci (Vas megye).

${ }^{1124}$ Bgl. V. 114-115.
} 


\section{Ludbreg (Körös megye) [Ludbreg, HR]}

1362-ben Paksi Leusták szlavón bán bírótársaival királyi parancsra egy vitás földterület ügyében ítélkezett, amit Begna-i György fia Miklós, Begna-i János özvegye és fiai, Péter és Tamás (vélhetően a szomszédos Bednyaszentpéter nemesei) a sajátjuknak, míg Csúz János, az egykori horvát-dalmát bán Ludbreg birtokához tartozónak mondott. A peres felek a földdarabról okleveleket nem tudtak felmutatni, ezért a területet a kiszálló zágrábi káptalan tanúságával kettéosztották közöttük. A határjelek között a Plythuicha folyó révje is feltűnt. ${ }^{1125}$

\section{Magyarfalva ${ }^{1126}$ (Liptó megye) [Uhorská Ves, SVK]}

1380-ban a Vág-parti Magyarfalva határjárása érintett egy hidat az Alsovelsenech nevü vízfolyáson (rivulus). ${ }^{1127}$

\section{Margitta (Bihar megye) [Margitha, RO]}

1370-ből származik első adatunk a Lackfi Miklós ${ }^{1128}$ Martgitta birtokán Antiochiai Szent Margit napjához (július 13.) kötődően, királyi engedéllyel tartani szokott éves vásárra: június 24-én Lajos védelmet ígért a kereskedőknek, akár a margittai, akár az erdélyi püspök párhuzamosan zajló zilahi sokadalmát keresnék fel. ${ }^{1129}$

\section{Meggyes (Sopron megye) [Mörbisch am See, A]}

1352-ben Lajos címertfestője, Hertul fia Miklós kérésére a Miklós Meggyes falujában, a Fertő tavon szedett királyi vámot (tributum nostrum ... in lacu Ferteu exigi pro nostra maiestate est consuetum) neki és örököseinek adományozta. A meggyesi „tóvámot” (see

1125 caderet in fluvium Plythuicha ubi esset arbor tul crucesignata iuxta portum eiusdem fluvii - DF 101676 (Anjou-oklt. XLVI. 243. sz.).

1126 Korábbi történetére lásd Weisz B.: Vámok és vámszedés 262.

1127 et inde intraret ipsum rivulum Alsovelsenech et descenderet in eodem versus occidentem usque quandam viam vel pontem in inferiori parte eiusdem vie duas terreas metas habentem - Szent-Ivány 31.

1128 Vö. Engel P.: Genealógia: Hermán nem 2. tábla: Lackfi.

1129 F. IX/4. 222. (Az oklevelet csak Fejér kiadásában ismerem). 
mawtt auff medwisch: az elnevezés az adománylevél hátlapján későbbi kéztől olvasható) addig Wolfurti Ulrik soproni ispán szarvkői várnagya, Fondormel János ${ }^{1130}$ adminisztrálta. ${ }^{1131}$ A vám nem sokáig volt Miklósé, miután azt néhány évvel később, amikor 1356-ban új adomány címén (is) megkapta Meggyes birtokot, a király gyakorlatilag visszavette tőle. ${ }^{1132}$ Az 1356. évi adománylevél szerint Meggyes birtokot és haszonvételeit még Miklós apja, Hertul kapta I. Károlytól, aki az idők során elidegenítette azokat. Miklós a saját költségén visszaszerzett birtokra királyi adományt kért Lajostól ${ }^{1133}$ - talán ennek, és a kapott jótállásnak (szavatosságnak) az „ára” lehetett a meggyesi vám.

\section{Mikola (Valkó megye) [Bogdonovci (Bogdánfalva) területén, HR]}

Zsámboki Miklós nádor Valkóvár mellett tartott 1351. évi generalis congregacióján Mikolai Péter fia István azt állította, Mikola (és Boró) nevü birtokain szerdánként régóta hetivásárt (forum) tartanak, ${ }^{1134}$ amiket Szentmihályi Mihály mester újabban, szintén szerdánként rendezett pacsintai hetivásárai tönkretesznek. Kijelentésének igazolására bemutatta Lajos 1345. évi oklevelét, amiben a király Vadakoli File fia Lőrinc fia Lőrinc és Mikolai File fia Péter fia István mestereknek ${ }^{1135}$ megengedte, hogy Valkó megyei Mikola birtokukon minden héten szerdán szabad vásárt (forum liberum) tartsanak a megyebeli vásárok sérelme nélkül. ${ }^{1136}$

\section{Modor (Pozsony megye) [Modra, SVK]}

Modor királynéi falu keddi hetivására 1353-ban háromvásáros kikiáltás színtere volt. ${ }^{1137}$

\footnotetext{
1130 Engel P.: Archontológia 423.

1131 Sopron vm. I. 237-238.

1132 excepto tamen tributo quod de lacu Fertew in eadem villa exigitur, quod quidem tributum pro nostra maiestate reservamus - Sopr. Tört I/1. 108. (Anjou-oklt. XL. 116. sz.).

1133 Vö. Sopr. Tört I/1. 107-109.

1134 fora ab antiquo quartis feriis in singulis septimaniis consueta fuissent celebrari que a plurimis annis retroactis tenuisset et habuisset - DL 2197.

1135 Vö. Engel P.: Genealógia: Miskolc nem 1. tábla: Mikolai.

1136 DL 2197. (Anjou-oklt. XXIX. 547. sz.). Weisz B.: Vásárok és lerakatok 169.

1137 AO VI. 33.
} 
1361-ben Mojs falu hetivására háromvásáros kikiáltás színhelye volt. ${ }^{1138}$

\section{Monostor (Baranya megye) [Beli Manastir (Pélmonostor), HR]}

Monostor hetivásárán 1373-ban háromvásáros kikiáltás zajlott. ${ }^{1139}$

\section{Monostor (Valkó megye) [Nustar, HR]}

Monostor falu hétfői hetivására (forum generalis) 1355-ben háromvásáros kikiáltásnak adott otthont. ${ }^{1140}$

\section{Mórochely (Zala megye) [Nagykanizsa területén (Mórichely), H]}

Mórochelyi Basó 1374-ben Mórochely birtokán vámot szedetett - Kanizsai Lőrinc fia János fia Miklós ${ }^{1141}$ szerint kanizsai vámjának sérelmére, amiért Basónak Szepesi Jakab országbíró előtt kellett felelnie. ${ }^{1142}$

\section{Muhi (Borsod megye) [Muhi, H]}

Muhi faluban a 14. század közepén, csütörtöki napokon hetivásárt tartottak. ${ }^{1143}$

\footnotetext{
1138 A vásár napja nélkül. DL 63 076. (Justh 34. sz.). Vö. Weisz B.: Vásárok és lerakatok 168.

1139 Z. III. 525. Weisz B.: Vásárok és lerakatok 136.

1140 DL 33 604., DL 33 605. Weisz B.: Vásárok és lerakatok 169.

1141 Vö. Engel P.: Genealógia: Osli nem 5. tábla: Kanizsai.

1142 idem [...] tributum in dicta possessione sua Morochel in detrimentum et diminucionem tributi predicti Nicolai filii Iohannis in possessione sua Kanisa [...] exigi faceret minus iuste - DL 24 915. (a hiányzó részeken az oklevél szövege nem olvasható).

1143 1343: AO IV. 301. (Anjou-oklt. XXVII. 45. sz.). Vö. Weisz B.: Vásárok és lerakatok 141.
} 


\section{Munkács (Bereg megye) [Mukacsevo, UKR]}

Munkács csütörtöki hetivására 1348-ban háromvásáros kikiáltás színhelye volt. ${ }^{1144}$

\section{Nagyfalu (Valkó megye) [Semeljci (Szemelce) vidékén, HR]}

Nagyfalu vasárnapi hetivására 1377-ben háromvásáros kikiáltás színtere volt. ${ }^{1145}$

\section{Nagykapos (Ung megye) [Vel'ké Kapušany (Nagykapos), SVK]}

1354-ben Druget Miklós ${ }^{1146}$ országbíró Nagykapos falujában hetivásárt tarthattak: december 26-án, pénteken ${ }^{1147}$ a leleszi prépost és Druget Miklós egy-egy jobbágya oda tartott vásározni, ${ }^{1148}$ amikor Csicseri Domonkos fiai, János és István Csicserre csalták őket, ahol egy lovat és két vég popprengi posztót (duas pecias panni de Popring) vettek el tőlük. ${ }^{1149}$

\section{Nagykemlék (Körös megye) [Kalnik területén, HR]}

Paksi Leusták szlavón bán 1362-ben megtiltotta a kemléki várnagynak és helyettesének, hogy a nagykemléki nemes várjobbágyok egyházakhoz, mások házaiba (ad ecclesias vel aliroum domos) vagy extra metas tárolásra (ad conservandum) szállított, saját borát és gabonáját megvámolják. ${ }^{1150}$

\footnotetext{
1144 Z. II. 349. (Anjou-oklt. XXXII. 924. sz.).

1145 DL 91841.

${ }^{1146}$ Vö. Engel P.: Genealógia: Druget 1. tábla: gerényi ág.

${ }^{1147}$ A vásárt későbbi adatok szerint szombatonként tartották. Weisz B.: Vásárok és lerakatok 168.

1148 more mercatorum in una societate ad villam Kapus eiusdem comitis Nicolai accedere voluisset causa forizandi - DF 233685.

1149 DF 233685.

${ }^{1150}$ DF 231 912. (Anjou-oklt. XLVI. 186. sz.).
} 


\section{Nagymarton (Sopron megye) [Mattersburg, A]}

Lajos 1354-ben Szent Jakab ünnepén (július 25.) tartandó éves vásár (nundine seu forum annuale liberum) megrendezését engedélyezte Nagymartoni Lörinc fia Nykul (Miklós) ${ }^{1151}$ Nagymarton birtokán. ${ }^{1152}$

\section{Nagymihály ${ }^{1153}$ (Zemplén megye) [Mihalovce, SVK]}

Nagymihály vásárvámja a Lajos korból $\left(1358^{1154}\right)$ is adatolható, így, habár a helyi vásártartásra utaló legkorábbi közvetlen adataink 1399-ből (szeptember 8-i sokadalom), illetve 1449-ből (keddi hetivásár) származnak, ${ }^{1155}$ nyilvánvaló, hogy a település már a 14. század közepén vásáros hely volt. Kérdés, hogy 1346-ban is a vásárvámról értesülünk-e a váci káptalan okleveléből, ami tanúsítja Nagymihályi Jakó fia András fia Mihály ${ }^{1156}$ rokoni szeretetből tett ígéretét többek közt nagymihályi vámja harmadának (tercia parte sui tributi similiter in eadem Nogmyhal sibi pertinenti) testvére, Lőrinc, fiai, György, László, Miklós és örököseik részére történő átadásáról. ${ }^{1157}$ A nagymihályi vásárvám 1358-ban, Nagymihályi László fia János lánya, Fruzsina ${ }^{1158}$ (Eufrozina) leánynegyedének ügyében „került elő”, amikor nagyapja kiadta számára elhalt apja birtokrészeinek negyedét. Mivel László és másik három fia még életben volt, a lánynak nagyapja birtokainak elhunyt apját, Jánost illető ötödrészének negyede - vagyis a teljes birtokállomány huszada - járt, a nagymihályi vásárvám bevételének arányos részével együtt (tributo fori in eadem possessione Nogmihal exigi consueto quantum ad porcionem eiusdem nobilis puella cedere deberet). ${ }^{1159}$

\footnotetext{
1151 Vö. Engel P.: Genealógia: Fraknói (Nagymartoni, Gróf).

${ }^{1152}$ F. IX/2. 311-313. (Anjou-oklt. XXXVIII. 361. sz.).

1153 Korábbi történetére lásd Weisz B.: Vámok és vámszedés 275.

1154 Sztáray I. 301.

1155 Weisz B.: Vásárok és lerakatok 175.

${ }^{1156}$ Engel P.: Genealógia Kaplyon nem 7. tábla: Nagymihályi ág.

1157 Sztáray I. 188.

1158 Vö. Engel P.: Genealógia: Kaplyon nem 13. tábla: Nagymihályi (Jákó ága).

1159 Sztárai I. 299-303. (DL 85 326). DL 24807 alatt hibás, 1355. évi kelettel 18. századi másolata található.
} 
László mg.

$1307-1360$

1. N.

2. Ráskai Klára 1356-73

1.-től:

2.-től:

$\begin{array}{ccccccccc}\text { János } & \text { Jakó } & \text { Tamás } & \text { László } & \text { Dénes } & \text { Jakab mg. } & \text { Péter } & \text { Miklós } & \text { Anna } \\ \text { udvari vitéz } & 1335-46 & 1337-46 & 1346 & 1346 & 1346-1412 & 1356-57 & 1356-1423 & 1356-73\end{array}$

$1335-52$

Fruzsina

1358

Engel P.: Genealógia: Kaplyon nem 13. tábla: Nagymihályi (Jákó ága) (részlet)

\section{Nagyszombat ${ }^{1160}$ (Pozsony megye) [Trnava, SVK]}

1360-ban I. Lajos a Nagyszombatra bel- vagy külföldről letelepedés céljából utazókat (commorandi causa ... se transferunt), ${ }^{1161}$ 1363-ban pedig, örök érvénnyel, az építőanyagot (fát, cementetet, követ) a városba szállító nagyszombatiakat, illetve Gerencsér, Magyarád, Szili és Parna lakóit mentesítette a vámfizetés alól. ${ }^{1162}$ A király 1360-ban, 1365-ben és 1366ban is fellépett a gyakorlat ellen, cum igitur hoc inconveniens sit et iniustum, hogy a lóháton közlekedő (equites) nagyszombatiakat a vámhelyeken megvámolják. ${ }^{1163}$ A praxis nem a polgárok speciális felmentését hagyta figyelmen kívül, hanem alapjában véve volt jogszerütlen. ${ }^{1164}$ 1365-ben I. Lajos kimondottan Vöröskői (Wolfurt) Eglolfot szólította fel, hogy a nagyszombatiaktól csak akkor szedjen vámot, ha árukat visznek magukkal, ${ }^{1165}$ és

\footnotetext{
1160 Korábbi történetére lásd Weisz B.: Vámok és vámszedés 384-385.

1161 DF 279571.

1162 quod ipsi de lignis de cemento de lapidibus per eosdem ad dictam civitatem undecunque deferentibus a solucione cuiuslibet tributi perpetuo exempti haberent nullumque tributum nullamque tributariam exaccionem de eisdem rebus iamnominatis solvere tenerentur - DF 279 577. Vö. Lexikon stredovekých miest 525.

1163 1360: DF 279 572; 1365: DF 279 573, DF 279 574; 1366: DF 279575.

1164 Vö. Vámmentességek c. fejezet.

1165 contentis solum de tributaria solucione quam ipsos de rebus mercimonialibus secum deferentibus facere consuetudinarie oportebit - DF 279573.
} 
vámhelyein, különösen Ciferen, ne terhelje őket jogtalan (indebita) és túl magas (superflua) vámok követelésével. ${ }^{1166}$

A nagyszombati pénteki hetivásár 1361-ben háromvásáros kikiáltás helyszíne volt. ${ }^{1167}$

\section{Namény (Szatmár megye) [Vásárosnamény, H]}

A naményi hetivásárra vonakozó legkorábbi adatunk 1368-ból való, egy perhalasztó oklevélből. Opuliai László nádor augusztus 8-án elhalasztotta a Lónyai Bencenc fiai, János és György, továbbá Jakab fia Miklós, ${ }^{1168}$ illetve Csaholyi János fia Sebestyén ${ }^{1169}$ közötti oklevélbemutatást a szalkai és naményi vásár tárgyában. ${ }^{1170}$ Feltételezhető, hogy a pereskedést a lónyaiak naményi és a csaholyiak szalkai, azonos napon (csütörtök) ${ }^{1171}$ tartott vásárainak egymásnak kárt okozó közelsége ${ }^{1172}$ váltotta ki - a két település egymástól légvonalban csupán 7 kilométerre fekszik a Tisza egyik, illetve másik partján. Az elképzelés létjogosultsága annál is valószínübb, mivel az elnépteledett szalkai csütörtöki hetivásár „revitalizálására” néhány évvel korábban, 1361-ben került sor a király jóvoltából. ${ }^{1173}$ A per kifutását nem ismerem, mindenesetre mindkét csütörtöki vásár későbbi megléte kimutatható. ${ }^{1174}$

\footnotetext{
1166 DF 279573.

1167 DF 248 391. Házi J.: Pozsony vármegye 56. Vö. Weisz B.: Vásárok és lerakatok 156.

1168 Vö. Engel P.: Genealógia: Lónyai.

1169 Vö. Engel P.: Genealógia: Káta nem 7. tábla: Csaholyi.

1170 DL 64077.

1171 Vö. DL 5071, DL 84344.

1172 A Károly-korban már kimutatható a vásárokra vonatkozó, a már meglévő vásárokat védő mérföldjog, amelynek értelmében 1 mérföldön belül nem lehetett más vásárt tartani - legalábbis ugyanazon a napon. Weisz B.: Vásárok és lerakatok 37.

1173 forum in possessione religiosarum dominarum sororum Sancte Clare de Veteri Buda Zalka vocata in comitatu Zothmariensi existenti singulis feriis quintis olim celebrabetur abolitum extitit et anichilatum ideo nos ... ipsum forum ... de novo duximus annuendum sine preiudicio tamen fororum vicinorum - DL 5071. Vö. Szalka, Szatmár megye.

1174 Szalka - 1413: DL 53 656. Namény - 1412: DL 84344 (ZsO. III. 2462. sz.). Mindkettőt idézi: Weisz B.: Vásárok és lerakatok 161-162.
} 


\section{Nempti (Zala megye) [Lenti, H]}

1343-ban Hahót nembéli Miklós királynéi lovászmester ${ }^{1175}$ Lajostól adományba kapta Nempti várát uradalmával - a vár tartozékai közt Nempti hétfői hetivásárát is felsorolták. ${ }^{1176}$

\section{Novák (Arad megye) [Aradul Nou-tól [Újarad] DNY-ra, RO]}

A Szeri Pósafiak Ároki és a Lackfiak Novák birtokai között rév üzemelt a Maroson (portus aque Morusy inter possessiones Noak et Aruky vocatas), ${ }^{1177}$ ami a két birtok határát képezte. ${ }^{1178}$ 1360. július 27-én, Kont Miklós temesvári nádori közgyülésén Szeri Pósa fia István ${ }^{1179}$ azt állította, Lackfi András ${ }^{1180}$ a két birtok között hajókat tart fent, vámot szed az átkelöktől (naves conservari et tributum ab hominibus inibi transitum facientibus exigi faceret), és az egész bevételt megtartja, holott annak fele őt illeti. ${ }^{1181}$ Néhány évvel később, 1363. augusztus 1-jén István Arad megye előtt tiltakozott, amiért Lackfi Pál és Miklós a rév egész jövedelmét maguknak szedik be, holott az átkelőt közösen bírják, így jövedelmének fele az övé. ${ }^{1182}$

\section{Nyen (Pozsony megye?) [helye ismeretlen]}

1376-ban Szencsei Pál, Garai Miklós óvári várnagya levelet címzett minden vámszedőnek és harmincadosnak Nyentől Óvárig, föleg a pozsonyi tricesimatornak tributariusnak, és helyetteseiknek. ${ }^{1183} \mathrm{~A}$ menlevélben a várnagy a pozsonyi ispánságot is betöltő ${ }^{1184}$ Garai Miklós nádor kérését tolmácsolva arra kérte a címzetteket, hogy a fákat (de una strue

\footnotetext{
1175 Vö. Engel P.: Archontológia I. 57.

1176 Nempty in qua ... forum singulis feriis secundis celebraretur - Zala I. 409. Weisz B.: Vásárok és lerakatok 173.

${ }^{1177}$ DL 91693.

${ }^{1178}$ DL 91556.

1179 Vö. Engel P.: Genealógia: Bár-Kalán nem 1. Szeri ág 2. tábla: Pósafi (szeri, sződi).

${ }^{1180}$ Vö. Engel P.: Genealógia: Hermán nem 2. tábla: Lackfi. Engel Pál adatai szerint Lackfi András, akit a nádor a közgyülésről való távolmaradása miatt megbírságolt, ekkor már nem élt.

1181 DL 91 556. (Domokos N.: Források 21-22.).

${ }^{1182}$ DL 91693.

1183 1376. szeptember 7.: universis tricesimatoribus et tributariis tam in terris quam super aquis a Nyen usque Owar ubique constitutis specialiter tricesimatori et tributario de Posonio eorumque vices gerentibus - DF 238940.

${ }^{1184}$ Engel P.: Archontológia I. 167.
} 
lignorum), amiket a nádor házainak építéséhez visznek Visegrádra, illetve az épületfák szóban forgó levelét felmutató szállítóit ne vámolják és harmincadolják meg. ${ }^{1185}$ A többes szám használata miatt (tricesimatoribus) eleve feltehető, hogy az útvonalon a pozsonyi mellett más harmincadhellyel (-helyekkel?) is számolnunk kell (például Óvárral). ${ }^{1186}$

Nyitott kérdés - akár harmincadja volt, akár vámja -, vajon melyik települést takarhatja Szencsei Pál levelében a leginkább Nyennek kiolvasható helynév. Az irat hátlapján olvasható regeszta a „kényelmes” és logikus, ám az előlapi olvasat által kevésbé támogatott „Vienna”, vagyis Bécs megoldást kínálja. Ugyanakkor Zsigmond 1418-ban egy birtokpert az országba „in Kyrkche/Kwkcha vagy in Nyen” való visszatéréséig halasztott el. ${ }^{1187}$ Az okmánytár szerkesztői az oklevél - későbbi átírásokból ismert - Kyrkche/Kwkcha helységet a mosoni Köpcsénnyel azonosították, ${ }^{1188}$ Nyent pedig ismeretlen Pozsony megyei(?) helységként interpretálták. ${ }^{1189}$

\section{Nyitra ${ }^{1190}$ (Nyitra megye) [Nitra, SVK]}

Nyitra keddi hetivására 1381-ben háromvásáros kikiáltás színtere volt. ${ }^{1191}$

\section{Óbuda ${ }^{1192}$ (Pilis megye) [Budapest része, $\mathrm{H}$ ]}

Az óbudai hajóvámot, vagyis a borral vagy sóval a folyón felfelé, vagy más áruval lefelé tartó hajók vámját II. Géza 1148-ban az óbudai káptalannak adta. ${ }^{1193}$ A hajóvám ezt követően 14. század közepi forrásokban, az Óbuda 1355. évi felosztásáról tudósító oklevelekben tűnik fel. ${ }^{1194} \mathrm{Az}$ óbudai vár és a káptalan területeinek és jogainak körülhatárolásával megbízott bárók és főpapok előtt a káptalan jogot formált (iura eorum exhiberent ${ }^{1195}$ / se ... habere

\footnotetext{
1185 DF 238940.

1186 Vö. Óvár.

1187 1418. május 12.: ZsO. VI. 1903. sz.

1188 ZsO. VI. 735.

1189 ZsO. VI. 753.

${ }^{1190}$ Korábbi történetére lásd Weisz B.: Vámok és vámszedés 282-283.

1191 DL 75 553. Weisz B.: Vásárok és lerakatok 154.

1192 Korábbi történetére lásd Weisz B.: Vámok és vámszedés 284-285.

1193 Weisz B.: Vámok és vámszedés 224.

1194 1355. aug. 17.; 1356. okt. 17.: Kumorovitz L. B.: Óbuda 1355. évi felosztása 284-285.

${ }^{1195}$ Kumorovitz L. B.: Óbuda 1355. évi felosztása 284.
} 
pretendebant ${ }^{1196}$ ) ugyan a hajóvámra, de jelentésük szerint annak nem volt a birtokában, ugyanis a vám egészen addig a vár, ${ }^{1197}$ következésképpen I. Lajos anyja, Piast Erzsébet jövedelmeit gyarapította, aki azzal 1343 óta rendelkezett. ${ }^{1198}$ Az 1355 . évi rendezés alkalmával az uralkodó és anyja a káptalan óbudai hajó- és vásárvámszedési jogát, illetve a polgárok feletti bírói joghatóságát néhány Zala és Somogy megyei birtokkal (Komár, Galambok, Szentpéter és Karos) megváltotta: ezek éves jövedelme elvileg meghaladta a káptalantól elvont jogok 200 budai márkára becsült bevételét - Lajos és Erzsébet legalábbis igyekezett a cserét a káptalan számára előnyösként feltüntetni. ${ }^{1199}$ Az anyakirályné óbudai dunai vámját (tributum aquaticum, seu Danubiale) fia jóváhagyásával 1366-ban az általa alapított óbudai Szüz Mária-kolostor klarissza apácáinak adta, cserébe az 1351-ben a kolostornak juttatott szentjakabfalvi szárazvámért. ${ }^{1200}$ 1367-ben Erzsébet már a szentjakabfalvi vám jövedelméből rendelte kiutalni azt az évi 240 forintot, amit az opuliai herceg lányának, az óbudai klarissza kolostorban apácaként élő Kunigundának addig az óbudai vám bevételéből biztosított. ${ }^{1201}$ Ugyanekkor értesülünk arról, hogy az óbudai (hajó)vámmal együtt a klarisszák a téli időszakban a Dunán, Óbudán halászott (tartott?) halak vámját (proventibus pisscium) is megkapták az özvegy királynétől. ${ }^{1202}$ 1401-ben egy elhagyatott ház adásvételekor említették az apácák óbudai vámhelyét (loci tributi), amely Pethy-i András és Borosjenői András telkeinek (fondorum) szomszédságában helyezkedett el. 1406-ban Anich apátnő a kolostor óbudai vámját szeptember 22-től egy évre 50 forintért (forintját száz dénárral számolva) adta bérbe Pál vámszedőnek (toloniatori). ${ }^{1203}$ Igen tanulságos az 1435-től csaknem másfél évtizedig elhúzódó vámper, amelyet az esztergomi polgárok indítottak több vámbirtokos, köztük az óbudai klarisszák ellen. Pálóci László országbíró 1449. évi ítélete kimondta a polgárok vámmentességét az apácák ceglédi, szondi, széplaki és egyedújfalusi vámjain, mégpedig az esztergomi örmények IV. Bélától kapott, 1243. évi kiváltságlevele alapján. ${ }^{1204}$ Az esztergomi polgárok az óbudai vám fizetése alól már nem tudták kivonni magukat, az apácák képviselője ugyanis sikerrel érvelt a klarisszák kiváltságának az esztergomiakénál régebbi voltával. Ez úgy fodulhatott elő, hogy a bíróság

\footnotetext{
${ }^{1196}$ Kumorovitz L. B.: Óbuda 1355. évi felosztása 285.

1197 tributum navium, quod ad presens pro castro nostro exigitur, licet iura eorum exhiberent, non tamen in ipsorum possessione a tempore, cuius non extaret memoria - Kumorovitz L. B.: Óbuda 1355. évi felosztása 284. 1198 AO IV. 297.

${ }^{1199}$ Kumorovitz L. B.: Óbuda 1355. évi felosztása 284-285.

${ }^{1200}$ F. IX/3. 528-531. Vö. 1351: F. IX/2. 53-55.

1201 DL 5631.

1202 DL 5631. Vö. 1399: tributum pisscium earum a piscatoribus in Danubio transeuntibus ad tributum earundem in eadem Veteribuda habitum exigi consuetum spectans - Bp. III/1. 134. (DL 8521.).

1203 Bp. III/1. 239. (ZsO. II/1. 5203. sz.).

1204 1449: DL 14 211. Vö. Weisz B.: Vámok és vámszedés 152.
} 
előtt nem a kolostor, hanem az óbudai káptalan vámszedési jogát megalapozó és alátámasztó okleveleket mutatták be: az apácák procuratora az Óbuda felosztásáról szóló 1356. évi oklevelet, a káptalané pedig II. Géza 1148-ban kelt adománylevelét. ${ }^{1205}$ A klarisszák a 15. század közepén újra és újra felléptek a vámfizetést megtagadók ellen: ${ }^{1206}$ 1465-ban például a gúti Ország Mihály nádor által az apácák panaszára elrendelt, Pilis megye hatósága által lefolytatott vizsgálat megállapította, hogy az esztergomi érsekké kinevezett Vitéz János váradi püspök megtiltotta az érsekség jobbágyainak a dunai hajóvám (tributum navale danubiale) fizetését, így a klarisszáknak 600 forint kárt okozott. ${ }^{1207}$

A 14. század derekán a király és az anyakirályné nem szűnő jóindulatát élvező óbudai apácák - 1351-ben a nyúl-szigeti domonkosok, majd mintájukra ${ }^{1208}$ 1365-ben az óbudai klarisszák is - arra hivatkozva, hogy vámjaikat ${ }^{1209}$ alamizsnaként kapták, kijárták, hogy az uralkodó hatálytalanítsa mind a külföldi, mind a hazai kereskedők vámmentességet biztosító okleveleit vámjaik vonatkozásában. ${ }^{1210}$

\section{Ófalu (Szepes megye) [Spišská Stará Ves (Szepesófalu), SVK]}

1362-ben Ófalu polgárai és a falvat birtokló lechnici kartauzi monostor között nézeteltérés támadt a zsemlye- és mészárszékek miatt. A vita rendezéséről tudósító irat szerint ekkor az

\footnotetext{
1205 1449: DL 14 211. Zsigmond parancsára a káptalan 1435-ben vállalta, hogy a vámszedés miatt az apácák ellen indított perekben a védelmükben bemutatja az óbudai dunai vámmal kapcsolatos okleveleit (littere et literalia instrumenta super facto tributi in eadem Veteribuda super fluvio Danubii exigi soliti). DL 12662.

${ }^{1206}$ 1452: DL 14540, 14541.; 1465: DF 16247.

${ }^{1207}$ DF 16187.

${ }^{1208}$ Kiváltságleveleik (lásd következő jegyzet) szövege gyakorlatilag megfelel egymásnak.

${ }^{1209}$ A 15. század közepén az óbudai, a ceglédi, a szondi, a széplaki és az egyedújfalusi vámok voltak az óbudai klarisszák birtokában. 1449: DL 14 211. Az óbudai hajóvámhoz 1366-ban jutottak, a szentjakabfalvi vámért cserébe (1366: F. IX/3. 528-531. Vö. 1351: F. IX/2. 53-55.); a Bács megyei Széplak útvámját, Egyedújfalu útés vásárvámját, valamint Belszond vámját (tributum fori Danubium) 1382-ben kapták meg I. Lajostól, cserébe többek közt a szepesi Lucsivna, Podolin és Tótfalu, valamint a Szabolcs megyei Révbács vámjaiért. 1382: DL 6905.

1210 quod quamquam plerisque hominibus, regnicolis nostris et extraneis ac hospitibus, instantiis eorumdem, et supplicationibus interuenientibus, huiusmodi gratiam fecisse dignoscimur: vt ipsi nullas in regno nostro tributa dare et soluere teneantur ... nam volumus, et testimonio praesentium committimus mediante, vt omnes homines tam regnicolae nostri, quam extranei, tributum soluere debentes, in locis tributorum earumdem Dominarum tributum consuetum plene dare et soluere teneantur; non obstante gratia eisdem facta praenotata; cui, vt praemittitur, praesentibus volumus derogari - 1351: F. IX/2. 73-74.; 1365: F. IX/3. 498-500. Az idők folyamán mindkét kolostor gondosan ügyelt arra, nehogy kiváltsága érvényét veszítse. A Margit-szigetiek oklevélmegerősítéseit lásd 1365: F. IX/3. 493-495. (I. Lajos), 1393: DL 7823. (Mária), 1397: DL 4181. (Zsigmond). Óbudai klarisszák: 1393: Bp. III/1. 78. (Zsigmond), 1406: DL 9123. (Zsigmond).
} 
ófalusi piacteren álló (in foro ... positis) összes zsemle- és mészárszék censusa a polgárokat illette. ${ }^{1211}$

\section{Ond (Zemplén megye) [Szerencs része, H]}

Ond birtok 1348. évi felosztása során a telekhelyek közti határok megjárása egy kő határjelnél kezdődött, ami a Szerencs folyó mellett, ,és bizonyos híd végénél” volt. ${ }^{1212}$

\section{Osztroluka (Zólyom megye) [Ostrá Lúka, SVK]}

1358-ban, amikor Gunde, Erzsébet, Klára, Ilona és Margit követelésére Miklós fia Mikó és János fia Péter kiadták a lányoknak apjuk, Osztralukai Zima fia Mihály birtokaiból járó leánynegyedet, a számukra elkülönített birtokdarab határai között a Szelesrév 1213 (Scelesrew $^{1214} /$ Selesrew $^{1215}$ ) is szerepelt. ${ }^{1216}$ Elképzelhető, hogy ehhez a révhez köthető a Zsigmond 1393. évi - Zólyom Nagyboldogasszony napja utáni vasárnaphoz kötődő évesvásár-tartási engedélyét tartalmazó - diplomájában említett osztralukai vámszedés. ${ }^{1217}$

\section{Óvár ${ }^{1218}$ (Moson megye) [Mosonmagyaróvár része, H]}

Óvár harmincadát, amely az 1498. évi, a harmincadok régi helyeit is felsoroló dekrétum 34. cikkelyében sem a fö-, sem a fiókharmincadok között nem jelent meg, ${ }^{1219}$ az Acsády Ignácra hivatkozó Pach Zsigmond Pál szerint csak „1531-ben, a marhakivitel nagy föllendülése idején állították fel”. ${ }^{1220}$ Ha volt is olyan időszak, amikor Óváron nem szedtek

\footnotetext{
${ }^{1211}$ DF 266 977. (Anjou-oklt. XLVI. 503. sz.).

1212 prima meta inciperet a plaga orientali prope dictum fluvium Zerench et in fine cuiusdam pontis ubi essent unus lapis pro meta positus - AO V. 232. (Anjou-oklt. XXXII. 569. sz.).

1213 Vö. Szamota I.: Oklevél-szótár 905-906. ('szeles', 'szélës').

1214 DF 254212.

1215 DL 72988.

1216 Keglevich: Garamszentbenedek 114-115. (124. szám), 115-116. (125. szám). (Anjou-oklt. XLII. $326 ., 327$. Sz.).

${ }^{1217}$ DF 268 912. (ZsO. I. 3037. sz.).

1218 Korábbi történetére lásd Weisz B.: Vámok és vámszedés 291.

1219 DRMH IV. 110.

${ }^{1220}$ Pach Zs. P.: A harmincadvám az Anjou-korban 258. 140. j.; Acsády I.: Magyarország pénzügyei 126.
} 
tricesimát, a helyi harmincadállomás fennállásával - legalábbis Lajos, Mária és Zsigmond idejében, a 14. században - számolnunk kell. Erre vonatkozóan a legkorábbi, annak idején már Csánki által is idézett adat ${ }^{1221}$ 1359-ből való, amikor Csenkeszfalvi Him fia Simon a pozsonyi alispánnál amiatt tett panaszt, hogy fratere, a volt óvári harmincados (condam tricesimatoris de Owar), János mester 20 márkát érő lovát, amit Simon éppen Pozsonyba vitt Jánosnak, a kiscsütörtöki villicus útközben lefoglaltatta (arestari fecisset). ${ }^{1222}$ Ugyancsak érdekes iratot őrzött meg a pozsonyi városi levéltár 1376-ból: Szencsei Pál, Garai Miklós óvári várnagya minden vámszedőnek és harmincadosnak Nyentől Óvárig, főleg a pozsonyi tricesimatornak tributariusnak, és helyetteseiknek szóló levelét. ${ }^{1223}$ A menlevélben a várnagy a pozsonyi ispánságot is betöltő ${ }^{1224}$ Garai Miklós nádor kérését tolmácsolva arra kérte a címzetteket, hogy a fákat (de una strue lignorum), amiket a nádor házainak építéséhez visznek Visegrádra, illetve az épületfák szóban forgó levelét felmutató szállítóit ne vámolják és harmincadolják meg. ${ }^{1225}$ A többes szám használata miatt (tricesimatoribus) eleve feltehető, hogy az útvonalon a pozsonyi mellett más harmincadhellyel (-helyekkel?) is számolnunk kell, az óvárival az 1359-es adatból kiindulva meglehetős bizonyossággal.

Az óvári harmincad 1359. évi fennállását alátámasztó adat fényében talán bátrabban foglalhatunk állást amellett, hogy Mária királynő 1383. évi, Zsigmond által 1387-ben és 1406ban is megerősített, a szebeni és más erdélyi városok kereskedői érdekében kibocsátott, a királyság összes harmincad- és vámszedőjéhez, különösen az óváriakhoz intézett oklevelének inscripciója $^{1226}$ - Pach véleményével ellentétben ${ }^{1227}$ - nem, vagy nem csak az óvári vámszedőhelyre, hanem a helyi harmincadállomás müködésére (is) utal. ${ }^{1228} \mathrm{~A}$ szebeniek kérésére Mária ekkor megtiltotta, hogy kereskedőiktől a vámokat és harmincadokat jogtalanul szedjék, és áruikat akár a vámszedők, akár a harmincadosok felbonthassák. Hacsak a felbontás előtt „,a régi szokás és szabadság szerint” nem akasztottak a szekérre egy márka

\footnotetext{
1221 Csánki III. 676.

1222 1359. augusztus 17.: DF 226978.

1223 1376. szeptember 7.: universis tricesimatoribus et tributariis tam in terris quam super aquis a Nyen usque Owar ubique constitutis specialiter tricesimatori et tributario de Posonio eorumque vices gerentibus - DF 238940.

${ }^{1224}$ Engel P.: Archontológia I. 167.

${ }^{1225}$ DF 238940.

1226 fidelibus suis universis et singulis tricesimatoribus et tributariis ubique intra ambitum regni nostri signanter in Owar nunc constitutis et in futurum constituendis - ZW. II. 573.

${ }^{1227}$ Pach Zs. P.: A harmincadvám az Anjou-korban 258. 140. j.

1228 1383. március 29.: ZW. II. 573., 1387. június 5.: ZW. II. 611-612., 1406. április 7.: ZW. III. 401-403.
} 
aranyat - ebben az esetben ugyanis, ha bármilyen letagadott vagy elrejtett dolgot találtak a szekéren, azt megtarthatták maguknak. ${ }^{1229}$

\section{Őr ${ }^{1230}$ (Szepes megye) [Strážky (Nagyőr), Spišská Belá (Szepesbéla) része, SVK]}

I. Lajos 1344. évi oklevele szerint Nehrer (Nyrer) és Rókusz - a szepesi káptalan tanúságával történő - határjárásakor a két birtokot Lándok birtoktól és a bélai németektől elkülönítő határok bejárása során érintették a Nirer nevü hidat, ami az azonos nevü patakon vezetett át. ${ }^{1231}$ A királyi oklevél azonban, amelyet már Fekete Nagy Antal is gyanúsnak minősített, ${ }^{1232}$ későbbi hamisítványnak tekinthető. Az 1344. évi iratnak csupán egy 1365. évi átírásáról tudunk - utóbbi a király állítólagos, 1353. évi átírását is magában foglalja. Írásképe semmiképpen nem 14., inkább 16. századi. A Nirer nevü „hidacskát” (ponticulus) és vízfolyást említi III. András 1290. évi, ugyancsak hamis, ${ }^{1233}$ Lándok, Nirer és Rókusz határait leíró, I. Károly 1322-i megerősítésében fennmaradt, írásképe alapján a 16. században elkészített ${ }^{1234}$ oklevele is; az ebben olvasható magyarázat szerint a hidat azért hívják Nirernek, mert Nirer birtok lakói szabadon vághatnak tűzifát Rókusz erdeiben a hídig. ${ }^{1235}$ A híd - illetve az azonos nevü vízfolyás - nevének 16. századi érdekek motiválta (határvita, esetleg erdőhasználati jog) népetimológiája, ami a nehreriek faizási jogának kontextusán keresztül a Nyír ér magyar jelentést igyekszik sugalmazni, ${ }^{1236}$ szándékosan ferdítő és hibás. A Nirer név többszörös átvitelén (birtok>vízfolyás (ér)>híd) alapuló konstrukció mögött az oklevél-hamisító aktuális érdekei állhattak, a Nehrer birtoknév ugyanis német, a magyar birtoknév (Őr) tükörfordítása: a nähren ige másodlagos, őrizni, vigyázni jelentésével bíró foglalkozásnévi változata (Nährer). ${ }^{1237}$ A fentiekből kifolyólag az őri hídról hiteles 14. századi adatunk egyelőre nincs.

\footnotetext{
1229 si autem ipsas res mercimoniales vultis dissolvere et disiungere, tunc unam marcam auri ipsi currui prius appendatis iuxta antiquam consuetudinem et libertatemegye Et quidquid deinde in ipso curru denegatum aut occultatum inveneritis, pro vobis conservetis - ZW. II. 573.

${ }^{1230}$ Korábbi történetére lásd Weisz B.: Vámok és vámszedés 292.

1231 quendam rivulum sive pontem nirer vocatum - DF 281 698. (Anjou-oklt. XXVIII. 757. sz.).

1232 Fekete Nagy 221. 121. jz.

1233 Kar., HH. 38-39.

1234 Tagányi K.: Egy hamisítvány 512.

1235 qui ponticulus ideo Nirer vocatus, quia incole possessionis Nirer habent libertatem secandi ligna, et hoc pro igne duntaxat, in siluis Rokus usque ad prefatum pontem - W. X. 10. (DL 1281).

1236 Vö. Tagányi K.: Egy hamisítvány 514.

${ }^{1237}$ Vö. Tagányi K.: Egy hamisítvány 514.
} 
Más kérdés, hogy mihez kötődhetett az őri, a Károly- és a Lajos-korban is kimutatható vámszedés. Az őri vámot I. Károly - csak említésből ismert - pátensével valamikor 1327 és 1342 között Druget Fülöp ${ }^{1238}$ nádor özvegyének, Margitnak és árváinak engedte át életük tartamára. ${ }^{1239}$ Margit a vámot 1350-ben lányának, Klárának és férjének, Mikcsfi Ákosnak ${ }^{1240}$ adta a Károly oklevelében leírt feltételek mellett; ${ }^{1241}$ az adományt 1351-ben a király is jóváhagyta, ráadásul Ákos örököseire is kiterjesztette. ${ }^{1242}$

\section{Pacsa (Zala megye) [Zalalövőtől D-re, H]}

I. Lajos 1356-ban Gersei Pető ${ }^{1243}$ Pacsa birtokán hétfői hetivásár (forum liberum) tartását engedélyezte. ${ }^{1244}$

\section{Paks (Tolna megye) [Paks, H]}

Paks szerdai hetivására 1381-ben háromvásáros kikiáltás helyszíne volt. ${ }^{1245}$

\section{Pálfalva [helye ismeretlen] ${ }^{1246}$}

Pálfalva hetivásárára 1371-ből adatolható: január 12-én Töttös fia László néhány karakói $^{1247}$ jobbágyát és Miklós nevü famulusát, akik a pálfalvi vásárból (de libero foro in possessione Palfalua vocata celebrari solito) tartottak hazafelé, András cikádori apát elfogatta, megverette és kifosztatta. ${ }^{1248}$

\footnotetext{
${ }^{1238}$ Vö. Engel P.: Genealógia: Druget 1. tábla: gerényi ág.

1239 Weisz B.: Vámok és vámszedés 292.

${ }^{1240}$ Vö. Engel P.: Genealógia: Ákos nem 4. Mikcs ága 1. tábla: Mikcsfi.

${ }^{1241}$ Tringli I.: Perényi 58-59. (Anjou-oklt. XXXIV. 150. sz.). Az oklevelet átírta a budai káptalan 1351. mácius 7-én (Tringli I.: Perényi 59-60.).

1242 DL 42 781. A király az 1351. évi oklevelet privilegiális formában is átírta 1352. február 10-én. DL 42781.

${ }^{1243}$ Vö. Engel P.: Genealógia: Nádasd nem 3. tábla: Pető (gersei).

1244 Zala I. 565. (Anjou-oklt. XL. 420. sz.).

1245 DL 106 191. (F. IX/5. 524.). Weisz B.: Vásárok és lerakatok 165.

${ }^{1246}$ Weisz Boglárka a települést Marjančaci vidékére (Horvátország) lokalizálja. Weisz B.: Vásárok és lerakatok 136.

${ }^{1247}$ Vö. Gy. I. 322.

1248 Z. III. 417-418.
} 


\section{Palocsa ${ }^{1249}$ (Sáros megye) [Plaveč, SVK]}

Palocsa királyi vámját az 1355. évi sárosi vámvizsgálat említette. A közlekedési vámot a Palocsa vára alatt, a Poprád folyó hídján átkelőktől szedték. ${ }^{1250}$ A vámvizsgálat kiderítette, hogy a Rusz felé Bártfán keresztül tartókat az útjukról egy mérföldnyi kitérőre kényszerítik, a palocsai vámhoz, máskülönben minden javuktól megfosztják őket. ${ }^{1251}$

\section{Pápa (Veszprém megye) [Pápa, H]}

Pápa hetivására 1363-ban háromvásáros kikiáltás színtere volt. ${ }^{1252}$ A településnek az Anjou-kor végén a szombati hetivására adatolható: elsőként az 1382. december 27-i, amikor az ajkai János fia Miklós famulusai és jobbágyai a béli apát szerviensét, Fejes Mihályt, aki az egyház számára halakat vásárolt, halálosan megsebesítették. ${ }^{1253}$ Pápán vásárvámot is szedtek, ami - legalábbis részben biztosan - a helyi plébánost illette. Egy 1378-as adat szerint a veszprémi káptalan gyimóti jobbágyai emberemlékezet óta, évente egyszer mansiónként 1 mérő zabot adtak a helyi (gyimóti), szokásos mértékkel mérve a pápai plébánosnak, a pápai vásárvám fejében. ${ }^{1254}$

\section{Pápoc (Vas megye) [Pápoc, H]}

1360-ban Magyar Pál felesége, Margit (a Nádasd nembéli Gersei Csapó fia András fia László lánya) ${ }^{1255}$ az esztergomi káptalan tanúsága mellett úgy végrendelkezett, hogy vásárlás révén szerzett Pápoc birtokának kétharmad része az ottani vásárvám (tributum fori) kétharmadával együtt halála után, lélekváltságként az általa 1359-ben alapított ${ }^{1256}$ pápóci

\footnotetext{
1249 Korábbi történetére lásd Weisz B.: Vámok és vámszedés 295-296.

1250 quorum unum esset sub castro vestro Palocha habens pontem super fluvio Paprad - Draskóczy I.: Sáros megye vámhelyei 58 .

${ }^{1251}$ quod transeuntes de diversis partibus regni vestri versus Rusyam per Bardfa per viam scilicet directam a distancia unius miliaris compellerentur ire extra viam ad tributum de Palocha predicta, alias bonis suis omnibus spoliarentur vel alias multum perturbarentur - Draskóczy I.: Sáros megye vámhelyei 61.

1252 DL 5196. (Anjou-oklt. XLVII. 102. sz.).

1253 P. VIII/1. 413-414.

${ }^{1254}$ VVOS 315-316. (Veszpr. Reg. 724. sz.).

1255 Vö. Engel P.: Genealógia: Nádasd nem 3. tábla: Pető (gersei).

${ }^{1256}$ Romhányi B.: Kolostorok és társaskáptalanok 'Pápóc'.
} 
Szűz Mária Ágoston-rendi remete kolostort illesse. ${ }^{1257}$ A pápoci vásár napja - 15. század eleji (1438) adat alapján - a szombat volt. ${ }^{1258}$

\section{Parlagrév(e) (helye ismeretlen)}

Egy 1357. évi királyi parancslevél említi a Parlag(?)rév(e) ${ }^{1259}$ (Porloghriwy ${ }^{1260}$ Porloghriw ${ }^{1261}$ ) nevü Dráva-révet, ami szerint az abban szereplő Farkasrév(e) rév - valahol Ludbreg és Apajkeresztúr térségében -, a folyó Zákányrév(e) és Parlagrév(e) nevü átkelői közt biztosított átkelést a Dráván. ${ }^{1262}$

\section{Pásztó ${ }^{1263}$ (Heves megye) [Pásztó, H]}

Pásztó a Lajos-korban vásáros hely volt, keddi hetivására 1345-ben ${ }^{1264}$ és 1347-ben ${ }^{1265}$ is háromvásáros kikiáltás helyszíne volt.

\section{Patak $^{1266}$ (Zemplén megye) [Sárospatak, H]}

Patak szombati hetivásárán 1348-ban háromvásáros kikiáltásra került sor. ${ }^{1267}$

\footnotetext{
${ }^{1257}$ F. IX/3. 175-176.

1258 Weisz B.: Vásárok és lerakatok 170.

1259 Vö. Szamota I.: Oklevél-szótár 749. ('parlag').

1260 DF 101907.

1261 DF 103295.

1262 DF 101907 = DF 103295 = DF 106 786. (Anjou-oklt. XLII. 35. sz.).

1263 Korábbi történetére lásd Weisz B.: Vámok és vámszedés 297.

1264 DL 38 962. (Anjou-oklt. XXXI. 171. sz.).

1265 DL 38 963. (Anjou-oklt. XXXI. 459. sz.).

1266 Korábbi történetére lásd Weisz B.: Vámok és vámszedés 299.

${ }^{1267}$ DF 252596 (Anjou-oklt. XXXII. 909. sz.). Vö. Weisz B.: Vásárok és lerakatok 175.
} 
Pécs ${ }^{1268}$ (Baranya megye) [Pécs, H]

Pécs pénteki hetivására 1373-ban ${ }^{1269}$ és 1376 -ban is ${ }^{1270}$ háromvásáros kikiáltás színhelye volt.

\section{Peker(szerdahely) ${ }^{1271}$ (Körös megye) [Gornji Sređani, Horvátország]}

A pozsegai káptalan 1352. évi oklevele alapján Peker ${ }^{1272}$ (Pukur) vásáros hely volt, miután ekkor Pekri Lőrinc fia Pál, és Pál fiai, Miklós és Benedek ${ }^{1273}$ itteni birtokrészüket a vásárral együtt (cum foro) zálogosították el Kasztellán ${ }^{1274}$ Péternek. ${ }^{1275}$ A település szerdai hetivásárára már 1338-ból van adatunk. ${ }^{1276}$

\section{Pereszlény (Hont megye) [Presel'any nad Ipl'om, SVK] ${ }^{1277}$}

1374-ben Lajos Pereszlény királyi falunak volentes ... villam nostram ... populosam efficere ac multitudine populorum decorare keddenként hetivásár tartását engedélyezte a szomszédos vásárok sérelme nélkül. ${ }^{1278}$

\footnotetext{
${ }^{1268}$ Korábbi történetére lásd Weisz B.: Vámok és vámszedés 300.

1269 Z. III. 525. Weisz B.: Vásárok és lerakatok 137.

${ }^{1270}$ DL 6388.

${ }^{1271}$ Korábbi történetére lásd Weisz B.: Vámok és vámszedés 302.

1272 Azonosítása: Weisz B.: Vásárok és lerakatok 150.

${ }^{1273}$ Vö. Engel P.: Genealógia: Tétény nem Pekri.

${ }^{1274}$ Vö. Engel P.: Genealógia: Kasztellánfi (szentléleki).

1275 DL 100052.

${ }^{1276}$ Weisz B.: Vásárok és lerakatok 150.

1277 A vásártartást lehetővé tevő oklevél nem nyújt támpontot arra nézve, hogy a benne szereplő villa nostra (sc. regis - K. V.) Perezlyen a Hont vagy a Nyitra megyei Pereszlénynek (Nyitrapereszlény, Presel'any, SVK) feleltethetö-e meg. (A nyitrai Pereszlénnyel való azonosításra l. Weisz B.: Vásárok és lerakatok 153.) Azonosításához további birtoklástörténeti adatokra lenne szükség. Engel Pál a Hont megyei Pereszlényt térképén a drégelyi uradalom részeként tüntette fel 1370 és 1390 között (Engel P.: Térkép - a vonatkozó okleveles adatokat nem sikerült megtalálnom). Miután Drégely vára a Lajos-korban királyi vár volt (Fügedi E.: Vár és társadalom 128.; Engel P.: Királyi hatalom 108.), következésképpen tartozéka, Pereszlény, ebben az időszakban királyi birtok kellett, hogy legyen, a kérdéses királyi falu Hont megyei lokalizáslása legalábbis megalapozottan feltételezhetö.

${ }^{1278}$ Iványi, Eperjes 36-37. (83. sz.).
} 


\section{Pest (Pest megye) [Budapest része, $\mathrm{H}]^{1279}$}

Garai Miklós nádor Pest és Pilis megyék számára Szenterzsébet falu mellett 1381. április 22-én tartott közgyülésén Zsidói István fia Domonkos panaszt tett Lack fia Miklós és István fia János veresegyházi nemesek ellen, mivel embereik az előző évben, 1380. január 16-án, kedden rablók módjára lerohanták és kifosztották két, a pesti vásárról (de foro in civitate Pestyensi habito) a közúton (in libera via) hazafelé tartó zsidói jobbágyát. ${ }^{1280}$ A történtek minden valószínűség szerint a keddi pesti hetivásárhoz köthetők, aminek megtartására az eddig ismert legkorábbi adatot szolgáltatják. ${ }^{1281}$

\section{Petend (Szentbenedek) (Bars megye) [Hornský Beňadik (Garamszentbenedek), SVK]}

I. Lajos 1347. június 11-én Szigfrid garamszentbenedeki apát kérésére hétfőként hetivásár (forum) tartását tette lehetővé a monostor Petend falujában. ${ }^{1282}$ A petendi vásárról hamar kiderült, hogy Bát hétfői hetivásárának kárára van, így a megtartására vonatkozó engedélyt a király ősszel, október 25-én visszavonta, és helyette az apátnak pénteki napokra garantált vásárt (forum liberum) Petenden. ${ }^{1283}$

\section{Petre (Temes megye) [Jebel-től K-re, RO]}

Petre falunál hídon lehetett átkelni a Temes folyón. Az aradi káptalan és Temes megye Szeri Pósa és fia, László érdekében 1346-ban lefolytatott vizsgálata szerint Ravasz Miklós, Magyar Pál petrei officialisa cinkosaival és a falu népével a Krassó megyéből, honorjukról (de honore suo) $)^{1284}$ a birtokaikra tartó, és ott átkelni tartozó Pósát, Lászlót, feleségeiket és familiárisaikat megtámadta, háromszáz juhukat és más javaikat elvette, három nemes

\footnotetext{
1279 Korábbi történetére lásd Weisz B.: Vámok és vámszedés 307-311.

1280 DL 64956.

1281 Vö. Weisz B.: Vásárok és lerakatok 154. (1388-as adat).

1282 Juck I. 147. (Anjou-oklt. XXXI. 537. sz.). Az oklevelet super collacione fori a király az apát kérésére 1347. július 28-án privilégium formájában is kiadta. Str. III. 647-648. (Anjou-oklt. XXXI. 735. sz.).

1283 Juck I. 157. (Anjou-oklt. XXXI. 1002. sz.).

1284 Vö. Engel P.: Archontológia I. 142.
} 
famulusukat és az asszonyok három szekérhúzó lovát nyíllövésekkel megsebesítette, a hidat pedig szétszedette, és Pósáékat három napra feltartóztatta. ${ }^{1285}$

\section{Pinkafő (Vas megye) [Pinkaveld, A]}

Pinkafőn legkésőbb 1346-ban már hetivásárt (forum) tartottak, ahol vásárvámot is szedtek. ${ }^{1286}$ A vásár napja egy 1391-es adat szerint szerda volt. ${ }^{1287}$

\section{Pócs ${ }^{1288}$ (Szabolcs megye) [Máriapócs, H]}

A Bátoriak ${ }^{1289}$ Pócs faluja a Lajos korban vámszedő-hely volt. ${ }^{1290}$ A család a birtok 1353. évi osztályakor a pócsi vámon is megosztozott: a bevétel kétharmad részét, Bátori Bereck fia Lőkös fia Péter egyetértésével, Bereck fia János fiai, László, György és István szedhették a saját curia-jukban, míg a harmadik harmad beszedése Bereck fia Miklósnak jutott. ${ }^{1291} \mathrm{Az}$ osztálylevél szerint Pócson híd állt, így - noha ezt az oklevél konkrétan nem mondja ki elképzelhető, hogy a vámszedés ehhez kötődött; ${ }^{1292}$ az mindenesetre bizton állítható, hogy a pócsi vámot közlekedési vámnak tekinthetjük.

\section{Podolin (Szepes megye) [Podolínec, SVK]}

1356-ban az egri káptalan Mikcsfi Ákosnak iktatta a szepesi Somogy birtokot, valamint Podolin, Lucsivna, és Ófalu vámját, amelyek - így az oklevél - Ákost a király és a néhai Druget Fülöp ${ }^{1293}$ nádor özvegye, Margit adománya révén illetik. ${ }^{1294}$ A szóban forgó

\footnotetext{
1285 pontem in fluvio Temes habitum per quem transire debuissent destruendo deposuisset per eosdem per tres dies ibidem sedere seu manere fecisset - DL 91 375. (Anjou-oklt. XXX. 898. sz.). Temes megye oklevelét l. DL 91 376. (Anjou-oklt. XXX. 909. sz.).

1286 Bgl. V. 11. Vö. Weisz B.: Vásárok és lerakatok 170.

${ }^{1287}$ F. X/3. 199. Weisz B.: Vásárok és lerakatok 170.

1288 Korábbi történetére lásd Weisz B.: Vámok és vámszedés 313.

1289 Vö. Engel P.: Genealógia: Gútkeled nem 1. Rakamazi ág 6. tábla: Bátori (ecsedi).

1290 AO VI. 157-158. (Anjou-oklt. XXXVIII. 35. sz.).

1291 AO VI. 161. (Anjou-oklt. XXXVIII. 35. sz.).

${ }^{1292}$ AO VI. 161. (Anjou-oklt. XXXVIII. 35. sz.).

1293 Vö. Engel P.: Genealógia: Druget 1. tábla: gerényi ág.

${ }^{1294}$ AO VI. 485-486. (Anjou-oklt. XL. 382. sz.).
} 
adományozás tényéről Margit 1350. évi, - többek között - Somogy birtokot és az őri vámot lányának, Klárának és rajta keresztül férjének, Mikcsfi Ákosnak ${ }^{1295}$ átruházó oklevele ${ }^{1296}$ és I. Lajos 1351. évi, I. Károly és Margit adományát tanúsító oklevele tudósít. ${ }^{1297}$ A két irat alapján Somogyot és az őri vámot még I. Károly engedte át - csupán említésből ismert pátensével - valamikor 1327 és 1342 között Druget Fülöp nádor özvegyének, Margitnak és árváinak életük tartamára. ${ }^{1298}$ 1351-ben a király jóváhagyta apja, Károly (és Margit) adományát, sőt Mikcsfi Ákos örököseire is kiterjesztette. ${ }^{1299}$ Somogy említett, 1356. évi iktatását talán Klára halála indokolta, a birtok felesége halálával Ákos közvetlen birtokába kerülhetett. Feltünő, hogy az 1356 előtti, Somogy átruházását tárgyazó oklevelek egyike sem említi a podolini, a lucsivnai és az ófalusi vámot, holott a háromból kettő - Podolin és Lucsivna vámja - 1382-ben is a birtokkal együtt cserélt gazdát, így joggal gyanítható, hogy a birtok tartozékai voltak. A podolini vám a lucsivnaival és a tótfalusival, Somogy birtokkal és kamarahasznájával együtt 1382-ben az óbudai klarisszáké volt; 1382. május 3-án az apácák és I. Lajos széleskörü, országszerte több birtokot, vám- és kamarahaszna-jövedelmet érintő „birtokcseréje” értelmében a király kezébebe került. ${ }^{1300}$

\section{Poroszló ${ }^{1301}$ (Heves megye) [Poroszló, H]}

A király Poroszlói Gyula ${ }^{1302}$ örökös nélkül elhalt ember birtokát, ${ }^{1303}$ Poroszlót 1347-ben tiszai rév- és szárazvámjával együtt (cum tributo tam in portu dicti fluvii Tycie quam in terra ibidem exigere consueto) Neszmélyi Miklós pécsi püspöknek ${ }^{1304}$ és testvérének, Mátyásnak ${ }^{1305}$ adományozta, egyúttal megtiltotta, hogy az átkelő kárára Poroszló és Várkony között bárki - a kereskedők és utazók előtt is nyitva álló - révet létesítsen a folyón. ${ }^{1306}$ Lajos

\footnotetext{
1295 Vö. Engel P.: Genealógia: Ákos nem 4. Mikcs ága 1. tábla: Mikcsfi.

1296 Tringli I.: Perényi 58-59. (Anjou-oklt. XXXIV. 150. sz.).

${ }^{1297}$ DL 42781.

1298 Weisz B.: Vámok és vámszedés 292.

1299 DL 42781.

${ }^{1300}$ Somogy in comitatu Scepsiensi cum tribus tributis in possessionibus Paladyn Tothfaluw et Luchyna vocatis in eodem comitatu habitis exigi consuetis - DL 6905.

${ }^{1301}$ Korábbi történetére lásd Weisz B.: Vámok és vámszedés 315-316. Vö. Kovács B.: Középkori vámok 21-22.

1302 Gyulát Weisz Boglárka a Sártiványvecse nembeli Gyulával azonosítja. Weisz B.: Vámok és vámszedés 316. Vö. Engel P.: Genealógia: Sártiványvecse nem.

1303 Vö. Weisz B.: Vámok és vámszedés 315-316.

${ }^{1304}$ Engel P.: Archontológia I. 73.

1305 Engel P.: Genealógia: Poroszlói (Neszmélyi).

1306 adiecisset eciam ipse ... Lodovicus rex, quod quia inter predictam possessionem Porozlow et possessionem Warkun nominatam in aliquo locorum portus seu transitus viatorum aliquo unquam tempore inventum fuisse minime prohiberetur, obhoc commisisset, ut nullus omnino hominum inter dictas duas possessiones Porozlow et
} 
azt is kikötötte, hogy amennyiben Mátyás örökös nélkül halna meg, Poroszló Miklós és Mátyás carnalis fraterére, Valterra szálljon. Ha ö is utód nélkül halna el, a birtok lánytestvérük fiáé, Hankóé legyen. ${ }^{1307}$ 1355-ben Neszmélyi Miklós és a folyón a poroszlói révtől délebbre üzemelő abádi átkelő müködtetője, Tomaj nembéli Losonci István fia, Dénes ${ }^{1308}$ között jogvita támadt a két rév fenntartása és a hozzájuk kötődő vámszedés miatt $^{1309}$ - a királyi jelenlét előtti per folyományaképp a kereskedőket és utazókat végül eltiltották az abádi átkelő használatától. (Vö. Abád).

\section{Pósatelke (Sopron megye) [helye ismeretlen] ${ }^{1310}$}

Pósatelke határvitájában (1361-1362) feltünt egy bizonyos Hídere (Hydere) víz, ${ }^{1311}$ amin a nevéből adódóan híd állhatott.

\section{Pótharaszt (Pest megye) [Csévharaszttól D-re, H]}

I. Lajos 1350-ben szerdai hetivásár tartását engedélyezte a pótharaszti királyi hospeseknek, avagy jobbágyoknak. A király egyúttal megtiltotta minden rendủ és nációjú (cuiuscunque condicionis et quaruncunque nacionum), a pótharaszti vásárra igyekvő ember letartóztatását (prohibicio vel arrestacio) keddtől csütörtökig, és javaikkal együtt szabad járás-kelést biztosított számukra ebben az időszakban. ${ }^{1312}$

\section{Pozsony ${ }^{1313}$ (Pozsony megye) [Bratislava, SVK]}

Az Árpád-korban a pozsonyi vám(ok) jövedelmei háromfelé oszlottak: első harmaduk mint egyébként az összes Pozsony megyei vámé (a hagyomány szerint Szent István

Warcun nominatas qualicunque modo portum seu transitum viatorum quorumlibet in preiudicium porti in dicta possessione Porozlow habiti ad invenire vel pro se ipso construere minime posset atque valeret - AO VI. 305.

1307 AO VI. 305.

${ }^{1308}$ Engel P.: Genealógia: Tomaj nem 2. tábla: Losonci.

${ }^{1309}$ AO VI. 304-310. A jogitát részletesen lásd Abádnál.

${ }^{1310}$ Mártonháza (Apelton [Mosonbánfalva] területén, Ausztria) és Pomogy (ma Pamhagen, Ausztria) határosa.

${ }^{1311}$ F. IX/3. 330. (Anjou-oklt. XLVI. 284. sz.).

1312 DL 41 137. (Anjou-oklt. XXXIV. 447. sz.).

1313 Korábbi történetére lásd Weisz B.: Vámok és vámszedés 316-318. 
adományából) - a pannonhalmi bencés monostort, második harmaduk a pilisi ciszterci apátságot illette, a harmadik harmad pedig a pozsonyi ispán felügyelete alatt állt. ${ }^{1314}$ A vám tizede az esztergomi érseknek járt - ahogy minden vámé a megyében, Imre király 1198. évi adománya révén. ${ }^{1315}$ Utóbbi jövedelmet 1306 óta a pozsonyi káptalan birtokolta. ${ }^{1316}$ 1370-ben Jakab pozsonyi bíró egy évre 30 dénárfontért bérbe vette a káptalan vödrici és csallói „vámrészeit”, azaz tizedeit. ${ }^{1317}$ A pannonhalmi monostor vámbirtoklása a Lajos-korban a pozsonyi nagy-dunai (vödrici) és kis-dunai (csallói) rév, illetőleg a Szárazvámnál is kimutatható; a pilisi apátságé - adatolhatóan - csak a Szárazvámnál:

\section{Pannonhalmi apátság:}

- a pannonhami monostor „pozsonyi” (vödrici?) és csallói révvámjának harmadát Vilmos apát 1350-ben 1 évre 28 márka bécsi dénárért adta haszonbérletbe Jakus (Jakab) pozsonyi bírónak és Jakabnak, a pilisi apát vámszedőjének; ${ }^{1318}$

- Jakab pozsonyi bíró 1356-ban 10 évre évi 240 forintért vette bérbe az apátság nagydunai (és vereknyei) vámharmadait; ${ }^{1319}$

- Szigfrid pannonhalmi apát 1360-ban fellépett az ellen, hogy az apátság kapuvámharmadát Jakab pozsonyi bíró majd' húsz évig visszatartotta, amit később fiai is folytattak. Az apátnak végül hosszú pereskedést követően a győri káptalan előtt sikerült 1360-ban megállapodnia velük, 70 forint jóvátétel fizetésére kötelezték magukat. $^{1320}$

\section{Pilisi apátság:}

- 1361-ben Henrik pilisi apát Jakab bírónak és Miklósnak, Jakab fiának életük végéig bérbe adta a pozsonyi szárazvámból neki járó vámrészt. ${ }^{1321}$

A többször említett Szárazvám (németül Dürrmaut) a 14. században a Szent Mihálykapunál szedett vám elnevezése volt. ${ }^{1322}$ Lokalizálásához a győri káptalan 1360. évi, sajnos

\footnotetext{
1314 Weisz B.: Vámok és vámszedés 316.

1315 Weisz B.: Vámok és vámszedés 319.

1316 Weisz B.: Vámok és vámszedés 316., Király J.: Pozsonyi vám- és révjog 14. Vö. 1348: DF 238 721. (F. IX/1. 573-578.).

${ }^{1317}$ porciones nostras quas in tributo in vidricia et in challow exigi consueti - DF 238866.

1318 porciones nostras seu portus tributi Posoniensis et in Challo portuum nobis annis singulis proveniri debitas DF 207 482. (Anjou-oklt. XXXIV. 342. sz.).

1319 tertias partes tributorum nobis et monasterio nostro ab antiquo provenientes super magnam aquam Danubii in Posonio et in Challo in villa videlicet Verkenye exigi consuetas - P. II. 423.

${ }^{1320}$ DF 238782.

${ }^{1321}$ DF 238 800. Vö. 1367: in facto tributi nostri ibidem Posonii - DF 238840 (Henrik pilisi apát oklevele).
} 
csak másolatban ránk maradt oklevele nyújt támpontot, ami így fogalmaz: „a köznyelven Szárazvámnak, németül pedig Duermauthnak hívott vám a pozsonyi kapuban, amit Szent Mihálynak neveznek, Marhek ${ }^{1323}$ felé”. ${ }^{1324}$ 1349-ben, amikor I. Lajos a tributumot Jakab comes városi bírónak adta, „Pozsony városunk kapuvámja Szent Mihály arkangyal egyháza felől, amit közönségesen dywernek hívnak” formában írták körül. ${ }^{1325}$ A dywerben feltehetően szintén a német dürr ('száraz') szó romlott alakja őrződött meg. Ortvay Tivadar szerint a „Szárazvám” elnevezés a pozsonyi nagy-dunai révnél szedett vízivámmal való szembeállításából adódik. ${ }^{1326}$ I. Lajos a kapuvámot (tributum seu telonium porte civitatis nostre Posoniensis) (valójában a pilisi és a pannonhalmi egyházak birtoklása alá nem eső harmadot) 1349-ben Jakab pozsonyi bírónak és fiainak adta. ${ }^{1327}$ Szigfrid pannonhalmi apát azt állította 1360-ban, hogy az apátság kapuvám harmadát Jakab már majd’ húsz éve visszatartotta, amit később fiai is folytattak. Amikor az apát a hosszú pereskedést követően a győri káptalan előtt 1360-ban megállapodott velük, 70 forint jóvátétel fizetésére kötelezték magukat. ${ }^{1328}$ 1361-ben Henrik pilisi apát a Szárazvámban bírt vámrészét (partem nostri tributi ibidem que dürrmaut nuncupatur) Jakab bírónak és Miklósnak, Jakab fiának adta bérbe életük tartamára. ${ }^{1329}$ A bérleti viszony fennállásáról 1367-ből is van adatunk. ${ }^{1330}$ Ortvay Pozsony-monográfiájának a város középkori topográfiájával foglalkozó részében késő középkori, 15. századi, a számadáskönyvekből származó adatok alapján írt a Szárazvámról a róla elnevezett, elővárosi Szárazvám-kapuval (Dürrmautthor) kapcsolatban. E kapu nem a belső, hanem külső városfalon biztosított átjárást, és annak idején a Frigyes Főherceg (ma: Suché mýto - Szárazvám) ${ }^{1331}$ és a Konvent utcák (ma: Konventná ulica) egybetorkollásánál, a Grassalkovich Palotával (ma Prezidentský palác - Elnöki Palota) szemben állt. ${ }^{1332}$ A kapu közelében állhatott a vámház, amiről az utca és a kapu a nevét kapta - a vámszedés pedig természetszerüleg a város külső védvonalának kiépülésével tolódhatott át ide valamikor a 14. század végén, a 15. század elején.

\footnotetext{
1322 Vagyis nem a későbbi Szárazvám-kapunál. Vö. Ortvay, Pozsony 1898. 386., és Ortvay, T.: Stadt Preßburg 139-141.

${ }^{1323}$ A település az alsó-ausztriai, Morva-parti Marchegg-gel azonosítható.

1324 1360. június 13.: tributi in porta Posoniensi qua porta sancti Michaelis vocitatur versus Marhek wlgariter Zarrazwam teutonice vero Duermauth vocati - DF 207 269. Újkori másolata: DF 238782.

1325 1349. június 2.: item tributum seu telonium porte civitatis nostre Posoniensis predicte a parte ecclesie sancti Mychaelis archangeli existentis quod wlgo dywer vocatur - DL 4051.

1326 Ortvay, T.: Stadt Preßburg 140.

${ }^{1327}$ DL 4051. A király a vámadományt 1365-ben Jakab fiainak, Istvánnak és Pálnak is megerősítette. DL 4052.

${ }^{1328}$ DF 238782.

${ }^{1329}$ DF 238800.

${ }^{1330}$ DF 238840.

${ }^{1331}$ Legrégebbi neve 1439-ből: Sand Michelsgassen in Newsiedel. (1879-től Szárazvámkapu utca, majd 1883-tól egy ideig Frigyes Föherceg út.) Ortvay T.: Pozsony város utcái 122., 124.

1332 Ortvay, T.: Stadt Preßburg 139-141.
} 
A városban a korszakban a két egyházi intézményen - illetve Jakab bírón és családján kívül a város és a király is szerepel vámbirtokosként. 1378-ban egy királyi oklevélből megtudjuk, hogy I. Lajos Szegi Mihály útján visszavette pozsonyi (in civitate nostra Posoniensi) és csallóközi vámjait Pozsonytól, ${ }^{133}$ mivel a város nem fizette ki értük a királynak a korábban meghatározott összeget. ${ }^{1334}$ Az irat alapján nehéz megállapítani, milyen keretek között rendelkeztek a pozsonyiak az említett vámokkal - elképzelhető, hogy a város megpróbálta „kivásárolni” a király részesedését a pozsonyi (és a csallóközi) vámokból, vagy ami talán valószínübb - bérlet vagy zálog formájában a saját kezelésébe vette azokat.

A vödrici és a csallói átkelők révvámrészeinek Lajos-kori birtokosaiként (üzemeltetőjeként?) folyamatosan feltüntek helyi polgárok is. Király János véleménye szerint a pilisi monostor vámharmadai kerülhettek a „zilált anyagi viszonyok közt lévő” apátságnak adott kölcsönök fedezetének zálogaként magánszemélyek kezébe. ${ }^{1335}$ „Tény az - írja -, hogy az előttünk így okmányilag ismert magán tulajdona a révjognak jellemzőleg 1361-től eltelt 10 év után, 1371-ben kezdődik, tehát Frater Henricusnak a vepriczi víztorony iránt Jakab, pozsonyi bíróval és ennek Miklós fiával megkötött haszonbéri szerződésének keletkezése után”. 1336 1361-ben, amikor Henrik pilisi apát Jakab bírónak és Miklósnak, Jakab fiának életük végéig bérbe adta a pozsonyi szárazvámból neki járó vámrészt, a bérlőket a nagy dunai rév melletti víztornya felújítására kötelezte, mivel a helyreállításra az apátság saját erejéből képtelen volt (quam nostris sumptibus et expensis nequivimus reparare). ${ }^{1337}$ Mindazonáltal már 1344-ből is adatolható magánszemély, aki pozsonyi révrészről rendelkezett: ekkor a pozsonyi Kunigunda asszony, Fehér Péter özvegye a város melletti Vödric falunál működő nagy-dunai révben bírt részét adta el sógorának egy szőlővel együtt 36 talentumért. ${ }^{1338} \mathrm{~A}$ pozsonyi káptalan előtt 1345-ben Weisz Péter néhai pozsonyi polgár fratere, Bálint özvegye, Margit 30 talentum bécsi dénárért adott el Kcheser Bertalan helyi polgárnak 1 teljes részt a „pozsonyi rév” 12 magistralis részéből (unam integram partem ex duodecim (12) partibus magistralibus passagii seu navigii portus in Posonio). Az adásvételt 5 jelenlévő révmester

\footnotetext{
1333 ideo nos ipsa tributa a vobis duximus auferenda eadem pro nostra maiestate reservantes mandantes vestre fidelitati quatenus statim visis presentibus prefata tributa nostra manibus magistri Michaelis de Zeg aule reginalis iuvenis simulcum universis eorum pertinenciis resignetis et statuatis volumus insuper ut pecuniam prefatorum tributorum per vos non solutam cum illis literalibus instrumentis quibus ipsa tributa hactenus conservastis huc nostre maiestatis quantocinus poteritis apportatis et aliud non facturi - DF 238965.

${ }^{1334}$ notificamus vobis quod licet nos tributa nostra in civitate nostra posoniensi ac in Challochuz habita pro certa quantitate pecunie vobis perpetuo duxerimus assignandum tamen quia vos pecuniam qua racione dictorum tributorum nostrorum nobis tenemini in termino ad hoc deputato nobis non persoluistis - DF 238965.

1335 Király J.: Pozsonyi vám- és révjog 17-18.

${ }^{1336}$ Király J.: Pozsonyi vám- és révjog 17.

${ }^{1337}$ DF 238800.

1338 partem seu porcionem suam in navigio seu in portu circa domum [...] portus videlicet Posoniensi - Str. III. 542. (Anjou-oklt. XXVIII. 460. sz.).
} 
(magistri seu naute dicti portus), Márk, Fábián fia Reyhard, Cristan, István és Schreyner Miklós is jóváhagyta. ${ }^{1339}$ 1356-ban Vogl Henrik pozsonyi polgár és felesége, Erzsébet végrendeletükben misealapítványt tettek a városi Szent Márton-egyház plébánosa számára évenként 15 font bécsi dénár kiutalásával. A pénzt a plébános évi három meghatározott időpontban, 5 fontonként kapta meg. Az első, április 24-én esedékes részlet(ek) 5 fontjából 3at a végrendelkezők vödrici révrészéből (de portu navigii in Wedricz) kellett folyósítani. ${ }^{1340}$ 1371-ben a néhai Bertalan pozsonyi polgár felesége, Erzsébet a vödrici bíró és István, Reurler, Eberlinus, Vynnagul, Stephul és Teudul vödrici révmester (magister nautarum de dicta vidricia), jóváhagyásával két örökjogon bírt vödrici révrésze egyikét - vámjával együtt - 46 dénárfontért Adee Slaymkauf ${ }^{1341}$ pozsonyi polgárnak adta el. ${ }^{1342}$ 1374-ben Urmár György fia, Miklós a kis dunai (csallói) rév 1/12 részét testálta Mihály fia Jakabra. ${ }^{1343} \mathrm{~A}$ következő évben (1375) Hans Poll pozsonyi polgár végrendeletében fiának, Andrásnak hagyta „a torony körüli révet, a pénzt, a melyet rajta bír, melyet megváltanak, s addig, míg meg nem váltják, bírja ezt”. ${ }^{1344}$ 1381-ben Puczhan Jakab hagyta a Szent Márton-plébániára egy pozsonyi révrészét (und ein tä̈l eins urvars). ${ }^{1345}$ 1382-ben egy újabb végrendeletben tünt fel a „felső rév” (csallói rév): Haydn János és felesége rendelkezett annak 1/12 részéről. ${ }^{1346}$

Pozsony a 14. század második felében harmincadhely lett: az I. Lajos által felállított ${ }^{1347}$ pozsonyi harmincadhivatal a győri (és semptei?) állomás áthelyezésével jött létre. ${ }^{1348}$ Pach Zsigmond Pál szerint a „költözésre” valamikor 1365. április 26. és 1369. október 29. között került sor. ${ }^{1349}$ A korábbi dátumot I. Lajos országos harmincadosa (tricesimator regni), Szerecsen (Jakab) mester familiárisaihoz, kiemelten Simon győri alharmincadosához (is) intézett parancsa, ${ }^{1350}$ a későbbit a király harmincadosának, Henrik budai polgárnak és pozsonyi officialisainak címzett levele adja, amely szerint a hivatalt nemrég (nuper) helyezték

\footnotetext{
1339 DF 226 763. (Anjou-oklt. XXIX. 38. sz.).

1340 DF 238 752. (Anjou-oklt. XL. 114. sz.).

${ }^{1341}$ Király János olvasata: Slaginkauf.

1342 unam partem duarum porcionum suarum in portu in dicta vidricia exigi consueto iure hereditario ipsam precise contingentium habitam cum omnibus reditibus et proventibus earundem - Lederer E.: Középkori pénzüzletek 254. (DF 238 869). Hans Pollról és végrendeletéről lásd ugyanitt 145-148.

1343 Király J.: Pozsonyi vám- és révjog 15.

1344 Auch schaff ich meinem sün Andren daz vrvar an dem Twern, daz gelt daz ich darauf han, ob man daz abloset vnd die weil daz man daz gelt nicht abloset, so sol er daz inne han - DF 238 910. Király János fordítása. Király J.: Pozsonyi vám- és révjog 15.

1345 DF 238 997. Király J.: Pozsonyi vám- és révjog 15.

${ }^{1346}$ DF 239 020. Király J.: Pozsonyi vám- és révjog 15-16.

1347 quia in illis partibus tricesimam nostram regalem in civitate nosra Posoniensi constituisse et exigi commisisse - F. IX/6. 175.

${ }^{1348}$ Vö. F. X/8. 180. A semptei harmincadra a Lajos-korból nincs adatunk.

1349 Pach Zs. P.: A harmincadvám az Anjou-korban 235.

${ }^{1350}$ F. IX/3. 489-490.
} 
Pozsonyba „korábbi és szokásos” helyéről (locus pristinus et consuetus). ${ }^{1351}$ Hogy e korábbi helyen Győr értendő, abból az iratból világos, amit 1385 augusztusában a Pozsony melletti mezőn táborozó Luxemburgi Zsigmond brandenburgi őrgróf állított ki a város bírójának és esküdtjeinek kérésére. ${ }^{1352}$ A későbbi uralkodó ekkor ígéretet tett arra, hogy a jövőben, amint hatalmában lesz, visszahelyezi Pozsonyból a harmincadot Győrbe és Semptére. ${ }^{1353}$ A vámhivatal „eltávolítása” a városból a pozsonyiak elemi érdeke volt, mivel a helyi kereskedők költségeit megnövelő (ezek árui is harmincadolás alá estek) ${ }^{1354}$ és a város élelmiszer-ellátását megnehezítő (megdrágító) ${ }^{1355}$ tricesima fizetése alóli általános felmentéssel nem rendelkeztek. A visszahelyezést illetően hiába kaptak ígéreteket, azok megvalósításából végül nem lett semmi. ${ }^{1356}$

A pozsonyi harmincad felállításának terminus post quemjét meghatározó, Szerecsen mester harmincadszedőihez intézett 1365. áprilisi királyi parancs egyetlen példánya éppen Pozsonyból ismert (a városi tanács iratai között maradt fent), ami, ha nagyon halványan is, de a helyi harmincad fennállására utalhat. A rendelkezés egyébként a kisebb élelmiszerek (kenyér, sajt, tojás, csirke) megharmincadolását tiltotta meg. ${ }^{1357} 1366$ februárjában mindenesetre már mindenképpen müködnie kellett az itteni hivatalnak, másképpen nehezen lenne értelmezhető az a kiváltság, ami a pozsnyiaknak a pozsonyi harmincad kivételével adott felmentést a Dalmáciából, főleg Zárából való áruk után fizetendő vámok alól. ${ }^{1358}$ A pozsonyi városi levéltár ennél korábbról, 1364-ből is őriz egy „gyanús”, a helyi harmincadhivatal müködését feltételező iratot: Lajos király a pozsonyiaknak kiadott, harmincadfizetés alóli mentesítő levelét eladandó élelmiszereik - „amik nélkül egy város sem tud létezni” - és saját háztartásaik szükségletére bárhonnan (de quibuslibet Regnorum partibus) a városba vitt (feltehetően import)posztót illetően. ${ }^{1359}$ (Ugyanaznap, 1364. június 11-én egyébként a soproniak is kaptak I. Lajostól egy, a pozsonyiakéval megegyező tartalmú

${ }^{1351}$ F. IX/7. 284-285.

1352 Vö. Pach Zs. P.: A harmincadvám az Anjou-korban 235-236.

1353 1385. augusztus 16.: F. X/8. 180-181.

${ }^{1354}$ Legvalószínűbben ezzel magyarázhatók a városba külföldről saját felhasználásra importált, illetve a városban értékesíteni kívánt élelmiszerek (victualia) harmincadmentesítési törekvései. Vö. 1364: DF 238821 (F. IX/3. 389-390.; 1371: DF 240 822_31 (F. IX/4. 341-342.).

1355 A pozsonyiak harmincadmentességére lásd Skorka R.: Pozsony Bécs árnyékában 304-305.

${ }^{1356}$ Pach Zs. P.: A harmincadvám az Anjou-korban 235-236.

1357 Vö. DF 238 827. (F. IX/3. 489-490.).

1358 1366. február 21.: ab omnibus rerum et mercibus maritimis cuiuscunque generis maneriei vel speciei eedem existant que de Dalmacia et specialiter de Jadra per mercatores regni nostri in ipsum regnum nostrum deferuntur et importantur nullum tributum nullaque tributaria exaccio vel tricesima per tributarios vel tricesimatores nostros exigantur excepta una tricesima quam ab ipsis rebus in Posonio persolvi et exigi iubemus ab omni tributaria et tricesimatoria exaccione et quovis alio datio perpetuo absolute habeantur penitus et exempte - DF $238835=$ DF 238 836. I. Lajos 1361. január 23-i oklevele a pozsonyiak „tengeri” áruk (res et merces maritime) után fizetendő harmincadát még Budán rendelte megfizetni. DF 238791 = DF 239015 (F. IX/7. 198-199.).

1359 1364. június 11.: F. IX/3. 389. 
kiváltságlevelet.) ${ }^{1360}$ Az eladásra szánt posztók után a tricesimát le kellett róni. Az uralkodó ugyanekkor a városiak külföldi kivitelre termelt boraira (vina eorundem quocumque exportanda) is egy évre szóló harmincadmentességet biztosított. ${ }^{1361}$ Az exportra szánt borok pontos számát a király tricesimatorának vagy a városiak erre kijelölt emberének kellett rögzítenie egészen az év leteltéig, tételes beszámolási kötelezettséggel a király felé ${ }^{1362}$ - a kért regisztrumot természetszerüleg (a pozsonyi és a soproni esetben is) helyben készíthették. 1371-ben I. Lajos elrendelte a pozsonyi harmincadszedőknek, hogy a pozsonyiak élelmezésére (pro sustentatione ciuium) Ausztriából, Csehországról és a magyar területekről a városba szállított állatokat (ökröket, teheneket, disznókat), olajat, halakat, terményeket és az egyéb élelmiszereket ne harmincadolják. A tricesimát a Pozsonyon kívülre, Ausztriába és Csehországba vitt áruk után továbbra is fizetni kellett. ${ }^{1363}$ 1374-ben a király a kiváltságot - a pozsonyi polgárokat illetően - kiterjesztette: már nem csak élelmiszert, de bármilyen árut harmincadmentesen importálhattak és rakhattak le a városban, harmincaddal csak az exportjuk után tartoztak. ${ }^{1364}$

A pozsonyi harmincadot - legalábbis a szárazföldi úton közlekedő kereskedőktől - egy 1375-ös adat szerint a „Szárazvámnál” (in Duermauth) szedték. ${ }^{1365}$ A pozsonyi káptalan 1375. évi oklevele szerint a városfalon kívül élők a pozsonyi városvezetésnek arról számoltak be, hogy I. Lajos tricesimatora, Miklós deák a körükben (in medio eorum) a Szárazvámnál harmincadoló familiarisai július 21-én felgyújtották a saját házukat (a tetthelyről aztán állítólag „ágyasaikkal, az összes nép szeme láttára menekültek el”), a tovább terjedő tűz pedig elpusztította a külvárosiak terményeit, szénáját és házait. ${ }^{1366} 1373$. évi végrendeletéből név

\footnotetext{
${ }^{1360}$ Házi I/1.130-131.

${ }^{1361}$ F. IX/3. 389-390. A behozatal mellett az országból kivitt áruk megharmincadolásának gyakorlatát Pozsony esetében az uralkodó 1371-ben és 1374-ben is „,szokásosnak” minősítette. Pach Zs. P.: A harmincadvám az Anjou-korban 267. 189. j.

1362 volumus, quod tricesimator noster, vel homo suus, per ipsum ad hoc deputatus, huiusmodi vinorum exportandorum numerum certum habeat in Registro usque completionem Anni prenotati, et seriatim sub certo numero nostrae referre teneatur Maiestati - F. IX/3. 390.

1363 1371: DF 240 822_31 (F. IX/4. 341-342.).

1364 ut a modo in antea tamdiu quousque ipsam tricesimam inibi servaverimus prefati cives et communitas de Posonio de nullis rebus et bonis ipsorum venalibus mercimonialibus victualibus et ceteris cuiuscumque generis existant et quovis nomine vocitentur undecumque et de quibuscumque partibus seu locis per ipsos vel quemquam eorum in ipsam civitatem deferendis et inibi deponendis aliqua tricesima vel datium aliquod racione ipsius tricesime dare et solvere teneantur nec ad id sint astricti per quempiam modo aliquali res autem et bona omnia que exinde vendicionis mercimonie per ipsos exportantur tricesimentur ut est moris nec volumus in eo ipsos custodire - DF 238901 (F. IX/6. 175-176.).

1365 1375. július 26.: familiares magistri Nicolai litterati tricesimatoris domini nostri regis in ipsorum medio in duermauth tricesimas exigentes - DF 238925.

1366 DF 238925.
} 
szerint is ismerünk egy pozsonyi harmincadszedőt: a néhai Hertlin pozsonyi bíró lánya, Katalin fia, István fia „Harmincados” (dictus tricesimator) Jánost. ${ }^{1367}$

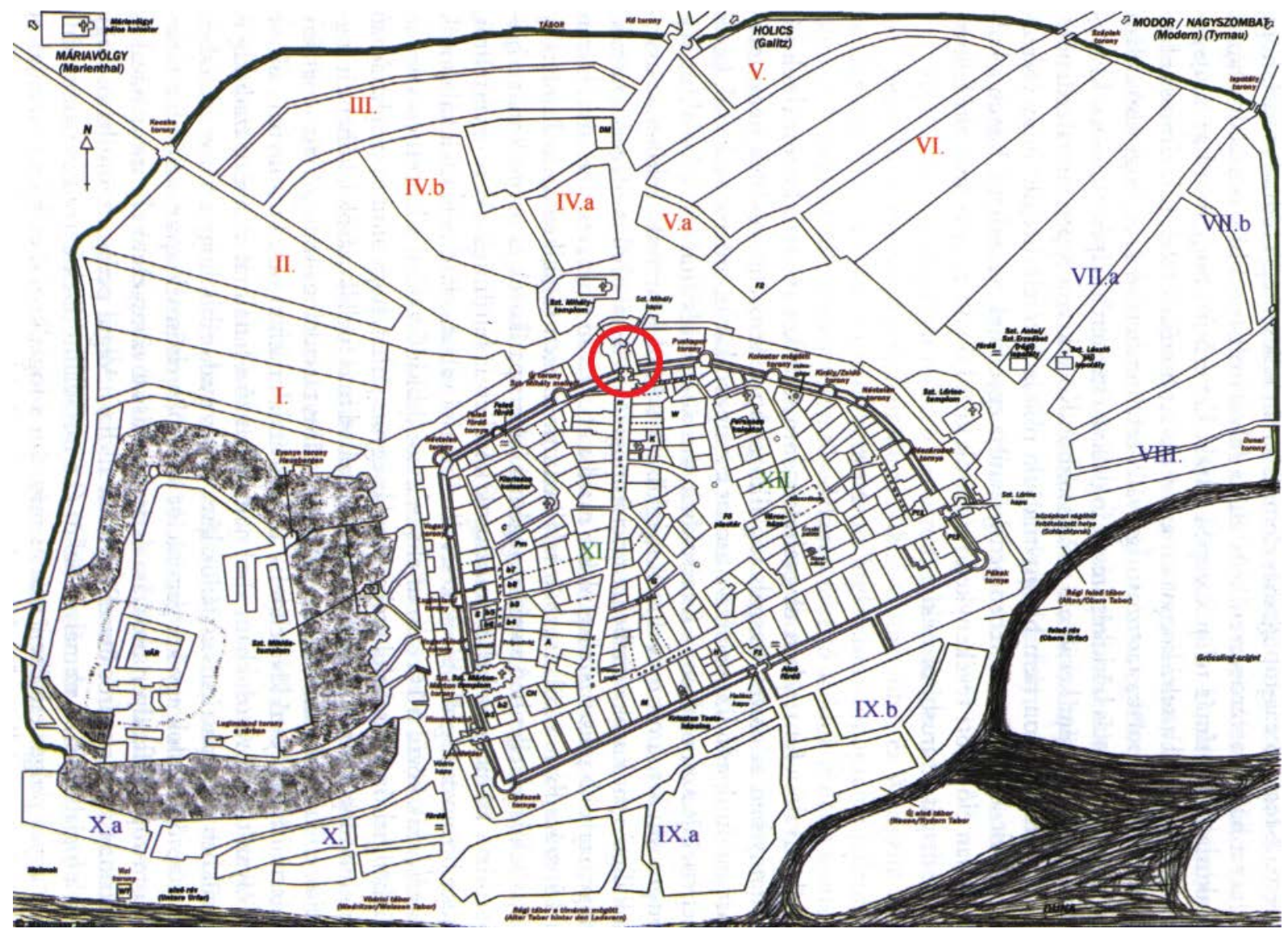

A Szent Mihály-kapu, a Dürrmaut szedésének helye a Lajos-korban (bekarikázva) (térkép: Majorossy J.: A foglalkozás topográfiája 122.) $)^{1368}$

A pozsonyiak III. Andrástól kapott, 1291. december 2-án kelt városprivilégiumában rendelte el az uralkodó: az országban áruikkal vagy szekereikkel kereskedés céljából közlekedő pozsonyi hospesek sem áruik, sem az árukkal vagy anélkül közlekedő lovaik és embereik után nem tartoztak vámot fizetni. Az uralkodó a vámszedőhelyek közül kiemelte a pozsonyi (Duna-)révet Hainburg felé, a Csalló révét, Szőlőst, a Morva folyó átkelőjét és a Pozsony megyei vámokat. ${ }^{1369}$ A vonatkozó történeti kutatás - részben Lajos-kori adatok

1367 DF 238899.

1368 Kovács V.: Bártfa, Óvár, Pozsony 126.

1369 Statuimus insuper, ut cum iidem hospites no[stri cu]m suis mercibus vel cu[rri]b[us] ubicun[que in regno nostro causa mercandi voluerint proficiasci, nec de mercibus nec de equis vel personis eorum] cum mercibus [et sine] mercibus euntibus et redeuntibus nullum tributum nullamque exaccionem, videlicet in portu Posonien[si 
alapján - kétféleképpen interpretálta a város 1291. évi kiváltságlevelét: a kutatók egy része szerint a városprivilégium a polgároknak csak Pozsony megyében garantált vámmentességet, ${ }^{1370}$ míg egy másik részük úgy vélte, hogy az egész országban. ${ }^{1371} \mathrm{Az}$ első álláspontot elfogadók egy része pedig a pozsonyiak országos vámmentességével csak 1328tól számolt. ${ }^{1372}$ Arra, hogy ne országos, hanem területileg korlátozott felmentésként értelmezzék a rendelkezést, főleg a kiváltságlevél „,nevesített” vámokat elősoroló szövegrésze adott alapot, ami így csak a felsorolt vámhelyeken lenne érvényesíthető. A szöveg ugyanakkor kétségtelenül jelzi, hogy a mentesség érvénye a bárhol máshol lévő vámszedőhelyekre is kiterjed. Ezt megerősíti az is, hogy a király néhány nappal később, december 6-án elrendelte az ország összes vámszedőjének, hogy a pozsonyi hospesektől akik szent elődei (a sanctis progenitoribus nostris) és az ő jóvoltából annak a szabadságnak örvendenek, hogy a vámhelyeken nem tartoznak vámot adni - akár az országon kívülre vagy máshová, akár visszafelé tartanak (tam in eundo extra regnum nostrum, vel alias, quam in veniendo), ne szedjenek vámot. ${ }^{1373}$ A pozsonyi kereskedők tehát városi kiváltságlevelük révén országos vámmentességhez jutottak, noha a gyakorlatban kereskedelmi tevékenységük a 13. század végén az országos mérvünél jóval korlátozottabb lehetett, erre utalnak legalábbis az 1291. decemberi oklevelek Pozsony megyével, a külföldre vezető utakkal és a határkapukban szedett vámokkal kapcsolatos kiemelései, amelyek leginkább a pozsonyiak külkereskedelemben való részvételét hangsúlyozzák. ${ }^{1374}$ A kiváltságlevélben említett átkelőhelyek egy része elsősorban Alsó-Ausztria felé irányuló kereskedelmi forgalmat feltételez, mivel a pilisi apát víztornya mellett müködő ${ }^{1375}$ pozsonyi Duna-réven átkelve, a folyó jobb partján haladva Hainburg érintésével Bécsbe lehetett eljutni, és ugyanide tartott a Morva folyó dévényi átkelőjén keresztül a Duna bal partján, a Morvamezőn át vivő

\footnotetext{
versus Haimburgam,] in portu [Challow, in Zeuleus, in transitu fluvii Morawa et in aliis locis quibuscunque in comitatu Posoniensi] et alias, [ubi tributum exigi] consuevit, solvere teneantur - Juck 75. (Reg. Arp. 3837. sz.). Juck a hiányzó, az eredeti oklevélben olvashatatlan részeket I. Károly 1313. évi megerősítése alapján egészítette ki. Juck 77.

${ }^{1370}$ Vö. Kováts F.: Dunai hajózás 436-437., Fügedi E.: Középkori magyar városprivilégiumok 39-40.; Skorka R.: Zálogszerződések 433-434. Fügedi, bár a kérdésben elfogadni látszik Kováts véleményét, megjegyzi, hogy „a kiváltságlevél homályos fogalmazásából országos vámmentesség is kiolvasható”. Utal arra is, hogy az 1496os zsitvatôi vámperben is az 1291. évi oklevél alapján ismerték el a pozsonyiak mentességét a Komárom megyei zsitvatöi vám fizetése alól. Fügedi E.: Középkori magyar városprivilégiumok 40.

1371 Vö. Szende K.: Otthon a városban 35.; Weisz B.: Vámok és vámszedés 318.

1372 Vö. Kováts F.: Dunai hajózás 437. Véleményét Fügedi is átveszi. Fügedi E.: Középkori magyar városprivilégiumok 40.

${ }^{1373}$ F. VI/2. 299. (Reg. Arp. 3840. sz.).

1374 Vö. Weisz B.: Vámok és vámszedés 43., 318.

1375 Weisz B.: Vámok és vámszedés 317.
} 
szárazföldi út is. ${ }^{1376} \mathrm{~A}$ (pozsony)szőlősi úton Cseklészen át Nagyszombat felé közlekedhettek a pozsonyiak, a Csalló réve pedig a Csallóközbe való átkelést tette lehetővé. ${ }^{1377}$

A pozsonyi hospesek országos vámmentességüket is megalapozó városi kiváltságlevelüket először 1313-ban íratták át I. Károly királlyal, ${ }^{1378}$ majd - miután az uralkodó 1323-ban új pecsétet kezdett használni ${ }^{1379}$ - ezt az átírást 1323. március 31-én is megerősíttették vele. ${ }^{1380}$ Mindez pedig azt jelentette, hogy az országos vámmentesség Károly korában is érvényben maradt. Mindenképpen meg kell jegyezni, hogy I. Károly 1313-ban nem a pozsonyiak eredeti oklevele alapján erősítette meg kiváltságaikat, hanem Tamás esztergomi érsek (1305/13061321) ${ }^{1381}$ saját pecsétjével ellátott átirata alapján ${ }^{1382}$ - egyébként érdekes módon a későbbiekben sem tudunk olyan esetről, amikor a pozsonyiak közvetlenül az 1291. évi oklevél átírását kérték volna, holott az eredeti kiváltságlevél máig megvan. ${ }^{1383}$ Szövege viszont több helyen, például a vámmentességi kiváltságnál is erősen romlott, olvashatatlan, ami azt jelenti, hogy a teljes privilégium - I. Károly 1313. évi oklevelén keresztül - csak az érsek átírásából ismert.

Kováts Ferenc szerint a pozsonyiak 1291-ben csak a Pozsony megyei vámok fizetése alól kaptak felmentést, országos vámmentességgel csak I. Károly jóvoltából, 1328 óta rendelkeztek. ${ }^{1384}$ Érvelésének alátámasztására I. (Nagy) Lajos egyik 1357. évi oklevelére hivatkozott, „,a melyben a király határozottan kimondja, hogy a pozsonyi polgárság általános, az egész ország területére kiterjedő vámmentességét Róbert Károlytól kapta", ${ }^{1385}$ továbbá I. Károly két, 1328-ban kelt parancslevelét hozta fel véleményének alátámasztására. ${ }^{1386}$

I. Károly 1328. november 8-án a nagyszombatiaknak, majd november 13-án rajtuk kívül Vörös Ábrahám fiainak is megtiltotta, hogy a pozsonyiaktól akármilyen ürüggyel (nulla penitus racione) vámot szedjenek. Rendelkezését mindkét esetben azzal indokolta, hogy a

\footnotetext{
1376 Skorka R.: Pozsony Bécs árnyékában. 301-302. Kováts Ferenc szerint Pozsonyt a Morva folyó átkelője a Lamacs-Beszterce-Stomfa-Malacka útvonalon keresztül Morvaországgal kötötte össze. Kováts F.: Dunai hajózás 435.

1377 Kováts F.: Dunai hajózás 435.

1378 DF 238 656. (F. X/7. 762-763.). (Anjou-oklt. III. 644. sz.).

1379 Gárdonyi A.: I. Károly nagypecsétjei 36.

${ }^{1380} \mathrm{Az}$ 1323. évi átírás során a kiváltságok sorát a király kiegészítette azzal, hogy a pozsonyiak nem kötelesek elfogadni az új királyi pénzt, ugyanakkor az ezzel kapcsolatos adó, a ferto (collectam fertonis) fizetése alól is mentességet kaptak. DF 238 664. (F. X/7. 762-765.). (Anjou-oklt. VII. 91. sz.). Az oklevelet átírta a pozsonyi káptalan 1347. ápr. 9-én. (DF 238 715.) (Anjou-oklt. XXXI. 300. sz.).

1381 Engel P.: Archontológia I. 63.

1382 Vö. DF 238 656. (F. X/7. 762-763.). (Anjou-oklt. III. 644. sz.).

1383 Vö. DF 238636.

${ }^{1384}$ Kováts Ferenc érvelése során figyelmen kívül hagyta az 1291. december 2-i kiváltságlevél et alias kitételét, ugyanakkor, bár ismerte, az említett [1291.] december 6-i - a feltevésének szintén ellentmondó - oklevelet sem vette tekintetbe. Kováts F.: Dunai hajózás 436-437.

1385 Kováts F.: Dunai hajózás 437.

${ }^{1386}$ Kováts F.: Dunai hajózás 435-437.
} 
pozsonyi polgárok és hospesek sehol az országban (nusquam in regno nostro) nem tartoznak vámot fizetni, ${ }^{1387}$ amint erről az elődeitől elnyert és általa is megerősített szabadságukról privilegiális oklevelekből értesült (in ... litteris privilegialibus vidimus). ${ }^{1388}$ A pozsonyiak vámmentességi kiváltságát a nagyszombatiak a (székes)fehérvári káptalantól bérelt nagyszombati vámhelyükön, Vörös Ábrahám fiai pedig Cseklészen sérthették meg. ${ }^{1389} \mathrm{Az}$ eset kapcsán nem elhanyagolható a körülmény, hogy I. Károly a november 13-án kelt oklevele tanúsága szerint azzal együtt is elismerte a pozsonyiak vámmentességét Vörös Ábrahám fia András és testvéreinek vámhelyén, hogy utóbbiak olyan privilégium birtokában voltak, aminek köszönhetően különbség nélkül (sine differencia aliquali) mindenkitől vámot szedhettek. ${ }^{1390}$

Bár a királyi parancslevelekben leírtak, a korábbi királyoktól nyert országos vámmentességre vonatkozó utalások önmagukban cáfolnák azokat a véleményeket, amelyek 1291-től csak területileg korlátozott vámmenteséggel számolnak, a király 1328. július 4-én, Visegrádon kiadott oklevele, amelyben biztosította a pozsonyiakat az országos vámmentességről, első ránézésre már-már alátámasztani látszik, hogy az 1291. évi területileg korlátozott volt. ${ }^{1391}$ Sőt, úgy tünhet, ez lehetett az a privilégium, amit a pozsonyiak az év novemberében bemutattak a királynak a cseklészi és nagyszombati vámszedés körüli jogvitában. ${ }^{1392}$ A kérdésben a tisztánlátást nehezíti, hogy a privilégium csak tartalmi átírásban maradt ránk Mátyás király 1464. május 27-i oklevelében. ${ }^{1393}$ Mátyás a pozsonyiak kérésére számos gazdasági jellegű, nagyrészt mégis a polgárok vám- és harmincadmentességét érintő kiváltságait írta át és erősítette meg. Az átírás - a pozsonyiak kérésének megfelelően - nem érintette a bemutatott, formájukat tekintve vegyes oklevelek teljes szövegét, csak a szabadságokat és jogokat (libertates et iura) tartalmazó cikkelyeket (articulos), ezeknek azonban szó szerinti átírásával számolhatunk. ${ }^{1394}$ Mátyás oklevelének tartalmát 1493. február 10-én II. Ulászló király, elismerve egyúttal a pozsonyiak országos vámmentességét személyük, továbbá dolgaik és javaik tekintetében (tam de personis propriis, quam de

\footnotetext{
${ }^{1387}$ libertas dictorum civium et hospitum nostrorum per priores reges data et per nos confirmata id requirat, quod iidem nusquam in regno nostro tributum solvere teneantur - Juck 114. (Anjou-oklt. XII. 462. sz.); quod quia fideles cives nostros de Posonio in nostris et predecessorum nostrorum quondam illustrium regum Hungarie litteris privilegialibus vidimus et pro certo cognovimus hanc libertatis prerogativam habere et pro meritis obtinuisse quod iidem aut aliquis ipsorum nusquam in regno nostro dare et solvere tributa teneantur - Juck 113. Júl. 4-i napi kelettel. (Anjou-oklt. XII. 466. sz.).

1388 Juck 113. (Anjou-oklt. XII. 466. sz.).

1389 Weisz B.: Vámok és vámszedés 384., 110.

${ }^{1390}$ Weisz B.: Vámok és vámszedés 110.

1391 DF 240 491. (Anjou-oklt. XII. 351. sz.).

1392 Anjou-oklt. XII. 247. (462. sz.)., 249. (466. sz.).

1393 DF 240491.

1394 DF 240491.
} 
omnibus rebus et bonis suis), megerősítette, ${ }^{1395}$ majd ugyanő 1498. július $15-\mathrm{i}^{1396}$ oklevelével a pozsonyiak egy sor másik, szintén kiváltságaikat tartalmazó oklevelével együtt átírta és újfent megerősítette. ${ }^{1397} \mathrm{Az} 1464$. évi és az 1493. évi okleveleket mutatták be a pozsonyiak az 1495-1496 folyamán zajló zsitvatői vámperben, amelyben a város Budával, Pesttel, Fehérvárral, Esztergommal, Visegráddal, Komárommal és a budafelhévízi népekkel közösen lépett fel sikeresen a nyitrai egyház zsitvatői vámszedési joga ellen. ${ }^{1398}$ Visszatérve az 1328. július 4-i visegrádi oklevélre, úgy véljük, annak a tartalmi átírás által megőrzött articulusa alapján, ${ }^{1399}$ inkább egy királyi ítéletlevélre lehet gondolnunk, mintsem a szóba jöhető másik eshetőségre, egy kiváltságlevél megerősítésére, a szövegrész ugyanis formailag sokkal inkább tünik egy bírói ítélet, mint egy átírás/megerősítés indoklásának. A szövegben egyébként szó sincs megerősítésről. ${ }^{1400}$ Véleményünk szerint a július 4-i dokumentum a pozsonyiak által Vörös Ábrahám fiai és/vagy a nagyszombatiak ellen indított per ítéletlevele lehet, amit az oklevél és a november eleji királyi parancslevelek kiadásának időbeli közelségén kívül az is valószínűsít, hogy az 1328. november 13-i mandátumban szóról szóra megtalálható a július 4i iratból ismert articulus. A jogvitában az uralkodó a pozsonyiak vámmentességét az általa is megerősített városi kiváltságlevél alapján ismerhette el, a novemberi mandátumokat pedig az ítéletlevél alapján a polgárok eszközölhették ki, feltehetően kiváltságuk gyakorlati érvényesítését elősegítendő.

Nagy Lajos fent említett, 1357. január 25-én, Visegrádon kelt oklevele, amit Kováts Ferenc ugyancsak annak alátámasztására hoz fel, hogy a pozsonyiak I. Károlytól kapták országos vámmentességüket, a pozsonyiak és az esztergomi káptalan közt az esztergomi vám fizetésének ügyében támadt jogvitáról tudósít. ${ }^{1401} \mathrm{Az}$ 1357. január 19-én eszközölt, meglehetősen szűkszavúan ismertetett okleveles bizonyítás során a pozsonyi polgárok vámmentességük igazolására I. Károly király középső, a Havasalföldön elveszett pecsétjével megerősített privilégiumát mutatták be, ami tartalmazta korábbi és régebbi pecsétjével ellátott

\footnotetext{
1395 Neumann T.: Székesfehérvár 83-84.

1396 primo idus iulii.

1397 DF 240822.

1398 1496. jún. 15.: Neumann T.: Székesfehérvár 55-90., kül. 81-84.

1399 continetur iste articulus quod quia fideles cives nostros de Posonio in nostris et predecessorum nostrorum condam illustrium regum Hungarie litteris privilegialibus vidimus et pro certo cognovimus hanc libertatis prerogativam habere et pro meritis obtinuisse quod iidem aut aliquis ipsorum nusquam in regno nostro dare et solvere tributa teneantur - DF 240491.

1400 DF 240 491. Vö. Anjou-oklt. XII. 179. (351. sz.).

${ }^{1401}$ F. IX/2. 568-570. Vö. Kováts F.: Dunai hajózás 437.
} 
privilégiumát. ${ }^{1402}$ Ez alapján I. Lajos elismerte, hogy a pozsonyiak Károly király kegyéből a vámok fizetése alól mentesek (dicti cives de Posonio ex gracia ... Karoli regis ... ipsis facta a solucione tributorum exempti habeantur). ${ }^{1403}$ A pozsonyiak által bemutatott, a vámmentességi kiváltság Árpád-kori adományozását egy szóval sem említő privilégiumról leírtakat olvasva óhatatlanul felmerül a kérdés, milyen oklevélről lehet szó. Habár nem zárható ki, sőt a magunk részéről hajlunk arra, hogy itt tulajdonképpen az 1291. évi városi kiváltságlevél I. Károly 1313. évi megerősítését is magában foglaló, 1323-ban kelt átíró okleveléről beszélhetünk - miután az utóbbi oklevelet I. Lajos Jakab pozsonyi bíró és három esküdt: Jakab fia János, Reyhard fia Jakab és „Bruno” István kérésére 1357. január 18-án, tehát éppen az okleveles bizonyítást megelőző nap írta át és erősítette meg ${ }^{1404}$, más eshetőséggel is számolnunk kell.

Lajos-kori adatok alapján ugyanis úgy tünik, a pozsonyiak vámmentessége I. Károly idején nem kizárólag a városi kiváltságlevélen alapult. Erzsébet anyakirályné 1350. január 8-án az ország vámbirtokosait, valamint ezek száraz- és dunai vízivámszedőit (tributariis tam in terra quam super fluvio Danubii constitutis) arra utasította, hogy a pozsonyiaktól (predicti cives et hospites nostri), amikor borokat és élelmiszereket szállítanak Budára vagy másfelé (vel alias in regno nostro), ne szedjenek vámot. ${ }^{1405}$ Lajos 1356. január 26-án kiadott parancslevele a pozsonyi polgárok és hospesek Visegrádig (usque Vissegrad) hajókon vagy szekereken vitt borok, gabona, zab és más élelmiszerek (de vinis, frugibus, avenis, ac aliis victualibus ipsorum) utáni vámmentességét említi, ${ }^{1406}$ míg ugyancsak a király március 6-i oklevelei a Pozsony városából Visegrád felé (versus Vyssegrad) szállított borokét és gabonáét (de vinis et frugibus eorum). ${ }^{1407}$ Mivel a dunai, illetve Duna menti, vámmentes bor- és élelmiszerszállítást említő kitétel nem szerepel a városi kiváltságlevél vonatkozó részében, annak forrását valahol máshol kell keresnünk. E tekintetben az imént említett, 1356. január 26-i királyi parancslevél vezet nyomra, ami leírja, hogy a pozsonyiak szóban forgó kiváltságát I. Károly privilegiális oklevele biztosította (exhibuit nobis quasdam litteras privilegiales ... Karoli regis ... in

\footnotetext{
${ }^{1402}$ vbi etiam dicti ciues Posonien. priuilegium Domini Caroli regis [...] sub mediocri sigillo eiusdem, in partibus transalpinis casu deperdito, confectum, tenorem priuilegii sui, priori et antiquiori sigillo ipsis consignati, confirmatiue continens, nobis praesentarunt - F. IX/2. 569.

${ }^{1403}$ DF 237 234. (F. IX/2. 569-570.).

${ }^{1404}$ DF 238 757. A kérdéses Károly-privilégiumot Lajos néhány évvel korábban egyszer már megerősítette. Vö. 1352. jan. 30.: DF 238737.

${ }^{1405}$ DF 238 727. (F. IX/7. 100.). Anjou-oklt. XXXIV. 9. sz.

${ }^{1406}$ F. IX/7. 146. (Anjou-oklt. XL. 57. sz.).

1407 1356. márc. 6.: F. IX/7. 144-145. (DF 238 753.) (Anjou-oklt. XL. 111. sz.); 1356. márc. 6.: Kováts F.: Dunai hajózás 445. (DF 238 751.) (Anjou-oklt. XL. 112. sz.).
} 
quibus inter cetera expresse vidimus contineri). ${ }^{1408}$ Minden bizonnyal a január 26-án kelt oklevél alapján bocsátotta ki a király 1366. január 6-i mandátumát, szövegük ugyanis - a másolásnak betudható eltérésektől eltekintve - teljesen megegyezik. ${ }^{1409}$ Szintén Károly előbbi privilegiális oklevelére (quarundam litterarum ... Karoli regis) - amelyet tehát nem tartunk azonosnak sem a városprivilégiumot 1313-ban, illeve 1323-ban átíró diplomákkal, sem a király 1328. július 4-i oklevelével ${ }^{1410}$ - hivatkozhattak a pozsonyiak 1357-ben, Wolfurti Konrád óvári comes ellenében. Ugyanitt tudomást szerzünk arról, hogy apja oklevelét I. Lajos is megerősítette (nostrarum confirmatoriarum). ${ }^{1411}$ A megerősítés tényére, vagy legalábbis a kiváltság érvényesülésére utalnak az 1356. március 6-i királyi parancslevelek, ${ }^{1412}$ sőt már Erzsébet anyakirályné említett, 1350. január 8-án kiadott oklevele is. ${ }^{1413}$

I. Károly említett okleveléről Lajos-kori említései alapján sajnálatos módon csupán annyi állítható viszonylagos bizonyossággal, ${ }^{1414}$ hogy létezett. Kibocsátásának közelebbi idejét nem ismerjük, ahogy az sem egyértelmü, miért volt szüksége a pozsonyiaknak egy újabb vámmentességet biztosító oklevélre, vagyis miben volt más ez a kiváltság, mint az 1291. évi városi kiváltságlevélben leírtak. A felmerülő kérdések megválaszolását alaposan megnehezíti, hogy az oklevél - és feltételezett Lajos-kori megerősítése - eredetije nem ismert, teljes szövege nem maradt ránk, a tartalmáról szóló tudósítások információi pedig inkább ellentmondani látszanak, mintsem egymást kiegészíteni. A kiváltság alighanem a pozsonyiak borára és élelmiszereire volt érvényes, a polgárok szerint az eladásra szántakra és a más céllal szállítottakra is (ad vendendum, vel pro alia causa deferendis) ${ }^{1415}$. Habár néhányszor, amikor a szabadságról szintén a pozsonyiak tolmácsolásában értesülünk, arról hallunk, hogy a

\footnotetext{
${ }^{1408}$ quod iidem cives et hospites nostri de vinis frugibus et avenis ac aliis victualibus ipsorum tam in navibus quam in curribus usque Wyssegrad deferendis tributum vel aliquam tributariam exaccionem nullas in regno nostro dare et persolvere teneantur sed a premissa exaccione tributi absoluti et exempti habeantur - DF 238749 . $=238$ 750. (F. IX/7. 146.) (Anjou-oklt. XL. 57. sz.).

${ }^{1409}$ Kováts F.: Dunai hajózás 460. (DF 238831 = DF 238 832).

${ }^{1410}$ Vö. Anjou-oklt. XL. 79. (57. sz.).

1411 mandamus quatenus a modo et deinceps a prefatis civibus et hospitibus nostris necnon [rebus] et bonis [eorundem] prout in eorum instrumentis videbitis contineri nullum tributum nullamque tributariam exaccionem petere recipere vel exigere vel exigi facere quovis modo presumpmatis - DF 238 762. (Kováts F.: Dunai hajózás 446.) (szept. 21-i napi kelettel).

1412 cum nos fideles cives et hospites nostros Posonienses iuxta formam libertatum eorundem per dominum Karolum regem patrem nostrum et eciam per nos nunc eisdem consessarum - DF 238 753. (F. IX/7. 144.), Cum nos fideles Ciues et hospites nostros Posonienses confinia regni nostri tuentes iuxta formam libertatum eorumdem, per Illustrem principem quondam dominum Karolum olym Inclitum Regem Hungarum genitorem nostrum Karissimum, et eciam per nos efficacissimorum literalium Instrumentorum, ex vigore ipsis graciose concessarum - Kováts F.: Dunai hajózás 445.

1413 cum primum dominus Karolus quondam illustris rex Hungarie dominus et consors noster pie memorie et tandem dominus rex filius noster et nos iudici iuratis civibus et universis hospitibus nostris de civitate nostra Posoniensi de gracia speciali annuerimus - DF 238 727. (F. IX/7. 100.).

${ }^{1414}$ A következökben azokat az okleveles adatokat vonjuk ide, ahol a pozsonyiak dunai vámok alóli mentessége, illetve boraik, élelmiszereik vámmentes szállítása kerül elő.

1415 1357. dec. 6.: Kováts F.: Dunai hajózás 447.
} 
polgárok a Dunán, illetve Visegrádig a dolgaik és javaik után fizetendő vám alól (a solucione tributi super Danobio persolvendi de rebus et bonis ipsorum) mentesek. ${ }^{1416}$ A szabadság hangsúlyosan a dunai, valamint Duna menti, szekéren és hajón történő szállításra vonatkozhatott, ${ }^{1417}$ néhol azonban egyidejűleg valamilyen formában a „vagy máshol az országban” kitétel is szerepel, ${ }^{1418}$ ami bizonytalanságokat okoz a vámmentesség területi hatókörének megállapítása körül; ráadásul, bár az oklevelek legnagyobb része a Pozsonyból Visegrádra irányuló élelmiszer- és borszállítás vámmentességét emlegeti, egy esetben a Budára, egy másikban pedig a királyi udvar felé történő szállítás kerül elő. ${ }^{1419}$

Az elszórt utalások véleményünk szerint arra mutatnak, hogy I. Károlytól a pozsonyiak olyan területileg korlátozottnak mondható, a dunai és Duna menti közlekedésre és áruszállításra érvényes vámmentességet nyújtó privilégiumot kaptak, amely a város és Visegrád, illetőleg Buda közti mindennemű forgalomra érvényes volt, lévén a kiváltság alanyai a pozsonyi polgárok és hospesek és nem csak a pozsonyi kereskedők voltak. A kiemelt útvonal végpontja, úgy tünik, a királyi udvar volt, ami magyarázatot adhat arra, hogy 1350. évi oklevelével miért a Budára vagy máshová (in Budam vel alias in regno nostro) borokat és élelmiszereket szállító pozsonyiak vámolását tiltotta meg Erzsébet anyakirályné: ${ }^{1420}$ 1350-ben ugyanis a királyi székhely Budán volt, ${ }^{1421}$ így ebben az esetben a kiváltság fennálló viszonyoknak megfelelő értelmezéséről lehetett szó. Ugyanakkor más példa alapján az is elképzelhető, hogy a „dunai vámmentesség” a Visegrádra és Budára történő szállításra volt érvényes. ${ }^{1422}$ A jelenség, hogy egy város polgárainak „többféle” vámmentessége is legyen, nem szokatlan vagy egyedülálló, amit jól mutat a másik nyugati határváros, Sopron példája. Sopron kereskedői országos vámmentességhez a pozsonyiakhoz hasonlóan az Árpád-korban, feltehetően IV. Béla vagy V. István adományából jutottak. ${ }^{1423}$ Ezt a kiváltságot III. András már 1291-ben garantálta, majd 1297. évi privilégiumában újra kimondta ${ }^{1424}$ olyan formában, hogy a soproniak, a fehérváriakhoz és a budaiakhoz hasonlóan, az ország egész területén „mind a Duna vizén és más, az országunkban lévő folyókon le- és felhajózáskor, mind

\footnotetext{
1416 1357. szept. 23.: DF 238 762. (Kováts F.: Dunai hajózás 446.) (szept. 21-i napi kelettel); 1359. júl. 7.: de bonis et rebus eorum, in Wissegrad deferendis, nullum Tributum dare tenerentur - Kováts F.: Dunai hajózás 451. (júl. 3-i napi kelettel).

1417 1356. jan. 26.: F. IX/7. 146.

1418 tributum vel aliquam Tributariam exactionem nullas in regno Nostro dare, et persolvere teneantur - F. IX/7. 146.; in Budam vel alias in regno nostro deferunt - DF 238 727. (F. IX/7. 100.).

${ }^{1419}$ A teljesség igénye nélkül: in Budam - F. IX/7. 100.; in Wissegrad - Kováts F.: Dunai hajózás 451.; versus Curiam nostram - Kováts F.: Dunai hajózás 447.

1420 1350. jan. 8.: DF 238 727. (F. IX/7. 100.).

${ }^{1421}$ Iván L.: Visegrádi vár 26.

1422 Vö. 1374. júl. 4.: DF 238 909. (F. IX/4. 570.).

${ }^{1423}$ Weisz B.: Vámok és vámszedés 343.

${ }^{1424}$ Weisz B.: Vámok és vámszedés 343-344.
} 
szárazföldön” vámmentesek - a dunai vámok fizetése alóli mentesség ilyesformán a soproniaknál is feltűnik. ${ }^{1425}$ Az 1297. évi oklevelet 1317-ben I. Károly is megerősítette. ${ }^{1426}$ Utóbbi átírás legközelebb Zsigmond idején bukkant fel, 1397-ben, amikor a király erre hivatkozva tiltotta meg, hogy az országban a soproniak áruit megvámolják. ${ }^{1427}$ A soproniak ugyanakkor 1323-ban mentességet szereztek a királytól a vámfizetés alól a Lajtáig és a Rábáig, vagyis Vas és Sopron megye bizonyos részein is; „... a területileg korlátozott vámmentesség áruik mellett a gyalogosokra és az egyéb módon átkelökre is vonatkozott. Azaz nemcsak a kereskedés céljából jövő-menő soproniakat, hanem az egyéb ügyeiket intéző városlakókat is érintette ...”. ${ }^{1428}$

A királyi, illetve a királynéi udvarba igyekvők vámmentességének biztosítására is több példát hozhatunk. 1363-ban Lajos - mint nem illő dolgot (sicut non decet) - megtiltotta, hogy akárki vámot (és harmincadot) szedjen a soproniaktól, amikor ajándékaikat és adóikat szálltják a királyi udvarba. ${ }^{1429}$ Zsigmond 1389. évi, hasonló rendelkezésével szintén biztosította a királyi udvarba ajándékokat - és kiemelten az újévi ajándékot - vivő soproniak vámmentességét. ${ }^{1430}$ I. Lajos 1378 . évi rendelete szerint a szebeniek a király vagy a királyné elé küldött követeitöl (de ... ambasiatoribus seu nunciis specialibus) sem lehetett vámot követelni - abban az esetben legalábbis, ha a küldöttek áruk nélkül indulnak útnak. ${ }^{1431} 1391$ ben pedig, amikor a szebeniek, a szászok hét székét is képviselve, beszámoltak Zsigmondnak a vámhelyeken őket ért különböző sérelmekröl, az is előkerült, hogy a király vagy a királyné udvarába „ügyintézni” igyekvő polgárokat (illetve követeiket), valamint az uralkodópár ajándékait vivőket is vámokkal sújtják - jogtalanul. ${ }^{1432}$

\footnotetext{
1425 iidem hospites et quilibet ex ipsis ab omni solutione tributi, sicut cives Albenses et Budenses, per totius regni nostri climata tam super aquam Danubii et aliis fluviis(!) in regno nostro existentibus in descendendo aut asscendendo, quam super terram liberi, inmunes penitus sint et exempti - EFHU 99.

${ }^{1426}$ Házi I/1. 27-28.

${ }^{1427}$ Weisz B.: Vámok és vámszedés 344.

${ }^{1428}$ Weisz B.: Vámok és vámszedés 344.

${ }^{1429}$ Házi I/1. 130.

${ }^{1430}$ Házi I/1. 224. (ZsO. I. 875. sz.).

1431 ZW. II. 488-489.

1432 cumque etiam praefati cives et hospites nostri aut nuncii seu ambasiatores eorum aliqui ad nostram vel reginalem maiestates in factis et necessitatibus ipsorum venire voluerint [...] ex tunc praefati tributarii super ipsos et a [...] clenodiis seu muneribus nostrae vel reginali maiestatibus per ipsos portandis et exhibendis [...] tributariam exactionem peterent, reciperent et indefesse extorquerent - ZW. III. 9. Zsigmond az oklevelet a szebeniek kérésére még ebben az évben kiadta újra (ZW. III. 27-29.), majd 1397-ben (ZW. III. 187-190.), 1404ben (ZW. III. 315-317.) és 1405-ben is (ZW. III. 334-337.), ezenkívül még ismert belőle egy 1393. évi, a szebeniek és a hét szász szék folyamodására Szécsényi Frank erdélyi vajda által kibocsátott példány (ZW. III. 65-67.). A felsorolt oklevelek szövege lényegében megegyezik, nagyobb eltérés csak a vajda által kiadott példány szövegében figyelhető meg, miután Szécsényi Frank az rendelkezéseinek betartatását értelemszerüen csak a vajdai joghatósága alatt álló területekre nézve garantálhatta. Az uralkodó az oklevelet 1391-ben (ZW. III. 13-16.) és 1395-ben (ZW. III. 120-123.) a brassóiak részére is kiadta.
} 
Visszautalva a pozsonyiak és az esztergomi káptalan 1357. évi jogvitájára, annak során a város - az okleveles bizonyítás elnagyoltnak tünő leírása alapján - elméletileg akár Károly dunai vámmentességet biztosító privilégiumával is előállhatott, mégis úgy véljük, a városi kiváltságlevél megelőző napi királyi megerősítése erősebb érv az utóbbi bemutatása mellett. Az előbbi esetből viszont, miután az 1357. évi oklevél a bemutatott, Károly középső pecsétjével ellátott privilégiumot egy, a király korábbi pecsétje alatt kiadott privilégium megerősítésének mondja, az következne, hogy a dunai vámmentességet biztosító kiváltsággal a pozsonyiaknak már 1323 előtt rendelkezniük kellett, ettől az évtől használta ugyanis Károly új pecsétjét. ${ }^{1433}$

A helyzetet tovább bonyolítja I. Lajos intézkedése, amellyel 1366. március 22-én, illetve június 24-én meghatározta (duximus moderandas) a Bécsből vagy máshonnan az országba, valamint az ellenkező irányba, Bécs felé tartó dunai hajók vízivámtarifáját. A rajkai, győri, komáromi, zsitvatői, esztergomi, szobi, visegrádi és óbudai vámszedőkhöz intézett királyi parancs értelmében a folyón lefelé úszó hajók árurakománya után, ha posztóból vagy más áruból áll, 1 forint volt fizetendő a hajófenék szélességének minden lába (1 királyi láb = 31,26 cm) ${ }^{1434}$ után. Külön kategóriába estek a fazekakat (ollas), valamint a gyümölcsöket, például almát és körtét szállító hajók: előbbiek után 3 forint, utóbbiak után 2 forint vámot kellett adni hajónként. A folyón felfelé tartó hajók fél vámmal tartoztak. A szabályozás a harmincadfizetést változatlanul hagyta (tricesimis tamen salvis remanentibus a mercatoribus prenotatis). ${ }^{1435}$ 1374-ben Lajos a bécsi kereskedőknek belevésett címerpajzsával hitelesített lábmértéket küldött, miután a tudomására jutott, hogy a Bécs és Buda közti Duna-szakasz vámbirtokosainak és vámszedőinek újításai (nouitates et calumpnias) miatt a kereskedők félnek felkeresni az országot. A király egyúttal megtiltotta a kereskedők kényszerítését az újonnan átengedettnél rövidebb mérték használatára a hajófenék szélességének megmérésénél ${ }^{1436}$ - vagyis az újítás abban állhatott, hogy a vámosok a bevettnél rövidebb mértéket alkalmazva igyekeztek megrövidíteni a kereskedőket. Nagy Lajos 1366. június 27én átírta és megerősítette a március 22-i vámszabályozást, mégpedig Jakus pozsonyi bíró kérésére. ${ }^{1437}$ Az ellentmondás, tudniillik hogy milyen megfontolásból íratták át az egyébként vámmentes pozsonyiak a vámtarifát, feloldható akképpen, ha a pozsonyiak dunai forgalmának

\footnotetext{
1433 Vö. Gárdonyi A.: I. Károly nagypecsétjei 36.

1434 Bogdán I.: Magyarországi hossz- és földmértékek 79.

1435 1366. márc. 22.: DF 258 545_092-090.; 1366. jún. 24.: Teleki, Huny. X. 376-377. A két oklevél szövege megegyezik. Vö. 1370. febr. 22.: ZW. II. 337-339. Vö. Kubinyi A.: Budapest története 47.

1436 1374. jún. 15.: Wenzel, Dipl. Eml. III. 73-74.

${ }^{1437}$ DF 258 545_092-088.
} 
kettősségével számolunk, azaz hogy saját áruik mellett mások - vámköteles - áruit is szállították.

A pozsonyiakat 1297. november 1-jén III. András az áruátrakodás német területeken elterjedt, magyar viszonylatban azonban egyedülálló jogával (Umschlagsrecht) ruházta fel. ${ }^{1438}$ A rendelkezés értelmében azok a kereskedők, akik áruikat Bécs vagy Magyarország felé hajón szállítják, azokkal a hajósokkal, akik hajóin azokat a német területekről Pozsonyig vitetik, a városnál tovább nem szállíttathatják, csak a pozsonyi polgárok és lakosok hajósaival vitethetik tovább. ${ }^{1439}$ Habár elképzelhető, hogy az előbbi esetben éppen az átrakodási jog érvényesülésével állunk szemben, a jelenség egyébként sem mondható szokatlannak, mások áruit szállító pozsonyiakról a - későbbiekben részletezett - szárazföldi áruszállítás során a polgárok által elkövetett visszaélések révén szintén több alkalommal értesülünk. ${ }^{1440}$ Ha a fenti esetre - feltételezve, hogy a nem saját áruikat szállító pozsonyiaknak tisztában kellett lenniük azzal, hol és mennyi vámot kell fizetni - az Umschlagsrecht megnyilvánulásaként tekintünk, ${ }^{1441}$ a dunai vámszabályzat átíratása mindenesetre ellentmondani látszik az áruátrakodás joga olyasfajta értelmezésének, hogy az a pozsonyiak vámmentessége révén lehetővé tette volna a külföldi kereskedők áruinak vámmentes szállítását az országban. ${ }^{1442}$

A pozsonyiak vámmentességének érvényesítése a Dunán azonban a későbbiekben is nehézségekbe ütközhetett. I. Lajos 1371. július 12-i oklevelével kénytelen volt megparancsolni a vámokkal rendelkezőknek, különösen a rajkai, bodaki, királyszigeti, komáromi, neszmélyi, esztergomi, szobi, visegrádi és óbudai vámbirtokosoknak, ezek officialisainak és vámszedőinek, továbbá a király harmincadosának és az ő helyetteseinek, hogy a pozsonyi polgároktól és hospesektől Pozsonytól Budáig a hajókon vagy carrinakon szállított élelmiszerek (például: búza, rozs, zab, bor, széna) után se vámot, se harmincadot ne szedjenek. ${ }^{1443}$ Az 1371. évi mandátummal tartalmilag lényegében azonos a király 1374. július

\footnotetext{
1438 Skorka R.: Pozsony Bécs árnyékában 302.

1439 quod quicumque navigio versus Wyennam vel Hungariam cum rebus suis mercimonialibus se transferre intenderent, per nautas, qui de Theotonia in Posonium cum navibus suis ad deferendum mercatores venerint, de cetero transferri non valeant ullomodo, nisi per nautas civium nostrorum predictorum, vel commorancium in eadem - Juck 80-81.

1440 Vö. Weisz B.: Vámok és vámszedés 317.

${ }^{1441} \mathrm{Az}$ átrakodási jog érvényesülésével kapcsolatban kétséget támaszt, hogy III. András azt biztosító 1297. évi oklevelét ismereteink szerint elsőként 1453. szept. 12-én V. László erősítette meg. (DF 240 253). Utóbbi oklevél alapján már említett, 1464. máj. 27-i oklevelével Mátyás király is megerősítette az átrakodási jogot biztosító articulust (DF 240 491.). Mátyás oklevelének tartalmát II. Ulászló 1493. febr. 10-én megerösítette (Neumann T.: Székesfehérvár 83-84.), majd 1498. júl. 15-i oklevelében átírta és megerősítette. (DF 240822.$)$. Az 1453. évi királyi megerősítést megelőző időszakban az eredeti oklevélről csak egy káptalani átírás készült, ezt 1433. jún. 29-én bocsátotta ki a pozsonyi káptalan (DF 239 584.), amely az 1297. évi oklevelet 1516. jún. 17-én is átírta. (DF 241 147.).

1442 Vö. Weisz B.: Vásártartás 302.

1443 Kováts F.: Dunai hajózás 460-461.
} 
4-i oklevele, annyiban mégis eltér, hogy a kiemelt vámok listájában megjelenik Buda is, továbbá az irat kitér arra, hogy az uralkodó az oklevelét el nem fogadó dunai vámszedők és officialisok (tributarios vero et officiales tributorum ... super dicto fluvio constitutorum) megbüntetését, ha azok alá tartoznak, kincstartójára, János váci püspökre, ha pedig a prelátusok és bárók alá tartoznak, Lackfi Imre nádorra bízza. ${ }^{1444}$ Az oklevelek alapján úgy tünik, a pozsonyiak vámmentes dunai élelmiszer-szállítását lehetővé tevő Károly-kori kiváltsága Nagy Lajos - közelebbröl nem ismert privilegiális oklevele ${ }^{1445}$ (in litteris eorum privilegialibus per nos eis graciose concessis lucidius continetur et exprimitur) - révén valamikor 1371 júliusa előtt a harmincadvám fizetése alóli felmentéssel is kiegészült. ${ }^{1446} \mathrm{~A}$ király a polgároknak adott szabadságot - főleg városuk leégése miatti - szegénységükre és szükségükre való hivatkozással meg is újította. ${ }^{1447}$

A pozsonyiak dunai vámok fizetése alóli mentességét említő Lajos-kori oklevelek alapján Kováts Ferenc arra a következtetésre jutott, hogy a pozsonyiak országos vámmentessége Nagy Lajos idején „mindjobban összezsugorodik az élelmiszerek és bor szállítására a budai (visegrádi) víziúton”. ${ }^{1448}$ A jelenséget Kováts a pozsonyi kereskedelem irányának és szerkezetének Árpád-kori viszonyokhoz képest történő megváltozásával magyarázta: a pozsonyiak kiváltsága mintegy átértelmeződik, leszükül, „,más körülhatárolást nyer ..., most, a 14. század derekán, a vámmentesség a mezőgazdasági nyerstermékeknek Buda felé való szállítására vonatkozott”. ${ }^{1449}$ A Visegrád és Buda felé irányuló dunai kereskedelem nagyságrendjének vitathatatlan növekedése azonban nem jelentett egyet a másfelé, akár külvagy belföldre irányuló áruforgalom jelentéktelenségével - áru alatt főként a pozsonyi kereskedelem legfontosabb árucikkét, a bort értjük. ${ }^{1450}$ 1343-ban Károly morva őrgróf értesítette Olmütz, Brünn, Znaim és más morvaországi települések bíróit, esküdtjeit, polgárait és lakóit a pozsonyi polgároknak tett engedményéről, amellyel számukra őrgrófsága területén mindenféle áruik, különösen boraik szabad kereskedelmét és lerakását tette lehetővé a

\footnotetext{
${ }^{1444}$ DF 238 909. (F. IX/4. 569-571.).

1445 Amikor Mátyás király 1464. május 27-i oklevelében átírta és megerősítette a pozsonyiak több kiváltságát, pontosabban okleveleik szabadságokat és jogokat tartalmazó articulusait, a dunai vám- és harmincadmentességről szóló cikkely forrása nem a kiváltságot biztosító privilégium, hanem Nagy Lajos 1374. júl. 4-i oklevele volt. DF 240491.

1446 Vö. 1371. febr. 24.: DF 240 822. (F. IX/4. 131-132.). A pozsonyiak harmincadmentességére l. Skorka R.: Pozsony Bécs ányékában 304-305.

1447 ideo nos paupertatibus et inopiis eorundem civium et hospitum presertim propter combustione ipsius civitatis que perpessi sunt pie et misericorditer compatientes ipsam et eandem graciam eis duximus innovandam atque approbandam - DF 238 875. (Kováts F.: Dunai hajózás 461.).

1448 Kováts F.: Dunai hajózás 439.

1449 Kováts F.: Dunai hajózás 438.

1450 Szende K.: Sopron és Pozsony kapcsolatai 173.; Skorka R.: Pozsony Bécs árnyékában 302.
} 
morvaországi polgárok szokása szerint (iuxta morem). ${ }^{1451}$ Az intézkedés nyomán ebben az időszakban morvaországi borkivitellel is számolhatunk. 1382 áprilisában a pozsonyi várnagy, Kasztellánfi László familiarisai pedig a Roreynfurth nevü átkelőnél (in quodam vado seu transitu) olyan pozsonyi polgárokat rohantak le és fosztottak ki, akik egy szekér állatbörrel az alsó-ausztiai Stillfried sokadalmára tartottak. ${ }^{1452}$

Több dolog ellentmond annak a feltevésnek is, hogy a pozsonyiak országos vámmentessége a Lajos-korban ne érvényesült volna. Aligha lehet például elvonatkoztatni attól, hogy pozsonyiak városprivilégiumát, pontosabban annak 1323. évi átírását, amelyen, ahogy arra többször utaltunk, országos vámmentességük is alapult, Lajos változtatások nélkül erősítette meg először 1352. január 30-án ${ }^{1453}$, majd, ahogy az már fentebb előkerült, 1357-ben is. ${ }^{1454}$ Utóbbi privilégiumra 1365. január 22-én a király megerősítő záradéka és új, függő pecsétje is rákerült. ${ }^{1455}$ Másrészt a Lajos-kor végéről több, a városi kiváltságlevélből kizárólag a kereskedés céljával közlekedő polgároknak és hospeseknek vámmentességet biztosító részt ${ }^{1456}$ átíró királyi parancslevelet ismerünk, amelyekben az uralkodó megtiltja a vámszedést a pozsonyi kereskedőktől. Ezek közül Lajos 1378. június 9-i, három eredeti példányban ránk maradt mandátumát általánosságban az ország összes vámbirtokosához (tributa ... tam in terris quam in aquis habentibus) és ezek vámszedőihez intézi, ${ }^{1457}$ ahogy két korábbi, 1375. május 3-án ${ }^{1458}$ és május 22-én ${ }^{1459}$ kelt oklevelét is, utóbbiakban azonban a címzettek közül külön kiemeli a pozsonyi és a vereknyei vámszedőket (tributariis de eodem Posonio et de Berkenye). Ráadásul, ha nem is tömegesen, de történetesen adatolhatóak olyan konkrét esetek, amikor a pozsonyiak vámmentessége nem dunai, illetve Duna menti vámhelyek kapcsán merült fel. 1371. december 6-án Erzsébet ifjabb királyné manigai ${ }^{1460}$ officialisát tiltotta el a

\footnotetext{
1451 1343. jan. 3.: F. IX/7. 36. (Anjou-oklt. XXVII. 5. sz.).

1452 A támadás helyszíneként megjelölt, Roreynfurth (Koorfurd, Rorefud) nevű átkelő helye ismeretlen. A pozsonyiak panasza nyomán lefolytatott vizsgálat alkalmával a zobori konvent által tanúságul kiküldött László pap Vereknyei András királyi emberrel Pozsony megyében tudakozódott a történtek felől, vagyis az átkelőhely alighanem a megye területén keresendő. 1382. máj. 3.: DF 239 008.; 1382. júl. 12.: DF 239021.

1453 DF 238737.

1454 1357. jan. 18.: DF 238757.

1455 DF 238 757. Átírta a pozsonyi káptalan 1382. aug. 20-án. (DF 239 024.).

1456 Vö. 1291. dec. 2.: Juck 75. (Reg. Arp. 3837. sz.).

1457 mandamus quatenus [...] cives nostros cum suis mercibus vel curribus ac equis ubicumque in regno nostro causa mer[candi profici]sscentes [...] nullomodo audeatis molestare vel quovismodo impedire nec de mercibus nec de equis [vel per]sonis eorum cum mercibus et sine mercibus euntibus et redeuntibus [...] nullum tributum nullamque tributariam [exaccion]em videlicet in portu Posonyensi versus Haymburgam in portu Challow [in] Zeuleus in transitu fluvii Marwa et in aliis locis quibuscumque in comitatu Posonyensi et alias ubique ubi tributum exigi consuevit petere vel exigere presumpmatis - DF 238 962. = DF 238 963. = DF 238964.

${ }^{1458}$ F. IX/7. 372-374. A király nyílt, titkos pecsétjével ellátott oklevelét István bíró és a pozsonyi esküdtek 1375. máj. 11-én átíratták a pozsonyi káptalannal. DF 238914.

1459 1375. máj. 22.: DF 238 915. = DF 238916.

1460 A középkori Nyitra megyében, ma: Malženice, Szlovákia.
} 
pozsonyi polgároktól és hospesektől való, szabadságuk ellenére történő vámszedéstől. ${ }^{1461}$ 1376-ban a pozsonyiak Mikcsfi Istvánnal - majd 1377-től István fiaival, Istvánnal és Ákossal, akikre az ügy apjuk halálával szállt - pereskedtek Szepesi Jakab országbíró és a királyi városok bírája előtt a tőlük Cifer birtokon szabadságaik ellenére kikényszerített vám miatt. A vádakra a nemesek azt felelték, hogy ciferi vám vöröskői várukhoz tartozik (predictum tributum in dicta Chyfer exigi consuetum ad castrum Wereskw dictum(?) ipsorum magistrorum Stephani et Akus pertineret), a várról, következésképpem a vámról pedig okleveleik vannak; ezekről azonban már nincs tudomásunk, a per kimenetele sem ismert. ${ }^{1462}$ Az azonban bizonyos, hogy Cifer a Nagyszombatról Cifer és Paty (Pát) birtokok között Szencre tartó, és a Bazinból Csanakon és Báhonyon át vezető út vámhelye volt. ${ }^{1463}$ Végül Mária uralkodásának idején, 1384-ben a pozsonyi káptalan előtt Bazini Sebes fia János mester özvegye, Margit és János mester testvére Miklós mester özvegye, Barbara ${ }^{1464}$ elismerte a polgárok mentességét a bazini ${ }^{1465}$ vám fizetése alól, amivel pont került a felek Szécsi Miklós országbíró előtt hosszú ideje folytatott pereskedésének a végére. ${ }^{1466}$

A vámmentességi kiváltságo(ka)t a „helyszínen” már nem mindig sikerült zökkenőmentesen érvényesíteni. Az Anjou-kor második felében a pozsonyiaknak legtöbbször a dunai és a Duna menti vámhelyek birtokosaival gyült meg a bajuk, ami közvetetten a visegrádi, illetve budai kereskedelmi irány jelentőségét is mutatja: Wolfurti Konrád óvári comesszel, ${ }^{1467}$ Köpcsényi Mihály óvári várnaggyal, ${ }^{1468}$ a tölük az oroszvári éves vásáron vámot szedető Szegi Mihállyal, ${ }^{1469}$ „Kis” Lászlóval, Erzsébet ifjabb királyné manigai officialisával, ${ }^{1470}$ Komáromi Miklóssal és István fia Istvánnal a komáromi vámon, ${ }^{1471}$ a Héderváriakkal bodaki, ásványi és öttevényi vámhelyeiken, ${ }^{1472}$ Gönyüi Tamás fia János

\footnotetext{
${ }^{1461}$ Kováts F.: Dunai hajózás 462.

1462 1377. márc. 14.: DF 238948.

1463 1412. jan. 15.: DL 9865 (ZsO. III. 1580. sz.); ue. nap: DL 9869. = DF 283 504. (F. X/5. 353-354.) (ZsO. III. 1584. sz.).

1464 Vö. Engel P.: Genealógia: Hontpázmány nem 9. Szentgyörgyi-ág 2. tábla: Szentgyörgyi és Bazini.

1465 A középkori Pozsony megyében, ma: Pezinok, Szlovákia.

1466 1384. máj. 1.: DF 239 039. = DL 7078. A város és a bazini nemesek a bazini vám jogtalan kivetése miatt már korábban is pereskedtek. Vö. 1376. márc. 24.: DF 238 936.; 1376. jún. 9.: DF 238 938.; 1378. aug. 27.: DF 241 363.; 1378. okt. 15.: DF 238968.

1467 1357. szept. 23.: Kováts F.: Dunai hajózás 446. (szept. 21-i napi kelettel).

1468 1375. jún. 8.: Kováts F.: Dunai hajózás 462-463.; 1375. jún. 27.: Kováts F.: Dunai hajózás 466.

1469 DF 239 215. Szegi Mihály 1381-ben óvári várnagy (és vélhetően mosoni ispán) volt. Engel P.: Archontológia I. 385., 386.

1470 1371. dec. 6.: Kováts F.: Dunai hajózás 462.

1471 1359. júl. 5.: Kováts F.: Dunai hajózás 448-449. (jún. 28-i napi kelettel); 1359. júl. 7.: Kováts F.: Dunai hajózás 450-453. (július 3-i napi kelettel).

1472 1356. márc. 6.: F. IX/7. 144-145. (DF 238 753.) (Anjou-oklt. XL. 111. sz.); 1357. dec. 24.: Kováts F.: Dunai hajózás 446-447. (dec. 23-i napi kelettel); 1359. júl. 20.: Kováts F.: Dunai hajózás 453-454.; 1360. aug. 20.: DF 238 785.; 1360. okt. 20.: Kováts F.: Dunai hajózás 454-459.; 1375. jún. 15.: Kováts F.: Dunai hajózás 463-464.; 1375. jún. 27.: Kováts F.: Dunai hajózás 464-465.; 1376. márc. 6.: Kováts F.: Dunai hajózás 467-468.
} 
bakonyi, komáromi, győri és fejéri comesszel ${ }^{1473}$ a győri vámon, ${ }^{1474}$ Mikcsfi István fiaival, Istvánnal és Ákossal ciferi vámhelyükön, ${ }^{1475}$ Mikcsfi István fia Ákos fejéri comes győri és királyszigeti vámszedőjével, ${ }^{1476}$ a győri káptalannal annak abdai vámján, ${ }^{1477}$ a bazini nemesekkel a bazini, az esztergomi káptalannal pedig az esztergomi vámon. ${ }^{1478}$

A pozsonyiak a vizsgált, ismert kimenetelü esetekben előbb-utóbb érvényt szereztek vámmentességi joguknak az azt megkérdőjelező vámbirtokosokkal szemben, egyedül az esztergomi káptalan tudott sikerrel fellépni kiváltságuk ellen. A város és a káptalan többször említett, 1357. évi jogvitájában ugyanis a pozsonyiak maradtak alul. Döntésének indoklása során a király kiemelte, hogy a vámot az esztergomi egyház annak idején kegyes adományként, alamizsna gyanánt kapta (ex elemosynaria prouisione ... datum fuisse), másrészt arra hivatkozott, hogy a későbbi adomány nem lehet a korábbi kárára (priori donationi posterior preiudicare minime videatur), a káptalan vámszedési joga pedig a pozsonyiak vámmentességénél régebbi - amint ezt IV. László Imre, II. András és IV. Béla okleveleit tartalmazó, a káptalan által bemutatott privilégiuma igazolta. ${ }^{1479}$

Végül vannak arra utaló jelek, hogy a Lajos-kor végén átmeneti jelleggel számolhatunk a pozsonyiaktól a király rendeletére történő vámszedéssel, bár ennek pontosabb idejéről és körülményeiről kevés tudható. Az esetről Szentgyörgyi Tamás tárnokmester Pozsony városához intézett, keltezetlen leveléből értesülünk. ${ }^{1480}$ A tárnokmester - válaszul a pozsonyiak hozzá intézett levelére - megerősítette, hogy a király tőlük valóban vám szedését rendelte el (der Chünig fürnams geschaft hat von ew maut zenemen), neki küldött levelében is előírta, hogy tőlük a szokásos vámot (gwön dleichew maüt) kell szedni. Kitért arra is, hogy amikor a bíboros Budán tartózkodott, az övéikkel onnan elrendelte nekik, hogy járuljanak a király elé szabadságuk ügyében (umb ewer freyhait), a részükről azonban akkor senki nem jelent meg. ${ }^{481}$ A levél - a tárnokmester hivatali idejének figyelembe vételén túli - pontosabb keltezéséhez jó fogódzót nyújthatna a Budán tartózkodó bíboros említése. Ebben az időszakban azonban két bíboros is tartózkodott az országban. Mivel a kérdés, hogy az utalás Pileus de Prato pápai bíboros-legátusra ${ }^{1482}$ vagy a szintén VI. Orbán pápa által bíborossá tett

\footnotetext{
1473 Vö. Engel P.: Archontológia I. 102., 141., 133., 127.

1474 1375. jún. 27.: Kováts F.: Dunai hajózás 465-466.; 1376. márc. 6.: Kováts F.: Dunai hajózás 467-468.

1475 1377. márc. 14.: DF 238 948.; 1377. nov. 25.: DF 238953.

1476 1384. máj. 13.: Kováts F.: Dunai hajózás 468-469. (máj. 11-i napi kelettel).

1477 DF 239 200.; 1376. márc. 6.: Kováts F.: Dunai hajózás 467-468. Vö. 1385. okt. 13.: DF 239056.

1478 1357. jan. 25.: F. IX/2. 568-570.

1479 1357. jan. 25.: F. IX/2. 568-570.

${ }^{1480}$ DF 239222.

${ }^{1481}$ DF 239222.

1482 Vö. Fraknói V.: Magyarország és a Szentszék 284., Áldásy A.: Nyugati egyházszakadás 120., 131-132.; Eubel, K.: Hierarchia catholica 23.
} 
és az engedélyével a továbbiakban is érseki tartományát kormányzó Demeter esztergomi érsekre $^{1483}$ vonatkozhat-e, úgy véljük, nem dönthető el megnyugtatóan, a levél kelte jobb híján 1379-1382 közé tehető. ${ }^{484}$ Miután a vámszedésről a levélben leírtakon kívül mást nem tudunk, nehéz eldönteni, hogy a történteket a pozsonyiak vámmentességi jogának felfüggesztéseként kellene-e értelmeznünk, vagy esetleg arról lehetett szó, hogy egy vagy több vámbirtokos megtámadta a kiváltságot, és az uralkodó parancsával az ügy bírói úton történő eldöntéséig a fennálló helyzetet rendezte - a pozsonyiakra nézve hátrányosan. 1428ból ismerjük Zsigmond király egy hasonló köztes időszakra vonatkozó parancsát, amellyel a köpcsényi vámon a pozsonyiak szabadságát betartani rendelte addig, amíg - személyesen kívánva a polgárok szabadságairól meggyőződni - Pozsonyba nem érkezik (interim quousque nos ... in dictam civitatem nostram Posoniensem prout intendimus personaliter accedemus). ${ }^{1485}$

Említhető egy árucikk, aminek a kereskedelmére a pozsonyiak vámmentességi joga nem feltétlenül terjedt ki, méghozzá az osztrák területekről importált sóra. A 14. század első harmadától kezdve a só bányászata, szállítása és kereskedelme királyi monopólium volt, elosztásáról a kamarai szervezet gondoskodott, külföldröl való behozatala csak a király jóváhagyásával volt lehetséges. ${ }^{1486}$ „Az importra azért volt lehetőség, mert a királyi kamarai szervezet nem mindig tudott megfelelő mennyiségü ásványt eljuttatni az ország távoli pontjaira" az erdélyi részekről és Máramarosból. ${ }^{1487} \mathrm{Az}$ osztrák só Pozsonyba történő importját a király 1362-ben és 1381 táján is lehetővé tette. ${ }^{1488}$ A kérdés, hogy az importált só után a pozsonyiak tartoztak-e vámmal avagy sem, nem dönthető egyértelműen. Lajos 1355. január 9-én megtiltotta mindenkori pozsonyi várnagynak vagy alvárnagynak, hogy a korábbi gyakorlat ellenére az osztrák sók után vámot szedjen ${ }^{1489}$ - ehhez képest 1362-ben arra utasította a vámszedőket (különösen Szerecsen mester, a királyi sókamarák ispánja vámszedőit), hogy a pozsonyiakat, amíg másképp nem rendelkezik, persolutis eorum veris et

\footnotetext{
1483 Vö. Fraknói V.: Magyarország és a Szent-szék 284., Eubel, K.: Hierarchia catholica 24.

1484 Szentgyörgyi Tamás 1378. dec. 26.-1382. márc. 26. közt szerepel tárnokmesterként. Engel P.: Archontológia I. 38.

${ }^{1485}$ quod in ipsorum civium nostrorum et aliorum forensium hominum preiudicium et consuetudinis ac libertatis derogamen cedit satis grande undecum nos de libertatibus et consuetudinibus ipsorum civium et hospitum nostrorum Posoniensium et eciam aliorum mercatorum forensium in hac parte hactenus observatis per nos personaliter dum illac uti intendimus in brevi veniemus velimus experiri - DF 239498.

${ }^{1486}$ Draskóczy I.: Só a középkori Magyarországon 150-151. Vö. Draskóczy I.: Sóbányászat és -kereskedelem 58. Lásd még Kubinyi, A.: Königliches Salzmonopol.

1487 Draskóczy I.: Só a középkori Magyarországon 155. A kitermelés helyeire l. uo. 150.

1488 1362. jún. 30.: F. IX/7. 208-209.; 1381. dec. 14.: F. IX/7. 433-434. A király ugyanakkor 1379. június 29-én a pozsonyi polgároknak felrótta, hogy parancsaival ellentétesen nem foglalják le, és officialisainak sem engedik elvenni az eladott és eladásra kínált külföldi sót (sales extraneos). DF 238978.
}

1489 DF 238744. 
iustis tributis per loca tributorum vestrorum ne gátolják az osztrák só importjában, mert Szerecsen Erdélyből képtelen ellátni megfelelő mennyiségü sóval a vidéket. ${ }^{1490}$

Pozsony szerdai hetivására 1361-ben háromvásáros kikiáltás helyszíne volt. ${ }^{1491}$ Jakab comes pozsonyi bíró és köpcsényi várnagy érdemeiért 1344-ben Lajostól a város Szent Lőrinc mártír napjára (augusztus 10.), valamint az azt megelőző és követő hét-hét napra szóló sokadalomtartási engedélyt nyert. Az éves vásárt, amit a vásárengedély a modo et in antea ${ }^{1492}$ - „miként azelőtt is”- kitételéböl kiindulva valamilyen formában már korábban is megrendezték, ${ }^{1493}$ a „maguk idejében tartott” budai, a fehérvári és soproni sokadalmak mintájára kellett megtartani. ${ }^{1494}$ A vásározókat a király védelméről biztosította, amit nevében a pozsonyi ispán és alispán volt hivatva garantálni. ${ }^{1495}$

\section{Putnok $^{1496}$ (Gömör megye) [Putnok, H]}

A Gömör megyei Putnokon IV. László 1283-ban tette lehetővé a vámszedést a Rátót nembéli Olivér fiainak, Rénoldnak és „Vecse” Miklósnak. ${ }^{1497}$ A putnoki vám a Lajos-korban is adatolható: 1363-ban Miklós unokája, Putnoki László fia Mihály ${ }^{1498}$ Putnok faluban - saját állítása szerint - vámján (in suo telonyo) elvette Sánta (Claudus) Miklós tolvajtól Simon forrói hospes két ökrét. ${ }^{1499}$

\section{Radovan (Szentpál) (Körös megye) [Pavlovac, HR]}

1363-ban Izdenci Móric fia Simon mester ${ }^{1500}$ Radovan és Egyed fia Dezső, János és Miklós, András fia János, továbbá Pál fia Tamás és más patruelis fratereik (szentandrási ${ }^{1501}$

\footnotetext{
1490 de partibus Transsilvanis sufficientes sales deferri facere et aministrare minime valuit - 1362. jún. 30.: F. IX/7. 208-209.

${ }^{1491}$ DF 248 391. Házi J.: Pozsony vármegye 56. Vö. Weisz B.: Vásárok és lerakatok 156.

1492 a modo et in antea singulis annis subsequentibus, in festo S. Laurentii martyris, et septem diebus praecedentibus, ipsum festum immediate, et septem diebus sequentibus, in toto usque quindenas liberum forum annuale in ipsa civitate nostra Posoniensi [...] libere celebretur - Juck 138.

1493 Datálására lásd Szende K.: Sokadalomtartási engedélyek 238.

1494 Juck 137-138. (Anjou-oklt. XXVIII. 26. sz.).

1495 Juck 138. (Anjou-oklt. XVIII. 27. sz.).

1496 Korábbi történetére lásd Weisz B.: Vámok és vámszedés 321.

${ }^{1497}$ Weisz B.: Vámok és vámszedés 321. Vö. Engel P.: Genealógia: Rátót nem 1. tábla: elágazás.

1498 Vö. Engel P.: Genealógia: Rátót nem 6. tábla: Putnoki.

1499 DL 89 365. (Anjou-oklt. XLVII. 482. sz.).

1500 Vö. Engel P.: Genealógia: Pok nem 1. tábla: Meggyesi (Mórichidai, Izdenci).
} 
nemesek) Alberthegye (Alberthyge) birtokát elválasztó határok között szerepelt a Csázma folyó hídja, amin keresztülmegy a Gordováról Izdencre tartó út (in fluvio Chasme circa pontem per quem itur de Gordoua versus Izdench et circa ipsum pontem est via). ${ }^{1502}$ Alberthegye (Alberthege) birtok egy részét Simon mester már néhány évvel korábban, 1357ben megvette a Szentandrásiaktól - a Csázma hídja e birtokdarab határainak leírásakor is feltünt. ${ }^{1503}$

\section{Rajka $^{1504}$ (Moson megye) [Rajka, H]}

A Moson megyei Rajka falu vámjának első említése 1339-ből való: I. Károly a Duna túlpartján fekvő Gutorszeg vámját eladományozó oklevelének tanúsága szerint a rajkai vám ekkor a királyé volt (tributi nostri in villa Rayka). ${ }^{1505}$ A vámszedőhely a pozsonyiak vámmentes dunai élelmiszer-szállítását érintő királyi rendelkezésekben $(1371,1374)$ is feltűnik. ${ }^{1506}$ 1418-ban Zsigmond a pozsonyiak panaszára arra utasította Kapler Péter pozsonyi comest, akadályozza meg, hogy az országba és a Csallóközbe tartó (in regnum nostrum Hungariae, et ad districtum Challokwz causa mercandi proficisci volentes) bécsi - és más ausztriai - kereskedők Pozsony elkerülésével Rajkánál és Eberhardnál (in villis Raykendorf et Ebersdorf) keljenek át a Dunán. ${ }^{1507}$

\section{Rakamaz (Szabolcs megye) [Rakamaz, H]}

1355-ben Lajos Bátori Bereck fia Miklósnak ${ }^{1508}$ érdemeiért, kérésére rakamazi birtokrészén (porcio) pénteki hetivásár tartását engedélyezte. ${ }^{1509}$

\footnotetext{
1501 Vö. AO VI. 617.

1502 DL 24 806. (Anjou-oklt. XLVII. 615. sz.).

1503 AO VI. 618.

1504 Korábbi történetére lásd Weisz B.: Vámok és vámszedés 323.

1505 Weisz B.: Vámok és vámszedés 323.

1506 1371: Kováts F.: Dunai hajózás 461., 1374: DF 238 909. (hiányosan: F. IX/4. 569-571.).

${ }^{1507}$ F. X/6. 134-135. (ZsO. VI. 2618. sz.).

1508 Vö. Engel P.: Genealógia: Gútkeled nem 1. Rakamazi ág 4. tábla: Bátori (somlyói).

${ }^{1509}$ DL 71 880. Weisz B.: Vásárok és lerakatok 160. Az oklevelet a király 1369-ben megerősítette. DL 71880.
} 


\section{Rakonok (Körös megye) [Rakovec, HR]}

1361-ben a Rakonokon részbirtokos néhai Mikcs bán fia István ${ }^{1510}$ ott álló mészárszékének elfoglalása kapcsán a falu piacterét (locus fori) is említették. ${ }^{1511}$ Rakonokon késő középkori adatok $(1393,1481)$ alapján vasárnaponként hetivásárt tartottak. ${ }^{1512}$

\section{Raszinya (Körös megye) [Rasinja, HR]}

Raszinya csütörtöki hetivására 1350-ben ${ }^{1513}$ háromvásáros kikiáltás színhelye volt.

\section{Remete (Temes megye) [Berzovia mellett, RO] ${ }^{1514}$}

1370-ben Lajos Himfi Benedek volt bolgár bán érdemeire tekintettel Benedek, testvérei, Péter és Miklós és frater patruelise, János fia László ${ }^{1515}$ Temes megyei Remete és Krassó megyei Bácstövise birtokaira szerdai, továbbá az ugyancsak temesi Bulvenc birtokukra szombati hetivásár tartására adott engedélyt a szomszédos és más megyebeli vásárok sérelme nélkül. ${ }^{1516}$

\footnotetext{
${ }^{1510}$ Vö. Engel P.: Genealógia: 1. tábla: Mikcsfi.

${ }^{1511}$ DL 41 513. (Anjou-oklt. XLVII. 67. sz.).

1512 Weisz B.: Vásárok és lerakatok 150.

${ }^{1513}$ DL 101903 (Anjou-oklt. XXXIV. 579. sz.).

${ }^{1514}$ Engel Pál e Remetét (a továbbiakban: temesi Remete) tette meg vásáros helynek és a Himfiek remetei ága névadó birtokának. Engel P.: Térkép. Remetét Pogányosremetével (Remetea-Pogănici, RO) azonosítja: Weisz B.: Vásárok és lerakatok 165., Tringli I.: Perényi 489., Csánki II. 106. (Krassó megye alatt hozza). A Csánkinál Pogányosremete (a továbbiakban: a krassói Remete) birtokra hozott adatok inkább a temesi Remetére vonatkozhatnak, így pl. 1343-ban (vö. Anjou-oklt. XXVII. 834.) egy bizonyos sósdi kenéz hajtott el Benedek Remetéjéről disznókat (Sósd a temesi Remete határosa, a krassói Remete Sósdtól $25 \mathrm{~km}$ távolságra fekszik légvonalban). 1369-ben (DF 285 838) Benedek (illetve Péter és mások) jogot kaptak a gonosztevők üldözésére Egerszeg és Remete birtokon (Egerszeg és a temesi Remete szomszédos birtokok). 1404-ben a Gyertyános (a temesi Remete szomszédosa) és a Himfiek Remete birtoka közti határvitáról hallunk. Krassó III. 245.

${ }^{1515}$ Vö. Engel P.: Genealógia: Him rokonsága 2. tábla: Himfi.

${ }^{1516}$ DL 70 654. (Tringli I.: Perényi 120. sz.).
} 


\section{Rendek (Zala megye) [Csabrendek, $\mathrm{H}$ ]}

Rendek pénteki hetivására 1344-ben háromvásáros kikiáltás színhelye volt. ${ }^{1517}$

\section{Rojcsa (Körös megye) [Rovišće, HR]}

Rojcsa keddi hetivására 1350-ben ${ }^{1518}$ és 1363-ban ${ }^{1519}$ is háromvásáros kikiáltás színhelye volt.

\section{Röjtökör (Sopron megye) [Neudörfl an der Leitha (Lajtaszentmiklós), A]}

Röjtökör falunak a 14. században útvámja volt, amelyet 1346-ban „a régi időktől fogva” szedettnek írtak le (Ruhtukewr cum tributo in via exigi tempore antiquo consueto). Röjtökör falun és vámján - Kövesd faluval és útvámjával, valamint Kabold várával és vámjával egyetemben - 1346-ban Nagymartoni Simon comes fia Pál országbíró és unokaöccse, Lőrinc fia Miklós; továbbá rokonuk, Mihály comes fia Nyklul fia Miklós ${ }^{1520}$ fele-fele arányban osztozott meg. ${ }^{1521}$

\section{Rum (Vas megye) [Rum, H]}

Rumnál a Rábán hídon lehetett átkelni. 1350-ben I. Lajos a Rumi „Német” János udvari lovag birtokán álló hidat a Rába folyó (használatá)val együtt Jánosnak, testvérének, Gergelynek és rokonaiknak, Doroszló fia Doroszlónak, Jánosnak és Imrének ${ }^{1522}$ adományozta. $^{1523}$

\footnotetext{
1517 Zala I. 443. (Anjou-oklt. XXX. 913. sz.).

1518 DL 101903 (Anjou-oklt. XXXIV. 579. sz.).

1519 DL 41 513. (Anjou-oklt. XLVII. 67. sz.).

1520 Vö. Engel P.: Genealógia: Fraknói (Nagymartoni, Gróf).

1521 Sopron vm. I. 186-189. (Anjou-oklt. XXXI. 657-658. sz.).

1522 Vö. Engel P.: Genealógia: Tengerdi rokonság 1. tábla: Rumi.

${ }^{1523}$ AO V. 413-414. (Anjou-oklt. XXXIV. 707. sz.).
} 


\section{Ruttka (Turóc megye) [Vrútky, SVK]}

Alsó- és Felsőruttka birtokok 1363. évi osztályakor a határvonal átszelte a Turóc folyó révét (fluvium Thurucz pertransiendo ibi in uno portu). ${ }^{1524}$

\section{Ság (Nógrád megye) [Karancsság, H]}

1348. július 6-án I. Lajos engedélyével Szécsényi Tamás krassói és kevei comes, valamint fia, Kónya ${ }^{1525}$ szepesi és sárosi comes endrefalvi hétfơi hetivásárukat Cselen fia Sándor fia, János ${ }^{1526}$ gömöri és csongrádi comes, szegedi várnagy nógrádi Ság falujába helyezték át. ${ }^{1527}$ (Vö. Endrefalva)

\section{Ság (Vas megye) [Alsóság: Celldömölk része, H]}

Ság falu csütörtöki hetivására 1358-ban háromvásáros kikiáltás színtere volt. ${ }^{1528}$

\section{Salamon (Ung megye) [Solomonovo (Tiszasalamon), UKR]}

Salamon keddi hetivására 1348-ban háromvásáros kikiáltás helyszíne volt. ${ }^{1529}$ 1352-ben Druget János fiai, János és Miklós ${ }^{1530}$ panaszt tettek Lajosnak, amiért e hetivásárukat és salamoni révvámjukat (tributum portus) tönkreteszi a Losonci Dénes fia István ${ }^{1531}$ Szentmárton birtokán (Salamon szomszédosa) a király által engedélyezett keddi hetivásár, főleg, mivel Losonci István kihirdettette, hogy senki nem tartozik a Drugetek salamoni révjén

\footnotetext{
${ }^{1524}$ DL 41536.

1525 Vö. Engel P.: Genealógia: Kacsics nem 4. tábla: Szécsényi.

1526 Vö. Engel P.: Genealógia: Ákos nem 2. Sági.

${ }^{1527}$ Károlyi I. 175-176. (Anjou-oklt. XXXII. 441. sz.). Az oklevelet a király 1354-ben megerősítette. Károlyi I. 217-220. (Anjou-oklt. XXXVIII. 97. sz.).

${ }^{1528}$ DL 108 127. (Savaria-Szombathely 75. sz.). Vö. Csánki II. 790., Weisz B.: Vásárok és lerakatok 170.

${ }^{1529}$ DF 252596 (Anjou-oklt. XXXII. 909. sz.).

1530 Vö. Engel P.: Genealógia: Druget 1. tábla: gerényi ág.

1531 Vö. Engel P.: Genealógia: Tomaj nem 2. tábla: Losonci.
} 
átkelni a folyón. ${ }^{1532}$ A király - miután a szentmártoni vásárt megtartását a szomszédos vásárok jogsérelme nélkül tette lehetővé - meghagyta a kereskedőknek és a vásározóknak, hogy ne hagyjanak fel a salamoni vásár felkeresésével, ${ }^{1533}$ és hangsúlyozta, hogy eztán is a szokásos révnél, Salamonnál keljenek át a folyón. ${ }^{1534}$

\section{Sarló ${ }^{1535}$ (Bars megye) [Tekovské Lužany (Nagysalló), SVK]}

A sarlói szerdai hetivásár 1345-ben ${ }^{1536}$ és 1366-ban ${ }^{1537}$ háromvásáros kikiáltás színtere volt. ${ }^{1538}$

\section{Sár (Vas megye) [Sár: Sárvár része, H]}

Sár szombati hetivására 1358-ban háromvásáros kikiáltásnak adott otthont. ${ }^{1539}$

\section{Sárkány (Fogarasföld) [Şercaia, RO]}

1372-ben Vlad (Lajk) havasalföldi vajda, szörényi bán és fogarasi herceg a saját és Lajos király nevében (ex parte domini nostri regis et nostri) rokonának, Dobokai János fia Lászlónak ${ }^{1540}$ adományozta a fogarasföldi Sárkány vásárát az Olt mellett, minden tartozékával. A vajda úgy rendelkezett, a vásárt Dobokai János halála után fia, Miklós, vagy életben lévő lánya örökölje. ${ }^{1541}$

\footnotetext{
1532 DF 209827.

1533 ad predictum forum ... in dicta possessione ... celebrari consuetum ire et accedere non postponatis quia nos per forum predicti ... Stephani in prelibata possessione sua per nos celebrari concessum foro eorundem magistrorum Nicolai et Johannis prenotato nolumus preiudicium generari - DF 209827.

1534 nichilominus eciam si per portum eorundem memoratum ab antiquo transire sunt consuetum ex tunc per ipsum portum transire debeatis non facientes transitum per portus inconsuetos et de novo adinventos - DF 209827.

1535 Korábbi történetére lásd Weisz B.: Vámok és vámszedés 331.

1536 DL 40 992. (Anjou-oklt. XXIX. 754. sz.).

${ }^{1537}$ DF 207 314. (P. VIII/1. 351-352. Hiányosan, a báti vásári kikiáltást nem írja át).

1538 DL 40 992. (Anjou-oklt. XXIX. 754. sz.).

1539 DL 108 127. (Savaria-Szombathely 75. sz.). Vö. Weisz B.: Vásárok és lerakatok 170.

1540 Vö. Engel P.: Genealógia: Kökényesradnót nem 1. tábla: Dobokai.

1541 ZW. II. 386.
} 


\section{Sáró (Bars megye) [Vel'ké Šarovce (Nagysáró), SVK]}

I. Lajos 1348-ban Sárói Vörös Bede comes fia Péter ${ }^{1542}$ Sáró birtokán szombati hetivásár (forum) tartására adott engedélyt. A vásárt feltehetően már korábban is megtartották, I. Lajos hetivásár-tartási engedélye szerint ugyanis apja, I. Károly korábban már lehetővé tette Péter apjának, Bede comesnek a sárói vásártartást. ${ }^{1543}$

\section{Segesd (Somogy megye) [Segesd, H]}

Segesd hétfői hetivására 1374-ben ${ }^{1544}$ háromvásáros kikiáltás színtere volt.

\section{Simontornya (Tolna megye) [Simontornya, $\mathrm{H}$ ]}

1377-ben I. Lajos Lackfi István volt erdélyi vajda és unokaöccse, a néhai Lackfi Dénes erdélyi vajda fia, István királyi lovászmester ${ }^{1545}$ kérésére Simontornya oppidumukon Szent György napjának quindenájától 15 napon át tartó (május 8-22.) éves vásár megrendezésére adott engedélyt a budai sokadalom mintájára. ${ }^{1546}$ A vásátartási engedély értelmében a simontornyai sokadalom ideje alatt a vásár területén a vásározóktól vámot szedni nem lehetett. $^{1547}$

\section{Sitke (Vas megye) [Nagysitke, $\mathrm{H}$ ]}

1362-ben Sitke keddi hetivására háromvásáros kikiáltásnak adott otthont. ${ }^{1548}$

\footnotetext{
1542 Vö. Engel P.: Genealógia: Lévai 1. tábla.

1543 sicut eciam dominus rex genitus noster predicto Bede patri ipsius Petri dictum forum contulit mediantibus litteris suis sub maiori sigillo suo emanatis - AO V. 216-217. (Anjou-oklt. XXXII. 486. sz.).

${ }^{1544}$ DL 6190. (Borsa I.: A somogyi konvent oklevelei 363. sz.).

1545 Vö. Engel P.: Genealógia: Hermán nem 2. tábla: Lackfi.

${ }^{1546}$ C. Tóth N.: Simontornya 98-99.

1547 nullus de eisdem forensibus, mercatoribus et hominibus ac ipsam congregationem confluentibus et etiam ab incolis et habitatoribus dicte possessionis in area dumtaxat dicte congregationis et fori generalis dum mercantium (inkább: mercantur - K. V.) aliquid tributum seu exactionem tributariam recipere valeat atque possit $-C$. Tóth N.: Simontornya 98.

${ }^{1548}$ F. IX/7. 516. (Anjou-oklt. XLVI. 457. sz.).
} 


\section{Somogyvár (Somogy megye) [Somogyvár, H]}

Somogyvár szombati hetivására 1374-ben ${ }^{1549}$ és 1379-ben ${ }^{1550}$ háromvásáros kikiáltás színtere volt.

\section{Somos ${ }^{1551}$ (Sáros megye) [Drienov, SVK]}

A Somoson szedett, a kassaiak szerint túl magas tarifájú közlekedési vámról Lajos idejéből 1344-ben hallunk először, amikor a király érdekükben a gyalogosok régi szokás ellenére történő megvámolása ellen lépett fel - a magas vám és a gyalogosok vámolása miatt a kassaiak ekkor Somoson kívül Szina és Középnémeti vámállomásai ellenében is panasszal éltek. ${ }^{1552}$ 1349-ben Sáros, Eperjes és Kisszeben polgárai panaszkodtak az uralkodónak, amiért őket a Patakra tartó útról eltérítik, és Somoson vámfizetésre kényszerítik. Lajos Egyed fia Péternek és Somosi Ivánka fiainak, ${ }^{1553}$ a vám birtokosainak parancsba adta, hogy ne akadályozzák a panaszosokat szokásos útvonalaik használatában. ${ }^{1554}$ Az 1355-ben lefolytatott sárosi vámvizsgálat szerint Egyed fia Miklós és Somosi Ivánka fia János annak ellenére szedette a vámot Somoson, hogy, habár nagy szükség lett volna rá a Tárca folyón való átkeléshez, hidat nem üzemeltettek ${ }^{1555}$ - ráadásul túl magas vámokat állapítottak meg (például a szekerek után). ${ }^{1556}$ Utóbbi visszaélés miatt István sárosi alispán a szepesi káptalan tanúságával Miklóst és Jánost a vámjuk birtoklására jogosító okleveleikkel együtt a királyi jelenlét elé idézte - a szinyeújfalusi, pécsújfalusi és sztracsinai vámbirtokosokkal egyetemben. ${ }^{1557}$ 1357-ben a Kassán idéző uralkodó is a vámszedésre jogosító oklevelei bemutatására kötelezte Egyed fia Miklóst, miután az eperjesi, a sárosi és a kisszebeni polgárok a Somoson kiszabott, jogszerütlenül magas vámról panaszkodtak neki. ${ }^{1558}$ 1373-ban

\footnotetext{
1549 DL 6190. (Borsa I.: A somogyi konvent oklevelei 363. sz.).

1550 DF 233 330. (Borsa I.: A somogyi konvent oklevelei 427. sz.).

1551 Korábbi történetére lásd Weisz B.: Vámok és vámszedés 340-341.

1552 DF 287 451_7. (Anjou-oklt. XXVIII. 814.).

1553 Vö. Engel P.: Archontológia: Aba nem 12. Somosi 1. tábla.

1554 Iványi, Eperjes 25. (50. sz.). (Anjou-oklt. XXXIII. 885. sz.).

1555 in possessione Sumus, ubi pons maxime necessarius esset sed non servatur - Draskóczy I.: Sáros megye vámhelyei 59.

${ }^{1556}$ Draskóczy I.: Sáros megye vámhelyei 60.

${ }^{1557}$ Draskóczy I.: Sáros megye vámhelyei 61.

1558 ab ipsis superfluum et ultra consvetum modum tributum in dicta possessione sua Somus vocata exigeret et exigi faceret - Iványi, Eperjes 27-28. (60. sz.).
} 
Lajos - a Tárcán történő biztonságos átkelést lehetővé tévő híd fenntartásának fejében megerősítette Ivánka fia Pétert a somosi vámszedés jogában, egyúttal a vám tarifáját is megállapította. ${ }^{1559}$ A vámszedési jogát megújító (visszaállító?) (tributum ... eidem Petro ... reddidimus restituimus et remisimus), oklevelet Péter IV. László somosi vámszedést legitimáló oklevelének ${ }^{1560}$ állítólagos elkallódására hivatkozva eszközölte ki: elmondása szerint az iratnak, amit annak megerősítése végett Miklós esztergomi érseknek ${ }^{1561}$ (olym domino Nicolao archyepiscopi Strigoniensis aule nostre vicecancellario) adott át, az érsek halála idején nyoma veszett. ${ }^{1562}$ A király vámadományleveléből kiindulva feltételezhető, hogy az uralkodó a somosi vám szedését valamikor 1373 előtt és - a fenti adatok figyelembe vételével - 1357 után felfüggesztette. Erre utal Lajos 1381-ben, Somosi Péternek címzett parancslevele is, ami ugyancsak a vám(szedés) meghatározott feltételekkel történt visszaállítását említi - tudniillik, hogy a vámbirtokos cserébe köteles hidat fenntartani a Tárcán. ${ }^{1563}$ A kellő híd hiányára az eperjesiek és a kiszebeniek hívták fel az uralkodó figyelmét, akik egyúttal a magas vámokat és a gyalogosok megvámolását is sérelmezték. ${ }^{1564}$

Somoson szombatonként hetivásárt tartottak, ami 1357 és 1367 között, Kont Miklós nádorsága idején ${ }^{1565}$ háromvásáros kikiáltásnak adott otthont. ${ }^{1566}$ A vásárhoz vásárvámszedés is kötődött: e jövedelmet (tributum fori) az 1344-ben Somosi Miklós fia Tamás és fiai, valamint Miklós fia Kajol fiai ${ }^{1567}$ között tett birtokosztály közös birtoklásban hagyta. ${ }^{1568}$

\section{Solymos (Heves megye) [Gyöngyössolymos, H]}

1363-ban, amikor Tamás fia Demeter ${ }^{1569}$ solymosi birtokrészének visszavétele (recaptivacio) után bejárták a földdarab szomszédos birtokokkal tartott határait, érintettek egy

\footnotetext{
1559 Lásd a Vámtarifák c. mellékletben!

${ }^{1560} \mathrm{Az}$, hogy az Árpád kori oklevél eredetijét a somosiak sosem mutatták be, az irat elvesztésének narratívájával súlyosbítva Weisz Boglárka szerint felkelti a gyanút az oklevél hitelét illetően. Weisz B.: Vámok és vámszedés 340.

1561 Talán Apáti Miklósnak. Vö. Engel P.: Archontológia I. 64.

1562 Iványi, Eperjes 34-35. (80. sz.).

1563 undecum vobis ipsum tributum sub certis limitacionibus restituemur ut dicitur et specialiter ut pontem bonum conservaretis - DF 228 497. (Iványi, Eperjes 39. [93. sz.]).

1564 DF 228 497. (Iványi, Eperjes 39. [93. sz.]).

1565 Vö. Engel P.: Archontológia I. 3.

1566 DL 5896.

1567 Vö. Engel P.: Archontológia: Aba nem 12. Somosi 1. tábla.

1568 Str. III. 543-544. (Anjou-oklt. XXVIII. 499. sz.).

${ }^{1569}$ Engel P.: Genealógia: Aba nem 11. Solymosi.
} 
Hydas Patak nevü medret (alveus), ${ }^{1570}$ ami alapján a mederhez tartozó vízfolyáson híd állhatott.

\section{Sopron (Sopron megye) [Sopron, H]}

A soproni keddi hetivásár 1363-ban, ${ }^{1571}$ míg a pénteki 1378 -ban ${ }^{1572}$ adott otthont háromvásáros kikiáltásnak.

1344-ben Lajos Sopronban Antiochiai Szent Margit napjához (július 13.) kötődő évesvásár-tartást (congregatio seu nundine et liberum forum annuale) engedélyezett. A sokadalom július 6-tól az ünnep utáni nyolcadik napig, július 20-ig tartott. ${ }^{1573}$ A király 1371ben újabb sokadalmat (nundine libere seu forum annuale) adományozott a városnak, amit Szent Erzsébet napján (november 19.), valamint előtte és utána 14-14 napig lehetett megtartani a budai - és más civitasokban tartani szokott - éves vásárok mintájára. ${ }^{1574}$

\section{Szajk/Zovajk (Vas megye) [Hosszúperesztegtől D-re]}

Zovajk 1347-i évi határjárása egy Zovajkszarm nevü révet (portus seu transitus Zwaykzorm vocatus) is érintett. ${ }^{1575}$ A rév a Zovajk folyón történő átkelést biztosította. ${ }^{1576}$

\section{Szalka (Szatmár megye) [Mátészalka, H]}

1361-ben Lajos az óbudai klarisszák Szalka birtokán újra engedélyezte a hetivásár (forum) megtartását, amit hajdan (olim) csütörtökönként tartottak, de teljesen elnéptelenedett. ${ }^{1577}$ Szalka birtokosa 1325-től Magyar Pál volt, aki a birtokot 1354-ben hozomány, jegyajándék, leánynegyed és 200 márka kölcsön fejében feleségének, Gersei Margitnak és lányának,

\footnotetext{
1570 DL 73 467. (18. századi másolatban) (Anjou-oklt. XLVII. 251. sz.).

${ }^{1571}$ DL 87 383. (Anjou-oklt. XLVII. 328. sz.)

1572 Sümeghy 79. Weisz B.: Vásárok és lerakatok 159.

1573 Sopr. Tört I/1. 82-83. (Anjou-oklt. XXVIII. 11. sz.).

${ }^{1574}$ DF 201 850. (Sopr. Tört I/1. 159.)

${ }^{1575}$ AO V. 156. (Anjou-oklt. XXXI. 1108. sz.).

1576 Vö. AO V. 156.

${ }^{1577}$ DL 5071.
} 
Erzsébetnek adta. 1355-ben Margit és Erzsébet Szalkát az óbudai klarissza apácáknak adományozta (halálukig tartó haszonélvezeti joggal). A klarisszák a birtokkal 1361-1367 között rendelkeztek, ekkor 220 márka finom ezüstért eladták a Káta nembéli Csaholyi „Nagy” János fiainak, Jánosnak és Sebestyénnek, ${ }^{1578}$ valamint unokaöccsüknek, Péter fia Lászlónak. ${ }^{1579}$ 1368-ból ismerünk egy perhalasztó oklevelet, amivel Opuliai László nádor augusztus 8-án elnapolta a Lónyai Bencenc fiai, János és György, továbbá Jakab fia Miklós, ${ }^{1580}$ illetve Csaholyi János fia Sebestyén közötti oklevélbemutatást a szalkai és naményi vásár tárgyában. ${ }^{1581}$ Feltételezhető, hogy a pereskedést a lónyaiak naményi és a csaholyiak szalkai, azonos napon (csütörtök) ${ }^{1582}$ tartott vásárainak egymásnak kárt okozó közelsége ${ }^{1583}$ váltotta ki - a két település egymástól légvonalban csupán 7 kilométerre fekszik a Tisza egyik, illetve másik partján. A per kifutását nem ismerem, mindenesetre mindkét csütörtöki vásár későbbi megléte kimutatható. ${ }^{1584}$

\section{Szamosszeg (Szatmár megye) [Szamosszeg, H]}

Lajos Szamosszeget Beuldre Mihály mester királyi sókamaraispánnak juttatta, akitől aztán, miután a sóbevételek elsikkasztása miatt a király adósaként számüzték az országból, visszavette a birtokot. ${ }^{1585}$ Szamosszeg 1362-ben - Cudar Péter szolgálatai és a Cudarok abaúji Fony birtokáért cserébe - vámjaival együtt (cum ... tributis ad eandem spectantibus) királyi adomány révén Cudar Péter királyi pohárnokmester és fraterei (István, Mihály, Simon, György, János, Imre) ${ }^{1586}$ birtokába került. ${ }^{1587}$

\footnotetext{
1578 Vö. Engel P.: Genealógia: Káta nem 7. tábla: Csaholyi.

1579 Németh P.: A középkori Szatmár megye 270-271.

1580 Vö. Engel P.: Genealógia: Lónyai.

1581 DL 64077.

1582 Vö. DL 5071, DL 84344.

1583 A Károly-korban már kimutatható a vásárokra vonatkozó, a már meglévő vásárokat védő mérföldjog, amelynek értelmében 1 mérföldön belül nem lehetett más vásárt tartani - legalábbis ugyanazon a napon. Weisz B.: Vásárok és lerakatok 37.

1584 Szalka - 1413: DL 53 656. Namény - 1412: DL 84344 (ZsO. III. 2462. sz.). Mindkettőt idézi: Weisz B.: Vásárok és lerakatok 161-162.

1585 DL 87 382. (Anjou-oklt. XLVI. 120. sz.).

1586 Vö. Engel P.: Genealógia: Cudar (bőcsi, ónodi) 2. tábla: Cudar.

${ }^{1587}$ DL 5119. (Anjou-oklt. XLVI. 155. sz.).
} 


\section{Szeben $^{1588}$ (Szászföld) [Sibiu (Nagyszeben), RO]}

A szász kereskedővárosnak a Lajos-kori adatok alapján mind a bel-, mind a külkereskedelme jelentős volt. I. Lajos 1351-ben arra utasította a királyság vámszedőit, hogy engedjék szabadon továbbhaladni az országban az áruikat szállító szebenieket iustis et consuetis tributis ipsorum persolutis, akár a Meszesi kapun, akár Váradon, akár Déván át utaznak. ${ }^{1589}$ 1359-ben a szebeniek három megrakott mázsaszekérrel hajtottak Budára. A királytól az útra menlevelet kaptak. ${ }^{1590}$ Külkereskedelmük nyugat felé irányult, ideértve az Adriát (Zárát, Velencét), Bécset és Prágát, ahová 1367-től solutis eorum veris, consuetis et iustis tributis szabadon, Buda árumegállító jogától nem zavartatva utazhattak. ${ }^{1591} 1370$ februárjában a király a város Bécs, a cseh területek és Dalmácia felé irányuló kereskedelmét sújtó vámokat igen előnyösen szabályozta: ha a Buda-Bécs útvonalon a Dunán, hajókkal utaztak, a dunai vámokon a folyón felfelé hajózva negyed, lefelé haladva fél forinttal tartoztak a hajófenék szélességének minden lába (pes) után (1 királyi láb $=31,26 \mathrm{~cm})^{1592}$ - ezen felül a vámszedőknek semmivel nem tartoztak. ${ }^{1593}$ A tarifa érvényre juttatása érdekében a király egyúttal érvénytelenítette a rendelkezésének ellentmondó vámszedési jogokat (privilegia, consuetudinines, indulta et gracie). Szebenből Csehországba menet, vagy onnan jövet a tarifa minden vámhelyen (a Nyitra megyei Fehéregyházán is) ${ }^{1594} 4$ cseh garas volt egy nagy szekér

\footnotetext{
${ }^{1588}$ Korábbi történetére lásd Weisz B.: Vámok és vámszedés 355.

1589 mandamus quatenus predictos cives et hospites de Cybinyo ac ad eandem pertinentes ad quascumque partes regni nostri et per quascumque vias videlicet sive per alpes Mezes sive per Waradinum sive autem per Devam cum rebus ipsorum mercimonialibus processerint et transitum fecerint iustis et consuetis tributis ipsorum persolutis sine molestia et perturbacione aliquali abire permittatis salvis rebus et personis nec res et bona eorundem indebite et calumniose arestare audeatis nec eciam aliis permittatis - ZW. II. 84 .

1590 ZW. II. 171.

1591 commissimus ... ut iidem cum rebus eorum et mercantiis cuiuscumque generis vel speciei existant quocumque voluerint sive in Viennam Pragam Jadram et Venetias ac alias ad instar ceterorum mercatorum regni nostri proficisci easdemque res venales et mercantias cuiusque maneriei existant iuxta nutum eorum voluntatis ubicumque maluerint disligare deponere commutare et vendicioni exponere non obstante libertate civitatis nostre Budensis in hac parte possint atque valeant - ZW. II. 297-298. Vö. 1370: ab eisdem libertate civibus nostris Budensibus per nostram maiestatem graciose ipsis concessa in eo ut nullus mercatorum regni nostri predicti vel aliarum partium res suas mercimoniales ultra ipsam civitatem Budensem transportare vel deducere nequeant sed in ipsa Budensi vendere vel commutare aut ibidem reponere teneantur non obstante quibus civibus nostris Budensibus quantum ad alios mercatores in ipsorum libertate nullum volumus ex hoc prejudicium generari ZW. II. 339.

1592 Bogdán I.: Magyarországi hossz- és földmértékek 79.

1593 ZW. II. 337-338. A I. Lajos korábban, 1366-ban már meghatározta a Bécsből vagy máshonnan az ország ba, valamint az ellenkező irányba, Bécs felé tartó dunai hajók vízivámtarifáját. A rajkai, győri, komáromi, zsitvatői, esztergomi, szobi, visegrádi és óbudai vámszedőkhöz intézett királyi parancs értelmében a folyón lefelé úszó hajók árurakománya után, ha posztóból vagy más áruból áll, 1 forint volt fizetendő a hajófenék szélességének minden lába után. DF 258 545: 092-090; Teleki, Huny. X. 376-377.

1594 in loco tributi nostri castri Wywar nuncupati in vulgari Tewtonicali Wezker vocati - ZW. II. 339. A Wezker a Weißkirche (Fehéregyház) romlott alakja lehet.
} 
(rudasszekér) után, míg egy kis ajoncásszekér ${ }^{1595}$ után 2 cseh garassal tartoztak. Zára (vagy más dalmáciai területek) és Buda között a szebeniek - a brassóiakhoz és a pozsonyiakhoz hasonlóan ${ }^{1596}$ - vámmentességet kaptak, csak Budán kellett tricesimát fizetniük. ${ }^{1597}$ A király a szebeni kereskedőkre nézve újra kimondta Buda árumegállító jogának felfüggesztését is. ${ }^{1598}$ Bécsbe a szebeni kereskedők nemcsak Buda, hanem Fehérvár útbaejtésével is jártak, ${ }^{1599}$ ahol a városi pecsétjük nyomatával ellátott, formába öntött viaszt is árulták, amit pedig nem tudtak eladni belőle, azt továbbvitték Bécsbe. ${ }^{1600} 1373$ márciusában Gönyüi Tamás királyi ajtónállómester és győri comes elrendelte, hogy - saját, és honorjai révén bírt - vámhelyein a budai és a fehérvári úton Bécsbe, vagy onnan hazafelé tartó szebeni kereskedőtől a budaiak mintájára kell vámot szedni. ${ }^{1601}$

Az 1370-es években Szeben a lengyel piacra is megpróbált „betörni ”: Kassa és Lőcse után 1371-ben a szász kereskedőváros is kivívta a jogot, hogy vámfizetés tekintetében a krakkóiakkal egyenlő feltételekkel kereskedhessen Lengyelországban. ${ }^{1602}$

Szebent a király 1382-ben a Havasalföld felöl, a Vöröstoronyi-szoroson át a Magyar Királyságba szállított levantei áruk (sáfrány, bors, más füszerek) lerakatává tette. ${ }^{1603} \mathrm{Az}$ árukat, amiket a külföldi (advene) kereskedők a városba egyszer behoztak, onnan nem vihették ki, és az éves várások kivételével kis tételben sem kereskedhettek velük. ${ }^{1604}$

A szebeniek az oda- és a visszaúton is vámmentesen szállíthatták az udvarba az ajándékokat és egyéb javakat, amikkel a királynak és a királynénak tartoztak, ${ }^{1605}$ ugyanígy a király vagy a királyné elé küldött követeiktől (de ... ambasiatoribus seu nunciis specialibus) sem lehetett vámot követelni - abban az esetben legalábbis, ha a küldöttek áru nélkül indultak útnak. ${ }^{1606}$

\footnotetext{
1595 A két szekértípusra lásd Domanovszky S.: Mázsaszekér 47-51.

1596 Vö. Pozsony, Brassó.

${ }^{1597}$ Vö. 1370: ZW. II. 361-362.

1598 ZW. II. 337-339.

1599 1372: annuimus eisdem et presentibus concessimus ut iidem cives nostri de Cybinio vel alter eorum a modo cum rebus suis et mercibus quibusvis as Vyennam per civitatem nostram Albensem vel per alias vias per quas maluerint solutis tamen iustis tricesimis et tributis eundi et redeundi tutam et libertatem atque absolutam habeant facultatem - ZW. II. 393-394. 1373 (királyi megerősítés): ZW. II. 402.

1600 1373: ZW. II. 402-403.

1601 super ipsis et de rebus ipsorum tributum prout de rebus seu mercimoniis civium Budensium recipere vel exigere consuevistis vel solvere consueverunt ita et eodem modo tantum tributum de curribus civium Cibiniensium de partibus Transsilvanis recipere et extorquere facere debeatis et non ultra - ZW. II. 401.

1602 ut ipsi a modo et deinceps et eorum quilibet de ipsa civitate cum rebus mercibus suis quibuslibet ad partes et provincias regni nostri Polonie sub ea libertatis prerogativa et solucione telonii qua ceteri mercatores nostri de Cracovia necnon de Cassa et de Leucha quibus similem graciam fecimus in ipso regno Polonie transire sunt consueti profiscantur - ZW. II. 369-370.

1603 Pach Zs. P.: Levante 4.

1604 ZW. II. 555. Az oklevél értelmezésének történetét lásd Pach Zs. P.: Levante 4-5.

1605 1360: ZW. II. 180.

1606 1378: ZW. II. 488-489.
} 
A Lajos-korban Szebenben kétségkívül tartottak éves vásárokat, hiszen 1382-ben a király a külföldi kereskedőknek megengedte, hogy a szebeni sokadalmakon füszereikkel kis tételben kereskedhessenek. ${ }^{1607}$

\section{Szécs (Zemplén megye) [Sečovce (Gálszécs), Szlovákia]}

Szécs csütörtöki hetivására 1361-ben háromvásáros kikiáltás helyszíne volt. ${ }^{1608}$ A hetivásár 1379-ben és 1380-ban is feltünt a leleszi konventnek küldött vizsgálati parancsokban: 1379ben Jakabot, Eszenyi Tamás fia Imre egyik, a szécsi vásárról hazafelé tartó (de foro libero in villa Zeech celebrari consueto) bozzai jobbágyát támadták meg Pornó és Bozza között a mezőn, és vettek el tőle 8 forintot, ${ }^{1609}$ 1380-ban pedig Szécsi István fia Gál verette meg a vásáron Somosi Péter fia János terebesi várnagy Koleszár András nevü vécsei(?) (Veyche) ${ }^{1610}$ jobbágyát. ${ }^{1611}$

\section{Szécsény (Nógrád megye) [Szécsény, H]}

Szécsény szerdai hetivására 1375-ben háromvásáros kikiáltás színtere volt. ${ }^{1612}$

\section{Szeged $^{1613}$ (Csongrád megye) [Szeged, H]}

A 14. század utolsó harmadában, 1374 körül készült ${ }^{1614}$ váradi káptalani statútumok szerint Szeged vámjának (tributum, quod in Sceged exiguntur) 1/3 része a váradi káptalan, 2/3-a a váradi püspöké volt. ${ }^{1615}$

\footnotetext{
1607 in foris autem nundinarum ipsum piper crocum et alias species libere vendere poterint et secure - ZW. II. 555. Szende K.: Sokadalomtartási engedélyek 239.

${ }^{1608}$ DL 31 301. Vö. Weisz B.: Vásárok és lerakatok 175.

${ }^{1609}$ DF 219864.

${ }^{1610}$ Bizonytalan olvasat.

${ }^{1611}$ DF 219912.

1612 DL 65787.

${ }^{1613}$ Korábbi történetére lásd Weisz B.: Vámok és vámszedés 357-358.

${ }^{1614}$ Weisz B.: Váradi vámper 150.

${ }^{1615}$ Vár. Kápt. Stat. 57.
} 
Zsigmond 1389-ben egyik oklevelében felidézte, hogy Piast Erzsébet annak idején megengedte a szegedieknek áruikkal ex pristine libertatis eorum prerogativa gracia eis concessa, hogy Buda és Félegyháza felé, vagy akárhová máshová az országban szabadon járhatnak a sáregyházi úton, vagy amelyiken akarnak. ${ }^{1616}$ Mivel a király Erzsébet e rendelkezésére hivatkozó 1389. évi oklevelével azt tiltotta meg, hogy a szegedieket korábban garantált szabadságuk ellenére ${ }^{1617}$ a szeri vám felé kényszerítsék, és ott vámot szedjenek tőlük, biztosra vehető, hogy Erzsébet (és Zsigmond) nem(csak) a szegediek szabad közlekedését, hanem vámmentességét (is) garantálta: a vámmentesség ugyanis mentesített az útkényszer alól. ${ }^{1618}$

\section{Szemenye (Zala megye) [Muraszemenye, $\mathrm{H}$ ]}

1366-ban Szécsi (felsőlendvai) Miklós és testvére, Domonkos erdélyi püspök elcserélte a borsodi Ónodot I. Lajossal a Zala megyei Letenyére, Csatárra és Herjóra. A cserét tanúsító királyi oklevél a zalai birtokok tartozékai közül kiemelt egy, a Murán müködő révet. ${ }^{1619}$ A réven Letenye és - az 1322-ben a lendvai vár tartozékai között felsorolt ${ }^{1620}$ - Szemenye között lehetett átkelni a Murán. ${ }^{1621}$ Bár a szemenyei révvám csak a késő középkortól, 1469-től adatolható, ${ }^{1622}$ a murai átkelöhöz kötődő vámszedés minden bizonnyal korábbi eredetü. ${ }^{1623}$

\section{Szemes (Valkó megye) [Sotintót DNy-ra, HR]}

Bebek István országbíró 1367. évi oklevele Kis- és Nagyszemes (Kétszemes) birtokkal kapcsolatban megemlítette az ottani (heti)vásárt is (forum in eisdem celebrari consuetum). ${ }^{1624}$ Az országbíró döntése alapján Maróti Mihály fiai, Miklós, Mihály és János ${ }^{1625}$ Kétszemes birtokában maradhattak, mivel a Druget Vilmos nádor ítéletlevelében elöírt 50 márkáért

\footnotetext{
1616 Reizner, Szeged IV. 4-5. Vö. Szeged atlasz 65.

1617 A szegediek országos vámmentességüket IV. Bélától kapták. Weisz B.: Vámok és vámszedés 358. A szegediek vámmentessének kérdésére vonatkozó szakirodalmi diskurzust összefoglalta Uö: Uo. 3123-3125. jz. 1618 Vö. Vámmentességek fejezet.

1619 ac signanter cum portu super fluvio Mura habito - Zala II. 10.

1620 Weisz B.: Vámok és vámszedés 361.

1621 1394: Zala II. 264.

1622 DL 16853.

${ }^{1623}$ Weisz B.: Vámok és vámszedés 361.

${ }^{1624}$ DL 5569. Weisz B.: Vásárok és lerakatok 169.

1625 Vö. Engel P.: Genealógia: Gútkeled nem 2. Maróti.
} 
megváltották a birtokot Ibrányi Györk fia István lányától, Margittól (Szászteleki Miklós fia György feleségétöl $\left.{ }^{1626}\right)$. Bebek István okleveléből az is kiderül, hogy Kétszemest Ibrányi Györk két fia, István (Margit apja) és Pál ${ }^{1627}$ annak idején Benedek fia Keledtől ${ }^{1628}$ vásárolta meg a kői káptalan előtt 50 márkáért, akiktől - Keleddel közeli rokonságára hivatkozva Maróti Mihály (Miklós, Mihály és János apja) bírói úton (Druget Vilmos ítélőszékén) szerezte meg. ${ }^{1629}$

\section{Szenc (Pozsony megye) [Senec, SVK]}

Szenc hétfői hetivására 1353-ban ${ }^{1630}$ és 1361-ben is háromvásáros kikiáltás helyszíne volt. ${ }^{1631}$

\section{Szentágota (Szászföld) [Agnita, RO]}

1376-ban Lajos Szentágotán (villa nostra Zenthagota) éves vásár (nundinas seu forum annuale) tartását tette lehetővé Keresztelő Szent János születésének ünnepén (június 24). ${ }^{1632}$ Szentágota vására (forum) - amint ezt 1379-ben a király is elismerte - Nagysink (vásárának?) kárára volt. Ennek ellenére Lajos nem vonta vissza Szentágota vásárengedélyét (sőt azt 1381ben újból jóváhagyta), ${ }^{1633}$ csupán ígéretet tett arra, hogy Nagysink rovására több vásár megtartását nem engedélyezi Nagysinkszék területén. Egyebekben a Széket eltiltotta attól, hogy az ügyben elötte panaszt tegyen, és a vita elsimítását 1381. július 16-i oklevelével Goblin gyulafehérvári püspökre és Scharfenecki János talmácsi várnagyra bízta.

\footnotetext{
${ }^{1626}$ Első férje Maróti Mihály féltestvére, István volt. Engel P.: Genealógia: Gútkeled nem 2. Maróti.

1627 Vö. Engel P.: Genealógia: Ibrányi (Valkó megye).

${ }^{1628}$ Vö. Engel P.: Genealógia: Gútkeled nem 6. Farkas ága 1. tábla: elágazás.

1629 DL 5569.

1630 AO VI. 33.

1631 DF 248 391. Házi J.: Pozsony vármegye 56. Vö. Weisz B.: Vásárok és lerakatok 156.

1632 ZW. II. 452-453.

1633 licet super annullacione fori in villa sancte Agnethis per nos celebrari commissi per nonnullos ex vobis fuerimus exhortari attamen quia ipsum forum est per nostram maiestatem pro honore dicte provincie institutum ideo dictum forum in predicta villa celebrari commissum presentibus approbamus adeo ut a modo et in aevum semper absque ullius cuiusvis contradiccionis obice libere celebretur - ZW. II. 543-544.
} 


\section{Szentgál (Baranya megye) [Vásárosszentgál: Királyegyháza területén ${ }^{1634}$ ]}

A szentgáli szombati hetivásár 1376-ban háromvásáros kikiáltás színhelye volt. ${ }^{1635}$

\section{Szentgrót (Zala megye) [Zalaszentgrót, H]}

Szentgrót szerdai hetivására 1369-ben háromvásáros kikiáltás helyszíne volt. ${ }^{1636}$

\section{Szentgyörgy (Keve megye) [Žitište (Bégaszentgyörgy), SRB]}

1342 novemberében Keve megye törvényhatósága előtt Kartal nembéli Etele mester ${ }^{1637}$ nevében szerviense, „Vértes” (Vertus) János comes tiltakozott többek között amiatt, hogy „Vámos” Domonkos becskereki villicus és felfegyverkezett társai - Gehan fia István becsei várnagy tudtával és akaratából - rátörtek Etele mester Szentgyörgy birtokára, széttörték a vámot jelző keresztet (signum tributi videlicet crucem confregissent), a vámházból eltulajdonítottak három márkányi dénárt és 500 sót, és terményekkel megrakott hajókat vittek el a kikötőből. ${ }^{1638}$ Az oklevél a vám típusára ugyan nem utal, de a falunál folyó Béga és a hajók említése miatt valamilyen vízi vámra gyanakodhatunk.

\section{Szentgyörgy (Zala megye) [Szentgyörgyvár puszta Nagykanizsa határában, H] ${ }^{1639}$}

1351-ben Szentgyörgyi Egyed fia András fia Péter 4 pensa széles dénárért elzálogosította 3 szentgyörgyi (Zenthgerd) sessióját Kanizsai Lörinc fia Jánosnak az újudvari keresztes konvent előtt. A telkek lokalizálásakor megemlítettek egy hidat, amit a Mórochely felé közlekedők használtak. ${ }^{1640}$

\footnotetext{
${ }^{1634}$ A két település 1940-ben egyesült. Baranya megye földrajzi nevei 866.

1635 DL 6388.

${ }^{1636}$ DL 101 694. Weisz B.: Vásárok és lerakatok 174.

${ }^{1637}$ Vö. Engel P.: Genealógia: Kartal nem 2. tábla: Etele (Ittebei, kartali).

1638 ÓMO. 158-159. (Anjou-oklt. XXVI. 602. sz.).

1639 Azonosítás: Csánki III. 105.

1640 infra usque fluvium et pontem ubi transiretur per viatores ad Moruchhel - Zala I. 515.
} 


\section{Szentillye (Valkó megye) [Vinkovci, HR]}

Szentillye falu vasárnapi hetivására (forum generalis) 1355-ben háromvásáros kikiáltásnak adott otthont. $^{1641}$

\section{Szentjakabfalva ${ }^{1642}$ (Pilis megye) [Budapest része, $\mathrm{H}$ ]}

1350 augusztusában I. Lajos öccse, István szlavón-dalmát-horvát herceg a kölni, a hoyai és más Rajna-melléki kereskedők kérésére felhívta az ország vámszedőinek figyelmét arra, hogy a kereskedőtől a Holics-Buda útvonalon apja, I. Károly 1336. évi előírásai szerint szedjék a vámot. A kereskedelmi út vámhelyei között Szentjakabfalva is szerepelt: az itteni vám - mint már a Károly-korban is ${ }^{1643}$ - az óbudai vár bevételeit gyarapította (in villa Sancti Jacobi pro castro veteris Bude). ${ }^{1644}$ A szentjakabfalvi vámot (tributum ... in villa sancti Jacobi prope civitatem nostram Budensem ab antiquo exigi consuetum) Piast Erzsébet néhány hónappal később, 1351 januárjában lélekváltságként ${ }^{1645}$ az általa alapított óbudai klarissza kolostornak adományozta. ${ }^{1646} \mathrm{Az}$ anyakirálynő intézkedéséhez fia jóváhagyását is megszerezte. ${ }^{1647}$ Habár a vám útvám/szárazvám volt (in sicciis terris ab antiquo exigitur), így az 1351. évi, a jogtalan út- és hajóvámok szedését eltörlő törvény e vámhelyre is vonatkozott, I. Lajos 1352-ben arra hivatkozva, hogy bevétele alamizsnaként a klarissza apácák megélhetését szolgálta, mégis lehetővé tette fenntartását: éppen a szentjakabfalvi vám 1352-es “müködési engedélyének” megadására szokás a király első, az 1351. évi törvénnyel ellenkező vámrendeleteként hivatkozni. ${ }^{1648}$ 1366-ban Erzsébet - a király jóváhagyásával - a szentjakabfalvi helyett (amit visszacsatolt az óbudai várhoz) ${ }^{1649}$ az óbudai dunai vámot (tributum aquaticum, seu Danubiale) adta az apácáknak: ${ }^{1650}$ 1367-ben az anyakirályné már Szentjakabfalva vámjának jövedelméből rendelte kiutalni azt az évi 240 forintot, amit az

\footnotetext{
1641 DL 33 604., DL 33 605. Weisz B.: Vásárok és lerakatok 169.

1642 Korábbi történetére lásd Weisz B.: Vámok és vámszedés 366.

1643 Wenzel, Dipl. Eml. II. 390-392. (Anjou-oklt. XXXIV. 587. sz.).

${ }^{1644}$ Weisz B.: Vámok és vámszedés 366.

$1645 \mathrm{ob}$ remedium anime nostre et spem future beatitudinis quam in gloriosa Virgine Marie nemine in se sperante deferente optinendam speramus et habemus - DL 4170 (F. IX/2. 80-81.).

${ }^{1646}$ DL 4170 (F. IX/2. 80-81.).

1647 1351: DL 4168 (F. IX/2. 53-56.). A király az oklevelet új pecsétje ráfüggesztésével 1364-ben megerősítette.

${ }^{1648}$ Vö. pl. Sólyom J.: A magyar vámügy 67., Holub J.: Zala vármegye vámhelyei 46.

1649 tributo sancti Jacobi quod Bude in terra sicca pro predictis dominabus ex sua donacione hactenus exigi fuisset consuetum ab eisdem ablato et iuri reginali ac castris Veteris Bude reapplicato et annexo - DL 5445 (F. IX/3. 529.).

${ }^{1650}$ DL 5445 (F. IX/3. 528-531.). Vö. 1351: F. IX/2. 53-55.
} 
opuliai herceg lányának, az óbudai klarissza kolostorban apácaként élő Kunigundának addig óbudai vámja bevételéből biztosított. ${ }^{1651}$ Kunigunda halála után a 240 forintos járadékot a királyné e kolostorban élő rokonainak rendelte folyósítani - haláluk után a jövedelem a vám birtokjogával együtt a királyra kellett, hogy szálljon. ${ }^{1652}$

\section{Szentkirály (Gömör megye) [Král' (Sajószentkirály), SVK]}

A Gömör megyei Szentkirály egy részének 1347. évi határjárása érintett egy tavat, és azon egy régi hidat. ${ }^{1653}$

\section{Szentmargita (Sáros m.) [Margecany, SVK]}

Az 1355. évi sárosi vámvizsgálat szerint a Gölnicbánya melletti Szentmargita faluban, ahol híd biztosította az átkelést a Hernád folyón, királyi vámszedőhely működött. ${ }^{1654}$

\section{Szentmária (Somorja) (Pozsony megye) [Samorín, SVK]}

Szentmária falu szombati hetivására 1353-ban háromvásáros kikiáltás színtere volt. ${ }^{1655}$

\section{Szentmárton (Alsok) (Győr megye) [Pannonhalma területén, H]}

1350-ben Lajos a pannonhalmi apát panaszára, aki nehezményezte, hogy szentmártoni hetivásárát Écs szerdai hetivására tönkreteszi, az écsi vásárt hétfői napokra tette át. ${ }^{1656}$

\footnotetext{
1651 DL 5631.

1652 et si ex nutu divino cognate et proxime nostre morte prevente defecerint tunc totum ius et dominium eiusdem tributi cum dictis proventibus ad manus regie maiestatis devolvantur et disposicioni sue reliquantur pleno iure DL 5631.

1653 prope sanctuarium ecclesie sancti regis Stephani in eadem possessione fundata in uno antiquo ponte super quodam lacu habito - AO V. 28. (Anjou-oklt. XXXI. 202.). Átírta az ergi káptalan 1356-ban: DL 3891. (Anjouoklt. XL. 100. sz.).

1654 Draskóczy I.: Sáros megye vámhelyei 59.

1655 AO VI. 33.

1656 1350. május 28.: P. II. 404-405. (Anjou-oklt. XXXIV. 436. sz.). Az oklevelet 1350. július 18-án Erzsébet királyné Vilmos pannonhalmi apát kérésére átírta és megerősítette. (Anjou-oklt. XXXIV. 537. sz.)
} 


\section{Szentmárton (Szabolcs megye) [Tiszaszentmárton, H]}

1352-ben Druget János fiai, János és Miklós ${ }^{1657}$ panaszt tettek Lajosnak, amiért salamoni keddi hetivásárukat és révvámjukat (tributum portus) tönkreteszi a Losonci Dénes fia István ${ }^{1658}$ Szentmárton birtokán (Salamon szomszédosa) a király által engedélyezett keddi hetivásár, föleg, mivel Losonci István kihirdettette, hogy senki nem tartozik a Drugetek salamoni révjén átkelni a folyón. ${ }^{1659}$ A király - miután a szentmártoni vásárt megtartását a szomszédos vásárok jogsérelme nélkül tette lehetővé - meghagyta a kereskedőknek és a vásározóknak, hogy ne hagyjanak fel a salamoni vásár felkeresésével, ${ }^{1660}$ és hangsúlyozta, hogy eztán is a szokásos révnél, Salamonnál keljenek át a folyón. ${ }^{1661}$

\section{Szentmárton (Turóc megye) [Martin (Turócszentmárton), SVK]}

Szentmárton királyi civitas csütörtöki hetivásárán vásárvámot (tributum) szedtek, ami az uralkodó jövedelmeit gyarapította. ${ }^{1662}$ Az 1359. június 6-i vásári napon a vámot Kusalyi Jakcs turóci comes famulusa és vámszedője, Ivánka fia Miklós szedte be, akit két nappal korábban a közeli Szucsányban, a keddi hetivásáron a helyiek megvertek. Miklósnak a szentmártoni vásáron újra meggyült a baja egy szucsányi hospesszel, aki a vásárról 4 ökörrel akart vámfizetés nélkül, lopva távozni: a vámszedő követte a hospest, és emiatt (ratione premisse clandestine recessionis) elkobozta ökreit. A szucsányiak erre Miklós után mentek, visszaszerezték tőle a 4 ökröt, és a vámszedőt először Vendég, majd Priekopa királyi faluig kergették. ${ }^{1663}$

Szentmárton csütörtöki hetivására 1359-ből adatolható. ${ }^{1664}$ 1361-ben a szentmártoni (circa Sanctum Martinum) vásár háromvásáros kikiáltás színtere volt. ${ }^{1665}$

\footnotetext{
1657 Vö. Engel P.: Genealógia: Druget 1. tábla: gerényi ág.

1658 Vö. Engel P.: Genealógia: Tomaj nem 2. tábla: Losonci.

1659 DF 209827.

1660 ad predictum forum ... in dicta possessione ... celebrari consuetum ire et accedere non postponatis quia nos per forum predicti ... Stephani in prelibata possessione sua per nos celebrari concessum foro eorundem magistrorum Nicolai et Johannis prenotato nolumus preiudicium generari - DF 209827.

1661 nichilominus eciam si per portum eorundem memoratum ab antiquo transire sunt consuetum ex tunc per ipsum portum transire debeatis non facientes transitum per portus inconsuetos et de novo adinventos - DF 209827.

1662 tributum [...] in singulis feriis quintis inibi ab hominibus forensibus praedicto Domino nostro regi exigi consuetum - F. IX/3. 79.

${ }^{1663}$ F. IX/3. 78-79.

${ }^{1664}$ F. IX/3. 78. Weisz B.: Vásárok és lerakatok 168.

1665 A vásár napja nélkül. DL 63 076. (Justh 34. sz.). Vö. Weisz B.: Vásárok és lerakatok 168.
} 


\section{Szentmihály (Miholja) (Zágráb megye) [Gora vidékén, HR] ${ }^{1666}$}

Szentmihály birtok 1353. évi határjárása említette a Kulpa folyó régi révjét (antiquus portus). ${ }^{1667}$

\section{Szentmiklós (Kolozs megye) [Sânnicoară, RO]}

A településen a Lajos-korban közlekedési vámot szedtek, aminek a jövedelmét a mindenkori erdélyi vajda élvezte. 1361-ben Lackfi Dénes (1359-1367) erdélyi vajda a kolozsvári polgárok és hospesek folyamodására jóváhagyta Raholcai Kont Miklós (13511356) és Gönyüi Péter fia Tamás (1350-1351) volt erdélyi vajdák rendelkezéseit: ezek értelmében a Buza, Teke, (Szász)Régen, Sárpatak, Monyoró és Székelyvásárhely felé utazó kolozsváriak Szentmiklós falun és vámján keresztül közlekedhetnek a Kályánon és Ménesen áthaladó úton ${ }^{1668}$ - Bonchidát és vámját pedig nem kell útba ejteniük. ${ }^{1669}$ A rendelkezés tiszteletben tartását Lackfi Dénes minden erdélyi comesének, várnagyának és officialisának meghagyta - közülük kiemelten Járai Mihály fia Péter ${ }^{1670}$ alvajdának és Nagy Lászlónak, a bonchidai vajdai officialisnak és vámszedőinek. ${ }^{1671}$ A kolozsváriak a rendelkezést 1368-ban az új vajdával, Lackfi Miklóssal $(1367-1368)$ is megerősíttették, ${ }^{1672}$ aki újra utasította betartására Járai Péter alvajdát és Nagy Lászlót, saját bonchidai officialisát. ${ }^{1673} 1376$-ban a király Losonci László erdélyi vajda (1376-1385) ${ }^{1674}$ szentmiklósi (és bonchidai) vámszedőihez intézte parancsát, amivel megtiltotta, hogy a „városaiba” (ad ipsas civitates nostras) - vélhetően Désaknára és Désvárra - élelmiszereket szállító désaknai hospeseit, laboratorait és sóvágóit ne vámolják, vámot csak abban az esetben szedjenek tőlük, ha árut

\footnotetext{
1666 Vö. Engellex.

1667 Alsószlavónia 46-47. (Anjou-oklt. 293., 294. sz.; Erdődy 390-391. sz.). Kalyan et Menus eunte transire permittatis - ZW. II. 192. euntem ad villam sancti Nicolai procedere deberent - ZW. II. 191.

${ }^{1670}$ Engel P.: Archontológia I. 12.

1671 ZW. II. 191-192.

1672 ZW. II. 308-309. A vajdák hivatalviselési idejére l. Engel P.: Archontológia I. 12.

1673 ZW. II. 309.

${ }^{1674}$ Engel P.: Archontológia I. 13.
}

1668 si autem versus Reugun, Teke et forum Syculorum accesserint per villam et tributum sancti Nicolai in via per

1669 ut dum ipsi et ad eos pertinentes cum rebus ipsorum mercimonialibus per viam Klyan versus villa Buza, Teke, Regun, Sarpatak, Monyorow et forum Siculorum procedere vellent in villam Bonchyda ire non tenerentur sed recta via ipsorum esset ad villam sancti Nicolai per viam de Kalyan euntem et sic ad tributum solvendum in predictam villam Bonchyda de via eorum directa compelli non deberent sed per viam de Kalyan et Menyus 
szállítanak. ${ }^{1675}$ Egy későbbi, 1405. évi adat szerint a szentmiklósi vám Léta várához tartozott: ${ }^{1676}$ vagyis királyi vám volt, aminek a jövedelme honorként a mindenkori erdélyi vajdát illette, legalábbis 1321 után biztosan - ekkor szerezte meg I. Károly Létát Kán László fiaitól ${ }^{1677}$ (magáról a vámról a Károly-korból nincs adatunk). Az 1405. július 4-i adat egyébként éppen a szentmiklósi vám eltörléséről szól, amire alkalmasint a kolozsváriak lobbija nyomán kerülhetett sor ${ }^{1678}$ a vámosok visszaélései (az irat konkrétan terror ipsorum tributariorumot emleget), ennek eredményeképpen az országlakos, de nyilván föleg a külföldi kereskedők elmaradozása miatt. ${ }^{1679}$ Az ügyet Luxemburgi Zsigmond előtt Nürnbergi Márk királyi harmincad- és urburaispán referálta. ${ }^{1680}$ A király a vám beszedésének felfüggesztéséről még aznap értesítette Tamási János és Szántói Lack Jakab erdélyi vajdákat, ${ }^{1681}$ továbbá a létai várnagyot és alvárnagyot. ${ }^{1682}$

\section{Szentpál (Somogy megye) [Iharosberénytöl Ény-ra, H]}

A szentpáli csütörtöki hetivásár 1369-ben háromvásáros kikiáltás helyszíne volt. ${ }^{1683} 1371$ ben szintén említés történik a somogyi Szentpál hetivásáráról, amit a király Szentpál birtokával együtt Kanizsai István zágrábi püspöknek és Csornai Lőrinc fia János fiainak, Miklósnak, Jánosnak, Lörincnek és Istvánnak ${ }^{1684}$ adott egy több várat és birtokot érintő birtokcsere során. ${ }^{1685}$

\footnotetext{
1675 quatenus de victualibus cuiuscumque generis existant que quandocumque et quotiescumque per loca ipsorum tributorum hospitibus et laboratoribus nostris ac eciam excisoribus salium nostrorum de Desakana ad ipsas civitates nostras deferuntur exceptis mercantiis et de conductoribus eorundem numquam tributum petere vel exigere audeatis sed sinatis ipsa victualia semper deferri absque recepcione tributi aliqualis ut excisio salium nostrorum per hoc facilius et melius expediatur demptis rebus et mercantiis de quibus tributum recipere non inhibetur - ZW. II. 454.

${ }^{1676}$ ZW. III. 361.

1677 Vö. Engel P.: Archontológia I. 358.

${ }^{1678} \mathrm{Az}$ 1405-ös oklevelet a városi levéltár örizte meg.

1679 nolentes itaque incommoditates nostrorum regnicolarum et precipue fisci nostri defectum exinde provenientes ulterius tollerare quin immo cupientes saluti nostre cui racione previa cum ipsi tributarii non propria sed regia auctoritate suffulti talia facere valeant et exercere posset in die examinis districti iudici derogare consulere et huiusmodi hucusque male gestis finem dare salutarem prefatum tributum ipsiusque exaccionem et recepcionem ... revocamus cassamus annihilamus et penitus abolemus perpetuis futuris temporibus per nos aut successores nostros seu alios quavis causa vel racione nequaquam ulterius erigendum instituendum recipiendum et exigendum - ZW. III. 361.

1680 relacio Marci de Neuremberga tricesimarum et urburarum regalium comitis - DF 281151 (a pecsét alatt és az oklevél elölapján).

${ }^{1681}$ Engel P.: Archontológia I. 14.

1682 ZW. III. 363-364.

${ }^{1683}$ DL 101 694. Weisz B.: Vásárok és lerakatok 158.

${ }^{1684}$ Vö. Engel P.: Genealógia: Osli nem 5. tábla: Kanizsai.

${ }^{1685}$ Sopron vm. I. 395-396.
} 


\section{Szentpéter (Liptó megye) [Liptovský Peter, SVK]}

I. Lajos 1363. évi, 1391-ben, a liptói regisztrum összeállításakor hitelesnek minősített pátensével Szentpéternek vásártartási jogot adott. ${ }^{1686}$

\section{Szenttamás (Veszprém megye) [Veszprém területén, $H$ ]}

Veszpémben szerdai és szombati napokon tartottak hetivásárt, utóbbit feltehetően már az Árpád-kor óta, a mai Óváros téren, az akkori Szenttamás(falva) területén ${ }^{1687}$ (locus forum in villa episcopali Santi Thome martyris in suburbio castri Wesprimiensis sita). ${ }^{1688}$ A 14. században a vásártartás polémia tárgyát képezte a veszprémi püspökök és a helyi székeskáptalan között: 1370-ben Zsámboki László püspök ${ }^{1689}$ amiatt emelt szót Lajosnál, hogy a káptalan elödei idején a szombati vásárt a püspöki faluból (Szenttamás) olykor a káptalan veszprémi birtokrészeire helyezte át, így a vásár hol itt, hol ott volt megtartva. A király a vitát László püspök javára döntötte el, és elrendelte, hogy a szombati hetivásárt, ahogyan korábban is, a püspöki faluban kell megtartani, ahonnan sem a káptalan, sem a veszprémi ispánok és alispánok nem mozdíthatják el. A káptalan az ügyben többé nem pereskedhetett. ${ }^{1690}$

\section{Szenttrinitás (Somogy megye) [Beleznától ÉNY-ra, H]}

1358-ban Mikefalvi Mike fia Péter felesége, Margit szenttrinitási és kakonyai birtokrészeit minden haszonvéleleikkel - köztük a Mura és a Kanizsa folyók hídjainak vámjaival (tributis pontium fluviorum Mura et Kanysa vocatorum) - eladta Hahóti Mihály fia Jánosnak 20 bécsi dénármárkáért (minden márkát 10 pensával számolva). ${ }^{1691}$

\footnotetext{
1686 exhibuerunt etiam quasdam litteras patentes eiusdem domini Lodovici regis, super donatione fori in dicta possessione Zenthpetur celebrari consueti, per eundem dominum Lodovicum regem facta ... similiter veras Tur. Reg. 42. (Anjou-oklt. XLVII. 29. sz.).

1687 Weisz B.: Vámok és vámszedés 432.

1688 1370. február 7.: VVOS 286.

1689 Engel P.: Archontológia I. 78.

1690 VVOS 286-287.

${ }^{1691}$ AO VII. 344. (Anjou-oklt. XLII. 982. sz.).
} 


\section{Szepesszombat (Szentgyörgy) (Szepes megye) [Spišská Sobota: Poprád (Poprad) településrésze, SVK]}

1380-ban Lajos Szentgyörgyön (oppidum nostrum Montis Sancti Georgii) szombati hetivásár (forum liberum) tartására adott engedélyt. ${ }^{1692}$ A szentgyörgyi szombati hetivásárt ettől függetlenül már jóval korábban is megtartották, ${ }^{1693}$ 1353-ban háromvásáros kikiáltás színtere volt. ${ }^{1694}$

\section{Szepetnek (Zala megye) [Szepetnek, H]}

1371-ben Szepetnek vasárnapi hetivására háromvásáros kikiáltás színtere volt. ${ }^{1695}$

\section{Szepesváralja (Szepes megye) [Spišské Podhradie, SVK]}

Szepesváralja csütörtöki hetivására 1355-ből is adatolható. ${ }^{1696}$

\section{Széplak (Bács megye) [Sontától (Szond) Ny-ra, SRB]}

1382-ben a király és az óbudai klarisszák között több birtokot, vámot és az illető birtokok kamarahasznáját érintő birtokcserére került sor: ennek során Széplak és útvámja (tributum viaticum) az itt szedett kamarahasznával együtt az apácáké lett. ${ }^{1697}$

\footnotetext{
1692 Schmauk, Supplementum 135. Vö. Weisz B.: Vásárok és lerakatok 163.

1693 IV. Béla 1256. évi oklevele már említette Forum Sabbathit. W. VII. 432. Weisz B.: Vásárok és lerakatok 163.

1694 DF 272 391. (Anjou-oklt. XXXVIII. 70. sz.).

1695 DL 41864.

1696 feria quinta ... in dicta Scepsii in foro - DF 232797.

${ }^{1697}$ DL 6905.
} 


\section{Szer (Csongrád megye) [Ópusztaszer, H]}

Szeren a Zsigmond-kor elején közlekedési vámot szedtek, ami a szeri nemesek birtokában volt. Szer a Szegedről a Tisza partján Csongrád érintésével Kőrösre tartó út vámhelye lehetett, amivel többé-kevésbé párhuzamosan Félegyháza érintésével is el lehetett jutni Kőrösre. ${ }^{1698}$ A szegediek áruikkal Félegyházára és Buda felé az utóbbi, 1389-ben Sáregyháznak (per viam Saareghaaz vocatam) hívott úton járhattak, és nem kellett betérniük a szeri vámra (tributum ... in ... villa Zer nuncupata exigi consuetum). Az út használatát Piast Erzsébet (olim ... domine Elizabeth senioris regine Ungarie) oklevele nyomán Zsigmond is jóváhagyta a szegedieknek, a rendelkezését áthágó szerieknek pedig vámjuk elvételét és a szegedi várhoz történő csatolását helyezte kilátásba. ${ }^{1699}$

\section{Szerdahely (Zemplén megye) [Streda nad Bodrogom (Bodrogszerdahely), SVK]}

Szerdahely szerdai hetivására 1361-ben háromvásáros kikiáltás helyszíne volt. ${ }^{1700}$

\section{Szeremlyén (Bodrog megye) [Szeremle, H]}

Becsei Töttös Bátmonostor birtokának 1344. évi határjárása megemlítette András hídját ${ }^{1701}$ (pontem Andree), ami Bátmonostort a szomszédos Szeremlyéntől válaszotta el. ${ }^{1702}$

A pécsváradi konvent egyik, 1362-ben kiadott jelentéséből szerzünk tudomást a bátai bencés apátság szeremlyéni vásáráról (forum). ${ }^{1703}$ A vásárt a közelmúltban tönkretették, emiatt a konvent „Herceg” Péter özvegyét, fiát, Pétert, valamint szekcsői várnagyukat és officialisukat a királyi jelenlét elé idézte. ${ }^{1704}$

\footnotetext{
1698 Vö. Gy. I. „Csongrádvármegye a XIV. század elejéig” c. térképmellékletét.

${ }^{1699}$ DF 210 889. (Hornyik 198-199.) (ZsO. I. 978. sz.).

${ }^{1700}$ DL 31 301. Vö. Weisz B.: Vásárok és lerakatok 175.

${ }^{1701}$ A híd eddig csak egy 14. századi hamisítványból volt adatolható. Weisz B.: Vámok és vámszedés 378.

1702 1344. március 30.: DL 87 162. Anjou-oklt. XXVIII. 282. sz.

1703 Vö. Weisz B.: Vásárok és lerakatok 140.

1704 1362. január 2.: Z. III. 203-204. (Anjou oklt. XLVI. 2. sZ.).
} 


\section{Szeszárma (Belső-Szolnok megye) [Săsarm (Szészárma), Románia]}

Lajos 1360-ban kihirdetés útján hívta fel a kereskedőket Szeszármai Farkas István és Farkas ${ }^{1705}$ Szeszárma birtokán királyi engedéllyel szerdánként megtartott, de időközben elnéptelenedett (desolatum et abolitum) hetivásárának (forum liberum) látogatására. ${ }^{1706}$

\section{Szinyeújfalu (Vámosújfalu) (Sáros megye) [Chimianská Nová Ves, SVK]}

$\mathrm{Az}$ 1355. évi sárosi vámvizsgálat a Szinyei Merse fia Benedek fiainak birtokában lévő szinyeújfalusi vám kapcsán egyrészt megállapította, hogy ,jogszerü, szükséges hidak vannak, és a köves útról azt mondják, ki lett javítva az áthaladóknak”, ${ }^{1707}$ másrészt, hogy a (híd)vám öt - nem részletezett - vámtétele túl magasnak (immoderatus) minősül. ${ }^{1708}$ Utóbbi visszaélés miatt István sárosi alispán a szepesi káptalan tanúságával a szinyei vámbirtokosokat, Tót Péter mestert és Merse fia Lőrincet a vám birtoklására jogosító okleveleikkel együtt a királyi jelenlét elé idézte - a somosi, pécsújfalusi és sztracsinai vámbirtokosokhoz hasonlóan. ${ }^{1709}$

\section{Sziget (Máramaros) (Sighetu Marmației [Máramarossziget), RO]}

1352-ben Lajos Benedek a szigeti Szent Imre hitvalló egyház plébánosának kérésére a szigeti királyi népeknek vagy jobbágyoknak Visk, Huszt, Técső és Hosszúmező népeinek és hospeseinek apja, I. Károly által 1329-ben garantált, és általa elismert szabadságait biztosította. Károly 1329-es rendelkezése szerint „e falvak vásárait a rendelt napokon, szabadon, vámmentesen kell megtartani”. ${ }^{1710}$

\footnotetext{
1705 Vö. Engel P.: Genealógia: Kacsics nem 5. tábla: Farkas (szeszármai, harinai).

${ }^{1706}$ DL 41 414. (F. IX/6. 109.). Vö. Weisz B.: Vásárok és lerakatok 163.

1707 competentes pontes necessarii servarentur et via petrosa pertranseuntibus diceretur emendari - Draskóczy I.: Sáros megye vámhelyei 59.

${ }^{1708}$ Draskóczy I.: Sáros megye vámhelyei 59-60.

${ }^{1709}$ Draskóczy I.: Sáros megye vámhelyei 61.

1710 Item volumus, quod fora habita in eisdem villis, sub constitutis diebus libere et absque tributo aliquali celebrentur - DL 2539. Az oklevelet a király 1365-ben átírta és megerősítette. Vö. Weisz B.: Vásárok és lerakatok 152.
} 


\section{Szob (Hont megye) [Szob, H]}

A Hont megyei ${ }^{1711}$ Szob és a túlparti Nagymarót közt már az Árpád-korban is rév müködött, így, bár a szobi dunai vámot elsőként I. Lajos 1366. évi dunai vámtarifája ${ }^{1712}$ említi, az itteni vámszedés feltehetően korábbi keletű. ${ }^{1713}$ A vámhely a pozsonyiak vámmentes dunai élelmiszer-szállításáról rendelkező oklevelekben $(1371,1374)$ is megjelenik. ${ }^{1714}$ I. Lajos Szob királyi falu száraz- és vízi vámját 1382 júliusában az általa alapított ${ }^{1715}$ nosztrai pálos kolostor remetéinek adta. ${ }^{1716}$ A királyi adomány csak a szobi vámra vonatkozott, magát a birtokot nem érintette: az a későbbiekben is a damásdi vár tartozéka volt. ${ }^{1717}$ 1453-ban Hunyadi János juttatott a kolostornak a vámszedés céljaira egy üres háztelket (unum fundum curie liberum) Szobon, ígéretet téve arra, hogy adományát a királlyal, V. Lászlóval is megerösítteti. ${ }^{1718}$

Két héttel I. Lajos halála után, 1382 szeptemberében özvegye, Erzsébet rendelkezett részletesebben az itteni vámmal kapcsolatban. Elrendelése szerint a nosztrai pálosok a szokásos vámot szedhették be a szárazföldön és a Dunán kereskedés céljából szállított javak, áruk és élelmiszerek, szállítóik és a szállítóeszközök - carina-k, hajók, szekerek és állatok után is. Nem lehetett azonban vámot kérni a saját és gyermekei részére, valamint curiái, prelátusai, udvari bárói vagy familiarisai ellátására szállított élelmiszerek után. ${ }^{1719}$ Erzsébet oklevelét 1388-ban Zsigmond is megerösítette. ${ }^{1720}$

\footnotetext{
${ }^{1711}$ A birtokot a késő középkorban elvétve Nógrád megyéhez számítják. Csánki I. 108.

1712 DF 258545.

1713 Weisz B.: Vámok és vámszedés 382.

1714 1371: Kováts F.: Dunai hajózás 461.; 1374: DF 238909 (hiányosan: F. IX/4. 569-571.).

1715 Romhányi B.: Kolostorok és társaskáptalanok ’Nosztre (Nosztra)'.

1716 DL 6937.

1717 Vö. 1419: DL 8823 (ZsO. VII. 878. sz.); 1419: DL 10 837. (ZsO. VII. 774. sz.); 1453: DL 14662.

1718 pro exigendo tributo in possessio[ni] regali Zob vocata in comitatu Newgradiensi exsistenti et ad castrum Damas vocatum pertinenti de quo olim [...] [Lodov]icus Hungarie et cetera rex prefato claustro beate Mar[ie] virginis provisionem fecisse dicitur - DL 14662.

1719 de omnibus rebus bonis mercibus et victualibus cuiuscumque generis vel speciei existant que quandocumque quocienscumque et undecumque super fluvio Danubii seu in terris per locum tributi ipsorum fratrum heremitarum in villa nostra Zub vocata exigi consueti per regnicolas mercatores et alios homines forenses mercancie causa deferuntur et a delatoribus eorundem necnon carinis navibus curribus et animalibus in quibus deferuntur et deducuntur salvis dumtaxat et exceptis victualibus pro nostra et puerorum nostrorum maiestatibus ac sustentacione curiarum nostrarum necnon prelatis baronibus curiensibus seu familiaribus nostris quandocumque et quocienscumque deferendis tributum iustum licitum et consuetum exigendi et recipiendi habeant liberam facultatem - DL 6950.

1720 DL 7349.
} 


\section{Szomajom (Ördögháza) (Szabolcs megye) [Hajdúszoboszló területén, H]}

Szomajomnál híd állt a Hortobágy folyón, és kikötő is működhetett - e létesítményekhez kapcsolódóan pedig híd-, illetve révvámot (tributum pontis seu portus) szedtek. 1346-ban a Szomajomiak $^{1721}$ a birtokon és vámján is megosztoztak: a bevétel egyik fele Péter fia Kozmának és fiainak, Péternek, Istvánnak, valamint Jánosnak, a másik fele Pál fia Lászlónak és Pál fia János fiainak, Tamásnak és Mátyásnak jutott. ${ }^{1722}$ Az osztályos felek ugyanekkor a híd helyreállításáról is megállapodtak. A híd negyedrészét - annak középső felén - László és János fiai, negyedrészét - a híd (egyik) végén - pedig Kozma és fiai kell, hogy karbantartsák. ${ }^{1723}$ A híd másik, a Szomajomiak osztálya alá nem eső fele a Káta nem túlparti Zámmonostora birtokához tartozhatott. ${ }^{1724}$ (Vö. Zámmonostora)

\section{Szombathely (Vas megye) [Szombathely, H]}

Szombathely a középkorban a györi püspöké volt, aki a városban egy 1399. évi adat szerint - akkor éppen a soproniak vámmentességének sérelmére - vámot szedetett. ${ }^{1725}$

\section{Szovát (Sopron megye) [Bágyogszovát, H]}

Szovátnál a Rábán egy Untató (Vntato) nevű híd állt. Szovát eredetileg várföld volt, Kapuvár tartozéka, 1350-ben azonban Kanizsai János és testvére, István budai prépost, továbbá Csornai Imre fia Lőrinc fia Benedek ${ }^{1726}$ adományul kapta I. Lajostól. ${ }^{1727}$ A hídnak vámja is volt, amire ekkor ugyancsak szert tettek a Kanizsaiak (ac ponte Untathou dicto super fluvium Raba nuncupato adiacenti tributoque in eodem ab antiquo exigi consueto). ${ }^{1728} 1351$ augusztusában, amikor a fehérvári káptalan megjárta a Kanizsaiak Szovát, Martonfölde és

\footnotetext{
1721 Vö. Engel P.: Genealógia: Szomajomi (Szabolcs megye).

1722 DF 219 457. (Anjou-oklt XXX. 801. sz.).

${ }^{1723}$ DF 219 457. (Anjou-oklt XXX. 801. sz.).

1724 Vö. 1343: Z. II. 56-59.

1725 Sopr. tört. I/1. 260-261.

1726 Vö. Engel P.: Genealógia: Osli nem 5. tábla: Kanizsai.

1727 Sopron vm. I. 212-213. (Anjou-oklt. XXXIV. 628. sz.).

1728 1351: DL 4186.
} 
Untató birtokainak határait, a határjárás érintette a hidat (inde per descensum et cursum ipsius fluvii Raba veniret et circumdaret pontem et possessionem Vnthatho nuncupatam). ${ }^{1729}$

\section{Sződi (Arad megye) [Frumușeni (Szépfalu) helyén, RO]}

1354-ben Ivánka fia Domonkos bikei officialis az aradi káptalan előtt tiltakozott - többek között - azért, mert 1354. június 24-én ura, a Bár-Kalán nembéli Szeri Pósa fia István ${ }^{1730}$ Sződi birtokánál müködő marosi révjéből/kikötőjéből (portus) a királyi hadjáratba tartó egynémely nemesek hatalmaskodva eltulajdonítottak egy hajót. ${ }^{1731}$

\section{Sződi (Zaránd megye) [helye ismeretlen]}

A sződi vám a Fekete-Körösön szedett vízi vám volt. A vámszedőhelyet valamikor 1321 és 1324 között Nekcsei Sándor fia Sándor körösszegi várnagy áttelepítette Bátorba. ${ }^{1732}$ 1324-ben I. Károly tett sikertelennek tünő kísérletet sződibe történő visszahelyezésére, majd I. Lajos 1350-ben újból erről rendelkezett: ${ }^{1733}$ április 4-én arról értesítette a bátori (Bihar megye) vámon át közlekedő kereskedőket, kalmárokat és utazókat, hogy a bátori vámot, ami egykor Lépes Demeter és testvérei, Loránd és János ${ }^{1734}$ Sződi birtokáról került Bátor faluba, visszahelyezte Sződi faluba. ${ }^{1735}$

\section{Szőlős (Pozsony megye) [Vajnory (Pozsonyszőlős), SVK]}

Pozsony város Szőlős birtokának 1348. évi határjárása érintett egy régi hidat egy iszapos vízmedren (ad meatum aque lutose devenissent ... ubi dicti cives pontem antiquus [sic!] fuisse dixissent). ${ }^{1736}$

\footnotetext{
${ }^{1729}$ Sopron vm. I. 232.

1730 Vö. Engel P.: Genealógia: Bár-Kalán nem 1. Szeri ág 2. tábla: Pósafi (szeri, sződi).

1731 DL 91 465. (Anjou-oklt. XXXVIII. 334. sz.).

1732 Weisz B.: Vámok és vámszedés 390-391.

1733 Weisz B.: Vámok és vámszedés 390-391.

1734 Vö. Engel P.: Genealógia: Treutel-rokonság 2. tábla: Lépes (váraskeszi).

1735 DL 94 421. (Anjou-oklt. XXXIV. 255. sz.).

${ }^{1736}$ DF 238 768. (Anjou-oklt. XLII. 1066. sz.).
} 


\section{Sztracsina ${ }^{1737}$ (Zemplén/Sáros megye) [Stročín (Szorocsány), SVK]}

Az 1355. évi sárosi vámvizsgálat szerint Sztacsinán az Ákos nembéli Mikcs fia Loránd ${ }^{1738}$ túlzottan magas (immoderatum) vámot szedetett a Bodrog hídjánál. ${ }^{1739}$ A visszaélés miatt István sárosi alispán a szepesi káptalan tanúságával a vámszedésre jogosító okleveleivel együtt a királyi jelenlét elé idézte Loránd mestert. ${ }^{1740}$ A sztracsinai vámot, ami a Sáros megyei Újvár ${ }^{1741}$ tartozéka volt, Loránd testvérei, Ákos és István 1370-ben a várral és uradalmával együtt elcserélték az ónodi Cudarokkal ${ }^{1742}$ több szlavóniai (Zágráb megyei) birtokért. $^{1743}$

\section{Szucsány (Turóc megye) [Sučany, SVK]}

Szucsány keddi hetivásárán vásárvámot (tholonium seu tributum fori) szedtek, ami az uralkodó jövedelmeit gyarapította. ${ }^{1744} \mathrm{Az}$ 1359. június 4-i vásári napon a vámot Ivánka fia Miklós, Kusalyi Jakcs turóci comes famulusa és vámszedője szedte be, egészen addig, amíg a comes elmondása szerint - egy csapat szucsányi rá nem támadt, meg nem verte, és vissza nem kergette a vámházba. Az affér miatti jövedelemkiesést Jakcs 50 forintra becsülte. ${ }^{1745}$

\section{(Szurdok)Püspöki (Heves megye) [Szurdokpüspöki, H] ${ }^{1746}$}

Lajos 1344. évi, Aba nembeli Petőc fia Sirokai Miklós ${ }^{1747}$ erdélyi vajda és szolnoki comes $^{1748}$ számára kiadott oklevele, amelyben a vajda Jobbágy és Püspöki nevű birtokainak

\footnotetext{
${ }^{1737}$ Korábbi történetére lásd Weisz B.: Vámok és vámszedés 393.

${ }^{1738}$ Vö. Engel P.: Genealógia: Ákos nem 4. Mikcs ága 1. tábla: Mikcsfi.

1739 Draskóczy I.: Sáros megye vámhelyei 59., 60.

${ }^{1740}$ Draskóczy I.: Sáros megye vámhelyei 61.

${ }^{1741}$ Ma Hanigovce, Szlovákia.

1742 Bőcsi Dénes fia Domonkos fiaival (Cudar Péter szlavón bán, István, Mihály, György, János fehérvári őrkanonok, Imre kalocsai prépost). Vö. Engel P.: Genalógia: Cudar (bőcsi, ónodi) 2. tábla: Cudar.

1743 DL 5816 = DL 6179 = DL 41800 (F. IX/7. 583.: 1374. évi kelettel, hibásan). Vö. DL 33 674, DL 5824, DL 33 675. Engel szerint a birtokcserét 1373-ben érvénytelenítették, azonban a megállapítását alátámasztandó oklevél (DL 5959) ezt nem bizonyítja. Engel P.: Archontológia I. 453.

1744 ad exigendum tholonium seu tributum fori in singulis feriis terciis ab hominibus in dicta Zuchan ad forum convenientibus predicto domino nostro regi exigi consuetum - DL 4862. (F. IX/3. 78.).

${ }^{1745}$ F. IX/3. 78.

1746 Vö. Gy. III. 127-128.

${ }^{1747}$ Vö.: Engel P.: Genealógia: Aba nem 13. Szalánci ág 2. tábla: Sirokai, Fricsi, Hedri.
} 
határain belül engedélyezte a gonosztevők elfogását és elítélését, a két birtok vásárait (fora) is említette. $^{1749}$

\section{Szvinusa (Szentkelemen) (Varasd megye) [Jalžabet (Kelemen), HR]}

Leusták fiai, István és Péter Szvinusa (Zwynusa), más néven Szentkelemen birtokának 1358. évi határjárása, amely során Szvinusát a szomszédos Toplicától, a zágrábi káptalan birtokától különítették el, érintette a Szvinusa folyó révjét (portus). ${ }^{1750}$

\section{Tapolca (Zala megye) [Tapolca, $\mathrm{H}$ ]}

Tapolcán az Árpád-korban vásárvámot szedtek. A vámjövedelem egy részére (a harmadára vagy a hatodára) 1272-ben a veszprémi püspökség tett szert - ugyancsak a veszprémi egyház birtokolta a vásárvám tizedét. ${ }^{1751}$ A püspökség vámtizede az Árpád-kor végén ideiglenesen Tapolcai Lőrinc comes kezébe került, aki 1290-ben mondott le arról Benedek püspök javára. ${ }^{1752} \mathrm{Az}$ 1290. évi lemondó oklevél fontosságát, tovább élő jogbiztosító szerepét mutatja, hogy az iratot először 1370-ben Nagymihályi Péter fia Jakab királynéi udvari ifjú íratta át a kápolnaispánnal, a király titkos kancellárjával, Vilmos pécsi püspökkel, ${ }^{1753}$ majd az 1370. évi oklevelet 1375-ben László veszprémi püspök Szepesi Jakab országbírótól kérte a saját és egyháza részére átírni a kápolnaispáni pecsét alatt. ${ }^{1754}$

A tapolcai vám fizetése alól I. Károly 1328-ban felmentette a sárvári vendégeket, ${ }^{1755}$ akiknek tapolcai vámmentességét 1344-ben I. Lajos is elismerte. ${ }^{1756}$

\footnotetext{
1748 Vö. Engel P.: Archontológia 12.

1749 AO V. 548-550. (Anjou-oklt. XXVIII. 449. sz.).

${ }^{1750}$ Smič. XII. 502-503. (Anjou-oklt. XLII. 919. sz.).

1751 Weisz B.: Vámok és vámszedés 394-395.

1752 Weisz B.: Vámok és vámszedés 394-395.

1753 VVO 154-155.

1754 VVO 153-155.

1755 Weisz B.: Vámok és vámszedés 395.

${ }^{1756}$ DL 3743. (Anjou-oklt. XXVII. 835. sz.: F. alapján tévesen 1343. december 20-i kelettel). Vö. F. IX/1. 99.
} 


\section{Tapolcaszentgyörgy (Körös megye) [Zdenci (Izdenc) vidékén, HR]}

Tapolcaszentgyörgy 1345. évi határjárása a Toplica folyó átkelőjét (transitus communis) is érintette. ${ }^{1757}$

\section{Tard (Valkó megye) [Klisa, Horvátország]}

1359-ben Asszonyfalvi Domokos bán fiai, Miklós, János és Demeter, illetve Asszonyfalvi Osl fia János fia János ${ }^{1758}$ (telek)osztályt tettek birtokaikon, így a Valkó megyei Tardon is, ami addig Demeter birtokában volt. ${ }^{1759}$ Vonatkoztatási alapként többször is említették Tard piacterét, ${ }^{1760}$ végül - bizonyára Tard - vásárvámját (tributum fori), amit a felek osztatlanul hagytak, bevételéből pedig fele-fele arányban részesültek. ${ }^{1761}$

\section{Tárnok (Csanád megye) [Makótól DK-re, H]}

1343-ban I. Lajos Csanád nembéli Csanád esztergomi érsek kérésére neki és rokonainak Lörinc fia Jánosnak és Tamásnak, Miklós fia Istvánnak, Györgynek és Miklósnak, továbbá Pongrác fia Kelemennek és Tamásnak ${ }^{1762}$ - adományozta a birtokaik szomszédságában, a Maros folyó mentén fekvő Tárnok királyi birtokot minden haszonvételével és tartozékával különösen a szárazon és a Maros folyón fel- és lefelé közlekedő hajóktól régóta szedett vámokkal. ${ }^{1763}$

\footnotetext{
1757 Smič. XI. 188. (Anjou-oklt. XXIX. 60 sz.).

${ }^{1758}$ Engel P.: Genealógia: Osli nem 3. tábla: Ostfi (asszonyfalvi)

1759 apud manus annotati masgistri Demetrii filii eiusdem Dominici bani habitis et existentibus - Sopron vm. I. 300.

1760 item in platea, qua exit de loco fori - Sopron vmegye I. 309., et e converso fundi curiarum in eadem contrata, a fine scilicet a parte fori incipiens ad occidentem - Sopron vm. I. 309.

${ }^{1761}$ hoc non pretermisso imo specialiter declarato, quod universas utilitates omnium premissarum possessionum indivias, videlicet patronatum monasterii beati Michaelis archangeli depredicta Chorna et aliarum ecclesiarum ipsorum parocialium, circuitum montis vinearum, tributum fori $[\ldots]$ ac alias quaslibet utilitates earundem possessionum, que indivise forent partes suprascripte equa lance communiter, rectas medietas ipsorum magister Johannes filius Johannis pro se et alias similiter rectas dimidietates eorundem utilitatum, magistri Nicolaus, Johannes et Demetrius filii Dominici bani possidere tenere et conservare deberent et tenerentur - Sopr. vm. I. 310-311.

${ }^{1762}$ Vö. Engel P.: Genealógia: Csanád nem 1. Főág 2. tábla: Telegdi.

1763 et specialiter tributis, tam in terris, tam in dicto fluvio Morosy, a descendentibus scilicet et ascendentibus ab antiquo exigi consuetis - Str. III. 493. (Anjou-oklt. XXVII. 210. sz.). Átírta és megerősítette I. Lajos 1373-ban: DL 322. Vö. Weisz B.: Vámok és vámszedés 396.
} 


\section{Temesvár (Temes megye) [Timişoara, RO]}

Engel Pál, amikor 1982-ben kiadta a temesi ispáni háztartás 1372. április 28. és június 27. közötti bevételeit és kiadásait regisztráló, 6 lapos papírfüzetke szövegét, ${ }^{1764}$ a számadás(töredék)ben felfigyelt egy nehezen meghatározható, valószínüleg Temesvárra vonatkozó tételre, bizonyos Szent László-napi (június 27.) 40 forintra (item in festo sancti regis Ladislai $X X X X$ flor.), ami véleménye szerint akár a temesvári éves vásár idejeként és bevételeként is interpretálható. ${ }^{1765}$

\section{Terebes (Zemplén megye) [Trebišov (Tőketerebes), SVK]}

Terebes keddi hetivására 1361-ben háromvásáros kikiáltás helyszíne volt. ${ }^{1766}$

\section{Tiba (Ung megye) [Tibava, SVK]}

I. Lajos 1351-ben a Nagymihályi Jakó fia László fia János Tiba birtokán Jánosnak, apjának és testvéreinek (fratribus) új adomány címén keddi hetivásár tartására adott engedélyt más szomszédos, megyebeli vásárok sérelme nélkül. ${ }^{1767}$

\section{Timár (Szabolcs megye) [Timár, H]}

Timár hetivására (forum) először 1354-ben tünt fel a forrásokban, a Gútkeled nem Rakamazi ágának birtokosztályakor: ekkor Timár birtok egyik fele Bátori Bereck fia Lőkös fia Péter ${ }^{1768}$, másik fele pedig Bereck fia János fiai, László, György és István ${ }^{1769}$ birtokába

\footnotetext{
${ }^{1764}$ Engel P.: Honor 917-920.

1765 Engel P.: Honor 890-891.

1766 DL 31 301. Vö. Weisz B.: Vásárok és lerakatok 175.

1767 Sztáray I. 227-228. Az oklevelet átírta és megerősítette I. Lajos 1352-ben: DL 85 296. (Sztáray I. 229-230.).

1768 Vö. Engel P.: Genealógia: Gútkeled nem 1. Rakamazi ág 6. tábla: Bátori (ecsedi).

1769 Vö. Engel P.: Genealógia: Gútkeled nem 1. Rakamazi ág 4. tábla: Bátori (somlyói).
} 
jutott. ${ }^{1770}$ A vásár, amelynek napja a hétfő volt, 1370-ben háromvásáros kikiáltás színhelye volt. $^{1771}$

\section{Tolmács (Nyitra megye) [Tolmácspuszta Šuranytól (Nagysurány) nyugatra, SVK]}

Szegi János fiai, Péter és Mihály ${ }^{1772}$ a Nyitra folyó melletti Tolmács birtokának 1348. évi határjárása érintette a Horvátrév (Horuathreu) nevü átkelőt (vadum). ${ }^{1773}$

\section{Tótfalu (Szepes megye) [Slovenská Ves, SVK]}

Az óbudai klarisszák tótfalusi vámja 1382. május 2-án, az apácák és I. Lajos széleskörü, országszerte több birtokot, vám- és kamarahaszna-jövedelmet érintő „birtokcseréje” értelmében királyi kézbe került. A tótfalusi vám a podolinival és a lucsivnaival együtt az ekkor szintén gazdát cserélő, a klarisszákéból I. Lajos birtokába jutó Somogy birtokhoz tartozhatott. $^{1774}$

\section{Tótselymes (Sáros megye) [Šarišské Sokolovce, SVK]}

Tótselymes 1349. évi határjárása egy révet érintett a Hyspotakaba (talán: Kispatak) tartó vízfolyáson. ${ }^{1775}$

\footnotetext{
1770 AO VI. 161-162. (Anjou-oklt. XXXVIII. 35. sz.). Weisz B.: Vásárok és lerakatok 160.

${ }^{1771}$ Bánffy 321. (Erdődy 568. sz.).

1772 Vö. Engel P.: Genealógia: Hontpázmány nem 7. Szegi-ág 1. tábla.

${ }^{1773}$ AO V. 176. (Anjou-oklt. XXXI. 241. sz.).

${ }^{1774}$ Somogy in comitatu Scepsiensi cum tribus tributis in possessionibus Paladyn Tothfaluw et Luchyna vocatis in eodem comitatu habitis exigi consuetis - DL 6905.

1775 ad unum portum infra rivulum caderet ad hyspotaka - DF 262 706. (Anjou-oklt. XXXIII. 917. sz.). Vö. Weisz B.: Vámok és vámszedés 402.
} 


\section{Töltszék (Sáros megye) [Tulčik, SVK]}

Töltszék vámja ${ }^{1776}$ 1347-től mutatható ki; Draskóczy István szerint Kapi vámját helyezhették át ide, valamikor 1347 előtt, mivel Kapi 1347. évi eladományozásakor a kapi vámot nem említették. ${ }^{1777}$ A töltszéki vám királyi vám volt, ${ }^{1778}$ és a sárosi várhoz tartozott ${ }^{1779}$ - ekkoriban Szécsényi Kónya sárosi (szepesi és nógrádi) comes adminisztrálta. Kónya sárosi ispánsága idejéből (1346-1349) ${ }^{1780}$ egymást érték az eperjesi kereskedők panaszai a király és az anyakirályné felé, amiért az ispán vámszedői öket a töltszéki vám felkeresésére és ott, szokásuk ellenére, vámfizetésre kényszerítik. Lajos és Erzsébet mindannyiszor az eperjesiek által sérelmezett gyakorlat felfüggesztésére utasították Kónyát és vámszedőit ${ }^{1781}$ - úgy tünik, kevés foganattal. 1364-ben a király egy újabb panasz nyomán Kont Miklós nádort és sárosi comest utasította az eperjesiek Töltszékre kényszerítésének felfüggesztésére. ${ }^{1782}$

Az 1355. évi sárosi vámvizsgálat szerint Töltszéken híd állt, amit azonban a kereskedők nem használtak (per quem tamen mercatores transire non dicuntur). ${ }^{1783}$ A vámrevízió során arra is fény derült, hogy Töltszéken mértéken felüli vámot szednek; ráadásul az a hír járta, hogy a helyi vámosok a vámhely 1-2 mérföldes körzetében lévő utakon feltartóztatják, kifosztják és meggyilkolják a Töltszéken vámot nem fizetőket. ${ }^{1784}$

\section{Trencsén megye}

Domonkos nyitrai püspök 1382-ben azt állította Erzsébet királynénak, hogy a Trencsén megyében a vásárokon és kikötőkben szedett vámok harmada és tizede „régóta” a nyitrai egyházat illeti, ${ }^{1785}$ és annak az egyház a birtokában is volt egészen addig, amíg Ostfi János

\footnotetext{
1776 Vö. Weisz B.: Vámok és vámszedés 403.

1777 Draskóczy I.: Sáros megye vámhelyei 48.

1778 Draskóczy I.: Sáros megye vámhelyei 58-59.

1779 1364: ad dictum locum tributi, in ipsa villa Tulchig existentis ac etiam ad alia loca tributorum in tenutis dicti comitatus et castri nostri Sarus - Iványi, Eperjes 29.

1780 Vö. Engel P.: Archontológia 170.

1781 1347: in villa Teuchyk tributum ab eis exigere faceretis ubi prius tributum non soluissent quia viam aliquam ad ipsam villam Teuchyk non haberent - DF 228 448; 1348: DF 228455 (Juck 161-162.); 1349: 228456 (Juck I. 163.); 1349: Juck 163.

1782 Iványi, Eperjes 29-30.

1783 Draskóczy I.: Sáros megye vámhelyei 58-59.

1784 verum eciam in diversis viis ab ipso thelonio in spacio unius miliaris aut duorum obsidentes transeuntes occasione tributi spoliari, predari, mactare et interficere non vererentur - Draskóczy I.: Sáros megye vámhelyei 61.

1785 decima et tercia pars tributorum in portibus et foris per comitatum Trenchyniensem exigi consuetorum semper et ab antiquo ad prefatam ecclesiam suam Nitriensem pertinuisset - DF 273059.
} 
nem kapta meg a trencséni várat és ispánságot a királytól (1381-1382), ${ }^{1786}$ és le nem foglalta az egyháznak járó vámrészeket. ${ }^{1787}$ A nyitrai püspök jogai bizonyítására egy régi kiváltságlevelet - István hajdani országbíróét ${ }^{1788}$ (quoddam privilegium antiquum Stephani videlicet olym aule regie iudicis) - mutatott be. Erzsébet végül, miután Domonkos állítását többen megerősítették (Zámbó Miklós királyi tárnokmester, a trencséni vár korábbi birtokosa is), visszaállította a püspök vámjogát, és parancsba adta a jelenlegi (Treutel Miklós) és a mindenkori trencséni comesnek és várnagynak, hogy azt tartsa tiszteletben. ${ }^{1789}$

\section{Türe (Kolozs megye) (Turea, RO)}

A váradi káptalan 1373-ban megalapozottnak találta Ottó kolozsmonostori apát panaszát, aki nehezményezte, hogy Péter fia Demeter erdélyi püspök (1368-1376) ${ }^{1790}$ Türe birtokán vámot szedet - jogtalanul, mivel itt vámszedés a püspök ideje előtt nem volt szokásban. ${ }^{1791} \mathrm{~A}$ püspök türei officialisai (Miklós és Bálint de Wtas) az apát egyik jobbágyától - aki vélhetően nem volt hajlandó kifizetni a vámot - 4 ökröt vettek el szekerestől és egy hordó bort: az állatokat a gyalui püspöki curiába hajtották, a bort pedig megtartották maguknak. ${ }^{1792}$

\section{Ugod (Veszprém megye) [Ugod, H]}

Ugod faluban keddenként hetivásárt (forum provincie) tartottak, ${ }^{1793}$ ami legkorábban 1350ből adatolható. ${ }^{1794}$

\footnotetext{
${ }^{1786}$ Engel P.: Archontológia I. 212.

${ }^{1787}$ DF 273059.

${ }^{1788}$ Személyére az oklevél más támpontot nem ad.

1789 DF 273059.

${ }^{1790}$ Engel P.: Archontológia I. 70.

1791 tamen in dicta possessione episcopali Tyre tributum consuetum fuisse usque huc per veteres minime memorerentur, nisi tempore episcopatus prefati domini Demetrii episcopi in eadem possessione Tyre dictum tributum recipiendi et persolui faciendi in consuetudinem habuissent sine omni racione - DF 275192.

1792 DF 275192.

${ }^{1793}$ Weisz B.: Vásárok és lerakatok 171.

${ }^{1794}$ DL 41159.
} 


\section{Ugróc (Bars megye) [Vel'ké Uherce (Nagyugróc), SVK]}

Lajos Jakab fia Miklós mester udvari familiáris Ugróc birtokán 1364-ben keddi hetivásár (forum liberum) tartását engedélyezte - nem először, az oklevél ugyanis egy korábbi ugróci vásárengedélyre is utal, amit a király boszniai hadjárat során ellopott királyi nagypecsétjével hitelesített. ${ }^{1795}$

\section{Ujak (Sáros megye) [Údol (Sárosújlak), SVK]}

1349-ben a palocsai districtusi Fábián fia Miklós soltész Ujak falu soltészságát - amelyet korábban Lajos király engedélyével szerzett meg Berzéte Miklós mester szabolcsi ispántól, Adorján várnagyától ${ }^{1796} 20$ kassai márkáért - egy fertó híján 56 szepesi garasmárkáért eladta Levkfalvi Ménárd fia Wyllamnek és a Szepes megyei csütörtökhelyi (Quintumforum) Chunczmannus fia Hannusnak. A szepesi káptalan okelevele a soltészsággal járó jogok és haszonvételek között vámmentességet (exempcione a telonio et tributo) is felsorol. ${ }^{1797}$

\section{Újfalu (Pest megye) [Monortól DK-re, H]}

Újfalu a 14. század közepén vámos hely volt, Harsundorfi Wlueng és testvére, Sedul birtoka. A testvérek Újfalut és vámját 1346. június 7-től 100 budai márka súlyú bécsi dénárért 3 évre elzálogosították Telegdi Csanád esztergomi érseknek (non nomine ecclesie seu archi[epis]copatus sui sed in solidum racione sue nobili[tatis]) és rokonainak, Lörinc fia Tamásnak, Miklós fia Györgynek, illetve Pongrác fia Kelemennek. ${ }^{1798}$ A zálogszerződésben a Harsundorfiak Hont megyei Visk birtokukat (szintén vámos hely) ajánlották fel arra az esetre, ha a Telegdieket Újfalu és vámja birtokában nem tudnák szavatolni. ${ }^{1799}$ 1347-ben, miután Wlueng Zára alatt örökös nélkül meghalt, Lajos összes birtokát Szécsényi Kónya ${ }^{1800}$ mester sárosi comesnek, udvari lovagnak és feleségének, Wlueng mester lánytestvérének,

\footnotetext{
${ }^{1795}$ DL 16117.

1796 Vö. Engel P.: Archontológia I. 184.

${ }^{1797}$ DF 263 709. (Anjou-oklt. XXXIII. 26. sz.).

1798 Vö. Engel P.: Genealógia: Csanád nem 1. Főág 2. tábla: Telegdi.

${ }^{1799}$ DL 30644.

1800 Vö. Engel P.: Genealógia: Kacsics nem 4. tábla: Szécsényi.
} 
Erzsébetnek adományozta - Újfalut is, vámjával egyetemben (cum tributo quod ibidem exigitur). ${ }^{1801}$

\section{Újfalu ${ }^{1802}$ (Sáros megye) [Pečovská Nová Ves (Pécsújfalu), SVK]}

Újfalu vámja 1347-ban ${ }^{1803}$ és 1355-ben, a sárosi vámvizsgálat idején Ákos nembéli Mikcs fia Loránd ${ }^{1804}$ birtokában volt, és - hosszú idő után - mintegy három éve hídja is megépült. ${ }^{1805}$ A felülvizsgálat során a vám tarifáját is feljegyezték, ${ }^{1806}$ ahogy azt is, mennyire hamvába holt ötlet volt vámosa visszaélései miatt Lorándtól elégtételt várni. ${ }^{1807}$ Az újfalusi vámot, ami a Sáros megyei Újvár ${ }^{1808}$ tartozéka volt, Loránd testvérei, Ákos és István 1370ben a várral és uradalmával együtt elcserélték az ónodi Cudarokkal ${ }^{1809}$ több szlavóniai (Zágráb megyei) birtokért. ${ }^{1810}$

\section{Ungvár (Ung megye) [Uzshorod, UKR]}

Ungvár keddi hetivásáráról (forum in possessione Unguar celebrari consuetum) első ízben 1380-ban hallunk, amikor Ung megye hatósága királyi parancsra kivizsgált egy ott történt verekedési és sebesítési esetet. ${ }^{1811}$

\footnotetext{
${ }^{1801}$ DL 64 714. (F. IX/2. 207-209., HO. VII. 402-403.). Az adománylevelet a király 1353-ban megerősítette. DL 64714.

${ }^{1802}$ Korábbi történetére lásd Weisz B.: Vámok és vámszedés 410-411.

${ }^{1803}$ DL 874. (Anjou-oklt. XXXI. 824.), DL 64 662. (Anjou-oklt. XXXII. 702. sz.).

${ }^{1804}$ Vö. Engel P.: Genealógia: Ákos nem 4. Mikcs ága 1. tábla: Mikcsfi.

${ }^{1805}$ Draskóczy I.: Sáros megye vámhelyei 59.

${ }^{1806}$ Lásd a Vámtarifák c. fejezetben.

1807 cum autem tributarius ipsius magistri Lorandi aliquem per ipsum tributum transeuntem calumpniatus fuisset et idem calumpniatus se cum plebano vel iudice aut aliis probis viris de possessione Wyfalu predicta voluisset iustificare et eciam iustificasset idem magister Lorandus iustificacionem ipsius huiusmodi non advertisset, nec recepisset stans tantum et credens assercioni sui theloniatoris - Draskóczy I.: Sáros megye vámhelyei 60.

${ }^{1808}$ Ma Hanigovce, Szlovákia.

${ }^{1809}$ Bőcsi Dénes fia Domonkos fiaival (Cudar Péter szlavón bán, István, Mihály, György, János fehérvári őrkanonok, Imre kalocsai prépost). Vö. Engel P.: Genalógia: Cudar (bőcsi, ónodi) 2. tábla: Cudar.

1810 DL 5816 = DL 6179 = DL 41800 (F. IX/7. 583.: 1374. évi kelettel, hibásan). Vö. DL 33 674, DL 5824, DL 33 675. Engel szerint a birtokcserét 1373-ben érvénytelenítették, azonban a megállapítását alátámasztandó oklevél (DL 5959) ezt nem bizonyítja. Engel P.: Archontológia I. 453.
}

${ }^{1811}$ DL 52 333. Weisz B.: Vásárok és lerakatok 168. 


\section{Üzbég (Nyitra megye) [Zbehy, SVK]}

Üzbég szombati hetivására 1381-ben háromvásáros kikiáltás színtere volt. ${ }^{1812}$

\section{Vadkert (Nógrád megye) [Érsekvadkert, H]}

1343-ban, miután Telegdi Csanád érsek IV. Béla 1255. évi oklevelével ${ }^{1813}$ bizonyította, hogy Vonuntótelek, Mokafölde és Lukafölde mellett Donkos tizedszedő földje (terra Donkus decimatoris) is az érseki Vadkert birtok határain belül fekszik (a Szentlőrinc felöli részen), az óbudai káptalan bejárta a négy föld határait, ennek során pedig érintett egy régi hidat, ami, úgy tünik, a Lokos (Lulkus) patakon ${ }^{1814}$ vezetett át. ${ }^{1815}$

\section{Vajszló (Baranya megye) [Vajszló, H]}

I. Lajos 1354-ben a Nyúl-szigeti apácák Vajszló birtokán keddi hetivásár tartását engedélyezte a királyi és más vásárok sérelme nélkül. ${ }^{1816}$

\section{Valkó (Somogy megye) [Barcstól É-ra, H]}

1359-ben Valkó faluban hetivásárt tartottak - ez év május 2-én (csütörtöki nap) a vásárról jövő Péter fia Pált Péter visontai villicus, királynéi jobbágy elfogta, elvette javait, és három napig fogságban tartotta. ${ }^{1817}$

\footnotetext{
1812 DL 75 553. Weisz B.: Vásárok és lerakatok 154.

1813 Reg. Arp. 1048. sz.

${ }^{1814}$ A Vadkerttől keletre folyó Lokos-patak mindhárom katonai felmérésen szerepel.

1815 iret usque ad anticum pontem, et sic incipiendo a dicta magna via usque ad Lulkus [seu usque ad ipsum anticum pontem, novem signa nova pro metis posuissent, et inde transiret ipsum Lulkus, ascenderet ad quedam] - Str. III. 514. (Anjou-oklt. XXVII. 572., 629. sz.).

${ }^{1816}$ F. IX/2. 318-319. (Anjou-oklt. XXXVIII. 242. sz.).

${ }^{1817}$ DF 200951.
} 


\section{Válus (Somogy megye) [Somogyviszlótól É-ra, H]}

Válus a 14. század közepén vásáros hely volt. A pécsi káptalan a Szerdahelyiek birokát 1363-ban vásárával együtt (cum ... foro in eadem celebrari consueto), Szerdahelyi Ders fia Péter fia Mihály mester ${ }^{1818}$ (képviselőjének) jelenlétében Viszlói Vörös Lászlónak és fiának, Jánosnak iktatta. Válust Szerdahelyi Mihály a Viszlóiakkal történt megegyezése (composicio) feltételeként, az általa elkövetett jogtalanságok váltságaként, elégtétel gyanánt (pro sua expedicione et satisfaccione) adta át. ${ }^{1819} \mathrm{Az}$ iktatásról szóló jelentésében a káptalan megemlítette, hogy a statutio napján (november 9.) Mihály mester a válusi vásártartásra jogosító királyi oklevelét nem mutatta be Lászlónak és Jánosnak. ${ }^{1820}$

\section{Várad (Bihar megye) [Oradea (Nagyvárad), RO]}

Várad szombati hetivására 1374-ben háromvásáros kikiáltás helyszíne volt. ${ }^{1821}$

\section{Váralja (Turóc megye) [Kláštor pod Znievom (Znióváralja), SVK]}

1361-ben Váralja hetivására háromvásáros kikiáltás színtere volt. ${ }^{1822}$

\section{Varannó (Zemplén megye) [Vranov nad Topl'ou, SVK]}

I. Lajos 1350-ben Rozgonyi János fia László és unokatestvére, Péter fia Miklós ${ }^{1823}$ kérésére Varannó birtokukon hétfőnkénti hetivásár (forum liberum) tartását engedélyezte. ${ }^{1824}$

\footnotetext{
1818 Vö. Engel P.: Genealógia: Győr nem 2. Szerdahelyi-ág 1. tábla.

${ }^{1819}$ DL 5262. (Anjou-oklt. XLVII. 573. sz.).

1820 litteras autem maiestatis vestre quarum vigore forum in dicta possessione Walus celebraretur in dicto statucionis termino ... non presentasset - DL 5262.

${ }^{1821}$ DF 233883.

1822 A vásár napja nélkül. DL 63 076. (Justh 34. sz.). Vö. Weisz B.: Vásárok és lerakatok 168.

1823 Vö. Engel P.: Genealógia: Básztély nem 2. tábla: Rozgonyi (Miklós ága).

${ }^{1824}$ F. IX/1. 768-770. (Anjou-oklt. XXXIV. 626. sz.). Weisz B.: Vásárok és lerakatok 175.
} 


\section{Várda (Kisvárda) (Szabolcs megye) [Kisvárda, H]}

Várda szerdai hetivására 1348-ban ${ }^{1825}$ és 1370-ben ${ }^{1826}$ háromvásáros kikiáltás színhelye volt.

\section{Vári (Bereg megye) [Vari, UKR]}

Várinak 1354-ben Erzsébet királyné Buda és az ország más királyi városainak szabadságait biztosította. A vári polgárok és hospesek ekkor országos, a száraz- és a vízi vámokra is érvényes vámmentességet nyertek. ${ }^{1827}$

A Bereg megyei ${ }^{1828}$ Váriban a 14. században vasárnaponként hetivásárt tartottak. 1354ben, a település kiváltságolásakor Erzsébet királyné egyúttal a vári polgárok és hospesek vásártartási jogát is megerősítette. ${ }^{1829}$

\section{Várkony (Külső-Szolnok megye) [Tiszavárkony, H]}

1347-ben, amikor a király Poroszlót tiszai rév- és szárazvámjával együtt Neszmélyi Miklós pécsi püspöknek és testvérének, Mátyásnak adományozta, megtiltotta, hogy az átkelő kárára Poroszló és Várkony között bárki - a kereskedők és utazók előtt is nyitva álló - révet létesítsen a folyón. ${ }^{1830}$

\footnotetext{
1825 Z. II. 349-350. (Anjou-oklt. XXXII. 924. sz.).

${ }^{1826}$ Bánffy 321. (Erdődy 568. sz.).

${ }^{1827}$ ipsi cives et hospites nostri de Vary nullum in regno nostro Hungarie tam in terris quam super aquis tributum dare et solvere teneantur - DL 4471. (Anjou-oklt. XXXVIII. 533. sz.). Az oklevelet a váradi káptalan 1361-ben átírta: DL 4471.

${ }^{1828}$ Vári Békés megyébe történő lokalizálása és Gyulavárival (ma Gyula része, H) való azonosítása ellen szól, hogy az oklevélben, amiben átírják Erzsébet privilégiumát, a váriak 1479-ben Beregszásszal pereskedtek bizonyos Czybikfölde (az MNL OL-regeszta Czytikföldéje inkább Czybikföldének olvasható) prédium miatt (DL 4471_4), ami pedig a Bereg megyei Vári mellé lokalizálható (Gy. I. 536.). Vö. Weisz B.: Vásárok és lerakatok 138.

${ }^{1829}$ DL 4471. (Anjou-oklt. XXXVIII. 533. sz.).

1830 adiecisset eciam ipse ... Lodovicus rex, quod quia inter predictam possessionem Porozlow et possessionem Warkun nominatam in aliquo locorum portus seu transitus viatorum aliquo unquam tempore inventum fuisse minime prohiberetur, obhoc commisisset, ut nullus omnino hominum inter dictas duas possessiones Porozlow et Warcun nominatas qualicunque modo portum seu transitum viatorum quorumlibet in preiudicium porti in dicta possessione Porozlow habiti ad invenire vel pro se ipso construere minime posset atque valeret - AO VI. 305.
} 


\section{Vasvár (Vas megye) [Vasvár, H]}

A vasvári hétfői hetivásáron 1358-ban ${ }^{1831}$ és 1362-ben is háromvásáros kikiáltásra került sor. ${ }^{1832}$

\section{Vátka (Zala megye) [Zalaszántótól Ék-re, H]}

Amikor Vátkai Dénes fiai 1347-ben a veszprémi káptalan előtt Uzsai Miklós fiainak adták Vátka egy részét - részben nagyanyjuk leánynegyede fejében, részben azért a 15 márka széles bécsi dénárért cserébe, amit korábban az Uzsaiaktól kaptak -, az átadott terület határai között szerepelt egy folyómedren átívelö kőhíd. ${ }^{1833}$ A híd a Gyöngyös patak egyik mellékfolyásán vezethetett át.

\section{Véged (Zala megye) [Zalavég, H]}

A Ják nembéli Sitkeiek Véged falujában a Károly-korban csütörtökönként hetivásárt tartottak, ami az 1340-es évekre tönkrement. I. Lajos 1346-ban Sitkei István és Lőkös ${ }^{1834}$ kérésére újra kihirdettette a vásárt, ${ }^{1835}$ hogy az régi állapotát visszanyerje. ${ }^{1836}$

\section{Velemér (Zala megye) [Velemér, $\mathrm{H}$ ]}

1349-ben a kapornaki konvent tanúságával sor került Velemér - IV. László 1273. évi oklevele szerinti - határjárására, ami Torsey hídját (pontem Torsey) is érintette. ${ }^{1837}$

1831 DL 108 127. (Savaria-Szombathely 75. sz.).

1832 F. IX/7. 516. (Anjou-oklt. XLVI. 457. sz.). 1363-ban a vasvári vásár szintén háromvásáros kikiáltás helyszíne volt. DL 5196. (Anjou-oklt. XLVII. 102. sz.).

1833 inde eundo cadit iuxta pontem lapideum ad meatum fluvii iuxta metas terre Zwe - Zala I. 468. (Anjou-oklt. XXXI. 1073. sz.).

1834 Vö. Engel P.: Genealógia: Ják nem 3. Rába-jobbparti fóág 2. tábla: Sitkei.

1835 Zala I. 428-429. (Anjou-oklt. XXX. 29. sz.). Vö. Weisz B.: Vásárok és lerakatok 174.

1836 supplicantes exinde nostre maiestati ut ipsum forum per novas proclamaciones literis nostris mediantibus fiendas in suum pristinum statum revocari et restaurari facere dignaremur - Zala I. 428. 


\section{Vereb(ély) (Nógrád megye) [Mátreverebély, H]}

A szepesi káptalan 1348. augusztus 26-án királyi parancsra kivizsgálta Csetneki Péter nógrádi alispán állításait, akire, miután augusztus 15-én, Nagyboldogasszony ünnepén Vereb faluban elfogott és a szállására vitt egy tolvajt, Hasznosi Domonkos fia, „Nagy” Domonkos és fia, István kompániájával hatalmaskodva rátámadt, több rokonát és famulusát megölte vagy megsebesítette, 200 márkányi javát elvitte, a tolvajt pedig kiszabadította. A káptalani vizsgálat az alispán állításait lényegében megerősítette - fontos eltérés azonban, hogy a relatoria szerint az eset nem augusztus 15-én, hanem 14-én, Nagyboldogasszony vigíliáján történt, hogy az alispán a tolvajt a vásáron (in foro) ejtette foglyul, és hogy a szabadon engedését sikertelenül követelő Domonkossal és Istvánnal együtt az egész vásárnép (omnes forenses et advene) is Csetneki Péter házára támadt. ${ }^{1838}$ Kérdés, milyen verebi vásárról lehet szó az iménti esetben. Habár a forrás forum kifejezése önmagában inkább hetivásárra utalna, korántsem zárható ki, hogy a Nagyboldogasszony ünnepéhez (augusztus 15.) kötődő verebi sokadalmat, amelynek ismert vásárengedélye 1398. évi keletű, ${ }^{1839}$ már ekkor is megrendezték.

\section{Veszprémvölgy (Veszprém megye) [Veszprém mellett, H]}

1364-ben Lajos megtiltotta a királyság száraz- és vízivámszedőinek, hogy a veszprémvölgyi apácák birtokairól a kolostorba, élelmezésükre szállított bort, gabonát, marhákat és más élelmiszereket (és azok szállítóit) vámmal sújtsák, ${ }^{1840}$ mivel „a nemesek és más birtokosok élelmiszerei után, amit egyik birtokukról a másikra, vagy telekhelyeikre szállítanak, semmilyen vám nem szedhető". ${ }^{1841}$ Az apácák e kiváltságát Rusint (Rusynth) apátnő kérésére a király 1373-ban megerősítette. ${ }^{1842}$

1837 DL 3968. (Anjou-oklt. XXXIII. 802. sz.). Vö. Weisz B.: Vámok és vámszedés 429. A zalai-vasi megyehatáron fekvő Velemér Zala megye alatt szerepeltetését az indokolja, hogy az üggyel a Hahót nembéli Miklós zalai ispán foglalkozott. Vö. DL 3968., Weisz B.: Vámok és vámszedés 429.

1838 AO V. 222-224. (Anjou-oklt. XXXII. 584. sz.).

1839 Weisz B.: Vásárok és lerakatok 153.

1840 VVOS 272.

1841 cum de victualibus nobilium et aliorum possessionatorum hominum que de una possessione ipsorum ad aliam possessionem vel ad alia loca mansionis eorundem deferuntur, tributum exigi non liceat aliquale - VVOS 272.

1842 VVOS 312-313. 


\section{Vezseny (Külső-Szolnok vmegye) [Vezseny, H]}

Lajos Vezsenyi Domokos fia Miklós ${ }^{1843}$ udvari vitéz és vitányi várnagy érdemeiért, annak kérésére 1349-ben a Tisza melletti Vezseny faluban csütörtöki napokon hetivásár (forum) tartását tette lehetővé a szomszédos vásárok sérelme nélkül. ${ }^{1844}$

\section{Visk (Hont megye) [Vyškovce nad Ipl'om (Ipolyvisk), SVK]}

Visk a 14. század közepén vámos hely volt, ${ }^{1845}$ Harsundorfi Wlueng és testvére, Sedul birtoka. Amikor a testvérek Újfalut és vámját 1346. június 7-től 100 budai márka súlyú bécsi dénárért 3 évre elzálogosították Telegdi Csanád esztergomi érseknek (non nomine ecclesie seu archi[epis]copatus sui sed in solidum racione sue nobili[tatis]) és rokonainak, Lörinc fia Tamásnak, Miklós fia Györgynek, illetve Pongrác fia Kelemennek, ${ }^{1846}$ a zálogszerződésben a Harsundorfiak Hont megyei Visk birtokukat ajánlották fel arra az esetre, ha a Telegdieket Újfalu és vámja birtokában nem tudnák szavatolni. ${ }^{1847}$ 1347-ben, miután Wlueng Zára alatt örökös nélkül meghalt, Lajos összes birtokát Szécsényi Kónya ${ }^{1848}$ mester sárosi comesnek, udvari lovagnak és feleségének, Wlueng mester lánytestvérének, Erzsébetnek adományozta Visket is, vámjával (cum tributo) és a hozzá tartozó Sztarcsán és Szemeréd birtokokkal együtt. ${ }^{1849}$

\section{Visonta (Heves megye) [Visonta, $\mathrm{H}$ ]}

A visontai hetivásár ${ }^{1850}$ 1363-ban háromvásáros kikiáltás színhelye volt. ${ }^{1851}$ Kérdés, melyik, az Anjou-korból ugyanis a péntekire (1322) és a szombatira (1358) is van adatunk. ${ }^{1852}$

\footnotetext{
1843 Vö. Engel P.: Genealógia: Vezsenyi.

1844 DF 244 325. (Anjou-oklt. XXXIII. 409. sz.).

1845 Vámjának korábbi történetére lásd Weisz B.: Vámok és vámszedés 434.

1846 Vö. Engel P.: Genealógia: Csanád nem 1. Főág 2. tábla: Telegdi.

${ }^{1847}$ DL 30644.

1848 Vö. Engel P.: Kacsics nem 4. tábla: Szécsényi.

1849 DL 64 714. (F. IX/2. 207-209., HO. VII. 402-403.). Az adománylevelet a király 1353-ban megerősítette. DL 64714.

${ }^{1850}$ Vö. Kovács B.: Középkori vámok 23.

1851 DL 64 067. (Anjou-oklt. XLVII. 175.).

1852 Weisz B.: Vásárok és lerakatok 146.
} 
A szombati hetivásár Visontai Pál fia Imre fiai, János, István és Imre ${ }^{1853} 1358$. évi birtokfelosztó okleveléből ismert, ami a vásárral kapcsolatban azt írta elő, hogy egy bizonyos kőhíd körül kell tartani, mégpedig úgy, hogy a kalmárok és a mészárosok a székeiket a híd felől, amellett állíthatják fel. A vásárt egyik szombaton János mester, a másikon István, a harmadikon Imre rendezte, akik „saját napjukon” a bírságpénzeket és a vásár egyéb más jövedelmeit is élvezték. ${ }^{1854}$ A szombati vásár rendjét is megszabó oklevelet 1365-ben a testvérek privilegiális formában átíratták az egri káptalannal. ${ }^{1855}$

Az 1358. évi oklevél az említett kőhíd közelebbi lokalizálásához is támpontot ad, eszerint „a Magyarfalunak mondott harmadik utcát a kőhídtól kezdve” (terciam plateam Magyarfalu dictam ab ipso ponte lapideo incipiendo) Imre kapta. ${ }^{1856}$

\section{Zágráb (Zágráb megye) [Zagreb, HR]}

A 14-15. században Zágrábban a vámszedés különböző formái éltek. Vámot szedett, illetve szedetett a zágrábi püspök, a székeskáptalan, a gréchegyi királyi polgárok és a királyné is. A zágrábi egyházmegye területén a vásár- és révvámok tizede (így a zágrábi vásárvámé is) a püspököt illette; a zágrábi vásárvám bevételét - a püspök tizedén kívül - a káptalan élvezte; ezen kívül az Anjou-kori forrásokban találkozunk a polgárok nehezen definiálható filarchinum, valamint star nevü vámjával, végül a Száva folyó Zágráb melletti, Királyrévének nevezett átkelőjénél harmincadállomás működött - a feltételezések szerint már az Árpád-kor óta. ${ }^{1857}$

1292-ben III. András a zágrábi vásárvám (tributum fori nostri de Monte Grecensi) harmadát a vám kétharmadára már András uralkodása előtt királyi adományt kieszközlő zágrábi káptalannak juttatta. ${ }^{1858}$ Az egyházat a vásárvám birtokában 1318-ban I. Károly is megerősítette, és egyben ígéretet tett arra, hogy a városban másfajta vámot senki nem állíthat

\footnotetext{
1853 Vö. Engel P.: Genealógia: Aba nem 7. Kompolt ága 2. tábla: Visontai.

1854 commiserunt eciam statuentes quod in ipsa possessione Vissontha forum non alias nisi circa ipsum pontem lapideum locari posset et celebrari et quod institores et carnifices sedes suas a parte ipsius pontis et prope eundem semper locandi habeant facultatem et quod ordo eciam ipsius fori sic haberi deberet quod una die sabbati ipsum forum cum iudicatu et aliis quibuslibet proventibus suis per dictum Johannem magistrum in alio sabbato per memoratum Stephanum et tercio vero sabbato similiter quo supra per eumdem Emericum regeretur et gubernaretur et sic talis ordinis circuitis in regimine saepedicti fori per prefatas partes et partium heredes in sempiternum habere deberet et possideri contradiccione quorumlibet non obstante - AO VII. 62. (Anjou-oklt. XLII. 191. sz.).

${ }^{1855}$ DL 4732. (F. IX/. 598-602.).

1856 AO VII. 59-60.

1857 Pach Zs. P.: A harmincadvám az Anjou-korban 233., Weisz B.: Az Árpád-kori harmincadvám 14.

1858 1292. június 26.: Smič. VII. 96-97. (Reg. Arp. 3880. sz.). Weisz B.: Vámok és vámszedés 437.
} 
fel (nullus ... presumat ... in eo loco aliquod aliud tributum quacumque arte vel ingenio constituere vel eciam ordinare $)^{1859}$ - mindez persze nem érintette a zágrábi királynéi tricesimát.

A zágrábi vásárvám tizede, ahogy a zágrábi egyházmegye területén szedett összes vásárvagy révvámé, a püspököt illette. ${ }^{1860}$

A vásárvám tarifáját 1343-ban maga a zágrábi, ${ }^{1861}$ 1346-ban pedig - előbbi kérésére - az esztergomi káptalan is írásba foglalta (lásd 1. táblázat). ${ }^{1862}$ A zágrábi káptalan vámszedője 1346 márciusában György villicus volt, aki a vámot egy könyvecskében (quarta) leírtak alapján szedte. ${ }^{1863}$ A két vámtarifa szinte teljesen megegyezik, az 1346. éviben a korábbihoz képest két - talán szándékosnak minősíthető - eltérés érhető tetten: egyrészt új vámalapként szerepel benne az értékbecslés alapján vámolandó (vám = a vámérték 1/100 része), légelyben szállított tengerentúli olaj, füge és szőlő, másrészt 1 szekér gabona után már nem tizenkét dénár vámot róttak ki (hatot a vevőre és hatot az eladóra), mint 1343-ban, hanem csak nyolcat (négyet a vevőre és négyet az eladóra ). A lóteherként (pondus equi) szállított gabona vámja ellenben nem változott, vámtétele mindkét évben négy (2-2) dénár volt.

A két hetivásár-vámszabásban valójában három különböző vámfajtát találunk: a szigorúan vett, a vásárok áruforgalmát érintő vásárvámot, ${ }^{1864}$ a Zágrábon (ideértve a Gréc-hegyet és a káptalan területeit is értve) árukat átszállító, nem lekötözött bálás szekerekre átalányban kirótt, fix tarifájú, útvámnak minősíthető illetéket (összege 12 jó báni dénár, amiből 70 ért egy tiszta aranyforintot vagy dukátot), ${ }^{1865}$ illetve a mesteremberektől szedett, évi 15 dénárt kitevő, három 5 dénáros részletben fizetendő, ,iparüzési adó”-nak tekinthető vámot. ${ }^{1866}$ Az útvámot a káptalan feltehetően a Zágrábon át- vagy amellett elhaladóktól szedte a hetivásárok idején, az

\footnotetext{
1859 1318. június 28.: Smič. VIII. 503. (Anjou-oklt. V. 173. sz.). Weisz B.: Vámok és vámszedés 437.

1860 Weisz B.: Vámok és vámszedés 437. A megyéspüspököt a vámok tizedének birtokában 1217-ben II. András, 1318-ban pedig I. Károly is megerősítette. Uo. 3771. sz. jz.

1861 Tkalčić, Mon. ep. Zagr. II. 20-21. (Anjou-oklt. XXVII. 23. sz.).

1862 Smič. XI. 283-286. (Anjou-oklt. XXX. 264. sz.).

1863 Smič. XI. 284.

1864 item de curribus ballarum, qui ducuntur ad montem grecensem, sive castrum, quorum merces vel ex eis alique vendicioni exponuntur - Tkalčić, Mon. ep. Zagr. II. 20.

1865 primo igitur de singulis curribus ballarum cum mercibus honeratis, non disligatis, Zagrabie transeuntibus quocumque et undecumque per territorium ipsorum grecensium vel nostrum prope Zagrabiam ... exigitur eciam tributum ordine inferius distincto de animalibus et rebus aliis venalibus, que transeunt vel ducuntur per Zagrabiam vel circa quocumque, semper tamen previa racione - Tkalčić, Mon. ep. Zagr. II. 20.

1866 item quilibet suam vitam ducens cum aliqua arte vel magisterio, sive sit tabernator potus cuiuscumque, sive pellifex aut lucifigulus cum similibus tenetur solvere pro tributo annuatim ad festum nativitatis domini quinque denarios et similiter ad festum resurreccionis eiusdem, et eodem modo ad festum beati regis Stephani - Tkalčić, Mon. ep. Zagr. II. 21.
} 
éves vám megfizetése pedig a zágrábi kocsmárosoknak, szücsöknek, fazekasoknak és más iparosoknak tehette lehetővé a vásárok napján történő vámmentes kereskedést. ${ }^{1867}$

A zágrábi hetivásárokon a vámszabások szerint élöállatok (ökör, tehén, disznó, juh, ló), különféle élelmiszerek (só, bor, olaj, gabona, zöldségek, sózott és friss halak, rák, méz, gyümölcsök), posztó és egyéb iparcikkek és nyersanyagok, így vas, épületfa, len, fonal, ruhák, állatbőrök és viasz cseréltek gazdát.

A káptalan vámszedői a vámköteles kereskedők a Gréc-hegyen vagy máshol is feltartóztathatták. ${ }^{1868}$ A vámszedésből fakadó viták eldöntését Gréc 1324-ben, majd 1343-ban is a káptalannak engedte át. ${ }^{1869}$

Utóbbit föleg azért fontos kiemelni, mert a vásárok feletti joghatóságot különben a város gyakorolta. ${ }^{1870}$ Zágrábban napi piacot, illetve heti, és éves vásárokat is tartottak. ${ }^{1871} \mathrm{~A}$ mindennapi árusítást (forum cottidianum) és a város hétfői és csütörtöki hetivásárait a város 1242. és 1266. évi kiváltságlevele engedélyezte. ${ }^{1872}$ A 15. század '30-as éveiben már a vasárnap is hetivásári nap volt, egy 1435. évi városi oklevélből ugyanis megtudjuk, hogy virágvasárnap (április 10-én) a gréci vásáron (forum liberum) Mátyás zágrábi kanonok halárusokat vert, majd miután a vásáron a városbíró elé vitték, szidalmazni kezdte őt. Esetleg felmerülhetne, hogy az adat valójában az áprilisi zágrábi éves vásárra vonatkozik, de az április 25-i, a városi plébániatemplom patrónusa, Szent Márk napjához (április 25.) kötődő sokadalom IV. Béla 1256. évi vásárengedélye alapján az ünnep előtt 8 nappal kezdődhetett, április 18-án (és az ünnepet követő 8 napon át tarthatott, május 2-ig) ${ }^{1873}$ - az iménti atrocitás pedig április 10-én történt. ${ }^{1874}$ Zágrábban a Márk-napin kívül 1372-től Antiochiai Szent Margit ünnepén, július 13-án, ${ }^{1875}$ és az azt megelőző és követő 8-8 napon is sokadalmat tartottak. Utóbbit I. Lajos a budai és a fehérvári éves vásárok mintájára engedélyezte. ${ }^{1876}$

\footnotetext{
${ }^{1867}$ A vásárok napján történő iparüzés szabályozását lásd pl. Esztergomban: Weisz B.: Vámok és vámszedés 148. 1288. április 18.: Str. II. 236-241.; 1324: Str. III. 48-49.

1868 Smič. XI. 286.

1869 1324: Tkalčić, Mon. ep. Zagr. II. 135. Vö. 93. jz. 1343: Tkalčić, Mon. ep. Zagr. II. 20.

1870 1242: si quis de extraneis intrans civitatem ... in foro ... perpetraverit ... per iudicem civitatis iudicetur Smič. IV. 173.

${ }^{1871}$ A zágrábi vásárokra lásd. Weisz.: Vásárok és lerakatok 172.

1872 item statuimus, quod in eadem civitate forum sollempne duobus diebus in ebdomada, videlicet die Lune et die Jouis celebretur et preterea forum cottidianum cottidie habeatur - Smič. IV. 174. Vö. Tkalčić, Mon. civ. Zagr. I. 43. Az újabb szakirodalom a zágrábi forum cottidianumon lerakathoz kötődő, tehát nagy tételben történő adásvételt ért. Weisz B.: Vámok és vámszedés 437. Vö. Weisz B.: Vásárok és lerakatok 17-18.

1873 Szende K.: Sokadalomtartási engedélyek 235-236.

1874 Vö. 1256. március 21.: Tkalčić, Mon. civ. Zagr. I. 26.

1875 Vö. Varga Sz.: Zágráb 262.

1876 sub eisdem libertatibus, legibus, cosvetudinibus, usibus et prerogativis in dicta civitate nostra Grecensi celebrandas, sub quibus forum annuale seu nundine in civitatibus nostris Budensi et Albensi celebrantur, duximus perpetuo annuendo concedendas - Tkalčić, Mon. civ. Zagr. I. 243.
} 
Eredetileg mindkét éves vásár vámmentes volt ${ }^{1877}$ - a Márk-napin a káptalan a város jóváhagyásával 1468-tól vámot szedhetett. ${ }^{1878}$ A vásártartás helye, a piactér egy 1494. évi adat szerint a Szent Márk városi plébániatemplom mellett volt. ${ }^{1879}$

A gréciek 1425. évi, Péter fia János bíró idején kiadott, egy évig hatályos statútumai (vagy modernebb kifejezéssel: városi rendtartása) a helyi iparüzést és a vásárokon folyó kereskedelmet is szabályozta. ${ }^{1880}$ Sajnos a rendeletekről sok esetben nem dönthető el egyértelműen, melyik kereskedelmi fórum müködését szabályozták - a napi, a heti, vagy az éves vásárokon, avagy az állandó üzletekben, „,boltokban” történő árusítást. Emiatt, hogy ne essünk el a forrás belső logikája nyújtotta támpontoktól, a vonatkozó statútumokat abban a sorrendben tárgyaljuk, ahogy azok a szövegben követik egymást.

Az első négy határozat a patikáriusokat (stacionarius seu apotecarius), a kenyér- és zsemlesütő asszonyokat (pistrices) és a vargákat érintette. A legelsőben a városi communitas a patikáriusoknak hiteles súlyok és mérlegek, valamint a vászon- és posztórőf tartását írta elő. ${ }^{1881}$ Aki a mértéket meghamisította, elvesztette áruját. Mivel a rendelet a szövetek elkobzásával fenyegetve tiltotta a posztó vászonrőffel, és fordítva, a vászon posztórőffel történő mérését, a két hosszmérték nyilvánvalóan különbözött. (Az európai gyakorlatban jellemzően a vászonrőf volt hosszabb a posztó- és a selyemrőfnél.) ${ }^{1882}$ Zágrábban tehát a patikáriusok is árulhattak kis tételben posztót és vásznat, míg például a középkori Budán a patikáriusoknak tilos volt rőffel mérendő árukkal, így például különféle szövetekkel kereskedni - éppen ez különböztette meg őket az ugyancsak kis tételben vegyeskereskedést űző kalmároktól. ${ }^{1883} \mathrm{Az}$ 1425. évi második, valószínüleg szintén a patikáriusokra vonatkozó statútum az 1 font olaj eladásával szerezhető nyereséget 2 dénárban maximálta. ${ }^{1884} \mathrm{~A}$ kenyérsütő asszonyok 1 köböl gabonán - beleértve a korpát is - 40 dénárt kereshettek; akinek pedig közülük kemencéje volt, azt a város 60 dénár büntetéspénz terhe mellett zsemlék

\footnotetext{
1877 1256: sine tributo quolibet celebrentur - Tkalčić, Mon. civ. Zagr. I. 26.; 1372: simulcum exempcione tributorum a rebus et mercibus mercatorum ad ipsas nundinas undecumque confluencium - Tkalčić, Mon. civ. Zagr. I. 243.

1878 item primo, quod ipsi domini de dicto capitulo zagrabiensi, ipsorumque tributarii pro tempore per eosdem constituti, tributum in foro annuali seu nundinis in festo sancti Marci ewangeliste ac aliis diebus ante et post sequentibus, excepta dumtaxat consveta porcione eiusdem tributi, vulgo fylarschyna vocata, nobis et dicte civitati proveniente et spectante semper salva remanente, recipere, extorquere et exigere poterunt et valebunt Tkalčić, Mon. civ. Zagr. II. 326.

1879 ad forum nostrum seu civitatis prefate prope vel penes ecclesiam parochialem sancti Marci ewangeliste habitam et existentem ab antiquo laudabiliter et privilegialiter approbatam - Tkalčić, Mon. civ. Zagr. II. 496.

1880 Tkalčić, Mon. civ. Zagr. II. 47-50.

1881 item primo ... - Tkalčić, Mon. civ. Zagr. II. 48.

1882 Vö. Bogdán I.: Magyarországi hossz- és földmértékek 190.

1883 Budai jogkönyv 368. Vö. Kubinyi A.: A belkereskedelem 229-251.

1884 item, super una funta ... - Tkalčić, Mon. civ. Zagr. II. 48.
} 
sütésére kötelezte: ezekből 12 darabot kellett 1 dénárért adniuk. ${ }^{1885}$ A vargák egy pár nagyobb, a zsoldosoknak kellő, új sarut nem árulhattak 18 dénárnál drágábban (a kisebb, új saruk ára maximum 14 dénár lehetett), a régi saruk talpának körülvarrásáért legfeljebb 3 dénárt, új felsőrészek és talpak összevarrásáért pedig 14 dénárt kérhettek. ${ }^{1886}$

A következő négy statútum a halászokra és a rákárusokra vonatkozik. A nyers (crudus), szekéren szállított halat tilos volt otthon tárolni, hanem három napig a piacon kellett eladásra kínálni. A málhaként (in pondere) - tehát nem szekéren (K. V.) - vitt halakat Nagyböjt idején a Nagy Harang kongásáig, máskor délig lehetett árulni. Azoknak a halaknak a farkát, amelyek a három nap alatt nem keltek el, az esküdtek dékánjának a városi kikiáltóval kellett levágatnia. ${ }^{1887}$ Hasonlóan rendelkezett az „eladósorban maradt” halakról Buda város jogkönyve: farkukat, mielött hazavitték volna őket, a halászok levágni tartoztak. ${ }^{1888} \mathrm{~A}$ rákárusok a nagyobb rákokból egy tucatot, a kisebbekből két tucatot tartoztak 1 dénárért adni. ${ }^{1889}$ Tudható az is - miután a rákok az 1343/1346. évi zágrábi vámtarifa tételei közt is megtalálhatók -, hogy 1 kosár rák után annak vevőjétől és eladójától is 1-1 obulus (fél-fél dénár) járt a zágrábi káptalannak. Végül a város megtiltotta a zágrábi halászoknak, hogy a Száva partján - nyilván viszonteladás céljából - halat vásároljanak, ki-ki a saját fogását vihette be a városba és árulhatta. ${ }^{1890}$

Három előírás a délelőtti órákban folyó vásározást szabályozta annak érdekében, hogy „először a polgárok tudják megvásárolni az otthonra kellő dolgokat”: délig nem vehettek semmit a kofák (penestice); ${ }^{1891}$ a patikáriusok, a kalmárok (institores), de még a szabók sem szerezhettek be vásznat viszonteladásra; ${ }^{1892}$ és ugyancsak tiltották a zab, a széna és a búza viszonteladásra történő, délelőtti felvásárlását - az országlakosoknak és a külföldieknek is. ${ }^{1893}$ A szabályokat áthágók mindhárom esetben vásárolt dolgaik elvételével számolhattak. ${ }^{1894} \mathrm{E}$ rendeletekkel a város a kis tételben, saját szükségletre bevásárló polgárai elővásárlási jogát biztosította. Habár maga a forrás erre nem szolgál támponttal, a korabeli vásári

\footnotetext{
1885 item, pistrices panum ... - Tkalčić, Mon. civ. Zagr. II. 48.

1886 item, quilibet sutor ... - Tkalčić, Mon. civ. Zagr. II. 48.

1887 item, piscatores ... - Tkalčić, Mon. civ. Zagr. II. 48.

1888 Budai jogkönyv 373-374.

1889 item, venditores cancrorum ... - Tkalčić, Mon. civ. Zagr. II. 48.

1890 item piscatores in civitate, residentes ex ista parte fluvii Zawe, pisces sub ammissione eorumdem piscium emere non presummant; sed ipsimet quorum sunt, eosdem inportent et inportare teneantur” - Tkalčić, Mon. civ. Zagr. II. 48. Vö. Budai jogkönyv 372.

1891 item, penestice ... - Tkalčić, Mon. civ. Zagr. II. 48.

1892 item, nullus stacionariorum vel institorum - Tkalčić, Mon. civ. Zagr. II. 49.

1893 item, nullus hominum tam domesticorum quam eciam extraneorum - Tkalčić, Mon. civ. Zagr. II. 49.

1894 Tkalčić, Mon. civ. Zagr. II. 48-49.
} 
szabályozásokból kiindulva ${ }^{1895}$ az utolsó három előírás bizonyosan a zágrábi hetivásárokon volt érvényben.

A délelőtti vásározást illető rendeleteket három vegyes tartalmú statútum követi: elsőként a kereskedők szállásán - vagyis a vásárokon kívül - történő kereskedés tilalma. Ha valaki a szállásán árult, nem az illetőt, hanem a város jogát ismerő házigazdát kellett az eladott áruk értékében elmarasztalni. ${ }^{1896}$ „Minden házigazda ismertesse meg a vendégével, a kereskedővel a városi törvényeket és a rendet, és tudassa vele, hogyan viselkedjen a kereskedésben és árusításban” - olvashatjuk a Budai Jogkönyvben. A jogszabálygyüjtemény az azonos jogszemlélet mentén egy márka büntetést rótt ki az olyan szállásadóra, akinek ebbéli hanyagsága miatt vendége vétkessé vált. ${ }^{1897}$ A szepességi Késmárk 15. századi statútumai ugyancsak elöírták, hogy a kereskedőket befogadók ismertessék a náluk megszállókkal a városi rendeleteket és törvényeket, az adásvétel szabályait. A házigazda, aki ezt elmulasztotta, netalán szándékosan szemet hunyt vendégének a város jogával ellenkező árusítása felett, a tanács büntetésére számíthatott. ${ }^{1898}$ A fazekasok a vásárokon a kocsmárosoknak kellő boroskancsókkal és -serlegekkel tartoztak megjelenni - 4 serleg árát 1 dénárban határozták meg. ${ }^{1899}$ Végül a gréci communitas áruelkobzás terhe mellett a hiteles (verus), a város kőetalonjának (lapidea mensura) megfelelő, valamint a város, továbbá az azévi bíró pecsétjével ellátott bor- és gabonamértékek tartását is elöírta. ${ }^{1900}$ Hasonló rendelkezés található Pozsony 1497. évi borkimérési rendszabályában, ami előírta, hogy a kocsmárosoknál törvényes városi ürmérték legyen, amit valamely városbíró hitelesített, és amire aztán a város jelzését égették. ${ }^{1901}$

Az 1425. évi rendtartás következő öt rendelkezése a városfalak állagvédelméről - és ezzel összefüggésben a sertéstartásról -, illetve a szemét és az állati tetemek gyüjtéséröl és megfelelő elhelyezéséről szól, ${ }^{1902}$ végül az utolsó két statútum újra a kereskedelmet érinti. A sütő- és sóárus asszonyoknak (salaria) és a kofáknak tiltotta az árusítás közbeni fonást, „mivel az ilyesféle szennyek, a kenderkóc és a len, megfertőzik az embereket” (eo quia per tales inmudicias, stupe seu lini, homines inficiuntur). A rendelet áthágását 60 dénár,

\footnotetext{
1895 Ezekre lásd Tringli I.: Vásártér és vásári jog 1303-1309.

1896 item, universi et singuli cuiuscumque ... - Tkalčić, Mon. civ. Zagr. II. 49.

1897 Budai jogkönyv 361.

1898 Magyar törvényhatóságok II/II. 91.

1899 item lucifiguli ... - Tkalčić, Mon. civ. Zagr. II. 49.

1900 item, quilibet homo veras mensuras ... - Tkalčić, Mon. civ. Zagr. II. 49.

1901 item Das ain yeder leitgeb hab die Recht Statmass, die gehaymbt wirdt bey ainem Statrichtr - dorauf dan daselbst das statmarck aufgeprent wirdt - Király J.: Pozsony város joga 436. Idézi: Uö.: Uo. 214.

1902 item, nullus hominum in circuitu civitatis ...; „tem, nullus hominum spurcicias ..., item, omnes, porcos servantes ...; item, simili modo porci ...; item, nullus omnino hominum cadavera animalium ... - Tkalčić, Mon. civ. Zagr. II. 49-50.
} 
bünismétlés esetén három pensa (120 dénár) bírsággal, harmadszor pedig áruelkobzással szankcionálták. ${ }^{1903} \mathrm{Az}$ élelmiszeráruk körüli fonást tiltó rendelet „előképeit” Raguzában (1313) és Spalatóban (14. század) is megtaláljuk. ${ }^{1904}$ A többihez kapcsolt, utolsó statútum a borssal, olajjal és más kimért áruval kereskedőket, kiemelten a patikáriusokat és a kalmárokat, a mérlegelésnél a német font (funta seu pondus theuthonicalis seu theuthonicale) használatára kötelezte, máskülönben elvesztették a kimért árujukat, ráadásul 6 dénármárkát is kellett fizetniük - ez a rendtartásban előforduló legnagyobb összegü büntetéspénz. ${ }^{1905}$ A városi statútum nyilvánvalóan sértette Luxemburgi Zsigmond 1405. évi törvényét, ami elöírta, „hogy a fonttal, mérleggel, öllel való mérés, a bornak, gabonának kimérése s általában minden megmérhető és mázsálható dolgoknak kimérése és megmázsálása minden városban, mezővárosban, várakban, falvakban, mind a mieinkben, mind bárki máséban s egyáltalán országunk határain belül mindenütt Buda városunk mértéke szerint történjék.”1906

A zágrábi harmincadot elsőként I. Károly a Copia de Commemoriali című velencei államkönyvbe bemásolt 1316. évi diplomája említette: a tricesimát eszerint a Száva partján, a folyó átkelőjénél, a király építtette vár alatt (sub nostro castro, quod edificari fecimus in portu Zaue) szedték - megfizetésének fejében az uralkodó szabad utat engedett a külföldi kereskedőknek az országban. ${ }^{1907}$ A királyrévi harmincadot a király 1318. június 28-i oklevele a királyné birtokában lévőnek mondta (tricesimam dominae consortis nostrae). ${ }^{1908}$

A Zágráb melletti harmincad létesítésére mindenesetre korábban, már a 13. század hatvanas éveiben sor kerülhetett. 1267-ben IV. Béla a zágrábi polgároknak - kérésükre országos száraz- és vízivám-, illetve harmincadmentességet biztosított. ${ }^{1909}$ Pach Zsigmond Pál érvelése szerint a városiak kérelmét elsősorban éppen a zágrábi harmincadhivatal felállítása indokolta, ${ }^{1910}$ példaként hozva a pozsonyiak későbbi hányattatásait, akik terhesnek érezve, „hogy a harmincadszedők immár ott ülnek a nyakukon”, a helyi kereskedők költségeit megnövelő (ezek árui is harmincadolás alá estek), ${ }^{1911}$ és a város élelmiszerellátását

\footnotetext{
1903 item nulla pistrix, salaria, penestica ... - Tkalčić, Mon. civ. Zagr. II. 50.

1904 Putanec, V.: Etimološki Prinosi 84. Vö. 1313: quod aliqua tabernaria, que vendit vinum, donec vinum durabit, non debeat filare in scragno nec prope scragnum - Lexicon Latinitatis Iugoslavie Fasc. II. 460.

1905 item, nullus omnino hominum videlicet stacionariorum et institorum ... - Tkalčić, Mon. civ. Zagr. II. 50.

1906 Decr. Hung. 192. Magyar fordítása: Bertényi 312.

${ }^{1907}$ Wenzel, Dipl. Eml. I. 207. (Anjou-oklt. IV. 320. sz.). Vö. Weisz B.: Vámok és vámszedés 229.: ’Királyréve (Zágráb megye)'.

1908 Smič. VIII. 503. (Anjou-oklt. V. 173. sz.).

${ }^{1909}$ Smič. V. 424. (Reg. Arp. 1519. sz.).

${ }^{1910}$ Pach Zs. P.: A harmincadvám az Anjou-korban 233. 9. jz.

${ }^{1911}$ Pach Zs. P.: A harmincadvám az Anjou-korban 235., 20. jz.
} 
megnehezítő (megdrágító) ${ }^{1912}$ tricesima fizetése alóli általános kiváltság hiányában ${ }^{1913}$ jobb híján az 1365-1366 táján Pozsonyba áthelyezett harmincadállomás ${ }^{1914}$ Győrbe és a Nyitra megyei Semptére történő visszatelepítését próbálták kitartóan elérni I. Lajosnál, majd 1385ben a Pozsonynál táborozó Luxemburgi Zsigmond brandenburgi őrgrófnál - ígéreteket ugyan kaptak, azok megvalósításából azonban végül nem lett semmi. ${ }^{1915}$

Fontos kérdés, hogy a zágrábi polgárok harmincadmentességével számolhatunk-e a későbbi időkben, akár I. Károly, akár fia, I. Lajos korában. Habár az 1267. évi mentesítő oklevelüket a zágrábi és a fehérvári káptalan is átírta 1329 novemberében, ${ }^{1916}$ legkorábbi ismert királyi megerősítései I. Mátyás és II. Lajos nevéhez köthetők. ${ }^{1917}$ Az 1267. évi oklevél hitelével szemben mindenesetre eleve némi kétséget támaszt, hogy annak eredetijét a város ha leszámítjuk az 1329-es alkalmakat - tudtunkkal soha sehol nem mutatta be: Béla privilégiumát 1464-ben I. Mátyás, majd 1717-ben III. Károly is a fehérvári káptalan átírásában látta (II. Lajos 1523-ban Mátyás, I. Ferdinánd 1528-ban pedig II. Lajos megerősítő oklevelében). ${ }^{1918}$ Ennél jóval erősebb érv az oklevél hitele ellen, hogy a két 1329. évi oklevél kiállítása közt (Zágráb: november 7.; Fehérvár: november 13.) gyanúsan rövid idő, alig egy hét telt el, az átíratók köre (Zágráb: Lamblinus iudex, Márk, Francha és Mikula zágrábi

\footnotetext{
1912 Legvalószínűbben ezzel magyarázhatók a városba külföldről saját felhasználásra importált, avagy a városban értékesíteni kívánt élelmiszerek (victualia) harmincadmentesítési törekvései. Vö. 1364. június 11.: DF 238821. (F. IX/3. 389-390.), 1371. február 24.: DF 240 822_31. (F. IX/4. 341-342.). Pach Zsigmond Pál az oklevelet kiadása alapján (Fejér tévesen Máténak olvasta Mátyást az oklevél napi keltezésében) szeptember 21-re keltezte. Pach Zs. P.: A harmincadvám az Anjou-korban 264.

${ }^{1913}$ A pozsonyiak harmincadmentességére lásd Skorka R.: Pozsony Bécs árnyékában 304-305.

${ }^{1914}$ Pach Zsigmond Pál adatai szerint a pozsonyi harmincadhivatal Győrből való áthelyezésére valamikor 1365. április 26. (királyi oklevél Szerecsen Jakab országos harmincados győri alharmincadosához) és 1369. október 29. között (Lajos király harmincadosának, Henrik budai polgárnak és pozsonyi officialisainak küldött levele, amelyben a király azt is megemlíti, hogy a hivatalt nemrég áthelyezték Győrből Pozsonyba) kerülhetett sor. Pach Zs. P.: A harmincadvám az Anjou.korban 235. 1366 februárjában már müködnie kellett a pozsonyi hivatalnak, így annak felállítása 1365/66-ra tehető. 1366. február 21.: DF 238835 = DF 238 836. Az 1366 februárjában kelt királyi oklevél biztosította a Dalmáciából - és különösen Zárából - a pozsonyi vagy más kereskedők által Pozsonyba vitt áruk vámmentességét; az áruk után csak egy harmincadot kellett fizetni - Pozsonyban (ab omnibus rerum et mercibus maritimis cuiuscunque generis maneriei vel speciei eedem existant que de Dalmacia et specialiter de Jadra per mercatores regni nostri in ipsum regnum nostrum deferuntur et importantur nullum tributum nullaque tributaria exaccio nec tricesima per tributarios vel tricesimatores nostros exigantur excepta una tricesima quam ab ipsis rebus in Posonio persolvi et exigi iubemus ab omni tributaria et tricesimatoria exaccione et quovis alio datio perpetue absolute habeantur penitus et exempte - DF 238835 = DF 238 836). 1366 elött a pozsonyiak a tengeri árukkal (res et merces maritime) csak Buda felé mehettek, és a harmincadot utánuk ott tartoztak megfizetni. 1361. január 23.: DF 238791 = DF 239015 (F. IX/7. 198-199.).

${ }^{1915}$ Pach Zs. P.: A harmincadvám az Anjou-korban 235-236.

1916 Zágrábi káptalan: 1329. november 7.: DF 255 418. (Anjou-oklt. XIII. 580. sz.)., fehérvári káptalan: 1329. november 13.: DF 255 419. (Anjou-oklt. XIII. 591. sz.).

1917 1464/1523/1528: DF 255420.

1918 1464/1523/1528: DF 255 420., 1717: A 57. Magyar Kancelláriai Levéltár. Libri regii 29. kötet. 204-211.
} 
polgárok; Fehérvár: Márk villicus, Mikula ötvös) viszont úgy mutat átfedést, hogy közben a gréci bíró (iudex/villicus) személye a két oklevélben eltér. ${ }^{1919}$

1343 július-augusztusában az anyakirályné, Piast Erzsébet rendeletére a zágrábi harmincadszedési gyakorlat felülvizsgálatára került sor. Ennek kiváltója Nicolet gréci bíró panasza volt, aki szót emelt amiatt, hogy a zágrábiak kárára, régi szokása és joga ellenére (contra ipsorum consvetudinem et ius ab antiquo observatam) harmincadot szednek a városból és Szlavóniából Velencébe, a német és más külföldi területekre exportált áruk után. ${ }^{1920}$ A tengerentúlra tartó királyné ${ }^{1921}$ megbízásából az ügyben eljáró Hahót Miklós szlavón bán a zágrábi káptalant és Frangepán Duim veglai, modrus-i és pozsegai comest ${ }^{1922}$ bízta meg annak a kiderítésével, hogy az előbbi - áruk és más igásállatok (jumenta) után kivetett - királynéi harmincad (tricesime reginales) jogszerü vagy jogtalan-e, hogy az elmúlt időkben milyen áruk és milyen módon estek harmincadolás alá, valamint hogy szokás-e harmincadot szedni a külföldröl Zágrábba vagy Szlavóniába hozott forintok és készpénz (prompta pecunia) után. ${ }^{1923}$ Duim comes a maga részéről hamar letudta a vizsgálatot: valószínűleg a modrusi piacon, ahonnan oklevelét keltezte, egy kereskedőtől érdeklődött a zágrábi harmincadszedésről. A megkérdezett állítása szerint Zágrábban a külföldről importált áruk után szednek tricesimát, a behozott pénz után viszont nem, és szintén nem esnek harmincadolás alá a Tengermellékre vagy a német területekre Zágrábból kivitt áruk. ${ }^{1924}$ A zágrábi káptalan 1343. augusztus 2-i relaciójában lényegében ugyanezek olvashatók annyi különbséggel, hogy a székeskáptalan fontosnak tartotta kiemelni, hogy „korábban emiatt soha nem zaklattak a harmincadosok egyházi személyeket, csak azokat, akik efféle árukat kereskedés céljából a határokon túlról Zágrábba vittek”, illetve hogy - ha a készpénz nem is a Zágrábba importált arany és ezüst harmincadolás alá esett. ${ }^{1925}$ Az ügy vizsgálati anyaga alapján a városba a 14. század derekán kiemelten állatokat - ökröket, disznókat, aprómarhát/juhokat (pecudes) -, állatbőröket, viaszt, füszereket és posztót importáltak.

Hahót Miklós bán augusztus 8-án, a Körösön tartott szlavóniai nemesi generalis congregación megjelent István és Mikcs egykori gréci bírák kérésére a káptalan és Frangepán

1919 1329. november 7.: DF 255 418. (Anjou-oklt. XIII. 580. sz.)., 1329. november 13.: DF 255 419. (Anjou-oklt. XIII. 591. sz.).

1920 Tkalčić, Mon. civ. Zagr. I. 165. (Anjou-oklt. XXVII. 446. sz.).

1921 „super exaccione tricesimarum domine regine per eandem domine regine clemenciam nobis rescire in suo transitu ultra partes maritimas adeunti commissarum” - Tkalčić, Mon. civ. Zagr. I. 168.

1922 Vö. Tkalčić, Mon. civ. Zagr. I. 166-167. (Anjou-oklt. XXVII. 452. sz.).

1923 1343. július 2.: Tkalčić, Mon. civ. Zagr. I. 165-166. (Anjou-oklt. XXVII. 446. sz.).

1924 1343. július 4.: Tkalčić, Mon. civ. Zagr. I. 166-167. (Anjou-oklt. XXVII. 452. sz.).

1925 et specialiter primis temporibus persone ecclesiastice nuncquam racione talium fuerunt per tricesimatores angariate, nisi tales, que mercandi causa res huiuscemodi Zagrabiam de extra finibus, ut predicitur, apportassent - Tkalčić, Mon. civ. Zagr. I. 167. (Anjou-oklt. XXVII. 524. sZ.). 
Duim jelentését is átírta, és miután a harmincadszedés bennük leírt módját a gyülésen jelenlévők is megerősítették, arról oklevelet állított ki. ${ }^{1926}$ Az iméntiekből a zágrábi harmincadolási gyakorlat megváltoztatási kísérlete, vagyis az árubehozatal mellett - a káptalan, a kereskedők és a szlavóniai nemesek által jogszerütlennek minősített újításként - a külföldre kivitt áruk megvámolása ${ }^{1927}$ egyértelműen kiolvasható, ${ }^{1928}$ az azonban már kevésbé, hogy miért érintette ez hátrányosan a zágrábi kereskedőket: mert eddig csak importáruik után tartoztak tricesimával, vagy mert alapjaiban sértette harmincadmentességi kiváltságukat?

Nicolet bíró 1343. évi panaszában a zágrábiak régi szokásának és jogának kárát általánosságban emlegette, a város 1267-ben IV. Bélától kapott kiváltságáról feltünően hallgatott. Ennél az argumentum ex silenciónál mindenképpen beszédesebb, hogy egy 1366. évi királyi oklevél szerint a zágrábiak Szerencsen Jakabbal, ${ }^{1929}$ I. Lajos országos harmincadosával - az uralkodó által is jóváhagyott - megállapodást (composicio) kötöttek a harmincad beszedéséről, aminek értelmében a zágrábiak bora, gabonája és sója nem esik harmincadolás alá. 1366 augusztusában a király a gréciek panaszára a megállapodás betartására szólította fel Jakabot és zágrábi alharmincadosát. ${ }^{1930}$ A nézeteltérés óhatatlanul azt sugallja, hogy a zágrábiak ekkor legfeljebb élelmiszereik után voltak harminadmentesek. Azonban hogy ez a mentesség az importra vagy az exportra, a saját felhasználású vagy az áruba bocsátott élelmiszerekre értendő, pusztán e forrás alapján nem világos. ${ }^{1931}$

A Zágrábból külföldre exportált áruk harmincadolásának ügye később, 1379-ben is elökerült, amikor a néhai Szomszédvári Tót Miklós özvegye az országos harmincados (tricesimator per regnum nostrum Hungarie), Szerecsen (Jakab) ${ }^{1932}$ zágrábi harmincadszedőire panaszkodott, akik újabban harmincadot szedtek be a lovak, disznók és más aprómarhák (pecora) után, amiket eladás céljából kivitt az országból. Az özvegyre és fiaira sérelmes vámszedést a király megtiltotta. ${ }^{1933}$ Érdekes, hogy Zágrábból külföldre exportált áruk harmincadolásának gyakorlatát I. Lajos még ekkor, a 80-as évek küszöbén is novitasnak, újításnak minősítette, holott a Lublóból külországba szállított áruk utáni

\footnotetext{
1926 Tkalčić, Mon. civ. Zagr. I. 168-169. (Anjou-oklt. XXVII. 531. sZ.).

1927 forenses mercatores ... si quas merces Zagrabie deferendas extra regnum comparassent - Tkalčić, Mon. civ. Zagr. I. 167. (Anjou-oklt. XXVII. 524. sz.).

${ }^{1928}$ Vö. Pach Zs. P.: A harmincadvám az Anjou-korban 266-267.

1929 Vö. Weisz B.: A szerémi és pécsi kamarák 43.

1930 1366. augusztus 29.: in pretactis convencionibus ... in exaccione tricesimarum conservetis absque retractacione aliquali - Tkalčić, Mon. civ. Zagr. I. 233-234.

1931 Pach Zsigmond Pál szerint a gabona és a bor zömében bizonnyal belföldröl származott. Pach Zs. P.: A harmincadvám az Anjou-korban 255.

1932 Weisz B.: A szerémi és pécsi kamarák 48.

1933 Smič. XVI. 45.
} 
harmincadszedést 1365-ben, a hasonló pozsonyi eljárást pedig 1371-ben és 1374-ben is „Szokásosként” interpretálta. ${ }^{1934}$

A zágrábi tricesima kapcsán a források még néhány kisebb-nagyobb, a harmincadszedők és a városi polgárok közötti konfliktus emlékét őrizték meg. 1369. március 29-én három gallicinek mondott, nagy valószínűséggel firenzei származású ${ }^{1935}$ zágrábi kereskedő, Tádé (Tadeus de Karbonibus), Péter és Puchocius állítólag megölte Ferenc egykori zágrábi harmicadszedőt. (A vádlottak a történtekre másképp emlékeztek, elmondásuk szerint a Péterrel összevitatkozó - szintén gallicinek mondott - Ferencet Szláv Miklós bortól lerészegedett (vini insania infectus) jobbágya, Lörinc szúrta hátba az összezördülés körül támadt csődületben). ${ }^{1936}$

Az előbbieknél nagyobb horderejü ügynek tünik a zágrábi harmincadház (curia seu domus nostra [sc. regis - K. V.] tricesimalis) 1436. évi kirablása, amiről Luxemburgi Zsigmond Bajmóci Noffri Lénárt harmincad-, urbura-, és pénzverőkamara-ispán beszámolójából értesült. A zágrábiak Szilágyi Pál, a püspöki udvar provisora kérésére és jelenlétében feltörték a harmincadházat, és onnan - az alharmincadosok által bizonyos álúton harmincadot kerülni próbáló kereskedőktől jogszerüen elvett - barhentet és más árukat, Lénárt familiárisainak holmiját és a király harmincadbevételét elvitték. A támadók Lénárt szerint 400 forint kárt okoztak, két familiárisát elfogták, a többiek pedig szétfutottak, és még a megyéből is elmenekültek. A király éktelen haragra gerjedt bevételeinek eltulajdonítása miatt, és egyenesen fejvesztés terhe mellett adta parancsba a zágrábiaknak, hogy hiánytalanul adják vissza az elvett dolgokat Bajmóci embereinek, a jövőben pedig tartózkodjanak a harmincadosok elleni fellépésektöl, helyette a régi szokás szerint (more ab olim observato) adjanak meg nekik minden segítséget a király jövedelmeinek beszedése során. ${ }^{1937}$

1437 nyarán Péter tricesimator a harmincadszedőházban ejtett foglyul egy zágrábi polgárt, György ötvöst. Péternek Asztalnok Pál (feltehetően azonos az 1436-os, a harmincadházat érintő ügyben feltűnő Szilágyi Pállal), a zágrábi püspöki udvar provisora előtt kellett felelnie tettéért, akit Tallóci Matkó szlavón bán jelölt ki a gréciek protectorául. A jogvitát végül Pálnak és ítélőtársának, a bán egyik emberének, Sándor orvosnak sikerült elsimítania. A bírótársak a tricesimatiort bünösnek találták, de kegyelmet kértek számára a zágrábiaktól.

\footnotetext{
${ }^{1934}$ Pach Zs. P.: A harmincadvám az Anjou-korban 267. 189. jz.

1935 Budak, N. - Piljac., S. P.: I fiorentini nella Slavonia 687-688.

${ }^{1936}$ Az ügyet lásd: 1369. június 1.: Tkalčić, Mon. civ. Zagr. I. 234., 1369. június 2.: Tkalčić, Mon. civ. Zagr. I. 235-236., 1369. július 9.: Tkalčić, Mon. civ. Zagr. I. 236.

1937 Tkalčić, Mon. civ. Zagr. II. 125-126.
} 
Péter, miután maga is elismerte, hogy vétett a város jogai ellen, és bocsánatot kért, megígérte, hogy a jövőben tartózkodik az ilyen tettektől, és jó viszonyt fog fenntartani a várossal. ${ }^{1938}$

A gréciek által birtokolt zágrábi vámok először 1321-ben érhetők tetten a forrásokban. A zágrábi káptalan ekkor panaszolta be I. Károlynál a polgárokat, akik új vámokat vetnek ki a sóra és más árukra, „amiket mikor filarchinának, mikor másnak hívnak” - teszik pedig ezt a káptalan vásárvámjának a sérelmére és a tengeri sót használó országlakosok kárára. A király az ügyet február 2-án Babonics János szlavón bánra bízta, akit a kifogásolt vámra nézve pontos instrukciókkal látott el: ha a vámot indokoltnak találja, csatolja a székeskáptalan királyi vámjához, ha alaptalannak, akkor ne engedje, hogy a polgárok szedjék, miután a vámszedés felségjog, ezért új vámok létesítése „sem a városoknak, sem másoknak nincs megengedve, az ilyen hatalom egyedül a hercegeknek és a királyoknak van fenntartva”. 1939 Az ügyben való ítélethirdetésre augusztus 21-én, a bán által Zágrábban tartott generalis congregación került sor. Korábban a gréciek sikertelenül próbálták, a báni joghatóságot megkérdőjelezve, a király elé vinni az ügyet, a város szabadságairól átiratban bemutatott királyi oklevelük pedig - hiába állította a város képviselője, Tamás mester, a városi főjegyző (principalis notarius) - nem jogosította fel őket arra, hogy a vámok és más „adók” beszedését megreformálják (tam in tributis, quam in aliis exaccionibus inducere novitates). A pert így kevésbé meglepő módon - a káptalan nyerte: az egyház a sérelmezett filarchinát és a „sóvámot” (salinaria) a bán döntése értelmében, (vásár)vámjának részeként ezután magának szedhette be. A városnak ráadásul a két vámból származó bevételét és a hiteles (só)mérték örzéséért felszámított összeget, vagyis a káptalan kárát is meg kellett fizetnie az egyháznak. 1940

A báni ítéletlevél arra nézve is eligazít, hogy milyen típusú vámot kell értenünk a filarchinán és a salinarián; eszerint a két vám valójában olyan illeték volt, amit a káptalan képviselői szerint a gréciek a só méréséért (occasione mensure salis) kezdtek kivetni. ${ }^{1941}$ Egy

\footnotetext{
1938 Tkalčić, Mon. civ. Zagr. II. 132-134.

1939 nova tributa sive pedagia sive salinaria vel quecumque alia nec civitatibus nec aliquibus aliis instituere est permissum, sed huiusmodi potestas solis principibus et regibus reservatur” - Smič. IX. 1. (Anjou-oklt. VI. 28. sz.). Károly ugyanakkor azt is hangsúlyozta, hogy a városi rendeletek kizárólag a polgárokra érvényesek, és azok hatályát nem lehet mások kárára kiterjeszteni („licet autem civitates constituciones, banna sive mulktas (!) inter semetipsos et per se ipsos observandas constituere possint vel edere, eas tamen non possunt extendere in ecclesiarum vel quorumlibet gravamen, qui ex suorum numero concivium non existunt - IX. 1.).

1940 Smič. IX. 27-28. (Anjou-oklt. VI. 227. sz.).

1941 Smič. IX. 27-28. Valentin Putanec a filarchinát a filarka szóval hozta összefüggésbe. A „piaci eladó” jelentésü filarka szót a horvát nyelvészeti szakirodalom egy része a magyar (német eredetü) fillér, más része a latin filare, fonni igéből próbálta eredeztetni (filarka = „nő, aki fon”). Hadrovics László 1985-ben mindkét etimológiát elvetette - a fonást például azért, mert szerinte képtelenség, hogy a kofákat pont arról a tevékenységről (fonás) nevezzék el, ami több helyen, például Zágrábban is tiltott volt nekik. Hadrovics a filarkát a német *vilaere szóból vezette le, és eladóként értelmezte. (Hadrovics, L.: Ungarische Elemente im
} 
1324. évi, a zágrábi káptalan statútumai közé bemásolt oklevél szövegében a filarchina mellett feltünt egy star nevü vám is, ${ }^{1942}$ a név mögött azonban az iménti salinariát sejthetjük, a vám neve ugyanis a zágrábi vámtarifákban ${ }^{1943}$ feltünő, a tengeri só mérésére használt

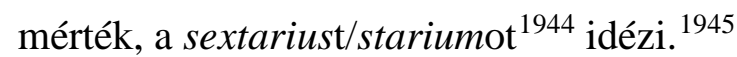

A star nevű vámot említő oklevél 1324-ben a káptalan és a város kiegyezését rögzíti abban a perben, amit az egyház a sérelmére elkövetett jogtalanságok miatt indított a gréciek ellen I. Károly előtt. A megállapodás első pontjában a polgárok ígéretet tettek arra, hogy engedik az egyházat a vámszedés során felmerülő vitás ügyekben eljárni, és nem szednek vámot a káptalani vám sérelmére, kivéve - így a város - „a filarchinát és a start, amiket nekünk rendeltek, maguknál hagyva”. ${ }^{1946}$ 1339-ben végül - egy újabb jogvitát követő megállapodásban - maga a székeskáptalan is lemondott a filarchinához füződő jogairól, és a vám beszedését a grécieknek engedte át. A megegyezést 1339. május 11-én Szécsényi Tamás erdélyi vajda, királyi tárnokmesteri ügyvivő (procurator magisterii tavarnicatus nostri), 1340-ben pedig I. Károly is megerősítette. ${ }^{1947}$

A zágrábi káptalan Károly halálát követően, az új uralkodó, I. Lajos trónra léptével, úgy tünik, hirtelenjében „megfeledkezett” az 1339. évi, a fenti illetékekhez kapcsolódó jogairól való lemondását (is) tartalmazó paktumról. 1343 tavaszán a pécsi káptalan tanúságával Zágrábban eljáró királyi ember, Ravasz a polgárok által a só és a viasz után szedett, a káptalan

Serbokroatischen 233.). Putanec utóbb a filarkát olyan kofaasszonyként interpretálta, aki a piacon árul, méghozzá leginkább élelmiszert. Ebből kiindulva a filarchinában olyan piaci adót látott, ami minden élelmiszerrel kapcsolatba hozható, amit a város piacán árultak. Putanec, V.: Etimološki Prinosi 83-86.

1942 Tkalčić, Mon. ep. Zagr. II. 135.

${ }^{1943}$ Lásd a táblázatot!

${ }^{1944}$ Vö. 1. táblázat 1. jz.

1945 Vö. Latinitatis Iugoslavie Fasc 6. 1122. ('star').

1946 ad talem concordiam devenimus super articulis prenotatis: primo videlicet eis permisimus quod nullum tributum ad ipsorum iusti tributi diminucionem exigere intendimus vel constituere quandocumque, salvis filarchina et star vocatis, pro nobis ordinatis, apud nos remanentibus, sed quod eorum iusta tributa plenarie exigantur sine defalcacione aliqua, sicut actenus extitit observatum, nec ad querelam quorumcumque solvencium tributa nos intromittemus, ymmo discussioni eiusdem capituli totum reliquimus et ad ipsum transmittemus querelantes - Tkalčić, Mon. ep. Zagr. II. 135.

1947 1339. április 28.: nos [sc. capitulum Zagrabiensis ecclesie - K. V.] quoque loco premissorum omnium iuri quod habemus per regale privilegium in tributo filarschina vocato cedimus et renunciamus ipsum tributum ipsis percipiendum more solito et debito perpetuo relinquentes - Tkalčić, Mon. ep. Zagr. II. 136-137. 1339-ben város arról is lemondott, hogy a király, I. Károly által nekik beszedni engedett, bizonyos „,poztoua” nevü adót(?) (exaccio) a káptalan népeitöl is követelje (tandem inter cetera super exaccione, poztoua vocata, per ipsos villicum et communitatem a domino nostro Karolo rege Hungarie illustri impetrata, per eumque suis mediantibus litteris concessa, (cum) eisdem ad talem pacis et concordie unionem devenimus, quod ipsi villicus et communitas numquam in perpetuum ipsam exaccionem poztoua dictam vel alio nomine vocandam petent nec recipient a pertinentibus ad zagrabiensem ecclesiam quoquomodo, nec eius occasione vel cuiuscumque alterius exaccionis de novo aliquod gravamen inducent ipsi vel aliqui ex eisdem quocumque ingenio vel colore, renunciantes omni iuri quod eis in hac parte ex litteris regiis vel aliis conpetebat vel conpetere poterat quoquomodo - Tkalčić, Mon. ep. Zagr. II. 136-137.). 
privilégiumaival ellenkezőnek minősített vámot a zágrábi egyház birtokába juttatta ${ }^{1948}$ - tette mindezt a király 1342. december 14-i, egyébként semmiféle vámot nem említő oklevelére hivatkozva. ${ }^{1949}$

A jogvita végére azonban korántsem került pont 1343-ben. A vámvitán kívül a káptalan Lajos uralkodásának első éveiben egy, a Gréc-hegy alatt ásott árok miatt, ami állítólag a káptalan területén végződött, amit és így elárasztott a víz, valamint Kasina káptalani birtok egy részének elfoglalása miatt is egy elhúzódó perben állt a várossal. A különböző vitás ügyek együttes, érdemi tárgyalására végül 1346 elején került sor. Az eredetileg Szécsényi Tamás tárnokmester elött indított perek ekkor már Raholcai Tót Lőrinc tárnokmesteri ítélőszéke előtt folytak. Jakab zágrábi prépost a tárnokmester előtt a káptalan „szokásos” érvét hangoztatta: a vám, amit a város a só, a viasz és hasonló kisebb áruk után (de ... aliis minutis rebus, his similibus) hatalmaskodva szed, sérti vámjogát. A város két esküdt képviselője, a volt bíró, Nicolet (nem mellesleg ő volt a bírói hivatal betöltője az 1339. évi kiegyezés idején) ${ }^{1950}$ és Jaxe ötvös ezzel szembe azzal érveltek - a vám szó használatát minden bizonnyal szándékosan mellőzve -, hogy „amit” a város az említett áruk mérlegeléséért polgárai közt szedni rendelt, nem sérti az egyház jogait (et quod pro mensuracione ... in medio sui ordinassent, quod dicto capitulo ... in nullo derogaret nec tributi ipsorum preiudicium aliquod generaret). A vámok ügye a per hátralévő részében nem került elő. ${ }^{1951} \mathrm{~A}$ két birtokvitában a káptalan alulmaradt, ráadásul patvarkodásban marasztalták el, ${ }^{1952}$ vagyis a vitás birtokrészek tárgyában a jövőben nem pereskedhetett a várossal. ${ }^{1953}$

Jelenlegi ismereteink szerint az 1346. április 11-i ítéletlevél az utolsó forrás, amiben a gréciek ,jogtalan vámszedéséről” hallunk. A filarchinát a város minden bizonnyal a későbbiekben is beszedte - és nem csak saját polgáraitól. A zágrábi káptalannak például csak

\footnotetext{
1948 1343. március 13.: Tkalčić, Mon. civ. Zagr. I. 161-163. (Anjou-oklt. XXVII. 105. sz.).

${ }^{1949}$ Vö. Tkalčić, Mon. civ. Zagr. I. 158-159. (Anjou-oklt. XXVI. 651. sz.).

${ }^{1950}$ Tkalčić, Mon. ep. Zagr. II. 136.

${ }^{1951}$ Közben (1346.) március 20-án - még az áprilisi ítélethirdetés előtt - a hétfő̉i zágrábi hetivásáron vizsgálódó esztergomi káptalan a zágrábi vámszabásban nem szereplő filarchináról annyit tudott meg a káptalani vámszedő, György villicus jelenlétében, hogy a vámot az újabb időkben rendelték el, és ez az egyedüli vám, amit a gréci polgároknak szednek be (1346. április 5.: salvo quodam tributo ab aliquibus novissimis temporibus ordinato, fylarchyna vocato, solo, quod pro civibus Grecensibus percipiebatur - Smič. XI. 284. [Anjou-oklt. XXX. 264. sz.]).

${ }^{1952}$ Smič. XI. 289-296. (Anjou-oklt. XXX. 290. sz.).

1953 A város az ítéletlevelet 1346-ban a zágrábi Szüz Mária-egyház ciszterci apátjával (DF 257 254. [Anjou-oklt XXX. 595. sz.]), 1354-ben Hahót Miklós horvát-szlavón bánnal is átíratta (DF 230 406. [Anjou-oklt. XXXVIII. 337. sz.). 1361. május 8-án a zágrábi káptalannak Zsámboki János tárnokmester előtt - I. Lajos 1354 előtti perbeli bírságokat eltörlő rendeletére hivatkozva - valahogy sikerült elérnie, hogy feloldják a patvarkodásért kirótt hallgatás alól, cserébe 50 budai dénármárkát kellett fizetnie a grécieknek. 1361. március 8.: Tkalčić, Mon. civ. Zagr. I. 217-226. A város az ítéletet nem fogadta el. 1361. augusztus 17.: Tkalčić, Mon. civ. Zagr. I. 228229.
} 
1392-ben sikerült elérnie, hogy jobbágyai, népei és prédiálisai a város területén mentesüljenek a fizetése alól. ${ }^{1954}$

Összességében úgy véljük, a zágrábiak a Károly-korban a (tengeri) a só, a viasz és más áruk után egyrészt mérlegpénzt, másrészt - a hiteles mérőeszköz(ök) használatának fejében mérési illetéket szedtek filarchina, valamint salinaria/star néven. ${ }^{1955}$ A két vám a későbbiekben filarchina néven olvadhatott össze.

Zágráb királyi hospeseit IV. Béla 1242. és 1266. évi városprivilégiumai ${ }^{1956}$ királysága határain belül minden vám fizetése alól felmentették, ${ }^{1957}$ majd 1267-ben - kérésükre országos száraz- és vízivám-, illetve harmincadmentességet biztosított polgárai számára. ${ }^{1958}$ Gréc a középkorban két városi kiváltságlevele közül rendre az utóbbival élt: ${ }^{1959}$ IV. Béla 1266. november 23-i oklevelét I. Károllyal három (1318, ${ }^{1960} 1322,{ }^{1961} 1324^{1962}$ ), I. Lajossal ugyancsak három (1345, ${ }^{1963}$ 1359, ${ }^{1964} 1364$ - megerősítő záradék $\left.{ }^{1965}\right)$, Luxemburgi Zsigmonddal pedig két alkalommal (1406, $\left.{ }^{1966} 1435^{1967}\right)$ is megerősíttették. Zsigmond ugyanakkor, 1405. április 15-én kiadott városi törvénykönyvére ${ }^{1968}$ hivatkozva, egy héttel később, április 22-én, a behozatali és a kiviteli harmincad megfizetése fejében a zágrábiak számára (is) külön oklevélben biztosította a királyi vámok alóli mentességet. ${ }^{1969}$

\footnotetext{
1954 1392. május 12.: annotati cives assumpserunt et sponponderunt, ut et ipsi et ipsorum tributarii nunc constituti et in futorum constituendi ab universis nostris iobagionibus, populis, predialibus et hominibus ubilibet in nostris possessionibus et territoriis commorantibus et causa commorandi ad nos et ad nostra territoria seu possessiones venire volentibus nullum tributum nec aliquam tributariam exaccionem, que vlgariter filarschyna dicitur vel nuncupatur, vel alio quovis nomine seu nominis vocabulo in futurum vocitaretur in predicta civitate et in area vel territorio ipsorum nec exigi facient, nec per suos tributarios recipi permittent nunc et in futurum modo aliquali Tkalčić, Mon. civ. Zagr. I. 344. A filarchina még a késő középkorban is élt: 1468: excepta dumtaxat consveta porcione eiusdem tributi, vulgo fylarschyna vocata, nobis et dicte civitati proveniente et spectante - Tkalčić, Mon. civ. Zagr. II. 326., 1494: simulcum filarsthyna - Tkalčić, Mon. civ. Zagr. II. 494. Utóbbi kettőt idézi Latinitatis Iugoslavie. Fasc 2. 460.

${ }^{1955}$ Vö. 1494: Tkalčić, Mon. civ. Zagr. II. 494-495.

1956 1242. november 16.: Smič. IV. 172-176. (Reg. Arp. 723. sz.)., 1266: Tkalčić, Mon. civ. Zagr. I. 40-44. (Reg. Arp. 1504 sz.).

1957 item tributa infra regales terminos in nullo loco solvere teneantur - Smič. IV. 173.

1958 quod ipsi cives nostri infra terminos regni nostri aliquod tributum, tam in aquis, quam in terris, nec aliquam tricesimam in nullo loco solvere teneantur, sed sint a solucione eorum exempti penitus et inmunes - Smič. V. 424. (Reg. Arp. 1519. sz.).

1959 Ennek magyarázatára lásd: Szende K.: Mennyit ér a kiváltság 297.

1960 1318. november 25.: Tkalčić, Mon. civ. Zagr. I. 94. Vö. Reg. Arp. 1504. sz., Anjou-oklt. V. 303. sz., Szende

K.: Mennyit ér a kiváltság 297.

1961 1322. október 14.: Tkalčić, Mon. civ. Zagr. I. 105-106. (Anjou-oklt. VI. 813. sz.).

1962 1324. március 8.: Tkalčić, Mon. civ. Zagr. I. 108-109. (Anjou-oklt. VIII. 93. sz.)

1963 1345. június 27.: Tkalčić, Mon. civ. Zagr. I. 178-179. (Anjou-oklt. XXIX. 412. sZ.)

1964 1359. szeptember 27.: Tkalčić, Mon. civ. Zagr. I. 215-216.

1965 1364. február 25.: DF 230183.

1966 1406. január 10.: Tkalčić, Mon. civ. Zagr. II. 9-11. (ZsO. II/1. 4375. sz.).

1967 1435. október 7.: Tkalčić, Mon. civ. Zagr. II. 113-115.

1968 Decr. Hung. 206.

1969 Tkalčić, Mon. civ. Zagr. II. 7-8. (DF 230 842). Az eredetiben és a kiadásban is 1404. évi dátummal!
} 
A zágrábiaknak a káptalan helyi vásárvámját sem kellett fizetniük. A város és a káptalan 1339. évi, már említett megállapodása azt is tartalmazta, hogy e mentességet kizárólag a polgárok érvényesíthették, a külvárosok - és nyilván a város vagy a városiak birtokainak más jogállású népessége nem, valamint hogy a gréciek nem hozhattak létre idegenekkel anyagi ellentételezés fejében (kereskedelmi) társulást, ${ }^{1970}$ vagy vonhatták ki őket más módon a káptalani vám lerovása alól. ${ }^{1971}$ Gréc-hegy polgárainak a 14. század végén, 1392-ben sikerült mentesítenie Dedicsi, Gracsani, Kraljevec, Kobiljak, Szvibje, Nart, Novavesz, Podbrezsje, Cernomerec, Hrascse és Petrovina falvakban élő népeit (iobagiones seu populi) a zágrábi káptalan vámjának fizetése alól - cserébe felhagytak a filarchina szedésével a káptalan népeitöl. ${ }^{1972}$ A püspökség és a káptalan népei az Árpád-korban, 1217-ben mentességet kaptak a vásárvámok fizetése alól; ezt a kiválságukat 1318-ban I. Károly is megerősítette. ${ }^{1973}$ A zágrábi káptalan 1217-ben II. Andrástól azt a kiváltságot is megkapta, hogy az évenként, augusztus 20-ig 50 márka értékben nekik juttatott sót Szegedről vámmentesen szállíthatják Zágrábba, és szabadon értékesíthetik. ${ }^{1974}$

A zágrábi polgárok vámmentességének tiszteletben tartását 1345-ben Erzsébet anyakirályné, 1347-ben I. Lajos, 1350-ben pedig István szlavón-dalmát-horvát herceg adta parancsba - az anyakirályné és a herceg a szlavóniai, az uralkodó az egész királyság vámszedőinek. ${ }^{1975}$ 1347-ben a város képviselői - Jaxe bíró és egy gréci polgár, Benedek - I. Lajosnak a kiváltságot megerősítő saját oklevelét, vélhetően városprivilégiumuk megerősítését is bemutatták. ${ }^{1976} 1435$ novemberében a Pozsonyban tartózkodó Zsigmond, majd decemberben (Podravicból) Tallóci Matkó szlavón bán is a zágrábi polgárok vámmentességének betartására szólította fel a királyság - illetve a bán esetében: Szlavónia vámszedőit. ${ }^{1977}$

\footnotetext{
${ }^{1970}$ Vö. Kovács V.: A pozsonyiak vámmentessége 363-364.

1971 item quod villicus et cives predicti tributum per suos subditos vel singulorum ex eis de villis forensibus, salvis concivibus ipsorum exterius conmorantibus nobis ex collacione regia debitum, facient semper plene persolvi nostris tributariis sicut per alios communi iure de banatu vel aliunde persolvitur vel debet persolvi, nec aliquem forensem de cetero in detrimentum nostri tributi predicti assumpment in suum consorcium, racione dacii eis persolvendi vel aliter defendent a solvendo tributo - Tkalčić, Mon. ep. Zagr. II. 137.

1972 1392. május 12.: Tkalčić, Mon. civ. Zagr. I. 343-344.

${ }^{1973}$ Weisz B.: Vámok és vámszedés 438.

1974 Weisz B.: Vámok és vámszedés 438.

1975 1345. december 11.: Smič. XI. 259. (Anjou-oklt. XXIX. 874. sz.); 1347. október 16.: Smič. XI. 411-412. (Anjou-oklt. XXXI. 970. sz.); 1350. július 9.: Tkalčić, Mon. civ. Zagr. I. 197-198. (Anjou-oklt. XXXIV. 515. Sz.).

1976 litteras ... tam predecessorum nostrorum quam nostras confirmatorias - Smič. XI. 411.

1977 1435. november 8.: iuxta eorum antiquas libertates et prerogativas per divos reges Hungarie, nostros scilicet predecessores, eisdem graciose concessas et per nos nunc confirmatas - Tkalčić, Mon. civ. Zagr. II. 116. A bán oklevele: 1435. december 16.: Tkalčić, Mon. civ. Zagr. II. 118-119.
} 
1396. július 30-án Bebek Detre szlavón bán - Zsigmond parancsára - arról értesítette medvei várnagyát, Tárkányi „Higgyed” Jánost, ${ }^{1978}$ alvárnagyait és a szávai réveken szolgálatot teljesítő vámosaikat, hogy a király 10 évre felmentette a városba épületfát szállító polgárokat (de lignis ad dictam civitatem per eosdem cives pro edificiis faciendis conducendis) a szávai révvámok fizetése alól. ${ }^{1979}$ A kedvezmény a folyón leúsztatott fák vámjára ${ }^{1980}$ vonatkozhatott, amire, úgy tünik, már nem terjedt ki a zágrábiak általános mentesítő kiváltságának hatálya.

\section{Zaheus (Pest megye) [Tápiószekcső határának DNY-i negyedén, H] ${ }^{1981}$}

Zaheus birtokot a Lajos-kor elején Kürti Gyármán fia Pető és a Kartal nembeli Cikó fia Cikó ${ }^{1982}$ is magának követelte, előbbi örökjogon, utóbbi - állítólag 50 éve tartó - elbirtoklás jogcímén. A felek közti pereskedés folyamán 1343-ban sor került a birtok határainak bejárására is - a határvonal a Szecsőrév (Zecheureu; más olvasatokban: Szecsőér, ${ }^{1983}$ Zentheureu ${ }^{1984}$ ) nevü helyet is érintette. ${ }^{1985}$

\section{Zákány (Somogy megye) [Zákány, H]}

1371-ben Zákány (Zakan) szerdai hetivására háromvásáros kikiáltás színtere volt. ${ }^{1986}$

\footnotetext{
1978 Vö. Engel P.: Archontológia I. 366.

1979 Tkalčić, Mon. civ. Zagr. I. 371. A gréciek vámmentességéről ugyanaznap János várnagy is kiadott egy azonos tartalmú oklevelet. Tkalčić, Mon. civ. Zagr. I. 372.

${ }^{1980}$ A tutajok és úsztatott fák vámjára lásd Weisz B.: Vámok és vámszedés 14., és uo. 80. jz., 1255: Bp. I. 57., 1376: DF 238 940., 1423: ZsO. X. 1275. sz.

1981 Azonosítása: Gy. IV. 564.

1982 Vö. Engel P.: Genealógia: Kartal nem 3. tábla: Cikó (pomázi).

1983 Gy. IV. 564.

1984 Anjou-oklt. XXVIII. 235. sz.

1985 DL 24 467. (Anjou-oklt. XXVIII. 235. sz.).

${ }^{1986}$ DL 41864.
} 
Egy 1357. évi királyi parancslevél őrizte meg a Dráva Zákányrév(e) (Zakanrewy ${ }^{1988}$ Zakanriw ${ }^{1989}$ ) nevü révjének a nevét - eszerint az abban szereplő Farkasrév(e) rév a folyó Zákányrév(e) és Parlagrév(e) nevü átkelői közt biztosított átkelést a Dráván. ${ }^{1990}$ Zákányrév(e) vélhetően Somogy megyében, Alsó- (ma Zákány település) vagy Felsőzákány (ma Örtilostól ÉNy-ra) térségében lehetett, a rajta átkelők a Dráva túlpartján, már Körös megyében szálltak partra.

\section{Zalavár (Zala megye) [Zalavár, H]}

A zalai Szent Adorján bencés apátság konventje 1359-ben abban állapodott meg a Hahót nembéli János fia Jánossal és Atyusszal, ${ }^{1991}$ hogy amikor a nemesek jobbágyai a monostor búcsúikor és felszentelésének idején, Szent Ilona (május 22.), vagy Szent Vitus (június 15.) ünnepén hajóikkal a monostor vizein közlekednek, hajónként 8 dénárt tartoznak fizetni az apátság rév- avagy vámhelyén. Ha erre a jobbágyok nem lennének hajlandóak, a vámot helyettük utólag Atyusz és János fizesse meg. ${ }^{1992}$

\footnotetext{
1987 Vélhetően Somogy megyében (az átkelők a Dráva túlpartján, Körös megyében szállak partra), Alsó- (ma Zákány település) vagy Felsőzákány (ma Örtilostól ÉNY-ra) térségében.

1988 DF 101907.

${ }^{1989}$ DF 103295.

1990 DF 101907 = DF 103295 = DF 106 786. (Anjou-oklt. XLII. 35. sz.).

${ }^{1991}$ Vö. Engel P.: Genealógia: Hahót nem 2. tábla: Buzád ága.

1992 hoc inserto quod amodo et deinceps quandocunque iobagiones predictorum magistrorum Iohannis et Othyuz filiorum Iohannis et alii ad eosdem pertinentes cum navibus ipsorum super aquas predicti monasterii de Zala tempore indulgenciarum et dedicacionis ipsius monasterii ac ecclesie beate Elene regine necnon in festo beati Vitii martiris procederet et accederet tunc iidem iobagiones dictorum magistrorum ... nec magis nec ultra et nec minus nisi pro una qualibet navi seu singulis navibus octo denarios in die cuiuslibet congregacionis prelibato domino abbati et conventui monasterii beati Ardiani martyris prenotati vel officialibus eorundem dare deberent et tenerentur. Si autem quicunque ex eisdem ibidem in loco ipsius portus seu tributi dare et persolvere nollent tunc ad peticionem duorum proborum et nobilium virorum in comitatu Zaladiensi existencium per dictum dominum abbatem et suum conventum ad ipsos transmissorum tercio die ipsius termini prescripti magistri ... ex parte eorundem iobagionum ... predictos octo denarios ut premittitur de qualibet navi solvere deberent et tenerentur occasione qualibet procul mota domino abbati et suo conventui - DF 253838.
} 


\section{Zámmonostora (Szabolcs megye) [Zám-puszta (Hortobágy), H]}

Zámmonostoránál híd biztosította az átjárást a Hortobágy folyón. Áradások idején amikor a híd használhatatlanná válhatott - hajókkal lehetett átkelni a folyón. ${ }^{1993}$ A folyón való átkelésért hídvámot (illetve áradások idején gyakorlatilag révvámot) kellett fizetni. Zámmonostora 1343. évi birtokosztályakor a birtok, a folyó és a vám egyik fele Káta nembéli István fiai, Lőrinc és János ${ }^{1994}$ továbbá Gúg fia Gúg ${ }^{1995}$, a másik fele Debreceni Dózsa fiai, Jakab és Pál ${ }^{1996}$ birtokába került. Az osztályos felek közösen vállalták az átkeléshez szükséges hajók biztosítását és fenntartását, ahogy a Hortobágy hídja őket illető részének (in quantum ipsos dictus pons contingeret) karbantartását is. ${ }^{1997}$ A hídnak ugyanis, úgy tűnik, csak az egyik fele tartozott Zámmonostorához; felerészben a túlparti Szomajom birtokosait illette. ${ }^{1998}$ (Vö. Szomajom)

\section{Zazárbánya (Nagybánya/Asszonypataka) (Szatmár megye) [Baia Mare, RO]}

I. Lajos 1347-ben a nagybányaiak kérésére írásba foglalta és kibővítette városuk régi kiváltságait, mivel régi kiváltságlevelük állítólag elégett. ${ }^{1999}$ A kiváltságlevél lehetővé tette, hogy a levágott állatok húsát (a szalonnát nem) és a kisütött kenyereket a város hétfői hetivásárára szinte vámmentesen lehessen behozni - a két árucikk után csak a zazárkői vámot kellett kifizetni. ${ }^{2000}$ A kedvezmény céljaként a város élelmezésének megkönnyítette és olcsóbbá tétele sejthető.

Nagybánya 1347. évi városprivilégiumával a király egyrészt hétfői hetivásár tartását tette lehetővé a városban (vagy foglalta írásba a már meglévő vásártartási jogot), ugyanakkor a Szent Gál hitvalló ünnepe (október 16.) előtti vasárnapon kezdődő, 15 napig (október 9-23.) tartó éves vásár megtartására kaptak engedélyt kassai mintára (more civitatis nostrae

\footnotetext{
1993 Weisz B.: Vámok és vámszedés 439.

1994 Vö. Engel P.: Genealógia: Káta nem 1. tábla: elágazás.

1995 Vö. Engel P.: Genealógia: Káta nem 6. tábla: Kátai (Csekekátai).

1996 Vö. Engel P.: Genealógia: Debreceni.

1997 Z. II. 56-59. (Anjou-oklt. XXVII. 98. sz.).

1998 Vö. 1346: DF 219 457. (Anjou-oklt XXX. 801. sz.).

${ }^{1999}$ F. IX/1. 497-503. (Anjou-oklt. XXXI. 883. sz.).

2000 Item carnes mactatae, exceptis lardonibus, et panis pistus, sine omni solucione tributi, in aliis tributis omnibus saluo tributo in Zazurkeu duntaxat, introducantur libere, et semel in septimana cum aliis mercibus, videlicet singulis feriis secundis pro libero exponantur, et vendantur in civitatibus nostris praenotatis - F. IX/1. 502. Vö. Németh P.: A középkori Szatmár megye 250.
} 
Cassensis). ${ }^{2001}$ 1376-ban, amikor I. Lajos kibővítette a bányaváros kiváltságait, a (heti)vásár napján minden kereskedőnek tam forenses, siue aduenae, quam etiam ciuitatenses megengedte a posztó kis- és nagybani kereskedelmét, tehát rőfönként és végenként történő árusítását, míg a hét többi napján csak a helyiek kiskereskedelmét tette lehetővé - a többi kereskedő csak bontatlan végeket árulhatott. ${ }^{2002}$

\section{Zics (Somogy megye) [Zics, H]}

Zics szerdai hetivására 1379-ben háromvásáros kikiáltás színhelye volt. ${ }^{2003}$

\section{Zilah (Közép-Szolnok megye) [Zalău, RO]}

1370-ből származik első adatunk az erdélyi püspök Zilah birtokán Antiochiai Szent Margit napjához (július 13.) kötődően, királyi engedéllyel tartani szokott éves vásárra: június 24-én Lajos védelmet ígért a kereskedőknek, akár a zilahi, akár Lackfi Miklós párhuzamosan zajló margittai sokadalmát keresnék fel. ${ }^{2004}$

\section{Zólyom (Zólyom megye) [Zvolen, SVK]}

A sági konvent 1346. november 27-én kiállított eltiltó és tiltakozó oklevelében megemlítették Jánost, Paksi Olivér zólyomi ispán ${ }^{2005}$ zólyomi (in antiquo Zolyo) vámszedőjét. ${ }^{2006}$

\footnotetext{
${ }^{2001} \mathrm{~F} . \mathrm{IX} / 1.502$.

${ }^{2002}$ vt in die fori in ipsis ciuitatibus nostris tam forenses, siue aduenae, quam etiam ciuitatenses pannos cum petiis, et etiam vlnis libere venditioni exponant, sed in septimana ciuitatenses ibi residentes cum vlnis, et etiam petiis, et forenses cum petiis tantum pannos vendendi habeant facultatem - F. IX/5. 99.

2003 DF 233 330. (Borsa I.: A somogyi konvent oklevelei 427. sz.).

${ }^{2004}$ F. IX/4. 222. (Az oklevelet csak Fejér kiadásában ismerem).

${ }^{2005}$ Engel P.: Archontológia I. 244.

${ }^{2006}$ DF 254168 = DF 254 210. (Anjou-oklt. XXX. 844. sz.).
} 


\section{Zsarnóca (Bars megye) [Žarnovica, SVK]}

Goznica falu garami vízivámját (tributum supra aquam Goron in villa Gozancha exigi consuetum), aminek a harmada a garamszentbenedeki monostort illette, Léva (1321-1332) 2007 és Saskő várnagya (1325-1327), ${ }^{2008}$ Becsei Imre barsi ispán (1321-1333) ${ }^{2009}$ hatalmaskodva Zsarnóca faluba helyezte át - amint ezt a zobori konvent, ${ }^{2010}$ az esztergomi ${ }^{2011}$ és a nyitrai káptalanok ${ }^{2012}$ 1344-ben, Szigfrid garamszentbenedeki apát érdekében lefolytatott vizsgálatai is igazolták - a vámharmad elidegenítésének céljából. ${ }^{2013}$ A vám Zsarnócára történő áthelyezése maradandónak bizonyult. 1344 után a falu és vámja Revistye várának tartozékaként tűnt fel a 14. század végén: a várat Zsigmond 1391-ben elcserélte Sárói Péter fia Lászlóval, a Lévaiak ősével ${ }^{2014}$ annak néhány nyitrai birtokáért. ${ }^{2015}$ Úgy tűnik, a zsarnócai vám harmadát időközben megszerezte a garamszentbenedeki apátság, vagy legalábbis igényt tartott rá, amikor ugyanis Lászlónak az esztergomi káptalan a vámot iktatni akarta, csak 2/3-át sikerült (Sarnocha cum duabus partibus tributi in eadem Sarnocha), a harmadik vámharmad iktatásának Henrik, a monostor apátja ellentmondott. ${ }^{2016}$ Zsarnóca az 1424. évi barsi vámvizsgálatban is szerepelt mint ahol Lévai Cseh Péter (az előbbi László fia) ab antiquo vámot szedet a Velkapolyáról Újbánya felé menőktől. ${ }^{2017}$

\section{Zseliz (Bars megye) [Želiezovce, SVK]}

Imre fia Vesszős mester zólyomi comes ${ }^{2018}$ és Mikolai Péter fia András mester ${ }^{2019} 1354-$ ben az esztergomi káptalan előtt kibékültek, és megállapodtak, hogy felosztják egymás közt azt a Mikola és Zseliz falvak között fekvő birtokrészt, aminek a hovatartozása közöttük addig

\footnotetext{
${ }^{2007}$ Engel P.: Archontológia I. 358.

${ }^{2008}$ Engel P.: Archontológia I. 406.

${ }^{2009}$ Engel P.: Archontológia I. 106.

2010 Str. III. 540-541. (Anjou-oklt. XXVIII. 364. sz.).

2011 Str. III. 546-547. (Anjou-oklt. XXVIII. 611. sz.).

2012 Str. III. 552-553. (Anjou-oklt. XXVIII. 813. sz.).

2013 ut predictum ius ipsius ecclesie sancti Benedicti, in ipsa tercia porcione posset suffocare - Str. III. 541.; ut ius ipsius monasterii quod in eodem habuisset usurpare valuisset - Str. III. 547.

2014 Vö. Engel P.: Genealógia: Lévai 1. tábla.

2015 DL 87619.

${ }^{2016}$ DL 87 619. (ZsO. I. 2161. sz.).

2017 quicumque autem de possessione Velykapolya versus Uybanya transirent, ad solutionem tributi in dicta Sarnocha exigi soliti intrare tenerentur - ZsO. XI. 478.

${ }^{2018}$ Vö. Engel P.: Genealógia: Töttös (bátmonostori).

${ }^{2019}$ Vö. Engel P.: Genealógia: Mezőpilis nem Mikolai.
} 
vita tárgyát képezte. A felosztás során két földhatárjelet a Garam folyó révjénél (portus) létesítettek. ${ }^{2020}$

A faluban átmenetileg hetivásárt is tartottak a 14. század közepén, miután Vesszős mester az esztergomi káptalan régi, damásdi, vasárnapi hetivásárát (forum quod in die dominico in villa Damas capituli Strigoniensis fuisset ab antiquo celebratum) áthelyezte (abstulisset) ide. A király ráhatására a vásár 1354-ben visszakerült Zselizről Damásdra. ${ }^{2021}$

\section{Zsitvatő (Keltekő) (Komárom megye) [Radvaň nad Dunajom (Dunaradvány) területén, SVK]}

A zsitvatői dunai kikötő, illetve rév és vámja a középkor nagy részében a nyitrai püspökségé volt. Az egyház vámszedési jogát II. Géza már a 15. században is erősen gyanúsnak minősített (que non parvam suspicionem et ambiguitatem nobis importare videbantur), ${ }^{2022}$ hamis oklevele alapozta meg. ${ }^{2023}$ Az uralkodó a Zsitva Dunába torkollásánál lévő Keltekő földet a püspökségnek adta, a censusszal együtt, amit addig a királyi mensa számára szedtek be a Dunán felfelé és lefelé haladóktól (a transeuntibus super et infra in Danubio) ${ }^{2024}$, és amely a nyitrai egyház karbantartására (ad reparandam ecclesiam) fordítható. ${ }^{2025}$ A nyitrai püspökséget 1271-ben - szintén kétes hitelü oklevelével - V. István megerősítette a Komárom megyei Zsitvatő birtok, a dunai kikötő és a vám birtokában. ${ }^{2026}$ 1326-ban I. Károly parancsára az esztergomi stefanita konvent határjárást követően beiktatta a nyitrai egyházat a Demeter mester ${ }^{2027}$ által nekik visszaadott Zsitvatő birtokba és haszonvételeibe, többek közt a vámba és a kikötőbe (cum tributo, portu). ${ }^{2028} 1335$-ben a király, miután Piast Meskó nyitrai püspök ${ }^{2029}$ bemuttata V. István 1271. évi oklevelét, újfent visszahelyezte a nyitrai egyházat a birtok, a kikötő és a vám birtokába nullum ius regali honori exinde adtunc conservando. Az oklevélben az uralkodó Zsitvatőről megemlítette, hogy az korábban tárnokmestere, Nekcsei Demeter kezén volt (tenuisset). ${ }^{2030}$ A birtok korábbi, 1326. évi iktatásról kiállított oklevelet I. Károly 1326. november 11-én privilegiális fomában

\footnotetext{
${ }^{2020}$ DL 87 294. (Anjou-oklt. XXXVIII. 294. sz.).

${ }^{2021}$ DF 235 838. (Str. IV. 74.).

2022 1496: Neumann T.: Székesfehérvár 89.

${ }^{2023}$ Weisz B.: Vámok és vámszedés 444.

2024 Vö. Weisz B.: Vámok és vámszedés 444.

2025 +1158: CDES. I. 83. (Reg. Arp. 94. sz.).

2026 Weisz B.: Vámok és vámszedés 444.

${ }^{2027}$ Nekcsei Demeter királyi tárnokmesterről van szó. Vö. Neumann T.: Székesfehérvár 60.

2028 Neumann T.: Székesfehérvár 62.

${ }^{2029}$ Neumann T.: Székesfehérvár 60. 8. sz. jz.

2030 Neumann T.: Székesfehérvár 60.
} 
megerősítette, majd - a diplomáról az 1496. évi zsitvatői vámper ítéletlevelében olvasható leírás alapján - I. Lajos is elátta függő, kettős pecsétjével. Érdekes, hogy az iménti leírás szerint 1496-ban az oklevélen mind Károly, mind Lajos függő pecsétje megtalálható volt, holott ugyanezen leírás jegyzi meg, hogy Lajos a diplomát Károly pecsétjének elveszése (propter amissionem sigilli) miatt hitelesítette. ${ }^{2031} 1360$ táján a nyitrai püspökség zsitvatői birtok- és/vagy vámjoga újra vita tárgyát képezhette. Miután úgy tünik, a püspökség Bebek István országbíró - tartalmi átírásból ismert - ítéletlevelét 1361-ben, majd 1364-ben is megerősíttette a királlyal, biztosra vehető, hogy a részleteiben nem ismert ügy kimenetele az

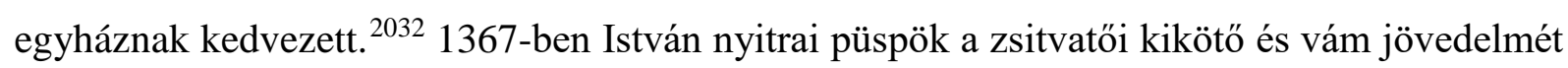
(proventus portus et tributi) Jakab pozsonyi bírónak adta bérbe - úgy látszik, nem először. ${ }^{2033}$ A bérlet február 22-től egyévi időtartamra szólt, amiért Jakab bíró 400 forintot (forintját 100 dénárral számolva) fizetett azzal a kikötéssel, hogy a vámként szedett halak és minden más élelmiszer felét a püspök zsitvatői házának és lakóinak juttatja. ${ }^{2034}$ Az összeg, legalábbis részben, a püspöki egyház építésére fordítandó, ${ }^{2035}$ ami, talán nem véletlenül, a II. Géza vámadományában foglaltakat idézi. A pozsonyi bírónak egyébként ezidőtájt nem csak Zsitvatőn, hanem az átellenben, a Duna túlpartján fekvő Neszmélyen is voltak vámérdekeltségei. ${ }^{2036}$ 1373-ban Domonkos nyitrai püspök a zsitvatői vámbevételek csökkenéséről számolt be a királynak, ami abból adódott, hogy az itt áthaladni/átkelni tartozók ${ }^{2037}$ vámját és révjét (tributum suum in dicta Sythwathew exigi consuetum et navigium de eadem) újabban elkerülték, és más átkelőhelyeket, főként az újfalusi ${ }^{2038}$ révet használták. Az uralkodó megtiltotta a zsitvatői rév jogtalan elkerülését, azt ezt megkísérelőket pedig óvta attól, hogy - ha valami kárt szenvednének - panaszt tegyenek előtte (nec de eis nostre poterunt imputare maiestati). ${ }^{2039}$

\footnotetext{
${ }^{2031}$ Neumann T.: Székesfehérvár 62. Ugyancsak a zsitvatői vámper ítéletlevele említi I. Károly 1341. január 26-i oklevelét, amely vélhetően Károly említett, 1326. évi privilégiumának megerösítését tartalmazta. Neumann T.: Székesfehérvár 63. (Anjou-oklt. XXV. 79. sz.).

2032 Neumann T.: Székesfehérvár 57-58.

${ }^{2033}$ sicut aliis temporibus quibus dictos nostros proventus sub arrenda tenuit - DL 41696 (F. IX/7. 260.).

${ }^{2034}$ medietatem piscium et omnium aliorum victualium in dicto nostro tributo proveniencium ad nostram curiam in Sythuatw existentem ac ibidem commorantibus plene et absque fraude faciet amministrari - DL 41696 (F. IX/7. 260.).

${ }^{2035}$ pro necessitatibus operis et fabrice ecclesie nostre nostrisque aliis necessitatibus sublevandis - DL 41696 (F. IX/7. 260.).

2036 1364: F. IX/7. 227-230.

2037 mercatoribus et aliis quibuslibet hominibus per portum Sythwathew transire debentibus et grandientibus Neumann T.: Székesfehérvár 63.

${ }^{2038}$ Neumann Tibor szerint a mai Nyergesúffaluról lehet szó. Neumann T.: Székesfehérvár 98. 45. sz. jz.

2039 Neumann T.: Székesfehérvár 63-64.
} 


\section{Zsolna (Trencsén megye) [Žilina, SVK]}

A zsolnai polgárok és hospesek János plébános, Peturman polgár és Wolfardus városi jegyző tolmácsolta kérésére Lajos 1357. október 28-án éves vásár (nundine seu ferie ac congregatio fori annui) tartását engedélyezte Úrnapján egészen az ünnep quindenájáig a budai sokadalom mintájára (ad instar libertatis fidelium civium et hospitum nostrorum Budensium), Zsolna bírájának joghatósága alatt. A vásárra szárazföldi és vízi úton érkezőket a király felmentette a város területén a vámfizetés alól, egyben megtiltotta feltartóztatásukat és áruik lefoglalását. ${ }^{2040}$ Szécsi Miklós országbíró, turóci comes a következő évben, 1358-ban, néhány nappal az úrnapi sokadalom kezdete (1358. május 31.) előtt, május 28-án kiállított parancsában emlékezette várnagyait, főleg a budetinit, az újhelyit, a sztrecsényit és rajecit, valamint az összes Turóc vármegyei és Vág menti officialist és vámost a király előző évi vásárengedélyére, aminek értelmében a vásár idején (június 14-ig) a város területén senkitől nem szedhető vám - ennek megfelelően hagyják a vásározókat szabadon jönni-menni. ${ }^{2041}$

\section{Zsombor (Doboka megye) [Zimbor (Magyarzsombor), RO]}

1376-ban Drági Jakab comes és fiai, Miklós, Péter és János ${ }^{2042}$ a zsombori vám (tributum de Sumbur) őt illető felét elzálogosította Mosdatlan András comes dési polgárnak 100 aranyforintért. Megegyezésük értelmében a bérlet tartama alatt az álutakon járóktól elkobzott javak harmada járt Andrásnak. ${ }^{2043}$

\section{VÁMTARIFÁK}

\footnotetext{
2040 de telonio etiam seu tributo tam per vias terrestres seu aquatiquas accedentibus undecunque vel de quibuscunque partibus ad congregationem saepedictam occurrerint ubique in territorio seu metis ipsius civitatis dictas nundinas seu ferias illas per omnia liberas et ab omni exactione tributi exemptas sic eis esse volumus ut ab ipsis nil penitus exigi valeat census novi per quempiam vel imponi, in ipsa duntaxat nundinalis fori area dum mercatur - F. XI. 513-515. Az oklevelet a turóci konvent 1358. május 6-án átírta. DF 274 714. (Anjou-oklt. XLII. 525. sz.).

${ }^{2041}$ F. XI. 515-517. (Anjou-oklt. XLII. 609. sz.).

2042 Vö. Engel P.: Genealógia: Brassói-rokonság 2. tábla: Drági.

2043 in dicto tributo donec ipsum tributum ipsorum redimere valuerint quicquam de viatoribus indebite procedentibus recipere poterint de talibus rebus idem comes Andreas terciam partem recipiendi habeat potestatem - DL 26868.
} 
1343, 1346: Zágráb (Zágráb megye) [Zagreb, HR] 2044

\begin{tabular}{|c|c|c|}
\hline vámalap & $\begin{array}{l}\text { vám } \\
\text { (1343) }\end{array}$ & $\begin{array}{l}\text { vám } \\
(1346)\end{array}$ \\
\hline 1 vég skarlát & fél fertó tiszta ezüst & ua. \\
\hline $\begin{array}{l}\text { mindenféle más posztó és } \\
\text { egyéb dolgok }\end{array}$ & $\begin{array}{l}\text { minden márka érték után } 2 \\
\text { dénár } \\
\text { (becslés történjen az eladás } \\
\text { helyszínén) }\end{array}$ & ua. \\
\hline gabonával megrakott szekér & $\begin{array}{l}12 \text { dénár (6-6) } \\
\text { (hat a vevőtől, és } \\
\text { ugyanannyi az eladótól is, ez } \\
\text { a további áruknál is } \\
\text { odaértendő) }\end{array}$ & $\begin{array}{l}8 \text { dénár (4-4) } \\
\text { (a vevőtől, és ugyanannyi } \\
\text { az eladótól is, ez a további } \\
\text { javaknál is odadértendő) }\end{array}$ \\
\hline $\begin{array}{l}1 \text { lóteher (pondus equi) } \\
\text { bármilyen gabona }\end{array}$ & 4 dénár (2-2) & ua. \\
\hline 1 viaszrúd & 2 dénár (1-1) & ua. \\
\hline $\begin{array}{l}1 \text { messzely só és } 1 \text { adag } \\
\text { darabolt vas (de singulis } \\
\text { stariis salis }^{1} \text { ac singulis peciis } \\
\text { ferri seccati }^{2} \text { ) }\end{array}$ & 2 obulus (1-1) & ua. \\
\hline 1 bort szállító szekér & 4 dénár (2-2) & ua. \\
\hline 1 friss halat szállító szekér & 12 dénár (6-6) & ua. \\
\hline 1 sózott halat szállító szekér & 24 dénár (12-12) & ua. \\
\hline ha utóbbiak vizák & darabja után 12 dénár (6-6) & ua. \\
\hline $\begin{array}{l}1 \text { légely olaj, füge és szőlő } \\
\text { után, amit a tengerentúlról } \\
\text { hoznak }\end{array}$ & & $\begin{array}{l}\text { becslés után szedjék a } \\
\text { vámot }\end{array}$ \\
\hline 1 kosár nagy hal & 4 dénár (2-2) & ua. \\
\hline 1 kosár kisebb hal & 2 dénár (1-1) & ua. \\
\hline 1 kosár rák & 2 obulus (1-1) & ua. \\
\hline 1 ló & 12 dénár (6-6) & ua. \\
\hline 1 kanca & 8 dénár (4-4) & ua. \\
\hline $\begin{array}{l}1 \text { emberrakomány (pondus } \\
\text { hominis) }{ }^{3} \text { közönséges vászon, } \\
\text { posztó, és hasonlók után }\end{array}$ & 4 dénár (2-2) & ua. \\
\hline $\begin{array}{l}\text { nagyobb vagy kisebb } \\
\text { emberrakomány }\end{array}$ & az értéke szerint & ua. \\
\hline $\begin{array}{l}1 \text { ökör, tehén, üszőborjú, } \\
\text { bikaborjú }\end{array}$ & 2 dénár (1-1) & ua. \\
\hline kisebb állat & 2 obulus (1-1) & ua. \\
\hline 1 bárány, kecskegida & 2 obulus (1-1) & ua. \\
\hline 1 nagyobb disznó & 2 dénár (1-1) & ua. \\
\hline $\begin{array}{l}1 \text { kisebb disznó } \\
\text { (fél éves vagy fiatalabb) }\end{array}$ & 2 obulus (1-1) & ua. \\
\hline
\end{tabular}

2044 1343: Tkalčić, Mon. ep. Zagr. II. 20-21. (Anjou-oklt. XXVII. 23. sz.); 1346: Tkalčić, Mon. civ. Zagr. I. 180183. (Anjou-oklt. XXX. 264. sz.). 


\begin{tabular}{|c|c|c|}
\hline 1 kosár malac & 2 obulus (1-1) & ua. \\
\hline házi és erdei állatok böre & $\begin{array}{l}2 \text { obulus vagy } 2 \text { dénár a } \\
\text { méretüktől függően }(1-1)\end{array}$ & ua. \\
\hline 1 csöbör méz & 2 obulus $(1-1)$ & ua. \\
\hline $\begin{array}{l}\text { kecskegidák után, amiket az } \\
\text { anyjukkal együtt visznek a } \\
\text { vásárra, egészen Húsvét utáni } \\
\text { 40. napig }\end{array}$ & semmit ne kérjenek vámként & ua. \\
\hline $\begin{array}{l}\text { szürke posztóból készült férfi } \\
\text { és női tunika és köpeny } \\
\text { (pallium) }\end{array}$ & 2 obulus (1-1) & ua. \\
\hline $\begin{array}{l}\text { más posztóból készült tunikák } \\
\text { és köpenyek (mantelli) után }\end{array}$ & a posztó minősége szerint & ua. \\
\hline $\begin{array}{l}1 \text { - emberrakománnyi } \\
\text { (pondus hominis) - zsák } \\
\text { bármilyen gabona vagy } \\
\text { hüvelyes zöldség (legumen) }\end{array}$ & $\begin{array}{l}2 \text { kis mérő (mensurelle seu } \\
\text { metretelle) }(1-1)\end{array}$ & ua. \\
\hline $\begin{array}{l}\text { sajtok, gyümölcsök, fonal, len } \\
\text { és más hasonló javakból }\end{array}$ & $\begin{array}{l}\text { anyaguk és minőségük } \\
\text { alapján }\end{array}$ & ua. \\
\hline 1 szekér gerenda & 2 gerenda (1-1) & ua. \\
\hline 1 szekér deszka & $\begin{array}{l}2 \text { obulus vagy } 2 \text { dénár a } \\
\text { méretük szerint (1-1) }\end{array}$ & ua. \\
\hline $\begin{array}{l}1 \text { épületfát szállító szekér } \\
\text { (főleg, ha az efféle fákat a } \\
\text { káptalan erdőiből hozzák) }\end{array}$ & 2 obulus (1-1) & ua. \\
\hline $\begin{array}{l}\text { minden mesterember (quilibet } \\
\text { suam vitam ducens cum aliqua } \\
\text { arte vel magisterio) } \\
\text { (kocsmáros, szücs, fazekas } \\
\text { stb.) vámként évente }\end{array}$ & $\begin{array}{l}\text { december 25-ig } 5 \text { dénár, } \\
\text { húsvétvasárnapig } 5 \text { dénár és } \\
\text { Szent István király ünnepég } \\
\text { (augusztus 20.) } 5 \text { dénár }\end{array}$ & ua. \\
\hline $\begin{array}{l}\text { egyéb, nem részletezett javak } \\
\text { után }\end{array}$ & $\begin{array}{l}\text { megállapított értékük } \\
\text { századrészét }\end{array}$ & ua. \\
\hline
\end{tabular}

1 A messzely (sextarius, itáliai oklevelekben stare: Du Cange: Glossarium VII. col. 585a.; online: http://ducange.enc.sorbonne.fr/STARE4 [utolsó letöltés: 2018. 02. 12.], lásd pl. 1412: „50 staria frumenti et 100 staria avene” - ZsO. III. 2027. sz.) főleg folyadékok és gabona ürmértékeként volt használatos. Bogdán I.: Ür-, térfogat-, súly- és darabmértékek 577., passim. Zágrábban a szemes tengeri só mérésére is használhatták. A sextariust só mérésére lásd még: 1315: eisdem donatione irrevocabili inter vivos concedimus quadraginta staria salis omni anno - Frangepán I. 38. Kérdés, milyen viszonyban lehetett a sextarius 1482. évi szlavóniai vámtarifában feltűnő, köznyelven csötörtnek nevezett mértékkel. Vö. Bogdán I.: Ür-, térfogat-, súly- és darabmértékek 285. A vámszabás szerint a tengeri sóval megrakott szekerek után fél zágrábi mérő, közönségesen egy csötört sót és 4 dénárt kellett fizetni (item de salibus maritimis de quolibet curru onerato, medietas unius metrete wlgariter chetert, mensure civitatis montis Grecensis de iisdem salibus et denarii quatuor recipiantur). MonCivZagr II. 415. Ugyanekkor a szekéren kockákban szállított kősó (sal lapideus) vámját, ha a rakomány 100 vagy több sókockát tett ki, 1 kocka sóban és 4 dénárban, ha a szekér kevesebb, mint 100 sókockát vitt, 4 dénárban határozták meg. MonCivZagr II. 415. 
${ }^{2}$ Darabolt laposvasról lehet szó. A seccatus formában a seco 1 (cui, sectum), „vágni” jelentésű ige helytelenül képzett participiumát sejtjük. A pecia használatát kohászati termékekre lásd Zupko, R. E.: A Dictionary of Weights and Measures 290-291.

${ }^{3}$ Az emberrakományra (pondus hominis) lásd még az 1478-as, Ország-féle váradi vámtarifát: Hunyadiak kora XII. Pest 1857. 68-69. Fordítása: Kubinyi A.: A városi rend 212-214.

1343: Bihar (Bihar megye) [Biharia, RO] ${ }^{2045}$ - révvám

\begin{tabular}{|l|l|}
\hline vámalap & vám (1343) \\
\hline terménnyel megrakott szekér menetben & 2 dénár \\
\hline jövetben, ha terhelt & a kellö vámot \\
\hline jövetben, ha üres & semmit ne szedjenek \\
\hline 1 mázsaszekér 2046 & 1 forint \\
\hline fél mázsaszekér[nyi rakomány] & fél forint \\
\hline sóért menö szekér & 2 dénár és 2 kenyér \\
\hline sóval rakott szekér & 2 só \\
\hline 1 hordó bor & 1 garas \\
\hline 1 vég yperni posztó & 8 dénár \\
\hline 1 vég nehéz tournai posztó & 4 dénár \\
\hline 1 vég poperingei posztó & 2 dénár \\
\hline [1 vég] könnyü tournai posztó & 2 dénár \\
\hline ló után, ha el tudják adni & 4 dénár \\
\hline ökör, marha után & 1 dénár \\
\hline 2 lábasjószág, ti. kisebb állat & 1 dénár \\
\hline 1 vég szürkeposztó & 1 dénár \\
\hline gyalogosok, akik nem visznek semmit & ne szedjenek tőlük vámot \\
\hline
\end{tabular}

1350: Bény (Pozsony megye) [Biňovce (Binóc), SVK], Bikszárd (Pozsony megye) [Buková, SVK], Farkashida (Pozsony megye) [Vlčkovce, SVK], Szentjakabfalva (Pilis megye) [Budapest része, H], Sasvár (Nyitra megye) [Šaštín, SVK], Sempte (Nyitra megye) [Šintava, SVK], Szenic (Nyitra megye) [Senica, SVK], Nyárhíd (Nyitra megye) [Nové Zámky (Érsekújvár), SVK], Udvard (Komárom megye) [Dvory nad Žitavou, SVK] - csökkentett közlekedési vám, Nyárhídon hídvám ${ }^{2047}$

\begin{tabular}{|l|l|}
\hline vámalap & vám (1350) \\
\hline rudas szekér & 1 lat vagy 3 pondus \\
\hline ajoncás szekér & fél lat \\
\hline
\end{tabular}

2045 DF 245 024. (Anjou-oklt. XXVI. 1. sz.).

${ }^{2046}$ A mázsaszekérre és rakományára mint mértékegységre lásd Domanovszky S.: Mázsaszekér 37-46.

2047 Wenzel, Dipl. Eml. II. 391. 
1350: Jablonca (Nyitra megye) [Jablonica, SVK] - csökkentett hídvám²048

\begin{tabular}{|l|l|}
\hline vámalap & vám (1350) \\
\hline kocsit húzó ló vagy ökör & 1 bécsi dénár \\
\hline 2 eladásra szánt nagyobb állat & 1 bécsi dénár \\
\hline 4 kisebb állt (pl. juh, kecske, disznó) & 1 bécsi dénár \\
\hline
\end{tabular}

1350: Sopron, Keresztes udvar (Sopron megye) [Sopron, H] ${ }^{2049}$

\begin{tabular}{|l|l|}
\hline vámalap & vám (1352) \\
\hline egy nehéz vég tournai posztó után & 6 bécsi dénár \\
\hline egy könnyủ vég tournai posztó után & 4 bécsi dénár \\
\hline egy hosszú vég kölni posztó után & 6 bécsi dénár \\
\hline egy vég yperni posztó után & 9 bécsi dénár \\
\hline egy hosszú vég löweni posztó után & 9 bécsi dénár \\
\hline egy rövid vég löweni posztó után & 6 bécsi dénár \\
\hline egy vég aacheni posztó után & 4 bécsi dénár \\
\hline egy hosszú vég mainzi posztó után & 4 bécsi dénár \\
\hline egy vég lengyel posztó után & 2 bécsi dénár \\
\hline egy vég loden vagy szürke posztó után & 3 bécsi fillér (másfél bécsi dénár - H. J.) \\
\hline
\end{tabular}

1355: Pécsújfalu ${ }^{2050}$ (Sáros megye) [Pečovská Nová Ves, SVK] ${ }^{2051}$

\begin{tabular}{|l|l|}
\hline vámalap & vám (1355) \\
\hline társzekér vagy lekötözött szekér & 1 ferto \\
\hline közönséges, nem lekötözött szekér & fél ferto \\
\hline $\begin{array}{l}\text { szekér, amin } 12 \text { vagy } 4 \text { légely } \\
\text { tonh2 }\end{array}$ & 3 garas \\
\hline
\end{tabular}

2048 1350: Wenzel, Dipl. Eml. II. 391.

${ }^{2049}$ Házi J.: Sopron legrégibb német oklevele 169-170.

2050 Az alábbi jegyzék a sárosi vámvizsgálat alkamával készült, a tényleges helyi, több esetben bizonyosan jogszerütlen vámszedési gyakorlatot tükrözi (például a füszerekre a vámszedők belátása szerint kivetett vám, vagy a nemesek egyik birtokáról a másikra szállított - nem kereskedelmi - javak megvámolása) így csak fenntartásokkal minősíthető vámtarifának.

${ }^{2051}$ Draskóczy I.: Sáros megye vámhelyei 59-60.

2052 Vö. Néprajzi lexikon III. 424.: „légely” szócikk.

2053 Vö. A középkori latinság szótára I/2. 133. A szótár „allec, -ecis vagy allecium, i n.” szócikke szerint a szó (1) „(tengeri?) halfajtát”, vagy (2) halból készült mártást jelöl. Migne szerint a szó a sózni való kisebb halakat, heringet, szardíniát, szardellát - tehát mindenképpen tengeri halat - jelöl. Lexicon manuale 127. („alecium”). Visszatérve az előbbi szótár szócikkére, az allecium (2) mártás jelentésénére a ZsO. I. 5218. számú regesztájából 


\begin{tabular}{|c|c|}
\hline ha egy szekéren 6 vagy 2 légely tonhal van & 3 garas \\
\hline $\begin{array}{l}\text { a helyi kereskedőktől, akik minden héten } \\
\text { vásárról vásárra viszik a posztókat, minden } \\
\text { vég vagy posztó után }\end{array}$ & $\begin{array}{l}1 \text { garas } \\
\text { (és ugyanígy } 1 \text { garast akár kisebb, akár } \\
\text { nagyobb a vég) }\end{array}$ \\
\hline $\begin{array}{l}\text { minden köteg szövet után, amit azokon a } \\
\text { részeken bálának hívnak, és a } \\
\text { bányavárosokba visznek }\end{array}$ & 3 garas \\
\hline bármilyen szekér után, ami halat szállít & 1 garas \\
\hline $\begin{array}{l}\text { és szállított halakból a már beszedett vámon } \\
\text { felül }\end{array}$ & $\begin{array}{l}\text { egy jobb halat, ami egy fertót vagy többet } \\
\text { ért, és ha jót nem találtak, } 2 \text { vagy } 3 \text { halat }\end{array}$ \\
\hline rezet, vasat vagy ólmot szállító szekér után & egyenként 3 garas \\
\hline $\begin{array}{l}\text { ha az ilyen a szekér csak egy mázsányit } \\
\text { szállított [ezekből], bár nem volt annyira } \\
\text { megrakva }\end{array}$ & 3 garas \\
\hline $\begin{array}{l}\text { mindenfajta malomkő után, amit } \\
\text { átszállítanak a vámon }\end{array}$ & 3 garas \\
\hline $\begin{array}{l}\text { sáfránnyal, malátával vagy liszttel } \\
\text { megrakott után }\end{array}$ & 2 garas \\
\hline $\begin{array}{l}\text { zabbal vagy árpával megrakott szekér (akár } \\
10 \text { köbölnyit, akár többet, akár kevesebbet } \\
\text { visz) }\end{array}$ & 1 garas \\
\hline $\begin{array}{l}1 \text { teljes vagy fél szekér termény, hagyma és } \\
\text { más efféle dolgok után }\end{array}$ & 1 garas \\
\hline ezen felül a gyümölcsökből vagy effélékből & 1 nagy tálnyit \\
\hline 1 eladásra szánt ló & 1 garas \\
\hline 1 ökör vagy igavonó marha után & 2 dénár \\
\hline 1 disznó után & 1 dénár \\
\hline 1 juh vagy 1 (nőstény) kecske & 1 dénár \\
\hline $\begin{array}{l}\text { és ugyanígy minden egyes hasonló állat } \\
\text { után }\end{array}$ & 1 dénár \\
\hline $\begin{array}{l}\text { egyik birtokról a másikra a családjukkal } \\
\text { átköltözőktől }\end{array}$ & 40 dénár \\
\hline $\begin{array}{l}\text { bámilyen gyalogostól, legyen az férfi vagy } \\
\text { nő, és a zarándokoktól is }\end{array}$ & 1 dénár \\
\hline $\begin{array}{l}\text { ha ezek az áthaladást követő nap nem térnek } \\
\text { vissza, csak a harmadik napon vagy később }\end{array}$ & 1 dénár \\
\hline $\begin{array}{l}\text { a szepességi kalmároktól, akik a vámhelyen } \\
\text { keresztül Kassára, vagy akik Kassáról a } \\
\text { Szepességbe mentek, először beszedték a } \\
\text { vámot }\end{array}$ & \\
\hline $\begin{array}{l}\text { a borsból, sáfrányból, szegfüszegből és más } \\
\text { effélékből }\end{array}$ & amennyit a vámszedő akart \\
\hline
\end{tabular}

hoz szöveghelyet: Unum centenarium olei olive ac unam lagenam allecum vulgo 'thimam'. Az 1398. évi oklevél 1444-es közjegyzői átírásából (DL 8836) származó szokatlan „thimam” helyett azonban valójában a „thunam” olvasat lehet a helyénvaló, annál is inkább, mivel az oklevél eredetijében (DL 7818., Zala II. 258.) a kérdéses szöveghelyen wlgo tun olvasható; a köznyelvi ton szó a közjegyző latinizálásának eshetett áldozatul. Az allec kifejezéssel tehát az iménti, 1398. évi esetben mindenképpen a tonhalat írták le. 
a nemesek szekerei után, amelyek az

összegyüjtött élelmiszereket - halakat, bort, gabonát vagy mást - egyik birtokról a

másikra szállítják több vámot szedetett be, mint a

kereskedőktől

1366: Rajka (Moson megye) [Rajka, H], Győr (Győr megye) [Győr, H], Komárom (Komárom megye) [Komárom, H], Zsitvatő (Komárom megye) [Radvaň nad Dunajom (Dunaradvány) területén, SVK], Esztergom (Esztergom megye) [Esztergom, H], Szob (Hont megye) [Szob, H], Visegrád (Pilis megye) [Visegrád, H], Óbuda (Pilis megye) [Budapest része, H] ${ }^{2054}$ - dunai vámtarifa

\begin{tabular}{|l|l|}
\hline a Dunán lefelé úszó hajók & vám (1366) \\
\hline vámalap & $\begin{array}{l}1 \text { forint a hajófenék szélességének minden } \\
\text { lába }^{2055} \text { után }\end{array}$ \\
\hline posztót vagy mást szállít & hajónként 3 forint \\
\hline fazekakat (ollas) szállít & hajónként 2 forint \\
\hline gyümölcsöket (pl. alma, körte) szállít & \\
\hline
\end{tabular}

a Dunán felfelé haladó hajók

\begin{tabular}{|l|l|}
\hline vámalap & vám (1366) \\
\hline posztót vagy mást szállít & fél vám \\
\hline fazekakat szállít & fél vám \\
\hline gyümölcsöket (pl. alma, körte) szállít & fél vám \\
\hline
\end{tabular}

1373: Somos (Sáros megye) [Drienov, SVK] ${ }^{2056}$

\begin{tabular}{|l|l|}
\hline vámalap & vám (1373) \\
\hline 1 lekötözött szekér & 12 dénár \\
\hline $\begin{array}{l}1 \text { nem lekötözött szekér (terményt, halakat } \\
\text { és akármi mást szállít) }\end{array}$ & 6 dénár \\
\hline 1 hordó szerémi vagy máshol termelt bor & 6 dénár \\
\hline 1 eladásra szánt ló & 2 dénár \\
\hline 1 marha vagy eladásra szánt ökör & 1 dénár \\
\hline 2 juh, kecske, disznó és hasonló állatok & 1 dénár \\
\hline 1 málhát cipelő ember & 1 dénár \\
\hline
\end{tabular}

2054 1366. március 22.: DF 258 545: 092-090.; 1366. június 24.: Teleki, Huny. X. 376-377. A két oklevél szövege megegyezik. Vö. 1370. február 22.: ZW. II. 337-339.; Kubinyi A.: Budapest története 47. 20551 királyi láb = 31,26 cm. Bogdán I.: Magyarországi hossz- és földmértékek 79.

${ }^{2056}$ Iványi, Eperjes 80. sz. 


\begin{tabular}{|l|l|}
\hline üres szekér & nem fizet vámot \\
\hline málhát nem szállító lovas vagy gyalogos & nem fizet vámot \\
\hline
\end{tabular}

1379: kolozsváriak csökkentett vámtarifája (fél vám) a Drági nemesek vámjain ${ }^{2057}$

\begin{tabular}{|l|l|}
\hline vámalap & vám (1379) \\
\hline 1 hordó bor & 10 szerecsendénár \\
\hline 1 vizákat szállító szekér & 9 szerecsendénár-garas \\
\hline 1 szekér másfajta hal & 6 szerecsendénár-garas \\
\hline 1 sajttal megrakott szekér & 4 szerecsendénár-garas \\
\hline 1 eladásra szánt ló & 2 szerecsendénár \\
\hline 1 eladásra szánt ökör & 1 szerecsendénár \\
\hline 6 disznó & 2 dénár \\
\hline 6 szalonna & 2 dénár \\
\hline 1 vég jó, finomabb posztó & 2 garas \\
\hline $\begin{array}{l}\text { más posztók végei után, amik kevésbé } \\
\text { finomak és értékesek }\end{array}$ & 1 garas \\
\hline 1 vég zeférnek mondott szürkeposztó & 1 dénár \\
\hline $\begin{array}{l}1 \text { nagy, lekötött, bármilyen áruval megrakott } \\
\text { szekér, amit közönségesen mázsának hívnak }\end{array}$ & 16 dénárgaras \\
\hline 1 bör & 1 dénár \\
\hline
\end{tabular}

1381: Köpcsény (Moson megye) [Kittsee, A] ${ }^{2058}$

\begin{tabular}{|l|l|}
\hline vámalap & vám (1381) \\
\hline 1 teljes/érintetlen (integrus) szekér & 12 dénár \\
\hline
\end{tabular}

1 teljes/érintetlen (integrus) szekér $\quad 12$ dénár

1381: Öttevény (Győr megye) [Öttevény, H] ${ }^{2059}$

vámalap

1 teljes/érintetlen (integrus) szekér vám (1381)

15 dénár

\footnotetext{
2057 ZW. II. 508-509.

${ }^{2058}$ AT WStLA HAUrk 1005. ${ }^{2058}$ In: monasterium.net, URL <http://monasterium.net/mom/AT-

WStLA/HAUrk/1005/charter> [utolsó letöltés: 2017. 09. 22.]. (F. IX/5. 491.).

2059 AT WStLA HAUrk 1005. In: monasterium.net, URL http://monasterium.net/mom/ATWStLA/HAUrk/1005/charter [utolsó letöltés: 2017. 09. 22.]. (F. IX/5. 491.).
} 
1383: Privigye (Nyitra megye) [Prievidza, SVK] ${ }^{2060}$

\begin{tabular}{|l|l|}
\hline vámalap & vám (1383) \\
\hline 1 vég yperni (Iprii) posztó & 16 dénár \\
\hline 1 vég nehéz tournai (dorneti) posztó & 12 dénár \\
\hline 1 vég könnyü tournai $($ dorneto) posztó után & 8 dénár \\
\hline 1 vég kaytots(?)nak ${ }^{2061}$ mondott posztó & 4 dénár \\
\hline 1 vég szürkésfehér(?) $($ Grisei Albi) posztó & 2 dénár \\
\hline 1 ló, marha vagy nagyállat & 2 dénár \\
\hline terhet cipelö gyalogos & 1 dénár \\
\hline gyalogos, aki nem visz semmit & ne szedjenek vámot \\
\hline
\end{tabular}

${ }^{2060}$ DL 6982. (F. X/1. 63.).

2061 Az azonosíthatatlan „kaytots” nevü posztó olvasata erősen bizonytalan, az oklevél másik másolatában (DF 286 775) talán kajtoth-nak olvasható. 


\section{FELHASZNÁLT FORRÁSOK ÉS IRODALOM}

A középkori latinság szótára = Lexicon Latinitatis medii aevi Hungariae (A magyarországi középkori latinság szótára). Szerkbiz. elnöke Harmatta János; Szerkbiz. Benkő Loránd et al.; szócikkeit összeállította Bellus Ibolya et al. I-V., I. Pótkötet. Budapest 1987-2014.

Acsády I.: Magyarország pénzügyei = Acsády Ignác: Magyarország pénzügyei I. Ferdinánd uralkodása alatt 1526-64. Budapest 1888.

Áldásy A.: Nyugati egyházszakadás = Áldásy Antal: A nyugoti nagy egyházszakadás története VI. Orbán haláláig 1378-1389. Esztergom 1896.

Alsószlavónia = Alsó-Szlavóniai okmánytár (Dubicza, Orbász és Szana vármegyék). Codex diplomaticus partium regno Hungariae adnexarum (Comitatuum Dubicza, Orbász et Szana). 1244-1718. Szerk. Thallóczy Lajos - Horváth Sándor. Budapest 1912.

Anjou-oklt. = Anjou-kori oklevéltár I-XV., XVII., XIX-XXXI., XXXIII-XXXIV., XXXVIII. Szerk. Almási Tibor - Blazovich László - Géczi Lajos - B. Halász Éva - Kőfalvi Tamás - Kristó Gyula - Makk Ferenc - Piti Ferenc - Sebők Ferenc - Teiszler Éva - Tóth Ildikó. Budapest-Szeged 1990-2017.

AO = Anjoukori Okmánytár. Codex diplomaticus Hungaricus Andegavensis I-VII. Szerk. Nagy Imre - Tasnádi Nagy Gyula. Budapest 1878-1920.

Apponyi I. = A Pécz nemzetség Apponyi ágának az Apponyi grófok családi levéltárában örizett oklevelei. I. 1241-1526. Budapest 1906.

AT WStLA HAUrk = Österreich, Wiener Stadt- und Landesarchiv, Hauptarchiv - Urkunden.

Bakács, Pest megye = Bakács István: Iratok Pest megye történetéhez 1002-1437. Budapest 1982.

Bándi Zs.: Körmend = Bándi Zsuzsanna: Újonnan elökerült források Körmend középkori történetéhez. Vasi Szemle 48. (1994) 257-260. 
Bánffy = Oklevéltár a Tomaj nemzetségbeli Losonczi Bánffy család történetéhez I-II. 12141457. Szerk. Varjú Elemér. Budapest 1908.

Baranya megye földrajzi nevei $=$ Baranya megye földrajzi nevei I. Szerk. Pesti János. Pécs 1982.

Bertényi = Magyar történeti szöveggyüjtemény 1000-1526. Szerk. Bertényi Iván. Budapest 2000.

Bgl. = Urkundenbuch des Burgenlandes und der angrenzenden Gebiete der Komitate Wieselburg, Ödenburg und Eisenburg I-V. Bearbeitet von Hans Wagner - Irmtraut LindeckPozza - Leonhard Prickler. Wien-Graz-Köln 1955-1999.

Bogdán I.: Magyarországi hossz- és földmértékek = Bogdán István: Magyarországi hossz- és földmértékek a XVI. század végéig. Budapest 1978.

Bogdán I.: Ür-, térfogat-, súly- és darabmértékek = Bogdán István: Magyarországi ür-, térfogat-, súly- és darabmértékek 1874-ig. Budapest 1991.

Borsa I.: A somogyi konvent oklevelei = Borsa Iván: A Somogyi Konvent oklevelei az Országos Levéltárban (Forrásközlés) (Ötödik közlemény) 1371-1380. Somogy megye múltjából. Levéltári évkönyv 30. (1999) 7-54.

Bp. = Budapest történetének okleveles emlékei I-III. Budapest 1936-1987.

Budai jogkönyv = Buda város jogkönyve II. Közreadja Blazovich László - Schmidt József. Szeged 2001.

Budak, N. - Paić-Piljac, S.: I fiorentini nella Slavonia = Budak, Neven - Paić-Piljac, Sandra: I fiorentini nella Slavonia e nella Croazia nei secoli XIV e XV. Archivio Storico Italiano 153. (1995) 681-695.

Buzás G. - Eszes B.: Görög monostor Visegrádon = Buzás Gergely - Eszes Bernadett: XI. századi görög monostor Visegrádon. In: Középkori egyházi építészet Erdélyben (Arhitectura 
religioasă medievală din Transilvania) IV. Szerk. Szőcs Péter Levente - Rusu, Adrian Andrei. Satu Mare 2007. 49-93.

CDES. = Codex diplomaticus et epistolaris Slovaciae I-II. Ed. Marsina, Richard. Bratislavae 1971-1987.

Csánki = Csánki Dezső: Magyarország történelmi földrajza a Hunyadiak korában I-V. Budapest 1890-1913.

Csánki D.: Hazánk kereskedelmi viszonyai = Csánki Dezső: Hazánk kereskedelmi viszonyai I. Lajos korában. Budapest 1880.

Csánki D.: Körös megye = Csánki Dezső: Körös megye a XV-ik században. Székfoglaló értekezés. Budapest 1893.

Csukovits E.: Az Anjouk Magyarországon II. = Csukovits Enikő: Az Anjouk Magyarországon II. I. (Nagy) Lajos és Mária uralma (1342-1395). Budapest 2019.

Decr. Hung. = Decreta Regni Hungariae. Gesetze und Verordnungen Ungarns 1301-1457. Ed. Franciscus Döry - Georgius Bónis - Vera Bácskai. Budapest. 1976.

Dettné I.: Vámtarifák = Dettné Légrády Ilona: Középkori magyar vámtarifák. Budapest 1995.

Dettné I.: Vámszedés = Dettné Légrády Ilona: A magyar vámszedés kialakulása és fejlődése a honfoglalástól 1300-ig. Kandidátusi értekezés. Budapest 1994.

DF = Magyar Nemzeti Levéltár, Országos Levéltár, Diplomatikai Fényképgyüjtemény, Budapest.

Divéky A.: Felső-Magyarország = Divéky Adorján: Felső-Magyarország kereskedelmi összeköttetése Lengyelországgal föleg a XVI.-XVII. században. Budapest 1905.

DL = Magyar Nemzeti Levéltár, Országos Levéltár, Diplomatikai Levéltár, Budapest. 
Doc. Trans. = Documenta Romaniae Historica. C. Transilvania. Volumul X. 1351-1355. Red. Ștefan Pascu. București 1977.

Doc. Val. $=$ Documenta historiam Valachorum in Hungaria illustrantia usque ad annum 1400 p. Christum. Curante Emerico Lukinich et adiuvante Ladislao Gáldi. Ediderunt Antonius Fekete-Nagy et Ladislaus Makkai. Budapest 1941.

Domanovszky S.: A harminczadvám = Domanovszky Sándor: A harminczadvám eredete. Székfoglaló értekezés. Értekezések a történeti tudományok köréből 24/4. Budapest 1916.

Domanovszky S.: Mázsaszekér = Domanovszky Sándor: Mázsaszekér. In: Emlékkönyv Fejérpataky László életének hatvanadik évfordulója ünnepére. Szerk. Szentpétery Imre. Budapest 1917. 37-74.

Domanovszky S.: Szepesi városok = Domanovszky Sándor: A szepesi városok árumegállító joga. Lőcse és Késmárk küzdelme az árumegállításért, 1358-1570. Budapest 1922.

Domokos N.: Források = Források az 1360-as év nádori közgyüléseinek tanulmányozásához. Szerk., ford. Domokos Noémi. Szeged 2015.

Draskóczy I. - Soós I.: Középkori oklevélpublikációk 1945-1990. = Draskóczy István - Soós István: Középkori oklevél-publikációk Magyarországon 1945-1990 között. Bibliográfia. Levéltári közlemények 62. (1991/1-2.) 9-55.

Draskóczy I.: A somosi vám = Draskóczy István: A somosi vám a 13-14. században. In: R. Várkony Ágnes emlékkönyv. Szerk. Tusor Péter. Budapest 1998. 50-56.

Draskóczy I.: Gyöngyös = Draskóczy István: Gyöngyös település- és birtoklástörténete a középkorban. In: Tanulmányok Gyöngyösről. Szerk. Havassy Péter - Kecskés Péter. Gyöngyös 1984. 91-128.

Draskóczy I.: Sáros megye vámhelyei = Draskóczy István: Sáros megye vámhelyei a 14. században. In: Tanulmányok Borsa Iván tiszteletére. Szerk. Csukovits Enikő. Budapest 1998. 45-61. 
Draskóczy I.: Só a középkori Magyarországon = Draskóczy István: Só a középkori Magyarországon. In: Gazdaság és gazdálkodás a középkori Magyarországon: gazdaságtörténet, anyagi kultúra, régészet. Szerk. Kubinyi András - Laszlovszky József Szabó Péter. Budapest 2008. 147-161.

Dreska G.: A pannonhalmi hiteleshely = Dreska Gábor: A pannonhalmi konvent hiteleshelyének müködése a Zsigmond-korban. (A pannonhalmi konvent hiteleshelyének 1387 és 1437 között készült kiadványai a Pannonhalmi Bencés Főapátsági Levéltárban.) Levéltári Közlemények 68. (1997/1-2) 3-61.

DRMH II. = The laws of the medieval Kingdom of Hungary. Decreta Regni Mediaevalis Hungariae II. 1301-1457. Eds. Engel, Pál - Bak M., János - Sweeney, James Ross. Salt Lake City 1992.

DRMH IV. = The laws of the medieval Kingdom of Hungary. Decreta Regni Mediaevalis Hungariae IV. 1490-1526. Eds. Döry, Ferenc - Banyó, Péter - Rady, Martyn C. - Bak M., János. Budapest 2012.

DRMH online = Bak M., János, "Online Decreta Regni Mediaevalis Hungariae. The Laws of the Medieval Kingdom of Hungary" (2019). All Complete Monographs 4. (https://digitalcommons.usu.edu/lib_mono/4) (utolsó letöltés: 2019. 08. 18.).

Du Cange: Glossarium = Du Cange et al.: Glossarium mediae et infimae latinitatis. Niort 1883-1887.

Eckhart F.: Királyi adózás = Eckhart Ferenc: A királyi adózás története Magyarországon. Budapest 1908.

EFHU = Elenchus fontium historiae urbanae III/2. Ed. Kubinyi, András - Jánosi, Mónika - E. Kovács, Péter - Köblös, József - Tringli, István. Budapest 1997.

Engel P.: A királyi hatalom = Engel Pál: Királyi hatalom és az arisztokrácia viszonya a Zsigmond-korban (1387-1437). Budapest 1977. 
Engel P.: Archontológia = Engel Pál: Magyarország világi archontológiája 1301-1457. I-II. Budapest 1996.

Engel P.: Genealógia = Engel Pál: Középkori magyar genealógia. In: Arcanum DVD Könyvtár IV. Családtörténet, heraldika, honismeret. Budapest [2004.].

Engel P.: Honor = Engel Pál: Honor, vár, ispánság. Tanulmányok az Anjou-királyság kormányzati rendszeréről. Századok 116. (1982) 880-922.

Engel P.: Térkép = Magyarország a középkor végén. Szerk. Engel Pál. Térinformatika: Kollányi László, Sallay Ágnes. Kiadja: Térinfó Bt., MTA BTK TTI. Szoftver: Kollányi Péter MindMap v1.1.

Engellex = Engel Pál „Magyarország a középkor végén” című térképének (Engel P.: Térkép) település-adatbázisa.

Erdődy $=$ Az Erdődy család bécsi levéltárának oklevelei (1001-1387). Szerk. B. Halász Éva Piti Ferenc. Kézirat.

Eubel, K.: Hierarchia catholica = Eubel, Konrad: Hierarchia catholica medii aevii sive summorum pontificum, S.R.E. cardinalium, ecclesiarium antistitum series I. (1198-1431). Münster 1913-1914.

F. = Codex diplomaticus Hungariae ecclesiasticus ac civilis I-XI. Ed. Georgius Fejér. Budae 1829-1844.

Fekete Nagy = Fekete Nagy Antal: A Szepesség területi és társadalmi kialakulása. Budapest 1934.

Földesi F.: Dávod = Földesi Ferenc: Dauid-tól Dávodig: Történelmi morzsák egy településtörténethez. Honismeret 38. (2010) 56-63.

Fraknói V.: Magyarország és a Szentszék = Fraknói Vilmos: Magyarország egyházi és politikai összeköttetései a római szent-székkel I. 1000-1417. Budapest 1901. 
Frangepán = Codex diplomaticus comitum de Frangepanibus. A Frangepán család oklevéltára I-II. Szerk. Thallóczy Lajos - Barabás Samu. Budapest 1910-1913.

Fügedi E.: Eperjes város hetipiacjövedelme = Fügedi Erik: Eperjes város hetipiacjövedelme 1497-1526. Történeti Statisztikai Évkönyv 4. (1965/1.) 3-25.

Fügedi E.: Középkori magyar városprivilégiumok = Fügedi Erik: Középkori magyar városprivilégiumok. Tanulmányok Budapest Múltjából 14. (1961) 17-109.

Fügedi E.: Vár és társadalom = Fügedi Erik: Vár és társadalom a 13-14. századi Magyarországon. Budapest 1977.

Gábor Gy.: A megyei intézmény = Gábor Gyula: A megyei intézmény alakulása és müködése Nagy Lajos alatt. Budapest 1908.

Gárdonyi A.: Felső-Magyarország = Gárdonyi Albert: Felső-Magyarország kereskedelmi útjai a középkorban. Közgazdasági Szemle 1908. (klny.)

Gárdonyi A.: I. Károly nagypecsétjei = Gárdonyi Albert: I. Károly király nagypecsétjei. Turul 25. (1907) 30-57.

Gy. = Györffy György: Az Árpád-kori Magyarország történeti földrajza I-IV. Budapest 19631998.

Győr megye $=$ Györ megye hatóságának oklevelei (1328-1525). Szerk. Horváth Richárd. Győr 2005.

Hadrovics, L.: Ungarische Elemente im Serbokroatischen = Hadrovics, László: Ungarische Elemente im Serbokroatischen. Budapest 1985.

B. Halász É.: Hercegek és hercegnők = B. Halász Éva: 14. századi hercegek és hercegnők oklevelei. In: Hercegek és hercegségek a középkori Magyarországon. Szerk. Zsoldos Attila. Székesfehérvár 2016. 129-225. 
Haraszti Szabó P.: Harmincad = Haraszti Szabó Péter: Harmincadbérlők, harmincadispánok, ispánok. A harmincadvám szedése Magyarországon a 14. század első feléig. In: Magister Historiae. (Válogatott Tanulmányok a 2012-ben és 2013-ban megrendezett középkorral foglalkozó, mesterszakos hallgatói konferenciák előadásaiból.) Szerk. Belucz Mónika - Gál Judit - Kádas István - Tarján Eszter. Budapest 2014. 72-100.

Házi = Házi Jenő: Sopron szabad királyi város története I/1-II/6. Sopron 1921-1943.

Házi J.: Pozsony vármegye = Házi Jenő: Pozsony vármegye középkori földrajza. Pozsony 2000.

Házi J.: Sopron legrégibb német oklevele = Házi Jenő: Sopron város legrégibb német nyelvü oklevele. Soproni Szemle 17. (1963) 169-170.

Historiae Patriae Monumenta II. = Historiae patriae monumenta edita iussu regis Caroli Alberti. Liber iurium reipublicae Genuensis II. Taurini 1857.

HO. = Hazai okmánytár. Codex diplomaticus patrius I-VIII. Kiadják: Ipolyi Arnold - Nagy Imre - Paur Iván - Ráth Károly - Véghely Dezső. Győr-Budapest 1865-1891.

HOkl. = Hazai oklevéltár 1234-1536. Szerk. Nagy Imre - Deák Farkas - Nagy Gyula. Budapest 1879.

Holub J.: Zala vármegye vámhelyei = Holub József: Zala vármegye vámhelyei és úthálózata a középkorban. Századok 51. (1917) 45-60.

Hornyik = Hornyik János: Kecskemét város története oklevéltárral I-IV. Kecskemét 18601866.

Horváth R.: Középkori oklevelek publikálása 1991-2004. = Horváth Richárd: Középkori oklevelek publikálása Magyarországon 1991-2004 között. (Szövegközlések és regeszták.) Levéltári Közlemények 78. (2007/2.) 3-34.

Iván L.: Visegrádi vár = Iván László: A visegrádi vár története a kezdetektől 1685-ig. Visegrád 2004. 
Iványi B.: Bihar- és Bars-vármegyék = Iványi Béla: Bihar- és Bars-vármegyék vámhelyei a középkorban. Magyar Gazdaságtörténelmi Szemle 12. (1905) 81-132.

Iványi B.: Tiszaluczi vám = Iványi Béla: A tiszaluczi vám bevételei és azok felhasználása 1516-1520-ig. (Bevezetésül a tiszaluczi rév- és vámjog története.) Gazdaságtörténelmi Szemle 13. (1906) 1-54.

Iványi, Bártfa = Iványi Béla: Bártfa szabad királyi város levéltára 1319-1526. Budapest 1910.

Iványi, Eperjes = Iványi Béla: Eperjes szabad királyi város levéltára 1245-1526. Szeged 1931.

Jakó: Kolozsmonostor = Jakó Zsigmond: A kolozsmonostori konvent jegyzőkönyvei (1289_ 1566) I-II. Budapest 1990.

Janota, E.: Bardyjów = Janota, Eugeniusz: Bardyjów. Historyczno-topograficzny opis miasta i okolicy. Kraków 1862.

Juck = Výsady miest a mestečiek na Slovensku I. 1238-1350. Ed. Juck, Lubomir. Bratislava 1984.

Justh = A Justh család levéltára 1274-1525. Szerk. Borsa Iván. Budapest 1991.

Kádas I. - Skorka R. - Weisz B.: Kereskedelmi források = Kádas István - Skorka Renáta Weisz Boglárka: Kereskedelmi források a középkori magyar gazdaság szolgálatában. Történelmi Szemle 61. (2009/2.) 329-337.

Kar., HH. = Karácsonyi János: A hamis, hibáskeletủ és keltezetlen oklevelek jegyzéke 1400ig. [A Történelmi Tár 1908. évi számában megjelent „Pótlások...”-kal kiegészítve.] Szerk. Koszta László. Szeged 1988.

Karácsonyi J.: Magyar nemzetségek = Karácsonyi János: A magyar nemzetségek a XIV. század közepéig. Budapest 1900. 
Károlyi = A Nagy-Károlyi gróf Károlyi család oklevéltára I-V. Összeáll. Géresi Kálmán. Budapest 1882-1897.

Keglevich: Garamszentbenedek = Keglevich Kristóf: A garamszentbenedeki apátság 13. és 14. századi oklevelei (1225-1403). Szeged 2014.

Király J.: Pozsony város joga = Király János: Pozsony város joga a középkorban. Budapest 1894.

Király J.: Pozsonyi vám- és révjog = Király János: Pozsonyi nagy-dunai vám- és révjog története. Pozsony 1890.

Királyi könyvek = Magyar Kancelláriai Levéltár. Libri regii.

KMTL = Korai magyar történeti lexikon (9-14. század). Főszerk. Kristó Gyula. Budapest 1994.

W. Kovács A.: Oklevélközlések Romániában = Magyar vonatkozású oklevélközlések Romániában. Szerk. W. Kovács András. (Erdélyi Tudományos füzetek 261.) Kolozsvár 2009. Internetes változat: http://eda.eme.ro/handle/10598/8961 (utolsó letöltés: 2019. 08. 22.)

W. Kovács A.: Pótlások = W. Kovács András: Pótlások a Magyar vonatkozású oklevélközlések Romániában című bibliográfiához. I. Pótlások és a 2009-2013 között megjelent közlések. Kézirat. Internetes változat:

http://www.academia.edu/2761706/Potlasok_a_Magyar_vonatkozasu_oklevelkozlesek_Roma niaban_c._bibliografiahoz (utolsó letöltés: 2013. 05. 09.)

Kovács B.: Elpusztult kolostorok = Kovács Béla: Elpusztult középkori kolostorok Heves megyében. Az Egri Múzeum Évkönyve - Annales Musei Agriensis 4. (1966) 71-95.

Kovács B.: Középkori vámok = Kovács Béla: Középkori vámok és vásáros helyek Heves megyében. Archívum - A Heves Megyei Levéltár közleményei 1. (1973) 15-30.

Kovács V.: A leleszi premontreiek = Kovács Viktória: A leleszi premontreiek szalókai birtoklásának háttere. Történelmi Szemle 57. (2015) 265-280. 
Kovács V.: A pozsonyiak vámmentessége = Kovács Viktória: A pozsonyiak vámmentessége az Anjou- és a Zsigmond korban. In: Pénz, posztó, piac. Gazdaságtörténeti tanulmányok a magyar középkorról. Szerk. Weisz Boglárka. Budapest 2016. 341-366.

Kovács V.: Álutazó átutazók = Kovács Viktória: Álutazó átutazók. Vámkerülés és csempészet a magyar középkor forrásaiban. (https://tti.btk.mta.hu/lendulet/kozepkorigazdasagtortenet/havi-szines/2388-alutazo-atutazok-vamkerules-es-csempeszet-a-magyarkozepkor-forrasaiban.html (utolsó letöltés: 2019. 07. 30.)

Kovács V.: Bártfa, Óvár, Pozsony = Kovács Viktória: Bártfa, Óvár, Pozsony. Újabb adatok az I. Lajos kori harmincadok történetéhez. In: Márvány, tárház, adomány. Gazdaságtörténeti tanulmányok a magyar középkorról. Szerk. Kádas István - Skorka Renáta - Weisz Boglárka. Budapest 2019. 115-130.

Kovács V.: Korábbi adományok elve = Kovács Viktória: Korábbi adományok elve. Vezérfonalak az Anjou- és a Zsigmond-kor vámjogi ítélkezési gyakorlatában. In: Hatalom, adó, jog: Gazdaságtörténeti tanulmányok a magyar középkorról. Szerk. Weisz Boglárka Kádas István. Budapest 2017. 263-282.

Kovács V.: Vámszedés Zágrábban = Kovács Viktória: Vámszedés Zágrábban az Anjou- és a Zsigmond-korban. In: Veretek, utak, katonák. Gazdaságtörténeti tanulmányok a magyar középkorból. Szerk. Kádas István - Skorka Renáta - Weisz Boglárka. Budapest 2018. 247268.

Kováts F.: Dunai hajózás = Kováts Ferenc: Adalékok a dunai hajózás és a dunai vámok történetéhez az Anjouk korában. Magyar Gazdaságtörténelmi Szemle 8. (1901) 431-470.

Kováts F.: Pozsonyi harmincad = Kováts Ferenc: Nyugatmagyarország áruforgalma a XV. században a pozsonyi harmincadkönyv alapján. Budapest 1902.

Kőfalvi T, Pécsváradi konvent = Köfalvi Tamás: A pécsváradi konvent hiteleshelyi oklevéltára 1254-1526. Szeged 2006.

Krassó = Pesty Frigyes: Krassó vármegye története III. Oklevéltár. Budapest 1882. 
Kretschmayr, H.: Bruck an der Leitha = Kretschmayr, Heinrich: Archivalische Beiträge zur Geschichte der niederösterreichischen Städte und Märkte: Bruck an der Leitha. Blätter des Vereines für Landeskunde von Niederösterreich 34. (1900) 189-227.

Kub. = Oklevelek Hontvármegyei magán-levéltárakból I. 1256-1399. Szerk. Kubinyi Ferenc. Budapest 1888.

Kubinyi A.: A belkereskedelem = Kubinyi András: A belkereskedelem a késő középkori Magyarországon. In: Gazdaság és gazdálkodás a középkori Magyarországon: gazdaságtörténet, anyagi kultúra, régészet. Szerk. Kubinyi András - Laszlovszky József Szabó Péter. Budapest 2008. 229-251.

Kubinyi A.: A városi rend = Kubinyi András: A városi rend kialakulásának gazdasági feltételei és a főváros kereskedelme a 15. század végén. In: Tanulmányok Budapest múltjából 15. (1963) 189-226.

Kubinyi A.: Budapest története = Kubinyi András: Budapest története a későbbi középkorban Buda elestéig (1541-ig). In: Budapest története a későbbi középkorban és a török hódoltság idején. Szerk. Gerevich László - Kosáry Domokos. Budapest 1975.

Kumorovitz L. B.: Óbuda 1355. évi felosztása = Kumorovitz L. Bernát: Óbuda 1355. évi felosztása. (I. Lajos király és Erzsébet anyakirályné 1355. augusztus 17-i és 1356. október 17i oklevele.) Budapest régiségei 24. (1976/1) 279-302.

Ladányi E.: Terminológiai kérdések = Ladányi Erzsébet: Libera villa, civitas, oppidum. Terminológiai kérdések a magyar városfejlődésben. Történelmi Szemle 23. (1980) 450-477.

Lederer E.: Középkori pénzüzletek = Lederer Emma: A középkori pénzüzletek története Magyarországon (1000-1458). Budapest 1932.

Lexicon Latinitatis Iugoslavie $=$ Lexicon Latinitatis medii aevi Iugoslavie. Red. Marko Kostrenčić et al. Zagrabiae 1969-1978.

Lexicon manuale $=$ Lexicon manuale ad scriptores mediae et infimae latinitatis, ex glossariis Caroli Dufresne, D. Ducangii, D. P. Carpentarii, Adelungii, et aliorum, in compendium 
accuratissime redactum; ou Recueil de mots de la basse latinité, dressé, pour servir à l'intelligence des auteurs, soit sacrés, soit profanes, du moyen age. Paris 1866.

Lexikon stredovekých miest $=$ Štefánik, Martin - Lukačka, Ján et al.: Lexikon stredovekých miest na Slovensku. Bratislava 2010.

Magyar törvényhatóságok II/II. = A magyar törvényhatóságok jogszabályainak gyüjteménye. II. kötet II. fele. A tiszáninneni törvényhatóságok jogszabályai. Szerk. Kolosvári Sándor Óvári Kelemen. Budapest 1890.

Majorossy J.: A foglalkozás topográfiája = Majorossy Judit: A foglalkozás topográfiája. A társadalmi tértől a személyes térig: a társadalmi mobilitás térbeli elemei a 15. századi Pozsonyban. Korall 12. (2011) 102-135.

Makkai, Kolozsvár = Makkai László: Kiadatlan oklevelek Kolozsvár középkori történetéhez. Kolozsvár 1947.

Maksay F.: Magyarország birtokviszonyai = Maksay Ferenc: Magyarország birtokviszonyai a 16. század közepén I-II. Budapest 1990.

Mályusz E.: Turóczmegye vámhelyei = Mályusz Elemér: Turóczmegye vámhelyei és forgalma a középkorban. Századok 53. (1919) 34-56.

Máriássy = Iványi Béla: A márkusfalvi Máriássy család levéltára 1243-1803. I. Különlenyomat a Közlemények Szepes vármegye múltjából IX. évfolyamához. Lőcse 1917.

Mollay K.: Soproni harmincad = Mollay Károly: A soproniak harmincadvámja 1383-1542. In: Házi Jenő emlékkönyv. Sopron város főlevéltárosa születésének 100. évfordulója tiszteletére. Szerk. Dominkovits Péter - Turbuly Éva. Sopron 1993. 129-153.

Mollay K.: Szélmalom utcai vám = Mollay Károly: A Szélmalom utcai vám 1217-1564. Soproni Szemle 45. (1991) 97-121.

Musso, R.: GUARCO, Nicolò = Musso, Riccardo: GUARCO, Nicolò. In: Dizionario Biografico degli Italiani - $\quad$ Volume 60. Rome 2003. 
(http://www.treccani.it/enciclopedia/nicolo-guarco_\%28Dizionario-Biografico\%29/) (utolsó letöltés: 2019. 08. 18.).

Németh P.: A középkori Szatmár megye = Németh Péter: A középkori Szatmár megye települései a 15. század elejéig. Nyíregyháza 2008.

Néprajzi lexikon = Magyar néprajzi lexikon I-V. Főszerk. Ortutay Gyula. Budapest 19771982.

Neumann T.: Székesfehérvár = Neumann Tibor: Források Székesfehérvár középkori kiváltságainak történetéhez. In: Székesfehérvár középkori kiváltságai. Szerk. Zsoldos Attila Neumann Tibor. Székesfehérvár 2010. 43-122.

ÓMO. = Ó-magyar olvasókönyv. Összeáll. Jakubovich Emil - Pais Dezső. Pécs 1929.

Ortvay T.: Pozsony város utcái = Ortvay Tivadar: Pozsony város utcái és terei. A város története utca és térnevekben. Pozsony 1905.

Ortvay, Pozsony = Ortvay Tivadar: Pozsony város története II/2. A város középkori jogszervezete, 1300-1526. Pozsony 1898.

Ortvay, T.: Stadt Preßburg = Ortvay, Theodor: Geschichte der Stadt Preßburg II/1. Mittelalterliche Topographie der Stadt, 1300-1526. Preßburg 1895.

P. = A pannonhalmi Szent-Bendek-rend története I-XII/B. Szerk. Erdélyi László - Sörös Pongrác. Budapest 1902-1916.

Pach Zs. P.: „A harmincadvám eredete” = Pach Zsigmond Pál: „A harmincadvám eredete”. Budapest 1990.

Pach Zs. P.: A harmincadvám az Anjou-korban = Pach Zsigmond Pál: A harmincadvám az Anjou-korban és a 14-15. század fordulóján. Történelmi Szemle 41. (1999) 231-277.

Pach Zs. P.: A középkori Levante = Pach Zsigmond Pál: A középkori Levante-kereskedelem és Magyarország. Történelmi Szemle 17. (1974) 476-482. 
Pach Zs. P.: Huszad = Pach Zsigmond Pál: Hogyan lett a harmincadból huszad? Történelmi Szemle 37. (1995) 257-276.

Pach Zs. P.: Levante = Pach Zsigmond Pál: A Levante-kereskedelem erdélyi útvonala I. Lajos és Zsigmond korában. Századok 109. (1975) 3-32.

Pach Zs. P.: Levante-kereskedelem = Pach Zsigmond Pál: A középkori Levantekereskedelem „sorsa" XIX-XX. századi történetírásunkban. Történelmi Szemle 15. (1972) 343-377.

Paradisum plantavit $=$ Paradisum plantavit. Bencés monostorok a középkori Magyarországon . Kiállítás a Pannonhalmi Bencés Főapátságban 2001. március 21-től november 11-ig. Szerk. Takács Imre. Pannonhalma 2001.

Pleidell A.: A nyugatra irányuló külkereskedelem = Pleidell Ambrus: A nyugatra irányuló magyar külkereskedelem a középkorban. Budapest 1925.

Pór A.: Háborúság a vám miatt = Pór Antal: Háborúság Esztergom város és az esztergomi káptalan közt a vám miatt. Magyar Gazdaságtörténelmi Szemle 11. (1904) 161-205.

Pór A.: Jegerndorfi Pál = Pór Antal: Jegerndorfi Pál nyitrai főesperes. Első közlemény. Századok 39. (1905) 693-711.

Putanec, V.: Etimološki Prinosi = Putanec, Valentin: Etimološki Prinosi: 1. bilka. 2. filarka/pilajrica. Rasprave ZJ. SV. 13. (1987) 79-91.

Rădvan, L.: At Europe's Borders = Rădvan, Laurenţiu: At Europe's Borders: Medieval Towns in the Romanian Principalities. Boston-Leiden 2010.

Reg. Arp. = Az Árpád-házi királyok okleveleinek kritikai jegyzéke. Regesta regum stirpis Arpadianae critico-diplomatica I-II. Szerk. Szentpétery Imre - Borsa Iván. Budapest 19231987.

Reg. Slov. = Regesta diplomatica nec non epistolaria Slovaciae I-II. Ed. Vincent Sedlák. Bratislavae 1980-1987. 
Reizner, Szeged = Reizner János: Szeged története I-IV. Szeged 1899-1900.

Romhányi B.: Kolostorok és társaskáptalanok = Kolostorok és társaskáptalanok a középkori Magyarországon. CD-ROM. Főszerk. F. Romhányi Beatrix. Szerk. Laszlovszky József Szakács Béla Zsolt. Budapest [2008].

Savaria-Szombathely $=$ Tóth Endre - Zágorhidi Czigány Balázs: Források SavariaSzombathely történetéhez. A római kortól 1526-ig. Szombathely 1994.

Schmauk, Supplementum $=$ Supplementum analectorum terrae Scepusiensis. Pars II. Collegit Michael Schmauk. Szepesváralja 1889.

Skorka R.: Csökkentett vámtarifájú út = Skorka Renáta: A csökkentett vámtarifájú út kialakulása I. Károly uralkodása alatt. Történelmi Szemle 55. (2013) 451-470.

Skorka R.: Pozsony Bécs árnyékában = Skorka Renáta: Pozsony a bécsi közvetítő kereskedelem árnyékában. In: Tiszteletkör. Történeti tanulmányok Draskóczy István egyetemi tanár 60. születésnapjára. Szerk. Mikó Gábor - Péterfi Bence - Vadas András. Budapest 2012. 301-309.

Smič. $=$ Codex diplomaticus regni Croatiae, Dalmatiae et Slavoniae. Ed.: Tadija Smičiklas Marko Kostrenčić. I-XVII. Zagrabiae 1904-1981.

Sólyom J.: A magyar vámügy = Sólyom Jenő: A magyar vámügy fejlődése 1519-ig. Budapest 1933.

Sopron vm. = Sopron vármegye története. Oklevéltár I-II. Szerk. Nagy Imre. Sopron 18891891.

Sörös P.: A komáromi rév és vám = Sörös Pongrác: A komáromi rév és vám 1373-tól 1490ig. Magyar Gazdaságtörténelmi Szemle 7. (1900) 138-141.

Sörös P.: A komáromi vámpör = Sörös Pongrác: A komáromi vámpör a XIV. században. Magyar Gazdaságtörténelmi Szemle 6. (1899) 478-483. 
Sroka, S. A.: A középkori Bártfa = Sroka, Stanisław Andrzej: A középkori Bártfa és kapcsolatai Kis-Lengyelországgal. Budapest 2016.

Sroka, S. A.: Sredniowieczny Bardiów = Sroka, Stanisław Andrzej: Sredniowieczny Bardiów i jego kontakty z Malopolska. Kraków 2010.

Sroka, S.: Dokumenty polskie = Sroka, Stanisław Andrzej: Dokumenty polskie z archiwów dawnego Królestwa Węgier. I-V. Kraków 1998-2012.

Str. = Monumenta ecclesiae Strigoniensis I-III. Collegit et edidit Ferdinandus Knauz Ludovicus Crescens Dedek. Strigonii 1874-1924., IV. Ad edendum praeparaverunt Gabriel Dreska - Geysa Érszegi - Andreas Hegedűs - Tiburcius Neumann - Cornelius Szovák Stephanus Tringli. Strigonii-Budapestini 1999.

Surányi B.: Kereskedőgilde Nagyszombaton = Surányi Bálint: Kereskedőgilde Nagyszombaton a Visegrádi Kongresszus évében. Történelmi Szemle 2. (1959) 249-271.

Sümeghy = Sopron vármegye levéltárának oklevél-gyüjteménye. I. rész: Középkori oklevelek (1236-1526). Összeáll. Sümeghy Dezső. [H. n.] 1928.

Süttő Sz.: Okmányi kalászat = Süttő Szilárd: Okmányi kalászat a bécsi Erdődy-levéltárból. Késő Anjou-kori és egyéb oklevelek 1244-1400. Gesta 7. (2007) 22-45.

Szamota I.: Oklevél-szótár = Pótlék a magyar nyelvtörténeti szótárhoz. Magyar Oklevélszótár. Régi oklevelekben és egyéb iratokban előforduló magyar szók gyüjteménye. Összeáll. Szamota István. Szerk. Zolnai Gyula. Budapest 1902-1906.

Szaszkó E.: A Szeri Pósafiak = Szaszkó Elek: A Szeri Pósafiak. Egy dél-alföldi előkelő család története a 14-15. században. Doktori disszertáció. Budapest 2014.

Szeged atlasz = Szeged. Magyar várostörténeti atlasz 3. Összeáll. Blazovich László - BaliaNagy Judit - Horváth Ferenc - Kelemen Gábor - Kratochwill Mátyás - Máté Zsolt Szemerey Anna - Szerdahelyi Péterné - Takács Máté. A történeti topográfiai adattárat készítették: Apró Ferenc - Berta Tibor - Blazovich László - Farkas Csaba - Horváth Ferenc - 
Kelemen Gábor - Kormányos András - Kratochwill Mátyás - Petrovics István - Szerdahelyi Péterné - T. Knotik Márta - Takács Máté. Szeged 2014.

Szende K.: Mennyit ér a kiváltság = Szende Katalin: Mennyit ér a kiváltság? Városprivilégiumok kibocsátása és rendelkezéseik betartása I. Károly alatt. In: Pénz, posztó, piac. Gazdaságtörténeti tanulmányok a magyar középkorról. Szerk. Weisz Boglárka. Budapest 2016. 285-339.

Szende K.: Otthon a városban = Szende Katalin: Otthon a városban. Társadalom és anyagi kultúra a középkori Sopronban, Pozsonyban és Eperjesen. Budapest 2004.

Szende K.: Sokadalomtartási engedélyek = Szende Katalin: Nundinae seu forum annuale. Sokadalomtartási engedélyek Nagy Lajos várospolitikájában. In: Hatalom, adó, jog. Gazdaságtörténeti tanulmányok a magyar középkorról. Szerk. Kádas István - Weisz Boglárka. Budapest 2017. 231-262.

Szende K.: Sopron és Pozsony kapcsolatai = Szende Katalin: Sopron és Pozsony kapcsolatai a késői középkorban. Soproni Szemle 46. (1992) 168-179.

Szende, K.: Kraków and Buda = Szende, Katalin: Kraków and Buda in the Road Network of Medieval Europe. In: On Common Path. Budapest and Kraków in the Middle Ages. Ed. Benda, Judit - Kiss, Virág - Grazyna Lihonczak-Nurek - Magyar, Károly. Budapest 2016. $31-37$.

Szent-Ivány = Mályusz Elemér - Borsa Iván: A Szent-Ivány család levéltára 1230-1525. Budapest 1988

Szentpétery I.: A harminczadvám eredete = Szentpétery Imre: Domanovszky Sándor: A harminczadvám eredete. Székfoglaló értekezés. Budapest 1916. (Értekezések a történeti tudományok köréből, 24/4.) Századok 52. (1918) 525-528.

Szilágyi, M.: Mobility, Roads and Bridges = Szilágyi, Magdolna: Mobility, Roads and Bridges in Medieval Hungary. In: The Economy of Medieval Hungary. Eds. Laszlovszky, József - Nagy, Balázs - Szabó, Péter - Vadas, András. Leiden-Boston 2018. 64-78. 
Szilágyi, M.: On the Road = Szilágyi, Magdolna: On the road. The History and Archaeology of Communication Networks in East-Central Europe. Budapest 2014.

Szilágyi, M.: Road Systems in Western Transdanubia = Szilágyi, Magdolna: Árpád Period Communication Networks. Road Systems in Western Transdanubia. PhD dissertation. Budapest 2012.

Sztáray = A nagymihályi és sztárai gróf Sztáray család oklevéltára I-II. Kiadja gróf Sztáray Antal. Szerk. Nagy Gyula. Budapest 1887-1889.

Tagányi K.: Egy hamisítvány = Tagányi Károly: Egy hamisítvány. Századok 27. (1893) 512514.

Takács S.: Vámrendszer = Takács Sándor: A magyar vámrendszer az Árpádok és az Anjouk alatt. In: A székesfehérvári községi felsőbb leányiskola értesítője. Székesfehérvár 1907. 1-34.

Tardy L.: A tatárországi rabszolgakereskedelem = Tardy Lajos: A tatárországi rabszolgakereskedelem és a magyarok a XIII-XV. században. Budapest 1980.

Teleki, Huny. = Teleki József: Hunyadiak kora Magyarországon I-XII. Pest 1852-1863.

Tkalčić, Mon. civ. Zagr. $=$ Monumenta historica liberae regiae civitatis Zagrabiae, metropolis regni Dalmatiae, Croatiae et Slavoniae. I-XI. Ed. Joannes Bapt. Tkalčić. Zagrabiae 18891905.

Tkalčić, Mon. ep. Zagr. = Monumenta historica episcopatus Zagrabiensis. I-II. Ed. Joannes Bapt. Tkalčić. Zagrabiae 1873-1874.

Tolna = Szakály Ferenc: Ami Tolna vármegye középkori okleveleiből megmaradt 13141525. Szekszárd 1998.

C. Tóth N.: Simontornya = C. Tóth Norbert: Oklevelek Simontornya középkori történetéhez, 1264-1543. Levéltári Közlemények 71. (2000) 93-127. 
Tringli I.: Perényi = A Perényi család levéltára 1222-1526. Összeáll. Tringli István. Budapest 2008.

Tringli I.: Vásártér és vásári jog = Tringli István: Vásártér és vásári jog a középkori Magyarországon. Századok 144. (2010) 1291-1344.

Túr. Reg. = Horváth Sándor: A liptói és turóczi registrum. 1391. Első közlemény. Történelmi Tár (új folyam) 2. (1902) 1-57.

Vár. Kápt. Stat. = Bunyitay Vincze: A váradi káptalan legrégibb statutumai. Nagyvárad 1886.

Varga Sz.: Zágráb = Varga Szabolcs: Zágráb szerepe a magyarországi városhálózatban a késő középkorban. Urbs. Magyar várostörténeti évkönyv 3. (2008) 249-273.

Vásáry, I.: Cumans and Tatars = Vásáry, István: Cumans and Tatars: Oriental Military in the Pre-Ottoman Balkans, 1185-1365. Cambridge 2005.

Veszp. Reg. = Veszprémi regeszták (1301-1387). Összeáll. Kumorovitz L. Bernát. Budapest 1953.

VVO = Veszprém város okmánytára. Oklevelek a veszprémi érseki és káptalani levéltárakból (1002-1523). Összeáll. Gutheil Jenő. Veszprém 2007.

VVOS = Érszegi Géza - Solymosi László: Veszprém város okmánytára. Pótkötet. Veszprém 2010.

W. = Árpádkori új okmánytár I-XII. Közzé teszi Wenzel Gusztáv. Pest-Budapest 1860-1874.

Wagner, Sáros = Diplomatarium comitatus Sarosiensis. Ed. Wagner, Carolus. Posonii et Cassoviae 1780.

Wass = Valentiny Antal - W. Kovács András: A Wass család cegei levéltára. Kolozsvár 2006. 
Weisz B.: A Felső-Tisza vidék vámszedése I. = Weisz Boglárka: A Felső-Tisza-vidék vámszedése az Árpád-korban I. Szabolcs-Szatmár-Beregi Szemle 39. (2004) 251-257.

Weisz B.: A Felső-Tisza vidék vámszedése II. = Weisz Boglárka: A Felső-Tisza-vidék vámszedése az Árpád-korban II. Szabolcs-Szatmár-Beregi Szemle 40. (2005) 92-97.

Weisz B.: A győri vám = Weisz Boglárka: A győri vám Árpád-kori története. In: Középkortörténeti tanulmányok 3. Szerk. Weisz Boglárka. Szeged 2003. 227-236.

Weisz B.: A kassaiak vámmentessége = Weisz Boglárka: Megszerezni és megtartani egy kiváltságot: A kassaiak vámmentessége. In: Ünnepi kötet Dr. Blazovich László egyetemi tanár 70. születésnapjára. Szerk. Balogh Elemér - Homoki-Nagy Mária. Szeged 2013. 749_ 760.

Weisz B.: A szerémi és pécsi kamarák = Weisz Boglárka: A szerémi és pécsi kamarák története a kezdetektől a XIV. század második feléig. Acta Historica 130. (2009) 33-53.

Weisz B.: A Szilágyság helye = Weisz Boglárka: A Szilágyság helye a középkori magyar királyság gazdasági életében. In: A Szilágyság és a Wesselényi család (14-17. sz.). Erdélyi Tudományos Füzetek 277. (2013) 237-254.

Weisz B.: A vásár és a vám = Weisz Boglárka: A vásár és a vám Árpád-kori törvényeinkben. In: Tanulmányok a középkorról. A II. medievisztikai PhD-konferencia (Szeged, 2001. április 3.) előadásai. Szerk. Weisz Boglárka - Balogh László - Szarka József. Szeged 2001. 169182.

Weisz B.: Abaúj megye vámszedőhelyei = Weisz Boglárka: Abaúj megye vámszedőhelyei az Árpád-korban. Acta Historica 119. (2004) 31-38.

Weisz B.: Átkelőhelyek a Tiszán = Weisz Boglárka: Átkelőhelyek a Tiszán az Árpád-korban. Acta Historica 122. (2005) 21-30.

Weisz B.: Az Árpád-kori harmincadvám = Weisz Boglárka: Az Árpád-kori harmincadvám. In: Erősségénél fogva várépítésre való. Tanulmányok a 70 éves Németh Péter tiszteletére. Szerk. Cabello, Juan - C. Tóth Norbert. Nyíregyháza 2011. 267-278. 
Weisz B.: Az esztergomi vám = Weisz Boglárka: Az esztergomi vám Árpád-kori története. Századok 137. (2003) 973-981.

Weisz B.: Bars megye vámhelyei = Weisz Boglárka: Bars megye vámhelyei az Árpád-korban. Acta Historica 115. (2001) 13-23.

Weisz B.: Debrecen = Weisz Boglárka: Debrecen kereskedelmi életének jogi háttere a középkorban. In: Debrecen város 650 éves. Várostörténeti tanulmányok. Szerk. Bárány Attila Pál - Papp Klára - Szálkai Tamás. Debrecen 2011. 143-160.

Weisz B.: II. András vámmentesség-adományai = Weisz Boglárka: II. András vámmentességadományai. Acta Historica 117. (2003) 43-61.

Weisz B.: II. András vámmentesség-adományai világiak számára = Weisz Boglárka: II. András vámmentesség-adományai világiak számára. Acta Historica 113. (2001) 41-53.

Weisz B.: Kassa kereskedelmi életének jogi háttere I. = Weisz Boglárka: Kassa kereskedelmi életének jogi háttere a középkorban. In: Arcana tabularii. Tanulmányok Solymosi László tiszteletére I-II. Szerk. Bárány Attila - Dreska Gábor - Szovák Kornél. Budapest 2014. 899908.

Weisz B.: Kassa kereskedelmi életének jogi háttere II. = Weisz Boglárka: Kassa kereskedelmi életének jogi háttere a középkorban II. In: Kassa az európai történelem kontextusában. Szerk. Hajdu Mária - Bartoš, Martin. Kassa 2015. 94-111.

Weisz B.: Kolozsvár = Weisz Boglárka: Városi gazdálkodás a középkorban. Kolozsvár gazdasági kiváltságai. (kézirat).

Weisz B.: Közlekedési vámtarifák = Weisz Boglárka: Közlekedési vámtarifák az Árpádkorban. In: Medievisztikai tanulmányok. Szerk. Marton Szabolcs - Teiszler Éva. Szeged 2005. 221-240.

Weisz B.: Sóvámolás = Weisz Boglárka: Megjegyzések az Árpád-kori sóvámolás és kereskedelem történetéhez. Acta Historica 125. (2007) 43-57. 
Weisz B.: Vámok és vámszedés = Weisz Boglárka: A királyketteje és az ispán harmada. Vámok és vámszedés Magyarországon a középkor első felében. Budapest 2013.

Weisz B.: Vámok és vámszedés az Árpád-korban = Weisz Boglárka: Vámok és vámszedés az Árpád-kori Magyarországon. (Történeti áttekintés, adattár.) Szeged 2006.

Weisz B.: Vámvizsgálatok Bihar megyében = Weisz Boglárka: Vámvizsgálatok Bihar megyében a 13-14. század fordulóján. In: Nagyvárad és Bihar az Árpád-kor végén. Szerk. Zsoldos Attila. Nagyvárad 2016. 155-174.

Weisz B.: Váradi vámper = Weisz Boglárka: A 15. századi váradi vámper Árpád-kori gyökerei. Nagyvárad és Bihar a korai középkorban. Nagyvárad 2014. 147-165.

Weisz B.: Vásárok és lerakatok = Weisz Boglárka: Vásárok és lerakatok a középkori Magyar Királyságban. Budapest 2012.

Weisz B.: Vásártartás = Weisz Boglárka: Vásártartás az Árpád-korban. Századok 141. (2007) 879-942.

Weisz, B.: Košice = Weisz, Boglárka: The legal background of the trade life of Košice in the Middle Ages. In: Košice in the Coordinates of European History. Eds. Hajduová, Mária Bartoš, Martin. Košice 2013. 94-111.

Weisz, B.: Operaţiuni de vămuire în comitatul Bihor = Weisz, Boglárka: Operaţiuni de vămuire în comitatul Bihor la cumpăna veacurilor al XIII-lea şi al XIV-lea. In: Oradea şi Bihorul la sfârşitul epocii Arpadiene. Ed. Zsoldos, Attila. Oradea 2017. 169-190.

Weisz, B.: Právne pozadie obchodného života Košíc = Weisz, Boglárka.: Právne pozadie obchodného života Košíc. In: Košice v súradniciach európskych dejín. Ed. Hajduová, Mária Bartoš, Martin. Košice 2014. 110-126.

Weisz, B.: Proces vămilor din Oradea = Weisz, Boglárka: Rădăcinile din epoca Arpadiană ale procesului vămilor din Oradea din secolul al XV-lea. In: Oradea şi Bihorul în evul mediu timpuriu. Ed. Zsoldos, Attila. Oradea 2017. 181-202. 
Wenzel G.: Nyitra megye vámhelyei = Wenzel Gusztáv: Nyitra vármegyének XV. századbeli vámhelyei. Tanulmány hazánk közlekedési viszonyainak történetéhez. Értekezések a történeti tudományok köréből II/II. 1872.

Wenzel, Bányászat = Wenzel Gusztáv: Magyarország bányászatának kritikai története. Budapest 1880.

Wenzel, Dipl. Eml. = Magyar diplomacziai emlékek az Anjou-korból. Acta extra Andegavensia I-III. Szerk. Wenzel Gusztáv. Budapest 1874-1876.

Z. = A zichi és vásonkeői gróf Zichy-család idősb ágának okmánytára I-XI. Szerk. Nagy Imre - Nagy Iván - Véghely Dezső - Kammerer Ernő - Döry Ferenc. Pest-Budapest 1871-1915.

Zala = Zala vármegye története. Oklevéltár I-II. Szerk. Nagy Imre - Véghely Dezső - Nagy Gyula. Budapest 1886-1890.

Zupko, R. E.: A Dictionary of Weights and Measures = Zupko, Ronald Edward: A Dictionary of Weights and Measures for the British Isles: The Middle Ages to the Twentieth Century. Philadelphia 1985.

ZW. = Urkundenbuch zur Geschichte der Deutschen in Siebenbürgen I-VII. Bearb. von Zimmermann, Franz - Werner, Carl - Gündisch, Gustav. Hermannstadt-Köln-WienBucureşti 1892-1991.

ZsO. = Zsigmondkori oklevéltár I-XIII. Szerk. Mályusz Elemér - Borsa Iván - C. Tóth Norbert - Neumann Tibor - Lakatos Bálint - Mikó Gábor. Budapest 1951-2017. 